\title{
De algemene wet bestuursrecht en het maken van bezwaar : zwaartepunten van een bestuurlijke voorprocedure
}

Citation for published version (APA):

Notten, J. H. W. (1998). De algemene wet bestuursrecht en het maken van bezwaar : zwaartepunten van een bestuurlijke voorprocedure. [Doctoral Thesis, Maastricht University]. Sdu Uitgevers. https://doi.org/10.26481/dis.19981029jn

Document status and date:

Published: 01/01/1998

DOI:

10.26481/dis.19981029jn

Document Version:

Publisher's PDF, also known as Version of record

Please check the document version of this publication:

- A submitted manuscript is the version of the article upon submission and before peer-review. There can be important differences between the submitted version and the official published version of record.

People interested in the research are advised to contact the author for the final version of the publication, or visit the DOI to the publisher's website.

- The final author version and the galley proof are versions of the publication after peer review.

- The final published version features the final layout of the paper including the volume, issue and page numbers.

Link to publication

\footnotetext{
General rights rights.

- You may freely distribute the URL identifying the publication in the public portal. please follow below link for the End User Agreement:

www.umlib.nl/taverne-license

Take down policy

If you believe that this document breaches copyright please contact us at:

repository@maastrichtuniversity.nl

providing details and we will investigate your claim.
}

Copyright and moral rights for the publications made accessible in the public portal are retained by the authors and/or other copyright owners and it is a condition of accessing publications that users recognise and abide by the legal requirements associated with these

- Users may download and print one copy of any publication from the public portal for the purpose of private study or research.

- You may not further distribute the material or use it for any profit-making activity or commercial gain

If the publication is distributed under the terms of Article 25fa of the Dutch Copyright Act, indicated by the "Taverne" license above, 
DE ALGEMENE WET BESTUURSRECHT EN HET MAKEN VAN BEZWAAR 


\section{De Algemene wet bestuursrecht en het maken van bezwaar}

Zwaartepunten van een bestuurlijke voorprocedure

\section{PROEFSCHRIFT}

ter verkrijging van de graad van doctor aan de Universiteit Maastricht, op gezag van de Rector Magnificus, Prof.dr. A.C. Nieuwenhuijzen Kruseman, volgens het besluit van het College van Decanen, in het openbaar te verdedigen op donderdag 29 oktober 1998 om 16.00 uur

door

JOSEPH HUBERTUS WINAND NOTTEN

Sdu Uitgevers Den Haag 1998 
Promotor: $\quad$ Prof.mr. F.A.M. Stroink

Beoordelingscommissie: Prof.mr. A.W. Heringa (voorzitter)

Prof.mr. J.B.J.M. ten Berge (Universiteit Utrecht)

Mr. H.J. Simoin

(C) 1998/ Sdu Uitgevers/ Den Haag

Omslagontwerp: Villa Y Den Haag

Van deze studie is een handelsuitgave verschenen bij Sdu Uitgevers onder ISBN 9054091983 


\section{Inhoud}

Voorwoord

Lijst van afkortingen

xiii

Inleiding

Hoofdstuk $\mathbb{1}$

De heroverweging en het bezwaarschrift

1.1 Inleiding

1.2 Het karakter van de heroverweging

1.2.1 Heroverweging als besturrlijk fenomeen

1.2.2 De bestuurlijke theroverweging op grond van de Awb als juridisch kader: oude wijn in nieuwe zakken?

1.3 Uitgangspunten en normen

1.3.1 Algemene karakterisering

1.3.2 Normen

1.4 De omvang van de bestuurlijke toetsing

1.4.1 Een nadere invulling van de omvang van de heroverweging

1.4.2 De toetsing ex nunc als uitgangspunt; een grondbeginsel van de heroverweging met relatieve trekken

1.4.4 Het beginsel van non-reformatio in peius en de omvang van de heroverweging

1.4.4.1 De begripsvorming van het beginsel

1.4.4.2 De toepassing van het non-reformatio in peius beginsel door de rechter

1.4.4.2a De Wet arob en hel verbod van reformatio in peius

1.4.4.2b Hel verbod van reformatio in peius onder de werking van de Awb

1.4.4.3 Enkele conclusies ten aanzien van het verbod wan reformatio in peius, afgezet tegen de wetenschap en de jurisprudentie

1.5 Uitgangspunten bij de heroverweging

1.5.1 Heroverweging en de Algemene wet bestuursrecht

1.5.2 De ontwikkeling van de heroverwegingsplicht

1.5.3 Een drietal uitgangspunten

1.5.3.1 Verantwoording vooraf

1.5.3.2 Het uitgangspunt van schriftelijkheid

1.5.3.3 Het uitgangspunt van behoorlijke dossiervorming 
Hoofdstuk 2

Het verbod van vooringenomenheid: tegen vriendjespolitiek of onzorgvuldigheid?

2.1 Enkele uitgangspunten bij de publieke taakvervulling door bestuursorganen; het tapijt van de wederkerigheid bedekt de eenzijdigheid

2.2 De Awb en het verbod van wooringenomenheid:

enkele desiderata

2.3 Een kritische beschouwing over de noodzaak van het verbod van vooringenomenheid

2.4 Wettelijke bepalingen terzake integriteit en onpartijdigheid

2.4.1 Integriteitsvereisten

2.4.2 Wettelijke randvoorwaarden ter woorkoming van partijdigheid in het openbaar bestuur

2.4.3 Regelingen die het belang van de zuiverheid van het besturen en de onpartijdigheid positief kunnen beïnvloeden

2.5 De zuiverheid van de bestururlijke taakvervulling vóór de $\mathrm{Awb}$ : een doorkijk op hoofdlijnen

2.5.2 Voorbereiding besluitvorming formeel-wettelijke adviescommissie 136

2.5.3 Voorbereiding besluitworming door een materieel-wettelijke adviescommissie

2.5.4 Bijzondere uitspraken inzake objectiviteit bij

de voorbereiding van de besluitvorming

2.5.5 Uitspraken over (on)partijdigheid bij de beslissingsprocedure

2.6 De objectieve besluitworming door bestuursorganen onder de werking van de $\mathrm{Awb}$

2.6.1 Inleidende overwegingen

2.6.2 Voorbereiding besluitvorming formeel-wettelijke adviescommissie

2.6.3 Voorbereiding besluitworming door een materieel-wettelijke adviescommissie

2.6.4 Uitspraken inzake (on)partijdigheid bij de beslissingsprocedure 163

2.7 Conclusies

Hoofdstuk 3

Het horen: cen belangrijke formele bepaling met materielle betekenis voor de beslissing op het bezwaarschrift

3.1 Een verkenning

3.2 De functie van het horen

3.2.1 Het procedureelrechtelijk aspect

3.2.1.1 De procedureelrechtelijke uitgangspunten van de hoorplicht nader belicht 
3.2.1.3 De juridische consequenties van het achterwege laten van de hoorplicht

3.2.2 Het horen als kans woor burgers en bestuursorganen 198

$\begin{array}{lll}3.2 .2 .1 \quad \text { Algemene aspecten } & 198\end{array}$

3.2.2.2 Hoor en wederhoor 203

(a) De onvoorwaardelijke selectieplicht van het bestuursorgaan om de bij het bestreden besluit betrokken belanghebbenden te horen

(b) Hoor en wederhoor als structuurbepalende (wettelijke) verplichting

(c) Hoor en wederhoor in relatie tot de kennisvergaringsplicht naar relevante feiten en af te wegen belangen

(d) Hoor en wederhoor en de aanwezigheid van getuigen en deskundigen

3.2.2.3 Het horen als informatiefunctie; enige karakteristieken

\section{Hoofdstuk 4}

Het adviseren omtrent de op het bezwaarschrift te nemen beslissing
4.1
Type van advisering

Een schets van de Wet arob als proeftuin voor de ontwikkeling van de advisering op het terrein van de bezwaarschriftenprocedure

4.3 Het adviseren over het bezwaarschrift op grond van de Awb

4.3.1 Impressies en accenten

4.3.2 De grondslag van het adviseren en beslissen orntrent bezwaarschriften

4.3.2.1 Het grondslagvereiste voor het adviseren

4.3.2.2 De grondslag voor het beslissen op het bezwaarschrift

4.3.3 Aanbevelingen voor de besliscommissie

4.3.3.1 Conclusies en aanbevelingen voor het bepalen van de instellingsgrondslag van de hoor-en adviescommissic als bedoeld in artikel $7: 13 \mathrm{Awb}$

\section{Hoofdstuk 5}

Naar cen 'definitief' concept voor het adviseren op grond van de Awb: de advisering als kwaliteitsfactor in de besluitvorming en

als object van rechtsbescherming

5.2.1 Het bestuursorgaan als voorbereider van de beslissing op het bezwaarschrift 
5.2.2 Het voorbereiden van de beslissing door een adviescommissie

5.3 Bijzondere aspecten

5.3.1 De Awb en de keuzevrijheid van het adviseren

5.3.2 De kritiek op de vrijheid van het adviseren

296

5.3.3 De twijfels over artikel 7.5 als inrichtingsconditie voor het horen

5.3.4 Artikel 7:13 en de waarborgen tegen belangenverstrengeling

5.3.5 Het openbaar lichaam als belanghebbende vergunninghouder: artikel 7:5 onder druk en de (rechterlijke) voorkeur voor artikel $7: 13$

5.3.6 Kanttekeningen bij de ambtelijke advisering

5.3.7 Enkele 'leemten' in de onafhankelijkheidsaspecten van artikel 7:13

5.3.8 De literatuur en de adviescommissie

5.3.9 De procedurele bevoegdheden van de adviescommissie

5.3.10 Kritische kanttekeningen bij de competentieverdeling van de preparatoire bevoegdheden

5.3.11 De differentiatie van de beslistermijn in artikel $7: 10 \mathrm{Awb}$

5.4.1 De Awb en de keuzevrijheid voor het adviseren

5.4.2 De kritiek op de vrijheid van het adviseren

5.4.4 Artikel 7:13 Awb en de waarborgen tegen belangenverstrengeling Het openbaar lichaam als (belanghebbende) vergunninghouder: artikel 7:5 onder druk en de rechterlijke voorkeur voor artikel 7:13

5.4.6 Kanttekeningen bij de ambtelijke advisering

5.4.7 Enkele leemten in de onafhankelijkheidsaspecten van artikel 7:13

5.4.7.1 De vormgeving van artikel $7: 13$; conclusies en aanbevelingen

5.4.8 De literatuur en de adviescommissie

5.4.9 De procedurele bevoegdheden van de adviescommissie

5.4.10 Kritische kanttekeningen bij de competentieverdeling van de procedurele bevoegdheden

5.4.11 De differentiatie van de beslistermijn in artikel 7:10 Awb

Hoofdstuk 6

De bezwaarschriftenprocedure ter discussie: evaluatie, standpunten, literatuur en aanbevelingen

6.1 Inleiding en verantwoording

6.2

De verplichte bezwaarschriftenprocedure 
6.3.1 De financiële beschikkingverlening 361

$\begin{array}{ll}6.3 .2 & \text { Subsidiebeschikkingen } \\ 6.3 .3 & \text { Ruimtijke }\end{array}$

6.3.3 Ruimtelijke ordening, milieu en standplaatsen 365

6.4 Het adviseren over het bezwaarschrift 367

$\begin{array}{ll}\text { 6.4.1 De financiële beschikkingverlening } & 372\end{array}$

6.4.2 Het ruimtelijk bestuursrecht c.a. 373

$\begin{array}{lll}\text { 6.4.3 De subsidiebeschikkingen } & 375\end{array}$

6.5 De tijdigheid van de beslissing op het bezwaarschrift 377

$\begin{array}{lll}6.6 & \text { Conclusies } & 380\end{array}$

$\begin{array}{ll}\text { Ter afronding } & 383\end{array}$

1 Samenvatting en conclusies $\quad 383$

1.1 De heroverweging en het bezwaarschrift 385

1.2 Het verbod van vooringenomenheid: tegen vriendjespolitiek of onzorgvuldigheid? 390

1.3 Het horen: een belangrijke formele bepaling met materiële betekenis voor de beslissing op het bezwaarschrift 397

1.4 Het adviseren omtrent de op het bezwaarschrift te nemen beslissing

1.5 Naar een 'definitief' concept voor het adviseren op grond van de Awb: de advisering als kwaliteitsfactor in de besluitvorming en als object van rechtsbescherming

1.6 De bezwaarschriftenprocedure ter discussie: evaluatie, standpunten, literatuur en aanbevelingen $\quad 417$

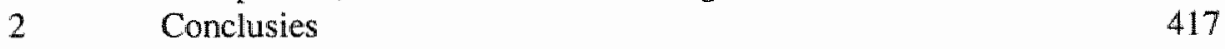

3 Aanbevelingen $\quad 420$

The general administrative code and the procedure governing objections Summary

Literatuurlijst

Jurisprudentieregister 441 Curriculum vitae 



\section{Voorwoord}

Toen ik dit voorwoord schreef, herinnerde ik mij een citaat van Vondel op de eerste pagina van het Tijdschrift voor Overheidsadministratie van 2 januari 1959: 'De welvaart spruit uit kloeck beleit van amptenaren die nacht en dagh zich zelfs niet spaeren, geschapen tot een ieders nut'. In de voorbije jaren voltrokken zich vele boeiende veranderingen op het tertein van het bestuursrecht. Het hoger bestuurlijk toezicht werd gaandeweg teruggedrongen ten faveure van de rechtsbescherming van de burger tegen de overheid.

De Algemene wet bestuursrecht sloot met de invoering van de verplichte bezwaarschriftenprocedure een periode af, waarin de fundamenten werden gelegd voor de totstandkoming van dit proefschrift dat is afgerond op 1 januari 1998. Voorzover mogelijk is het boek globaal nog aangepast an de laatste ontwikkelingen in het bestuursrecht.

Mujn dank gaat uit naar mijn promotor Prof.mr. F.A.M. Stroink voor het vertrouwen dat hij van meet af aan in mij stelde. Dankbaar zie ik terug op de momenten dat weer een bijdrage aan het proefschrift werd besproken. Zijn kritische adviezen, aanwijzingen en commentaar op het manuscript wezen mij de weg naar het viteindelijke resultaat.

Ook de leden van de beoordelingscommissie ben ik bijzonder erkentellijk voor hun opmerkingen en aanbevelingen die de kwaliteit van het proefschrift ten goede zijn gekomen.

Daarnaast zie ik terug op de vele momenten dat mijn vrouw Mientje mij stimuleerde op de ingeslagen weg door te gaan. Zonder haar intense steun en hulp bij dit proefschrift zou ik 'de klus' niet hebben geklaard. Zij deelt mede in mijn inspanningen. Met voldoening heb ik de permanente belangstelling van Frank en Yvonne ervaren. Jammer dat mijn vader er niet meer is. Ook Harry en Marlies bliff ik bijzonder dankbaar voor hun steun.

Maria Kuipers heeft mij geholpen met de tekstverwerking van het manuscript, Niet in de laatste plaats ben ik dank verschuldigd aan Elly Peters die binnen korte tijd het proefschrift camera-ready maakte. 


\section{Lijst van afkortingen}

AA

AAW

$A B$

ABAR

ABRS

ABW

AGVB

a.m.v.b.

APK

ARAR

ARB

ARRS

art.

Awb

AWT

$\mathrm{BB}$

b en w

IB/S

Best.w.

$\mathrm{BNB}$

BR

burg.

BW

c.a.

Cbsf

CdK

$\mathrm{CBB}$

CRvB

Ctsv

EHRM

EVRM

gem.w.

Gem.w.

Grw.

GS

Gst.

Hand.

HR
Ars Aequi

Algemene Arbeidsongeschiktheidswet

Administratiefrechtelijke beslissingen

Algemene Bepalingen van Administratief Recht

Afdeling bestuursrechtspraak van de Raad van State

Algemene bijstandswet

Afdeling geschillen van bestuur van de Raad wan State

algemene maatregel van bestuur

Algemene periodieke keuring

Algemeen Rijks ambtenarenreglement

Administratieve en Rechterlijke beslissingen

Afdeling rechispraak van de Raad van State

artikel/artikelen

Algemene wet bestuursrecht

Algemene wet inzake rijksbelastingen

Binnenlands Bestuur

burgemeester en wethouders

Ten Berge/Stroink, Wet Arob (voortgezet als Ten Berge/De Waard/Widdershoven, thans RAwb)

Bestuurswetenschappen

Beslissingen in Belastingzaken

Bouwrecht

burgemeester

Burgerlijk Wetboek

cum annexis

College van Beroep Studiefinanciering

Commissaris van de Koning

College van Beroep voor het bedrijfsleven

Centrale Raad van Beroep

College van toezicht sociale verzekeringen

Europees Hof voor de Rechten van de Mens

Europees Verdrag betreffende de Rechten van de Mens en de fundamentele vrijheden (Verdrag van Rome 1950)

gemeentewet

Gemeentewet

Grondwet

gedeputeerde staten

de Gemeentestem

Handelingen

Hoge Raad 
JABW

JB

JG

$\mathrm{KB}$

$\mathrm{KG}$

Kiesw.

LNV

m. aant.

$\mathrm{M}$ en $\mathrm{R}$

M.nt.

MvA

MVT

$\mathrm{NG}$

NJ

NJB

NJCM

N.o.

NTB

$\mathrm{OB}$

P.A.R.

P.B.R.

PG Awb I

PG Awb II

Pres.

Prow.w.

PS

RAwb

Rb.

red.

RMTh

RSV

RV

RvS

SFB

Stb.

Stcri.

Sv

T\&C PGW

(Graat)

TAR

TVO
Jurisprudentie Algemene Bijstandswet en Rijksgroepsregelingen Jurisprudentie Bestuursrecht

Jurisprudentie Gemeenten

Koninklijk Besluit

Kort Geding

Kieswet

Landbouw, Natuurbeheer en Visserij

met aantekening

Milieu en Recht

met noot

memorie van antwoord

memorie van toelichting

De Nederlandse Gemeente

Nederlandse Jurisprudentie

Nederlands Juristenblad

Nederlands Juristencomité voor de Mensenrechten

Nationale ombudsman

Nederlands Tijdschrift voor Bestuursrecht

Openbaar Bestuur

Praktijkboek Administratief Recht (tot 1994)

Praktijkboek Bestuursrecht (sinds 1994)

E.J. Daalder/G.R.J. de Groot, De parlementaire geschiedenis van de Algemene wet bestuursrecht, Eerste Tranche (1993)

E.J. Daalder/G.R. de Groot, J.M.E. van Breugel, De parlementaire geschiedenis van de Algemene wet bestuursrecht, Tweede Tranche, (1994)

President

Provinciewet

provinciale staten

Rechtspraak Awb

Rechtbank

redactie

Rechtsgeleerd Magazijn Themis

Rechtspraak Sociale Verzekering

Wetboek van burgerlijke Rechtsvordering

Raad van State

Sociaal Fonds Bouwnijwerheid

Staatsblad

Staatscourant

Wetboek van Strafvordering

J.B.J.M. ten Berge (red.), Provincie-, Gemeente- en Water-

schapswet

Tijdschrift voor ambtenarenrecht

tijdschrifi voor Openbaar bestuur 


$\begin{array}{ll}\text { TwK } & \text { Tijdelijke wet Kroongeschillen } \\ \text { VAR } & \text { Vereniging voor Administratief Recht } \\ \text { VINEX } & \text { Vierde Nota Ruimtelijke Ordening Extra } \\ \text { VNG } & \text { Vereniging van Nederlandse Gemeenten } \\ \text { VZ. } & \text { Voorzitter } \\ \text { WAO } & \text { Wet Arbeidsongeschiktheidsverzekering } \\ \text { Watersch.w. } & \text { Waterschapswet } \\ \text { Wet AB } & \text { Wet van } 15 \text { mei } 1829, \text { Stb. } 28, \text { houdende algemene bepalingen } \\ & \text { der Wetgeving voor het Koninkrijk } \\ \text { Wet Arbo } & \text { Wet administratieve rechtspraak bedrijfsorganisatie } \\ \text { Wet arob } & \text { Wet administratieve rechtspraak overheidsbeschikkingen } \\ \text { Wet BAB } & \text { Wet beroep administratieve beschikkingen } \\ \text { Wet BO } & \text { Wet op de Bedrijfsorganisatie } \\ \text { WGR } & \text { Wet gemeenschappelijke regelingen } \\ \text { Wm } & \text { Wet milieubeheer } \\ \text { Wno } & \text { Wet Nationale ombudsman } \\ \text { WOB } & \text { Wet openbaarheid van bestur } \\ \text { WRO } & \text { Wet op de Ruimtelijke Ordening } \\ \text { WSW } & \text { Wet sociale werkvoorziening } \\ \text { WUV } & \text { Wet uitkeringen vervolgingsslachtoffers } \\ \text { WVC } & \text { Welzijn, Volksgezondheid en Cultuur } \\ \text { WW } & \text { Woningwet } \\ \text { ZW } & \text { Ziektewet }\end{array}$




\section{$+$}


Voor Mientje, Frank en Yvonne 


\section{Inleiding}

Op 1 januari 1994 is de Awb in werking getreden. De invoering van deze wet is een ingrijpende legislatieve operatie met belangrijke gevolgen voor het bestuursrecht. De Awb is gedeeltelijk geëffectueerd door de invoering van een drietal tranches.

De eerste tranche van de Awb' legde de basis woor een algemene bestuursrechtelijke regeling voor:

het verkeer tussen burgers en bestuursorganen (hoofdstuk 2), algemene en bijzondere bepalingen over besluiten (hoofdstuk 3 , respectievelijk hoofdstuk 4 ), alsmede algemene en bijzondere bepalingen over bezwaar en (administratief) beroep (hoofdstukken 6 en 7 ).

Gelijktijdig met deze eerste tranche van de Awb kreeg ook de tweede tranche rechtskracht. Hierdoor werd de eerste fase van de herziening van de rechterlijke organisatie een feit. ${ }^{2}$ Met deze tweede tranche (22495) werd een aantal bestuursprocesrechtelijke aspecten in samenhang met de Awb gerealiseerd. Bij de rechtbanken vond enerzijds een aantal organisatorische maatregelen plaats, terwijl daarnaast een algemene regeling van het bestuursprocesrecht werd ingevoerd. Voor de rechtbanken werden administratieve kamers ingesteld, en werd daarnaast in beginsel (behoudens enkele uirzonderingen) bestuursrechtspraak in twee instanties gerealiseerd. Een groot aantal bestuursprocesrechtelijke wetten werd gewijzigd, waaronder de Wet op de Raad van State, de Beroepswet, de Ambtenarenwet en de Wet administratieve rechtspraak bedrijfsorganisatie. Belangrijk was tevens dat de Wet arob werd ingetrokken. ${ }^{3}$ Deze wetgevingsoperatie had ook gevolgen voor de aan het begin van deze inleiding genoemde (aanvankelijk) opgenomen algemene regels voor het bestuursrecht. De Awb werd door de tweede tranche uitgebreid met hoofdstuk 8 dat bijzondere (procedure)bepalingen bevat voor het beroep bij de rechtbank. Daarmede werd gedeeltelijk afgerekend met de grote verscheidenheid van procesregelingen. ${ }^{4}$

De Awb is niet zo maar voor bestuurlijk Nederland uit de lucht komen vallen. De grondslag voor een regeling van het algemeen bestuurstecht is sinds 1983 neergelegd in art. 107, lid 2 Gr.w. Dit artikel bepaalt:

Wet van 4 juni 1992, houdende algemene regels van bestuursrecht, Stb. 1992, 315.

Wet van 23 december 1993 , Stb. 690 .

PG Awb II, p. 1 en p. 2.

R.E. Bakker, Commentaar art. 8. 1, in: Algemene wet bestuarsrecht, losbl., "s-Gravenhage, p.

8.1.1.1.-1 a. . 
2. De wet stelt algemene regels van bestuursrecht vasi."

Het bestuursrecht heeft sinds de Tweede Wereldoorlog een snelle groei doorgemaakt als gevolg van de toegenomen taken van de overheid op uiteenlopende maatschappelijke gebieden. De regelgeving op het terrein van het bestuursrecht nam imposante wormen aan. Door de groei van het bestuursrecht namen ook de taken toe van de bestuursorganen. Aan deze bestuurlijke taken werden steeds hogere eisen gesteld, mede onder invloed van de jurisprudentie. Gevoed door wetenschappelijke inspanningen, zoals onder andere het rapport $\mathrm{ABAR}^{5}$, werd hierdoor mede de kiem gelegd voor een codificatie van het algemeen bestuursrecht. Uiteindelijk resulteerde dit in de totstandkoming van de Awb. ${ }^{6}$

Met de grondwettelijke opdracht tot het verplicht vaststellen van algemene regels voor het bestuursrecht, had de wetgever niet de intentie een allesomvattende codificatie van het algemeen bestuursrecht te effectueren. Het codificatiestreven van de Gr.w. is niet gericht op een integrale regeling van het algemeen bestuursrecht in de Awb. Daarvoor is het bestuursrecht te complex. Wel ligt aan de gerealiseerde codificatie van het algemeen bestuursrecht in de Awb een aantal belangrijke uitgangspunten ten grondslag, te weten:

de eenheid van wetgeving, het systematiseren en vereenvoudigen, het codificeren en het treffen van algemene voorzieningen voor die onderwerpen die zich niet lenen voor regeling buiten een algemene wet. Op grond van dit laatste uitgangspunt is in de Awb gekozen woor een regeling voor het gehele bestuursrecht.

Een verdere uitbreiding van de algemeen bestuursrechtelijke codificatie is gerealiseerd; ingaande 1 januari 1998 is de derde tranche Awb in werking getreden. ${ }^{8}$ Hierdoor is de Awb belangrijk uitgebreid met regels voor de subsidiering (titel 4.2), de vaststelling van beleidsregels (titel 4.3) en de handhaving van het bestuursrecht (hoofdstuk 5). Er zijn regels opgenomen met betrekking tot mandaat en delegatie (titel 10.1 ), alsmede het toezicht op bestuursorganen (titel 10.2). Het ligt in het voornemen een nieuw hoofdstuk 9 in de Awb op te nemen

5 ABAR, wijfde dr. Alphen aan den Rijn 1984.

- P.D.A. Claessen, Artikel 107, in: Akkermans/Koekkoek, de Grondwet, tweede dr, Zwolle 1992 p. 954 e.v.

7 Zie woor een uitwoerigere beschowwing: PG Awb I, p. 18 e.v.

8. Wet van 20 juni 1996, Stb. $1996,333$. 
aangaande het klachtrecht. Het Voorontwerp Klachtrecht is inmiddels uitgebracht. ${ }^{9}$

Uit de parlementaire geschiedenis blijkt dat de grondwetgever met art. 107, did 2 niet beoogde om bij formele wet een verplichte regeling te geven van het bestuursprocesrecht, zoals die gedeeltelijk door de tweede tranche is ingevoerd. Een grondwettelijke codificatie-opdracht voor het bestuursprocesrecht werd afgewezen. ${ }^{10}$ Dat ook het bestuursprocesrecht bij de parlementaire behandeling van de Awb een rol speelde is niet zonder betekenis. De ontwikkeling van het bestuursrecht liet het bestuursprocesrecht niet ongemoeid. Het gevolg hiervan was een warrige en nogal chaotische situatie door het ontstaan van vele 'administratieve rechtsgangen'. Dat door de harmonisatie van het bestuursprocesrecht deze negatieve ontwikkeling tot staan is gebracht, kan alleen maar positief worden gewaardeerd. "Ofschoon de CRvB en het CBB voorlopig als bijzondere administratieve rechters zullen blijven functioneren, ligt toch nog enige herstructurering van de rechterlijke organisatie in het verschiet. De rechtspraak inzake de studiefinanciering zal waarschijnlijk worden ondergebracht binnen de (gewone) rechterlijke macht. Daarnaast bestaat er het voornemen om de Tariefcommissie te integreren bij het gerechtshof Amsterdam.!'

Een verdere uniformering van het bestuursprocesrecht verdient aanbeveling. Hierdoor wordt bereikt dat in het belang van de justitiabele de "wegmarkeringen" voor de rechtsbeschermingsvoorzieningen worden verbeterd.

Met dit proefschrift wordt beoogd een uitvoerige beschouwing te geven over de bezwaarschriftenprocedure. Dat dit boek wordt ingeleid met een globale aandacht voor het bestuursprocesrecht heeft te maken met de omstandigheid dat de bezwaarschriftenprocedure geen geissoleerd bestuursrechtelijk fenomeen is. Allereerst gelden voor deze bestuurlijke voorprocedure de bepalingen van hoofdstuk 6 die ook gemeenschappelijke toepassing vinden voor het administratief beroep en het beroep op de bestuursrechter.

Afd. 7.2 Awb geeft een bijzondere regeling voor de bezwaarschriftenprocedure. Met uitzondering van de in art 7:11, lid 1 opgenomen belangrijke verplichting

1) Voorontwerp kJachtrecht, Den Haag 1996. Zie ook in dit verband o.a. H. Borgers en H. wan der Tas, Klachtrecht, de aanvulling van de Awb. AA 1997, 9, p. 589 e.v. en M.P. Gerrits-Janssens, Het Voorontwerp Klachtrecht, NTB 1997 , p. 175 e.v.

10 Zie o.a. J.H. Kreveld, Systeem en algemene begrippen van de Algemene wet besturrsrecht, Monografieën Algemene wet bestumrsrecht A1, Deventer 1995, p. 11 e.v.

i) Zie in dit verband R.J.G.M. Widdershoven, Gespecialiseerde rechtsgangen in het administratieve recht, Zwolle 1989.

12 Nieuwsbrief Algemene wet bestuursrecht, 1997 , nr. 3, p. 4 en 5. 
voor het bestuursorgaan, om het in het bezwaarschrift bestreden primaire besluit te heroverwegen, bevatten de regels voor de bezwaarprocedure grotendeels bepalingen van procedurelle aard. Dit laatste geldt overigens ook voor de in hoofdstuk 3 opgenomen afdelingen 4 en 5 betreffende de openbare voorbereidingsprocedures. Eenzelfde procedurerecht bevat hoofdstuk 4 van de bijzondere bepalingen over besluiten. Door de overheveling van de motiveringsnormen in afd 4.1.4 (beschikkingen) bevat dit hoofdstuk uitsluitend procedurevoorschriften.

Gesteld is dat de bezwaarschriftenprocedure in de Awb geen geïsoleerde voorprocedure is. Dit komt tot uitdrukking in de systematiek van de Awb. Voor de bezwaarschriftemprocedure gelden eveneens de bepalingen van hoofdstuk 2 Awb dat regels geeft voor het verkeer tussen burgers en bestuursorganen. Deze bepalingen zijn van een gemengd karakter; deels wordt een regeling gegeven van procedurele voorschriften (bijstand, vertegenwoordiging, door-en terugzendplicht en geheimhoudingsplicht). Daarnaast beval hoofdstuk $2 \mathrm{Awb}$ door het verbod van vooringenomenheid (art. 2:4) bij de taakvervulling door bestuursorganen, voorschriften van materiële aard.

Hoofdstuk 3 Awb is mede van toepassing op de bezwaarschriftenprocedure, behoudens de in art. 7:14 Awb gemaakte uitzonderingen. Afdeling 3.2 stelt zowel eisen voor de zorgvuldigheid en de belangenafweging in het kader van de primaire besluitvorming als voor de beslissing op het bezwaarschrift. Een identieke situatie geldt voor afdeling 3.3, betreffende de regels voor de (wettelijke) advisering. Art. 3:1 Awb brengt voorzover hier van belang deze toepasselijkheid tot uitdrukking. De bepalingen van hoofdstuk 3 zijn van belang voor de inhoud van de door het bestuursorgaan op het bezwaarschrift te nemen beslissing.

Het vorenstaande zou er op kunnen duiden dat voor de bezwaarschriftenprocedure alle aan de hoofdstukken 6 en 7 voorafgaande bepalingen van de Awb van toepassing zijn. Dit is niet het geval. Art. $7: 12$ bevat bijzondere bepalingen voor een deugdelijke motivering en de bekendmaking van de beslissing op het bezwaar. Volgens art. 7:14 Awb is een aantal bepalingen van de Awb niet van toepassing op de bezwaarschriftenprocedure. Art. $7: 14$ bepaalt:

'Artikel 3:6, tweede lid, de afdelingen 3.4 en 3.5, de artikelen 3:41 tot en met 3:45, afdeling 3.7 , met uitzondering van artikel $3: 49$, en hoofdstuk 4 zijn niet van

Dit artikel is gewijzigd bij de derde tranche Awb die per 1 januari 1998 in werking is getreden. 
De bezwaarschriftenprocedure als schakel in de rechtsbescherming van de burger tegen de overheid, wordt zowel beinvloed door bestuursrechtelijke regels van materiële aard (bijzondere wetgeving), alsmede die met een bestuursprocesrechtelijk karakter. Dit laatste is niet zonder betekenis voor het plaatsen van de bezwaarschriftenprocedure in een juiste context. Bij de opzet van dit boek zullen daarom de normen en beginselen die gelden voor een rechtens juiste taakvervulling door bestuursorganen een belangrijke rol spelen. Ook de invloed van de rechtspraak op het bestuurlijk handelen en besluiten kan hierbij niet ontbreken.

De bezwaarschriftenprocedure is geen nieuw verschijnsel in het bestuursrecht. In het belastingrecht kent de bezwaarfase een lange historie, en heeft deze een belangrijke functie als informele voorprocedure bij de belastinginspecteur. ${ }^{\text {is }}$ Daarnaast waren vóór de Wet arob ${ }^{15}$ vooral de gemeentelijke bestuursorganen de wegbereiders van de introductie van bezwaarprocedures. Vele verordeningen voor de behandeling van bezwaar- en beroepschriften door de gemeentelijke bestuursorganen, kwamen tot stand. ${ }^{16}$

De invoering van de Wet arob op $\mathbb{1}$ juli 1976 , betekende een belangrijke inspiratiebron voor de totstandkoming van één algemene verplichte bezwaarschriftenprocedure (behoudens enkele uitzonderingen) in de Awb. Wél werd vooruitlopend op de $A w b$, reeds tot invoering overgegaan van de bezwaarschriftenprocedure voor besluiten van bestuursorganen van de centrale overheid; aanvankelijk gold de arobbezwaarschriftenprocedure voor besluiten van bestuursorganen van de lagere overheden. Ook voor het sociaal-economisch bestuursrecht werd reeds vóór de Awb de verplichte bezwaarschriftenprocedure ingevoerd, voorafgaande aan het beroep bij het CBB.

Er is op geattendeerd dat bij de opzet van dit proefschrift niet voorbij kan worden gegaan aan de belangrijke invloed van de rechtspraak op het handelen door bestuursorganen. Zoals bleek, is de bezwaarschriftenprocedure geen nieuw werschijnsel. De Wet arob heeft door het invoeren van de voorprocedure bijzondere betekenis gehad voor de verdere ontwikkeling van dit bestuurlijke 'voorportaal' van het beroep op de bestuursrechter. Daarom is voor de arob-periode een belangrijke plaats ingeruimd in dit boek, en wervult dit rechtsbeschermingstijdvak mede een functie ten dienste van het onderzoek.

14. J.A. Smit, Bezwaar in belastingzaken, Deventer 1992, p. 19 e.w.

15 Wet wan 1 mei 1975, Stb. 284.

16. Blauwe reeks nr. 48, Behandeling van bezwaar-en beroepschriften door de gemeentebesturen, $\mathrm{VNG}_{*}$ "s-Grawenhage 1972. 
Voor de onderzoeksaspecten die hierna aan de orde komen zullen nogal wat aanknopingspunten worden gezocht bij de arob-jurisprudentie. Ook een aantal bepalingen van de Wet arob zal hierbij worden betrokken. Genoemd kunnen hier worden de heroverweging, de hoorplicht, het adviseren en het beslissen op het bezwaarschrift. Met de komst van het nieuwe bestuursrecht is immers ondanks de vernieuwingen, niet met het bestuursrechtelijk ver]eden afgerekend. In veel gevallen wordt in de Awb daarop voortgeborduurd. De 'arob-kennis' is van wezenlijke betekenis voor een inhoudelijke benadering en verklaring van de "zwaartepunten' van de bestuurlijke voorprocedure die in dit boek onderwerp van studie zijn.

De Awb en het nieuwe bestuursprocesrecht regelen vele onderwerpen die ook vóor 1 januari 1994 terug te vinden waren in bijzondere regelingen, alsmede in de jurisprudentie en in de wetenschap als informele rechtsbron. Ofschoon de Awb de normen voor het handelen door bestuursorganen, en de rechtsbescherming tegen het optreden door bestuursorganen, op een nieuwe leest heeft geschoeid ${ }^{17}$, betekent dit niet dat gesproken kan worden wan een volledige breuk met het verleden. Dit laatste is niet zonder betekenis voor de studie over het onderwerp van dit boek; van de ervaringen uit het "verleden" is dankbaar gebruik gemaakt.

In art. $7: 1$, lid $1 \mathrm{Awb}$ is een belangrijk recht neergelegd voor de justitiabele dat hem de mogelijkheid verschaft om (verplicht) bezwaar te maken tegen een door het bestuursorgaan genomen besluit. Tevens kan de belanghebbende door het maken van bezwaar beroep instellen bij de bestuursrechter art. $7: 1$, lid 2 jo art. 8:1 Awb. ${ }^{18}$

Voor de justitiabele wiens belang rechtstreeks bij een besluit door een bestuursorgaan is betrokken (art. 1:3), is deze bezwaarschriftenprocedure in de Awb, algemeen verplicht gesteld. Een uitzondering daarop bestat woor die gevallen dat een bijzondere (formele) wettelijke bepaling direct beroep toestaat op de bestuursrechter, dan well dat het overgangsrecht vooralsnog de reikwijdte van de Awb beperkt. Daarnaast maakt art. 7:1 Awb voor bepaalde gevallen een uitzondering

17 H.J. Simom, Handleiding Awb-praktijk, 's-Gravenhage 1995, p. 1 .

18 Ofschoon het met de komst van de Awb meer voor de hand ligt aansluiting te zoeken met het citeerartikel (9:4) van deze wet lijki de Awb moeilijk afstand te kumnen nemen van het verleden. Opvallend is dat de term administratieve rechter nog in de Awb blift voortleven als herinnering aan de periode vo6r $\mathbb{1}$ januari 1994. In tegenstelling to het gebruik van de term administratieve rechter" in de artikelen 1:4, lid 1 en 1:5, lid 3 wordt in dit boek zoveel mogelijk gekozen voor het gebruik wan de term "bestuursrechter". Ter voorkoming wan misverstanden wordt hierbij opgemerkt dat artikel 9:4 deel uitmaakt van de tweede tranche Awb. Bij die tweede tranche werd de $A$ wb aangevuld met hoofdstuk 9. 
voor het verplicht vollgen van de voorprocedure. In het tweede lid wordt naast de gemaakte uitzondering voor het goedkeuringsrecht en de uitgebreide openbare voorbereidingsprocedures, als bedoeld in afdeling 3.5, van het maken van bezwaar uitgesloten de beslissing op het bezwarschrift zelve, alsmede de in administratief beroep genomen beslissing. De in art. $7: 1$ Awb genoemde uitzonderingen - behoudens de beslissing op bezwaar genomen - betreffen bestuursrechtelijke figuren die gerekend kunnen worden tot de woorprocedures.

In het geval van goedkeuringsprocedures is sprake van fiattering van bestuursbesluiten door een (hoger) toezichthoudend bestuursorgaan. Bij de voorbereidingsprocedures als bedoeld in afdeling $3.5 \mathrm{kan}$ gesproken worden van 'preventieve' rechtsbescherming omdat deze procedures zich richten op de voorbereiding van besiuiten. Het administratief beroep is ook een voorprocedure die de eerste schakel vormt in het rechtsbeschermingstraject. ${ }^{19}$

Naast de bezwaarschriftenprocedure kan ook het administratief beroep als voorprocedure worden gekwalificeerd. De hoedanigheid van het administratief beroep als voorprocedure wordt gekarakteriseerd door een (impliciete) opdracht tot heroverweging van het bestreden besluit (art. 1:5 jo art. 7:25). Toch zijn er enige afwijkingen te constateren; bij de bezwaarschriftenprocedure beslist het oorspronkelijk orgaan terwijl in een administratief beroep een ander bestuursorgaan de beslissing neemt. Voor zover het administratief beroep relevant is voor "het bezwaarschriftenkader" van het onderzoek, zal het, zij het summier, in dit boek aan de orde komen.

Met enige nadruk is in deze inleiding gesproken over "een min of meer" uitvoerige beschouwing over de bezwaarschriftemprocedure. Hierin ligt een restrictie opgesloten die tot uitdrukking komt in een verhandeling over de "zwaartepunten" van deze bestuurlijke voorprocedure. De beperking van het in dit boek verrichte onderzoek, is gelegen in de omvangrijke aspecten die betrokken zijn bij een studie over een onderwerp als het onderhavige. Vanwege de vele aspecten van de bezwaarschriftenprocedure is een aantal procedure-bepalingen van de hoofdstukken 6 en $7 \mathrm{Awb}$ slechts in hoofdlijnen in het onderzoek betrokken. Deze beperking geldt vooral voor hoofdstuk 6 Awb. Voorzover bepalingen in hoofdstuk 6 worden aangestipt, geschiedt dit met het oog op de kwaliteit van de beslissing op het bezwaarschrift. Hoofdstuk $7 \mathrm{Awb}$ is uitvoeriger betrokken in het onderzoek vanwege de kwaliteitsaccenten in dit proefschrift. Uitgangspunt van het onderzoek is de kwaliteit van de voorbereidingsfase, voorafgaand aan de beslissing op

19 C.P.J. Goorden, Awb-procesdossier, Nijmegen $1996, p .9$ en 10. Zie ook J.A. Smit, De Administratieve voorprocedures, in: Nieuw bestumsprocesrecht, Deventer 1992, p. 47 e.w. 
het bezwaarschrift. De bepalingen in de Awb over de bezwaarschriftenprocedure worden vooral gekenschetst door formaliteiten die zijn ingekaderd in (formele) procedure-regels.

Met de opzet van dit proefschrift wordt weliswaar niet voorbijgegaan aan het procedurele karakter van de $A w b$, maar is méér het accent gelegd op de betekenis van het procedurerecht van de Awb voor de kwaliteit van de beslissing op het bezwaarschrift. Dit leidde tot een onderzoek, waarin het zwaartepunt meer rust op het materiële dan op het formele aspect van de voorbereidingsfase van de beslissing op het bezwaarschrift. Met dit onderzoek is daarom beoogd aan te tonen dat het algemene bestuursrecht van de Awb meer is dan procedurerecht. Door de procedurevoorschriften van de Awb manifesteert zich de materiële kant van het bijzonder bestuursrecht. Van fundamenteel belang is hierbij de bestuurlijke plicht tot heroverweging van het bestreden primaire besiuit.

De bovengenoemde onderzoeks-uitgangspunten van dit boek zijn gebaseerd op de 'drie-fasen-filosofie' van de Awb. Het proces van het beoordelen van een besluit of beschikking wordt conform het Awb-model onderscheiden in drie fasen. ${ }^{20}$ Hierbij wordt de eerste fase gevormd door de voorbereiding en de vaststelling van het primaire besluit (de lichtere fase). De bezwaarschriftenprocedure stelt vervolgens hogere procedurele en beslis(eisen) aan het bestuursorgaan. De procedurele waarborgen voor een goede besluitvorming nemen dus in iedere fase toe, ten opzichte van de worige. Indien het bestuursorgaan een beslissing neemt op het bezwaarschrift waartegen beroep is ingesteld wordt het orgaan geconfronteerd met de derde (zwaarste) fase.

De betekenis van het bestuursprocesrecht (hoofdstuk $8 \mathrm{Awb}$ ) voor de bezwaarschriftenprocedure is alleen onderzocht woorzover dit uit een oogpunt van samenhang nodig is in het belang van de onderzoeksaspecten.

Het onderzoek in het kader van dit proefschrift bevat zes hoofdstukken.

De literatuur en de discussie over de betekenis en het nut van de bezwaarschriftenprocedure hebben de auteur mede geinspireerd tot het schrijven van dit proefschrift. Vooral de suggesties over een mogelijke differentiatie van deze voorprocedure hebben hierin mede een rol gespeeld. ${ }^{21}$ Daarom wordt in hoofdstuk

20 PG Aw I, p. 107.

2 Zie in dit verband 0. a.: M.B.W. Bieshen wel, Weg met de bezwarschriftemprocedure, NJB 1996 , p. 930 , J.B.J.M. ten Berge e.a., Erwarimgen met de Awb, Het bestuursprocesrecht, Deventer 1996. p. 22 e.\%. en p. 301 en A.J.G.M. wan Montfort en H.B. Wüter, Kleine gebreken geen bezwaar?: een evaluatie wan de bezwaarschriftenprocedure uit de Awb, in: In wederkerigheid, 
6 van dit boek uitwoerig ingegaan op de evaluatie van de Awb, het kabinetsstandpunt en voorzover er raakvllakken zijn met de bezwaarschriftenprocedure, wordt ook het rapport 'Bestuur in geding' besproken. ${ }^{22}$ Indien daartoe aanlaiding is wordt ook aandacht besteed aan de opvattingen in de literatuur over de inrichting van de bezwaarschriftenprocedure.

In deze studie over de bezwaarschriftenprocedure zijn de zwaartepunten van het onderzoek als volgt gerubriceerd, te weten:

- de heroverweging op het bezwaarschrift;

- het verbod wan vooringenomenheid: tegen vriendjespolitiek of onzorgvuldigheid?;

- het horen: een belangrijke formele bepaling met materiële betekenis voor de beslissing op het bezwaarschrift;

- het adviseren omtrent de op het bezwaarschrift te nemen beslissing;

- naar een "definitief" concept voor het adviseren op grond van de Awb: de advisering als kwaliteitsfactor in de besluitvorming en als object van rechtsbescherming;

- de bezwaarschriftenprocedure ter discussie: evaluatie, standpunten en aanbevelingen.

De volgorde van de bovengenoemde "zwaartepunten" is het resultaat van een weloverwogen keuze. De heroverweging (hoofdstuk 1) als bedoeld in art. 7:11, lid $1 \mathrm{Awb}$ is een wezenlijk aspect van de bezwaarschriftenprocedure en bepaalt het karakter van deze bestuurlijke voorprocedure. Een belangrijk uitgangspunt bij de bezwaarschriftenprocedure is een onbevooroordeelde heroverweging. Ondat een onbevooroordeeld verloop van de bezwaarschriftenprocedure in hoge mate mede van invloed is op de kwaliteit van de beslissing op het bezwaarschrift, wordt in hoofdstuk 2 uitvoerig ingegaan op een aantal aspecten dat van belang is voor een objectieve bestuurlijke besluitvorming in het algemeen en voor de bezwaarprocedure in het bijzonder. De hoorplicht die in hoofdstuk 3 wordt onderzocht is een essentieel onderdeel van de bezwaarschriftenprocedure. Naast het horen wan de belanghebbenden, is de advisering over de op het bezwaarschrift

Deventer 1997. p. 196.

22 Toepassing en effecten Algemene wet bestuursrecht, 's-Graventiage 1996;, Kabinetsstandpunt TK 1997-1998, 25600 VI, nr, 46; M.S. Beerten e.a., 1. Aspecten wan de financiele beschikking verlening, Dewenter 1996; F.B.A. Jorma e.a. 4. Subsidiebeschikkingen, "sravenhage 1997; B.J. Schueler e.a., 3. Besluiten over ruimtelijke ordenirg, milieu en standplatsen, Deverter 1996; J.B.J.M. ten Berge e.a. 2. Het bestursprocesrecht, Deventer 1996 en 'Bestuur in geding", Haarlem 1997. 
te nemen beslissing een belangrijk element in de voorbereidingsfase, voorafgaand aan de beslissing op het bezwaarschrift. Adviseren en beslissen zijn aspecten in de bezwaarschriftenprocedure die nauw met elkaar samenhangen. Daarom is het onderzoek van de adviesprocedure verdeeld in tweetal hoofdstukken (4 en 5). In hoofdstuk 6 (de bezwaarschriftenprocedure ter discussie), wordt ruim aandacht besteed aan de evaluatie van de Awb in relatie tot de bezwaarschriftenprocedure.

Deze studie over de bezwaarschriftenprocedure wordt in hoofdstuk 1 ingeleid met een onderzoek naar de plicht van het bestuursorgaan om op grondslag van een ontvankelijk bezwaar, het bestreden (primaire) besluit te heroverwegen (art. $7: 11$, lid 1 Awb). Deze heroverwegingsplicht benadrukt het bijzondere karakter van de bezwaarschriftenprocedure als voorfase van het beroep op de bestuursrechter. Het karakter van de heroverweging, de omvang van de (nieuwe) bestuurlijke toetsing van het bestreden besluit, en enkele andere uitgangspunten van de heroverweging worden in het onderzoek betrokken.

In hoofdstuk 2 wordt de zuiverheid van de bestuurlijke taakwervulling bij het nemen van besluiten onderzocht. Een belangrijke reden voor deze studie is gelegen in art. 2:4 Awb. Een dergelijke bepaling kwam in de wetten op het terrein van het bestuursrecht niet voor. Art. $2: 4$, lid 1 verbiedt het bestuursorgaan bij zijn taakvervulling (subjectief) vooringenomen te handelen. Het tweede hid van dit artikel draagt het bestuursorgaan op ervoor te waken dat persoonlijke (privé)belangen de besluitvorming beïnvloeden. Voor een uitgebreide behandeling van het vooringenomenheidsverbod is gekozen, omdat dit voorschrift van bijzondere betekenis is voor de kwaliteit en legitimiteit van de bestuurlijke beslissingen. Dit laatste is niet zonder belang voor de beslissing op het bezwaarschrift. Art. 2:4 beoogt partijdligheid en belangenverstrengeling in het openbaar bestuur tegen te gaan. Van het bestuursorgaan wordt geëist dat het zijn taken niet oneigenlijk vervult. Vermeden moet worden dat persoonlijke belangen of voorkeuren zoals vriendjespolitiek, de bestuursworming beïnvloeden. ${ }^{23}$ Naast het bestuursrechtelijk verbod van vooringenomenheid komen in het Nederlands recht well wettelijke bepalingen voor die verwantschap hebben met art. 2:4 Awb. Het organieke organisatierecht (bijvoorbeeld het gemeenterecht) kent van oudsher bepalingen die belangenverstrengeling ellimineren. Daarnaast zijn er wettelijke voorschriften die de zuiverheid van de bestuurlijke taakvervulling direct dan wel indirect positief beogen te beïnvloeden. Maar ook in die gevallen dat geen sprake is van specifieke wettelijke bepalingen (externe advisering), toetst de (bestuurs)rechter 
de besluitvorming steeds meer op aspecten van onbevooroordeeldheid. ${ }^{24}$ Het verbod van vooringenomenheid is daarom in een ruimer kader onderzocht met het oog op de belangen die gediend zijn met een 'zuivere' bezwaarschriftenprocedure.

Een belangrijk fundament dat bij het onderzoek naar integriteit en onpartijdigheid bij het bestuursoptreden is gelegd, wordt 'gevoed' door het 'wederkerigheidsperspectief' in de relatie tussen bestuursorganen en burgers. Dit aspect van wederkerigheid in de rechtsbetrekking tussen het bestuursorgaan en de burger kenschetst heden ten dage de dynamiek van het bestuursrecht. ${ }^{25}$ De inhoud van de rechtsbetrekking tussen deze beide actoren in het bestuursrecht, ziet er wat anders uit dan vroeger omdat de voorbereiding van de besluitvorming méer accenten vertoont van horizontalisering van de verhouding bestuursorgatan en burger.

In art 7:2, lid $1 \mathrm{Awb}$ is aan het bestuursorgaan de verplichting opgelegd om voorafgaand aan de beslissing op het bezwaarschrift, belanghebbenden in de gelegenheid te stellen te worden gehoord. Met deze bepaling is in de Awb voor de bezwaarschriftenprocedure, de formele basis gelegd voor een belangrijk fundamenteel beginsel wan een behoorlijke procedure, te weten het beginsel van hoor en wederhoor. Het beginsel van hoor en wederhoor pretendeert procedurele ge-lijkwaardigheid van de belanghebbenden in de bezwaarschriftenprocedure. In hoofdstuk 3 zal een aantal aspecten van deze procedurele gelijkwaardigheid worden onderzocht.

Art. 7:2, lid $1 \mathrm{Awb}$ wordt in de rechtspraak niet als een bepaling van openbare orde aangemerkt. ${ }^{26}$ Dit is anders bij het beoordelen van de bevoegdheid van het bestuursorgaan en het bepalen van de ontwankelijkheid van het bezwaarschrift. ${ }^{27}$ Men kan echter ook anders denken over het karakter van art. $7: 2$, lid 1 en de overige procedurebepalingen van afd. 7.2.

Naast de procedurele strekking van art. $7: 2$, lid 1, heeft deze bepaling een diepere betekenis. De hoorverplichting heeft een belangrijke functie ten dienste van de bestuurlijke heroverweging op grond van art. 7:11, en heeft daardoor een nauwe relatie met het materielle recht. Het bestreden besluit dat zijn oorsprong vindt in de materiële (bijzondere) wetgeving, staat immers bloot aan een (hernieuwde) toetsing. Deze omstandigheid heeft gevolgen voor de wijze waarop het

27 M. Schreuder-Wlasblom, de Algemene wet besuurstechi, vierde dr, Deventer 1996, p. 105. 
bestuursorgaan de wettelijke hoorplicht gestalte geeft. In het licht van het vorenstaande wordt de betekenis van het horen als procedure-bepaling afgezet tegen de op het bezwaarschrift te nemen beslissing.

De hoofdstukken 4 en 5 beogen inzicht te verschaffen in de bestuurlijke attvisering. Gelet op het belang dat wordt gehecht aan een goede advisering in het kader van de bezwaarschriftenprocedure, is in het onderzoek nagegaan of er aanleiding is tot het doen van aanbevelingen voor cen aanpassing van de wetgeving.

In hoofdstuk 6 wordt ingegaan op de bevindingen in het kader van de hiefvoor genoemde evaluatie van de Awb. Daarin komen de heroverweging, de hoorplicht, de adviesprocessen en de tijdigheid van de beslissing op het bezwaarschrift, nogmaals aanbod. Naast een analyse wan de evaluatie, en de hieromtrent relevante gepubliceerde literatuur, wordt een oordeel gegeven over de evaluatie-rapporten en het kabinetsstandpunt.

Afrondend zal in aansluiting op de samenwatting van dit boek, aan de hand van enige conclusies de balans worden opgemaakt en waar nodig zullen aanbevelingen tot verbetering worden gedaan. 


\section{De heroverweging en het bezwaarschrift}

\subsection{Inleiding}

De opdracht in art. $7: 11$, lid 1 Awb tot heroverweging van de in het bezwaarschrift bestreden beslissing, is een van de meest belangrijke materiële bepalingen van de $A w b$. Dit artikel bepaalt het karakter van de bezwaarschriftenprocedure. Het in art. 7:11 Awb opgenomen voorschrift heeft een inhoudelijke betekenis omdat het bestuursorgaan, dat met een ingediend bezwaarschrift wordt geconfronteerd "alle elementen van het oorspronkelijke besluitwormingsproces nog eens op zijn bestuurlijke en juridische merites moet controleren. Het bestuursorgaan moet hierbij letten op eventuele gebreken in het primaire besluit. Zo nodig zal het bestuursorgaan tot correctie van het bestreden besluit moeten overgaan. Het bestuursorgaan kan niet volstaan met het enkel herstellen van fouten die ten tijde van het aanvankelijk besluit zijn gemaakt; dit laatste zou tekort doen aan het in de Awb opgenomen begrip 'heroverwegen'. Het heroverwegingsbegrip in de zin van art. 7:11, lid $1 \mathrm{~A} w \mathrm{~b}$ is anders van inhoud en strekking dan doorgaans wordt bedoeld. In een woordenboek op het terrein van het openbaar bestuur" wordt als een van de typische kenmerken van heroverweging genoemd het evaluatie-aspect, waarbij de doelmatigheid en de actualiteitswaarde van het bestuursbeleid worden getoetst aan de budgetruimte en de politieke prioriteitsstelling. Heroverweging brengt in beginsel met zich dat het moment van de aanvankelijke besluitvorming wordt verlegd naar het moment van de heroverweging, in samenhang met het tijdstip waarop de beslissing op het bezwaarschrift wordt genomen.

Bestuurlijke heroverweging is een in het oog springend centrale thema dat bij een voorprocedure zoals de bezwaarschriftenprocedure aan de orde is. De heroverweging van het bestreden besluit vormt als het ware het 'kloppend hart' van de bezwaarschriftenprocedure wan de Awb. Daarmede is deze bestuurlijke activiteit de bron voor een eventuele rechterlijke toets, wanneer een bezwaarde burger zich niet met de op het bezwaarschrift gegeven beslissing kan verenigen en een beroep doet op de (administratieve) rechter. De uitspraakbevoegdheid van de rechter als bedoeld in art. 8:70 Awb en volgende wordt er als het ware door gevoed.

Art. 6, lid 1 EVRM voorziet niet in een recht op bestuurlijke heroverweging, maar eist alleen onafhankelijke rechtspraak. ${ }^{2}$ Toch kan dit EVRM-artikellid wel degelijk een rol spelen in die gevallen dat gesproken kan worden van een opmerkelijk lange doorlooptijd van bestuursrechtelijke procedures. De voorbereidings-

1 J.B.J.M. ten Berge e.a., Verklarend woordenboek Openbaar Bestuur, Alphen aan den Rijin 1992. D. 226 .

2 EHRM 23 juni 1981, NJ 1982,602. 
tijd van besluiten alsmede de bezwaarschriftenprocedure kan meetellen voor het bepalen van de totale lengte van de bestuursrechtelijke rechtsgang. ${ }^{3}$ In de par. 5.3.11 en 5.4.11 wordt op deze problematiek nog nader ingegaan.

Met de plaatsing van art. 7:11 in hoofdstuk 7 van de Awb wordt door de Nederlandse wetgever enerzijds een belangrijk recht op heroverweging gegeven aan de justitiabele. Tegelijkertijd heeft het bestuursorgaan de verplichting zijn besluitvorming in het kader van de bezwaarschriftenprocedure te doen steunen op de pijlers van 'heroverweging".

Hierna zal blijken welke invloed en betekenis de herowerwegingsplicht heef voor de beslissing op het bezwaarschrift en op welke wijze hieraan invulling behoort te worden gegeven.

De omstandigheid, dat art. 7:11 Awb het bestuursorgaan tot heroverweging noopt van het primaire besluit, betekent niet, dat zich nu een nieuw fenomeen op het terrein van de voorprocedures aandient. Art. 7, lid 2 van de vervallen Wet arob gaf invulling aan de heroverwegingsplicht in samenhang met artikel 14 , lid 4 van die wet.

Ook op het terrein van het sociaal-economisch recht (Wet arbo) en het belastingrecht bestond er vóór de Awb een verplichte bezwaarprocedure, gericht op het heroverwegen van een bestreden primaire beslissing. De gemeentelijke bestuursorganen kenden al vóor de inwerkingtreding van de Wet arob, verordeningen, waarin het recht tot het maken van bezwaar en het instellen van administratief beroep was vastgelegd.

Over het begrip heroverweging werd in art. 14 Wet arob met geen woord gerept. De opdracht aan het bestuursorgaan tot heroverweging was gebaseerd op de jurisprudentie van de Wet arob.

De verplichting tot heroverweging is nu expliciet in de Awb opgenomen op grond van minder gunstige praktijkervaringen. Heroverweging draagt een bestuurlijk karakter, maar bestuursorganen waren ten tijde van het arob-tijdperk op grond van de vrees om met rechterlijke vernietigingen te worden geconfronteerd veelal geneigd tot calculatie van risico's bij de besluitvorming. Dit leidde tot een praktijk waarbij het primaire besluit in de bezwaarschriftenprocedure onder de \.B.J.M.ten Berge e.a., Ervaringen met de Awb, Het bestuursprocesrecht, Deventer 1996, p.
288 en 289 .

4 Wet van 1 mei 1975 , Sth, 284 .

s Blauwe reeks nr. 48, $\mathrm{WNG}$, 's-Gravenhage 1972. 
Wet arob vaak getoetst werd aan de vraag of het bestreden besluit de toetsing van de rechter kon doorstaan. ${ }^{6}$

Heroverweging als bestuurlijke bezinning over oorspronkelijk genomen besluiten, kreeg vooral inhoud en betekenis onder de werking van de Wet arob. Maar ook voór het arob-tijdperk waren er bijvoorbeeld gemeentelijke verordeningen, waarin de heroverweging een rol speelde bij het nemen van beslissingen omtrent gemaakt bezwaar tegen beschikkingen. In dit verband kan worden gewezen op de model-verordening van de VNG (Blauwe reeks, nr. 48, "s-Gravenhage 1972, p. 12 e.v.).

Als gevolg van de invoering van de verplichte bezwaarschriftenprocedure in art. 7 , lid 2 van deze wet, welke procedure aanvankelijk beperkt bleef tot de lagere bestuursorganen, is de jurisprudentie rond het begrip heroverweging bij de behandeling van bezwaarschriften volledig tot ontwikkeling gekomen. Vooral de rol van de ARRS was van grote betekenis, daarbij gevoed door de besluitvorming van de bestuursorganen. Datzelfde kan gezegd worden van de wetenschappelijke literatuur. Naast de weekoverzichten van de RvS kunnen worden genoemd de wetenschappelijke onderzoeken naar de werking en het beeld van de bezwaarschriftenprocedure.

Bij een behandeling van de bestuurlijke heroverweging op grond van de $A w b$, kan een bespreking van de arob-jurisprudentie niet worden gemist. De in het kader van de Wet arob ontwikkelde jurisprudentie heeft immers een belangrijke basis gelegd voor het verder ontwikkelen van een aantal uitgangspunten voor de bestuurlijke heroverweging.

Juist de Wet arob heeft de grondslag gelegd voor belangrijke fundamentele beginselen van behoorlijkheid van handelen bij de besluitvorming van de op de bezwaarschriften te nemen beslissingen. De Awb geeft hierin gedeeltelijk nadere invulling door codificatie van regels voor het bestuurlijk handelen; zowel in procedureel als in materieel opzicht. Niet in de laatste plaats spelen hierbij de beginselen van behoorlijk bestuur een bellangrijke rol.

6 Kamersnkken II, 1988/1989, 21221 nr. 3 ,p. 153.

7 C.M. Breeuwsma, M. Oosting e.a., Beeld van de arob-bezwarschriftenprocedure, Deventer 1982 en C.M. Breeuwsma, M. Oosting e.a. Arob-praktijken, Deventer 1984. 


\subsection{Het karakter van de heroverweging}

\subsubsection{Heroverweging als bestuurlijk fenomeen}

Art. 7:11 Awb, dat is opgenomen in afdeling 7.2 (bijzondere bepalingen over bezwaar), is gelet op de overige bepalingen van hoofdstuk 7 die een overwegend procedureel karakter hebben, het enige zuiver inhoudelijke voorschrift in de bezwaarschriftenprocedureregeling van de $A$ wb. ${ }^{8}$

Art. 7:11, lid 1 Awb luidt als volgt:

'Indien het bezwaar ontvankelijk is, windt op grondslag daarvan een heroverweging van het bestreden beshuit plaats."

Waartoe heroverweging moet leiden vloeit voort uit het tweede lid van art. 7:11 Awb. Dit tweede lid bepaalt, dat voor zover de heroverweging dartoe aanleiding geeft, het betrokken bestuursorgaan het bestreden besluit herroept en voor zover nodig in de plaats claarvan een nieuw besluit neemt. De opdracht van de Awbwetgever richt zich tot het bestuursorgaan dat het oorspronkelijke besluit heef genomen (art. 1:5). Voor de administratieve rechter is hier alleen een toetsingstaak (de beoordeling van de rechtmatigheid van besluiten) en de juiste toepassing van deze bepaling door het bestuursorgaan weggelegd. Een uitzondering vormt de mogelijkheid van de rechter om zelf in de zaak te voorzien. Art. 8:72, lid $4 \mathrm{Awb}$ biedt deze alternatieve uitspraakbevoegdheid van de rechter. Dat de opdracht tot heroverweging aan het bestuursorgaan is voorbehouden, brengt art. 1:5 van de Awb, als algemene begripsbepaling tot uitdrukking.

Met de verwijzing naar de art. 7:11 en 1:5 van de Awb is evenwel nog geen kader geschapen dat kenmerkend is voor de heroverweging van besluiten als typisch bestuurlijk fenomeen. Daarvoor is een verdere raadpleging van hoofdstuk 7 van de Awb noodzakelijk. Voldoende aanknopingspunten woor de opvatting, dat heroverweging een bestuurlijke activiteit is, worden geboden in afdeling 7.1. Deze afdeling is van algemeen karakter en geeft fundament aan de verplichte bezwaarschriftenprocedure. Lezing van art. $7: 1$ in de Afdeling "Bezwaar voorafgaand aan beroep bij de administratieve rechter", leert, dat alvorens beroep tegen een besluit bij de administratieve rechter kan worden ingesteld, tegen dat besluit bezwaar moet worden gemaakt. Art. 7:11 in samenhang bezien met art. $7: 1$ geeft derhalve met zoveel woorden aan, dat in de bezwaarschriftenprocedure als voorprocedure heroverweging door het bestuur dient plaats te vinden alvorens een

8 C.W.I. Schoor, De bezwaarschriftenprocedure in de Awb, bezien in thet licht van die procedure op grond van de Wet arob (slot), Gst. 6946. 
beroep kan worden gedaan op de (administratieve) rechter. Tegelijkertijd is hiermee ook een onderscheid gemaaki tussen de bestuurlijke heroverwegingsplicht en de toetsingstaak van de bestuursrechter ten aanzien van door het bestuursorgaan genomen besluiten (art. 8:77, lid 2).

Kenmerkend voor het openbaar bestuur is, dat bestuursorganen in het kader van de hen op grond van bij of krachtens wettelijke voorschriften toebedeelde taken en bevoegdheden besluiten nemen, waarbij voorafgaand aan de besluitvorming een (her)overweging plaatsvindt. Overweging en heroverweging bij het nemen van besluiten zijn doorgaans gekoppeld aan een bevoegdheidsnorm, gebaseerd op wettelijke voorschriften.

Door het uitoefenen van bestuursbevoegdheden, komen de regels van het bestuursrecht in beweging.

Diezelfde regels van bestuursrecht hebben betrekking op de bevoegdheden van het bestuursorgaan en de rechten en plichten van de burger. Bevoegdheden door het bestuursorgaan worden op eigen naam en verantwoordelijkheid uitgeoefend. Daarom moet de term bestuursorgaan in het bestuursrecht duidelijk worden onderscheiden van de term rechtspersoon. Deze laatste term is van privaatrechtelijke oorsprong. Het bestuursorgaan en de rechtspersoon waar datzelfde bestuursorgaan deel van uitmaakt kunnen beiden wel tot actie worden gedwongen.

Op basis van het bestuursrecht kunnen dan zowel bestuursrechtelijke als privaatrechtelijke aspecten aan de orde zijn. Maar bestuursrechtelijke dan wel privaatrechtelijke bevoegdheden zijn voorbehouden aan het namens de rechtspersoon optredende bestuursorgaan. Besluit de rechter om aan het bestuur een dwangsom op te leggen of om het bestuur tot vergoeding van schade te veroordelen, dan zal hij aan de rechtspersoon (als drager van vermogen) de vereiste verplichtingen moeten opleggen. Daarom wordt in art. 8:72, zevende lid, Awb geregeld dat de rechtbank kan bepalen dat

indien of zolang het bestuursorgaan niet voldoet aan een uitspraak, de door haar aangewezen rechtspersoon aan een door haar aangewezen partij een in de uitspraak wast te stellen dwangsom verbeurt".

En in art. 8:73, eerste lid Awb is bepaald dat de rechtbank "de door haar aangewezen rechtspersoon kan veroordelen tot vergoeding van schade." 
Heroverwegen leidt ertoe, dat het oorspronkelijk genomen besluit opnieuw moet worden gewogen. De heroverweging houdt een hernieuwde verantwoording in van de beweegreden van het oorspronkelijk besluit. Bij herowerweging als bestuurlijke achiviteit kunnen bij beleidsvrijheid politieke prioriteitsstellingen in het geding zijn; ook de wijze van uitvoering van taken en bevoegdheden kan aan de orde zijn. Voorts kumnen bij heroverwegingsbesluiten zowel de doeleinden van beleid alsmede de wijze waarop met de financiële middelen wordt omgesprongen inzet van herbezinning zijn. Doeltreffendheid en doelmatigheid vormen bij die herbezinning omtrent genomen besluiten het heroverwegingskader. Bij dat herover-wegingsproces kan zich een mix voordoen van algemene en bijzondere belangen, welke tegen elkaar behoren te worden afgewogen.

Door deze mix van veelsoortige belangen hebben bestuursorganen in het kader van het heroverwegingsproces te maken met een scala van vele wettelijke voorschriften. Deze voorschriften kunnen al dan niet ruimte bieden voor een bestuurlijke invulling. De bestuurlijke invulling komt daardoor tevens in aanraking met de vraag naar de omvang en de wijze waarop bestuursorganen de relevante belangen behoren af te wegen (verbod van willekeur). Daarnaast speelt bij het nemen van besluiten de vraag een rol, welke belangen het bestuursorgaan mag afwegen. Deze laatste problematiek houdt verband met het specialiteitsbeginsel. De inhoud en de betekenis van dit begrip, wordt in dit boek buiten beschouwing gelaten.

Het heroverwegingsproces als onderdeel van de bestuurlijke besluitvorming is geen geissoleerde bestuurlijke activiteit. Integraliteit van het gehele besluitvormingsproces speelt hierbij een rol.

Niet uit te sluiten is, dat er bij de overweging van te nemen besluiten uiteenlopende opvattingen kunnen bestaan over te maken keuzen en afwegingen. Over de inhoud van problemen en de daarbij te bedenken oplossingen kan verschillend worden gedacht. Het besluit dat aan heroverweging ten grondslag ligt, zal inzicht behoren te geven in de gedane politiek-bestuurlijke keuzen en daarbij een verantwoording moeten bevatten omirent de na te streven doelstellingen, de daarbij te gebruiken bestuurlijke instrumenten en te ondernemen activiteiten. In het uiteindelijk zichtbaar wordende politieke besluitvormingsproces vindt het maken van deze keuzen plaats door diverse belangen en ideologieën. In de context van het openbaar bestuur geschiedt het doen van keuzen op basis van democratische besluitvorming. Kenmerkend voor deze democratische besluitvorming is dat een groot aantal personen hierbij betrokken is. ${ }^{\text {i0 }}$ 
Hierwoor is globaal aangegeven dat bij heroverweging het creëren van een besluitvorningsproces aan de orde is, waarbij een diversiteit van belangen een rol kan spelen. Inherent aan de heroverweging c.q. het besluitvormingsproces is het tegen elkaar afwegen van algemene en bijzondere belangen; uiteindelijk uitmondend in een besluitvorming. Het besluitvormingsproces, waarbij belangenafweging plaatsvindt wordit daarbij vaak vereenzelvigd met de term "het algemeen belang'.

Een bepaald besluit is als resultante van dit afwegingsproces in het algemeen belang'."

\subsubsection{De bestuurlijke heroverweging op grond van de Awb als juridisch} kader: oude wijn in nieuwe zakken?

De heroverweging in het kader van de bezwaarschriftenprocedure, zal niet in die omvang zoals hiervoor is geschetst, worden onderzocht. De aandacht zal zich richten op de juridische context van het heroverwegingsbegrip als rechtsnorm voor de bezwaarschriftenprocedure. Toch doet deze juridische context niets af aan het enigszins anders belichte aspect in de bekende brochure 'Besturen met minder middelen'. ${ }^{2}$ Conform de uitgangspunten in deze brochure wordt bij heroverweging het aanvankelijk genomen besluit opnieuw beoordeeld. De Awbwetgever heeft het heroverwegingsbegrip wél iets anders verwoord. In de juridische context van art. $7: 11$, lid 1 vindt heroverweging plaats van het besluit.

Heroverweging heeft juridische inhoud gekregen door de ARRS als belangrijke administratieve rechter ten tijde van de Wet arob op het terrein van de rechtsbescherming tegen de overheid. De wetgever, alsmede de ARRS hebben inhoud en betekenis gegeven aan de bestuurlijke heroverweging.

Het is in dit verband vreemd, dat de Awb de heroverwegingsplicht heeft gecodificeerd ten behoeve van de op een bezwaarschrift te nemen beslissing. Zeker nu in de voorgaande paragraaf is gebleken, dat heroverwegen bij de besluitvorming zo eigen is aan de aard van het openbaar bestuur. Het heeft er zelfs de schijn van dat de Awb-wetgever hier bevoogdend, en zelfs betuttelend in zijn rol als regelgever van het bestuursrecht opereert. De vraag is dan ook gewettigd welke bedoeling achter deze regulering van de herowerwegingsplicht als bedoeld in art. 7:11, schuilt. De MvT van de Awb licht een tipje van de sluier op. De Awb-wetgever stelt dat het eerste lid van art. 7:11, vastlegt op welke wijze het bestuursorgaan

11 E. Dommering, Algernene bellangen in het burgerlijk recht, Deventer 1982, p. 3.

12 A.W. 
het ingediende bezwaar moet beoordelen. Iets verderop, worden de bedoelingen van de wetgever beter uitgewerkt. Allereerst blijkt dat de te maken toets in het kader van de heroverweging niet beperkt moet blijven tot vragen van rechtmatigheid. Binnen de grenzen van de Awb dient naar de mening van de regering de toetsing zich mede te richten tot 'kwesties van beleid'." Tot zover lijkt er niets aan de hand en zou men gevoeglijk kunnen aannemen, dat art. 7:11 Awb het kader wil aangeven voor de beslissingsbevoegdheid van het bestuursorgaan in de bezwar-fase.

Tevens zou uit de redactiestructuur van art. 7:11 kunnen worden afgeleid dat beoogd is het karakter van de bezwalarschriftenprocedure als voorprocedure te typeren. ${ }^{14}$

Toch lijkt er meer aan de hand. Een zorgvuldige bestudering van de toelichting leert, dat de verplichting tot heroverweging in de Awb is vastgelegd omdat bij herhaling is gebleken, dat bestuursorganen de neiging hebben zich te beperken tot de vraag of hun besluit de toetsing door de rechter kan doorstaan. "s

De vraag is of een dergelijke houding door bestuursorganen wel zo ongewoon is. Het lijkt logisch dat door de intensief toegenomen rechtsbescherming bestuursorganen ook kijken naar externe effecten bij genomen besluiten. Deze omstandigheid wordt versterkt door de bijzondere positie van het bestuursorgaan, dat besluiten moet nemen die zowel behoren te voldoen aan de eisen van rechtmatigheid als doelmatigheid. Een probleem voor het bestuursorgaan is dat de rechter de rechtmatigheid van de besluiten aan het recht toetst op grond van de algemene beginselen van behoorlijk bestuur. Zeker nu w.a.--verzekeraars risico's als gevolg van schadeclaims bij uitgesproken administratiefrechtelijke vernietigingen steeds meer weigeren te dekken als niet aan bepaalde stringente voorwaarden is voldaan. ${ }^{16}$

Het is niet uitzonderlijk dat besturursorganen soms nauwlettend kijken naar de invloed van de jurisprudentic op de besluitvorming. Tot wat voor consequenties onoplettendheid vanwege bestuursorganen kan leiden heeft de zaak Sint Oedenrode-Driessen aangetoond. Hier werd het bestuursorgaan onbekendheid met een rechterlijk standpunt verweten, hetgeen het bestuursorgaan c.q. de publiekrechtelijke rechtspersoon in casu de gemeente Sint Oedenrode "duur" kwam te staan."

13 PG Awb I, P. 347.

14 G.P. Kleijn, Handboek Algemene wet bestuursrecht, losbl., Alphen aan den Rijn, III ArtikelsgeWijs commentaar Artikel $7: 11$, p. 2.

15 Kamerstukken II, $1988 / 1989,21221$, nr. 3, p. 153.

16. J. de Vries, Verzekeren wan overheidsaansprakelijkheid, Euroforum-smdiedag 16 mei 1995. Zie ook B.C. Knierum, De verzekerde gemeente verzekerd!? Bezwaar en administratief beroep, NTB 1995, p. 309 e.v. en C.I.N. Versteden, Tijd voor juridische kwaliteitszorg NTB 1997 , p. 68
en 69.

If HR 24 februar: 1984, AB, 399, m.nt. Van Eijjden. 
Ook kan een bestuursorgaan een 'hoge' rekening gepresenteerd krijgen in die gevallen dat bij een vergunning-houder een gerechtvaardigd vertrouwen is opgewekt dat een gemaakt bezwaar of een eventueel nog te maken bezwaar (hetzelfde geldt voor het beroep) niet tot een vernietiging zal leiden en toch vernietiging volgt. ${ }^{12}$ Het is niet onverstandig dat bestuursorganen bij de heroverweging en de daaromtrent af te ronden besluitworming, het calculerend kijken naar rechterlijke uitkomsten wat temperen. Bestuursorganen zouden hun eigen oordeelsvorming met meer beginselvastheid moeten presenteren door een weloverwogen zorgvuldigheid in de besluitvorming aan de dag te leggen.

Deze kritische noot is niet zonder betekenis, wanneer hierbij onderzoeksresultaten van de bruikbaarheid van rechterlijke beslissingen op het terrein van het bestuursrecht, in aanmerking worden genomen. Onderzoekscijfers tonen aan dat de rechterlijke consistentie inzake het toetsen van door bestuursorganen genomen besluiten, maar op 40 procent worden gesteld. Een onderzoek brengt een aantal jurisprudentie-analyses in beeld op het terrein van het CBB, de sociale verzekeringsrechter, alsmede de ARRS. ${ }^{\prime 9}$ Ten aanzien van de ARRS is onderzoek verricht naar de consistentie van uitspraken over de toepassing van art. 19 WRO. Uit dit onderzoek blijkt, dat de rechter bij de toetsing van vrijstellingsbesluiten op het terrein van de ruimtelijke ordening maar globaal genomen in $25 \%$ van de hem voorgelegde zaken tot een op basis van bestaande jurisprudentie consistente uitspraak komt. Bij dit opmerkelijke percentage moet wel worden aangetekend, dat dit type van besluiten op het terrein van de ruimtelijke ordening nogal gekenschetst wordt door een ingewikkeld complex van belangenafweging. Zowel publiekrechtelijke als privaatrechtelijke belangen moeten hierbij worden afgewogen. Tevens moet in aanmerking worden genomen dat bij veel zaken op het terrein van de ruimtelijke ordening de inhoud van de belangenafweging nogal verschillend is. De inhoud van procedures op het gebied van de ruimtelijke ordening is veelal riet identiek. Ofschoon het bovengenoemd percentage niet verder in de beschouwingen wordt betrokken, moet worden bedacht dat de kennelijke inconsistentie niet primair op het bord van de rechter moet worden gelegd. De opdracht tot het afwegen van alle relevante belangen zoals die in art. 3:4, lid 1 Awb tot uitdrukking komt is niet de geringste (voorbereidings)taak van de bestuursorganen. De jurisprudentie laat overigens zien dat er in de bestuurspraktijk hier en daar nogal wat schort aan de inhoud van genomen besluiten; formele en materiële zorgvuldigheid vormen principieel nu eenmaal de fundamenten voor een goede besluitvorming.

18 HR 29 april 1994, RvdW 1994, 107, AB 1994, 530 m.nt. FHvdG, BR 1994, p. 773 e.w. m.nt. NSI Koeman inza. GE BV/'s-Gravenhage (Schuttersduin).

19 A.R. Neerhof, Het geschil voorbij, Deventer 1995. 
Het bovengenoemde onderzoek ${ }^{30}$ geeft aanleiding tot nadere invulling van de tijdens de parlementaire discussie benadrukie eigen verantwoordelijkheid van bestuursorganen voor de door hen genomen primaire besluiten dan wel de ná heroverweging genomen besluiten. Toegegeven moet worden, dat het te zeer leunen door bestuursorganen aan jurisprudentie ook tot onverwachte risico's kan leiden, al is het letten door bestuursorganen op de uitkornsten van rechterlijke uitspraken niet afkeurenswardig. Zeker niet wanneer de rechtmatigheids- en doelmatigheidsuitgangspunten van de heroverweging maar in acht worden genomen. Jurisprudentie is immers van oudsher een belangrijke rechtsbron, en dat behoort ook zo te blijven. ${ }^{21}$ Wordt door rechterlijke inconsistentie de andere weg op gegaan, in die zin dat bestuursorganen weinig houvast hebben bij de (her)overweging van hun besluiten, dan zal hierdoor rechtsonzekerheid ontstaan zowel voor de bestuursorganen als de belanghebbende justitiabelen. Deze situatie was reeds enkele malen aan de orde in het kader van de toepassing van art. 8:5 Awb inzake de ontvankelijkheid van het beroep tegen uitgesproken weigeringen om bestemmingsplannen te herzien. Gelukkig heeft de ABRS als tweede instantie aan de voor bestuursorganen onbevredigende situatie een einde gemaakt en het oordeel uitgesproken dat geen beroep op de bestuursrechter mogelijk is.

Gelet op de bovengenoemde onderzoeksresultaten van Neerhof ${ }^{22}$, lijken deze niet het sterkste argument te zijn voor het regeringsstandpunt, dat bestuursorganen de neiging hebben zich te beperken tot de vraag of hun besluit de toetsing door de rechter kan doorstaan. Deze visie van de regering is enigszins kort door de bocht geformuleerd; hieruit blijkt niet in welke zin "bij herhaling is gebleken dat bestuursorganen de neiging hebben na te gaan of hun besluiten in de ogen van de rechter genade kunnen vinden'. Een reden zou kunnen zijn dat in verweerschriften dan wel in pleitnotities ten behoeve van de mondelinge behandeling van de zaak, gewag wordt gemaakt van rechterlijke standpunten of uitspraken. Op zichzelf genomen is niets tegen deze manier van het voeren wan verweer. Soms geven bestuursorganen toe uitsluitend aan de rechtmatigheid getoetst te hebben. ${ }^{3}$ Bestuursorganen willen het immers niet laten aankomen op een vernietiging van door hen genomen besluiten. De belangen voor zowel het bestuursorgaan als de bij de besluitvorming betrokken belanghebbende burgers zijn immers doorgaans
groot.

20 A. W. Neerhof, a,w.

21 Zie in dit verband het verslag van het symposilum 'Openbaan bestur im de knel door recht-
spraak?" NTB 1997, p. 1 t/m 32 .

22 A. W.

23 Vz. ARRS 1 maart 1979. AB 1979, 350 m, nt. C.L.R., tB/S II, 37 (winkelpand Borculo). 
De wens van de regering orn de heroverwegingsplicht in de Awb een wettelijke grondslag te geven in art. $7: 11$, eerste lid kan veeleer worden gebaseerd op onderzoeksresultaten ten tijde van de arob-periode en de jurisprudentie van de ARRS. Op grond van deze onderzoeksresultaten kan worden vastgesteld dat bestuursorganen soms weinig oog hadden voor het karakter van de heroverweging als kader voor de inhoud van beslissingen op bezwaarschriften. ${ }^{2 *}$ Het rapport Arob-praktijken bevatte een eindrapportage van een in opdracht van de ministers van Binnenlandse Zaken en wan Justitie gedane onderzoek naar het functioneren van de bezwaarschriftenprocedure ingevolge de Wet arob bij gemeenten en provincies. Het rapport Arob-praktijken wormde de tweede fase van een eerder uitgevoerd enquête-onderzoek onder alle provincies en gemeenten en verscheen in $1982 .{ }^{25}$

Op grond van het bovengenoemd rapport kon en kan het volgende onbevredigende "beeld" van de heroverweging worden vastgesteld.

De heroverweging tendeert volgens de betrokken onderzoekers naar een rechtmatigheidstoetsing van het primaire besluit. Het onderzoek toonde aan dat de inhoud van het beleid dat aan het primaire besluit ten grondslag lag, doorgaans door de bestuursorganen slechts marginal werd getoetst. Een rechtstreekse heroverweging van datzelfde beleid vond doorgaans niet plaats. Vervolgens stellen Breeuwsma c.s. 'Meestal gaat men niet verder dan een loetsing van de vraag of de beschikking in het concrete geval past in het gevoerde beleid, en of eventueel tot een bijzonder geval (al dan niet op grond van 'redelijkheid' of 'billijkheid") moet worden geconcludeerd.' Samenvattend stell het rapport ${ }^{26}$ dat in het kader van de heroverweging het alsnog toetsen door het bestuursorgaan van het primaire besluit meer gericht is op een controle naar de juistheid van feiten, alsmede het toetsen of het oorspronkelijk genomen besluit in overeenstemming is met de regelgeving watap het bestreden besluit steunt. De beginselen van behoorlijk besiuur en een toetsing aan het recht, zouden geen prominente rol spelen bij de heroverweging. De onderzoekers stellen dat bestuursorganen in feite een heroverweging van het bestreden besluit verrichten aan de hand van rechtmatigheidsmaatstaven. Duidelijk is bij het onderzoek komen vast te staan dat het karakter van de volledige heroverweging in het kader van de arob-bezwaarschriftenprocedure, onvoldoende in de beshuitvorming tot uitdrukking kwam.

25 Beeld van de arob-bezwaarschriftenprocedure, a.w.

Arob-praktijken, a.w. 
Opgemerkt is dat naast de wetenschappelijke onderzoeken, ook de ARRS een belangrijke bijdrage heeft geleverd aan de inhoudelijke betekenis en het karakter van de heroverweging. De toetsing door de arob-rechter of aan de eisen van behoorlijke heroverweging was voldaan, geschiedde op basis van het vierde lid van art. 14 van bedoelde wet. De eerste zinsnede van dat vierde lid bepaalde voor zover hierbij van belang:

'Het administratief orgaan beslist op het bezwaarschrift.'

De inhoud van deze bepaling bevatte geen aanwijzing voor een heroverwegingsplicht van het primaire besluit bij de beslissing op het bezwaarschrift. Toch hebben zowel de parlementaire behandeling van de Wet arob als de literatuur de 'juridische sluier' van deze bepaling weggenomen.

Zuiver juridisch geredeneerd werd de betekenis van de passage 'dat het administratief orgaan op het bezwaarschrift beslist' als volgt benaderd. Het betreffende artikellid bepaalt dat op een bezwaarschrift moet worden "beslist", hetgeen wil zeggen dat het bestuursorgaan in actie moet komen. Immers, het feit dat een beslissing op een bezwaarschrift moet worden gegeven, impliceert dat de oorspronkelijke beschikking door de instantie zelf nog aantastbaar is; anders zou van een niet intrekbare beschikking moeten worden gesproken en heroverweging niet aan de orde zijin. ${ }^{27}$

Ook in de jurisprudentie van de arob-rechter zijn voldoende aanknopingspunten te vinden voor de op art. 14, lid 4 van de Wet arob gebaseerde heroverwegingsplicht en het karakter van die heroverweging.

Indien de beslissing op het bezwaarschrift geen voldoende aanwijzingen bevatte van een volledige heroverweging doot het bestuursorgaan dan volgde vernietiging wegens strijd met art. 14 van de Wet arob.

Enkele hierna volgende citaten uit passages van uitspraken van de arob-rechter bevestigen de zienswijze omtrent de inhoud en strekking van art. 14:

'Het besiuit wordt derhalve vernietigd wegens strijd met artikel 14 Wet arob, volgens welke bepaling het administratief orgaan dat over een tegen zijn besluit ingediend bezwaarschrift dient te beslissen, zijn eerdere beslissing aan een volledige herowerweging dient te onderwerpen. ${ }^{*}$

-Deze zienswijze miskent naar het oordeel van de afdeling het karakter van de besllissing op een bezwatrschrif, als bedoeld in artikel 14, derde lid (thans: vierde lid), van

J.G. Steenbeek, Wet administratieve rechtspraak overheidsbeschikkingen, 's-Gravenhage 1976 , en Hand. 29 april1975, n.a. v. een wrag van het Eerste Kamerlid Polak, p. 189 noot 5.

ARRS 11 nowember $1985, t B / S$ IV 127, p. 557 . 
de Wet arob. Het bezwaarschrift dient er immers toe te leiden, dat burgemeester en wethouders met volledige heroverweging (...) oordelen en beslissen. ${ }^{30}$

Wanneer de betekenis van jurisprudentie en de uitkomsten van wetenschappelijk onderzoek worden afgezet tegen de bewoordingen in de MvT van de Awb ${ }^{\text {Bi }}$ dan is er reden om aan te nemen, dat de $A$ wb heeft beoogd het belang van her bestururlijk karakter van de heroverweging wettelijke regeling te geven in art. 7:11. Daar-mede heeft heroverweging als toetsingskader in art. 7:11 een gecodificeerde onderscheidende betekenis gekregen ten opzichte van de rechterlijke toetsingstaak als bedoeld in art. 8:77 Awb (toetsing aan het geschreven en ongeschreven recht en de rechtsbeginselen).

\subsection{Uitgangspunten en normen}

\subsubsection{Algemene karakterisering}

Kenmerkend voor de heroverwegingsplicht in art. 7:11 $\mathrm{Awb}$ is, dat het bestuursorgaan bij een ontvankelijk bezwaar 'het bestreden besluit' in casu het oorspronkelijk besluit opnieuw moet toetsen.

Dit alsnog geheel in ogenschouw nemen van het bestreden besluit dient volledig te zijn. Met dit volledig in ogenschouw nemen van het primaire besluit wordt bedoeld, dat alle aspecten die bij het in het geding zijnde besluit een rol hebben gespeeld opnieuw dienen te worden bezien." Volgens $\mathrm{H}$. Bolt (Nieuw bestuursrecht) kan dit betekenen, dat een bestuursorgaan dat tot heroverweging wordt geroepen, afhankelijk van de ruimte die de specifieke regeling laat, verplicht is zich opnieuw een oordeel te vormen over de feitelijke aspecten van het bestreden besluit, alsmede de daaraan ten grondslag liggende rechts- en beleidsaspecten. Het is evident dat bij regelingen, waarin geen beleidsruimte aanwezig is, een volledige heroverweging van het bestreden besluit een geheel andere invulling moet krijgen en het heroverwegen in een beperktere context moet worden geplaatst.

Een voorbeeld hiervan is de te maken heroverweging omtrent een bezwaar tegen een verleende bouwvergunning op grond van de Woningwet. Ter illustratie volgt hierna een kleine casus, waarbij de heroverweging aan de orde is van een ont-

3) H. Bolt, in: Nieuw bestuursrecht, Nijmegen 1994, p. 240. 
vankelijk bezwaarschrift van een belanghebbende tegen een verleende bouwvergunning voor een berging op het perceel van diens buuman.

$B$ en webben op de gevraagde bouwvergunning een positieve beslissing genomen en vergunning verleend voor de bouw van een berging. Gelet op het imperatieve stelsel van art. 44 van de Woningwet besloten $b$ en $w$ de gevraagde bouwvergunning te verlenen. Na ambtelijk onderzoek en na toetsing door de welstandscomriissie was gebleken, dat de voorgenomen bouw van de berging niet in strijd was met de voorschriften van het Bouwbesluit (Algemene maatregel van bestuur op grond van de Woningwet), de bouwverordening, het bestemmingsplan en de welstandseisen (eenvoudigheidshalve zijn enkele andere weigeringsgronden buiten beschouwing geldaten).

Bij de heroverweging komen $b$ en w niet toe aan een toetsing van het beleid. Het onderzoek voorafgaand aan de heroverweging is beperkt tot het rechtens toetsen van de feiten in samenhang met de overeenkomstige bepalingen van de Woningwet.

Blijkt bij de heroverweging dat de geplande bouw van de berging komt te liggen binnen een perceelsgedeelte waarop de bouw overeenkomstig het vigerend bestemmingsplan is toegelaten en is er geen twijfel omtrent de zorgvuldigheid van een uitgebracht positief welstandsadvies, dan zijn bij de heroverweging de feiten volledig an de orde geweest. Indien voor het overige is voldaan aan de technische voorschriften wan het Bouwbesluit, de bepalingen van de bouwverordening, dan is ook aan de heroverwegingseis van het toetsen aan het recht voldaan. Bij de beslissing op het bezwaarschrift op basis van de toetsing van deze feitelijke en rechtsaspecten, kunnen b en wolstaan met te constateren, dat zij na de toetsing van de feiten en het recht, niet anders konden besluiten, dan de bouwvergunning te verlenen. Hierdoor is dan gehandeld in overeenstemming met de inhoud en strekking van art. 44 van de Woningwet. Van enige mate van beleidsvrijheid kan in dit geval geen sprake zijn. Uit het bovengenoemd voorbeeld blijkt dat de bijzondere wetgever de toetsing van feiten, recht en beleid kan beperken en dat dit gevolgen heeft voor de omvang van de heroverweging.

De hierworen gegeven casus geeft een beperkte en globale indruk van de omvang van de heroverweging.

Uitgangspunt van de Awb is dat de (heroverwegings)toets niet beperkt moet blijven tot vragen van rechtmatigheid maar binnen de grenzen van de wet zich ook dient uit te strekken tot kwesties van beleid. ${ }^{32}$ De Awb-wetgever zegt dat er 
wettelijke grenzen zijn, maar geeft niet aan welke grenzen hierbij in acht dienen te worden genomen: de Awb-grens of de Woningwet-grens die als bijzondere wet als voorbeeld te berde is gebracht. De gegeven (voorbeeld)casus toont aan dat primair de bijzondere wet de grens van de heroverweging afbakent.

Een belangrijk uitgangspunt van de herowerwegingsplicht is, dat volledige heroverweging moet geschieden los van de gegrondheid wan het bezwaarschrift. ${ }^{3 *}$ Bij dit uitgangspunt is enige nuancering van belang. Het type besluit kan tot gevolg hebben dat de te maken heroverweging een min of meer beperkte betekenis heeft. De plicht wan een volledige heroverweging is beperkt van omvang, wanneer in de bijzondere wet de rechtsgevolgen zijn aangegeven en die wet een imperatief en limitatief stelsel van criteria voor de besluitvorming kent. Dit laatste bleek uit het voorbeeld van de bouwvergunning voor de berging.

Een ander argument tegen volledige heroverweging zou kunnen zijn dat een bezwaarde alsnog een positieve beslissing krijgt. Vooral in zaken van financiële aanspraken of lasten is de wettelijke heroverwegingsopdracht een zware bestuurlijke last. Te denken valt hier aan bijvoorbeeld bijstandszaken, sociale verzekeringszaken, belastingzaken, studiefinanciering en subsidiekwesties. Bij deze bestuurlijke aangelegenheden zijn geen derde-belanghebbenden betrokken, en zal de bezwaarde geen al te hoge eisen stellen aan de beweegredenen van het bestuursorgaan waarom het alsnog op zijn aanvankelijk negatief besluit is teruggekomen. De waarde van heroverweging moet daarom worden gezocht in het geven van een beter inzicht in het aanvankelijk genomen besluit en een verantwoording van de aspecten die bij de gemaakte heroverweging zijn betrokken.

Een primair uitgangspunt bij de heroverwegingsplicht is, dat het bezwaar ontvankelijk moet zijn. Met andere woorden: vóórdat heroverweging plaatsvindt dient eerst de ontvankelijkheid van het bezwaarschrift aan de orde te worden gesteld.

Tenslotte is het genoemde aspect van volledigheid uitgangspunt bij de heroverwegingsplicht. Bij de hernieuwde besluitworming moet de oorspronkelijke besluitvormingsprocedure nog eens worden herhaald. Van belang is hierbij dat het resultaat van de primaire procedure niet het werloop van de tweede procedure mag beïnvloeden. ${ }^{34}$ Dit voor de heroverweging essentiële aspect was ook punt van discussie tijdens de parlementaire behandeling van de Wet arob, zij het in wat andere en globale bewoordingen. Heroverwegen van beshiten overeenkomstig de

34 Nieuw bestuursrecht, a, w. p. 240. 
bezwaarschriftenprocedure ingevolge de Wet arob, zou in de parlementaire opvatting betekenen, dat het orgaan verplicht is de zaak in volle omvang opnieuw in overweging te nemen. ${ }^{35}$

Op grond van het vereiste dat bij heroverweging, het resultaat van de oorspronkelijke besluitvorming geheel los zou behoren te staan van de oordeelsvorming tijdens de herowerwegingsfase, ligt mede een belangrijk element opgesloten.

Het besluitvormende bestuursorgaan heeft de plicht tot een onpartijdige en onbevooroordeelde oordeelsvorming ten aanzien van het bestreden besluit. Openheid en objectiviteit zouden hier het bestuurlijke uitgangspunt behoren te zijn bij het opnieuw bezien van het bestreden besluit.

Besluitvorming op basis van objectiviteit past in het beeld van de overheid als hoedster van het algemeen belang. Van het bestuursorgaan wordt verwacht dat het bij het nemen van besluiten boven de partijen staat. ${ }^{36}$

Toch is er reden om te twijfelen aan het geschetste verwachtingspatroon over de bestuursorganen. Het proces van besluitvorming van bestuursorganen is niet altijd even rationeel. Zeker als bestuursorganen tot heroverwegung van eerder genomen beslissingen moeten overgaan. Een bijzonder probleem is dat regelmatig de termijn voor het beslissen op het bezwaarschrift niet wordt gehaald (zie par. 5.3.11 en 5.4.11). Hierdoor kan het steeds moeilijker worden voor het bestuursorgaan om tegen de achtergrond van de tijdsdruk voldoende aandacht te besteden aan de heroverweging. Bij de Wet arob bleek overschrijding van de beslistermijn veelvuldig voor te komen. Bij onderzoek bleek de gemiddelde duur van een bezwaarschriftenprocedure 144 dagen te bedragen..$^{37}$ Onder de werking van de Awb zal de praktijk niet veel anders zijn alle goede bedoelingen van de wetgever ten spijt. ${ }^{3 *}$ Verdaging en de mogelijkheid van verder uitstel in overleg met de bezwaarde belanghebbende zullen hierin weinig verandering brengen (art. 7:10 Awb).

Ter sprake kwam dat in het kader van de heroverweging de bestururlijke besluitvorming nog eens moet worden herhaald, hetgeen vanuit het perspectief van de volledige heroverweging er op neer komt, dat het aanvankelijke besluitvormingsproces in feite moet worden teruggedraaid. J.H. van Kreveld en M. Scheltema, parlementaire Geschiedenis wan de Wet arob, Groningen
1976, PG Awb I, p. 17.

M. Oosting, De arob-bezwaarschriftenprocedure als keuze-vraagstuk, Best.w., 1978, p. 119 e.v.
F. C.M. Brouw

PO Awb I, p. 345 e.v. 
Heroverweging dient zich immers volgens objectieve maatstaven te voltrekken. Heroverweging zou hiermee verwant zijn aan het model van rationele besluitvorming aldus Oosting. ${ }^{\text {j9 }}$ Volgens wetenschappelijk inzicht zou uit een oogpunt van psychologie van de besluitvorming, rationaliteit begrensd zijin. Slechts een beperkt aantal handelwijzen kan worden overwogen. Het aantal alternatieven zou afnemen in het proces dat aan de uiteindelijke beslissing vooraf gaat. ${ }^{*}$ Natar Leemans stelt zijn de marges voor de bepaling van het overheidsbeleid steeds nauwer door bepaalde factoren in het beleidsproces. "Het beleidsproces is als het ware een trechter: het kanaal dat leidt tot de beslissing wordt steeds nauwer. De vraag rijst dan ook of een terugkeer naar een punt voór de uiteindelijke belleidsbepaling (zo al mogelijk) de beslisser veel ruimte voor heroverweging zal. geven. ${ }^{\text {*z }}$

Objectieve heroverweging komt zoals is vastgesteld in de bestuurspraktijk onder druk te staan. Blijkens het rapport Arob-praktijken ${ }^{* 3}$ vond in het kader van de heroverweging in een op de vijf zaken een nieuw onderzoek omtrent de feiten plaats. Voor wat betreft de interpretatie van de voorschriften werd slechts zelden tot een ander oordeel gekomen. Een wijziging van het uit te voeren beleid kwam bij hoge uitzondering woor. Zelden werd alsnog tot een andere belangenafweging overgegaan. Doorgaans werd volstaan met het verschaffen wan uitleg over de gevolgde procedure. Indien heroverweging geschiedde in zaken, waarbij beleidsruimte aanwezig was, bleek dat slechts een enkele keer op aanvankelijk ingenomen bestuurlijke standpunten werd teruggekomen. Hiermee is niet gezegd, dat objectieve heroverweging een farce is, maar enige nuancering ten aanzien van de rationaliteit is gerechtvaardigd.

Het belang van de heroverweging ten aanzien van gebonden besluiten wordt doorgaans gering geacht. Bij gebonden besluitvorming staat de rechtmatigheid van het besireden besluit ter discussie. Toch is hier sprake van enige onderschatting. In het belang van een rechtens juiste heroverweging moeten immers toch de feiten worden onderzocht. Het voorbeeld van de casus van de bouwver gunning voor de berging, toont dit aan. Wat er ook van zij, hellemal overbodig is de bezwaarschriftemprocedure voor bestreden gebonden besluiten niet; zeker niet omdat deze voorprocedure zich op bestuurlijk niveau voltrekt en daarmee kansen

39 A. W.

40) H.A. Simon, Administirateve Behavior, A Study of Decision-Making Pucesses m Administrativa Organization, New York. P. XXVII en 80 en 81. Zie M. Oosting. a.w. p. 124.

45 A.F. Leerrans, Het bepalen yan het onderzoeksbeleid, in: A. Hoogerwerf (red.) Overherdske-

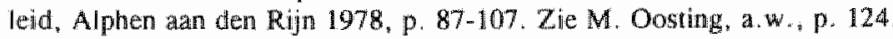

"2 M. Oosting, a.w., p. 124 .

43 C.M. Brecuwsma e.a., a.w. p. 210 e.v. 
biedt om de bezwaarde burger in te lichten omtrent de juistheid van het gebonden besluit. In de bestuurspraktijk blijkt op dat punt nogal wat misverstand te bestaan, en is het schriftelijk en verantwoordend uifleggen van een genomen besluit, doorgaans een moeilik probleem. Een voorbeeld uit de praktijk maakt dit duidelijk.

De welstandscommissie heeft een positief advies uitgebracht over een aanvraag voor een bouwvergunning. Omdat er verder geen weigeringsgronden zijn moet de bouwvergunning worden verleend. In een ander geval is er een negatief advies van de medisch deskundige in het kader van de beoordeling van een aanvraag om een sociale verzekeringsuitkering. De in deze procedures verwikkelde justitiabelen hebben onvoldoende inzicht en begrip voor het uitgebrachte advies. Voor een afweging van belangen is er geen ruimte. Toch heeft het bestuursorgaan bij deze in beginsel gebonden besluiten de plicht om de inhoud en het resultaat van het bestreden besluit aan belanghebbende te verantwoorden. Ook gebonden besluiten behoren zorgvuldig te zijn en dienen te worden gedragen door een voldoende motivering.

Gebonden besluitvorming is daarom een begrip, dat aanspraak maakt op enige nuancering. In het geval van de welstandscommissie en de medisch adviseur is er waak behoefte bij de bezwaarde aan informatie over de wijze van de totstandkoming wan het betrokken deskundigenadvies. Van het bestuursorgalan mag met het oog op de toepassing van de algemene beginselen van behoorlijk bestuur worden verwacht dat het 'zichtbaar' maakt op welke wijze toepassing is gegeven aan het recht, de feiten en het onderzoek naar die feiten.

Op grond hiervan moet met enige nuancering worden geoordeeld over het regeringsstandpunt dat het belang van de bezwaarschriftenprocedure voor 'gebonden beschikkingen" niet groot is. ${ }^{44}$ vastgesteld is dat bij heroverweging gesproken kan worden van een voortgezette bestuurlijke activiteit te weten het hernieuwd afwegen van het oorspronkelijk besluitvormingsproces. Heroverweging vormt hierdoor de basis voor de afronding van de besluitvorming op bestuurlijk niveau. De op grondslag van een ontvankelijk bezwaar ná de heroverweging genomen beslissing, treedt in de plaats van de oorspronkelijke beslissing en heeft daarmee conform het bepaalde in art. 7:11, lid 2 een devolutieve werking. ${ }^{\text {ts }}$ Dezelfde

44. J.H. Wan Kreveld en M. Scheltema, a.w., p. 108 e.v.

45. Van Wijk/KonijnenbelU/Van Male. Hoofdstukken wan administratief recht, Utrecht 1993. Hennekens denkt hier anders over indien het bezwaarschrift tegen het primaire besluit ongegrond wordt verklaard. Hij ziet dan in de beslissing op het bezwatr een 'herbewestiging' van het primaire beshluit. H.Ph.J.A.M. Hennekens, Vernietigen door de administratieve rechter wan een besluit: 
situatie doet zich overigens voor bij het opnieuw voorzien in de zaak (art. 8:72, lid 4). Bij een uitgesproken rechterlijke vernietiging van het bezwaarschrift moet de vernietigde beslissing opnieuw worden genomen en treedt de nieuwe beslissing van het bezwaarschrift daarwoor in de plaats. De Waard zegt met zoveel woorden: 'Als er een vóórprocedure is geweest alvorens de zaak bij de Afdeling rechtspraak komt, is de aangevochten beschikking niet de primaire beslissing, maar de in beroep of bezwaar gegeven beslissing. De nieuw te nemen beslissing is dan derhalve een nieuwe beslissing in beroep of bezwaar." ${ }^{* 6}$ Velen zien daarin aanleiding om te spreken van verlengde besluitvorming, waardoor tevens het karakter van de bezwaarschriftenprocedure tot uiting komt. Borman, Van Buuren en Polak, maar ook Stroink en Brouwer benadrukken dat gesproken kan worden van verlengde besluitvorming, al nemen beide laatsten een tussenstandpunt in. Dit tussenstandpunt komt er op neer, dat in het ingediende bezwaar tegelijkertijd een rechtsmiddel wordt gezien ondat bezwaar is gemaakt tegen een primair besluit. ${ }^{47}$ De Awb ziet de bezwaarschriftenprocedure en de in dat kader te maken heroverweging, als een proces, waarbij in een tweede fase het primaire besluit ter beoordeling staat. In een drietal fasen kan een besluit of beschikking ter beoordeling staan. De eerste fase omvat de vaststelling van het primaire besluit met als tussenfase de bezwaarprocedure. De derde en laatste fase omvat het beroep op de rechter. De Awb gaat er vanuit dat de procedurele waarborgen voor een goede besluitvorming in iedere fase ten opzichte van de vorige toenemen. ${ }^{48}$ De gemaakte koppeling met de procedurele waarborgen in iedere zo mogelijk opvolgende fase van het beoordelingsproces van een besluit, wijst in de richting van de rechtsmiddel-functie van de tweede fase in casu de bezwaarschriftenprocedure. Het heroverwegingsproces krijgt hierdoor een rechtsbeschermingsfunctie. Dit standpunt wordt overigens sterker benadrukt in een nadere beschouwing van de bezwaarschriftenprocedure. Ten tijde van de parlementaire behandeling is hierover het volgende gezegd:

'Deze vorm van rechtsbescherming heef in de afgelopen jaren sterk aan betekenis gewonnen. Was zij aanvankelijk gedacht als een middel om een te veelvuldig beroep op de administratieve rechter te voorkomen, zoals in belastingzaken en bij de invoering van de Wet arob, tegenwoordig is duidelijk geworden dat zij daamaast een zelfstandige functie vervult in een goede regeling van de rechtsbescherming en ook in de algemeen bestuurlijke zin."

enkele knellende punen belicht, Gst. 7027, p $\$ 27$.

46 B.W.N. de Walard, Na de uitspraak, NTB 1987, p. 80. Zie overigens voor een meer uitvoerige beschouwing: B.J. Schueler, Wernietigen en opnieuw voorzien, Zwolle 1994.

4 F.F.W. Brouwer, 10 Jaar Arob-bezwatarscheiftenprocedure, hoe nu verder?, Gst. 6829 .

48 PG Awb I, P. 107.

49 PG Awb I. P. 279. 
De Awb en de bestuursrechter lijken meer dan de literatuur dat doet, de dubbelfunctie van de heroverweging en de beslissing op het bezwaar te benadrukken en de heroverweging tevens alls een aspect van verlengde besluitvorming te zien. Verlengde besluitvorming omdat de wetgever hierin een scharnierpunt meent te onderkennen van het afronden van de bestuurlijke besluitvorming. Dit scharnierpunt wordt herkenbaar in de motieven voor de algemene en bijzondere regels voor bezwaar en beroep als bedoeld in hoofdstukken 6 en 7 van de Awb. De voorschriften van hoofdstuk 6 worden onder andere getypeerd als regels liggende op het grensvlak tussen de primaire besluitvorming en de rechtsbescherming. ${ }^{\text {so }}$

Ook Tak ziet een grensvlak tussen thet non-contentieuze besluitvormingsproces en het contentieuze rechtsbeschermingsproces. Hij markeert dit grensvlak met het moment $\mathrm{X}$; dit is naar de mening van Tak het moment waarop het bestuur in de betreffende aangelegenheid is uitgepraat. Maar tot aan de fase, waarin de rechter in plaats van het bestuur beslisser wordt, heeft het bestuur de verantwoordelijkheid voor de inrichting en de vorm van het voorproces. Tegelijkertijd vormt het "Moment" van Tak, het ultieme moment van het besluitvormingsproces. En juist in dat bestuurlijke besluitvormingsmoment (voorafgaande aan het Moment $\mathrm{X}$ ) is het recht nog niet doel op zichxelf van die besluitvorming. Bestuurskundige motiewen lijken eerder maatgevend dan juridische. ${ }^{51}$ Uit deze benadering van Tak blijkt, dat hij geen rechtsbeschermings-aspect ziet in de voorprocedure voorafgaand aan de beroepsfase bij de administratieve rechter. Wel benadrukt Tak de correctiemogelijkheid in de contentieuze fase, met dien verstande dat hij het primaat van de bestuurssoevereiniteit van de overheid als uitgangspunt bij de besluitvorming bestempelt. Tegen de bezwaarschriftenprocedure als zodanig heeft hij geen bezwaar, maar verwerpelijk acht hij de ontwikkeling, dat het rechtsbeschermingsdenken zodanig op alle fronten zegeviert, dat 'administratief bezwaar', geëvolueerd lijkt van verlengde besluitvorming naar 'eerste instantie'. Met dat laatste wijst Tak de toegedichte rechtsbeschermingsfunctie in de heroverwegingsfase af.

In het verlengde van het uitgangspunt, dat bestuurlijke heroverweging langs de weg van een hernieuwde besluitvorming op besiuursniveau moet leiden, dient de heroverwegingsplicht tevens als basis voor correctiemiddel. Dit klemt temeer nu het bestuurlijk toezicht in de organieke wetten verder is teruggedrongen. ${ }^{32}$ De Gem.w., de Prov.w. en de Watersch.w. geven blijk van een verdere terugdringing van het toezicht.

s0 PG Awb I, p. 278.

51 A.Q.C. Tak, Her Moment X. TvO 1990, p. 134.

52 A.Q.C. Tak, a.w., p. 134. 
Van belang is dat bij een ingediend bezwaarschrift gesproken kan worden van een correctie op verzoek, een en ander ter onderscheiding van de omstandigheid, dat het bestuursorgaan ook de mogelijkheid heeft tot zelfcorrectie van genomen besluiten, zonder dat evenwel een bezwaarschrift aan de orde is. Uiteraard leidt die zelfcorrectie door het bestuur wel tot een wijziging van de rechtstoestand van de justitiabelen die bij de oorspronkelijke bestuurshandeling waren betrokken. De Goede noemt het middel, dat het oorspronkelijk handelende bestuursorgaan voor correctie ter beschikking staat, "de herziening'. ${ }^{33}$ Dit middel omvat naar de mening van De Goede zowel de intrekking als de wijziging van de beschikking. Deze eigentijdse bewoordingen van De Goede hebben nu nog hun waarde behouden. In wat andere meer moderne bewoordingen zegt art. $7: 11 \mathrm{Awb}$ in het tweede lid, dat het bestuursorgaan het besluit herroept en zo nodig in de plaats daarvan een nieuw besluit neemt.

\subsubsection{Normen}

Wanneer aan de bovengenoemde uitgangspunten is voldaan en hernieuwde oftewel verlengde beshitworming zich op basis van het heroverwegings-proces heeft voltrokken, dan verkrijgen de in de vorige paragraaf genoemde uitgangspunten het karakter van rechtsvorming op het moment dat het besluit inhoudende de beslissing op het bezwaarschrift is bekend gemaakt.

Met deze rechtsvorming door middel van de beslissing op het bezwaarschrift, steit het bestuursorgaan de inhoud van het recht vast. Immers die opdracht tot rechtsvorming en de realisering daarvan in de vorm van de totstandkoming van rechtsnormen, behoort conform het bestuursrecht aan daartoe in de wet in casu de Awb algemeen en specifiek omschreven bevoegdheid van het bestuursorgaan om op het bezwaarschrift te beslissen. ${ }^{54}$ Een en ander met inachtneming van het bepaalde in art. 1:5 Awb. De wet drukt het hier iets anders uit en zegt dat bezwaar, in casu voorziening moet worden gevraagd bij het bestuursorgaan dat het oorspronkelijk besluit heeft genomen. Hierdoor ligt de competentie van het bestuursorgaan tot het beslissen op een bezwaarschrift mede in relatie tot art. 1:1 A wb vast. In dit artikel is het begrip bestuursorgaan nader omschreven en is deze bevoegdheid als zodanig geattribueerd."s

53 B. de Goede/H. van den Brink, Beeld wan het Nedertands Bestuursrecht wijfde dr., 's-Gravenhage 1986, p. 209.

54 R.M. van Male, Enkele aspecten van het begrip belanghebbende in de Algemene wet bestuursrecht, VAR 108, Alphen aan den Rijn 1992, p. 18 e.*.

55 Nicolai, Olivier, Damen en Troostwijk, Bestuursrecht, wjfde herziene druk. Amsterdam $1994 \mathrm{en}$ F. A. M. Stroink, Het leersuk der deconcentratie, "s-Gravenhage 1978. 
Terloops is aangestipt, dat een beshuit eerst in werking treedt nadat het is bekendgemaakt. Art. 3:40 van de Awb legt deze op basis van het recht ontwikkelde regel met zoveel woorden vast, terwijl de wijze van bekendmaking dient te geschieden conform de regels wan art. 7:12. Vreemd is hierbij dat de Awb vanuit haar harmoniserend karakter, in art. 7:14 de werking van art. 3:41 hiervan heeft uitgezonderd. Met enige aanpassing had art. 3:41 ook voor de bekendmaking van de beslissing op bezwaarschriften kunnen gelden.

Terugkomend op de constatering, dat de aan het besluit ten grondslag liggende uitgangspunten normerende werking krijgen leidt deze omstandigheid tot het volgende.

Op grond van het rechtsbeschermingsbelang, waardoor immers de weg naar de bestuursrechter openstaat, worden de bovengenoemde uitgangspunten tot rechtsnormen verheven. De op het bezwaarschrift genomen beslissing staat dan als bestuurlijk produkt bij toetsing door de bestuursrechter ter discussie. Binnen de schil van het besluit, vormt de kern daarvan in casu de heroverweging voorwerp van rechterlijke desiderata. Met andere woorden de intrede van de onafhankelijke rechtsbeschermingsfase vormt het heroverwegingsproces orn tot een rechtsnormerend proces. ${ }^{\text {st }}$

Het is van belang er op te wijzen, dat de vrijheid van het bestuurlijk handelen gaandeweg is ingeperkt door de toenemende betekenis van het geschreven en ongeschreven recht. De vergaand doorgevoerde procedurele en inhoudelijke normering trekt zijn wissel op de inhoud van de heroverweging. ${ }^{\text {s }}$ Die procedurele en inhoudelijke normering blijkt uit de algemene werking van hoofdstuk 3 Awb terzake besluiten. Dit betekent, dat ook de aan de beslissing op het bezwaarschrift ten grondslag liggende heroverweging, bij rechterlijke toetsing, aan de rechtmatigheidsregels ${ }^{5 B}$ is onderworpen. Naast enkele gecodificeerde beginselen van behoorlijk bestuur, waardoor deze beginselen tot normen voor behoorlijk bestuur zijn gepositiveerd, krijgt de rechtsvorming door middel van de beslissing op het bezwaarschrift in normerende zin gestalte."

36. Meevis, Rechtsbescherming Struikelblok of stimulans voor ondernemende gemeenten?, TvO 1988, p. 388 e.v.

57 J.B.J.M. Ten Berge en P.M. Langbroek, Van gemeenterecht naar algemeen bestuursrecht, NTB 1993, p. 89 e.

58 P. Nicollai e.a., a. w., p. 135.

59. Tonnaer is van mening, dat niet alle beginselen van behoorlijk bestuur wok echte "beginselen' zijn. Hij noemt als woorbeald het verbod van détoumement de pouvoir (artikel 3:3), dat voldoende concreet is; positivering door wetgever, bestuur of rechter is hier niet nodig. Het verbod wan détournement de pouvoir is naar de mening van Tonnaer dan ook geen rechtsbeginsel maar een rechtsnorm. Dit is volgens Tonnaer anders met het bepaalde in artikel $3: 2$ inzake de kennisver- 


\subsection{De omwang van de besturrlike toetsing}

\subsubsection{Een nadere invulling van de omvang van de heroverweging}

In dit hoofdstuk werd de in art. 7:11 Awb opgenomen plicht van het bestuursorgaan tot heroverweging van het bij een gemaakt bezwaar bestreden besluit, een van de meest belangrijke bepalingen van deze wet genoemd. Deze constatering is niet zonder belang. Aan deze heroverwegingsplicht ligt een aantal bestuursrechtelijke uitgangspunten ten grondslag dat de aard van de bezwaarschriftenprocedure als 'eindstation' van bestuurlijke besluitvorming, nader accentueert. De bezwaarschriftenprocedure vormt voor het bestuursorgaan in beginsel de laatste mogelijkheid om de kwaliteit van een genomen besluit in primo nog eens aan een volledige en hernieuwde toetsing te onderwerpen. Met enige nadruk wordt hierbij gesteld 'in beginsel'.

Art. 6:18 stelt immers in samenhang met art. 6:19 Awb een aantal eisen uit een oogpunt van behoorlijke proceswoering. Dit laatste heeft te maken met het uitgangspunt van art. 6:18, lid 1, te weten:

-1. Het aanhangig zijn van bezwaar en beroep tegen een besluit brengt geen verandering in een los van het bezwaar of beroep reeds bestaande bevoegdheid tot intrekking of wijziging van dat besluit.'

Op de inhoud en strekking van de art. 6:18 en 6:19 wordt hier niet verder ingegaan. Wel is het goed er op te wijzen, dat de rechtspraak inmiddels zeer hecht aan een strikte toepassing van art. 6:18. Dit laatste kan worden afgeleid uit een rechtsoverweging dienaangaande in het kader van een uitspraak in beroep:

- Een besluit dat (mede) naar aanleiding van een bezwaarschrilt is genomen, dient ecliter in beginsel te worden aangemerkt als een beslissing op bezwaar als bedoeld in art. $7: 1$, tweede lid A wb. Het los van de bezwaarschriftenprocedure met toepassing van art. 6:18 Awb wijzigen van een besluit waartegen inmiddels en bezwaarschrift is ingediend is gelet op de teksi van dit artikel - wel mogelijk, doch de anleiding voor doze wijziging zal dan toch niet in het ingediende bezwaarschrift moeten liggen."

Omdat in deze zaak appellante aan de bestuursrechter te kennen had gegeven haar formele bezwaren tegen een onjuiste toepassing van art. 6:18 Awb niet langer te

garingsplicht. Het primad ligt hier allereerst bij thet bestursorgaan; in tweede instantie kat de rechter ingeval van een beroep zich met de nodige terughoudendheid een oordeel vormen omtrent de rechimatigheid van het bestuursbestuit. F.P.C.L. Tonnaer, Regels voor het besturen, Gst. 6831 , p. 128 .

Rb. Urecht 19 maart 1997, AB-katem 1997, 34. 
handhaven, had de onjuiste toepassing van art. 6:18 door het bestuursorgaan, geen gevolgen. Zou appellante haar formele bezwaren tegen een rechtens onjuiste toepassing van art. $6: 18$ wél hebben gehandhaafd, dan zou dit tot gevolg hebben gehad dat de rechter het 'artikel 6.18 -besluit' zou hebben vernietigd. Dit besluit was immers niet voorbereid en genomen met inachtneming van de bepalingen van hoofdstuk $7 \mathrm{Awb}$. In de betreffende zaak had het bestuursorgaan een aanvankelijk te summier gemotiveerd besluit, waartegen een bezwaarschrift was ingediend, in zowerre hersteld door een geheel nieuw (primair) besluit te nemen.

De opdracht die de Awb-wetgever in art. 7:11 Awb het bestuursorgaan verstrekt om op grondslag van het bezwaar tot heroverweging van het bestreden besluit over te gaan, houdt in dat de nieuwe toetsing van het bestreden besluit volledig moet zijn. Volledig, betekent hier dat de beoordeling van het primaire besluit niet beperkt moet blijven tot aspecten van rechtmatigheid. Op dit aspect werd al gewezen. Binnen de wettelijke grenzen moet de beoordeling van het bestreden besluit zich mede richten op de beleidsmatige kant van de oorspronkelijke bestuurlijke beslissing.

De Awb geeft een tweetal belangrijke, maar niet volledige criteria voor de toetsing van het primaire besluit in het kader van de bezwaarschriftenprocedure. De verplichte nieuwe oordeelsworming van het bestuursorgaan kan niet aan de eisen van 'volledigheid' voldoen, zonder dat het bestuursorgaan zich opnieuw een mening heeft gevormd over de rechtsfeiten die aan de primaire beslissing ten grondslag liggen. Zonder toetsing van de feiten zou immers een beoordeling van de rechtmatigheidsaspecten en de beleidsaspecten niet mogelijk zijn. De toetsing van de feiten heeft een voorwaardenscheppende betekenis voor de beoordeling van de vraag of het bestreden besluit aan de eisen van rechtmatigheid en beleid of beter gezegd, doelmatigheid voldoet.

De vraag kan worden gesteld of de beoordeling van het bestreden besluit aan de hand van de te maken heroverweging iets zegt over de omvang van de toetsing wan het bezwaarschrift. Het antwoord daarop is niet zo eenvoudig te geven. Het begrip heroverweging is vanuit zijn 'volledigheidsprincipe' een moeilijk af te bakenen begrip. Strikt genomen is er nauwelijks een begrenzing aan te geven voor de omvang van de beoordeling van het bezwaarschrift. Het bestuursorgaan moet immers beoordelen of het genomen primaire besluit correct was. Daarmede is de beoordelingsmarge van het bestuursorgaan ruimer dan die van de bestuursrechter. ${ }^{63}$ Voor de bestuursrechter zijn de grenzen van de toetsing van een

6 PG Awb I, P. 347.

62 J.B.J.M. ten Berge (red.), Nieuw bestuursrech, Nijmegen 1994, p. 240.

63 J.B.J.M. ten Berge, Bescherming tegen de overheid, tweede druk, Zwolle $1994, \mathrm{p} .137$. 
beroepenbesluit enger. De rechter toetst immers aan het geschreven en ongeschreven recht en aan de algemene rechtsbeginse]en. Kortom de rechterlijke toetsing is beperkt tot het rechtmatigheidsaspect. Art. 8:77 Awb bepaalt met zoveel woorden, dat indien de uitspraak strekt tot gegrondverklaring van het beroep, in de uitspraak wordt vermeld welke geschreven en ongeschreven rechtsregel of welk algemeen rechtsbeginsel is geschonden.

Toch biedt art. 7:11, lid 1 Awb enkele aanknopingspunten om te komen tot een nadere invulling van de omvang van de heroverweging. Bij de bespreking van het afbakenen van de omvang van de heroverweging wordt hierbij vooropgesteld dat daarmede niet primair beoogd wordt de kwaliteit van de omvang van de heroverweging te beoordelen. Het begrip omvang doelt in de betekenis zoals het wordt onderzocht meer op de kwantitatieve aspecten van de heroverweging, en beoogt de reikwijdte van de heroverweging in kaart te brengen. Daarmee wordt overigens het kwaliteitsaspect niet helemaal van de heroverweging van het primaire besluit buiten spel gezet. De grenzen van de criteria voor de heroverweging zijn immers ruim.

Aangegeven is dat aan de heroverwegingsplicht een aantal bestuursrechtelijke uitgangspunten ten grondslag ligt. Juist deze uitgangspunten bepalen voor een groot deel de omvang van de heroverweging. De aanknopingspunten liggen als het ware opgesloten in de redactie van art. 7:11, lid $1 \mathrm{Awb}$.

Art. 7:11, lid 1, bepaalt dat het bezwaar 'ontvankelijk' moet zijn. Het eerste uitgangspunt betekent tevens 'het fundament' woor een daarmede gelegde formeel-juridische koppeling: 'heroverweging" vindt dan plaats "op grondslag' van het bezwaar. Dit tweede uitgangspunt dat zijn weerslag vindt in de tweede zinsnede van het eerste lid van art. 7:11, heeft belangrijke gevolgen voor het bepalen van de omvang van de heroverweging. Dit "grondslagvereiste" heeft voor wat betreft de omvang van de heroverweging een meervoudige betekenis. Enerzijds duidt dit vereiste op het voorwerp van het geschil, met andere woorden datgene wat de bezwaarde in zijn bezwaarschrift aan grieven te berde brengt. Aan de andere kant heeft dit bezwaarschrift een formeel-juridische reflex en behoort connexiteit te bestaan met een besluit. Zonder een besluit (of soms een handeling), bestaat er immers geen recht op bezwaar.

Art. $7: 1$ Awb wijst er op dat slechts het bestaan van een voor beroep vatbaar besluit de bezwaarde rechtens toegang verschaft tot de bezwaarschriftenprocedure. Dit betekent dat een besluit tevens het object van het geschil omvat. Het besluit en het bezwaarschrift, waarbij dit besluit wordt bestreden bepalen tezamen het object van het geschil, en daarmede de omvang van de heroverweging in het kader van de behandeling van het bezwaarschrift. Beter gezegd, het object van 
het geschil bepaalt de bandbreedte van de discussie met betrekking tot het ingediende bezwaar. ${ }^{\text {s. }}$

Voor de volledigheid wordt hierbij opgemerkt, dat de Awb aan het object van het geschil enerzijds een begrenzing toekent en anderzijds ook weer opteert voor een ruimere omvang van het object van het geschil.

Die onderdelen van het bestreden besluit die geheel los staan van de aangevoerde bezwaren, behoeven niet in de heroverweging te worden betrokken. De laatste beperking moet ook in omgekeerde zin worden opgevat; die onderdelen van het bezwaar die losstaan van het bestreden besluit, behoeven eveneens niet te worden heroverwogen. Daarmede zou buiten de grenzen van het object van het geschil in casu het besluit worden getreden. Een enkel voorbeeld maakt dit duidelijk.

Wanneer iemand in het bezwaarschrift tegen een bouwvergunning er tevens op wijst dat de voorwaarden van de bouwvergunning niet worden nageleefd, dan wordt met dit onderdeel van het bezwaar getreden buiten het object van het geschil. Slechts de bouwvergunning omvat het object van het geschil; het maken van bezwaar tegen het niet naleven van de vergunningsvoorschriften valt buiten het bestreden besluit. Wil iemand in dit verband als bezwaarde "aan zijn trekken komen" dan behoort hij buiten het gemaakte bezwaar tegen de bouwvergunning een verzoek in te dienen om toepassing van bestuursdwang. Wordt dit verzoek door het bestuursorgaan afgewezen, dan resteert voor de bezwaarde de mogelijkheid om een bezwaarschrift in te dienen.

Aan de andere kant wordt de omvang van het object wan het geschil, in de bezwaarschriftenprocedure (de gronden van het bezwaar) ruim beoordeeld. Indien het bezwaarschrift een beperkte omschrijving van de bezwaren bevat, betekent dat niet dat de inhoud van het bezwaarschrift (zie in dit verband de eisen als bedoeld in art. 6:5) het object van het geschil afbakent. Ook met bijvoorbeeld de op de hoorzitting gegeven nadere toelichting moet rekening worden gehouden. ${ }^{\text {"s }}$ Daarnaast is niet zonder bellang art. 7:9; feiten en omstandigheden van aanmerkelijk belang moeten op basis van de inhoud en de strekking van dit artikel mede in de heroverweging worden betrokken.

Schoor is echter van mening dat het grondslagvereiste een beperking kan inhouden voor de te maken heroverweging als bedoeld in art. $7: 11$, lid $\mathbb{l}$. Hij meent dat het aanbeveling zou verdienen dat in plaats van 'op grondslag daarvan" het heroverwegingscriterium zou moeten zijn: "naar aanleiding daarvan'. Op grond

64 A.Q.C. Tak, Hoofdlijnen van het Nederlands bestuursprocesrecht, 3e dr., Zwolle 1995. p. 155.

55 PG Awb I, p. 347. 
van de arob-jurisprudentie zou volgens Schoor de Awb een nadere uiteenzetting moeten bevatten over de omvang wan de toetsing van het bezwaarschrift. ${ }^{\text {sh }}$

Er werd op gewezen, dat het grondslagvereiste voor het bepalen van de omvang van de heroverweging een meervoudige betekenis heeft. Die meervoudige betekenis $\mathrm{kwam}$ vast te staan aan de hand van de gegeven omschrijving van het object van het geschil (het besluit en de grondslag van het bezwaarschrift). Deze meervoudige betekenis van het object van het geschil en de hieromirent te maken heroverweging heeft ook een bestuursprocesrechtehijke betekenis. Deze bestuursrechtelijke betekenis houdt eveneens verband met het antwoord op de vraag hoe flexibel het object van het geschil is, in geval van toetsing in beroep door de bestuursrechter van de beslissing op het bezwaarschrift. Tak wijst op een aantal problemen die zich kunnen voordoen bij de afbakening van het object van het geschil. Hij brengt onder de aandacht aspecten, zoals de keuzevrijheid van appellant, alsmede diens (on)mogelijkheden tot het wijzigen, intrekken of aanvullen van het object van het geschil. Tak betrekt hierbij tevens de positie van het bestuursorgaan ten opzichte van het object van het geschil. ${ }^{6 z}$

Deze aspecten die bij het bepalen van de omvang en inhoud van het object van het geschil een rol kunnen spelen, kunnen daarom nogal complex van aard zijn. Met het oog op de beperkingen die in dit boek moesten worden aangelegd wordt op de problematiek van het object van het geschil niet verder ingegaan. Volstaan wordi hier met het aanstippen van die aspecten van het object van het geschil die de lijnen uitzetten van de te maken heroverweging.

Een derde aspect dat de omvang van de heroverweging bepalt is gelegen in het uitgangspunt van de $\mathrm{Awb}$ dat de volledige heroverweging van het besluit in primo dient te geschieden op basis van de ten tijde van de beslissing op het bezwaarschrift, bekend zijnde feiten en omstandigheden, ${ }^{6}$. In de bestuursrechtelijke betekenis wordt deze wijze van toetsing wel aangeduid als een toetsing ex nunc. Deze toetsing die kenmerkend is voor de bezwaarschriftenprocedure (en ook voor het administratief beroep), onderscheidt zich ten opzichte van de toetsing door de bestuursrechter. In het bestuursprocesrecht is immers karakteristiek voor de rechtmatigheidstoetsing dat deze wijze van toetsing met zich brengt een beoordeling van het bestuursbesluit ex tunc. Met de feiten en omstandigheden zoals die zijn op het moment van de rechterlijke uitspraak wordt in beginsel geen rekening

66 C. W. I. Schoor, De bezwarschriften procedure in art. 7:11 Awb, NJB 1993, p. 859 en 860 .

6.) A.Q.C. Tak, a.w., p. 155 e.v.

68 PO Awb I, p. 346. 
gehouden. ${ }^{6 y}$ De bepaling van art. 8:72, lid 4 (zelf in de zaak voorzien) die een afwijking van dit bestuursprocesrechtelijk uitgangspunt mogelijk maakt, doet hier niet aan af *

Aangegeven is dat de bezwaarschriftenprocedure tot uitgangspunt heeft een toetsing ex nunc. De vraag kan worden gesteld of op het beginsel van deze ex nunc-toetsing door het bestuursorgaan geen uitzonderingen bestaan. De geopperde vraagstelling wordt hier ingegeven door een onderzoek naar het bepalen van de omvang van de heroverweging. In de volgende paragraaf zal worden onderzocht op welke wijze invulling moet worden gegeven aan het beginsel, dat een heroverweging behoort plaats te vinden op grond wan de feiten en omstandigheden op het moment van de beslissing op het bezwaarschrift.

Tenslotte ligt in de heroverwegingsplicht als bedoeld in art. $7: 11$, lid 1 nog een vierde aspect opgesloten dat de omvang van de heroverweging en het resultaat van de beslissing op het bezwaarschrift kan beperken. Deze "artikel 7:11-conditie" komt er op neer, dat conform de bedoelingen van de Awb uit het grondslagvereiste (heroverwegen op grondslag van het bezwaar), bestuurlijke restricties kunnen voortvloeien. Met zoveel woorden stelt de Awb-wetgever:

'In de tweede plaats mag het bezwaarschrift er niet toe leiden dat het bestuursorgaan de heroverweging gebruikt om cen verslechtering van de positie van de indiener te bereiken die zonder bezwaarschriftenprocedure niet mogelijk zou zijn."

Deze beperking van de omvang van de heroverweging, wordt in het bestuursrecht doorgaans aangeduid als het zogenaamde verbod van reformatio in peius. In welke mate de inhoud en de betekenis van dit verbod de ormvang van de heroverweging kan beperken komt aan de orde in par. 1.4.4.

1.4.2. De toetsing ex nunc als uitgangspun; een grondbeginsel van de heroverweging met relatieve trekken

Een belangrijk aspect bij de bestuurlijke heroverweging vormt het uitgangspunt dat bij de beoordeling van de beslissing op het bezwaarschrift die feiten en omstandigheden in aanmerking worden genomen die gelden ten tijde van de beslissing op het bezwaarschrift. Als bijvoorbeeld aan lemand aanvankelijk een

$69 \mathrm{PG} A \mathrm{wb} \mathrm{II}, \mathrm{p} .174$.

70 Zie overigens in dit verband: J.M.H.F. Teunissen, Toetsing ex tunc of ex nunc?, in: Nieuw bew stuursprocesrecht, Deventer 1992, p. $111 \mathrm{e} . \mathrm{v}$.

$71 \mathrm{PG}$ Awb I, p. 347. 
bouwvergunning is afgegeven waarvoor tevens met toepassing van art. 19 WRO vrijstelling werd verleend van de bepalingen van het vigerend bestemmingsplan, terwijl tijdens het beoordelingsmoment van de beslissing op het bezwaarschrift blijkt, dat de grondslag van de verleende vrijstelling is komen te vervallen - er is geen geldig voorbereidingsbesluit meer als bedoeld in art. 21 WRO - dan dient deze omstandigheid er rechtens toe te leiden dat de verleende bouwvergunning alsnog moet worden geweigerd. Voor de betrokken vergunninghouder is dit een onaangename verrassing.

Soms is de bestuursrechter bereid het bestuursorgaan op het goede spoor te zetten en het bestuur nog eens te wijzen op het heroverwegingskarakter van de bezwaarschriftenprocedure. Bij de behandeling van de hierna in het kort te bespreken kwestie kwam zowel bij de rechtbank als bij de ABRS vast te staan dat in een gevolgde anticipatieprocedure zowel ten tijde van het besluit in primo als op het moment van de beslissing op het bezwaarschrift geen voorbereidingsbesluit van kracht was. In deze WW/WRO-zaak overwoog de Vz. ABRS ten aanzien van het ex nunc karakter van de bezwaarschriftenprocedure het volgende:

'(...) Het verlenen van vrijstelling van het bestemmingsplan als bedoeld in artikel 19 WRO, waarbij wordt geanticipeerd op een nieuw bestemringsplan, is immers gelet op het bepaalde in het eerste lid wan dit artikel slechts mogelijk indien voor het betreffende gebied een voorbereidingsbesluit geldt, zodat burgemeester en wethouders, nu in dit geval cen voorbereidingsbesluit ontbrak, niet bevoegd waren tot het verlenen van viijstelling. De president heeft woorts ook terecht overwogen dat dit gebrek kon worden hersteld; uit de procedure die in dit geval is gevolgd, kan immers worden afgeleid dat met toepassing van de anticipatieprocedure vrijstelling zou worden verleend, zodat het zeer wel denkbaar is dat een nieuw woorbereidingsbesluit zal worden genomen, hetgeen tot gevolg zal hebben dat ten tijde wan een nieuwe beslissing op het bezwaarschrift van Slee wel aan de formele vereisten voor het verlenen van vrijstelling van het bestemmingsplan zal zijn voldaan. ${ }^{\text {? }}$

Deze uitspraak is overigens om meerdere redenen interessant. Allereerst werd door de $\mathrm{VZ}$. ABRS toch tot vernietiging van de uitspraak van de rechtbankpresident besloten omdat deze in het kader van de bovengenoemde zaak de strekking van art. 8:72, lid $4 \mathrm{Awb}$ had miskend. In het onderhavige geval had de betrokken president zelf in de zaak voorzien met voorbijgaan aan de omstandigheid, dat gebleken was dat het bestuursbesluit verder mank ging aan een tweede gebrek. B en $w$ hadden niet aangegeven van welke bepaling van het geldende bestemmingsplan vrijstelling was verleend. 
In een geval dat gesproken kan worden van een "herstelbaar" gebrek vindt toepassing van het vierde lid van art. 8:72 niet plaats. Naar het oordeel van de $V_{Z}$. ABRS had de president behoren te volstaan met vernietiging van de beslissing op het bezwaarschrift. Uit deze laatste conclusie van de voorzitter blijkt well de exclusiviteit van de bezwaarschriftenprocedure als mogelijkheid voor het bestuur tot het herstellen van gemaakte fouten.

Toch geeft deze uitspraak aanleiding tot het maken van een enkele kanttekening. De reden is gelegen in de kennelijke spraakverwarring van zowel de rechtbankpresident als de $V_{z}$. ABRS. De vrijstelling ex artikel 19 WRO heeft geen anticiperend karakter en betekent slechts dat vrijstelling wordt verleend van de bepalingen van het geldend bestemmingsplan. Met "anticipatie" van de bepalingen van het bestemmingsplan heeft deze vrijstelling niets van doen. Anders is dit bij de bevoegdheid die in de WW is toegekend om de aanhoudingsplicht in het kader van een bouwvergunning te doorbreken door op grondslag van een voorbereidingsbesluit als bedoeld in art. 21 WRO te anticiperen op de bepalingen van het in woorbereiding zijnde bestemmingsplan. Deze laatste bevoegdheid heeft een zuiver anticiperend karakter. Verwezen wordt hier naar het bepaalde in art. 50 , lid 5 WW.

Toch zijn de in de bovengenoemde casus geschetste problemen voor het bestuursorgaan niet zo eenvoudig, ook al geeft de bestuursrechter in zijn rechtsoverwegingen enige aanwijzingen hoe het bestuursorgaan behoort te handelen. Natuurlijk zal een klantvriendelijk bestuursorgaan in casu b en $w$, als er verder geen andere gebreken in het besluit in primo zijn geconstateerd, nog hangende de beslissing op het bezwaarschrift proberen, deze gebrekkige bouwvergunning alsnog te 'repareren'. Het bijzondere van de geschetste situatie is wel dat b en w afhankelijk zijn van het nemen van een nieuw voorbereidingsbesluit door de gemeenteraad. Dit heeft tot gevolg dat eerst dan een beslissing op het bezwaarschrift kan worden genomen nadat de gemeenteraad conform art. 21 WRO een nieuw voorbereidingsbesluit heeft genomen en datzelfde besluit is bekendgemaakt. Of de gemeenteraad tegen de achtergrond wan het ingediende bezwaarschrift tegen de verleende bouwverguming bereid is, alsnog een nieuw voorbereidingsbesluit te nemen, moet de houder van de bouwvergunning maar afwachten. De jurisprudentie onder de werking van de Wet arob vormde nog al eens op het punt van de heroverweging een onvoorspelbaar patroon. Dat een standpuntwijziging in een hernieuwde beoordeling door de gemeenteraad van een voorbereidingsbesluit wel eens tot onaangename verrassingen kan leiden valt op te maken uit een zaak van de gemeente Franekeradeel. In deze kwestie overwoog de ARRS samenvattend als volgt: 


\begin{abstract}
"A an verwerder kan niet de bewogdheid worden ontzegd alsnog van het nemen van een voorbereidingsbesluit af te zicn wanneer weliswaur niewwe rellevante aspecten onibreken, doch hemieuwde beoordeling van de ook reeds bij de eerdere beslissing betrokken gegevens tot zulk een besiuit noopt. Daarbij is van belang dat een herhaalde beoordeling inherent is aan de door de wetgever voorgeschreven bezwarschiftenprocedure. Van verweerder kan niet worden gevergd wast te houden alan een eerder gevormd voorlopig oordeel dat hij na heroverweging niet juist acht."
\end{abstract}

Op het grondbeginsel van de bestuurlijke heroverweging, dat de beslissing op het bezwaarschrift dient te steunen op de feiten en omstandigheden ten tijde van het beslissingsmoment is een nuancering op zijn plaats. Die nuancering van het ex nunc-beginsel betekent dat het beoordelingsmoment bij wijze wan uitzondering wordt verlegd naar de situatie ten tijde van de aanvraag van het bestreden besluit. Deze uitzondering vormt tevens het "tweede uitgangspunt" ten aanzien van het beoordelingsmoment bij de beslissing op het bezwaarschrift. In dit geval mogen naderhand gewijzigde feiten en omstandigheden er niet toe leiden dat een aanvankelijk onthouden gunstige beslissing alsnog wordt uitgesloten. Als voorbeeld kan hier worden genoemd de omstandigheid dat in het kader van de heroverweging blijkt, dat het bestuursorgaan iemand in strijd met een subsidieregeling over een bepaalde periode deze subsidie ten onrechte heeft geweigerd. In dit laatste geval behoort het beoordelingsmoment de subsidieperiode te bestrijken. ${ }^{74}$

Dit voorbeeld van de subsidieregeling geeft aan dat uit de regeling kan worden afgeleid dat een toetsing ex nunc in het kader van de heroverweging niet in de rede ligt. De hernieuwde beoordeling van de feiten en omstandigheden dient in zulke gevallen te worden gefixeerd naar de stand van de gegevens op een eerder tijdstip."

23 ARRS 17 matr. $1993,4 B / S 1993,25 \mathrm{~m}, \mathrm{nt}$. B.W.N. de Ward. Zie overigens in dit verband ook de uitspraken $V_{Z}$. ARRS 20 januari 1987, tB/S 1987, 9 (Brandweerkazerne Armerongen) wn ARRS 19 juli 1987, UBS 1987, 114 (Uitrit Stad Delden). Bij die lagtste uitsprablk overwoog de ARRS overigens wel dat de ard wan de bezwarschriftenprocedure met zich kan brengen dat een gunstige besllissing alsnog ongedaan kan worden gemaakt. De afdeling verbond aan deze standpuntwigiging wel de condite dat indien nieuwe relevante gegevens ontbreken tot een ongunstige wijziging van het anvankelijke besiluti kan worden overgegaan indien heroverweging van de ook bij het primaire besiuit betrokken gegevens tot deze gewijzigde (ongunstige) besissing adnleiding gever. Zie voor een koerswigziging ABRS 21 april 1997, Gsi. 7075, $7 \mathrm{~m}$.nt. J.M.H.F. Teurissen.

7.4 J.B.J.M. ten Berge, Bescherming tegen de overheid, tweede dr, Zwolle 1994, p. 164 e.v.

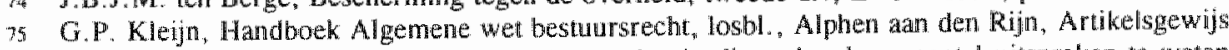
Commentar Artikel $7: 11$, p. 3. Vermeld worden in dit verband een aantal uitspraken te weten CBB 6 juli 1993. ABkott, 93, Vz. ARRS 12 april 1993, 18/S 1993, 53, V2. ARRS 17 mei 1991 , LB/S 1991, 67 en ARRS 18 jun 1991, tB/S 1991, 79. Ex tunc toetsing blijkti overigens ook voor de hand te liggen buj de toepassing var subsidieregelingen waarbij op basis varn een tendersysteem cen beoordeling van de aanwagen dient plaats te vinden. 
Naast de aard van de regeling kan ook uit de aard van het besluit, een heroverweging ex tunc gellndiceerd zijn. ${ }^{76}$ In die gevallen is slechts een beoordeling ex tunc mogelijk omdat conform de regeling slechts een beperkt aantal aanvragen wordt gehonoreerd. Te denken valt hier bijwoorbeeld aan de uitgifte van standplaatsen voor marktdagen. De bovengenoemde sitwatie doet zich eveneens voor bij deadline-regelingen. De regeling geeft in dit soort gevallen aan dat een aanvrage vớr een bepaalde datum moet zijn ingediend.

In deze categorie van gevallen is het tijdstip (ex tunc) van indiening van de aanvragen van beslissende betekenis. Ter illustratie van dleze "deadline-regelingen" 7 , kan bijwoorbeeld worden gewezen op de door de Stichting Watersnood Particulieren verstrekte aanvraagformulieren voor het verkrijgen van een uitkering krachtens het Uitkeringsreglement Watersnood 1995. Daarbij gold het procedurevoorschrift dat het schademeldingsformulier vóor een bij de regeling vastgestelde datum moest zijn ingediend. Het spreekt voor zich dat bij een heroverweging in het kader van een bezwaarschriftenprocedure een hernieuwde afweging beperkt dient te zijn tot een ex tunc situatie (in casu het tijdstip van de indiening van het aanvraagformulier).

Deze beperking van de heroverweging tot een ex tunc beoordelingsmoment kan er zelfs toe leiden dat gesproken kan worden van een niet voor herstel vatbaar bezwaar. Hierna volgen enige rechterlijke uitspraken die een aardig beeld geven van omstandigheden, waaronder heroverweging zelfs de facto lijkt uitgesloten. Wél heeft de bezwaarde soms de mogelijkheid om een nieuwe aanvraag in te dienen.

De staatssecretaris van LNV had een afwijzende beslissing genomen op een bezwaarschrift in het kader van de Regeling registratie diergeneesmiddelen. Ten behoeve van de besluitvorming in primo waren onvoldoende gegevens overgelegd. Het CBB owerwoog in beroep, welk beroep overigens werd verworpen dat de betreffende regeling stringente eisen stelt aan het aanleveren van gegevens. Kern van de overweging van het $\mathrm{CBB}$ was dat indien de wetgever de beoordeling van een aanvrage bindt aan gegevens die zijn verstrekt vóór het verstrijken van een in die regeling gestelde tijdslimiet, dit gevolgen heeft voor de te maken heroverweging in het kader van de bezwaarschriftenprocedure. Deze omstandigheid bracht in deze zaak met zich dat het CBB tot het oordeel kwam dat de indliening van een bezwaarschrift er niet toe behoefde te leiden dat de aanvankelijke afwijzende beslissing zou moeten worden heroverwogen. Die laatste

76 G.P. Kleijn, a.w. Zie ook CrvB 25 februari 1997, AB 1997, 238; JB 1997. 71 en AB 1997, 341.

7) Zie in dit verband: G.P. Kleijn, a.w. 
opvatting was gebaseerd op het bindend karakter van het aan de bovengenoemde regeling ten grondslag liggende voorschrift. ${ }^{38}$

Ook in een andere zaak die diende voor het CBB werd een gelijkluidend oordeel uitgesproken. De casus betreft een GSM-zaak (Mobiele telecommunicatie). Het CBB overwoog hier samenvattend als volgt:

(...) De aanvraag van verzoekster om in aanmerking te komen voor toewijzing van de tweede GSM-vergunning wordt niet in behandeling genomen omdat zij niet voldoet aan de gestelde eisen en de werstrekte gegevens en bescheiden bovendien onvoldoende zijn voor de beoordeling van de aanvraag. De daartegen opgeworpen bezwaren worden verworpen. De inschrijwingsprocedure vergt strikte discipline en dat betekent dat cen aanvraag in beginsel compleet moet zijn. Ook de bezwaarprocedure in het kader van de Awb biedt i.c. geen grondslag voor het aanvullen van gegevens. Verzoekster kan geen aanspraak maken op een bijzondere behandeling."

Ten aanzien van de problematiek van de onvolledigheid van gegevens in het kader van een aanvraag om vergunning wordt opgemerkt, dat deze onvolledigheid van gegevens niet steeds behoeft te leiden tot een niet herstelbaar gebrek in de bezwaarprocedure. De bovengenoemde regellingen zijn immers van bijzondere aard en gebaseerd op een wettelijke regeling van strikt formele aard. Doorgaans is art. 4:5 Awb van toepassing. Dit artikel formuleert een aantal strikte eisen met betrekking tot de situatie dat een aanvrager niet heeft voldaan aan 'enig wettelijk voorschrift' voor het in behandeling nemen van een aanvraag. Het artikel ziet tevens op de omstandigheid dat de aangereikte gegevens bij de aanvraag onvoldoende zijn voor de beoordeling. Uitgangspunt van het eerste lid van art. 4:5 Awb is, dat het bestuursorgaan de bevoegdheid heeft om een onvolledige aanvraag niet te behandelen. Deze bevoegdheid (geen verplichting) kan eerst dan worden gehanteerd nadat de aarvrager de gelegenheid is geboden tot herstel van thet verzuim binnen een daartoe te stellen termijn.

Enkele uitspraken hebben inmiddels geleerd dat in het kader van de heroverweging van het bezwaarschrift het bestuursorgaan 'subtiel" dient om te gaan mer zijn bevoegdheid om een aanvraag niet in behandeling te nemen en kritiscla de omstandigheden van het geval onder ogen behoort te zien. De uitkomst van de 
heroverweging tijdens de bezwaarprocedure moet het resultaat zijn van een zorgvuldige hernieuwde beoordeling. ${ }^{20}$

Een bijzonder probleem, waarbij een ex tunc beoordeling uitgangspunt is, dient zich aan in die gevallen dat de betreffende wetgeving een specifiek bestuursinstrumentarium kent. De huidige WW heeft een antal specifieke bestuursinstrumenten voor die gevallen dat er sprake is van een bouwwerk in de zin van de WW. De nieuwe WW kent de figuur van de meldingsplicht als bedoeld in art. 42 . Indien een bouwwerk conform de krachtens dit artikel vastgestelde a.m.v.b. is gemeld (Besluit meldingsplichtige bouwwerken), betekent dit voor zover hier van belang, dat de aspirant-bouwer van het betreffende bouwwerk kan volstaan met het melden van de voorgenomen uitvoering van het bouwwerk aan het bestuursorgaan. B en w moeten hier op grond van de WW reageren met het al dan niet akkoord verklaren van het gemelde bouwwerk. Reageren $b$ en w niet binnen de in de WW gestelde termijn, dan ontstaat er rechtens een fictieve akkoordverklaring. Deze fictieve akkoordverklaring is gericht op rechtsgevolg en heeft het karakter van een besluit in de zin van art. 1:3 Awb. Een eventuele strijdigheid met bepalingen van welstand doet hier niet aan af. Het constituerend karakter van de meldingsfigur staat niet toe dat $\mathrm{b}$ en $\mathrm{w}$, los van een bezwaar deze fictieve melding intrekken. Intrekking op grond van een ingediend bezwaar - de fictieve akkoordverklaring is immers een besluit - is niet mogelijk. De WW kent deze intrekkingsgrond niet. Samenvattend overwoog de ABRS als volgt:

"Het staat b en w niet vrij om anders dan op basis van een ingediend bezwaarschrift tot herroeping over te gaan. Evenmin kunnen zij deze fictieve akkoordverklaring intrekken, aangezien de wel wel een vorm van vervallen door tijdsverloop kent (artikel 42, lid 10), doch niet in het intrekken van een mededeling voorziet. Ook mogen zij niet het effect van een herroeping of intrekking trachten te bereiken door alsnog de mededeling te doen uitgaan dat bouwvergunning is vereist; de totstandkoming van een fictieve mededeling staat eraan in de weg dat nadien nog daadwerkelijk op de melding wordt gereageerd. ${ }^{38}$

Ook Steenbeek en Stroink hebben in het verleden gewezen op terminologische problemen die aanleiding kunnen geven tot 'een bron van moeilijkheden' in het kader van de behandeling van bezwaarschriften. Het hier bedoelde probleem diende zich aan in die gevallen dat een oorspronkelijk verleende bouwvergunning op basis van een ex tunc-beoordeling ongedaan moest worden gemaakt. Probleem vormde de omstandigheid dat de intrekkingsgronden op basis van art. 52 (oud)

80 Cbsf 23 maart 1995, JB 1995, 117, CBB 17 mei 1995, JB 1995, 175, mett verwifzende noot naar JB 1995, 117 en L.J.A. Damen, De minister die wél moest anticiperen in: Rechtspratak Bestuursrecht 1994-1995: de annotaties, "s-Gravenhage, p. 211 e.w. 
WW niet betrekking hadden op de situatie dat een aanvankelijk verleende bouw vergunning achteraf rechtens onjuist was verleend. Intrekking van de bouwvergunming in het kader van de beslissing op het bezwaarschrift was op grond van het oude art. 52 WW niet mogelijk. ${ }^{* 2}$

De bestuursrechtelijke praktijk heeft overigens dit probleem opgelost door het kiezen van de formule van het 'alsnog weigeren' van de bouwvergunning. In ieder geval kiest ook de hoogste bestuursrechter voor het gebruik van de terminologie van het 'alsnog weigeren' van de bouwvergunning. ${ }^{* 3}$

Een niet voor herstel in bezwaar vatbaar gebrek, kan ook een rol spelen in die gevallen dat verplichte inschakeling van eer wettelijk adviseur is voorgeschreven en de systematiek van de wet bepaalde gevolgen verbindt aan het verstrijken van de beslistermijn. In een aanvraag in het kader van een "erkenningsprocedure" ex AWBZ was niet tijdig beschikbaar het dwingend voorgeschreven adwies van de Ziekenfondsraad. Ondanks het gemis van dit advies werd door de minister van VWS een primaire beslissing genomen op de aanvrage om erkenning. De betrokken stichting had hiertegen bezwaar gemaakt. Het advies van de Ziekenfondsraad bereikte de Minister (alsnog) ná de primaire besluitvorming. Daarop besliste de Minister met toepassing van art. 6:18, lid $1 \mathrm{Awb}$ wederom afwijzend op het verzoek om erkenning.

Art. 6:19, eerste lid Awb bepaalt, dat de toepassing van een bestuurlijke bevoegdheid ex art. 6:18 met zich brengt dat het bezwaar en het beroep mede geacht wordt gericht te zijn tegen het 'gecorrigeerde' besluit, behoudens de omstandigheid dat aan het bezwaar of het beroep volledig wordt tegemoet gekomen. De Vz. ABRS was stellig in zijn overwegingen. Hij constateerde strijd met de kennisvergaringsplicht als bedoeld in art. 3:2 Awb vanwege de onzorgvuldige voorbereiding (het bestuursorgaan draagt het risico voor het gemis van een wettelijk voorgeschreven advies). Tevens knoopte hij toetsend 'ex turic' daaraan vast dat de systematiek van de AWBZ zich niet leent woor herstel van gebreken van het besluit in primo in de bezwaarschriftenprocedure. Hierop volgde schorsing van de (eerste) primaire beschikking. ${ }^{* 4}$ Voor de duidelijkheid en ter wille van de volledigheid wordt hierbij opgemerkt, dat zich de geschetste situatie bijwoorbeeld niet zal woordoen bij primaire beslissingen ontrent bouwaanvragen, waarbij het welstandsadvies ontbreekt. De beslistermijn van de WW op bouwaanvragen is immers van een adhortatief karakter; wan een fatale termijn kan

92 F.A.M. Stroink, Wet administratieve rechtspraak overheidsbeschikkingen, vierde herziene $\mathrm{dr}$, "s. Gravenhage 1988, p. 400 en 401 .

83. PG Awb II, p. 471.

84 VZ, ABRS 7 juli 1995, AB 1996, 177. 
hier niet worden gesproken. Dit laatste betekent dat b en $w$, beslissend op een bezwaarschrift, alsnog een ontbrekend welstandsadvies in hun besluitworming kunnen 'meenemen'.

In bijstandszaken zien besluiten op aanwragen naar hun aard op de toestand tot en met de datum waarop deze besluiten zijn genomen. Indien bijvoorbeeld een RWW-uitkering wordt aangevraagd en vervolgens een bezwaarschrift tegen het primaire besluit wordt ingediend, wordt de heroverweging beperkt tot een toetsing ex tunc. Aard en strekking brengen hier mede dat het object van het geschil ('op grondslag' van het bezwaar) beperkt wordt tot het beoordelingstijdvak ten tijde van het primaire besluit. Een volledige heroverweging in de zin van een ex nunc-toetsing vindt dan niet plaats. Wijzigingen in de omstandigheden ná het primaire besluit behoren te leiden tot een nieuwe aanvraag. ${ }^{85}$ Deze benadering van het CRvB lijkt juist. Zou voor een ex nunc-benadering worden gekozen, dan zou het in de bezwaarschriftenprocedure alsnog betrekken van feiten en omstandigheden die buiten het 'object' van het primaire besluit liggen, met een heroverweging als bedoeld in art. 7:11 niets meer van doen hebben. Van een beslissing op een bezwaarschrift zal in casu niet meer kunnen worden gesproken. Een nieuw primair besluit ziet alsdan "het licht". ${ }^{\text {sh }}$

Soms kan thet ex nunc-beginsel onder druk komen te staan bij het opnieuw voorzien in de zaak, waarbij het bestuursorgaan alsnog een nieuwe beslissing op het bezwaarschrift moet nemen (art. 8:72 Awb). Ook onder de werking van de Wet arob, kende de ARRS in art. 99 vóór 1 januari 1994 in het kader van de uitspraakbevoegdheden van de administratieve rechter, deze mogelijkheid. Terwille van de beperking van deze problematiek wordt hierbij verwezen naar de relevante literatuur. ${ }^{87}$ De jurisprudentie biedt soms weinig houvast voor die gevallen waarin bestuursbesluiten zijn vernietigd en terugverwijzing naar het bestuursorgaan heeft plaatsgevonden. In het kader van de evaluatie van het nieuwe bestuursprocesrecht wordt de problematick van de duidelijkheid ten aanzien van het nader te nemen besluit benadrukt. De effectieve en definitieve afdoening van het geschil zou hierdoor in gevaar komen. Er wordt voor gepleit dat de bestuursrechter zorgvuldiger zou moeten stilstaan bij zijn formulering van de uitspraak. Aan art. 8:72, vierde lid zou betere toepassing behoren te worden gegeven. ${ }^{\text {s }}$ 254.

86 CRvB 28 februari 1995, RSV 1995, 201.

87 Zie in dit verband O.a.: B.J. Schueler, Vernietigen en opnieuw voorzien, Zwolle 1994.

88 J.B.J.M. ten Berge e.a. Ervaringen met de Awb, a.w., p. 228 e.v. (4.4 Effectieve afdoening van hell geschill). 
Toch is het niet zonder betekenis er op te wijzen dat het verplicht opnieuw voorzien in de zaak tot een beperking van de heroverweging kan leiden; een beoordeling ex nunc in het kader van de nieuwe beslissing op het bezwaarschrift is soms als algemeen uitgangspunt uitgesloten. De arob-rechtspraak geeft in dit verband enkele fraaie voorbeelden van jurisprudentie te zien. Vanwege het belang worden hierna summier en bij wijze van voorbeeld enkele arob-zaken aangehaald.

In een zaak van een Pakistaanse vreemdeling ging de ARRS opnieuw over tot vernietiging van de nieuwe beslissing. Door ex nunc te toetsen kwam betrokkene in een slechtere positie te verkeren. De staatssecretaris van Justitie werd verweten dat hij had getalmd met zijn nieuwe beslissing. Als hij tijdig ná de uitspraak van de arob-rechter zou hebben beslist zou deze in een betere positie hebben verkeerd. Uitgesproken werd dat de Staatssecretaris zich niet mocht beperken tot een beoordeling van de situatie zoals die tijdens het opnieuw voorzien in de zaak, bestond. Deze was ongunstiger voor de betrokken vreemdeling. Het verzoek om een verblijfsvergunning moest naar het oordeel van de ARRS worden beoordeeld met inachtneming van een in de tijd begrensde periode. De Staatssecretaris had rekening moeten houden met de situatie zoals die zou zijn geweest als deze in overeenstemming met het recht had beslist. ${ }^{\text {"9 }}$

Een andere beperking van een beoordeling ex nunc kan voortvloeien uit de situatie, dat hel bestuursorgaan een beslissing op het bezwaarschrift ziet vernie tigd omdat een niet-ontvankelijkheid had behoren te worden uitgesproken door het bestuursorgaan. In dit laatste geval kan het bestuursorgaan in het kader van de nieuwe beslissing op het bezwaarschrift volstaan met alsnog het bezwaarschrift niet ontvankelijk te verklaren. Zoals uit art. 7:11, lid 1 blijkt, behoort dan geen heroverweging plaats te vinden.

Heroverweging van feiten en omstandigheden wordt in dit geval uitgesloten 'met behulp' van de uitspraak van de bestuursrechter.

Weer een andere beperking van de beoordeling ex nunc kan gelegen zijn in het feit, dat de betreffende regeling op grond waarvan een aanvrage wordt ingediend ziet op eenmalige gebeurtenissen, waaraan rechtsgevolgen zijn verbonden. In dit geval moeten de feiten ten tijde van de eenmalige gebeurtenis het beoordelingsmoment vormen yoor de beslissing op het bezwaarschrift. In de hier bedoelde zaak had dit tot gevolg dat $\mathrm{b}$ en $\mathrm{w}$ de betreffende bepaling van de Beschikking geldelijke steun huisvesting gehandicapten hadden miskend. De medische noodzaak voor de verhuizing diende in het kader van de beslissing op het be- 
zwaarschrift beoordeeld te worden aan de hand wan het moment waarop de gehandicapte de nieuwe woning betrekt. In dit geval moest de medische gesteldheid van de bezwaarde niet worden beoordeeld naar de toestand ten tijde van de beslissing op het bezwaarschrift. De beslissing op het bezwaarschrift werd immers veel later genomen. Een wettelijke regeling die zich richt op eenmalige gebeurtenissen kan daarom nopen tot een toetsing ex tunc."1

Een andere beperking van de beoordeling ex nunc bij de heroverweging kan ook ontstaan doordat een nieuwe aanvraag wordt ingediend nadat het bestuursorgaan op een identiek verzoek een geheel of gedeeltelijk afwijzende beslissing heeft genomen. Art. 4:6 codificeert hier de jurisprudentie onder de werking van de Wet arob door van de aanvrager te eisen dat deze alsdan in zijn nieuwe aanvraag melding moet maken van nieuw gebleken feiten en omstandigheden. Art. 4:6, lid 1 omvat met het tweede lid de problematiek van het ne-bis-in-idem-beginsel. Uitgangspunt van dit beginsel is, dat de rechtsbeschermingsvoorziening aan zijn doel voorbij zou schieten indien andermaal het bestuur wordt ingeschakeld om over dezelfde aangelegenheid wederom een beslissing te nemen. ${ }^{y z}$

Het eerste lid legt daarom een versterkte informatieplicht op aan de aanvrager. Het tweede lid van art. 4:6 geeft een verdere uitwerking van het eerste lid te zien. Indien geen nieuwe feiten of veranderde omstandigheden worden vermeld, kan het bestuursorgaan zonder toepassing te geven aan art. 4:5 (aanvulling onvolledige aanvraag) de aanvraag afwijzen onder verwijzing naar zijn eerdere beschikking.

Ook het tweede lid van art. 4:6 Awb, vormt de weerslag van de arob-jurisprudentie. ${ }^{y 3}$ Met enige nadruk wordt hierbij opgemerkt dat onder nieuw gebleken feiten en omstandigheden niet wordt begrepen de situatie dat het recht wordt gewijzigd. Is dat laatste het geval dan kan een nieuwe aanvraag conform het nieuwe geldende recht worden ingediend. ${ }^{94}$ Voor de volledigheid wordt hierbij opgemerkt dat onder het begrip 'recht' ook in het licht van het vorenstaande, gewijzigde jurisprudentie zou kunnen worden betrokken. In een zaak over de toepassing van de Bopa-regeling bleek dat de ARRS gewijzigde jurisprudentie in andere zaken niet ziet alls reden woor heroverweging indien betrokkene geen rechtsmiddel heeft aangewend tegen een afwijzende beschikking. Dienaangaande overwoog de ARRS:

91 ARRS 18 februari 1988, $1 B / S$ 1988, 22, m.nt. J.B.J.M. ten Berge.

2. PG Awb I, p. 245.

9 R.W.L. Loeb, B.K. Olivier en H. Troostwijk, De Wet arob toegepast, vierde dr, Nijmegen 1990, p. 21 e.v.

9.4 PG Awb I, p. 246. 
'De Afdeling is met verweerder van oordeel dat de uitspraak van de Centrale Raad van Beroep van 24 juni 1986 niet kan worden aangemerkt als een nieuwe terzake dienende onstandigheid die hem tot heroverweging had behoren te leiden. Deze uitspraak heeft betrekking op - en kan naar haar aard ook slechts betrekking hebben op - de daarin aan de orde zijnde rechtsbetrekking tussen partijen in dat geding, waartoe appellante niet behoorde. ${ }^{\text {ys }}$

Voor wat betreft de problematiek van de herhaalde aanvraag en de beoordeling daaromtrent in het kader van de bezwaarschriftenprocedure, blijkt inmiddels dat de Awb-jurisprudentie een voortzetting is van "het beeld' ten tijde van de Wet arob. Indien geen nieuwe feiten of veranderde omstandigheden worden aangedragen kan de herowerweging worden beperkt. Van een strikte toetsing ex nunc kan. niet worden gesproken omdat het bestuursorgaan kan volstaan met te verwijzen naar zijn eerdere afwijzende beschikking. ${ }^{*}$ Vanzelfsprekend hoort hierbij de aantekening dat het bestuursorgaan steeds voor ogen moet houden, dat het in beginsel behoort te voldoen aan de kennisvergaringsplicht als bedoeld in art. $3: 2$. Dit laatste wil zeggen dat het vanuit het perspectief van de formele zorgvuldigheidsnorm als bedoeld in art. 3:2 Awb voor het bestuursorgaan op straffe van vernietiging door de bestuursrechter, 'veiliger' is om bij een herhaalde beoordeling in het kader van het heroverwegingsproces kritisch te kijken naar de aangedragen feiten en omstandigheden.

Als uitgangspunt zou hier kunnen worden gekozen de aard van de feiten en omstandigheden, alsmede de mogelijkheid of de aard daarvan aanleiding zou kunnen geven tot een andere beslissing. Beide criteria zijn genoemd als handvatten voor een herhaalde beoordeling in het kader van de toepassing van art. 4:6," Vanzelfsprekend ligt het voor de hand deze criteria te "enten' op het heroverwegingsproces in het kader van de bezwaarschriftenprocedure. Tot welk een actieve opstelling de bestuurstechter het bestuursorgaan 'oproept', blijkt uit een uitspraak waarbij een nieuwe aanvraag ter beoordeling stond. In deze zaak werd geoordeeld dat het bestuursorgaan niet alleen rekening behoort te houden met de feiten en omstandigheden ten tijde van de aanvraag, maar ook met later opkomende omstandigheden.

ARRS 5 september $1991, \mathbb{B} / S_{*} 118$, m.nt. B.W.N. de Waard. Met verwijzing naar de annotatie moet overigens voorzichtigheid worden betracht. Uitspraken wan de CRvB geven zonder daar overigens op in te gaan aanleiding tot enige terughoudendhe id in lhet genoemde standpunt.

9 PG Awb 1, p. 245. 
Het betrof hier een kwestie in een voorlopige voorzieningszaak, waarbij een RWW-uitkering met terugwerkende kracht was ingetrokken.

Dienaangaande overwoog de rechtbank-president:

\begin{abstract}
'Verweerders hadden ar daarom van moeten uitgaan dat verzoeker op 6 april 1994 ook formeel geen uitkering meer ontwing. Het feit dat het besluit van 14 april 1994 nog niet in rechte onaantastbaar was geworden maakt dit niet anders. Een beslluit als dit treedt in werking zodra het is bekend gernaakt, terwijl ingevolge artikel 6:6 Awb bezwaar de werking van het besluit waartegen het is gericht niet schorst. Het vorenstaande betekent dat verweerders bij het nemen van hun beslissing op de aanvraag hadden moeten nagaan of sedert de beeindiging van de uitkering per 1 maart 1994 sprake is van zodanig gewijzigde omstandigheden dat verzoeker wederom in aanmerking komt voor een RWW-uitkering.
\end{abstract}

\title{
1.4.3. Conclusies
}

De in de vorige paragraaf onderzochte uitspraken tonen aan dat op grond van uiteenlopende omstandigheden van het vaste patroon van een ex nunc-beoordeling in de bezwaarschriftenprocedure moet worden afgeweken. De waardering van de feiten en omstandigheden wordt daardoor naar een eerder tijdstip verschoven dan het moment wan de beslissing op het bezwaarschrift. Dit eerdere beoordelingsmoment leidt dan tot een beperking van de heroverweging ex nunc. De beslissing op het bezwaarschrift moet hierdoor ten grondslag liggen aan de feiten en omstandigheden zoals deze bestonden vóór de beslissing op het bezwaarschrift. De omvang van de beslissing op het bezwaarschrift wordt beperkt tot een ex tunctoetsing.

Samenvattend ontstaat het volgende beeld van de toetsing ex tunc en is deze geindiceerd in de volgende gevallen, te weten:

1. door de aard van de regeling:

2. door de aard van het bestreden besluit;

3. bij het opnieuw voorzien in de zaak, ingeval van een uitgesproken vernietiging van de beslissing op het bezwaarschrift;

4. bij een ingediend herhaald verzoek;

5. bij een vernietiging van een besluit, voorzover het betreft de ontvankelijkheid van het bezwaarschrift;

98 Pres. Rb. Groningen 4 juli 1994, Awb-katern 1995, 64 en H.J. Simon, Handleiding Awbpraktijk, "s-Gravenhage 1995, p. 208 . 
6. op grond van de algemene beginselen van behoorlijk bestuur, met name het rechtszekerheidsbeginsel.

Ten aanzien van het gestelde in punt $6 \mathrm{kan}$ nog het volgende worden opgemerkt.

Soms kan een verplichte heroverweging ex tunc door het bestuursorgaan in het belang van de bezwaarde burger geboden zijn op grond van het rechtszekerheidsbeginsel. Hierdoor wordt voorkomen dat een verslechtering van de positie van de justitiabele zal optreden; vermeden wordt dat een 'reformatio in peius-situatie' ontstaat. ${ }^{9}$ In die gevallen dat de burger zijn financiële aanspraken tracht geldend te maken, bijvoorbeeld bij subsidiëring, wordt door de bestuursrechter gekozen voor het rechtszekerheidsbeginsel. Een beoordeling ex tunc kan hier compenserend werken doordat de rechter oog heeft voor de ongelijke positie van de justitiabelle ten opzichte van het bestuursorgaan. Indien het bestuursorgaan door gedragingen de schijn op zich heeft geladen van bestuurlijke trucjes ten nadele van de justitiabele, tracht de rechter een dergelijke handelwijze in te dammen. Zonder dat de administratieve rechter overigens motiveerde waarom hij in de hierna te noemen zaak een nieuwe omstandigheid niet in zijn oordeel betrok, bleek uit de rechterlijke overwegingen:

-De beslissing in eerste aanleg is genomen op grond van een bij verweerders levende misvatting. In de beslissing op het bezwaarschrift hebben verweenders dil aspect niet laten meewegen, omdat appellante heeft nagelaten de misvatting te verhelpen in een mondeling overleg, dat aan de beslissing in eerste aanleg vooraf ging. Het karakter van de bezwaarschriftenprocedure veronderstelt een volledige heroverweging en een i.c. alsnog subsidiabel stellen van de activiteiten van verzoekster. Gelet op het karakter van de bezwaarschriftenprocedure kan de omstandigheid, dat de beschikbare gelden inmiddels zijn uitgeput, de bestreden beschikking niet dragen. ${ }^{\text {'t00 }}$

De Limburgse Vereniging wan Voswerkgroepen kreeg in deze zaak haar gelijk. Met Ten Berge moet worden onderschreven dat de administratieve rechter met evenveel recht tot een ander beoordelingsresultaat had kumnen komen. Het geld was immers op, hetgeen als een "nieuw feit" de balans ten nadele van de vereniging had kunnen doen omslaan. Het 'rechtsgevoel' en de 'eis van rechtvaardigheid" lijken terecht naar de mening van Ten Berge te prevaleren boven elke juridische "spitsvondigheid".

b9 Zue in dit werband: noot 89 betreffende de zaak van de Pakistaanse vreemdeling.

$100 \mathrm{Vz}$. ARRS 16 december 1983 , $\mathrm{BB} / \mathrm{S} \mathrm{II}, 142 \mathrm{~m}$.nt. J.B.I.M. ten Berge. 
Ofschoon is komen vast te staan dat de uitgangspunten van een volledige heroverweging ex nunc kunnen worden beperkt, wil dit niet zeggen dat het beginsel van een toetsing ex nunc in de bezwaarschriftenprocedure wordt weggedrongen. Uitgangspunt is en blijft dat heroverweging op grondslag van het bezwaar dient te geschieden op basis van een beoordeling ex nunc. Naar zijn aard biedt de bezwaarschriftenprocedure de mogelijkheid voor het bestuursorgaan om rekening te houden met de (nieuwe) feiten en omstandigheden op het tijdstip van de beslissing op het bezwaarschrift.

Het onderzoek heeft aangetoond dat het heroverwegingsproces in de bezwaarschriftenprocedure, voor wat betreft de omwang, gekenschetst wordt door een drietal hierna volgende dimensies ${ }^{101}$ die daarmede de beoordelingsruimte van het bestuursorgaan nader inkaderen.

Dit betekent in de eerste plaats dat bij de hernieuwde afweging ten aanzien van een bezwaarschrift, voldaan dient te worden aan ruime criteria. Deze criteria dienen op grond van de bestuurlijke heroverwegingsplicht nader te worden ingevuld aan de hand van de eisen van het recht, de doelmatigheid en het beleid. Het besluit en het bezwaar vormen tezamen het voorwerp van het geschil en de grondslag voor de beoordelingsruimte (tweede dimensie). Ook in die beoordelingsruimte ligt een behoorlijke 'rek' opgesloten voor wat betreft het antwoord op de vraag in welke mate 'het twistpunt' moet worden afgebakend. De derde dimensie wordt bepaald tot de problematiek van de beoordeling ex nunc of ex tunc. Daarbij geldt het uitgangspunt van het beoordelingstijdstip. Belangrijke scharnierpunten vormen hier het moment van het bestreden besluit en thet tijdstip van de beoordeling in bezwaar of beroep.

Uitgangspunt voor de beslissing op het bezwaarschrift is "globaal" het moment dat op het bezwalarschrift wordt beslist, behoudens de omstandigheid dat daarop uitzonderingen bestaan. Toch doen die uitzonderingen niet tekort aran de bestuursrechtelijke uitgangspunten: het bestuur toetst ex nunc, de rechter toetst ex tunc. ${ }^{\text {in }}$ De 'houdbaarheid" van deze conclusie komt in de jurisprudentie als volgt tot uitdrukking:

- De rechtbank constateert dat verweerder na het indienen van het bezwaarschrift wel binnen de beslistermijn heeft gehoord, maar vervolgens eerst in jan. 1995 (derhalve na ruim acht maanden) een beslissing op het bezwaar heeft genomen. Door eerst ná zo'n tijdsverloop een beslissing te nemen loopt een bestuursorgaan het risico dat uitgegaan wordt van verouderde feiten en omstandigheden. Verweerder heeft naar een eventuele

101 J.B.J.M. ten Berge, a.w., p. 137 e.v.

102 J.B.J.M. ten Berge, a.w. 
wijziging van feiten en omstandigheden, in casu de medische toestand van eiseres geen onderzoek gedaan. Voorts is niet gebleken van enig onderzoek maar de door eiseres verlaten woning aan de $V$ an $N$ ispenstraat.

Gelet hierop is geen sprake van een zorgvuldige voorbereiding van het bestreden besiuit zoals bedoeld in artikel $3: 2$. Het besluit komt in zoverre op deze grond voor vernietiging in aanmerking." "os

Aan het eind van dit onderzoek naar de omvang van de heroverweging als bedoeld in art. 7:11 kan aanvullend nog worden geconcludeerd, dat het bepalen van de omvang van de hernieuwde bestuurlijke toetsing, nauwelijks vatbaar is voor het stellen van strikte criteria. Indien van enige 'begrenzing' in de omvang van de beoordelingsruimte kan worden gesproken kunnen. Ten Berge's 'dimensies" hiervoor bruikbare instrumenten zijn. ${ }^{104}$

De heroverwegingsplicht als grondbeginsel voor de beslissing op het bezwaarschrift, blijft daarom een complexe bestuurlijke taak.

Deze gevolgtrekking wordt mede 'gevoed' door het uitgangspunt van de Awb om bij de beslissing op het bezwaarschrift een verslechtering van de positie van de bezwaarde belanghebbende, te vermijden (het verbod van reformatio in peius). Op de inhoud en de betekenis van dit verbod, dat ligt opgesloten in art. 7:11, lid 1 wordt in de volgende paragraaf ingegaan.

1.4.4. Het beginsel van non-reformatio in peius en de omvang van de heroverweging

\subsubsection{De begripsvorming van het beginsel}

In par. 1.4.1 werd een aantal aspecten genoemd dat de omvang bepaalt van de door het bestuursorgaan te maken heroverweging. Het eerste hoofduitgangspunt van art. $7: 11$, lid 1 geeft aan dat het bezwaar "ontvankelijk" moet zijn. Dit uitgangspunt betekent tevens "het vertrekpunt" voor een daaropvolgende belangrijke koppeling: 'heroverweging' moet geschieden 'op grondslag' van her be zwaar. Dit tweede aspect vindt zijn weerslag in de tweede zinsnede van het eerste lid van art. 7:11 en heeft belangrijke gevolgen voor de omvang van de heroverweging.

Enerzijds duidt dit 'grondslagvereiste' op het woorwerp van het geschil. Dit voorwerp van het geschil bepaalt in beginsel de bandbreedte van de discussie over het bestreden besluit. 
Naast het woorwerp wan het geschil heeft het grondslagvereiste van art. 7:11, lid 1 nog een "tweede betekenis", hetgeen er op neerkomt dat de grondslag wan het bezwaarschrift gevolgen heeft voor de omvang van de heroverweging, voor zover het betreft de rechtspositie van de bezwaarde. Die rechtspositie zou als gevolg van het ingediende bezwaarschrift minimaal moeten worden 'geconserveerd'. Beter gezegd, indien de justútiabele bezwaar maakt tegen een besluil moet deze er op kunnen rekenen dat het maken van bezwaar er niet toe leidt dat de beslissing op het bezwaarschrift nog negatiever voor hem uitpakt. Kortom: het maken van bezwaar mag er niet toe leiden dat men als bezwaarde in een nog slechtere positie komt te verkeren dan onder de omstandigheden van de aanvankelijke rechtsgevolgen van het primaire besluit. Of nog anders gezegd: als gevolg van de te maken heroverweging en het nemen van de beslissing op het bezwaarschrifi mag men er even 'slecht' van afkomen als ten tijde van de primaire beslissing of als de heroverweging hiertoe aanleiding geeft, mag het resultaat van de 'tweede' bestuurlijke beslissing 'gunstiger' zijn.

Art. 7:11, lid 1 strekt er toe dat het "grondslagvereiste" een beperking van de heroverweging inhoudt ter bescherming van de rechtspositie van de bezwaarde. In bestuursrechtelijke zin wordt deze beperking gekwalificeerd als een tot het bestuursorgaan gericht verbod van reformatio in peius. Ook in art. 8:69, lid 1 , is bepaald dat de rechtbank uitspraak doet op grondslag van het beroepsschrift. De toelichting bepaalt dienaangaande het volgende:

"In de tweede plaats mag het instellen wan beroep er niet toe leiden, dat de indiener van het beroepsschrift in een slechtere positie komt. Een reformatio in peius in strikte zin is derhalve niet mogélijk.,

Voor de volledigheid wordt hierbij opgemerkt, dat in het kader van het administratief beroep in de MvT in het geheel niet wordt gesproken over de situatie, dat een uitspraak in beroep tot cen uitkomst leidt die de indiener van het beroepschrift in een slechtere positie brengt. Art. 7:25 Awb kent als equivalent van art. 7:11 een terughoudende redactie, waarin het 'grondslagvereiste' niet is opgenomen. Deze redactie van art. 7:25 komt nagenoeg overeen met het bepaalde in het eerste lid van art. $7: 11$ in het wetsontwerp (6.3.16), met dien verstande dat wel de eis wordt gesteld dat het beroep 'ontvankelijk' moet zijn. Art. 7:25 bepaalt het volgende:

105 PG Awb II, p. 463. Zie voor het grondslagvereiste van het bezwaar ook PG Awb I, p. 347 en 348. 
"Voorzover het beroepsorgaan het beroep ontvankeljk en gegrond acht, vernietigt het het bestreden besluit en neemt het voor zover nodig in de plats daarvan een nieuw besluit".

Zonder dat hierbij overigens wordt ingegaan op de problematiek van het verschil in redactie tussen art. 7:11 en 7:25 wordt er op gewezen dat de Awb-wetgever bewust heeft gekozen voor de afwijkende redactie van art. 7:25 ten opzichte van art. 7:11. De argumenten daarvoor zijn gelegen in een materièle nuancering van de toetsingsgronden van het administratief beroepsorgaan, bezien vanuit het gezichtspunt van het (hoger) bestuurlijk toezicht. Formeel is er weliswaar geen inhoudelijk werschil in de toetsingsgronden in het kader van het bezwaar en het administratief beroep; gradueel zijn er wel onderscheidende aspecten te constateren. Dit laatste heeft te maken met de positie van het administratief beroepsorgaan ten opzichte van het "primaire bestuursorgaan". Het herowerwegingsproces in het administratief beroep is materieel van beperktere betekenis. In het kader van de toetsing van het administratief beroep valt met name een terughoudende opstelling te constateren van het beroepsorgaan in die gevallen dat het beleid van een bestuursorgaan dat tot een ander openbaar lichaam behoort, voorwerp is van beroep. ${ }^{3: k 6}$

De vraag kan worden gesteld of het introduceren door de Awb van het beginsel van non-reformatio in peius niet tot 'warrige knopen' leidt, gelet op de aard wan de bezwaarschriftenprocedure als bijzondere bestuurlijke voorprocedure. Deze vraagstelling is niet zonder betekenis wanneer het karakter van deze procedure wordt afgezet tegen de daarop aansluitende bestuursprocesrechtelijke voorziening die immers geheel anders van aard is.

Van het bestuursorgaan wordt immers verwacht om in het kader van de bezwaarschriftenprocedure er op bedacht te zijn, dat het verbod van reformatio in peius niet mag worden geschonden. De gesignaleerde 'anti-verslechteringsaspecten' op grond van art. $7: 11$, id 1, compliceren het verbod van reformatio in peius.

In de MwT van art. 8:69 wordt door de Awb uitgesproken dat een reformatio in peius 'in strikte zin' niet mogelijk is. Deze 'niet strikte' betekenis van het verbod relativeert de $A w b$ als volgt:

'Indien het bestuursorgaan op grond van in de procedure gebleken nieuwe feiten en omstandigheden bevoegd en verplicht zou zijn het bestreden besluit ten nadele van appellant te wijzigen, is er echter onzes inziens geen bezwaar tegen, als de rechter in 
een dergelijk geval zelf in de zaak voorzlet, ondanks het feit dat dit voor de appellant per saldo tot een verslechtering leidt." ${ }^{3}$

Op grond hiervan lijkt de $A w b$ het verbod van reformatio in peius een relatieve betekenis toe te kennen, waarbij het van belang wordt geacht dat "de feiten en omstandigheden' fungeren als elementen voor de niet strikte toepassing van een reformatio in peius. Dit zou er op duiden dat het verbod van reformatio in peius alleen van toepassing is bij een rechterlijke toetsing ex tunc. Het verbod van reformatio in peius zou geen werking hebben in het geval dat er sprake is van "het zelf (ex nunc) voorzien in de zaak'. Een verdere relativering van het verbod van reformatio in peius zou kunnen worden afgeleid uit de MvA:

'dat geen sprake is van overtreding van het verbod van reformatio in peius als in een geschil waarin verschillende appellanten met tegengestelde belangen zijn betrokken, een appellant ten gunste van een of meer van de andere appellanten in een slechtere positie wordt gebracht. De figuur van reformatio in peius is conceptueel ook altijd gesitueerd in een enkelwoudige relatie bestuursorgaan-burger. "

De vraag is hoe het verbod van reformatio in peius nu moet worden uitgelegd en in hoeverre het mogelijk is de gesignaleerde knopen, in bestuursrechtelijke zin te ontrafelen.

Allereerst zijn enkele aanwijzingen te vinden in de MvT van art. $7: 11$. Hieruit is af te leiden dat het bovengenoemd beginsel niet absoluut behoort te worden toegepast.

Uit de parlementaire stukken is ten aanzien van de toepassing van het beginsel van non-reformatio in peius een viertal uitgangspunten geformuleerd. Weit De uitgangspunten zijn de volgende.

1. Wettelijke bepalingen zouden het beginsel kunnen beperken in die gevallen dat deze bepalingen het bestuursorgaan de bevoegdheid geven 'op andere gronden" het besluit te wijzigen ten nadele van de belanghebbende; art. 16

10\% PG Awb II, p. 463. Zie yoor het grondslagvereiste van het bezwaar ook: PG Awb I, p. 347 en 348.

108 D. Allewijn, Beschikkingsprocesrecht in: Het nieuwe bestuursprocesrecht, VAR 112, Alphen aan den Rijn 1994, p. 100.

109 TK 1991/1992, 22495, nr. 6, p. 54 en D. Allewijn, a.w., p. 100. Allewijn geeft in dit verband een voorbeld-casus wit het sociaal-zekerheidsrecht, warin op basis van de enkellvoudige relatie tussen het besuursorgaan en de burger de reformatio in peius conceptueel gesitueerd is. Hij komt tot een naar zijn oordeel curieuze bevindingen. In het kader van het bestek van dit boek wordt hierop niet verder ingegaan.

110 $\mathbb{P G}$ Awb 1, p. 347. 
Awr wordt hier als voorbeeld genoemd om alsnog te weinig geheven belasting in te vorderen.

2. Het wijzigen van het bestreden besluit ten nadele van bezwaarde mag in die gevallen, dat het bestuursorgaan ook zonder een ingediend berwaarschrift bevoegd zou zijn een wijziging ten nadele van bezwaarde 'uit te spreken'; daaraan wordt overigens de voorwaarde verbonden dat belanghebbende niet in zijn verweermogelijkheden in het kader van de bezwaarschriftenprocedure wordt geschaad.

3. Tot een wijziging van het bestreden besluit als bedoeld in punt 2 mag niet worden overgegaan indien betrokkene wél in zijn verweermogelijkheden is geschaad. Een wijziging ten nadele van de belanghebbende moet dan los van de bezwaarschriftenprocedure en wel bij afzonderlijk (primair) besluit geschieden.

4. Het verbod van reformatio in peius geldt niet indien bepalingen van openbare orde in het geding zijn zoals een niet-ontvankelijkheid van het bezwaarschrift en onbevoegdheid van het bestuursorgaan.

Welke conclusies kunnen uit deze aanwijzingen worden getrokken?

Ofschoon de Awb tot aitgangspunt heeft dat er geen verslechtering van de positie van de bezwaarde mag optreden als gevolg van de beslissing op het bezwaarschrift, worden daarop vele uitzonderingen gemaakt."

Daardoor blijft van de inhoud van het verbod weinig over. De wraag kan worden gesteld of voor de bezwaarschriftenprocedure van een strikt verbod van reformatio in peius nog wel gesproken kan worden. Het is daarom raadzaam de inhoudelijke betekenis van het verbod van reformatio in peius in ogenschouw te nemen. Getracht wordt de problematiek van het verbod van reformatio in peius te onderzoeken op basis van de (bestuurs) rechtspraak. Zowel de jurisprudentie in het arob-tijdperk als onder de werking van de Awb, wordt in het onderzoek betrokken.

\subsubsection{De toepassing van het non-reformatio in peius beginsel door de rechter} In de vorige paragraaf werd geprobeerd om het beginsel van non-reformatio in peius wan zijn complexiteit te ontdoen, teneinde zichtbaar te maken wat dit 
beginsel voor de bezwaarschriftenprocedure betekent. Allereerst werd gekeken naar de bedoeling van de Awb. Vast kwam te staan dat er nogal wat omstandigheden zijn waardoor het verbod van reformatio in peius buiten spel wordt gezet. Feitelijk, maar ook rechtens kan door deze "buitenspel-situatie" toch gesproken worden van een verslechtering van de rechtspositie van de belanghebbende justitiabele. Door de wettelijke uitgangspunten wordt de reikwijdte van het verbod beperkt. Als gevolg van het uithollen van het werbod lijkt er weinig van een echte reformatio in peius over te blijven. Daarom kunnen vraagtekens worden geplaatst bij de reformatio-figuur, als 'hoedend' beginsel ter woorkoming van een verslechtering van de positie van de bezwaarde/appellant.

Door de 'duistere' werking van het verbod is het zinvol de praktische betekenis te analyseren aan de hand van enige jurisprudentie.

Bij het jurisprudentie-onderzoek bleek dat het welhaast onmogelijk is voor volledigheid in te staan. Toch is er naar gestreefd een aantal uitspraken te rubriceren waardoor de betekenis, de zin en de toepassing van het verbod kunnen worden getoetst.

Bij de korte bespreking van de casus wordt aangegeven of er al dan niet sprake is wan een reformatio in peius.

Bij de puntsgewijze rubricering van de jurisprudentie wordt een onderscheid gemaakt tussen het arobtijdperk en de periode ná 1 januari 1994. Dit onderscheid is niet zonder belang omdat daarmede ook herkenbaar wordt of er verschillen zijn in de toepassing van het beginsel onder de werking van de Wet arob en de Awb.

\subsubsection{2a. De Wet arob en het verbod van reformatio in peius}

1. Het wijzigen van de gronden in de beslissing op het bezwaarschrift is toegestaan. Fouten of onduidelijkheden in de primaire beslissing alsmede de motivering kunnen op basis van de volledige heroverweging worden hersteld. De gronden voor afwijzing van een subsidie kunnen alsnog worden gewijzigd. Het resultaat van de beslissing op het bezwaarschrift is gelijk aan dat van het besluit in primo: geen subsidie.

Conclusie: geen reformatio in peius. ${ }^{112}$

2. Een wijziging in de (afwijzings)gronden in het kader van de bezwaarschriftenprocedure is toegestaan. Voorwaarde is wel dat bezwaarde in de gelegen-

112 ARRS 13 november 1990, tB/S 1990, 135, m.nt. B en noot B.W.N. de Waard in: $B / S 1992$, 93. 
heid moet zijn gesteld op dit voornemen te reageren. Geen reformatio in peius; toepassing van het zorgvuldigheidsbeginsel " ""

3. Het wijzigingen wan het object van het geschil door het maken van nieuwe toevoegingen in het kader van een aanschrijving tot woningverbetering ex art. $30 \mathrm{WW}$ (oud) is niet toegestaan. Uitbreiding van nieuwe elementen overschrijdt de bevoegdheidsgrenzen van het administratief beroep. Vernietiging van de uitbreiding van de aanschrijving. Van een reformatio in peius kan hierdoor geen sprake zijn..$^{114}$

4. Het alsnog weigeren van een eenmalige uitkering in het kader van de bezwaarschriftenprocedure is rechtens aanvaardbaar. Het zorgvuldigheidsbeginsel noopt tot het aangeven van de gronden, nu niet op grondslag van het bezwaar alsnog een afwijzende beslissing is genomen. Geen reformatio in peius; bij eenmalige uitkeringen geschiedt de beoordeling ex tunc. ${ }^{1 ! s}$

5. Een wijziging van de beslissing op het bezwaarschrift ten nadele van de bezwaarde is niet toegestaan. Gebondenheid van het bestuursorgaan aan de beslissing op het bezwaarschrift (in beroep) in het belang van het rechtszekerheidsbeginsel. Het bestuursorgaan heeft in de bezwaarschriftenprocedure de gelegenheid laten passeren om fouten te herstellen.

Geen reformatio in peius in strikte zin. ${ }^{1 / 4}$

6. Een administratieve fout kan nadat op het bezwaarschrift reeds een beslissing is genomen betrokkene niet alsnog in een nadeliger positie brengen door de aanvankelijke beslissing op het bezwaarschrift te wijzigen en de subsidie (alsnog) te weigeren. Geen reformatio in peius vanwege strijd met het rechtszekerheidsbeginsel.

7. De beslissing op een ingediend bezwaarschrift mag er niet toe leiden dat het bestuursorgaan alsnog terugkomt op een aanvankelijk gegeven interpretatie ten aanzien van de aanspraak op subsidie. Een reformatio in peius is niet

ARRS 12 jamuari 1978, IB/S III, 50, p. $226 \mathrm{~m}$.nt. tB/S en ARRS 4 tebruari $1985, \mathrm{tB} / \mathrm{S} \mathrm{II}, 154$ en noot B.W.N. de Ward in: $\mathrm{B} / \mathrm{S}$ 1992, 93.

Ili ARRS 6 juli 1990, tB/S, 73, m.nt. B.W.N. de Waard.

ARRS 2 september 1991, B/S 1991, 114, m.m. B.W.N. de Waard. 
toegestaan op grond van het vertrouwensbeginsel in samenhang met het dispositievereiste (bezwaarde heeft reeds investeringen gedaan). ${ }^{n g}$

8. Een reformatio in peius in het kader van de beslissing op een bezwaarschrift is toegestaan in die gevallen dat een wettelijke bepaling in casu art. 18b, lid 3 WVW geenszins uitsluit dat de betrokkene door de uitslag van het nader onderzoek in een nadeliger positie mag komen te verkeren ten opzichte van een eerder onderzoek. De geschiktheid voor het verkrijgen van een rijbewijs kan zich in de periode tussen de beide onderzoeken wijzigen. Het schorsingsverzoek naar aanleiding van het ongeldig verklaren van het rijbewijs wordt afgewezen. "

\subsubsection{2b. Het verbod van reformatio in peius onder de werking van de $A w b^{120}$}

1. Vanwege de bevoegdheid tot heroverweging van een bezwaarschrift tegen een beslissing in het kader wan de bijstandsverlening mag een andere grond woor beëindiging van de uitkering worden gehanteerd.

Een nieuwe grond behoort een nieuwe afweging (ex tunc) tot gevolg te hebben. De wijziging van de grondslag behoort in het dictum van de beslissing op het bezwaarschrift te worden opgenomen op grond van het zorgvuldigheids- beginsel en het rechtszekerheidsbeginsel. Aan de vraag of als gevolg van de gewijzigde grondslag ook de ingangsdatum behoort te worden gewijzigd is geen aandacht besteed. Geen rechtsoverweging ten alanzien van een reformatio in peius. ${ }^{121}$

2. De heroverweging als bedoeld in art. $7: 11$, eerste lid Awb op grondslag van het bezwaar, vormt geen beletsel om het primaire besluit ten nadele van de indiener van het bezwaarschrift te wijzigen. Aan deze bevoegdheid is een tweetal voorwaarden verbonden, te weten:

a. de bevoegdheid moet op een andere grond zijn gebaseerd en

b. de indiener van het bezwaarschrift moet niet in zijn verweermogelijkheden zijn geschaad. Van het schaden van de verweermogelijkheden is niet onder alle omstandigheden sprake. Feiten ná het horen zoals een naderhand uitgebracht ambtelijk advies nopen niet steeds tot het gelegenheid bieden van het voeren van verweer. Dit geldt alleen als dit advies nieuwe feiten en omstandigheden inhoudt. Bij het ambtshalve wijzigen van de grondslag van het primaire besluit in casu het vervan-

119 ARRS 13 matart 1990, EB/S, 26, m.nt. J.B.J.M. ten Berge (Pijnacker). 
gen van een bestuursdwangaanschrijving door een dwangsom is er reden geen uitzondering te maken op de plicht tot het gelegenheid bieden van verweer. Het belang daarvan is gelegen in het wijzigen van bestuurs-instrumenten.

Voorts zijn de volgende overwegingen om andere redenen niet zonder belang.

Een vervanging van de bestuursdwangaanschrijving door een dwangsom betekent op basis van het verschillend karakter van de beide bestuursinstrumenten - de dwangsom heeft naar verwachting een grotere effectiviteit - een wijziging ten nadele van 'verzoeker'. Bij de vervanging van een bestuursdwangaanschrijving door een dwangsom is de bevoegdheid van het bestuursorgaan nader geconditioneerd in art 5:36 Awb, waarbij een samenloop van dwangsom en bestuursdwang wordt uitgesloten.

Art. 5:36 Awb (derde tranche) ${ }^{122}$ bepaalt:

Een last onder dwangsom wordt niet opgelegd zolang een terzake van de betrokken overtreding reeds genomen beslissing tot toepassing van bestuursdwang niet is ingetrokken.'

Los van de beslissing in het kader van de bezwaarschriftenprocedure is verweerder 'in elk geval bevoegd' een bestuursdwangaanschrijving in te trekken en te vervangen door een dwangsombeschikking. ${ }^{123}$

3. Gedeputeerde Staten hebben de bevoegdheid om het classificatiebesluit van het waterschapsbestuur gewijzigd vast te stellen. In het kader van de beslissing op een administratief beroep mag deze beslissing voor betrokkene niet tot een ongunstiger resultaat leiden.

Het brengen van betrokkene in een nadeliger positie, verdraagt zich niet met het rechtszekerheidsbeginsel:

'Een en ander klemt temeer nu deze indeling in een hogere klasse niet in uitdrukkelijke bewoordingen doch slechts impliciet tot stand is gebrach. Uit het voorgaande volgt dat het bestreden besluit, voor zover daarbij genoemde percelen in een hogere klasse zijh ingedeeld dan bij het besluit van het waterschap thet geval was, voor vernietiging in aanmerking komt. De Afdeling is van

122 TKK 1993-1994, 23700.

123 Pres. Rb. 's-Gravenhage 11 mei 1995, RAwb 1996, 8, m. aant. G.H.A. 
oordeel dat verweerders bij de voorbereiding en het nemen van hun besluit op dit punt onvoldoende zorgvuldigheid hebben betracht". ${ }^{124}$

4. Toetsing aan de Interimwet ammoniak dient achterwege te blijven. Deze toetsing zou in dit geval leiden tot een lagere depositiewaarde voor de inrichting. Door het instellen van beroep wordt appellant (vergunninghouder) in een nadeliger positie gebracht dan wanneer hij dit beroep niet zou hebben ingesteld. Een zodanige situatie is niet aanwaardbaar "in het licht van de algemene beginselen van administratief procesrecht'. Diezelfde beginselen kunnen niet leiden tot een vernietiging omdat de Interimwet voorschriften geeft ter vermindering van de ammoniakdepositie. Deze woorschriften moeten aan de vergunning worden verbonden. Ter voorkoming van een reformatio in peius wordt een uitspraak contra legem gedaan. ${ }^{12 s}$

5. Toetsing aan de Interimwet ammoniak is verplicht. 'Blijkens de geschiedenis van de totstandkoming van deze wet heeft de wetgever het ongewenst geacht dat de rechter in overeenstemming met het in het administratief recht algemeen geldend uitgangspunt, toetst aan het recht dat gold ten tijde van de vergunningverlening. De rechter heeft in casu geen vrijheid om van de Interimwet af te wijken'. Het verweer wan vergunninghouder tegen een ingesteld beroep dat de toepassing van de Interimwet tot een ongunstig resultaat leidt kan niet slagen. Geen reformatio in peius omdat beroep was ingesteld door een derde belanghebbende. ${ }^{126}$

6. De omstandigheid dat het bestuursorgaan in het kader van de beslissing op het bezwaarschrift er rekening mee houdt dat bezwaarde niet in een slechtere positie komt te verkeren betekent nog niet dat hiermede voldaan is aan de uitgangspunten van het heroverwegingskader van art. 7:11 Awb (toetsing ex nunc). Verweerder heeft zich in het kader van de behandeling van het bezwaarschrift op juiste gronden op het standpunt gesteld, dat de bezwaarde ten onrechte bijzondere bijstand is verstrekt. Terecht diende naar verweerders opvatting de Verordening voorzieningen gehandicapten te worden toegepast (ten tijde van de beslissing op het bezwaarschrift was de oorspronkelijke regeling, te weten de Algemene Autohulpdienst Rotterdam op grond waarvan de aanvrage was beoordeeld, vervallen). Art. 1a, eerste lid ABW verzet zich tegen de verlening van bijzondere bijstand omdat de Verordening voorzienin- 
gen gehandicapten naar haar aard en doel voor bezwaarde een toereikende en passende voorziening is, waarop een beroep kan worden gedaan. B en w hadden gelet op de omstandigheden van het geval op grond van het bepaalde in art. $7: 11$ behoren na te gaan:

a. of de gehandicaptenverordening een ruimere vervoersvergoeding toelaat dan de aanvankelijk verstrekte bijzondere bijstand en

b. of tevens een toepassing van de hardheidsclausule van de verordening gelet op de omstandigheden van de persoon van de bezwaarde tot een hogere vervoersvergoeding had kunnen leiden. ${ }^{137}$

7. Er is geen sprake van een verboden reformatio in peius omdat de tweede beslissing op het bezwaarschrift, betrokkene in een nadeliger positie brengt. De eerste beslissing op het bezwaarschrift leidde er toe dat de hoogte van de scheidingsmuur tot een meter moest worden teruggebracht op basis van een na de hoorzitting uitgebracht verkeerskundig advies. In de tweede hoorzitting bij de nieuwe beslissing op het bezwaarschrift (ná de uitspraak tot gegrondverklaring van het beroep) werd in het verkeerskundig advies een correctie aangebracht en geopteerd voor een toegelaten hoogte van de scheidingsmuur van 75 $\mathrm{cm}$. Het beroep op het verbod van reformatio in peius mist doel:

"Blijkens zijn geschiedenis wan de totstandkoming verzet artikel 7:11 van de Awb zich immers niet tegen een verslechtering in bezwaar van de rechtspositie van de bezwaarde indien die verslechtering ook mogelijk zou zijn geweest bij afzonderlijk en ambtshalve genomen besluit. Verweerder was bevoegd om na het op de hoorzitting van 13 september 1995 nader verkregen advies van de verkeerskundige (...) en op grond van (daardoor) verkregen andere beleidsinzichten een nieuwe aanschrijving tot verdergaande verlaging van de mur te doen uitgaan. "128

1.4.4.3. Enkele conclusies ten aanzien van het werbod van reformatio in peius, afgezet tegen de wetenschap en de jurisprudentie

Getracht is het verbod van reformatio in peius van zijn lappendeken te ontdoen. De bedoeling van de $A$ wb ten aanzien van het in art. 7:11 (en ook art. 8:69) neergelegde non-reformatio in peius-beginsel, komt er enerzijds op neer dat in het belang van de bescherming van de rechtspositie van de justitiabele gekozen wordt voor een beperking van de heroverweging. Het resultaat van de beslissing op het bezwaarschrift moet in beginsel. niet leiden tot een verslechtering van de positie van de bezwaarde.

127 Rb. Rotterdam 8 februari 1996, JB 1996, 101, m.nt. MAH.

${ }_{28}$ Pres. Rb. Zutphen 9 april 1996, JB 1996, 149, m.nt. MAH. 
Dit beginsel wordt gekoppeld aan een belangrijk hoofduitgangspunt: de verslechtering van de positie van de indiener van het bezwaarschrift zou niet zonder het maken van bezwaar mogelijk zijn geweest. ${ }^{224}$ Op dit uitgangspunt zijn vele uitzonderingen.

Naast de door de Awb aangegeven beperkingen van de reikwijdte van het verbod van reformatio in peius ${ }^{130} \mathrm{kan}$ op basis van de arob-jurisprudentie worden geconcludeerd dat het verbod geen toepassing vindt indien:

a. de beslisgronden van het bezwaarschrift worden gewijzigd en het zorgvuldigheidsbeginsel in acht is genomen; de justitiabele moet in de gelegenheid zijn gesteld op het voomemen tot wijziging van de gronden te reageren;

b. sprake is van een wijziging van het object van het geschil en overschrijding van de bevoegdheidsgrenzen door het bestursorgaan tot vernietiging van het bestuursbesluit moet leiden (uitbreiding van nieuwe elementen bijv. in een aanschrijving tot woningverbetering);

c. een toetsing ex tunc dient plaats te vinden bij de beoordeling van eenmalige situaties (uitkeringen)" voorwaarde is wél dat het zorgvuldigheidsbeginsel noopt tot het aangeven van de gronden van de beslissing op het bezwaar;

d. de aard van de bijzondere wettelijke bepaling een verslechtering van de rechtspositie toestaat (geschiktheidsonderzoek voor het verkrijgen van een rijbewijs).

Buiten de onder de punten a tot en met d genoemde gevallen wordt het verbod wan reformatio in peius geëffectueerd door thet zorgvuldigheidsbeginsel, het rechtszekerheidsbeginsel en het vertrouwensbeginsel.

Op basis van deze bevindingen kan terecht met Tak de vraag worden gesteld wat er nog overblijft wan het verbod van reformatio in peius. ${ }^{13 !}$ In feite is het verbod een 'lege huls'; hierdoor heeft het door de $\mathrm{Awb}$ in het kader van art. 7:11, lid 1 voorgestane beginsel een inhoudsloze betekenis. Deze conclusie wordt naast de door de Awb gemaakte uitzonderingen op het verbod versterkt, door de toepassing van de beginselen van behoorlijk bestuur.

Een reformatio in peius is niet altijd te vermijden. Bij het voorzien in de zaak door de bestuursrechter ingeval van nieuwe feiten en omstandigheden tijdens de procedure, is een verslechtering van de positie wan de appellant niet altijd te

129 PG Awb I, p. 347.

130 PG Awb I, p. 347 e.\%.

13 A.Q.C. Tak, Hoofdlijnen van het Nederlands besnursprocesrecht, 3e ar., Zwolle 1995, p. 160 en 161 . 
voorkomen. Ook blijkt in het algemeen de onhoudbaarheid van het verbod in die gevallen dat de rechter in beroep constateert dat de justitiabele ten onrechte in diens bezwaar is ontvangen; een reformatio in peius ligt dan voor de hand.

De opvatting van Tak over de onhoudbaarheid van het verbod van reformatio in peius dat het verbod mede in relatie tot de algemene en bijzondere belangen van de justitiabelen, een miskenning is van het bestuursrechtelijk proces, lijkt derhalve niei zonder grond. ${ }^{132}$

Voor wat betreft het niet-ontvankelijkheidsaspect (achteraf blijkt dat men ten onrechte ontvangen is in zijn bezwaar), kan nog worden aangetekend dat ook Schreuder-Vlasblom van mening is dat regels inzake de ontvankelijkheid (en ook de bevoegdheid) als normen van openbare orde, prevaleren boven het voorkómen van een reformatio in peius. Deze regels moet de rechter in het kader van art. 8:69 immers ambtshalve toepassen omdat zij niet ter vrije beschikking staan van partijen in het geschil. ${ }^{33}$

Naast de gesignaleerde jurisprudentietrends uit het arobtijdperk, zijn ná $\mathbb{1}$ januari 1994 onder de werking van de Awb enkele nieuwe aspecten gesignaleerd die de inhoud, reikwijdte en betekenis van het verbod van reformatio in peius verder inkleuren. Op basis van enige recente jurisprudentie en standpunten uit de literatuur, wordt de betekenis van het verbod wan reformatio in peius nog nader inhoud gegeven.

1. De bevoegdheid tot het hanteren van een andere beslissingsgrondslag in het kader van de bezwaarschriftenprocedure wordt bevestigd, met dien verstande dat een nieuwe grond een nieuwe afweging tot gevolg moet hebben die in het dictum van de beslissing op het bezwaarschrift tot uitdrukking moet komen (zorgvuldigheidsbeginsel en rechtszekerheidsbeginsel).

2. Ter vermijding van een reformatio in peius als algemeen beginsel van administratief procesrecht moet de wet onder omstandigheden wijken voor het ongeschreven recht (contra legem).

3. De omstandigheid dat het bestuursorgaan in het kader van de heroverweging ex art. $7: 11$, lid 1 een reformatio in peius vermijdt, is op zichzelf genomen niet voldoende om tegemoet te komen aan de eisen van een integrale heroverweging alsmede het motiveringsbeginsel. 
Ook deze jurisprudentie brengt tot uitdrukking dat de toepassing van het verbod van reformatio in peius wordt vermeden omdat de bestuursrechter zijn oordeel baseert op de algemene beginselen van behoorlijk bestuur en de reikwijdte van art. $7: 11$. Daarnaast komt de bestuursrechter tot een opmerkelijke uitspraak door een toetsing contra legem ter vermijding van een 'reformatio'. Ofschoon deze laatste uitspraak ${ }^{134}$ een TWK-zaak betreft is zij niet zonder belang. In tegenstelling tot het oordeel van de belastingrechter in de zogenaamde doorbraak-arresten ${ }^{125}$ bleek tot nu toe weinig bereidheid te bestaan tot het honoreren van een beroep op ongeschreven beginselen door de ABRS. Nog daargelaten dat contra legem werd 'gegaan'. Zal in dit geval de visie van Tak alsnog gehoor vinden bij de hoogste bestuursrechter, waardoor ter vermijding van een reformatio in peius een toetsing plaatsvindt aan de algemene rechtsbeginselen? ${ }^{136}$ Luidt deze uitspraak een nieuw tijdperk in? ? $^{137}$

Of is de uitspraak een incident? De toekomst zal het leren. In ieder geval wordt een nieuwe dimensie toegevoegd aan het verbod van reformatio in peius.

Ter afsluiting van de besproken aspecten van het verbod van reformatio in peius dringt de vraag zich op of het aan art. 7:11, lid 1 ten grondslag liggend verbod van reformatio in peius niet tor 'gekunstelde' situaties leidt. ${ }^{138}$ 'Gekunsteld' of 'kunstig'; de introductie van het verbod van reformatio in peius geeft allerwegen aanleiding tot de conclusie dat het er op lijkt, dat de Awb voor wat betreft de bezwaarschriftenprocedure, het verbod er met de 'haren heeft bijgesleept'. Het is niet uitzonderlijk om Knoop met zijn pleidooi voor een reformatio in peius in de bezwaarfase, het gelijk aan zijn kant te geven. ${ }^{139}$ De Awb-uitzonderingen, maken onverminderd de bijzondere positie van het belastingrecht ${ }^{\text {it }}$ duidelijk, dat in samenhang met de beschikbaarheid van de beginselen van behoorlijk bestuur en de algemene rechtsbeginselen, voldoende mogelijkheden bestaan die de hantering van het verbod van reformatio in peius doen afnemen.

Hieraan doet overigens niet af de omstandigheid dat in de jurisprudentie van de CRvB en ABRS wél expliciet naar het verbod van reformatio in peius wordt verwezen. ${ }^{141}$

134 Zie noot 125 .

135 HR 12 april 1978, BNB 135-137, m.nt. C.P. Tuk, AB 1979, m.nt. Van der Burg en NJ 1979, $533 \mathrm{~m}$.nt. Scheltema.

136 A.Q.C. Tak, a.w.

"137 I.C. van der Vlies, Wer wijkt voor ongeschreven recht, AA, 1996, 6, p. 458.

138 A.Q.C. Tak, a.w.

139 T. Knoop, Reformatio in peius in bezwaarschriftprocedure mogelijk?, Gst. 6910, p. 465 e.v.

140. PG Awb I, p. 347 e.v.

141 Zie: CRvB 8 augustus 1997. JB 1997, 223, m.nt. HJS en ABRS 20 maart 1997, Gst. 7070, 7, m.nt. I.M.H.F. Teunissen. 


\subsection{Uitgangspunten bij de heroverweging}

\subsubsection{Heroverweging en de Algemene wet bestuursrecht}

De heroverweging op grond van art. 7:11, lid 1 die een essentieel aspect is bij de beslissing op het bezwaarschrift, vervult als bestuurlijke norm een belangrijke scharnierfunctie tussen de rechtsbeschermingsbepalingen in de hoofdstukken 6 tor en met $8 \mathrm{Awb}$.

Volgens de hoofdregel van de $A \mathrm{wb}^{142}$ die in art. 7:1 is neergelegd, kan degene wiens belang rechtstreeks bij een besluit is betrokken (art. 1:2) bij het bestuursorgaan (art. 1:1) bezwaar maken (art. 1:5, 6:4 en 8:1). Heroverweging geschiedt door het bestuursorgaan dat het oorspronkelijke bestreden besiuit heeft genomen. Heroverweging voltrekt zich binnen de kring van het bestuursorgaan. De Awb markeert dit uitgangspunt in het eerste artikel. Volgens de definitie van art. 1:1 wordt onder een bestuursorgaan verstaan, een orgaan van een rechtspersoon die krachtens publiekrecht is ingesteld dan wel een ander persoon of college, met enig openbaar gezag bekleed.

Deze in de Awb omschreven uitgangspunten accentueren ook een geheel andere benadering van de opdracht om op grondslag van het bezwaar het oorspronkelijk besluit opnieuw te toetsen. Het bestuursorgaan dat met bezwaren tegen een primair genomen besluit wordt geconfronteerd moet zijn oorspronkelijk besluit nog eens aan een nader oordeel onderwerpen. De houdbaarheid van de aanvankelijk genomen beslissing (feiten, recht en beleid) behoort nog eens op een open en onbevangen manier ter discussie te staan. Heroverweging, onderscheidt zich hierdoor volledig als interne bestuurlijke aangelegenheid ten opzichte van de externe en onafhankelijke geschilbeslechting. De bezwaarde justitiabelen kunnen zich door het instellen yan beroep met de aan de heroverweging ten grondslag liggende besluitvorming conform art. 7:1 jo 8:1 Awb tot de bevoegde bestuursrechter wenden.

Met dit beroep kan de vernietiging van de op het bezwaarschrift genomen beslissing worden uitgelokt. In tegenstelling tot de beslissingsbevoegdheid van het bestuursorgaan, wordt het rechterlijk oordeel over het in de bezwaarschriftenprocedure genomen beslissing, gegeven in een uitspraak-bevoegdheid. Art. 8:69 Awb bepaalt dat de rechtbank uitspraak doet op grondslag van het beroepschrift. Ofschoon dit artikel niets zegt over de rechterlijke uitspraak, geeft wél art. 8:77 
Awb duidelijkheid omtrent de inhoud van de rechterlijke uitspraak. Het tweede lid van art. 8:77 omlijnt de rechterlijke toetsingsbevoegdheid ten aanzien van het beroepen besluit:

'Indien de uitspraak strekt tot gegrondverklaring van het beroep, wordt in de uitspraak vermeld welke geschreven of ongeschreven rechtsregel of welk algemeen rechtsbeginsel geschonden wordt geoordeeld."

Hiermee wordt de rechterlijke bevoegdheid nader omlijnd: de rechter doet uitspraak omtrent de rechtmatigheid van de genomen beslissing. Ook de art. 8:70 en volgende geven inzicht in de uitspraakbevoegdheden van de bestuursrechter. In het kader van dit hoofdstuk wordt hierop niet ingegaan. Kortheidshalve wordt volstaan met naar de inhoud van deze artikelen te verwijzen.

Van enige bestuurlijke toetsingsbevoegdheid wan de rechter kan niet worden gesproken; het toetsen van de doelmatigheid van het besluit zoals bij de beslissing op het bezwaarschrift het geval is, behoort niet tot de bevoegdheid van de bestuursrechter. Toch past hier wel enige kanttekening. Gaandeweg zijn de grenzen tussen de rechtmatigheidstoets en de bestuurlijke doelmatigheidstoets vervaagd. De jurisprudentie op het terrein van het bestuursrecht deed door de ontwikkeling van de beginselen van behoorlijk bestuur, de begrippen doelmatigheid en rechtmatigheid naar elkaar toegroeien. Bestuurlijke doelmatigheid van genomen besluiten ligt vaak ingekapseld in geschreven of ongeschreven rechtsregels dan wel in de algemene rechtsbeginselen, zoals die in art. 8:77 als toetsingsnorm zijn aangegeven.

Deze toetsingsmaatstaven leggen tevens de objectieve inhoudelijke uitgangspunten bij de bestuurlijke besluitworming vast. Rechtsbeginselen en algemene beginselen wan behoorlijk bestuur hebben de afgelopen decennia een belangrijke rol gespeeld in de rechtspraak en daardoor invloed gehad op de taakvervulling van de bestuursorganen. De Awb heeft deze beginselen voor een belangrijk deel gecodificeerd en ook gemodificeerd (art. 2:4). Daardoor heeft zich een positivering van het recht voltrokken door het vaststellen van normen voor het handelen door bestuursorganen. Zorgvuldige voorbereiding, het verbod van détournement de pouvoir, het verbod van willekeur, alsmede het evenredigheidsbeginsel zijn beginselen, welke in afdeling $3.2 \mathrm{Awb}$ zijn gecodificeerd. Deze tot bestuursnormen getransformeerde beginselen, zijn van toepassing voor alle bestuursbesluiten. Niet alleen voor besluiten die voorwerp kunnen zijn van bezwaar en beroep krachtens de Awb, maar ook op overige bestuurshandelingen. Dat kunnen zowel privaatrechtelijke handelingen zijn, zoals de verkoop van een perceel bouwgrond aan een burger of de uitgifte van grond in erfpacht als wél 
feitelijk handelen, zoals de aanleg van een weg of groenstrook in een woonbuurt. Art. 3:1, lid $\mathbb{1}$ van de Awb makt hierop een uitzondering. De aard van de besluiten mogen zich daartegen niet verzetten. Maar de uitzonderingen op de regel van art. 3:1 zijn schaars. De jurisprudentie van de burgerlijke rechter leert, dat bestuurshandelingen genormeerd zijn door de algemene beginselen van behoorlijk bestuur. ${ }^{143}$

Dat het overheidsoptreden steeds strikter aan het recht is gebonden blijkt uit de invloed die de beginselen van behoorlijk bestuur hebben op het pre-contractueel optreden van de overheid. ${ }^{\text {t4t }}$

Gewezen is op de publiekrechtelijke bevoegdheid tot het verrichten van bestuurshandelingen. Deze aan het bestuursorgaan toegekende bevoegdheden doen over en weer rechten en plichten ontstaan in de relatie van het bestuursorgaan ten opzichte van de burger en omgekeerd.

De grondslag van deze bestuurlijke bevoegdheden vindt in beginsel zijn oorsprong in de wetgeving. ${ }^{145}$ Door de ontwikkeling van het ongeschreven recht in casu de beginselen van behoorlijk bestuur en de algemene rechtsbeginselen heeft de wetielijk geattribueerde bestuursbevoegdheid in materieel opzicht aan betekenis gewonnen. Uit de hiervoren genoemde beginselclausulering van het bestuurlijk handelen blijkt, dat de inhoud van de bevoegdheden datgene moet omvatten wat binnen de algemene grenzen van het recht mogelijk en nodig is voor de verwezenlijking van de doelstelling van de taken van de bestuursorganen. ${ }^{146}$

Deze genoemde beginselen die de inhoud en de kwaliteit van het bestuurlijk handelen bepalen, hebben ook een rol gespeeld in het kader van de algemene aanvullende rechtsbescherming zoals die tot I januari 1994 gold in het arobtijdperk.

Toch is door de Awb de invalshoek voor de beoordeling van het bestuurlijk handelen anders. Toetsing vóor 1 januari 1994 vond plaats op basis van de gronden genoemd in art. 8 van de Wet arob. In andere bewoordingen, dan het in de Awb opgenomen art. 8:77 terzake de uitspraakbevoegdheid bij gegrondverklaring van het beroep, bepaalde de Wet arob, dat beroep bij de ARRS kon worden ingesteld terzake dat (...). Vervolgens bepaalde het tweede lid van art. 8,

HR 3 mei 1985, NJ 1986 (Zuiderbad) en HR 27 maari 1987, AB 1987, 273 (Amsterdam-Ikon).

144 HR 24 april $1992, A B 1992,542$.

i.45 P. Nicolai e.a., a.w., p. 71 .

146 Brederweld, Schroot en Wijma, Begrip van de Nederlandse gemeente, deel I, Tweede gehed herziene dr., Alphen aan den Rijn 1990, p. 244. 
dat bij een gehele of gedeeltelijke vernietiging moest worden aangegeven, welk rechtsbeginsel ( $\mathrm{d}$-grond) geschonden werd geoordeeld. Vanuit het codificatieperspectief voor alle besluiten, dat is opgenomen in hoofdstuk $3 \mathrm{Awb}$, markeert deze codificatie van beginselen in feite eenzelfde uitgangspunt bij de bestuurlijke besluitvorming als onder de werking van de Wet arob. De Awb zegt dit overigens niet met zoveel woorden. Wel is het zo dat gesproken kan worden van een 'cosmetische" verandering van regels voor het besturen.:47 Immers de Awb converteert deze van oorsprong rechtsbeschermingsregels tot normen bij het bestuurlijk handelen. Scheltema ${ }^{\text {:q }}$ concludeert dat als gevolg van deze gecodificeerde regels niet meer van belang is of de administratieve rechter een besluit in strijd met de regels vernietigt. In beginsel is de kwaliteit van de regel en daarmee die van het bestuurlijk handelen in het geding.

Door deze codificering van de beginselen maakt het dan ook geen verschil welk type controle, in casu aanvullende civiele rechtsbescherming, (onrechtmatige daadsacties door de justitiabele), extern bestuurlijk toezicht (goedkeuring) of intern bestuurlijk toezicht (verantwoording binnen de organisatie van de publiekrechtelijke instelling waartoe het betreffende bestuursorgaan behoort), aan de orde is. Dit maakt duidelijk dat de Awb door zijn codificatie-pretentie de inhoud en de kwaliteit van het bestuurlijk handelen benadrukt, los van de gecreëerde beroepsmogelijkheid tegen een genomen beslissing op een bezwaarschrift. Primair staat immers ter discussie de inhoudelijke kwaliteit van genomen besluiten. De herinnering van art. 8:77 Awb aan art. 8 van de Wet arob doet hier niet aan af. Art. 8:77 is een overblijfsel uit de periode vóor 1 januari 1994 en moet de betekenis van dit artikel worden gezien als een concretisering van de rechterlijke motiveringsplicht in het kader van de uitspraakbevoegdheid. ${ }^{49}$

In art. $7: 11$ is de bestuurlijke heroverweging tot rechtsnorm gecodificeerd. De heroverwegingsplicht werd op grond van de Wet arob door de administratieve rechter gekoppeld aan het karakter van de in Hoofdstuk III van die wet geregelde bezwaarschriftenprocedure. Het bestuursorgaan moest beslissend op het bezwaar, volledig in de zaak voorzien. Naar het oordeel van de rechter diende aan de beslissing op het bezwaar een heroverweging ten grondslag te liggen. ${ }^{136}$

14 M. Scheltema, De Algemene wet bestuursrecht, NJB 1994, p. 6.

148 A.w.

149 M. Scheltema, De Algemene wet bestuursrecht, NJB 1994, p. 6.

15i Nast de vele uitspraken daterende uit het arobtijdperk wordt hier ter illustratie een enkele witspraak genoumd. Als voorbeeld kan hier dienen ARRS 24 april 1981, Gst. 6638, 5 (Valkenburg $\mathrm{ZH}$ ). 
De inhoud van deze bestuurlijke toetsing, werd naast de wettelijke regelingen in verband gebracht met de algemene beginselen van behoorlijk bestuur en rechtsbeginselen. Dit laat onverlet dat de Awb los van de genoemde geschreven en ongeschreven rechtsregels, weinig inzicht geeft over de betekenis van de inhoud en de context wan deze heroverwegingsbevoegdheid. De bevoegdheid tot heroverweging is afgeleid van de oorspronkelijke bevoegdheid tot bestuurlijk handelen. Op grond hiervan wordt het primaire besluit genomen.

Duidelijk is dat door de bovengenoemde (oorspronkelijke) bevoegdheden van de bestuursorganen, deze concrete inhoud krijgen door de bijzondere wetgeving. Als voorbeeld kunnen worden genoemd de bevoegdheden van gemeentelijke bestuursorganen op grond van de Gem.w. en de bijzondere wetten en verordeningen. Dat geldt evenzeer voor de bevoegdheden van de provinciale bestuursorganen en waterschapsbesturen. Hetzelfde kan worden gezegd van de organen van de publiekrechtelijke bedrijfsorganisatie. De sociale verzekeringsorganen hebben bestuursbevoegdheden op grond van de daarvoor geldende bijzondere wetgeving.

Op grond hiervan kan worden vastgesteld dat in de Awb de materiële aspecten van het bestuurlijk handelen een bescheiden rol spelen; ook de meest materiële bepaling terzake de opdracht tot heroverweging (en de normen in afdeling 3.2) doen hier niet aan af.

De Awb als jongste loot aan de boom van het bestuursrecht zoekt daarom haar kracht meer in de beschrijving van het formele dan die van het materiële recht. ${ }^{\text {si }}$ Donner ${ }^{152}$ zegt dat op grond van het bestuursprocesrechtelijke perspectief van het nieuwe bestuursrecht, slechts enkele hoofdpunten hieruit 'kunnen worden aangestipt', op grond waarvan dit bestuursprocesrecht nodig is:

a. de bestuurde moet aan zijn (haar) trekken komen,

b. het bestuur moet aan zijn trekken komen,

c. de rechtsbescherming mag geen doel op zichzelf zijn.

Naast de bescheiden materiële bepalingen in de $\mathrm{Awb}$, te weten de algemene bepalingen terzake besluiten, alsmede de bijzondere bepalingen van de beschikkingen voorzover deze van materieelrechtelijke aard zijn, worden deze ondersteund via de bestuursprocesrechtelijke regels zoals die zijn opgenomen in de hoofdstukken 6 en 8 van de Awb. Achteraf bezien is het een juiste beslissing geweest het bestuursprocesrecht (tweede tranche) alsnog op te nemen in hoofdstuk. $8 \mathrm{Awb}$. 1 s:

15 Donner, Nederlands beswursrecht, Algemeen deel, Vijfde herziene dr, Alphen aan den Rijn 1987, p. 334.

152. A.w. p. 334

153. Stb. $1993,581,650,671$ en 690 . 
Het nieuwe bestuursrecht is gelet op het vorenstaande door zijn opzet meer dan bestuurlijk procedurerecht. Bij de toetsing van de in de bezwaarschriftenprocedure bestreden besluiten is immers door de heroverweging een inhoudelijke beoordeling aan de orde.

De toetsingsaspecten die door het bestuursorgaan opnieuw in ogenschouw worden genomen, gaan veelal over de bestuurlijke concretisering van vage normen. Bijvoorbeeld wat moet worden verstaan onder een goede ruimtelijke ordening, de bescherming van het milieu, de openbare orde, of het algemeen belang. Of meer in het bijzonder de vraag of de burger aanspraak kan maken op bijstand wegens onvoldoende middelen van bestaan. Deze voorbeelden vormen een rijk scala van beoordelingsaspecten dat het bestuursorgaan in zijn besluitvorming moet betrekken. ${ }^{1.54}$

\subsubsection{De ontwikkeling van de heroverwegingsplicht}

In de vorige paragraaf is de materiële betekenis van de bestuurlijke heroverwegingsbevoegdheid behandeld in relatie tot de normen voor het bestuurlijk handelen. Die normen voor de bestuurlijke besluitvorming kregen en krijgen hun concretisering door het nemen van besluiten. Ten tijde van de Wet arob hebben de op het bezwaarschrift genomen beslissingen in het kader van de toepassing wan art. 14 van die wet catalyserend gewerkt op de vorming van jurisprudentie door de voormalige ARRS. Aanvankelijk gold de Wet arob voor beslissingen van bestuursorganen op lager gedecentraliseerd niveau, te weten de provincies, gemeenten, waterschappen en organen krachtens gemeenschappelijke regelingen ingesteld. Bijna aan het einde van het arob-tijdperk, in 1992, ook voor beschikkingen van de centrale overheidsorganen. $1{ }^{\text {ss }}$ Deze wijziging van de Wet arob was in feite het gevolg van de gegroeide praktijk in het kader van de toepassing van de facultatieve bezwaarschriftemprocedure op grond van art. 11 van deze wet. ${ }^{\text {ist }}$

De effecten van de administratiefrechtelijke uitspraken in het kader van de Wet arob hadden betekenis voor de inhoud van de heroverwegingsplicht door de toetsingsmaatstaven van art. 8 van deze wet. De toetsingscriteria ex art. 8 Wet arob waren strijd met de wet, het verbod van détournement de pouvoir, het verbod van willekeur, alsmede de algemene rechtsbeginselen (onder d). De betekenis van de arob-jurisprudentie is daarom van belang voor de toepassing van

154 N.S.J. Koeman, Bestuurstecht is meer dan procedurerecht, NTB 1995, p. 94.

155 Het betrof thier de inwerkingtreding van het wetswoorstel 21659 .

sis

De koptekst ran de betreffende circulatre wan 1 september 1989 , no 89 MO 17412, duidde als zodanig aan het voeren van een 'Interimbeleid behandeling beroepschrift als bezwarschrift", en had mede betrekking op de facultatieve bezwaarschriftenprocedure in de Wet arbo. 
art. 7:11 Awb. Met deze jurisprudentiebromen uit het arob-verleden zal de Awb niet of nauwelijks kunnen breken.

Het leggen van de nadruk op de door de Wet arob ontwikkelde jurisprudentie zou de indruk kunnen wekken, dat alleen deze wet de bestuurlijke heroverweging in de Awb inhoudelijke betekenis heeft gegeven. Dit doet echter tekort aan het bestaan van de administratieve rechtsgangen die ons land de afgelopen decennia kende. Vele gespecialiseerde rechtsgangen waren tot ontwikkeling gekomen. De grote omvang van deze administratieve rechtsgangen was het gevolg van de gestrande pogingen om tot een harmonisatie van het bestursprocesrecht te komen.

Ofschoon de vele administratieve rechtsgangen, doorgaans geen wettelijk verplichte bezwarenprocedure kenden, had het bestaan van deze rechtsgangen invloed op de kwaliteit van het nemen van besiuiten in casu het (her)overwegingskader dat aan deze besluiten ten grondslag lag. In dit verband kunnen worden aangestipt de jurisprudentie in de rechtspraak op het gebied van de sociale verzekeringen en de ambtenaren- en pensioenrechtspraak. Verder kunnen hier worden genoemd het Kroonberoep (Wet Bab) en de rechtspraak van de AGVB in het kader van de Tijdelijke Wet Kroongeschillen. Ook mag in de sfeer van het bedrijfseconomisch recht de rechtspraak door het CBB niet onvermeld blijven. De Wet administratieve rechtspraak bedrijfsorganisatie kende enkele jaren vóor de inwerkingtreding van de $\mathrm{Awb}$, na eerst een facultatieve bezwaarschriftenprocedure te hebben gekend, een verplichte bezwaarprocedure overeenkomstig het arobstramien. De belastingrechtspraak door de gewone rechter, werd voorafgegaan door een verplichte bezwaarschriftenprocedure. Het maken van bezwaar op dit rechtsgebied kent een lange historie, al moet worden gezegd dat behandeling van bezwaarschriften door de belastinginspecteur doorgaans op eenvoudige wijze geschiedde. Als laatste in de opsomming van dit rijtje past de belangrijke taak die de Hoge Raad (en ook lagere rechter) als restrechter voor die gevallen, dat geen beroep kon worden gedktan op de administratiefrechtelijke rechtsgangen. In het bijzonder wordi hierbij herinnerd aan de historische arresten van de Hoge Raad inzake de Zandvoortse en Doetinchemse woonruimtevorderingen, alsmede het Loosdrechts botenhuis-arrest. ${ }^{\text {sit }}$ Het maakt vanuit het rechtmatigheidsperspectief niet of nauwelijks verschil of de toetsing van een primair besluit al dan niet alsnog in een bezwarenprocedure heeft plaatsgevonden. Overwegen of heroverwegen ten behoeve van de besluitvorming door bestuursorganen is voor de

157 Zie in dit verband: R.J.G.M. Widdershoven, Gespecialiseer de rechtsgangen in het administratieve recht, Zwolle 1989.

158 HR 14 jamuari 1949 , NJ 557, ARB, p. 751, HR 25 februari 1949, NJ 558 en HR 3 aprill 1947, N] 381 . 
rechtelijke toetsingstaak voor wat betreft de houdbaarheid van het besluit in beginsel van weinig belang. Uitgangspunt is immers of het bestuursorgaan rechtmatig heeft besloten en de door het besluit ontstane rechtsgevolgen niet worden aangetast. Iets anders is, dat de bezwaarschriftenprocedures zijn ingevoerd vanwege argumenten van kwaliteitsverhoging van de besluitvorming, de filterwerking (vermindering beroep op de rechter) die van deze verlengde besluitvorming uitgaat en uit overwegingen van harmonisatie.

Ook buiten de administratieve rechtspraak hebben bestuursorganen een bijdrage geleverd aan een behoorlijke invulling van de aan hun besluiten ten grondslag liggende (her)overweging. Het inmiddels op de achtergrond geraakt spontane vernietigingsrecht van de Kroon speelde eveneens een rol in het ontwikkelen van de jurisprudentie. Tevens vervulde het administratief beroep bij gedeputeerde staten van de provincie en op gemeentelijk niveau het administratief beroep bij de gemeenteraad, een rol in het verbeteren van de kwaliteit van genomen besluiten. Zeker de provincies hebben in de vele administratieve geschillen die in het kader van het administratief beroep aan het oordeel van gedeputeerde staten werden onderworpen, geadviseerd door de kamers voor administratieve geschillen, een bijdrage geleverd aan het corrigeren en daarmede het stimuleren van de kwaliteit van het bestuurlijk handelen door lagere organen. Hierop hebben de bepalingen van art. 109 en volgende van de Prov.w. (oud) een positieve invloed gehad. Een belangrijke sturing daarin is geweest de op art. 109 oud van de Provinciewet gebaseerde procedure-verordeningen.

Op gemeentelijk niveau bewezen de procedure-verordeningen inzake de behandeling van bezwaar en beroep van vóór het arob-tijdperk hun waarde. Een belangrijke bijdrage in de ontwikkeling van het administratief bezwaar en beroep leverde de Vereniging van Nederlandse Gemeenten met haar modelverordening voor de behandeling van bezwaar- en beroepschriften. ${ }^{15 \%}$ Vooral de procedurebepalingen voor de voorbereiding van de op het bezwaar en beroep te nemen beslissing, hadden een stimulerend effect op de kwalitatief inhoudelijk kant van de aan de besluiten ten grondslag liggende heroverweging. Dat dit in de ogen van wetenschappelijke onderzoekers niet steeds voldoende bleek doet daar niet aan af. Naar deze onderzoekers stellen, speelden algemene beginselen van behoorlijk bestuur in de bezwaarschriftenprocedure geen prominente rol. Ofschoon, dat wellicht vóór het arobtijdperk, dan wel ten tijde van de onderzoeksperiode als juist kan worden bevonden, spreken de onderzokers zich in feite enigszins tegen.

159 Blauwe reeks ur. 48, Behandeling van bezwar-en beroepschriften door de gemeentebesturen, $\mathrm{VNG}$, "s-Gravenhage 1972 .

160 Arob-prakijiken, a.w., p. 328. 
Zeker als daarbij gesteld wordt, dat de inhoud van de heroverweging wordt bepaald door de heroverwegingsrumte. Daarbij nemen de onderzoekers in aanmerking, dat het type beschikking (al dan niet beleidsvrijheid) dan well de wijze van inhoud van de primaire besluitvorming, een rol kan spelen. Ook de bestuurlijke angst voor gezichtsverlies zou de heroverwegingsruimte kunnen beperken. Deze laatste constatering raakt de menselijke kant van het besturen; besturen geschiedt door personen, maar het is de vraag in hoeverre bestuurlijk psychologische aspecten uiteindelijk doorslaggevend zijn voor de veronderstelling, dat het aspect van gezichtsverlies een pregnante rol speelt in een kwalitatiefinhoudelijk minder verantwoorde heroverweging. Wat hier ook van zij, de filterfunctie in het kader van het gedane onderzoek naar de werking van de arobbezwaarschriftenprocedure bleek groot, namelijk $75 \% .^{161}$

Een belangrijk punt is de wetenschappelijke invloed als niet-formele rechtsbron op de zorgvuldigheid van de besluitvorming. Niet moet worden onderschat dat zowel de administratieve rechter, als de verantwoordelijke bestuursorganen, daardoor worden beinvloed.

Vermeldenswaardig zijn hier de rapporten van de commissie inzake de algemene bepalingen van administratief recht. ${ }^{162}$ Blijkens de toelichting behorende bij het voorontwerp van wet houdende algemene bepalingen van administratief recht, was de doelstelling van het ontwerp van gemengde aard. Enerzijds werd gestreefd naar aanscherping van de moderne bestuurstechniek, daarnaast werd versterking beoogd van de rechtspositie van mensen en groepen. Het belang van het ontwerp bleek, doordat het welhaast steeds vermeld werd in elke wetenschappelijke bijdrage over het bestuursrecht. Hoewel de betekenis van het betrokken wetsontwerp voor zover bekend in zijn werking voor het bestuur niet werd onderzocht, zal het zonder enige twijfel een positieve invloed hebben gehad op het bestuurlijk besluitvormingsproces.

De fundamenten die reeds vón de Awb zijn gelegd voor het bestuurlijk heroverwegingsproces, hebben zich niet van de ene op de andere dag ontwikkeid. Bestuursorganen, burgers, administratieve rechters en wetenschappers hebben gaandeweg een bijdrage geleverd aan de totstandkoming van beginselen en normen voor het bestuurlijk handelen. Daardoor werd mede de grondslag gelegd voor de betekenis wan de bestuurlijke heroverweging voor de voorprocedures.

161 Arob-praktijken, a.w., p. 312.

162 ABAR, vierde bijgewerkte dr., Groningen 1973 en de wifde geheel herziene dr., Alphen aan den Rijn 1984 en het rapport ABAR (78) VAR LXXI, Groningen 1974. 


\subsubsection{Een drietal uitgangspunten}

\subsubsection{Verantwoording wooraf}

In de vorige paragraaf is de herowerweging in het kader van de bezwaarprocedure verklaard aan de hand van een korte schets van de ontwikkelingen die dit zuiver bestuurijik fenomeen heeft gekend. Hierbij werd de basis gelegd voor een bespreking wan enkele uitgangspunten bij de heroverweging. Met deze fundamentele inkadering is beoogd de inhoud van de Awb-heroverwegingsnorm een betere invulling te geven. Met een globale beschrijving van een drietal (andere) Litgangspunten wordt geprobeerd het heroverwegingsbegrip verder juridisch inhoud te geven. Achtereenvolgens wordt aandacht besteed aan de volgende aspecten die bij heroverweging een rol spelen, te weten:
a. het uitgangspunt van schriftelijkheid;
b. het uitgangspunt van behoorlijke dossiervorming;
c. het uitgangspunt van connexiteit.

\subsubsection{Het uitgangspunt van schriftelijkheid}

$\mathrm{Bij}$ de uitgangspunten van de heroverweging ex art. 7:11, lid 1 Awb staat voorop, dat de inhoud van de heroverweging voor de justitiabelen herkenbaar moet zijn. Daarnaast is van belang dat de inhoud van de beslissing op het bezwaarschrift de bestuursrechter inzicht moet verschaffen, omtrent de beweegredenen van de beslissing op het bezwaarschrift. Deze aspecten stellen eisen aan de inhoud en de wijze van formulering van de heroverweging. Een van die eisen is, dat de gemaakte herowerweging schriftelijk moet zijn weergegeven. Dit laatste ligt opgesloten in de rechtsgevolgen die ontstaan door de beslissing op het bezwaatschrift.

De heroverweging 'draagt' als het ware de genomen beslissing op het bezwaarschrift. Mede in relatie tot de definitie-bepaling van art. 1:3 van de Awb is de schriftelijkheid van de beslissing op het bezwaarschrift vereist. Dit geldt ook voor de te maken heroverweging. Met andere woorden de koppeling van de heroverweging aan de op het bezwaarschrift genomen beslissing veronderstelt schriftelijkheid. Daarom dient het 'verlengde besluit' dat het primaire besluit vervangt voor de burger door een volledig schriftelijke heroverweging, kenbaar te zijn.

In samenhang hiermee kan het gemis van voldoende schriftelijkheid bij het adiëren van de administratieve rechter het bestuursorgaan 'duur' komen te staan op straffe van vernietiging van de beslissing op het bezwaarschrift. Deze eis van 'voldoende schriftelijkheid' is primair een afgeleide van het Awb-besluitbegrip als bedoeld in art. 1:3: "een schriftelijke beslissing van het bestuursorgaam, inhoudende een publiekrechtelijke rechtshandeling'. Secundair brengt dit met zich 
dat een besluit dat de pretentie heeft rechtmatig te zijn aan de algemene beginselen wan behoorlijk bestuur moet woldoen. Het besluit moet daarom bijwoorbeeld een draagkrachtige motivering "belichamen'. In het bijzonder geldt hierbij dat een met het oog op het besluit uitgebracht advies hierin moet worden vermeld. Als dit advies geen motivering bevat behoort deze in het besluit te worden opgenomen. Door de invoering van de derde tranche is deze eis gesteld in art. 3:49 (was: art. 4:19). Ook de voor de afwijking van een krachtens wettelijk voorschrift uitgebracht advies geldt deze motiveringseis (art. 3:50; derde tranche, was art. 4:20). Voor het geval dat niet krachtens een wettelijk voorschrift is geadviseerd, moet worden aangenomen dat deze advisering toch verplicht kan zijn en binnen het bereik valt van art. 3:2 (kennisvergaringsplicht). Ook in dit laatste geval brengt het motiveringsbeginsel met zich dat het bestuursorgaan in het besluit aangeeft, waarom van het advies wordt afgeweken. Deze situatie kan zich bijvoorbeeld voordoen bij de inschakeling van externe expertise.

Ook voor de rechtmatigheidsnormen van afd. 3.2 geldt deze eis van schriftelijkheid, alsmede voor de niet gecodificeerde algemene beginselen van behoorlijk bestuur en de algemene rechtsbeginselen.

Het verschuiven naar een eventuele rechterlijke zitting en het daarbij laten aankomen op een nader invullen van de inhoud van de heroverweging, houdt risico's in.

Een uitgebreide standpuntbepaling ter zitting ten spijt. Het bestuursorgaan loopt hiermede toch het risico dat de bestuursrechter tot strijdigheid met het bepaalde in art. 7:11, lid 1 van de Awb concludeert. Het maken van een kansberekening door de gemachtigden namens het bestuursorgaan, dat de rechter een wat magere weer-gave van de heroverweging door de vingers zal zien, moet worden ontraden. Bij de beoordeling van de heroverweging dient zowel in doelmatigheids-als in rechtmatigheidsopzicht, in ogenschouw te worden genomen of een volledige schriftelijke verantwoording heeft plaratsgevonden van de feiten, het beleid en het recht. Van belang kan hierbij zijn de mate van de uitgebreidheid van de gemaakte (her)overweging.

Afhankelijk van de zaak kunnen deze overwegingen summier, voldoende of uitvoerig zijn. Bij gebonden beschikkingen, waarbij de weigering van een bouwvergunning is uitgesproken en geen vrijstellingstoets in het oordeet is betrokken, kan met een lager heroverwegingsniveau worden volstaan. De motivering zou met vermelding van de relevante feiten en omstandigheden kunmen (art. 3:2 Awb) luiden: 
'burgemeester en wethouders konden de bouwwergunning niet anders dan weigeren, gelet op het imperatieve karakter van artikel 44 van de Woningwet, aangezien het bouwwerk in strijd is met het bestemmingsplan".

In gevallen van min of meer gebonden besluiten, is derhallve een standaardoverweging voldoende. Toch is hierbij enige voorzichtigheid geboden, angezien bij de besluitvorming omtrent beschikkingen een min of meer vrijere besluitvormingsmarge bestaat. In dit kader past een voldoende heroverweging. Uitgangspunt moet daarom zijn een op het geval toegesneden heroverweging, waarbij uiteraard de mate waarin inhoudelijk bezwaren zijn aangevoerd eveneens bepalend dient te zijn voor de omvang van de te maken heroverweging. ${ }^{\text {"63 }}$

In een uitspraak in een voorlopige voorzieningszaak overwoog de rechtbankpresident:

"Voorts merkt de president op dat tevens vrijstelling op grond van artikel 21 van de Kampeerwet is vereist. Weliswaar heeft verweerder de president per faxbericht medegedeeld, dat het bestreden besluit, zoals zou moeten blijken uit de aanbiedingsbrief van 2 juni 1995 , bedoelde vrijstelling impliceert, maar dat blijkt niet uit het bestreden besluit waarin slechts sprake is van artikel 17 wan de WRO, en waarin zelfs woordelijk staat vermeld: "Uiteraard dient tevens te worden beschikt over een vrijstelling ingevolge de Kampeerwet alvorens tot plaatsing van de betreffende kampeermiddelen kan worden overgegaan". Weliswaar heeft verzoekster slechts bezwaar gemaakt tegen de vrijstelling op grond van artikel 17 WRO, zodat dit aspect in het kader van deze procedure verder buiten beschouwing blijft, maar de president merkt op dat een en ander niet getuigt van een zorgvuldige besluitvorming. "hit

In deze zaak blijkt dat er twee verschillende besluiten aan de orde waren, die expliciet in de herowerweging hadden behoren te worden betrokken. Hoewel de onduidelijkheid omtrent het bovengenoemd aspect in de heroverweging door de rechter niet onrechtmatig werd bevonden, geeft deze uitspraak aan dat het niet opnemen van relevante aspecten in de heroverweging als minder fraai bestuurlijk handelen wordt bestempeld. Een voldoende mate van schriftelijkheid ten aanzien van de heroverweging blijft geboden. Dit is bijvoorbeeld vooral van belang in het kader van vrijstellingen op grond van de bouwverordening of het bestemmingsplan.

Vamuit het gezichtspunt van het zorgvuldigheidsbeginsel is in gevallen dat de weigering van een bouwvergunning in het geding is, maar die weigering zo nodig 
met behulp van een vrijstellingsbepaling in de bouwverordening of het bestemmingsplan kan worden voorkomen, dat de mogelijkheid van de toepassing van enige vrijstellingsbepaling moet worden overwogen, ook al heeft de betrokken bezwaarde burger daarop geen beroep gedaan. Uit de te maken heroverweging dient uitdrukkelijk van belangenafweging met expliciete vermelding van de vrijstellingsbepalingen te blijken. ${ }^{16 s}$ Het verweer van het bestuursorgaan dat impliciet uit de heroverweging kan worden opgemaakt dat toepassing van de vrijstellingsbepalingen aan de orde is geweest, kan leiden tot vernietiging van de beslissing op het bezwaarschrift of zo nodig het toewijzen van een verzoek om voorlopige voorziening. Het hiervoren gegeven voorbeeld uit de ervaringen van een arob-rechter illustreert dat overigens ook naast andere door deze rechter genoemde voorbeelden, bestuursorganen bedacht moeten zijn op voldoende schriftelijkheid van de gemaakte heroverweging.

\subsubsection{Het uitgangspunt van behoorlijke dossiervorming}

Behoorlijke dossiervorming is een van de belangrijke pijlers waarop het heroverwegingsproces steunt. Dit is af te leiden uit art. 7:4 Awb, welke bepaling nog afzonderlijk besproken wordt in de par. 5.2.1. en 5.3.9. Dit artikel geeft een regeling over de ter inzagelegging van de stukken. Lid 2 van art. 7:4 bepaalt voor zover hier van belang, dat het bestuursorgaan naast het bezwaarschrift alle op de zaak betrekking hebbende stukken ter inzage legt. Deze bepaling veronderstelt daarom dossiervorming. Ook de MvT van art. 7:4, tweede lid benadrukt het belang van een goede dossiervorming ten behoeve van een goed verloop van de bezwaarschriftenprocedure. De MvT zegt met zoveel woorden:

'Het inzagerecht, geregeld in het tweede lid, is als een van de fundamentele waarborgen woor een goed verlopen bezwaarschriftenprocedure te beschouwen. Zoveel mogelijk moet vermeden worden, dat het bestuursorgaan zijn beslissing doet steunen op informatie welke de betrokken belanghebbenden niet hebben kumnen kennen. Ongewenst ook is de situatie, dat pas in een latere fase (bijvoorbeeld bij de administratieve rechter) een belanghebbende kennis kan nemen van de stukken die voor hem in een eerdere fase ontoegankelijk waren. De consequentie daarvan zou immers kunnen zijn dat geschilpunten die in de bezwaarfase definitief beslist hadden kunnen worden indien alle stukken bekend waren geweest, zonder voldoende noodzalak tot een procedure voor de administratieve rechter leiden. In beginsel dient het bestuursorgaan daarom rapporten, adviezen en beleidsnota's die aan de beroepsinstantie plegen te worden toegezonden, ook reeds in de bezwaarschriftenprocedure ter inzage te leggen." ich

I. de Vries, Fouten bij de besluitvorming, (Ervaringen van een Arob-rechter), Gst. 6851. p. 102 en 103 .

166 PG Awb I, p. 338 e.v. 
Deze uitgangspunten zijn vanzelfsprekend. Immers het bestuursorgaan heeft een betere positie dan de justitiabele en door zijn 'dossierdomein' een informatievoorsprong op de bezwaarde burger. ${ }^{67}$ De Wet arob kende voor de bezwaarschriftenprocedure geen inzageregeling van de stukken. Dat de praktische betekenis van de aanwezigheid van een goed procesdossier ook onder de Wet arob werd onderkend, blijkt uit de bekende uitgave van Ars Aequi Libri. ${ }^{6: 3}$

Toch past enige bedachtzaamheid met dossiergegevens. Deze bedachtzaamheid is gerechtvaardigd omdat het dossier in de bezwaarschriftenprocedure overwegend uit ambtelijke stukken bestaat die in de omgeving van het bestuursapparaat zijn aangedragen. Sommigen zien hierin een gevaar omdat de zo zakelijk gestelde ambtelijke stukken gemakkelijk ingekleurd kunnen zijn door subjectieve inzichten van ambtenaren of aan ambtenaren gedane verklaringen door derden. Een dossier bevat niet zelden belangrijke verklaringen de auditu. "*;

Wat hier ook van zij, een zich zelf en zijn burgers respecterend bestuursorgaan, zal zo veel mogelijk trachten geen vertekende dossiervorming te voeren. Daar komt nog bij dat de bestuursrechter de dossiergegevens zal controleren. Gekleurde dossiervorming straft zichzelf en daardoor het aanzien en het handelen van het bestuursorgaan. De aanwezigheid van de pers tijdens de openbare zitting bij administratiefrechtelijke procedures en de naar aanleiding van de zitting verschenen verslagen in de dagbladen, zullen mogelijk preventief kunnen werken. Feitelijk juiste dossiervorming zal hierdoor worden gestimuleerd. Tot wat voor consequenties het overleggen van verkeerde processtukken dan wel het verstrekken van onjuiste of onvolledige informatie kan leiden, blijkt uit een antal door Loeb en anderen genoemde uitspraken. ${ }^{10}$ Overigens komt het belang van dossiervorming ook in het kader van de Awb regelmatig aan de orde. Enkele voorbeelden van uitspraken illustreren dit laatste. In een rechtbankzaak overwoog de enkelvoudige kamer voor bestuurszaken voor zover hier van belang:

'De rechtbank is evenwel van oordeel dat (...) en de overige zich in het procesdossier bevindende stukken blijkt, dat verweerder deze bezwaren heeft onderkend en heeft afgewogen dat $(\ldots){ }^{\prime \prime 1 /}$

167 P.J.J. van Buuren, De omwang van de rechtsbescherming, p. 33, Alphen aan den Rijn 1982. H. Bolt en H.G. Lubberdink, Procesdossiers 'De Arob-procedure', Nijmegen 1988. Interventie Van Butren in: Beginselen van administratief procesrecht, Van Galen en Van Maarseveen, Geschrift van de VAR LXXXI, Alphen aan den Rijn 1981.

170 Loeb e.a., De Wet arob toegepast, Nijmegen 1990.

171 Rb. Maastricht 13 jumi 1995 , reg. nr. 94/2420 WRO19 Z DAL. 
In een zaak waar de toepassing van de Algemene Bijstandswet aan de orde was overwoog de Centrale Raad van Beroep:

"nergens wit de gedingscukken blijkt, dat $Y$ op enig tijdstip daadwerkelijk in de woning van appellante is aangetroffen'. "n:

Ook hier bleek het belang van de gedingstukken. Tot wat voor onvoorziene consequenties yoor het bestuursorgaan gebrek aan dossiervorming kan leiden, kwam aan de orde in een andere rechtbank-zaak. In het kader van een verzetsprocedure bieek met betrekking tot een eerdere uitspraak van diezelfde rechtbank inzake een AAW-uitkering het volgende:

'De rechtbank heeft de uitspraak van 16 februari 1994 gegrond op de volgende overwegingen: Verweerder beschikt kennelijk niet over enig schriftelijk stuk waar de bestreden beslissing op berust. Gezien de inhoud en de aard wan de bestreden beslissing en de niet weersproken inhoud van het klaagschrift kan de bestreden beslissing zonder (een) dergelijke (stuk)ken niet voldoende gemotiveerd worden voorbereid geacht. Om deze redenen kan de bestreden beslissing niet in stand blijven.' ${ }^{m}$

Uit deze uitspraak van de Assense rechtbank is af te leiden, dat het niet voorhanden zijn van een goede dossiervorming, het bestuursorgaan kan opbreken.

Aangetoond is de noodzaak van een goede dossiervorming, zowel in het belang van de in het kader van de bezwaarschriftenprocedure te maken heroverweging, alsmede tegen de achtergrond van een eventuele procedure bij de rechter.

\subsubsection{Het uitgangspunt van connexiteit}

De heroverweging in de bezwaarschriftenprocedure heeft een connexiteitsaspect. Die connexiteit is aanwezig omdat uit art. 7:11, lid 1 van de Awb blijkt, dat de heroverweging gekoppeld is aan de aanvraag waaraan het bestreden primaire besluit ten grondslag ligt. Dit connexiteitsgegeven ligt opgesloten in de relatie met art. 1:5 van de Awb. Art. 1:5 bepaalt voor zover van belang, dat onder het maken van bezwaar wordt verstaan het vragen van voorziening bij het bestuursor gaan 'dat het besluit heeft genomen'. Met deze laatste passage in de begripisomschrijving wan 'bezwar", is de samenhang van het oorspronkelijke besluit met de heroverweging in art. $7: 11$ vastgelegd. Daarmee manifesteert zich de te maken heroverweging als een coherent bestuurlijk handelen, met de daaraan voorafgaande primaire besluitvorming. Van een geísoleerd verschijnsel van de herover 
wegingsfase ten opzichte van het doorlopen primaire besluitvormingstraject is daarom vanuit de juridische context van art. $7: 11$ geen sprake. ${ }^{74}$

Het connexiteitsaspect van de heroverwegingsfase met de primaire besluitvorming (de aanvraag van het primaire besluit) bepaalt in belangrijke mate de inhoud van de te maken heroverweging. Hoe zorgvuldiger het primaire besluit is geformuleerd, hoe minder corrigerend de heroverwegingsoperatie zijn invulling behoeft te krijgen.

Als een correcte toepassing van recht, beleid en een juiste inkadering van feiten bij de primaire besluitvorming heeft plaatsgevonden, is niet altijd te voorkomen, dat de te maken heroverweging zich onder omstandigheden kan manifesteren als "juridische overkill". Deze constatering zou een negatief beeld van de bezwatarprocedure kunnen schetsen en zeker voor wat betreft de mate van de gevraagde bestuurlijke inspanning bij de behandeling van het bezwaarschrift. Eerder in dit hoofdstuk is aangegeven dat de heroverwegingsfase slechts één aspect omvat van de motieven voor de invoering van deze bestuurlijke voorprocedure. Deze uitgangspunten geven inhoud aan het karakter van deze procedure als hernieuwde gelegenheid tussen bestuur en burger, zaken nog eens uit te leggen en besluiten te verduidelijken. Bij de bezwaarschriftenprocedure kunnen ook die zaken aan de orde komen, waarbij meer sprake is wan klachten over dan wel bezwaren tegen het door of het namens het bestuursorgaan handelen of besluiten.

In dit laatste geval kan gedacht worden aan slechte communicatie tussen medewerkers van het bestuursorgaan en de betreffende burgers. Dit geldt vooral in conflicterende omstandigheden, waarbij burgers grievend spreken over onbehoorlijke gedragingen van medewerkers van de bestuurlijke organisatie. In die gevallen kan naast de heroverwegingsfunctie van de bezwaarschriftenprocedure deze voorprocedure dienst doen als ombudsmogelijkheid.

De praktijk ten tijde van de werking van de Wet arob en de Awb-periode toont aan dat de heroverweging in het kader van de bezwaarschriftenprocedure geen sinecure is. De arob-jurisprudentie en de uitspraken van de bestuursrechter vanaf 1 januari 1994, maken dit duidelijk.

Bestuurlijke fouten en ambtelijke misslagen zijn niet altijd uit te sluiten. Er zijn altijd wel onvolkomenheden in besluiten te constateren; volledig perfecte besluiten bestaan nauwelijks en een gewaagde misschien wel niet geheel te onderbouwen inschatting leert, dat in $90 \%$ van de besluiten min of meer sprake is van schoonheidsfoutjes. In dit verband kunnen worden genoemd de vele mogelijkhe-

17.4 Arob-praktijken, a.w., p. 305. 
den die er zijn om al dan niet over de schreef te gaan bij besluiten met een meer of mindere beleids- en afwegingsmarge. Te denken valt hier aan bouwvergunningen die op basis van vrijstellingen zijn verleend, bestuursdwangzaken, waarbij door de rechter een stringente afweging van belangen wordt gevorderd. ${ }^{135}$

Iets anders is of besluiten waaraan gebreken kleven nu ook altijd door de bestuursrechter moeten worden vernietigd. Waar het om gaat is de objectiefrechtelijke aanvaardbaarheid. Waar mogelijk kan art. 6:22 bij formele gebreken uitkomst bieden. Al moet in het belang van de rechtsbescherming niet al te ruimhartig met deze Awb-bepaling worden omgesprongen.

Vastgesteld is de sterke inhoudelijke kant van de heroverwegingsplicht op een aantal deelterreinen van het bijzonder bestuursrecht, waarbij beleid en belangenafweging aan de orde is. Het belang daarvan wordt groter zodra beleidsaspecten voorwerp van toetsing zijn, waarbij grote maatschappelijke belangen op het spel staan. De connexiteit met het primaire besluit ten opzichte van de heroverweging, is bij dit type bestuiten bijzonder sterk. Regeimatig blijkt dat bestuursorganen op decentraal en lokaal niveau met wisselend succes bestuursbesluiten nemen die gevoelig liggen in de samenleving. Zaken als drugs-problematiek en woonwagenproblematiek, alsmede bouwprojecten van enige omvang en ingrijpende verkeersmaatregelen, liggen veelal in de publieke discussie onder vuur. Daarbij is een strikte en zorgvuldige belangenafweging in relatie tot de primaire besluitvorming evident. Vooral de heroverweging in woonwagenzaken vereist een behoorlijke bestuurlijke inspanning. Uiterste zorgvuldigheid wordt in administratiefrechtelijke uitspraken geëist ten aanzien van de afstandscriteria bij woonwagenstandplaatsen. ${ }^{176}$ Dit plaatst het bestuursorgaan voor problemen omdat deze criteria vanuit de jurisprudentie geen absolute betekenis hebben, maar slechis relatief moeten worden beoordeeld. Waar in gevallen om maar een voorbeeld te noemen 25 meter een aanvaardbare afstand is tot de woonbebouwing, kan in andere gevallen een afstand van 75 meter nog niet acceptabel zijn in de ogen van de rechter. Ook in zaken bij de aanwijzing van drugsopvanglocaties wordt een zorgvuldige bestuurlijke afwegingsinspanning gevraagd. De maatschappelijke weerstand tegen de aanwijzing van drugsopvanglocaties in de primaire besluitvorming, hetgeen veelal geschiedt in de bouwvergunningensfeer, leidt er toe dat de rechter in sterke mate inzicht wenst in de afweging van alterna-

175 Van Wijk/Konijnenbelt, a.w., p. 503, waar een staalkart wordt gegeven voor do algemene wereisten bij de bestursdwangaanschrijving, alsmede F.C.M.A. Michiels, Bestuursdwang in de gemeenten, Gst. 6832 en 6833 .

176 ABRS 4 maart $1996, J$ G 96,031 m.nt. 
tieven. Met andere woorden, waarom is voor plaats A gekozen en geen keuze gemaakt uit de locaties $\mathrm{B}$ en $\mathrm{C}$ die door bezwaarden worden bepleit.

Enkele hierna te noemen uitspraken benadrukken de samenhang met de primaire besluitvorming en de heroverweging en geven aan dat de heroverweging geen op zichzelf staand afwegingsproces is in het kader van de beslissing op het bezwaarschrift. De ABRS oordeelde in het kader van een beroep tegen een bezwaarschrift, dat een vrijstelling uitdrukkelijk en gemotiveerd moet zijn verleend en derhalve niet geacht kan worden stilzwijgend in een brief te zijn opgenomen. Voorts was de afdeling van oordeel dat in het kader van een beslissing op een bezwaarschrift de te verrichten volledige heroverweging niet zover kan strekken, dat alsnog een beschikking - in primo - gegenereerd kan worden. ${ }^{17}$ Het betrof hier de aanleg van een fietsvoetpad in de gemeente Pijnacker. Burgemeester en wethouders van die gemeente vatten hun brief aan een aantal inwoners op als een beschikking. In de bezwaarschriftenprocedure werd overwogen, dat in de eerste brief impliciet gebruik zou zijn gemaakt van de vrijstellingsbevoegdheid in het kader van het ter plaatse vigerende bestemmingsplan. Die laatste opvatting bleek voor de rechter niet door de beugel te kunnen.

In een andere zaak voor de ABRS stond eveneens de toepassing van art. 7:11 ter discussie. In de gemeente Amstelveen was door enkele bewoners bezwaar gemaakt tegen een verleende kapvergunning. In het primaire besluit hadden b en w ter motivering aangevoerd, dat omwonenden klachten hadden ingediend over een verminderde lichttoetreding door de ter plaatse aanwezige bomen. Beslissend op het bezwaar overwogen $b$ en $w$, in aanwulling op het primaire besluit, dat de verslechterde gezondheidstoestand van de bomen, alsmede de schade als gevolg van voortwoekering van de wortels aan aangrenzende tuinen en trottoirs, de reden was tot verlening van de kapvergunning. Van belang in die uitspraak is, dat de ABRS oordeelde, dat bij herowerweging op grondslag van een ontvankelijk bezwaar, sprake is van een integrale overweging en wel zodanig, dat ook eventuele gebreken in de motivering moeten worden hersteld. Het is niet van belang of die motivering van de beslissing op het bezwaar argumenten bevat die in het bezwaarschrift niet zijn vermeld. ${ }^{\text {I? }}$

Tenslotte is het in het kader van de bespreking van het connexiteitsuitgangspunt, interessart te wijzen op ontwikkelingen die een terugdringen hiervan in de hand werken. Gedoeld wordt hier op de verzelfstandiging van de voorlopige voorzieningsprocedure als bedoeld in art. 8:81. 
Het uitgangspunt van connexiteit lijkt onder druk komen te staan vanwege het intensieve gebruik van de voorlopige voorzieningsprocedure. Beter gezegd hat connexiteitsuitgangspunt in het kader van de toepassing van art. 8:81, zet diezelfde connexiteit onder druk. De te maken heroverweging in samenhang met het primaire besluit, dreigt verloren te gaan. Dit heeft te maken met enige waar te nemen ontwikkelingen in de voorlopige voorzieningsprocedure. Hierdoor lijkt deze procedure een min of meer zelfstandig karakter te krijgen. Door sommigen wordt gesproken van een materiële verzelfstandiging van de voorlopige voorzieningsprocedure. ${ }^{79}$ Bedoeld wordt hiermee, dat deze procedure een zekere beslissingsfunctie is gaan vervullen. Het oordeel in de voorlopige voorzieningszaak is kennelijk zodanig richtinggevend in de uitspraken van de bestuursrechters, dat het geschil hierdoor al dan niet bewust in een oplossingsrichting wordt gestururd. Bolt benadrukt die materiële verzelfstandiging van de voorlopige voorzieningsprocedure vanuit de resultaten van wetgevings- en jurisprudentieonderzoek. ${ }^{\text {*it }}$ Toegegeven moet worden dat het aantal onvrijwillige en vrijwillige schorsingen ook al ten tijde van het onderzoek in het kader van het rapport Arobpraktijken groot was. ${ }^{.81}$

Ter illustratie zij opgemerkt dat dit schorsingspercentage 40 bedroeg onder de werking van de Wet arob. Gebleken is dat in het arob-tijdperk van schorsingen tijdens de bezwaarschriftenprocedure een zekere filterwerking uitging. ${ }^{18 z}$ Hier ligt dan ook wellicht een oorzaak die wijst in de ontwikkeling van een zelfstandig administratiefrechtelijk 'kort geding". Een logisch gevolg lijkt, dat bij het toewijzen van een verzoek om voorlopige voorziening, het bestuursorgalan in een positie komt te verkeren, dat het niet conformeren aan de inhoud van de uitspraak van de adrninistratieve rechter, tot risico's van de verlengde besluitvorming zal kunnen leiden. Afhankelijk van de inhoud van de voorlopige voorzieningsuitspraak wordt de bezwaarschriftenprocedure nog al eens afgebroken. In overleg met de proces-partij komt het bestuursorgaan tot een vergelijk en wordt de bestreden primaire beslissing ingetrokken. Geen verstandig oordelend bestuursorgaan zal de uitspraak in het kader van de voorlopige voorziening kunnen negeren, ook al heeft deze uitspraak een voorlopig karakter. In deze voorlopige voorzieningszaken wordt die voorlopigheid van de uitspraak meestal na het citeren van art. 8:81 Awb, aan-geduid met: "(..) heeft het oordeel van de voorzitter daaromtrent een voorlopig karakter en is dat niet bindend in die procedure" of met een andere variatie in de tekst: "voor de uiteindelijke beslis-

179 A.M.M. M. Bots, Op weg naar een zelfstandig bestuursrechtelijk kort geding?, Deventer 1995

1 H. Holt. De voorlopige voorzieningsprocedure (diss.), Deventer 1986.

18. A. W. p. 309

182 Arob-praktijken, a.w, p. 312 
sing in de procedure". Men kan verschillend denken over de ontwikkelingen op het terrein van de voorlopige voorziening.

Toch geven deze ontwikkelingen aan, dat de voorlopige voorzieningsprocedure de heroverweging onder druk zet. Onder druk van de uitspraak van de bestuursrechter kan dit leiden tot het beëindigen van de bezwaarschriftenprocedure. Een beslissing op het bezwaarschrift en daarmee de samenhang met de primaire besluitvorming is niet meer opportuun. 


\section{Het verbod van vooringenomenheid: tegen vriendjespolitiek of onzorgvuldigheid?}

\subsection{Enkele uitgangspunten bij de publieke taakvervulling door bestuurs- organen; het tapijt van de wederkerigheid bedekt de eenzijdigheid}

Het verbeteren wan de inputzijde van het politiek-bestuurlijk systeem door het verhogen van de kwaliteit van de betrokkenheid tussen de burgers en de bestuursorganen, vormde een belangrijk uitgangspunt bij de discussie over de staatkundige en besturlijke vernieuwing. Toch is het vanuit de positie van de burger bezien meer van belang, hetgeen zich aan de outputzijde van het besturen aan zijn waarneming voltrekt. Daarbij let de burger primair op het belang dat hij heef bij de uitkomsten van de bestuurlijke besluitvorming. '

De kwaliteit van het owerheidsoptreden, is een belangrijke factor in het verkeer tussen burgers en bestuursorganen. ${ }^{2}$

De Awb benadrukt het kwaliteitsdenken over het handelen door bestuursorganen vooral in hoofdstuk 3. Hierin zijn ten behoeve van de zorgvuldigheid en de belangenafweging bij het nemen van besluiten, rechtsnormen opgenomen. Ook mag hierbij met het oog op het nu te bespreken onderwerp niet voorbij worden gegaan aan de bepalingen omtrent de advisering bij de voorbereiding van de besluitvorming, zoals deze zijn opgenomen in afdeling 3.3. Voor wat betreft de primaire besluitvorming kan overigens nog worden gewezen op de afdelingen 3.4 en 3.5 van de Awb, waarin respectievelijk de openbare voorbereidingsprocedure en de uitgebreide openbare voorbereidingsprocedure nadere regeling vinden. Indien deze procedures conform de uitgangspunten van de Awb plaatsvinden, kunnen zij een goede funcite vervullen in het belang van de kwaliteit van de voorbereiding van besluiten en de daarop volgende besluitvorming. Met enige nadruk zij hierbij gesteld 'kunnen'; over de noodzaak en de toegevoegde waarde van de voorbereidingsprocedure op grond van afdeling 3.4 wordt verschillend gedacht. Voor deze laatste procedure is de bezwaarschriftenprocedure toch wan toepassing. Daarentegen geldt de verplichte bezwaarschriftenprocedure niet ingeval het besluit is voorbereid met toepassing van de in afdeling 3.5 geregelde uitgebreide openbare voorbereidingsprocedure. In art. $7: 1$, lid 1 , onder $\mathrm{d}$ is de verplichte bezwaarschriftenprocedure uitgesloten.

1 C.I. Dales, De Awb en het bestuur, in: Bestuur, burger en rechtspraak, Alphen aan den Rijn 1994, p. 25 e.v.

2 M.C. Burkens, S.W. Couwenberg, H. Franken en J.B. Brinkhorst, Staatsrechtelijke vernieuwingen, Commentaar op het rapport van de Commissie Deetman, Zwolle 1991. 
Aangezien art. 2:4 mede van toepassing is op de openbare (uitgebreide) voorbereidingsprocedures wordt hierna globaal stilgestaan bij deze procedures. Deze staan in nauw verband met de bezwaarschriftenprocedure. De voorbereidingsprocedure als bedoeld in afdeling 3.4 is niet onbetwist gebleven. $\mathrm{Zij}$ zou de bezwaarschriftenprocedure kunnen vervangen.

Over het gebruik van de voorbereidingsprocedures als bedoeld in de afdelingen 3.4 en 3.5 zijn de eerste resultaten over de ervaringen met de Awb bekend. ${ }^{3}$ De eerste uitkomsten van een verrichte evaluatie naar het gebruik van afdeling 3.4 en 3.5 maken duidelijk dat deze voorbereidingsprocedures weinig worden toegepast." Voor de procedures inzake bestuursdwang en dwangsom geldt hetzelfde. Zelden worden deze procedures toegepast omdat in gemeentelijke kring deze als te omslachtig worden ervaren. ${ }^{5}$

De voorbereiding van de besluitvorming in het kader van het standplaatsenbeleid geeft ongeveer eenzelfde beeldvorming, zij het dat gemeenten wél overwegen om bij een gewijzigd vergunningenbeleid afdeling 3.4 toe te passen. ${ }^{6}$

De verplichte toepassing van de procedure van afd. 3.5 voor milieuvergunningen werd positief gewaardeerd omdat hierdoor een beter kwalitatief besluit zou worden bereikt; over een eventuele toepassing van afd. 3.4 werd in gemeentelijke kring minder positief geoordeeld. ?

De opvatting in provinciale kring verschilt niet ten opzichte van het gebruik van de afdelingen 3.4 en 3.5 bij gemeenten. De afdelingen 3.4 en 3.5 worden zelden toegepast; het rendement ten opzichte van hoofdstuk 4 (Bijzondere bepalingen over besluiten) wordt gering geacht. ${ }^{\mathrm{B}}$

Naast de bovengenoemde regels inzake de voorbereiding van besluiten geven in het bijzonder de bepalingen van hoofdstuk 4 , voorschriften voor de voorbereiding van beschikkingen.

Door de invoering van de derde tranche $A w b^{9}$ bevat hoofdstuk 3 overigens ruimere bijzondere bepalingen over besluiten. De huidige beschikkingentitel 4.2

3 B.J. Schueler e.a. Ervaringen met de $\mathrm{Awb}_{\text {, }}$ Besluiten over numtelijke ordening, milleu ent standplaatsen, Deventer 1996.

A.w., p. 37 .

A.W. p. 43.

A.W., p. 47 .

A.W. . P. 50 .

A.w., p. 100 .

wet van 20 juni 1996, Stb. 1996, 333, inwerkingtreding per $\mathbb{1}$ januari 1998. 
(wordt 4.1 ) is aangevuld met regels betreffende de subsidies (4.2). Een nieuwe titel 4.3 is toegevoegd voor het vaststellen van beleidsregels. Naast het belang van een goede kwaliteit van de primaire besluitvorming mag hierbij worden gewezen op de bepalingen van de hoofdstukken 6 en 7 , te weten de bezwaarschriftenprocedure.

Vooral de in art. 7:11 Awb verplichte heroverweging noopt het bestuursorgaan zijn aanvankelijk genomen bestreden primaire besluit tot een nadere toets, omtrent de kwaliteilt van zijn eerder genomen beslissing.

De kwaliteit van de bestururlijke besluitvorming is in relatie gebracht met het verwachtingspatroon dat de burger heeft met het oog op zijn rechtstreeks belang bij de uitkomsten van genomen besluiten.

Dit laatste is niet zonder betekenis, omdat dit 'rechtstreeks belang' voor de burger de ingang vormt bij het bestuursorgaan. In het ene geval vraagt de burger het bestuur een besluit te nemen omdat hem daarbij een bepaald concreet belang voor ogen staat en in het andere geval ageert deze burger tegen een hem onwelgevallig genomen besluit door datzelfde besluit te bestrijden; hij dient daartegen een berwaarschrift in.

Het genoemde rechtstreekse belang heeft in art. 1:2 Awb een juridische betekenis en verschaft de burger een rechtsingang.

Door deze rechtsingang en de bestuurlijke besluitworming ontstaat er met het oog op het veelvuldig beroep dat de burger noodgedwongen op het bestuursorgaan moet doen, een intensief verkeer tussen bestuur en burger. De dagelijkse praktijk van het openbaar bestuur geeft een beeld te zien van bijvoorbeeld aanvragen om een bouwvergunning, verzoeken om plansehade als bedoeld in art. 49 van de WRO, aanvragen om een sloopvergunning als bedoeld in art. 37 van de Monumentenwet, aanvragen om subsidieverlening, verzoeken om bijstand als bedoeld in de ABW en aanvragen om een uitkering in het kader van de sociale zekerheid.

Uit deze opsomming van door de burger van de bestuursorganen gevraagde dienstverlening, blijkt dat het contact tussen bestuur en burger frequent van aard is. Zeker als daarbij in aanmerking wordt genomen dat de gevraagde besluiten slechts een bescheiden greep zijn uit de van de bestuursorganen afkomstige besluitvormingsprodukten. Bijzonder is daarbij dat de burger gedwongen wordt tot "winkelnering" bij de bestuursorganen. Deze gemeentelijke bestuursorganen warop de bovengenoemde voorbeelden betrekking hebben, verrichten bijvoorbeeld op basis van hen daartoe verstrekte wettelijke bevoegdheden, publiekrechtelijke rechtshandelingen. Of de burger dat nu wel of niet leuk vindt, duidelijk zal zijn, dat hij voor het creëren van publiekrechtelijke rechtshandelingen, zoals die 
zijn terug te voeren tot het besluitprincipe van art. 1:3 van de Awb, afhankelijk is van het bestuursorgaan.

Met het oog op het primair belang dat de burger heeft bij de uitkomsten van de bestuurlijke besluitvorming, stelde de toenmalige minister van Binnenlandse Zaken mevrouw Dales, dat de Awb vanuit het kwaliteitsperspectief van het owerheidsoptreden, een markante ontwikkeling vastlegt tussen bestuur en burger.

"Het bestuur is niet langer de "Hoge overheid" die over de burger beslist, maar het bestuur dient te beslissen, met inachtneming van de belangen van de burger, zoals deze die belangen zelf ziet. De Awb dwingt het bestuur de burger bij besissingen te betrekken die hem direct aangaan. "16

Sprekend over de verplichtingen die de Awb aan de bestuursorganen oplegt voor een optimalisering van de verhouding tussen burgers en bestuursorganen, springt in thet oog de bepaling van art. 2:4 Awb. Deze noopt bestuursorganen tot een zodanige taakwervulling, dat zij niet vooringenomen zijn in het contact met de burgers. Het optreden van de overheid wordt hierdoor in de Awb nader geconditioneerd.

Art. 2:4 geplaatst in hoofdstuk 2 , houdende bepalingen terzake het verkeer tussen burgers en bestuursorganen, geeft de volgende bestuursrechtelijke opdracht aan de overheidsorganen:

'1. Het bestuursorgaan vervult zijn taak zonder vooringenomenheid.

2. Het bestuursorgaan waakt ertegen dat tot het bestuursorgaan behorende of daarvoor werkzame personen die een persoonlijk belang bij een besluit hebben, de besluitvorming beïnwloeden."

Met het opnemen van art. 2:4 wordt nog eens door de Awb het groot gewicht wan het geschreven recht onderstreept.

Voorafgaand aan de introductie van het hiervoren geciteerde voor bestuurs. organen geldende vooringenomenheidswerbod als bedoeld in art. 2:4 Awb, werd enkele malen gewezen op het bijzondere belang dat de burger heeft bij het kwaliteitsniveau van de uitkomsten van door bestuursorganen te nemen besluiten. In dit kwaliteitsdenken als uitgangspunt voor het bestuurshandelen bij de bestuurlijke besluitvorming, ligt tevens een deugdelijkheidseis opgesloten voor het bestuurlijk proces zoals zich dat ook in de bezwaarschriftenprocedure voltrekt. De plaatsing van art. 2:4 in hoofdstuk 2 van de Awb betekent dat de daarin 
vervatte rechtsnorm zich niet alleen richt op de primaire besluitvorming, maar ook op het verkeer tussen burgers en bestuursorganen tijdens de behandelingsprocedure van her bezwaar.

De bezwaarschriftenprocedure verplicht het tot heroverweging geroepen bestuursorgaan, het primaire besluitvormingsproces nog eens op zijn kwalitatieve merites te toetsen. Zowel de voorbereiding van het primaire besluit alsmede de beslissingsprocedure worden hierbij aan een herwardering onderworpen. Integraal op basis van de (heroverwegings)norm: naar feiten en omstandigheden, naar juistheid van bellangenafweging, alsmede naar de zorgvuldigheid in het kader wan de voorbereiding van de besluiten en daaromtrent uitgebrachte adviezen. Dit scala van aspecten geeft aan de bijzondere betekenis die deze kunnen hebben voor de bezwaarschriftenprocedure. Deze voorprocedure vormt immers de grondslag van een geschil over de uitoefening van bevoegdheden door bestuurs-organen.

Voor de ene burger kan dit betekenen dat hij bezwaar heeft tegen de weigering door of vanwege burgemeester en wethouders, om bestuursdwang toe te passen tegen een in de omgeving van zijn woning gelegen garage-bedrijf. Deze bezwaarde burger ziet zijn aanvrage om toepassing van bestuursdwang afgewezen, terwijl hij in tegenstelling tot $b$ en $w$ van oordeel is, dat als gevolg van de zich uitbreidende bedrijfsactiviteiten van deze onderneming, de woorschriften van de aan dit bedrijf verleende milieuvergunning zodanig worden overtreden, dat hij hierin een onaanvaardbare aantasting ziet van zijn woon- en leefmilieu. Een andere burger maakt bezwaar tegen een aan diens buurman verleende bouwvergunning voor het maken van een wintertuin aan zijn woning. Deze bezwaarde burger vreest, dat hij hinder zal ondervinden als gevolg van de vergunde uitbouw aan zijn buurman, doordat het aan te brengen electronisch schuifdak van deze uitbouw geluidsoverlast zal veroorzaken bij het openen en sluiten van de overkapping van de wintertuin. Weer een andere burger makt bezwaar tegen de bouw van een gemeentelijk muziektheater vanwege het slechte architectonische aanzien van het bouwplan. De betrokken burger is het niet eens met de door $b$ en $w$ aan de gemeente verleende bouwvergunning en geeft te kennen dat hij het welstandsadvies als partijdig beoordeelt, en dat andere op het gebied van architectuur gerenommeerde deskundigen hem daarin steunen. Tenslotte ziet een uitkeringsgerechtigde zijn bijstandsuitkering gekort omdat hij niet tijdig zijn inkomstenformulier bij de sociale dienst heeft ingeleverd.

Uit deze voorbeelden blijken de verschillende belangen die burgers hebben bij het uiteindelijk resultaat van bestuurlijke besluitwormingsprocessen. Daarbij komt tevens naar voren het aspect van de reeds eerder genoemde outputzijde van het besturen. Het oordeel van de burger over de kwaliteit van besluiten trekt hierdoor 
een parallel met de relatie tussen burgers en bestuursorganen, en daarmede ook het referentiekader dat de burger heeft omtrent de deugdelijkheid van de betrokken besluitvorming zellve. Als gevolg van het denken over de kwaliteit van het verkeer tussen burgers en bestuursorganen, worden door deze beide actoren in het besluitvormingsproces, waarderingsmaatstaven over het niveau van het functioneren van de bestuursorganen in hun relatie tot de burger uitgesproken. "Bezien vanuit het perspectief van de taakstelling van bestuursorganen die exclusief gericht is op de behartiging van het algemeen belang, is manifest de monopolistische positie van de overheid in de uitvoering van taken. Immers in de sfeer van het uitvoeringsniveau van wettelijke regelingen en verordeningen, komt de bijzondere positie van de overheid tot uitdrukking door de eenzijdige bevoegdheidstoekenning aan de bestuursorganen. Ondanks dit eenzijdigheidsaspect van het bestuurshandelen, heeft de relatie tussen burgers en bestuursorganen door de komst van de Awb een nieuwe bestuursrechtelijke optiek gekregen. De Awb brengt dit op de volgende wijze tot uitdrukking.

Ten aanzien van de inhoud van de rechtsbetrekking tussen bestuur en burger stelt de $A$ wb voorop, de grote betekenis die de algemene beginselem van behoorlijk bestuur hebben in de besluitwormingsprocessen. Schending van deze beginselen vormt voor de administratieve rechter regelmatig aanleiding, de vernietiging van genomen besluiten uit te spreken. Vanuit het perspectief van de grote waarde van de algemene beginselen in het bestuursrecht, motiveert de Awb de nadere precisering en de betere toegankelijkheid van algemene beginselen van behoorlijk bestuur. ${ }^{12}$ In samenhang daarmede accentueert diezelfde Awb dat de regels die in cleze beginselen tot uitdrukking komen, een andere benadering van de verhouding tussen bestuur en burger weerspiegelen. In het begin van deze eeuw legden de bestuursorganen verantwoording af van de wettelijk uit te voeren taken aan het daartoe democratisch gekozen vertegenwoordigend lichaam.

De rechtsbescherming van de burger tegen bestuurshandelingen was beperkt. Van enige toetsing aan de beginselen van behoorlijk bestuur was vanwege de gebondenheid van het bestuur aan de wet geen sprake. Incidenteel bestond de mogelijkheid van administratief beroep op een hoger bestuursorgaan. Indien bestuurshandelingen in het geding waren, waarbij gesproken kon worden van enige belleidsvrijheid, gold de politieke verantwoordingsplicht van het betrokken bestuursorgaan voor de burger, als ultinum remedium om te ageren tegen hem onwelgevallig genomen besluiten.

1. M. Oosting, Kwalliteit van de overheid, Deventer 1990, p. 6.

12. PG Awb I, p. 39. 
Zonder nu een uitwoerige behandeling te wijden aan het type bestuur dat zich thans in het verkeer met de burgers manifesteert, is duidelijk dat de ontwikkelingen van de algemene beginselen van behoorlijk bestuur die ver vóór de inwerkingtreding van de Awb werden ingezet, een geheel ander beeld te zien geven van de relatie tussen bestuursorganen en burgers. Deze algemene beginselen van behoorlijk bestuur zijn gaandeweg geëvolueerd tot belangrijke pijlers van de rechtsbetrekking tussen beide actoren op het terrein van het bestuursrecht. Besluiten, of dat nu primaire besluiten zijn dan well in bezwaar of administratief beroep genomen beslissingen, hebben niet of nauwelijks enige juridlische validiteit, zonder dat bij de besluitvorming een verankering met de algemene beginselen van behoorlijk bestuur heeft plaatsgevonden. De gaandeweg steeds mondiger burger, die zeer veelvuldig gebruik maakt van de professionele rechtshulpverleners, heeft zijn weg gevonden naar de administratieve rechter, die oordelend in beroep, besluiten die mank gaan aan de beginselen-conformiteit van handelen door bestuursorganen, doorgaans zal vernietigen.

Door het veranderde beeld van de overheid, en daarmede de gewijzigde invulling van de verhouding tussen bestuursorganen en burgers, zijn de algemene beginse len van behoorlijk bestuur stilaan een brugfunctie gaan vervullen in het contact tussen burger en bestuur.

Ofschoon het denken over de verhouding van de overheidsmacht en recht nog niet is uitgekristalliseerd, ook niet door de vondst van deze algemene bestuursbeginselen, zijn deze als leidinggevende principes gaan fungeren. Meer concreet kan hier gesproken worden van een continu proces, dat zich voltrekt in een permanente ontwikkeling in de rechtsbetrekking tussen bestuur en burger.

Het handelen door bestuursorganen dient daarop te zijn afgestemd. ${ }^{13}$ Dat het denken over de verhouding van de overheidsmacht en het recht, en daarmee de positie van de burger nog niet is uitgekristalliseerd, doet niet af aan de omstandigheid dat thans in de bestuurspraktijk gesproken kan worden van door wet en beginselen genormeerde taakuitoefening door bestuursorganen. Of dit leidt tot "normaal bestuur" in de rechtsbetrekking tussen bestuur en burger, mag vanuit het gezichtspunt van het hier te bespreken onderwerp onbeantwoord blijven. Deze onbeantwoorde vraagstelling kan als wolgt worden gerechtvaardigd.

Sommigen gaan uit van het principe dat de Awb via zijn samenstel van regels een ander type bestuur schept dat in een wederkerige rechtsbetrekking lijkt te staan tot

13 A.Q.C. Tak, Normal bestuur, in: Bestuur en norm, Deventer 1986, p. 256.

14. A.Q.C. Tak, a. , p. 255 . 
de burger. ${ }^{15}$ Dit wederkerig bestuur moet rekening houden met de belangen van bij de besluitworming betrokken burger, zoals die burger deze zelf ziet. ${ }^{16}$ Toch moet worden betwijfeld of de $\mathrm{Awb}$ ten opzichte van de arob-periode uitgaat van een ander type bestuur.

Over het uitgangspunt van wederkerigheid kunnen op $z^{\prime} n$ minst enige twijfels worden geuit. De gedachtenvorming ower wederkerig bestuur heeft immers meer relaties met de private rechtsbetrekking in het civiele recht. De term wederkerig bestuur voegt in feite niets toe aan de bestuursrechtelijke rechtsbetrekking, waarbij het bestuursorgaan aan de totstandkoming daarvan (eenzijdig) invulling behoort te geven aan de bestuurlijke normen van de Awb (hoofdstukken 3 en 4). Daarbij komt nog dat ook de niet gecodificeerde algemene beginselen van behoorlijk bestuur en de algemene rechtsbeginselen, een rol vervullen in de relatie tussen de burgers en het bestuursorgaan.

Toegegeven moet worden dat het bestuursrecht nu een ander beeld geeft te zien van de relatie tussen het bestuursorgaan en de burger. Bij het tot stand komen van besluiten valt steeds meer waar te nemen een verminderde aanvaarding van het overheidsoptreden. Er is sprake van een afnemende legitimatie van de besluitvorming. Het overheidsoptreden wordt steeds meer consensueel gefundeerd. Het gevolg hiervan is dat het rechtsstatelijk beginsel van gelijkheid voor de wet in nog sterkere mate wordt ondermijnd. Burkens en Stroink zien hierin een ondergraving van het voordeel van de traditionele, gegeneraliseerde gezagsgrondslag. ${ }^{17}$ Hun standpunt dat het staats- en bestuursrecht gefundeerd moet blijven op 'bevoegdheidsuitoefening' ${ }^{18}$ raakt de fundamenten van de rechtsstaat en daardoor ook de uitgangspunten van het legaliteitsbeginsel. Deze uitgangspunten dienen het belang van de rechtszekerheid van de justitiabele. Eenzijdige bevoegdheidsuitoefening behoort de grondslagen van het bestuursrecht te handhaven; dat er in 'cosmetisch opzicht' op basis van de bestuurlijke normen, beginselen van behoor-

is L.J.A. Damen, Bestaat de Awb-mens?, in: J.L. wan Boxum e.a. (red.), Aantrekkelijke gedachten', Beschouwingen over de Algemene wet bestuursrecht, Deventer 1993, p. 118.

16 PG Awb 1, p. 39.

17 M.C. Burkens en F.A.M. Stroink, Sociale verzorgingsstaat en consensuele besluitvorming, NJB 1980, p. 749. Zie in dit verband: Rb. "s-Gravenhage 10 april 1997, BR 1997, p. 663 e.v. (Vinex-locatie: Pijnacker-Zuid). Belangenafweging in het kader van planologische procedures (art. 19 WRO) mag niet bij voorbaat vaststaan op basis van een convenant. Toezeggingen in een convenant of anderszins passen miet in het systeem van vergunningverlening. AGVB 1 september 1992, AB 1993, 400 m.nt. ThGD.

A.w., p. 750 . 
lijk bestuur en rechtsbeginselen, kenmerken van wederkerigheid insluipen, doet hier niet aan af. ${ }^{19}$

De Awb trekt door de regels voor het bestuursrecht een sterke wissel op de zorgvuldigheid van de besluitvorming. Diezelfde zorgvuldigheidl lijkt de hoeksteen van de Awb in het besluiten-verkeer met de burger. De weerslag hiervan komt tot uitdrukking in art. 2:3 betreffende de doorzendplicht, de kennisvergaringsplicht als bedoeld in art. 3:2, alsmede het samenstel van regels, inzake het kenbaar maken van de zienswijze, voorafgaand aan de (primaire) beschikking, waarvan de uitwerking is te vinden in de art, 4:7, 4:8, 4:11 en 4:12 Awb. Daarnaast kan worden genoemd de motiveringsplicht op grond van art. 3:46 die noopt tot een zorgvuldige verantwoording van het genomen besluit. De beide voorbereidingsprocedures als bedoeld in de afdelingen 3.4 en 3.5 en de bezwaarschriftenprocedure kunnen aan het bovengenoemde zorgvuldigheidsrijtje worden toegevoegd. Getwijfeld wordt of het zorgvuldigheidsbeginsel wel voldoende is om het wederkerigheidsaspect van de relatie tussen bestuur en burger tot uitdrukking te brengen. ${ }^{20}$ De Awb legt immers bijvoorbeeld in hoofdstuk 2 strengere maatstaven aan voor de relatie tussen het bestuursorgaan en de burger. ${ }^{21}$ Gewezen wordt in dit verband op de hoorplicht zoals opgenomen in de art. 4:7 en 4:8. De in deze artikelen uitgewerkte hoorregeling in het kader van de voorbereiding van de primaire beschikking, zou vanwege de gemaakte restrictieve omschrijving geen royale erkenning betekenen van de betrokkenheid van de burger bij de voorbereiding van de besluitvorming. Daarenboven zou de MvT de in de art. 4:7 en 4:8 omschreven hoorplicht adstrueren vanuit het beginsel dat besluiten zorgvuldig dienen te worden voorbereid. ${ }^{22}$

Teneinde recht te doen aan de uitgangspunten van wederkerig bestuur in de relatie bestuursorgaan-burger, wordt bepleit dat het bestuursorgaan altijd de burger dient te horen in gevallen dat een beleidsmatige beschikking aan de orde is. ${ }^{23}$

Een dergelijke strikte toepassing van de art. 4:7 en 4:8 lijkt niet nodig om recht te doen aan de bestuurlijke wederkerigheidsoptiek van de Awb. In de praktijk van

19 Zie woor een meer wiw werige benadering: E.C.H.J. van der Linden en A.Q.C. Tak, Edenzijdig en wederkerig? en J.M.H. wan Erp, Contract als rechtsbetrekking, Zwolle 1990.

20 L.J.A. Damen, a.w., p. 119 en 120.

2. H.G. Lubberdink, De Awb: hoedster van de individuele vrijheid?, in: "Aantrekkelijke gedachten "Deverter 1993, p. 133.

22 Algemene regels van bestuursrecht (Algemene wet bestursrecht), MwT TK 1988-1989, 21221, ar. 3.

23 H.G. Lubberdink, a.w. p. 134 
het bestuur vindt bij de voorbereiding van besluiten veelal overleg plaats. Wordt bijvoorbeeld een bouwvergunning gevraagd, dan wordt doorgaans, buiten de procedureregeling van de WW en de Bouwverordening, met de aanvrager bouwplan-overleg gevoerd. In dit bouwplan-overleg komen zaken aan de orde zoals het welstandsaspect en het planologische kader in casu het bestemmingsplan. Welstandseisen worden regelmatig doorgesproken mef de aanvrager, de architect en een lid van de welstandscommissie. In dit overleg wordt getracht tot een aanvaardbaar plan te komen. Ten aanzien van de bestemmingsplan-aspecten wordt vóórdat een aanvrage on bouwvergunning wordt ingediend, overleg gevoerd met de ambtelijk stedenbouwkundige teneinde in het verdere verloop van de procedure, onaangename verrassingen voor de aspirantbouwer te voorkomen. Indien vrijstellingsaspecten bij de beoordeling van het bouwplan aan de orde zijn, wordt daarbij nogal eens in overleg getreden met de belanghebbende omwonenden. Ook hierdoor wordt zoveel mogelijk geprobeerd in gezamenlijk overleg problemen op te lossen alvorens de formele bouwaanvraag-procedure te starten.

Een zelfde overlegsituatie doet zich voor in die gevallen, dat wordt opgetreden tegen overtreders van voorschriften en de toepassing van bestuursdwang in het voornemen ligt. Niet zelden, vindt voorafgaand aan de formele waarschuwing tot toepassing van bestuursdwang een informele aanschrijving plaats. Daarbij wordt betrokkene op de hoogte gesteld dat het bestuursorgaan overweegt om tot toepassing van bestuursdwang over te gaan, indien de overtreder aan de rechtens strijdige situatie geen einde zal maken. De praktijk geeft het beeld te zien dat doorgaans overleg met belanghebbenden wordt gevoerd. Het geschetste beeld geeft een bestuurspraktijk te zien van wederkerig bestuur in de zin van de $A$ wb. Hierdoor wordt op een Awb geschoeide leest tegemoet gekomen aan de voorgestane communicatieve eisen die het nieuwe bestuursrecht voor ogen heeft. De omstandigheid dat de MvT van de Awb, de hoorplicht als bedoeld in de art. $4: 7$ en $4: 8$ benadert, vanuit het zorgvuldigheidsperspectief, doet hier niet aan af. In datzelfde zorgvuldigheidsperspectief ligt als het ware, zoals de hiervoren gegeven voorbeelden illustreren, het door de Awb bedoelde wederkerig bestuur opgesloten.

Vanzelfsprekend is, dat niet elk bestuursorgaan even zorgvuldig omspringt met de belangen van de betrokken burgers in de voorbereidingsfase van de besluitvorming. Maar in dit geval kan de rechter een wakend oog houden over het rechtens juist toepassen van de art. 4:7 en 4:8 van de Awb. In een Rotterdamse zaak betreffende een aanschrijving tot toepassing van bestuursdwang bleek bijvoorbeeld, dat door burgemeester en wethouders van de gelijknamige gemeente, de toepassing van art. 4:8 achterwege was gelaten. Tevens had het betrokken bestuursorgaan niet aangegeven of er redenen waren om dit verzuim te accepteren 
op grond van de in art. 4:11 genoemde tedenen. In deze voorlopige voorzieningszaak schorste de rechtbank de gegeven beschikking. ${ }^{24}$

De in het kader van de bezwaarschriftenprocedure voorgeschreven hoorplicht als bedoeld in art. 7:2, kan een belangrijke functie vervullen in het corrigeren van eventuelle bestururijke omissies of slordigheden in besluiten in primo. Dit laatste klemt temeer in die gevallen, dat de primaire beschikking voorwerp is geweest van een voorlopige voorzieningsprocedure als bedoeld in art. 8:81 Awb.

Het bestuursorgaan is dan meestal naar aanleiding van de openbare behandeling van de zaak gewaarschuwd en zal zich ongetwijfeld geen tweede misser veroor loven.

Terloops is gesproken over het wakend oog van de administratieve rechter over een juiste bestuurlijke invulling van de art. 4:7 en 4:8 Awb. Ook werd een relatie gelegd met de praktijk, dat bestuursorganen steeds meer in overleg treden met de belanghebbende burgers, als de voorbereiding van besluiten aan de orde is. Ofschoon het hierna aan de jurisprudentie ontleende voorbeeld uiteraard casuistisch is, kan aan het belang daarvan voor de praktijk niet voorbij worden gegaan. Voor de Pres. Rb. Alkmaar diende een zaak, waarbij aan het oordeel van de administratieve rechter werd onderworpen, een aanschrijving onder oplegging van een dwangsom door de gemeente Drechterland om het illegaal gebruik wan een supermarkt te beëindigen.

De Alkmaarse Pres., die tevens uitspraak deed in de hoofdzaak, overwoog in deze kwestie dat volgens de wetsgeschiedenis een hoorzitting niet nodig is noch een afzonderlijke verslaggeving van het horen:

-Anders dan verzoekster meent is de hier bedoelde hoorplicht beperkt van omvang. De in dit artikel neergelegde regeling ziet niet op het maken van bezwaar, maar betref het bieden van een mogelijkheid om gegevens te corrigeren dan wel bepaalde gegevens te verifieren. Vaststaat dat op 4 mei 1994 een gesprek heef plaatsgevonden tussen vertegenwoordigers van beide partijen, waarbij - blijkens het naar aanleiding hiervan opgemaakte schriftelijke verslag - van de zijde van verweerder te kennen is gegeven dat de door verzoekster in het leven geroepen illegale situatie niet zou worden geaccepteerd en dar hiertegen zou worden opgetreden. Blijkens dit verslag is verzoekster veryolgens om eer reactie gevraagd. Met inachtneming wan hetgeen hierwoor is overwogen, ziet de president dan ook geen grond voor het oordeel, dat verweerder bij de woorbereiding van het bestreden bes/uit niet overeenkomstig het bepaalde in artikel $4: 8$, eerste lid van de Awb verzoekster in de gelegenheid heeft gesteld haar zienswijze naar voren le brengen. ${ }^{25}$

24 Rb. Rotterdam 26 januari 1994, IB 1994,8.

25 Pres. Rb. Alkmaar 8 augustus 1994, Aw-katern, 1994, 165. 
De bovengenoemde uitspraak leert in ieder geval, dat het bestuursorgaan prudent moet omgaan met thet uitvoering geven aan de art. 4:7 en 4:8 Awb. Toch kan het wederkerigheidsperspectief een rol spelen voor het geval dat deze artikelen miet strikt formeel zijn toegepast. Van belang kan zijn het antwoord op de vraag of toepassing van deze artikelen al dan niet gelet op de omstandigheden van het geval geboden is. Gevoerd overleg tussen het bestuursorgaan en de burger, op grondslag van het beginsel van wederkerig bestuur, kan een compenserende invloed hebben op het niet toepassen wan de art. 4:7 en 4:8 (er is materieel voldaan aan de art. 4:7 en 4:8). Daarbij is niet zonder betekenis of het bestuursorgaan zich actief heeft opgesteld in het verkeer met de betrokken burgers. De A wb geeft immers minimum-eisen; het bestuursorgaan kan een kwalitatief hoger niveau van bestuursrechtelijk handelen nastreven. Uit een oogpunt van zorgvuldigheid kan het bestuursorgaan daarvan profijt hebben. Door een behoorlijke adstructie van het feitencomplex in het kader van de besluitvorming, kan het oordeel van de rechter positief worden beïnvloed. Dat laatste blijkt uit de Alkmaarse zaak.

Het niet wettelijk vereiste opgemaakte schriftelijk verslag, bood de rechter voldoende inzicht in de mate van zorgvuldigheid van het genomen besluit.

Ten aanzien van het wederkerigheidsaspect in het bestuursrecht kan nog het volgende worden opgemerkt.

Door Damen wordt gesteld, dat het primair bij de wederkerigheidsgedachte gaat om door het recht beheerste rechtsbetrekkingen, waarbij over en weer rechten en plichten bestaan en waarbij partijen over en weer met elkaars positie en belangen rekening moeten houden. Damen stelt dat bestuursorganen plichten, maar ook rechten hebben. Ditzelfde geldt mede woor de burgers. Het beeld van de calculerende burger met alleen maar rechten, én bestuursorganen met alleen maar plichten is erg eenzijdig. ${ }^{26}$

Wat hier ook van zij, voor een onevenwichtige balans in het wederkerig bestuur behoeft niet zozeer te worden gevreesd wanneer die aspecten bij de besluitvorming worden betrokken, welke hiervoren zijn besproken en het handelen van de bestuursorganen daarop is afgestemd. De omstandigheid dat de Awb zeer zuinig is met het inbouwen van plichten voor de burger, doet hier niet aan af ${ }^{27}$

26. L.J.A. Damen, a.w., p. 119 e.v.

27 R.M. van Male, De belanghebbende, VAR 108, Alphen aan den Rijn 1992, p. 20 . 
Het algemeen bestuursrecht zoals dat in de. Awb regeling vindt behoort in zijn toepassing en samenhang te worden bezien in relatie tot de bijzondere delen van het bestuursrecht, die hun uitwerking vinden in de bijzondere wetgeving en verordeningen. Als voorbeeld kan hier worden genoemd de WW en de hieraan ten grondslag liggende bouwverordening. De wetgeving op het terrein wan het bouwrecht wemelt immers van de bijzondere verplichtingen voot de justitiabelen die geconfronteerd worden met bouwactiviteiten en de daaruit resulterende rechtsgevolgen. Ten aanzien van de invoering van andere bijzondere delen van het bestuursrecht (bijvoorbeeld de regels terzake de subsidiëring, $3 \mathrm{e}$ tranche $\mathrm{Awb}$ kamerstukken 23700), moet met van der Vlies worden toegegeven, dat eveneens de verplichtingen van de burgers in de Awb zullen toenemen ${ }^{28}$ Betwijfeld moet worden of deze ontwikkeling stimulering behoeft. De invoering van bijzondere delen van het bestuursrecht zou er toe kunnen leiden, dat het specifieke karakter van de bijzondere rechtsgebieden wan het bestuursrecht verloren gaat; anderzijds zou door een te ver doorgevoerde verbijzondering in de Awb, door opname van bijzondere delen van het bestuursrecht, de oorspronkelijke gedachte opzet van de Awb als algemeen kader voor het bestuursrechtelijk handelen, aan systematiek en structuur inboeten. Het door de Awb voorgestane wederkerig bestuur zal er materieel gezien niet aan kracht door winnen. Wederkerigheid als sleutelbegrip in het bestuursrecht blijft immers nauw verbonden met het bestuursrecht. Het bestuursrecht is als vanouds gericht op de ordening van rechtsbetrekkingen. ${ }^{29} \mathrm{De}$ rechtsbetrekking tussen overheid en burgers schept over en weer verplichtingen: de burger kan bijvoorbeeld aanspraak maken op een bouwvergunning, het bestuursorgaan is gehouden tot vergunningverlening en diezelfde burger behoort de vergunningsvoorschriften na te leven. De beginselen van behoorlijk bestuur conditioneren daarbij de inhoud van de ontstane rechtsbetrekking en in casu de verleende bouwvergunning. De beginselen van behoorlijk bestuur die in de hoofdstukken 3 en 4 deels als rechtsnormen zijn geconditioneerd als regels voor bestuursorganen bij het nemen van besluiten, zouden het beeld kunnen oproepen van eenzijdig aan het bestuursorgaan opgelegde normen. Toch reflecteren diezelfde Awb-normen een verplichting voor de burger als meespelende actor in het proces van de besluitvorming. Rechtsnormen of niet gecodificeerde algemene beginselen van behoorlijk bestuur, geven niet alleen verplichtingen aan het bestuursorgaan maar ook aan de burger. Als voorbeeld kan hier worden genoemd de invuling van het rechtszekerheidsbeginsel. Meermaals heeft de Centrale Raad vam Beroep overwogen dat het rechtszekerheidsbeginsel niet alleen voor de ambtenaar maar ook voor hel bestuursorgaan geldt (CRvB 14 juli 1983, TAR, 7), 
hetgeen meebrengt dat het bestuursorgaan de ambtenaar in beginsel aan toezeggingen en akkoordverklaringen kan houden. Andere rechters komen in andere bewoordingen tot vergelijkbare resultaten. ${ }^{\text {30 }}$

Hirsch Ballin is van oordeel dat, voor een ontwikkelde rechtsstaat waarbij eenzijdig de aandacht wordt gericht op dat wat het bestuur over burgers beslist, een begrip van het bestuursrecht tekort schiet. Dat daarbij niet behoeft te worden getwijfeld dat de kern van het denken over het begrip bestuursrecht wederkerigheid impliceert bij de bestuurlijke beslissing, lijkt mede in het licht van hetgeen hiervoren is gesteld, boven elke twijfel verheven. Juridisch feit blijft echter, dat er verschil zal blijven bestaan in de rechtspositie tussen de actoren in het bestuursrecht, te weten bestuursorganen en adviesorganen enerzijds en burgers anderzijds. Dat verschil heeft voor zover hier van belang, voor de verhouding tussen bestuursorganen en burgers een onderscheidende betekenis, die afgezien van het gepropageerde wederkerig bestuur, alle argumenten die horizontalisering van het bestuur benadrukken ten spijt, een dominante betekenis. ${ }^{31}$ Met Stroink moet worden benadrukt, dat enige voorzichtigheid met het gebruik van de term wederkerige rechtsbetrekking geboden is. De publiekrechtelijke bevoegdheidsuitoefening door bestuursorganen in hun relatie met de burgers, is niet op een lijn te stellen met de verhoudingen tussen partijen zoals deze zich in het privaatrecht voltrekken. Van volledige consensualiteit en gelijkwaardigheid van partijen bij de besluitvorming, is in tegenstelling tot het privaatrecht in het bestuursrecht als onderdeel van het publiekrecht geen sprake. Besluitvorming in het bestuursrecht vindt plaats op basis van eenzijdige bevoegdheidsuitoefening door bestuursorganen. ${ }^{32}$

Ingegaan is op het aspect wederkerig bestuur zoals de Awb dit benadert vamuit het perspectief van het verkeer tussen burgers en bestuursorganen.

Hierbij ontstond aanvankelijk het beeld van de wederkerigheid van de rechtsbetrekking tussen diezelfde burgers eni bestuursorganen.

Bestuursorganen zouden in hun verhouding tot hun burgers bij hun taakvervulling en in het bijzonder bij hun besluitvorming in een gelijkwaardige positie staan. Deze conclusie blijkt echter niet voliedig recht te doen aan de uitgangspunten van het bestuursrecht. De bevoegdheidsuitoefening van bestuursorganen, zoals die onder andere zijn weerslag vindt in het nemen van besluiten vanuit het gezichtspunt van de Awb, blijft eenzijdig en autonoom voorbehouden aan het bestuursorgaan. Als dit laatste niet het geval zou zijn, dan zou de administratieve rechts-

30 E.M. Hirsch Ballin, a.w., p. 3.

3.1 I.A. Damen, a.W., p. 121 e.v.

32 F. A.M. Stroink, Algemeen Bestuursrecht, Zwolle 1994, p. 16. 
bescherming op het terrein van het bestuursrecht niet zo'n grote toevlucht hebben genomen. Nog steeds is een belangrijk kenmerk van de bestuursrechtspraak het aspect van de ongelijkheidscompensatie: de ongelijkheid in de rechtsbetrekking, veroorzaakt door de (eenzijdige) bevoegdheid van bestuursorganen om besluiten te nemen, wordt gecompenseerd door het bestaan van de bestuursrechtelijke procedure. ${ }^{33}$

\subsection{De Awb en het verbod van vooringenomenheid: enkele desiderata}

In de vorige paragraaf werd art. 2:4 Awb geciteerd. Deze bepaling is voor het bestuursrecht een novum omdat in het eerste lid expliciet tot uitdrukking wordt gebracht, dat het bestuursorgaan zijn taak zonder vooringenomenheid behoort te vervullen. In samenhang met het eerste lid van dit artikel vindt in het tweede lid een nadere uitwerking plaats. De in het eerste lid van art. 2:4 Awb gegeven norm, vindt nadere uitwerking in lid 2 van dit artikel. Van het bestuursorgatan wordt een zodanige inspanningsverplichting gevraagd teneinde te voorkomen, dat de tot het bestuursorgaan of daarvoor werkzame personen, die een persoonlijk belang hebben bij een besluit, de besluitvorming beïnvloeden.

Art. $2: 4$ van de Awb beoogt een rechtsnormerende werking te bevorderen teneinde aan belangenverstrengeling in het openbaar bestuur het hoofd te bieden. De inhoud en de redactiestructuur van art. 2:4 tenderen eerder naar vaagheid dan duidelijkheid. Vanuit een der hoofddoelstellingen van de Awb, te weten het codificatiestreven, roept de toepassing van de betreffende bepaling vraagtekens op. Dit laatste klemt temeer ondat het Awb-codificatieprincipe gedragen wordt door twee belangwekkende uitgangspunten, te weten: de kenbaarheid van het recht en het daardoor bevorderen van de rechtszekerheid. ${ }^{34}$

Er kunnen vraagtekens worden geplaatst bij deze bepaling in de Awb. Naar inhoud en strekking lijkt door het opnemen van art. $2: 4 \mathrm{Awb}$ eerder sprake van modificatie dan codificatie; het artikel vormt niet de weerslag van jurisprudentie. Dit laatste laat onverlet dat in dit hoofdstuk mede aan de hand van de jurisprudentie, gezocht wordt naar aanknopingspunten in het Nederlands recht, naar rechtsbronnen inzake de zuiverheid van het optreden door bestuursorganen.

Door het opnemen van een bepaling zoals art. $2: 4$ in de Awb, lijkt zich in eerste instantie een beeld te vormen, warbij de verwachting zou kunnen worden

39 D. Allewijn, Beschikkingsprocesrecht, in: Het Nieuwe bestuorsprocesrecht, VAR 112, Alphen aan den Rijn 1994, p. 108 e.v.

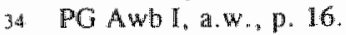


gewettigd, dat met een dergelijk voorschrift de problemen naar het bestuurlijke uitwoeringsniveau worden verschoven en uiteindelijk ook naar de rechter die immers in het administratiefrechtelijke traject het laatste woord heeft. In de context van hetgeen is gesteld, had ook de RvS enige aarzeling ten aanzien van de toepassing van art. $2: 4^{35}$

Het lijkt zinvol de achtergronden en uitgangspunten van de Awb nader te achterhalen. In samenhang daarmede wordt tevens betrokken de reikwijdte van art. 2:4 Awb.

De overheid moet haar taken zodanig vervullen dat zij daarbij de belangen behartigt van alle burgers. Bestuurders en ambtenaren vertegenwoordigen de overheid en dat schept bijzondere verplichtingen. Bestuurlijke integriteit bij die algemene en publieke belangenbehartiging staat voorop, waarbij de schijn van belangenverstrengeling moet worden vermeden. Daarbij moeten de burgers er op kunnen vertrouwen, dat die overheid en overheidsdienaren slechts het algemeen belang bij hun taakvervulling voorstaan. ${ }^{36}$ Bestuursorganen en ambtenaren behoren bij deze belangenbehartiging een zodanig onderscheidend vermogen te hebben, dat persoonlijke belangen worden uitgesloten van de publieke taakvervulling. Deze uitgangspunten bij het optreden van het openbaar bestuur behoren gedragen te worden door het grondbeginsel, dat bestuursorganen en de voor die bestuursorganen werkzame personen, in het verkeer met de burgers, zonder onderscheid van personen, handelen en besluiten nemen. Bij een zodanige overheidshouding ligt het wellhasst voor de hand dat hierdoor het oordeel van de burger over de zuiverheid en de objectiviteit van het overheidsoptreden aan kracht winnen en daarmede ook het vertrouwen van diezelfde burger in de overheid. Dat hierdoor het niveau van het democratische gehalte van de rechtsstaat positief zal worden beïnvloed behoeft nauwelijks enig betoog.

Hierin ligt een aantal accenten opgenomen dat ten grondslag ligt aan het opnemen van het vooringenomenheidsverbod bij de bestuurlijke taakvervulling. De beweegredenen voor het opnemen van een bepaling als art. 2:4 is door de Awb primair geadstrueerd vanuit het grondwettelijk beginsel, dat voor het overheidsoptreden besluiten behoren te worden genomen zonder aanzien des persoons. In dit verband werd een nadrukkelijke relatie gelegd met het eerste artikel uit de catalogus van grondrechten, welk artikel gelijke behandeling in gelijke gevallen propageert. ${ }^{37}$ Het gelijkheidsbeginsel zou naar de mening van de Awb in het bijzonder voor bestuursorganen met zich brengen, datt de grondhouding van het

3s PG Awb I, a.w., p. 99.

36 W. Derksen, Tussen correctheid en corruptie, Best.w. 1995, p. 245.

37 PG Awb I, P. 179. 
openbaar bestuur gebaseerd dient te zijn op objectiviteitsmaatstaven. Dit laatste betekent dat de besluitvorming van bestuursorganen moet bogen op deskundigheidsargumenten en op beleidsmatige motieven, waarbij een (objectieve) onpartijdige taakvervulling voorop moet staan. Bevooroordeeld handelen bij de besluitvorming behoren bestuursorganen apert uit te sluiten. Het is overigens nog van belang er op te wijzen, dat een onpartijdige taakvervulling door bestuursorganen niet verward moet worden met een onafhankelijk bestuursoptreden.

Bevooroordeeld handelen door bestuursorganen kan zich bij de voorbereiding en het nemen van besluiten manifesteren doordat deze organen zich bij het creëren van rechtsbetrekkingen tussen hun burgers laten leiden door persoonlijke belangen of voorkeuren. Persoonlijke belangen en voorkeuren kunnen een te grote betrokkenheid bewerkstelligen en bestuurlijke of ambtelijke verantwoordelijkheid negatief beinvloeden. Belangenverstrengeling kan daardoor de beeldvorming van een partijdig bestuur versterken. Vooringenomenheid bij de taakvervulling kan onder deze omstandigheden daardoor een gemakkelijke voedingsbodem krijgen. Het effect daarvan kan zijn, dat bepaalde (groepen van) belanghebbenden worden bevoordeeld of dat zelfs maar de indruk van "vriendjespolitiek" ontstaat.

Dit betekent dat de Awb aspecten als gelijkheid, het voorkomen van persoonlijke belangen en bevooroordeeldheid, het vermijden van belangenverstrengeling. alsmede het buiten de deur houden van partijdigheid, tot een besluitvormingscredo heefl geformuleerd voor bestuursorganen. Deze elementen moeten via het rechtsnormerend karakter van art. 2:4 borg staan voor een taakvervulling door het openbaar bestuur zonder enige vorm van vooringenomenheid.

De motivering van de plaatsbepaling van art. 2:4 in het hoofdstuk 2 Awb (verkeer tussen burgers en bestuursorganen) wordt beargumenteerd vanuit het beginsel zoals dal geld voor de taak van de administratieve rechters. Via een verwijzing naar de wrakings- en verschoningsbepalingen, zoals die aanwankelijk regelling vonden in art. 121 van de Wet op de Raad van State, art. 30 van de Wet administratieve rechtspraak bedrijfsorganisatie en art. 61 van de Beroepswet, wordt een relatie gelegd met het judiciële beginsel van 'nemo iudex in re sua'.

Deze wrakings- en verschoningsbepalingen hebben nu uniforme regeling gevonden in hoofdstuk $8 \mathrm{Awb}$ en wel in de art. 8:15 tot en met 8:20.

Ook de voor de administratieve rechtspraak geldende regels omtrent wraking en verschoning vinden gelijke toepassing in thet burgerlijk procesrecht (art. 29-36 $\mathrm{Rv}$ ) en het formele strafrecht (art. 512-219 Sv).

In relatie tot hetgeen is gezegd over de positie van de rechterlijke macht, wordt opgemerkt, dat ook vanuit het internationaal-rechterlijk perspectief bezien, art. 6 
van het EVRM (cn ook art. 14 IVBP) de justitiabele, het rechi verschaft op een cerlijke en openbare behandeling van zijn zaak door een bij de wet ingesteld onafhankelijk en onpartijdig gerecht.

Deze eis is overigens niet gesteld ten aanzien van bestuursorganen, omdat het EVRM met zoveel woorden spreekt over de onafhankelijkheid en onpartijdigheid van 'het gerecht'. Dat hiermede bestuurlijk handelen indirect van de internationaalrechtelijke toetsing is uitgesloten, is hiermee niet gezegd. Ofschoon de bestuursorganen die in een voorprocedure geschilbeslechtend optreden niet aan alle eisen van art. 6 EVRM behoren te voldoen, kunnen er wel consequenties ontstaan voor de daaropvolgende bestuursrechtelijke procedure.

De Waard noemt enkele aspecten, te weten:

a. de vóórprocedure mag het recht op een beslissing binnen redelijke termijn niet belemmeren;

b. indirect kan de vóórprocedure object van toetsing zijn indien de gang van zaken in deze procedure de toegang tot de bestuursrechter op onaanvaardbare wijze heeft geblokkeerd (bijvoorbeeld zware druk uitoefenen om afstand te doen wan het beroepsrecht). ${ }^{38}$

De bezwaarschriftenprocedure kan mede bepalend zijn voor de totale lengte van de bestuiursrechtelijke rechtsgang. ${ }^{39}$ Het aspect van de beslissing binnen redelijke termijn wordt nog nader besproken in de paragrafen 5.3.11 en 5.4.11. Er kan overigens geen misverstand bestaan over de vraag of art. 6 EVRM vereist dat ná de voorprocedure de rechtsbeschermingsvoorziening well EVRM-conform dient te verlopen. De berechting van geschillen ná de voorprocedure dient door een onafhankelijke (administratieve) rechtspraak plaats te vinden. ${ }^{40}$

Als laatste redengevend argument voor de invoering van art. 2:4 wordt blijkens de MvT genoemd de omstandigheid dat voor het optreden van bestuursorganen een beginsel, zoals dat in de rechtspraak geldt voor het algemeen bestuursrecht, ontbreekt. Toch zal nog in dit hoofdstuk blijken dat in het Nederlands recht niet over de gehele linie gesproken kan worden van ongeschreven recht. De Awb wijst met enige nadruk op het belang van de bestuurlijke onpartijdigheid in het Amerikaanse recht (Administrative Procedure Act), waarbij het beginsel van onpartijdigheid (no bias) een belangrijker rol zou spelen dan in het Nederlandse 
recht. Dit is eveneens het geval zijn bij andere vergelijkbare buitenlandse wetgeving."

Opgemerkt wordt hierbij dat de regel tegen vooringenomenheid in het Engels recht geldt in elk stadium van een procedure. In een bepaald geval wilde de politie-organisatie van Kent een agent van politie ontslaan op grond van zijn zwakke geestelijke gezondheid. Deze agent werd naar een arts gestuurd die kort tevoren zijn zwakke geestelijke gezondheid had vastgesteld. Geoordeeld werd dat deze arts daarmede in feite een quasi gerechtelijke taak kreeg opgelegd. Het 'Court of appeal' oordeelde dat in dit geval duidelijk sprake was van vooringenomenheid. In dit specifieke geval wordt gesproken over "bias by predetermination". ${ }^{42}$ In paragraaf 20 van het Duitse Verwaltungsverfahrensgesetz is gedetail leerd opgesomd in welke gevallen niet namens een 'Behörde' mag worden gehandeld. In hoofdzaak gaat het daarbij om ambtenaren die zelf 'Beteiligter" zijn, tot 'Beteiligte' in een nauwe relatie staan of die op enigerlei wijze woordeel bij de uitkomst van een procedure kunnen hebben. ${ }^{43}$

Het no bias-beginsel zoals dat uit vergelijkbare buitenlandse regelingen valt af te leiden, ontbrak in de Nederlandse bestuursrechtelijke wetgeving.

Maar het is de vraag of dit gemis, gelet op de Nederlandse staatsrechtelijke en bestuursrechtelijke situatie, niet wat al te ruimhartig wordt benadrukt, mede in het licht van een aantal verspreid voorkomende compenserende bepalingen.

Toch is de gedachte over het opnemen van een regeling zoals art. $2: 4$ voorstaat, niet geheel nieuw.

Art. 11 van het Rapport ABAR kende enkele regels, teneinde de rechten van belanghebbenden bij de voorbereiding van beschikkingen zoveel mogelijk veilig te stellen. ${ }^{4}$ In dit verband kan worden gewezen op de volgende bepalingen.

Art. 8 van het bovengenoemd rapport bepaalde:

41. PG Awb I, p. 179 en 93 e.v.

42 Sir Willam Wade. Administrative Law, Seventh Edition, Oxford, 1994, p. 476. Zie in dit verband overigens in dit boek: Part $V$ Nanral Justice, 14 The rule against bias, p. $471 \mathrm{~km} 484$.

C.P.J. Goorden, in: Algemene wet bestursrecht, losbl., "s-Gravenhage, P. E 2.1.4.-1.

44 VAR-rapport LXXII, Groningen 1974. Zie in dit verband: P. Nicolat a. a., Bestuurstecht, zeste herz. dr. Amsterdam 1997, p. 353 noot 27 met een verwijzing naar A. D. Belinfante, Kort begrip van het administratief recht. Alphen aan den Rijn 1985, p. 13. Belinfante ziel in het voorkomen van zelfs de schijn van invloed op de instandhouding van een administratieve rechoshandeling wegens een persoonlijk belang van beginsell van behoorlijk bestuur. 
'Indien een overheidsorgaan belanghebbenden in de gellegenheid stelt zich te doen horen, behandelt het orgaan hen daarbij op gelijke voet."

Uit dit artikel blijkt, dat bij de voorgestane facultatieve hoorbevoegdheid de commissie ABAR het gelijkheidsbeginsel voor ogen stond. Uitgangspunt was hierbij, dat bij het horen indien dat door het betrokken bestuursorgaan platsvond, de wijze van het horen niet er op neer zou mogen komen, dat de ene belanghebbende ten opzichte van de andere belanghebbende in een geprivilegieerde situatie zou komen te staan. Vond horen plaats, dan moest dat naar de visie van de commissie op basis van gelijke behandeling geschieden. Voorkeursbehandeling en het toekennen van voorrechten moesten worden uitgesloten. De preadviseurs in 1974 dachten hierbij aan de situatie dat het horen zich op een verschillend niveau van hiërarchie zou voltrekken. Horen zou dienen plaats te vinden op gelijk niveau:

'dus niet de ene belanghebbende door de minister en de ander door een ambtenaar die laag in de ambtelijke hiërachie staat."

Een andere bepaling uil het bovengenoernd VAR-rapport sluit meer aan bij het door de Awb ingevoerde no bias-beginsel. Deze bepaling gaf het initiatief aan de justitiabele zelf. Als de belanghebbende burger vermoedde dat er in zijn ogen sprake was wan vooringenomenheid, moest hij zich tot het bestuursorgaan wenden. De strekking van deze VAR-bepaling was in feite een soort wrakingsactie.

Art. 11 ABAR zag er in extenso als volgt uit:

'Een belanghebbende is gerechtigd, mits schriftelijk en behoorlijk gemotiveerd, als zijn oordeel te kennen te geven, dat een dergenen, die bij het overheidsorgaan belast zijn met het voorbereiden van de beschikking, niet onpartijdig kan handelen. omdat deze met persoonlijke belangen bij de beschikking betrokken is; in zodanig geval overweegt het orgaan of het nodig en mogelijk is de behandeling van de zaak aan een ander op te dragen."

Uit het vorenstaande is af te leiden, dat deze ontwerp-bepaling nogal wat haken en ogen had voor de betrokken burger. Uitgangspunt was immers een schriftelijk en gemotiveerd oordeel van de zijde van de belanghebbende die met kracht van argumenten de partijdigheid ter discussie moest stellen. Daarbij was de positie van het overheidsorgaan zodanig, dat in de overwegingen naar aanleiding van het adres van de burger, de noodzaak en de mogelijkheid om de behandeling van de zaak aan een ander op te dragen, moest worden betrokken. Dat laatste leek een niet al te sterk punt van deze anti-partijdigheidsbepaling. Ook anno 1974 werd het denken over onpartijdig bestuur stilaan op gang gebracht in de wetenschappelijke geschriften. 
Terugkomend op de inhoud van art. 2:4 Awb kan over de reikwijdte van dit artikel het volgende worden gezegd.

Het eerste lid van art. 2:4 stell aan het functioneren van het openbaar bestuur de eis dat, het parool is voor het besturen: zonder vooringenomenheid handelen. Daarmee lijkt het toepassingsbereik van dit eerste lid groter dan de condities die de wetgever van het bestuursorgaan vraagt in het tweede lid. Sommigen zijn er van overtuigd, dat de reikwijdte van het eerste lid groter is, omdat dit zou zien op alle soorten handelingen van bestuursorganen. Daarbij kan worden gedacht aan feitelijke handelingen, privaatrechtelijk handelen en de vorming van beleid in het algemeen. ${ }^{45}$ Dat het eerste lid voor wat betreft de daarin gegeven omschrijwing meer van algemeen karakter is, en dat de verbijzondering of wel een uitwerking daarvan terug te vinden is in het tweede lid, lijkt voor de hand te liggen. Onderscheidend in beide bepalingen is immers, dat het eerste lid op alle bestuurshandelingen (waaronder ook privaatrechtelijke) betrekking heeft. Het tweede lid daarentegen, bakent in zijn specificatie van het eerste lid door de gegeven uitwerking, het verbod van vooringenomenheid af tot het begrip 'besluit" zoals dat in art. 1:3 Awb centraal staat, vanuit het gezichtspunt van de rechtsbescherming. Of een dergelijke benadering geheel juist is, zal uit de feitelijke toepassing van art. 2:4 moeten blijken en niet in de laatste plaats uit 'het antwoord' van de bestuursrechter, dat zijn weerslag zal vinden in de jurisprudentie onder de werking van de Awb. Dat art, 2:4, lid 1 tendeert naar een ruimer toepassingsbereik zal moeten blijken.

Als voorbeeld van privaatrechtelijk handelen kan worden genoemd het door bestuursorganen gevoerde aanbestedingsbeleid. Aannemers die hebben ingeschreven voor een bepaald werk, zouden een beroep kunnen doen op het vooringenomenheidsverbod ondat zij denken dat het beoogde werk aan hun neus is voorbijgegalan omdat zich het betrokken bestuursorgaan partijdig zou hebben opgesteld door een 'vriendje' het werk te gunnen. Maar een beroep op beleid, en daartoe is ook het aannemingsbeleid van overheidswerken te rekenen, is een gevoelig en moeilijk punt. Dit laatste blijkt bijvoorbeeld uit een aantal corruptie-zaken in de provincie Limburg. Hierbij werd met wisselend succes, bescheiden aangetoond dat belangenverstrengeling tot onoorbare situaties voor de daarbij betrokken bestuursorganen en hun bestuurders aanleiding kan geven.

Zonder hierop verder in te gaan lijkt de problematiek van corruptie bij de overheid zich overigens wel in een bijzondere belangstelling te kunnen "verheu-

45. I.C. van der Vlies, in: Handboek Algemene wet bestuursrecht, Alphen aan den Rijn ${ }_{*}$ losbl., III artikelsgewijs commentarar $2: 4$, p. 1 . 
gen'. Corruptie als combinatie van irreguliere bevoordeling en infaam verraad trekt de aandacht. ${ }^{46}$

Gesuggereerd is dat art. $2: 4$, lid 1 mogelijk tot een ruimer toepassingsbereik zou kunnen leiden vanuit zijn algemeen karakter. Zo dat algemeen karakter wordi benadrukt vanuit de directe norm die uit het eerste lid voortvloeit, kan daarmede zonder nu all op hetgeen hierna in deze paragraaf volgt, worden ingestemd. Zodanige consensus wordt niet ingegeven vanuit de ruime omschrijving van het eerste lid, maar vanuit de gegeven redactiestructuur van het tweede lid. Datzelfde tweede lid geeft weliswaar zoals gezegd een nadere uitwerking van het meergenoemd eerste lid, maar dit tweede lid van art. $2: 4$ bevat slechts een opdracht aan het bestuursorgaan er voor te waken, dat de besluitvorming wordt beïnloed. Van enig verbod kan in art. 2:4, lid 2 niet worden gesproken. Wel wordt hierin 'de waakhondfunctie' voor het bestuursorgaan tegen partijdig optreden benadrukt. Hoe het rechterlijk oordeel onder de werking van de Awb voor de bestuurspraktijk uitpakt zal nog bespreking vinden bij de beschouwing van de werking van art. 2:4 aan de hand van enkele uitspraken van de bestuursrechter.

Afrondend passen nog enkele aanvullende opmerkingen ten aanzien het vooringenomenheidsverbod.

Duidelijk is dat het bestuurlijk handelen nu in de Awb meer dan voorheen beginselen van fatsoen in art. 2:4 als rechtsnorm positiveert.

Of hierdoor een nieuw algemeen beginsel van behoorlijk bestuur wordt gecreëerd moet worden betwijfeld. Iets anders is of de invoering tot zelfstandige rechtsvorming zal leiden. ${ }^{47}$ In par. 2.6 wordt op dit laatste aspect nader ingegaan.

De aandacht is gevestigd op de onderscheidende betekenis van het eerste lid ten opzichte van het tweede lid van art. 2:4. Onderscheidend, omdat het vooringenomenheidsverbod bij de bestuurlijke taakvervulling in het tweede lid van art. 2:4 nadere invulling krijgt, zij het dat daarbij meer een opdracht voor verantwoordelijkheidszin aan het bestuursorgaan wordt verschaft. Het verbod in het eerste lid wordt als het ware in het tweede lid tot een gebod voor het openbaar bestuur getransformeerd: het bestuursorgaan behoort er 'tegen te waken dat tot het bestuursorgaan behorende of daarwoor werkzame personen die een persoonlijk belang hebben bij een besluit, de besluitvorming beïnvloeden.'

46 D. Ruimschotel, NJB 1994, p. 1554 e.V.

47 F.H. van der Burg, Het voorontwerp Algemene wet bestuursrecht getoetst, NTB 1987, p. 7 . 
Hierdoor wordt aan de in het eerste lid gegeven rechtsnorm een belangrijke materiële betekenis gegeven. Vooruitlopend op een nadere bespreking van de jurisprudentie van het begrip persoonlijk belang wordt hierbij opgemerkt, dat van persoonlijk belang kan worden gesproken in die gevallen, dat individuele belangen bij de besluitvorming dan wel het nemen van het bij het besluit betrokken personen, in het geding zijn. Deze belangen vereisen een strikte persoonlijke betrokkenheid (huis bij een aan te leggen voetbalveld); van strikte persoonlijke belangen zou niet gesproken kunnen worden zodra deze een functioneel karakter dragen (vertegenwoordiger van een bedrijfstak). ${ }^{48}$ Preciezer gezegd is van persoonlijk belang sprake als een vermenging plaatsvindt van persoonlijke en bestuurlijke belangen, zodra dat betrokken belang individueel traceerbaar is, en in concreto tot resultaat kan hebben dat de besluitvorming wordt beïnloed. ${ }^{49}$ Die tracering van ongewenste individuele belangen(verstrengeling) is naar het oordeel van de Awb in beeld, zodra sprake is van ieder belang, dat niet behoort tot de belangen die het bestuursorgaan bij de hem opgedragen taak behoort te behartigen. De wetgever wenst hiermee te vermijden, dat personen die werkzaam zijn voor het overheidsbestuur hun privé-belangen aanwenden bij de voorbereiding van besluiten dan wel de besluitvorming zelve..$^{50}$

Tot de medewerkenden van bestuursorganen rekent de Awb niet alleen de bestuurder die deel uitmaakt van het betrokken bestuursorgaan. Naast de voor het bestuur werkzame ambtenaar valt ook de externe adviseur onder het toepassingsbereik van art. 2:4. Dat laatste zal eveneens nader worden geadstrueerd aan de hand van de jurisprudentie en enkele met art. 2:4 samenhangende bepalingen van de Awb. Dat ook andere voor de bestuursorganen werkzame personen die weliswaar niet in dienst van het bestuursorgaan zijn aangesteld, mede onder het regime wallen van art. 2:4 lijkt evident. Bestuursorganen laten zich veelvuldig bij de voorbereiding van besluiten adviseren door wettelijk en niet wettelijk voorgeschreven adviescolleges, dan well eenhoofdige adviseurs. Het spreekt daarom voor zich dat ook bij externe advisering, waarbij een schriftelijk en raadgevend oordeel wordt gegeven, door een door de overheid aangestelde adviseur, ook hier de betekenis van eventuele belangenverstrengeling een rol kan spelen. Deze externe adviezen spelen onder andere een rol bij de voorbereiding van het nemen van besluiten. ${ }^{5 !}$

48. I. van der Vlies, Algemene wet bestuursrecht, Wetswoorstel ingediend, Publiek domein 1989, $p$. 215

49 C.P.J. Goorder, Algemene wet bestuursrecht, losbl., "s-Gravenhage, p. 2.1.4.-3.

50 PG Awb I, p. 180.

5. H.R.B.M. Kummeling, Advisering in het Publiekrecht, Arnhem 1988 , p. 5. 
In de volgende paragraaf zal in de beschouwingen worden betrokken een aantal verspreide bepalingen in het recht, waarbij raakvlakken zijn met de problematiek van het (on)partijdigheidsaspect bij het besturen.

\subsection{Een kritische beschouwing over de noodzaak van het verbod van vooringenomenheid}

Uitgebreid is ingegaan op de toegenomen wederkerigheidsaspecten in de rechtsbetrekkingen tussen bestuursorganen en burgers. Geconstateerd is een verdergaande horizontalisering in de relatie tussen deze beide actoren in het besluitvormingsproces. Daarbij werd de kanttekening geplaatst dat alle wederkerigheid in de rechtsbetrekking ten spijt, een belangrijk uitgangspunt is en blijft de bijzondere positie van het bestuursorgaan. Deze positie bepaalt de dominante bestuurlijke rol bij het voorbereiden en nemen van besluiten. Dat daarbij rekening moet worden gehouden met de belangen van de burger en de rechtsnormen die het bestuur nopen tot beginselen-conformiteit van handelen, doet hier niet aan af. Burgers zullen vanwege het eenzijdig optreden door bestuursorganen deze organen, doorgaans als een met macht beklede organisatie ervaren. Vanuit die machtspositie kan het bestuursorgaan eenzijdig verplichtingen opleggen en deze zo nodig afdwingen.

Voor wat betreft de instrumentele kant van het bestuursrecht bedient het bestuur zich van rechtsnormen als middelen ter behartiging van het algemeen belang. Bestuursorganen zijn hierdoor - wellhaast per definitie - bevoegd om eenzijdig dat wil zeggen zonder consent van derden - deze bindende rechtsnormen vast te stellen. ${ }^{52}$

Vanwege deze eenzijdigheid in de bevoegdheidsuitoefening door de overheid, blijken hierna enkele aspecten die de positie van de burger in het verkeer met bestuursorganen benadrukken.

Voor de burger als onderdaan is de overheid feitelijk onontkoombaar, want een exil-optie is praktisch afwezig (daarvoor is het belang van de vergunning of de uitkering te groot, of is de dwang van politie, justitie of fiscus te zeer onontkoombarr). ${ }^{53}$ Daaraan vastknopend kan worden gezegd, dat gelet op de eigen aard van de owerheid, deze overheid een grote macht heeft en zeker met name ten opzichte van de burger vanwege haar monopolistische uitvoeringspositie. Daartegenover is de positie van de afzonderlijke burger doorgaans zwak. ${ }^{54}$

52 R.M. van Male, Onvoltooid recht, Zwolle 1993.

53 M. Oosting, Kwalliteit van de overheid, Deventer $1990, \mathrm{p} .11$.

5.4. M. Oosting, a.w. p. 12. 
Situaties zoals in de zaak Grubbenvorst/Caldenbroich ${ }^{55}$, zijn niet bepalend voor het beeld van een voldoende mate eigenstandige burger ten opzichte van het bestuursorgaan; de doorsnee burger is meestal niet gepokt en gemazeld in het recht. Niet iedere justitiabele is een 'grote bouwer'. Iets anders komt de situatie te liggen indien de aanvrager om een bouwvergunning bijvoorbeeld een woningbouwcorporatie blijkt te zijn. Van een dergelijke corporatie mag op redelijke gronden worden verwacht dat deze over voldoende expertise beschikt op het terrein van de bouwkunde, het bouwrecht en de ruimtelijke ordening. Los van de kwaliteit van de burger om het bestuursorgaan voldoende tegenspel te bieden, kan worden geconcludeerd dat indien de burger van de overheid enige dienstverlening vraagt, de gedwongen winkelnering bij diezelfde overheid uitgangspunt is en de burger het resultaat van het gevraagde besluit maar moet afwachten.

Tegen de achtergrond van het aangeduide verschil in positie tussen overheid en justitiabele, vraagt de positie van de namens deze overheid handelende bestuursorganen een hoge mate van kwaliteit van uitvoering. ${ }^{56}$ Dat daarom strenge eisen worden gesteld uit een oogpunt van belangenbescherming ten behoeve van de burger, lijkt welhaast vanzelfsprekend. Deze vanzelfsprekendheid heeft zich zoals hiervoor meermalen bleek, in het verleden ontwikkeld via een aanvankelijke bescheiden toepassing van de beginselen van behoorlijk bestuur naar een uitgebreide hantering van deze beginselen door de administratieve rechter, daartoe vóór 1994 aangestuurd door de geschreven rechtsnormen, ingevolge art. 8 van de Wet arob. Uiteindelijk bleek de stap naar een gedeeltelijke codificatie van de bovenbedoelde beginselen in de Awb in de vorm van rechtsnormen al gauw genomen.

In het licht van deze toetsingsmogelijkheden aan de beginselen van behoorlijk bestuur, de rechtsnomen voor het bestuurlijk handelen alsmede de mogelijkheid van toetsing door de rechter aan algemene rechtsbeginselen, als controlemiddelen voor het overheidsoptreden, ligt de vraag voor de hand naar de noodzaak van een bepaling als art. 2:4 Awb. Daarbij is zoals aan het einde van de vorige paragraaf is opgemerkt mede van belang, het bestaan van een aantal verspreide bepalingen die onzuiverheid bij het bestuurlijk handelen beogen te voorkomen. Deze bepalingen zijn er op gericht belangenverstrengeling tegen te gaan en onpartijdigheid in het openbaar bestuur te waarborgen. 
Gezien de opgeworpen vraagstelling naar de noodzaak van een artikel als het onderhavige, worden allereerst enkele kanttekeningen geplaatst bij de motieven, die uiteindelijk hebben geleid tot het opnemen van art. 2:4 in de $\mathrm{Awb}$. Daarbij zal globaal worden aangestipt de bijzondere aard van het besturen.

Vanuit de eigen aard van het bestuur kunnen vraagtekens worden geplaatst bij de noodzaak van het vooringenomenheidsverbod. Zeker omdat de bestuursrechtelijke normering van onpartijdigheid wordt bepleit vanuit de judiciële situatie door een relatie te leggen met de regel "nemo iudex in re sua", welke regel tot uitdrukking komt in de reeds aangestipte wrakings- en verschoningsbepalingen voor de rechterlijke macht. Besturen is iets anders dan rechtspreken. Dat deze beide overheidstaken geheel verschillend van inhoud en karakter zijn, behoeft nauwelijks enige adstructie. Daarbij komt nog dat voor beide 'machten' geheel verschillende inrichtings- en organisatie-eisen zijn gesteld.

Gewezen werd op het bijzondere karakter van het besturen. Dat besturen heeft zich de afgelopen jaren ontwikkeld tot een meer programmatische aanpak. Daarbij spelen aspecten zoals bezuinigen, prioriteitsstelling en wijze van uitwoering van bijvoorbeeld gemeentelijke taken een rol. Deze vernieuwde en vernieuwende aspecten bij bestuursorganen zoals bij gemeenten hebben te maken met schaarste van geldmiddelen. Doeleinden van beleid en de wijze waarop met middelen wordt omgesprongen zijn voortdurend in discussie bij de begrotingsbehandelingen. Bezuinigingen of heroverweging van reeds ingezet beleid zijn regelmatig aan de orde bij de plaatselijke politieke discussie. Niet in de laatste plaats speelt daarbij een rol de herstructurering van het Gemeentefonds.

Onder de druk van deze omstandigheden, alsmede vanuit het politieke aspect bij de vorming van colleges van burgemeester en wethouders, is al jarenlang regel dat bij aanvang van een nieuwe zittingsperiode van de gemeenteraad, een collegeprogram en beleidsplan voor een periode van vier jaar wordt vastgesteld. Dit collegeprogram kan worden omschreven als het geheel van schriftelijke uitspraken van de aan de collegevorming deelnemende partijen/fracties die dat hebben opgesteld en onderschreven. ${ }^{57} \mathrm{Bij}$ zo'n collegeprogramma worden hoofdlijnen vastgelegd ten aanzien van gemeentelijk beleid op bijvoorbeeld het terrein van milieu en mobiliteit, economie en bouwen en wonen. Het laat zich gemakkelijk raden dat door de ontwikkeling van dergelijke collegeprogramma's zich een vorm van planmatig bestuur ontwikkelt, maar tegelijkertijd ontstaat als gevolg daarvan een vorm van zelfbinding, waarbij zodra tot effectuering van dat voorgenomen en

57 Besturen met minder middelen VNG, Groene reeks, 's-Gravenhage 1984, p. 1.7 
geprogrammeerde beleid wordt overgegaan, de standpuntbepaling bij de concrete uilwoering als vooringenomen kan worden bestempeld. Ter nadere en globale adstructie moge dienen de situatie dat op een plek een woningbouw-project gepland is en ter realisering van datzelfde bouwproject, bouwvergunningen moeten worden verleend. Zodra tegen de verleende bouwvergunningen bezwaren door omwonenden om welke reden dan ook worden ingediend, is het niet uit te sluiten dat vooringenomen standpunten moeilijk zullen worden prijsgegeven, en de realisering van het project in relatie tot het bedoeld collegeprogramma en mede als gevolg van gesloten contracten met projectontwikkelaars, een dergelijk woningbouwproject koste wat het kost doorgang moet vinden.

Dit voorbeeld is tegelijkertijd een inleiding tot de geuite kritiek op het vooringenomenheidsverbod.

In haar kritiek had de VNG bezwaar tegen het opnemen van art. 2:4 (art. 2.1.4 Voorontwerp Awb) vanuit een overdrewen codificatie en streven naar volledigheid. De VNG zag niets in deze bepaling. Zonder afbreuk te willen doen aan het uitgangspunt, dat overheidsoptreden zonder alanzien des persoons dient te geschieden, had de VNG twijfels over de gekozen redactie van 2:4. Ook in haar kritiek wees de VNG op het karakter van het besturen als afwegingsproces, waarbij bestuurlijke keuzen worden gedaan.

De VNG stelde vast dat bij het maken van een (politiek) bestuurlijke keuze die aan besluitvorming ten grondslag ligt, nu eenmaal een aspect van partijdigheid ligt opgesloten. Teneinde de beladenheid van de term "vooringenomenheid' van Zujn 'partijdigheid' te ontdoen, werd er op aangedrongen om in de MvT tot uitdrukking te brengen dat het vooringenomenheidsverbod niet doelt op het maken van beleidskeuzen. ${ }^{58}$

Toch moet hierbij worden aangetekend, dat de VNG is uitgegaan van een verkeerde begripsvorming van art. 2:4. Het verbod van wooringenomenheid doelt naar unhoud en strekking niet op objectieve vooringenomenheid. Art. 2:4 beoogt de (schijn van) subjectieve vooringenomenheid zoveel mogelijk in te dammen bij de bestuurlijke taakvervulling.

Ook anderen uitten hun kritiek op de bepaling vanuit het bijzondere karakter van het bestuur. Enerzijds werd gewezen op het democratisch niveau waarop het besturen zich voltrekt (anders dan de rechterlijke macht). De 'positieve vooringe-

58 Ordening in het bestuurstecht (eerste fase), Groene reeks nr. 95, "s-Graventage 1987, p. 11 en 19 . 
nomenheid" vanuit het perspectief van de beleidskeuzen ligt nu eenmal opgeslloten in de natuur van de bestuurder en het bestuursorgaan. ${ }^{59}$

Anderzijds werd er op gewezen dat het artikel tot een verkeerde interpretatie aanleiding zou kunnen geven omdat het bestuur geen gezindheid zou mogen hebben bij de aanpak van bestuurlijke zaken. Deze interpretatie zou het principe wan het politiek bestuur en daarmede het democratische standpunt geweld aandoen. ${ }^{60}$ Ook de Raad van State bleek gezien haar opmerkingen niet erg positief te staan ten opzichte van het vooringenomenheidsverbod, getuige haar twijfels over de onduidelijkheid en de betekenis daarvan. Ook aspecten als "persoonlijk belang' en 'beinvloeding besluitvorming" werden, zonder dat hier nader op wordt ingegaan, nogal kritisch beoordeeld. ${ }^{61}$ Hoewel deze kritiek tot resultaat had, dat de eindtekst van de memorie van toelichting werd aangepast ${ }^{62}$, rijst de vraag of hiermee de kritiek achteraf bij toetsing door de rechter zonder grond is en art. 2:4 Awb tot een ruime toetsing door de bestuursrechter leidt. Bij de bespreking van de Awb-jurisprudentietrends over art. 2:4 zal hierop worden terug gekomen.

Zeker is in ieder geval wél dat de bezwaren en kritiek op de handhaving van art. 2:4 door de Awb zijn verschoven naar het uitwoeringsniveau in casu de vergunningverlening, het hieraan ten grondslag liggende beleid ten spijt.

In aansluiting op de genoemde bedenkingen tegen art. 2:4, welke gehouden zijn tegen het licht van het bijzondere karakter van de positie van het openbaar bestuur, worden hierna enkele aspecten beschreven in relatie tot het reeds aangestipte beginsel 'nemo iudex in re sua'. Dit beginsel vormt voor de Awb kennelijk mede cen van de drijfveren voor het invoeren van het vooringenomenheidsverbod. In de parlementaire stukken is verwezen naar de wrakings- en verschoningsbepalingen voor de rechterlijke macht. Dit is niet het sterkste argument.

Uit de literatuur blijkt dat de mogelijkheden van rechterlijke wraking wel zeer beperkt zijn. Ofschoon wordt erkend, dat het instituut van de wraking voor het vertrouwen in de rechter van onmiskenbare betekenis is en in de Awb in afdeling 8.1.4 naast verschoning regeling vindt, lijkt voor de toepassing in de praktijk geen aanleiding te zijn tot overdreven optimisme. Het is logisch dat een beroep op wraking minder voorkomt. Aangetoond moet immers worden dat zich feiten

59 F.P.C.L. Tonnder, Regels voor het besturen, Gst. 6831, p. 130.

60 C.J.N. Versteden, Voorontwerp Algemene wet bestuursrecht reden tot juichen woor het lokwal bestuur? Gst. 6845, p. 410.

6. PG Awb I, p. 179.

62 PG Awb 1 . 
en omstandigheden voordoen, waardoor de rechterlijke partijdigheid schade zou kunnen leiden. Art. 8:15 Awb stelt een dergelijke eis. Deze eis wordt zodanig verzwaard dat bij een zaak feiten en omstandigheden in het geding moeten zijn, die de gewraakte rechter in persoon betreffen. Niet de beslissing van de rechter wordt in de beoordeling betrokken.

Daarbij komt, dat er ook geen reden voor wraking is, wanneer de rechter in een eerder vergelijkbaar geval een voor enige partij ongunstige beslissing heeft gegeven. Onwelgevallige jurisprudentie dient niet met wrakingsverzoeken, maar met argumenten te worden bestreden. In de literatuur wordt gewaarschuwd voor misbruik en oneigenlijk gebruik van het instituut van de wraking. ${ }^{63}$

Voorts blijkt, dat het onderwerp wraking en verschoning in de handboeken van procesrecht doorgaans nogal kort wordt afgedaan. Voor de praktijk is het ook een geheel 'papieren' probleem. Immers, een rechter, die een te grote verbondenheid met een zaak of met de daarin optredende partijen aanwezig acht, zal zo mogelijk aan een collega vragen in zijn plaats te treden. ${ }^{64}$ Ook recent verschenen handboeken besteden weinig aandacht aan het 'gereglementeerde' fenomeen van wraking en verschoning. ${ }^{65}$

Het vorenstaande doet niet af aan de omstandigheid, dat in tijdschriften thans regelmatig wraking en verschoning, hetzij direct en indirect in wat meer belangstelling zijn komen te staan. Rechterlijke onafhankelijkheid staan immers ná "Procola' ${ }^{606}$ in een verhoogde belangstelling.

Veel kans van slagen hebben wrakingsverzoeken niet omdat bij dreigende belangenverstrengeling een beroep kan worden gedaan op verschoning. In het geval dat een beroep op verschoning wordt gedaan is men eventuele kritiek op belangenverstrengeling een stap voor. Een tweetal uitspraken bevestigen de geringe kans op succes bij wraking, zonder daarop overigens in dit verband in te

6. N.S.J. Koeman, De wraking gewrakt, NTB 1994, p. 93.

64 B.W.N. de Waard, Beginselen wan behoorlifke rechtspleging, Zwolle 1987, p. 363.

66 W. Hugenholtz/W.H. Heemskerk, Hoofdijnen van het Nederlands Burgertijk Procesrecht, Utrecht 1996 , p. 190 wijdt zeven alinea's aan de wrakings- verschoningsbepalingen in thet. burgerlijk procesrecht.

66 EHRM, 28 september 1995, AB 1995, 588, JB 1995, 252.

67 J.M. Polak, Combinaties van functies en betangenverstrengelingen. NJB 1996, p. 629 8.v, ook andere artikelem in deze speciaal bespreken deze door "Procola' geỉnspireerde problematiek. Ook kan in dit verband worden gewezen op de artikelen wan De Werd, Tobben met de rechtsitaat, NJB 1996 en het artikell van J.E. M. Polak, Kroniek van het Algemeen deel van het bestuursrecht, NJB 1996 , p. 391 e.v. 
gaan. ${ }^{68}$ Ook uit andere uitspraken blijkt, dat wrakingsverzoeken geen kans van slagen hebben. ${ }^{69}$

Een ander motief voor het opnemen van het vooringenomenheidsverbod in de Awb is het grondbeginsel van artikel $1 \mathrm{Grw}$; dit voorschrift beoogt voor de justitiabele gelijkheidsbescherming te bieden door te bepalen, dat gelijke gevallen gelijk behoren te worden behandeld. Naar de Awb stelt, brengt deze grondwettelijke bepaling met zich, dat bestuursorganen zich in het verkeer met burgers steeds objectief behoren op te stellen. ${ }^{70}$ Te dien aanzien kan het volgende worden opgemerkt.

Het gelijkheidsbeginsel is een beginsel van behoorlijk bestuur dat ook geldt in het algemeen bestuursrecht en als zodanig aan rechterlijke toetsing kan worden onderworpen. Het beginsel beoogt niet alleen dat gelijke gevallen gelijk behoren te worden behamdeld, maar het brengt tevens tot uitdrukking dat ongelijke gevallen ongelijk moeten worden behandeld. ${ }^{71}$ De kans van een succesvol beroep bij de rechter op het gelijkheidsbeginsel is, uitzonderingen daargelaten, niet bijster groot. Er is zelden sprake van gelijke gevallen. ${ }^{72}$

Hoewel het gelijkheidsbeginsel een fundamenteel rechtsbeginsel is, waarop nogal eens bij de rechter een beroep wordt gedaan, wordt dit doorgaans afgewezen.

In situaties dat geappeleerd wordt aan het gelijkheidsbeginsel, zijn er vaak toch verschillen die voor de te nemen beschikkingen zodanig relevant zijn dat de beschikkingen niet gelijk (hoeven) uit te vallen. ${ }^{73}$ Vaak blijkt overigens in de praktijk, dat de adstructieplicht voor de bezwaarde c.q. de appellant zo sterk geconditioneerd is, dat reeds hierdoor de kans van slagen van een beroep op het gelijkheidsbeginsel gering is. Dat Jaatste blijkt nogal eens in bestuursdwangzaken. Van de aangeschrevene die een beroep wenst te doen op het gelijkheidsbeginsel

68 ABRS 7 december 1995, AB 1996, 186 en ABRS 18 december 1995, AB 1996, 187.

69 ABRS 30 november 1995, Miliel en Recht 1996, nr. 31 en Stcrt. 1996, 86, p. 4 (Lidmaatschap partijbestuur geen reden voor wraking). Ook andere werzoeken om wraking hadden geen succes: Rb. Groningen 30 september 1994, KG 1994, 407 en ABRS 5 januari 1996, JB 1996, 56, m. nit. HIS.

70 PG Awb 1. p. 179

71 P. Nicolai e.a., vijfde herziene dr., Bestuursrecht, Amsterdam 1994, p. 153.

$72 \mathrm{~KB} 1$ juni 1981, AB 1981,483 m.nt. Van der Net inzake planschadebepaling artikel 49 (oud) WRO, waarbij recht op planschade door de Kroon ook werd uitgesproken voor artikel 19-WROgevallen. De Kroon oordeelde hier in afwijking van de WRO een ongerechtwaardigde ongelijke behandeling. Later werd de WRO in artikel 49 uitgebreid met de mogelijkheid om bij toepassing van artikel 19 eem wetrelijke aansprak op schadevergoeding te geven.

is Van Wijk/Konijnenbelt/Van Male, a,w. p. 354. Zie in dit verband overigens de jurisprudentie op 354 e.v. 
wordt verwacht, dat hij man en paard noemt. ${ }^{74}$ Bevreesd om als verrader te worden gekwalificeerd laten betrokkenen het daarbij nogal eens afweten, en zo al hierop een beroep wordt gedaan, blijkt geen sprake te zijn van gelijke gevallen. Hierna volgen nog enkele kanttekeningen bij art. $2: 4$.

Ofschoon het gelijkheidsbeginsel door de regering in verband wordt gebracht met art. $2: 4$, stelt Verheij dat hij met de regering van mening is dat beide normen niet samenvallen. Verheij is van mening, dat vooringenomenheid bijvoorbeeld ook denkbaar is in die gevallen warbij een vergelijkbaar geval ontbreekt en geen strijd met het gelijkheidsbeginsel valt aan te tonen.

Verheij kiest dan ook niet voor een integrale benadering van artikel 1 Grw. Discriminatie valt naar zijn mening terecht niet onder de reikwijdte van art. 2:4. Hij vindt dat de plaats van art. 2:4 in het bestuursrecht moet worden bepaaid vanuit hel gezichtspunt, dat het vooringenomenheidsverbod een norm is voor die gevallen, waarbij preciezer en concreter dan met algemene noties als gelijkheid of zorgvuldigheid wordt aangegeven, wat er schort aan de besluitvorming door het bestuur. ${ }^{\text {. }}$

\subsection{Wettelijke bepalingen terzake integriteit en onpartijdigheid}

Art. 2:4 is belicht vanuit het motiveringsperspectief van de Awb. Daarbij werden kanttekeningen geplaatst bij de noodzaak van het opnemen van het vooringenomenheidsverbod. Het gegeven commentaar op de wenselijkheid van art. $2: 4$ in het bestuursrecht werd behandeld in samenhang met het wederkerigheidsaspect in de relatie tussen bestuursorganen en burgers. Ook de bijzondere positie die de bestuursorganen in hun contact met de justitiabelen innemen, kreeg enig accent.

De overwegingen uit de MvT van de Awb geven aanleiding tot het doen van een onderzoek naar de betekenis van een aantal verspreid voorkomende bepalingen in enige organieke wetten, te weten de Provinciewet, de Gemeentewet, de Waterschapswet en de Wet op de bedriffsorganisatie. Globaal zal aandacht worden besteed aan bepalingen terzake integriteit en onpartijdigheid.

Het onderzoek wordt ingegeven door de enigszins beperkte benaderingswijze van de Awb ten aanzien van de keuze van de invoering van het vooringenomenheids-

74. P.J.J. van Butren en F.C.M.A. Michiels, Bestuursdwang. Zwolle 1989, p. 81 en 167.

75 L.F.M. Verheij. Stadsmobiel Amsterdam, in: Rechtspraak besuursrecht "De Annotaties" 1994 1995, "s-Gravenhage, p. 94/95-143. 
verbod. Bestudering van de relevante passages in de memorie van toelichting behorend bij de Awb leert immers, dat slechts enkele aspecten van doorslaggevende betekenis bleken om de opname van art. 2:4 in de Awb te bepleiten. Hierbij bleken het gelijkheidsbeginsel in art. 1 Grw, en de wrakings-en verschoningsbepalingen, zoals die gelden voor het verrichten van de rechterlijke taakvervulling, belangrijke drijfweren te zijn om het vooringenomenheidsverbod een plaats te geven in het algemeen bestuursrecht. Art. $2: 4$ is vooral verdedigd met het argument, dat "deze wrakings- en verschoningsregelingen tot doel hebben omstandigheden en factoren die het vormen van een onpartijdig oordeel bemoeilijken, zoveel mogelijk te elimineren.'

Met een verwijzing naar enkele jurisprudentie-gevallen in thet kader van art. 52 gem.w., waarin de wetgever bij persoonlijke betrokkenheid van enig raadslid hem van deelname aan de stemming uitsloot, afgezet tegen de aandacht die het buitenlands bestuursrecht heeft voor het no bias-beginsel bij de bestuurlijke taakvervulling, was de keuze voor art. 2:4 bezegeld. Dat de administratieve rechter daarnaast ook buiten de specifiek wettelijke bepalingen in toenemende mate de besluitvorming op het aspect onpartijdigheid toetst, bleek voor de Awbwetgever kennelijk onvoldoende.

De bovengenoemde geschetste ornstandigheden nopen tot een nader onderzoek omtrent regelingen die verwantschap vertonen met art. 2:4. De opgespoorde regelingen bieden direct dan wel indirect vooral aspecten die de $A$ wb onder de noemer van het vooringenomenheidsverbod heeft menen te brengen.

Er wordt op vertrouwd dat de hierna in beeld te brengen regelingen randvoorwaarden creëren, die een stimulerende werking kunnen hebben op de voor het openbaar bestuur gewenste integriteit en onpartijdigheid. Met enige nadruk wordt hierbij gesteld 'kunnen', omdat immers geen enkele wet waarbij regels worden gegeven in het belang van integere en onpartijdige bestuurlijke taakvervulling, een volledige waarborg kan scheppen tegen onzuiver handelen door bestuursorganen.

Daarbij is van belang dat bestuursorganen vertegenwoordigd worden door natuurlijke personen en diezelfde personen ieder hun voorkeuren, eigen drijfveren en zuivere en onzuivere motieven voor hun handelen kunnen hebben: 'de geest is (wel) gewillig, maar het vlees is zwak. (Math. 26:41).

Thans wordt overgegaan tot het in kaart brengen van enkele in verscheidene organieke wetten voorkomende bepalingen, waarin het bevorderen van integriteit, tot uitdrukking komt. 


\subsubsection{Integriteitsvereisten}

De Provinciewet, de Gemeentewet en de Waterschapswet kennen lidmaatschaps vereisten voor het bestuur van deze publiekrechtelijke rechtspersonen. Ook de Wet op de bedrijfsorganisatie kent vereisten voor de bedrijfsichamen als bedoeld in Hoofdstuk II van die wet. Zonder overigens op de taakstelling van deze openbare lichamen voor beroep en bedrijf in te gaan, betekent dit dat de Wet BO voor leden van het bestuur van de (hoofd)productschappen en de (hoofd)bedrijfschappen eveneens lidmaatschapswereisten kennen.

Deze lidmaatschapsvereisten voor het bestuur van deze bedrijfslichamen vinden hun grondslag in art. 5 van de Wet BO; de in dit artikel gestelde vereisten gelden in oorsprong voor de leden en de plaatsvervangende leden van de SER.

Voorop zij gesteld, dat de Prov.w. voor het lidmaatschap van PS de vereisten stelt, dat men Nederlander en ingezetene van de provincie moet zijn en de leeftijd van achitien jaar moet hebben bereikt.

Naast deze twee vereisten dient men voor het statenlidmaatschap niet van het kiesrecht te zijn uitgesloten. Zo van enige uitsluiting van het actief kiesrecht kan worden gesproken, dient zulks zijn grondslag te vinden in art. B 5 van de Kieswet. Van het kiesrecht zijn conform art. B 5 Kiesw., lid 1, uitgesloten: a. zij die bij onherroepelijke rechterlijke uitspraak van het kiesrecht zijn ontzet en b. zij die krachtens onherroepelijke rechterlijke uitspraak wegens een geestelijke stoornis onbekwaam zijn, rechtshandelingen te verrichten. Het spreekt voor zich dat voor het onderwerp, dat hier bespreking vindt, art. B 5 aanknopingspunten kan bieden voor integriteitseisen voor bestuurders. Ofschoon de eisen die voor het passief kiesrecht aan de statenleden zijn gesteld wellicht niet direct zijn terug te voeren tot expliciete eisen, die integriteit van het openbaar bestuur beogen te waarborgen, kunnen deze eisen wel uit het karakter en de strekking van art. B 5 Kiesw. worden afgeleid. Als voorbeeld kan worden genoemd de bestuurder die enig misdrijf pleegt zoals bijvoorbeeld verduistering, vervalsing in boeken en verduistering van bewijsstukken. Ook andere handelingen die de afgelopen jaren volop in de belangstelling stonden, en de integriteit van het openbaar bestuur een gevoelige klap toebrachten, zoals het aannemen van steekpenningen, kunnen in het geding zijn. In die gevallen dat de bovengenoemde misdrijven zijn gepleegd en het tot een rechterlijke veroordeling komt, kan de rechter in zijn uitspraak de veroordeelde bestuurder van het kiesrecht ontzetten en daarmee van deeiname aan het openbaar bestuur uitsluiten.

Deze wettelijke regels tonen aan dat in de kieswettelijke bepalingen in samenhang met de Prow.w., geschiktheidscondities zijn opgenomen die zodanige eisen stellen 
aan de hoedanigheid van personen die met de openbare drenst zijn belast, dat hienit integriteitseisen zijn af te leiden. Dat de betrokken bepalingen deze integriteitseisen niet met zoveel woorden tot uitdrukking brengen, doet niet af aan de witeindelijke effecten die hiervan uitgaan voor de zuiverheid van het lidmaatschap voor statenleden.

Voor wat betreft deze lidmaatschapsvereisten kan er gesproken worden van harmonisatie met de bepalingen inzake de lidmaatschapsvereisten die voorkomen in de Gem. w., de Watersch.w. en de Wet BO.

Art. 10 Gem.w. kent een identieke regeling zoals de in de Prov.w. voorkomende vereisten voor het statenlidmaatschap.

Voor wat betreft de in de Watersch.w. opgenomen vereisten voor het lidmaatschap van het algemeen bestuur van een waterschap, kan in dit verband worden gewezen op art. 31 Watersch.w. Ook in deze bepaling is een verwijzing opgenomen naar art. $\mathbb{B} 5$ Kiesw. door te stellen, dat men als lid van het algemeen bestuur niet van het kiesrecht moet zijn uitgesloten.

Tenslotte benadrukt de Wet $\mathrm{BO}$, als organieke wet de uniformiteit met de lidmaatschapsvereisten, door in art. 75 van die wet de benoemingseisen voor de leden of plaatsvervangende leden van het bestuur van een bedrijfslichaam, een koppeling te leggen met het passief en actief kiesrecht.

Globaal werd aangestipt de van art. B 5 Kiesw. afgeleide integriteitsvereisten voor het lidmaatschap van bestuursleden van organen van provincies, gemeenten, waterschappen en bedrijfslichamen. Voor de volledigheid zij hierbij nog vermeld, dat de Provinciewet, de Gemeentewet en de Waterschapswet geen organiekwettelijke lidmaatschapsvereisten stellen voor respectievelijk de commissaris van de Koningin, de burgemeester en de voorzitter van het waterschapsbestuur. Dat wil echter niet zeggen dat voor deze functionarissen geen vereisten gelden zoals in art. B 5 van de Kieswet zijn opgenomen. Toepassing van art. B 5 is immers bij rechterlijke uitspraak altijd mogelijk en het lijkt uitgesloten, dat iemand die zich kandidaat heeft gesteld voor een functie van burgemeester, commissaris of voorzitter bij het waterschap daarvoor in aanmerking komt, als betrokkene bij onherroepelijke rechterlijke uitspraak van het kiesrecht is ontzet. De benoemingsprocedures als bedoeld in art. 61 Prow.w., art. 61 Gem.w. en art. 46 Watersch.w. bieden voldoende waarborgen voor de benoemingen van de voor het ambt van commissaris, burgemeester en voorzitter van het waterschap, geschikte personen. De verantwoordelijke bestuursorganen in casu provinciale staten en de gemeenteraad worden in het kader van de benoemingsprocedure in de gelegenheid gesteld hun gevoelen kenbaar te maken, omtrent de bekwaamheid en de geschiktheid van de kandidaten voor het ambt van commissaris en burgemeester. Ook de vertrou- 
wenscommissies spelen een rol in het onderzoek naar de geschiktheid van de betrokken kandidaten.

Ofschoon art. 46 Watersch.w. geen benoemingsprocedure voor het voorzitterschap van het waterschap kent, overeenkomstig de in de Prov.w. en de Gem.w. voorgeschreven condities, biedt dit artikel ook redelijke garanties om de eisen van geschiktheid van kandidaten voor hel voorzitterschap voldoende aan bod te laten komen. Voorafgaand aan de benoeming door de Kroon vindt conform art. 46, hid 3 Watersch.w. een aanbeveling plaats door het algemeen bestuur van het waterschap. Vergezeld van hun beschouwingen zenden GS deze aanbeveling aan de minister van Verkeer en Waterstaat. Daarnaast is er een zorgvuldigheidsclausule ingebouwd in het vierde lid van art. 46 Watersch.w. voor die gevallen dat de Minister iemand op de voordracht tot benoeming plaatst die niet op de aanbeveling zijdens het waterschapsbestuur was geplaatst. Zonder op de details verder in te gaan, vindt in dit geval terugkoppeling plaats door de Minister met het algemeen bestuur van het waterschap en GS.

Ten aanzien van de benoeming van de voorzitter van het (hoofd)produktschap en hel (hoofd)bedrijfschap zijn nadere eisen gesteld in art. 78 en volgende van de Wet BO. Voor de voorzitter van het bestuur van een bedrijfslichaam is voor zover hier van belang in art. 81 Wet BO, art. 5 van deze wet van overeenkomstige toepassing. Art. 5 van deze wet zegt met zoveel woorden, dat ontzetting van de verkiesbaarheid (passief kiesrecht) en uitsluiting van het actief kiesrecht belletselen zijn voor de benoembaarheid van het voorzitterschap van openbare lichamen voor beroep en bedrijf. Daar komt nog bij dat het tweede lid van art. 5 Wet BO bepaalt, dat van het lidmaatschap van de bedrijfslichamen zijn uitgesloten zij, die zijn ontzet van het recht ambten te bekleden, dan wel bepaalde beroepen of functies ulit te oefenen.

Ook de rechtspositieregelingen betreffende de ambten van $\mathrm{CdK}$, burgemeester en voorzitter van het waterschap en de bedrijfslichamen, geven indicaties voor integriteitsvereisten.

Van belang is eveneens dat ook voor de eerste ambtelijke adviseurs van de bestuursorganen van de bovengenoemde publiekrechtelijke organen, geschiktheidseisen zijn gesteld die overeenkomen met de eisen van leden van diezelfde bestuursorganen. De hier bedoelde ambtelijke functionarissen zoals de griffier van de provincie, de gemeentesecretaris, de secretaris van het waterschap en de secretarissen in dienst bij de bedrijfslichamen, zijn weliswaar geen bestuursorganen, maar nemen door hun taakvervulling wél een bijzondere positie in als eerst verantwoordelijke en aan te spreken adviseur van deze bestuursorganen. In de 
HOOFDSTUK 2

Watersch.w. wordt de bijzondere positie van de secretaris van het waterschap zelfs zodanig benadrukt, dat deze niet in een hiërarchische verhouding staat tot het algemeen bestuur, het dagelijks bestuur en de voorzitter, maar dat de relatie tot deze bestuursorganen een functioneel karakter draagt. ${ }^{76}$

Een ander integriteitsaspect dat bij ambtsaanvaarding voor leden van organen van publiekrechtelijke rechtspersonen een rol speelt, vormt de beëdiging. Naar art. 14 Prov.w. stelt, leggen de leden van provinciale staten, alvorens hun functie te aamvaarden, in handen van de voorzitter zowel een zuiveringseed als een ambtseed, dan wel verklaring en belofte af. In de zuiveringseed c.q. de verklaring en belofte komt globaal genomen tot uitdrukking dat het tot de provinciale staten gekozen lid, geen handelingen heeft verricht dan well zal verrichten die 'de zuiverheid" van zijn of haar persoon geweld aandoet. Hierbij spelen ongewenste situaties zoals het aannemen van giften, gunsten, geschenken en beloften een rol. De voor de ambtsaanvaarding af te leggen ambtseed (belofte) komt er op neer, dat het betrokken statenlid in handen van de commissaris verklaart zich als een fatsoenlijk democratisch gekozene te zullen gedragen. Ook in de ambtseed zijn hierdoor aspecten van integriteit verdisconteerd. Met de Prow.w. overeenstemmende bepalingen komen voor in art. $14 \mathrm{Gem}$.w. (leden gemeenteraad), art. 34 Watersch.w. (leden algemeen bestuur).

Overigens zijn de in de Provinciewet voor de commissaris (art. 64), in de Gemeentewet voor de burgemeester (art. 65) en de Waterschapswet voor de voorzitter van het waterschap (art. 50), identieke eisen omtrent beëdiging opgenomen. Deze eisen gelden eveneens voor de eerste ambtelijke adviseurs van deze rechtspersonen (griffiers en secretarissen) en het daaraan in ondergeschiktheid werkzame personeel. De Wet BO kent overigens geen wettelijke beëdigingsregels.

2.4.2. Wettelijke randvoorwaarden ter voorkoming van partijdigheid in het openbaar bestuur

Hierna volgt een korte beschouwing op hoofdlijnen van enige in de bovengenoemde organieke wetten voorkomende bepalingen, die de zuiverheid van verhoudingen in het belang van een goed functioneren van bestuursorganen beogen te waarborgen.

Tegelijkertijd wordt met deze bepalingen er naar gestreefd het vertrouwen in het openbaar bestuur en zijn organen te bevorderen. Bij de bespreking van deze bepalingen moet overigens worden opgemerkt, dat met de strekking hiervan geen 
volledige garantie kan worden gegeven, dat hierdoor bij de besluitvorming door de bestuursorganen partijdigheid, dan wel de schijn van partijdigheid wordt uitgesloten.

Globaal genomen kan worden gesteld, dat aspecten van zuiverheid bij het functioneren van bestuursorganen regeling vinden in de bepalingen omtrent de incompatibiliteiten (onverenigbare betrekkingen), alsmede de wettelijke voorschriften omtrent verboden handelingen door de leden van bestuursorganen. Zijdelings wordt overigens ook ingegaan op het veel voorkomend voorschrift tot openbaarmaking van nevenfuncties. Een belangrijk element dat belangenverstrengeling en onbevooroordeeld handelen door leden van bestursorganen beoogt te voorkomen, vormt bovendien het op een breed terrein van de organieke wetgeving voorkomend verbod tot het deelnemen aan bepaalde stemmingen in die gevallen, dat persoonlijke belangen in het geding zijn. Dit stemverbod vindt in deze paragraaf overigens geen bespreking, omdat aan dit aspect een afzonderlijke beschouwing wordt gewijd in par. 2.5.5, waarin uitspraken inzake de (on)partijdigheid bij de beslissingsprocedure onder de loep worden genomen.

Art. 13 Prov.w. vermeldt een aantal functies dat onverenigbaar is met het statenlidmaatschap. Bij de in art. 13 opgesomde functies is niet naar volledigheid gestreefd omdat dit artikel slechts vanuit het provinciaal belang is geredigeerd. Art. 13 Prov.w. beoogt uitsluitend de zuiverheid in de provinciale verhoudingen te bevorderen door die ambten als incompatibiliteiten aan te geven die zonder meer met het statenlidmaatschap onverenigbaar zijn. ${ }^{n}$ Het spreekt voor zich dat het uit een oogpunt van belangenverstrengeling minder wenselijk is, dat een Minister, een Staatssecretaris, een lid van de RvS, een lid van de AR, alsook een provinciaal ambtenaar vanwege de betrokkenheid met het provinciaal werkterrein (toezicht, controle en dienstverband) uit dien hoofde in een bepaalde relatie zou mogen staan met het provinciaal werkterrein. In dit verband wordt er overigens op gewezen dat het een rechter, alsook een medewerker van de RvS, is toegestaan het statenlidmaatschap (en ook het raadslidmaatschap) te aanvaarden. Zoals is aangegeven is het niet de bedoeling van de provinciale wetgever om incompatibiliteiten in de Prov.w. op te nemen als andere dan provinciale belangen in het geding zijn. ${ }^{78}$ Dit laatste betekent, dat in andere wettelijke regelingen, bepalingen terzake incompatibiliteiten kunnen worden aangetroffen die een verwijzing geven naar lidmaatschappen van publiekrechtelijke colleges, waarvan de keuze ge- 
schiedt krachtens wettelijk voorschrift uitgeschreven verkiezingen. Een voorbeeld hiervan is de incompatibiliteitenregeling zoals deze is opgenomen in art. $5 \mathrm{WNo}$.

In samenhang met het vorenstaande zij vermeld dat ook art. 13 Gem.w., art. 33 Watersch.w. en art. 75 jo art. 6 Wet BO incompatibiliteitenvoorschriften kennen voor onderscheidenlijk de leden yan de gemeenteraad, het algemeen bestuur van het waterschap en de leden van het bestuur van de bedrijfslichamen. Deze voorschriften gelden ook voor de leden van het dagelijks bestuur van de betreffende publiekrechtelijke rechtspersonen. Verbodsbepallingen voor onverenigbare betrekkingen zijn er ook voor de functies van $\mathrm{CdK}$, burg., voorzitter van het wateschapsbestuur en voorzitter van de bedrijfs-lichamen.

In de aangepaste organieke wetten zoals de Gem.w. is overigens sprake van een beperking van het aantal incompatibiliteiten. Dit laatste betekent echter niet dat de uitgebreide opsomming van onverenigbare betrekkingen, zoals die onder de gem.w. gold voor het ambt van burgemeester (art. 68 en 69), geen actualiteitswaarde meer heeft. Doorgaans wordt thans voor wat betreft de incompatibiliteiten aan dit aspect aandacht besteed in de voor de betrokken ambten geldende rechtspositieregelingen. Zo vermeldt het Rechtspositiebesluit burgemeesters 1994 (Stb. 462) dat de burgemeester zich moet onthouden van gedragingen die de goede uitoefening van het ambt (kunnen) schaden. ${ }^{79}$

Er is globaal gesproken over een aantal wettelijke bepalingen inzake de onverenigbaarheid van een aantal betrekkingen met het lidmaatschap voor bestuursorganen, zoals die functioneren onder de werking van het provinciaal recht, het gemeenterecht, het waterschapsrecht en het sociaal-economisch ordeningsrecht. De beknopt in beeld gebrachte regelingen geven minimaal aan welke betrekkingen in ieder geval niet tezamen mogen worden vervuld met de onderscheidene bestuurslidmaatschappen. Zoals terloops werd aangeduid bestaan er als uitvloeisel van de betreffende incompatibiliteitenregelingen ook bepalingen inzake het openbaar maken van nevenfuncties.

In de Prov.w. vindt de openbaarmaking van nevenfuncties van de leden van provinciale staten onder de werking van het nieuwe recht als volgt regeling.

Art. 11 Prov.w., lid 2 bepaalt dat de leden van PS openbaar maken welke andere functies dan het lidmaatschap van de staten zij vervullen. In aansluiting hierop schrijft het tweede lid voor dat de openbaarmaking van deze nevenfuncties geschiedt door terinzagelegging van een opgave van de bedoelde functies op het provinciehuis.

A.w., aant. 1 art. 68 Gem.w., E. Brederveld, Gemeenterecht, derde dr., Zwolle 1994. p. 30 e.w. 
De betekenis van art. 11 Prow.w. is gelegen in het verkrijgen van inzicht in mogelijke tegenstrijdigheid van belangen, die kan ontstaan doordat de statenleden andere functies dan het statenlidmaatschap vervullen, waardoor een ongewenste belangenverstrengeling als gevolg van die andere functies kan ontstaan. Zowel de hoofd-als de nevenfuncties dienen de statenleden bekend te maken. ${ }^{80}$ Bij deze verplichte opgave van nevenfuncties gaat het om zowel betalilde als onbetaalde functies die naast het statenlidmaatschap worden vervuld. Dat ook op onbetaalde functies wordt gedoeld spreekt woor zich. Leden van PS die bijvoorbeeld bestuurslid zijn van stichtingen of verenigingen, kunnen hierdoor in hun hoedanigheid van bestuurslid persoonlijk betrokken zijn bij zaken als subsidieverlening voor hun verenigingen. Bij de behandeling en de besluitvorming met betrekking tot subsidiezaken kan de schijn van partijdigheid wegens belangenverstrengeling ontstaan. Het uitsluiten van onbetaalde functies lijkt derhalve plausibel. Ook voor de $\mathrm{CdK}$ is een soortgellijke regeling opgenomen in art. 66 Prov.W. In de redactie van art. $66 \mathrm{komt}$ de intentie van de bepaling over nevenfuncties wél sterker tot uitdrukking. Naast het gebod tot openbaarmaking van de nevenfuncties door de commissaris stelt dit artikel expliciet, dat deze geen nevenfuncties vervult waarvan de uitoefening ongewenst is met het oog op de goede vervulling van het ambt van commissaris of op de handhaving van zijn onpartijdigheid en onafhankelijkheid of van het vertrouwen daarin. Naast het bovengenoemde geciteerde eerste lid van art. 66 Prov.w. kent het tweede lid een zeer strikte opdracht aan de commissaris:

2. De commissaris meldt zijn voornemen tot aanvaarding van een nevenfunctie, anders dan wit hoofde van het ambt van commissaris, aan provinciale staten.'

De Gem.w. kent met de Prov.w. vergelijkbare voorschriften aangaande het vervullen en openbaar maken van nevenfuncties.

Deze voorschriften vinden regeling in de bepaling van art. 12 Gem.w. voor wat betreft het raadslidmaatschap. Art. 67 Gem.w. kent een regeling voor de burg. die geheel spoort met de inhoud van de regeling als bedoeld in art. 66 Prov.w. zoals die geldt voor de $\mathrm{CdK}$.

Ook art. 32 Watersch.w. kent een regeling inzake het openbaar makèn van functies van leden van het algemeen bestuur. Art. 48 Watersch.w. geeft gelijke voorschriften terzake het verbod van nevenfuncties, zoals die gelden woor onderscheidenlijk de CdK en de burg. De Wet BO kent geen voorschriften terzake het bekleden van nevenfuncties. Wel is er een sanctieregeling opgenomen in art. 7 van deze wet, waarin is bepaald dat bij algemene maatregel van bestuur ter 
verzekering van de nalewing van het bepaalde in art. 6 (incompatibiliteiten), regelen kunnen worden gesteld. Art. 7 is immers in art. 75 Wet $\mathrm{BO}$ voor het bestuur van het bedrijfslichaam van toepassing verklaard. Evenzo is in art. 81 Wet $\mathrm{BO}$, art. 7 van toepassing voor de voorzitter van het bedrijfslichaam.

Tenslotte wordt er op gewezen dat het voorkómen van belangenverstrengeling in het openbaar bestuur zeer in de actualiteit staat bij de wetgever, en het aspect van zuiverheid bij het bestuurshandelen sterk de aandacht krijgt. Dit laatste geldt overigens niet alleen voor de leden van bestuurscolleges maar ook voor de medewerkers in ambtelijke dienst bij diezelfde bestuursorganen.

Een voorbeeld hiervan is het ingediende wetsontwerp inzake de wijziging van de Ambtenarenwet en de Militaire Ambtenarenwet 1931 in verband met het verrichten van nevenwerkzaamheden. ${ }^{81}$ In dit voorstel van wet wordt een wijziging gelanceerd van art. 125, eerste lid van de Ambtenarenwet en art. 12 van de Militaire Ambtenarenwet. Het wetsvoorstel beoogt een registratieplicht van nevenwerkzaamheden in te voeren, alsmede een verbod voor ambtenaren. De toelichting behorend bij het wetsvoorstel laat aan duidelijkheid niets te wensen over:

'doel van de melding en de registratie is dat het bevoegd gezag tot toetsing kan overgaan of sprake kan zjjn van een verstrengeling of botsing van dienstbelangen met de belangern die betrokken zijn bij de nevenwerkzaamheid. Ook de kenbaarheid wordt hiermee gediend zowel naar de overheidswerkgever als naar de ambtenaar. Dit is met name van belang als er in de toekomst werkzaamheden worden opgedragen, waardoor er eerst dan een belangenverstrengeling kan optreden. ${ }^{92}$

Ter benadrukking van de bijzondere aandacht van de wetgever om regelingen te creëren die de zuiverheid van verhoudingen beogen te verzekeren, alsook het vertrouwen in de rechterlijke macht, de rechterlijke onafhankelijkheid en onpartijdigheid en het vertrouwen daarin in het bijzonder, moge ter afronding nog worden gewezen op het wetsvoorstel tot wijziging van de Wet rechispositie rechterlijke ambtenaren. ${ }^{83}$

Een tweede belangrijk element in de regelingen ter bevordering van de zuiverheid van de verhoudingen binnen de kring van de publiekrechtelijke rechtspersonen functionerende bestuursorganen, wordt gevormd door bepalingen, waarbij voor leden van bestuursorganen het verrichten van bepaalde handelingen imperatief en

8 TK 1995-1996, 24575, nrs. 1-2.

\$2 TK 24575, nr. 3, p. 7.

$\$$ TK 1994-1995, 24220. 
limitatief wordt verboden. Overigens geldt ook ten aanzien van de hierna kort aan te stippen regelingen, dat de bepalingen minimale condities betreffen ten behoeve van de zuiverheid van de bestuurlijke verhoudingen.

Art. 15 Prow.w. geeft een uitgebreide en scherp geformuleerde bepaling te zien, waarin een aantal handelingen is opgenomen die door een lid van provinciale staten in de ütoefening van zijn of haar ambt niet mogen worden verricht. Met het oog op de rechtszekerheid zijn de opgesomde verboden handelingen vrij exact omschreven. ${ }^{84}$ Zoals werd aangegeven geeft het artikel over de verboden handelingen, waarborgen voor zuiverheid in de verhoudingen binnen het provincial bestuurlijk bestel. ${ }^{85}$ Hierna wordt een globalle aanduiding gegeven van de aard van de betreffende verboden handelingen.

Allereerst verbiedt art. 15 Prov.w., lid 1 , onder a tot en met c het werkzaam zijn als advocaat, procureur of adviseur, het optreden als gemachtigde of het als vertegenwoordiger of adviseur werkzaam zijn ten behoeve van derden. Deze handelingen worden als verboden gekwalificeerd zodra er gesproken kan worden van enig verband met de provincie.

De opgesomde verboden handelingen in sub $d$ van art. 15 Prov.w. hebben betrekking op het overeenkomstenrecht, waartoe behoren: het aannemen van werk, het buiten dienstbetrekking verrichten van werkzaamheden, het doen van leweranties en het verhuren van roerende zaken aan de provincie. Daamnaast worden als verboden beschouwd, handelingen terzake het verwerven van betwiste worderingen ten laste van de provincie, het verwerven van onroerende zaken of beperkte rechten van de provincie en het onderhands huren of pachten. Uit het laatstgenoemde verbod moge worden afgeleid dat dit niet betrekking heeft op het openbaar huren of pachten. Dit lijkt ook logisch, omdat immers na een openbare bekendmaking belangstellenden kunnen inschrijven om voor het sluiten van een huur- of pachtovereenkomst in aanmerking te komen. Het zou niet realistisch zijn orm statenleden in dit geval van enige privaatrechtelijke transactie uit te sluiten, alleen vanwege de omstandigheid dat een betrokken gegadigde, statenlid is.

Overigens zij opgemerkt dat dit artikel niet zover strekt, dat het aan statenleden verboden is derden te adviseren in die gevallen dat er geen sprake is van een geschil met de provincie dan wel het aangaan van een overeenkomst als bedoeld in art. 15 Prov. w., lid 1 onder $d{ }^{86}$

84 A.w, arat 1 bja art. 15 Prov.w. en MvT 19403, nr. 3, p. 76.

95 A.w. en MVT, TK 19403, nr. 10, p. 136.

A.W. en MVA, TK 19403, wr. 10 , p. 136. 
Ingeval art. 15 Prov.w. niet wordt nageleefd verbindt art. X 7 Kiesw. daaraan de sanctie dat vervallenverklaring van het lidmaatschap van de staten volgt.

De Prov.w. kent een bepaling die verband houdt met de bijzondere positie van de provincie als administratief beroepsorgaan. Voor gedeputeerden is het in art. 47 Prov.w. werboden, in zaken die aan de uitspraak van GS zijn onderworpen, werkzaam te zijn als gemachtigde of als adviseur. In feite is hier sprake van een toevoeging aan de verboden handelingen als bedoeld in art. 15 Prov.w. Ook met deze bepaling wordt een waarborg geschapen in het belang van de objectiviteit en de onafhankelijkheid van het college van GS als beroepsorgaan.

Voor onderscheidenlijk de CdK en de burg. zijn in de art. 68 Prov.w. en 69 Gem.w., de art. 15 Prov.w. en Gem.w. van toepassing verklaard, zodat het ook voor deze ambtsdragers verboden is deze handelingen te verrichten. Voor de griffier der staten en de gemeentesecretaris zijn de regelingen voor de verboden handelingen eveneens van toepassing verklaard. Tevens moge worden gewezen op de voor deze beide functies in zowel de Prov,w. en de Gem.w. genoemde ambtsinstructies, waarin met het oog op het doelmatig functioneren regels zijn gesteld (Art. 100 Prov.w. en 103 Gem.w.). Ook art. 33 Watersch.w. geeft een overeenkomstige regeling te zien voor het verrichten wan verboden handelingen. De Wet BO heeft geen regeling getroffen voor het verrichten van verboden handelingen.

2.4.3. Regelingen die het belang van de zuiverheid van het besturen en de onpartijdigheid positief kunnen beïnloeden

In samenhang met de bepalingen die het oogmerk hebben zuiverheid van verhoudingen en onpartijdig bestuur te creëren, is er een aantal regelingen te traceren die indirect een bijdrage kunnen leveren aan de ondersteuning van de toepasselijke bepalingen die bevooroordeelde besluitvorming beogen te voorkomen.

In relatie met hetgeen in de vorige paragrafen is besproken, zijn enige hiermee verwante bepalingen waar te nemen. Op grond hiervan volgt een zeer beknopte behandeling van enkele zogenaamde "anti-beïnvloedlingsbepalingen".

Allereerst kent art. 167 Prov.w. een verantwoordings- en inlichtingenplicht voor de leden van GS. Deze verantwoordingsplicht is in bedoeld artikel, zowel geregeld als collectieve verplichting voor het college van GS en als individuele verplichting voor de afzonderlijke leden van het genoemd college. Voor de commissaris der Koningin is een eigen verantwoordingsplicht als eenhoofdig orgaan geregeld in art. 179 Prov.w. Deze verantwoordingsplicht biedt mogelijkheden voor provinciale staten om verantwoording te vragen en inlichtingen te verkrijgen in zaken, waarbij bijvoorbeeld vraagtekens kumnen worden geplaatst 
ten aanzien van die zaken, waarin de schijn van partijdigheid bij de besluitvorming in her geding kan zijn.

Ook art. 169 Gem.w. kent een identieke regeling. Evenals in de Prov.w. het geval is vindt in de Gem.w. een afzonderlijke verantwoordingsplicht, regeling voor de burg. (art. 180 Gem.w.).

In het waterschapsrecht wordt een verantwoordingsplicht aangetroffen in art. 89 Watersch.w. voor het dagelijks bestuur van het waterschap en in art. 97 voor de voorzitter van het schap.

In het sociaal-economisch recht komen geen bepalingen voor omtrent de verantwoordingsplicht. Wél biedt art. 92 Wet $\mathrm{BO}$ mogelijkheden voor het bestuur van het bedrijfslichaam tot inzicht in de werkwijze van het dagelijks bestuur. Dit artikel geeft het bestuur van een bedrijfslichaam de bevoegdheid bij verordening nadere regelen te stellen betreffende zijn werkwijze en die van de andere organen van dat lichaam en het secretariaat.

In aansluiting aan deze mogelijkheid tot het vragen van verantwoording, bieden de reglementen van orde, zoals die in een aantal organieke wetten zijn voorgeschreven, voldoende aanknopingspunten om via het daarin omschreven vragenrecht inlichtingen te verlangen omtrent 'verdachte' besluitvorming, waarbij partijdige besluitvorming bijwoorbeeld bij gerucht wordt vernomen.

Een bijzonder instrument om leden van het dagelijks bestuur ter verantwoording te roepen en in samenhang hiermede te ontslaan, vormen de zogenaamde tussentijdse ontslagregelingen voor leden van GS, wethouders en leden van het dagelijks bestuur van een waterschap.

De in deze toepasselijke artikelen, te weten art. 49 Prov.w., art. 49 Gem.w. en art. 46 Watersch.w. bieden voor de algemene besturen handreikingen om leden van de bovengenoemde bestuursorganen "heen te zenden", zodra onoorbare belangenverstrengeling en partijdigheid in het geding zijn bij de besluitvorming van deze dagelijkse besturen. Voor de voorzitters van deze dagelijkse besturen geidt een eigen specifieke regeling. Met name wordt hier gedoeld op de schorsings- en ontslagregelingen.

Overigens zij nog opgemerkt, dat art. 49 Prov.w. een nieuwe 'organieke loot aan de boom" is, woor wat betreft het tussentijds ontslag van leden van GS. Voor het nieuwe provincierecht betekent art. 49 een novum; in de gem.w. was er een soortgelijke regeling die was neergelegd in het hier niet nader te bespreken en beruchte "art. $87 \mathrm{a}$ ". Tenslotte is schorsing en ontslag van een slecht functionerende voorzitter van een hoofdproductschap of een productschap mogelijk bij Koninklijk besluit. 
Voor de volledigheid wordt aangestipt, dat via petities, brieven, publiciteit in de media, het spontane vernietigingsrecht zijn functie vervult in die zaken, waarbij belangenverstrengeling of de schijn daarvan wordt vermoed. Vrij recent was dit spontane vernietigingsrecht actueel in een zaak in de gemeente Simpelveld. Op deze kwestie wordt in de par. 2.5.5 en 2.6.4 nog terug gekomen.

Daarnaast is het wan belang te wijzen op de openbaarheid van vergadering zoals die in de organieke wetten regeling vindt. Dat wan openbaarheidsregelingen een controlerende en verantwoordende functie uitgaat behoeft niet of nauwelijks enige toelichting. Ook deze regelingen, waarbij ten aanzien van met name genoemde zaken, besluitvorming in de openbaarheid beoogt te geschieden, gaat in meer of mindere mate een filterende werking uit in het belang van het voorkomen van bevooroordeeld openbaar bestuur. Genoemd kunnen worden de art. 23 Prov.w. en Gem.w. en 35 Watersch.w. die gelden voor de algemene besturen. Voor de dagelijkse besturen geldt het beginsel van beslotenheid van vergaderen, tenzij anders is of wordt bepaall. In die gevallen dat achter gesloten deuren wordt vergaderd gelden bijzondere eisen; dat laatste geldt eveneens in die gevallen dat besloten wordt tot geheimhouding van beraadslaging.

Naast deze openbaarheidsregelingen beoogt de WOB regelen te geven met betrekking tot de openheid en de openbaarheid van bestuur, zulks in het belang van een goede en democratische bestuursvoering. De WOB heeft een groot toepassingsbereik en is blijkens art. 1a van die wet van toepassing op het rijk (Ministers), alsmede de bestuursorganen van provincies, gemeenten, waterschappen en de publiekrechtelijke bedrijfsorganisatie.

De WOB geeft zowel regels voor de passieve informatieplicht (informatie op verzoek) als voor de actieve informatieplicht (informatie uit eigener beweging), omtrent de voorbereiding en uitvoering van het beleid door deze bestuursorganen. Aangezien het verschaffen van informatie door de bestuursorganen veelal geschiedt in de vorm van documenten (schriftelijk of ander materiaal) kan hierdoor aan de justitiabelen de mogelijkheid worden geboden om een kijkje te nemen in de keuken van de bestuursorganisatie. Indien twijfels of geruchten bestaan over de zuiverheid van de besluitworming en de door de bestuursorganen verrichte taken, kan er bij inzage en raadpleging van de onder het bestuursorgaan berustende stukken, mogelijk meer duidelijkheid worden verschaft over eventueel vermeende belangenverstrengeling en vooringenomenheid bij het functioneren van het openbaar bestuur.

De laatste jaren is er een ontwikkeling waarneembaar waardoor steeds meer, vooral via de media, het instrumentarium wan de WOB in stelling wordt gebracht. 
Vooral in zaken als corruptie en belangenverstrengeling wordt deze tendens meer zichtbaar. De pers maakt in die gevallen dankbaar van de WOB gebruik om via raadpleging van overheidsdocumenten, informatie over beweerdelijk gestelde misstanden bij bestuursorganen verder uit te diepen.

De WOB heeft een geheel specifiek eigen karakter en geeft een regeling met het oog op een goede en democratische bestuursvoering. In het kader wan de bezwaarschriftenprocedure is er een specifieke op de rechtsbescherming toegesneden regeling die voorziet in het indienen en ter inzage leggen van stukken tijdens de bezwaarfase (art. 7:4 Awb). De regeling met betrekking tot de terinzagelegging van de stukken is bedoeld ten einde een deugdelijke voorbereiding van de hoorzitting mogelijk te maken. Belanghebbenden wordt de mogelijkheid geboden schriftelijke stukken in te dienen. Alle op de zaak betrekking hebbende bescheiden moeten in beginsel ter inzage worden gelegd. De inzageregeling, zoals die geldt in het kader van de bezwaarschriftenprocedure, is geschreven vanuit het gezichtspunt van een goede procesorde, en de belangen die gediend zijn met een goede rechtsbescherming.

Het specifieke en eigen karakter van de inzageregeling van stukken tijdens de bezwaarschriftenprocedure is ook af te leiden uit de jurisprudentie. Dit laatste blijkt naast hetgeen tijdens de parlementaire behandeling over de toepassing van art. 7:4 Awb is gezegd. Tijdens die behandeling is gesteld, dat het inzagerecht als een van de fundamentele waarborgen is te beschouwen voor een goed verlopen bezwaarschriftenprocedure. ${ }^{87}$ Dat het inzagerecht ex art. 7:4 Awb sterker van karakter is dan dat van de WOB, kan worden opgemaakt uit de MvT inzake de toepassing van het zesde lid van art. 7:4, waarbij de mogelijkheid bestaat de terinzagelegging van stukken achterwege te laten zo er gewichtige redenen in het geding zijn die nopen tot geheimhouding van bepaalde stukken. De MvT behorende bij art. 7:4, lid 6 zegt, dat de bedoeling van de in het zesde lid van art. 7:4 vermelde grond tot het achterwege laten van de ter inzagelegging, is om aan te geven, dat voor de weigering van inzage een sterkere grond aanwezig moet zijn dan de redenen waarom krachtens de WOB een verzoek om informatie kan worden geweigerd. ${ }^{88}$ In navolging van de Awb bevestigt de administratieve rechter dit standpunt, hetgeen blijkt uit een uitspraak in een zaak van de Stichting Woningbedrijf Den Haag tegen de staatssecretaris van Volkshuisvesting, Ruintelijke Ordening en Milieubeheer. De rechtbank van 's-Gravenhage deed in deze zaak waarbij de weigering van inzage van een stuk tijdens de bezwaarfase ter 
discussie stond, uitspraak dat tijdens bezwaar en beroep de bepalingen van de Awb en niet die van de WOB van toepassing zijn. In deze uitspraak betekende dit een strenge toets ten aanzien van de weigering door de staatssecretaris. Die strikte toets leidde er toe dat de rechtbank overwoog, dat juist door het openbaar maken van alle relevante stukken tussen rechtzoekende en bestuursorgaan een enigszins gelijkwaardige positie wordt gecreëerd. In casu werd strijdigheid met art. 7:4, lid 2 en 6 geconstateerd, en volgde vernietiging wegens strijd met het (formele) zorgvuldigheidsbeginsel. ${ }^{89}$

Ook in de WNo zijn aanknopingspunten te vinden voor een bescherming van de burger tegen vooringenomen handelen van het overheidsbestuur (bestuurders en ambtenaren). De WNo beoogt een algemeen aanvullend rechtsbeschermingskader te scheppen voor die gevallen, dat niet gesproken kan worden van besluiten als bedoeld in de $A w b$, en daarbij geen mogelijkheid bestaat om bestuursbestissingen via bezwaar en/of beroep aan te vechten. Centraal in de WNo staat het toetsen van gedragingen van een bestuursorgaan of een overheidsfunctionaris die in dienst is bij datzelfde bestuursorgaan aan behoorlijkheidsvereisten. Concreet wordt met de WNo beoogd, om naast de bestaande rechtsbeschermingsvoorzieningen een behoorlijke klachtenregeling tegen gedragingen van bestuursorganen en aan die organen ondergeschikte functionarissen te creëren.

Gaandeweg is naast het door het rechtsbeschermingsfenomeen gewonnen terrein, ook het beeld ontstaan, dat een behoorlijke klachtenbehandeling als een beginsel van behoorlijk bestuur moet worden beschouwd. De mening heeft hierbij postgevat, dat er bij elk bestuursorgaan een primaire verantwoordelijkheid ligt voor een interne klachtenbehandeling, waaraan tevens minimale eisen moeten worden gesteld. ${ }^{90}$ De Wno is nog niet van toepassing op alle bestuursorganen. De wet geldt momenteel voor de centrale overheid, de politietaken van de CdK en de burgemeester. Sinds 1 januari 1994 geldt de wet voor de waterschappen en ingaande 1 november 1995 is het aanwijzingsbesluit van kracht voor zelfstandige bestuursorganen. De notitie Bevoegdheid van de Nationale ombudsman ten aanzien van mede-overheden ${ }^{4 \|}$, beoogt (vrijwillige) aanwijzing van gemeenten bij de WNo mogelijk te maken, waardoor de klachtenbehandeling alsdan een extern karakter krijgt. De bedoeling is om de aanwijzing bij ministerieel besluit te doen plaatsvinden. Het lijkt er op, dat in tegenstelling tot de mogelijkheid van indivi-

89 Rb. 's-Gravenhage 19 februari 1996, Abw-katern 1996, 43.

90 Bevoegdheid van de Nationalle ombudsman ten aanzien van mede-overheden, Brief van de staatssecretaris van Binnenlandse Zaken aan de Voorzitter van de Tweede Kamer der Staten. Generaal, TK 1994-1995, 24206, nr 1, p. 7.

91 TK 24206. 
duele verzoeken tot aanwijzing van gemeenten, bij provincies en waterschappen gekozen zal worden voor een categoriale aanwijzing.

Een ombudsregeling zoals de WNo, en dat geldt mede voor de gemeentelijke ombudsregelingen, die veelal zijn geënt op het model van de WNo, biedt de burger verregaande mogelijkheden om bescherming van zijn belangen te vragen in die gevallen dat hij onheus is bejegend. Datzelfde geldt ook voor andere onbehoorlijke gedragingen door bestuursorganen en overheidsdienaren, hetgeen blijkt uit de vele uitspraken door de $\mathbb{N}$.o.

Ter afsluiting van het bovengenoemd aspect, wordt hierbij nog gewezen op een uitspraak van de N.o., waarbij in relatie met het besproken vooringenomenheidsverbod aan het oordeel van de N.o. was onderworpen een zaak, waarbij geklaagd werd over een bevooroordeelde en onzakelijke houding van een belastingambtenaar. Uit deze uitspraak van de N.o. blijkt, dat een medewerker van de belastingdienst zich bij het vervullen van zijn taak dient te beperken tot handelingen en het stellen van vragen die voor het verlenen van diensten strikt noodzakelijk zijn. Het geven van commentaar op verstrekte gegevens, dan wel het stellen van zodanige vragen die de grens van de strikte noodzakelijkheid overschrijden, oordeelde de ombudsman, als onbehoorlijk. In zulke omstandigheden krijgt naar het oordeel van de ombudsman de taakvervulling van de betrokken ambtenaar een onoorbaar karakter, en ontstaan er aanwijzingen die er op duiden dat gesproken kan worden van een bevooroordeelde houding door een overheidsfunctionaris. ${ }^{92}$

Er bestaan enige regelingen die beogen de objectiviteit bij de voorbereiding van besluiten te bevorderen en vooringenomenheid uit te sluiten. Genoemd kunnen worden art. 7:5 inzake het horen en de in art. 7:13 genoemde bezwaarschriftencommissie. Bespreking van beide bepalingen geschiedt in de hoofdstukken 4 en 5 . Ook kunnen worden genoemd de commissies voor bezwaar- en beroep voor de gemeenteraad en provinciale staten. Van belang zijn eveneens de bepalingen voor de mandatering van bevoegdheden aan de leden van GS, de wethouders en de leden van het dagelijks bestuur van het waterschap. In samenhang hiermede kan eveneens worden gewezen op de mandateringsbevoegdheid van bestuursorganen om het nemen van besluiten op te dragen aan ondergeschikte functionarissen. Bij deze mandaatregelingen die krachtens een besluit van het bestuursorgaan worden genomen, worden in het belang van een juiste uitvoering ter waarborging van de 
verantwoordelijkheid voor de door de mandataris te nemen besluiten, strikte aanwijzingen gegeven.

Deze aanwijzingen bieden ruimte om de zuiverheid van het bestuurlijk, dan wel ambtelijk handelen te warborgen. Overigens is met de inwerkingtreding van de derde tranche $A$ wb een formeel-wettelijke regeling van kracht voor de in de bestuurspraktijk bestaande (informele) regeling woor de mandatering aan ondergeschikten.

2.5. De zuiverheid van de bestuurlijke taakvervulling vóór de Awb: een doorkijk op hoofdlijnen

\subsubsection{Inleiding}

Hierna wordt een beeld geschetst van de jurisprudentie vóór de inwerkingtreding van de Awb, waarbij de zuiverheid van het bestuurlijk handelen in het geding is. Besproken worden het persoonlijk belang van leden van bestuursorganen en de invlloed hiervan op de besluitvorming. In deze schets wordt aandacht besteed aan het oordeel van enkele administratieve instanties. Zowel Kroon-uitspraken als uitspraken van de administratieve rechters komen aan bod. Omwille van de helderheid wordt gekozen voor een behandeling op hoofdlijnen.

Ten aanzien van de besluitvorming wordt een onderscheid gemaakt tussen enkele fasen die het besluitvormingsproces kenmerken. Deze fasen worden in de literatuur onderscheiden in de voorbereiding van de besluitvorming, de beslissingsprocedure en de eigenlijke besluitvorming. ${ }^{93}$ Bij de besluitvorming zijn doorgaans betrokken het bestuursorgaan en zijn bestuurders, de adviesorganen (zowel op basis van formele dan wel materiële wetgeving), alsmede de in ondergeschiktheid aan het bestuursorgaan, werkzame personen.

\subsubsection{Voorbereiding besluitvarming formeel-wettelijke adviescommissie}

De WW (Woningwet) 1962 bepaalde in art. 85, lid 3 dat de gemeenteraad een deskundig college moest aanwijzen voor het schriftelijk uitbrengen van een advies bij de toepassing van de voorschriften omtrent de welstand (welstandscommissie). Ofschoon in de WW 1962 in tegenstelling tot de huidige Woningwet (Wet van 29 augustus 1991. Stb 439) niet gesproken werd over een commissie van onafhanke-

93 P. Nicolai, Beginselen van behoorlijk bestuur, Deventer 1990, p. 288 . 
lijke deskundigen, kan uil de jurisprudentie worden opgemaakt dat uit deskundigheid onafhankelijkheid geacht wordt voort te vloeien.

In een zaak van de gemeente Bemmel bleek dat de rechter de deskundigheid wan de welstandscommissie in twijfel trok, hetgeen werd afgeleid uit de samenstelling van deze commissie. Van de welstandscommissie maakte deel uit de wethouder voor rumtelijke ordening, het hoofd van het gemeentelijke bouw en woningtoezicht alsmede de stedenbouwkundige van deze gemeente. Op basis van de MvT van art. 85, lid 2 WW 1962 oordeelde de administratieve rechter, dat nu hierin gesproken werd over een adviesinstantie, een dergelijk college een onafhankelijke positie dient in te nemen ten opzichte van $b$ en $w$ als beslissend bestuursorgaan. Aangezien de voorzitter geen strijdigheid van de bouwvergunning constateerde werd dit gebrek gesauveerd en volgde geen schorsing van de verleende bouwvergunning. ${ }^{94}$

In een zaak die vanwege andere aspecten met deze kwestie verband hield, kan zoals hierna zal blijken de Awb hernieuwde interesse kweken door de werking van het vooringenomenheidsverbod. De casus stond en staat bekend als de Amsterdamse zaak over de bouw van het stadhuis/muziektheater.

Een aantal personen had beroep ingesteld tegen het naar hun mening partijdig (positief) advies van de welstandscommissie. Appellanten waren van mening dat ten minste de schijn van partijdigheid was gewekt doordat een groot aantal andere deskundigen een duidelijk ander oordeel had ten aanzien van het uitgebrachte welstandsadvies. Dit (ander) oordeel werd niet betrokken bij de weistandsadvisering. Gebleken was dat in een eerste vergadering van de welstandscommissie de ontwerpers van het bouwplan van het stadhuis/muziektheater in de welstandscommissie slechts een toelichting hadden gegeven op het plan. Bij de uiteindelijke beoordeling die op de eerste voorbereidende vergadering van architecten volgde, waren drie ambtelijke en niet-ambtelijke leden van de welstandscommissie aanwezig. Omdat alle leden konden instemmen met het plan, en juist de nietambtelijke leden meer nog dan de ambtelijke leden zeer ingenomen waren met het bouwplan, bleek deze omstandigheid voor de arob-rechter van doorslaggevende betekenis voor het oordeel dat van een niet-onafhankelijke wijze van advisering geen sprake kon zijn. ${ }^{95}$

De uitspraak geeft wél aan, dat de arob-rechter zich zeer nauwkeurig vergewiste van de gang van zaken rond de advisering door de Amsterdamse welstands- 
commissie. Opvallend was dat appellanten een contra-expertise zoals die bij medische zaken doorgaans geschiedt, niet werd gegund.

In de Winterswijkse kwestie deed zich de omstandigheid voor, dat namens de welstandscommissie geadviseerd was door slechts én deskundige (lid welstandscommissie).

De arob-rechter oordeelde dat op zich genomen voor gevallen die zich daartoe lenen (minder ingewikkelde bouwplannen) het niet onjuist is dat namens de welstandscommissie een van haar leden het advies concretiseert. Maar dat laatste betekende naar het oordeel van de rechter niet, dat de visie van de welstandscommissie in het advies mocht ontbreken. Nu dit het geval was, werd de verleende bouwvergunning vernietigd wegens strijd met art. 85, derde lid jo 17 WW. De arob-rechter stelde nadrukkelijk, dat onder deze omstandigheden op basis van de strekking van de WW, de objectiviteit van het welstandsadvies in twijfel moest worden getrokken. ${ }^{96}$

Een vierde kwestie waarbij advisering door de Beverwijkse welstandscommissie ter discussie stond, leidde er toe dat de Vz. ARRS twijfelde aan de onafhankelijkheid van de commissie. Opmerkelijk was hier, dat uiteindelijk toch niet tot schorsing van de bouwvergunning werd overgegaan. De aard en de omvang van het bouwwerk oordeelde de voorzitter van geringe betekenis. Een merkwaardige uitspraak die toch het aspect van onpartijdigheid geweld aandoet, en bij de bezwaarde burger twijfels kan oproepen over de kwaliteit en de betrouwbaarheid van de rechtspraak. ${ }^{97}$

In een zaak van de gemeente Heilo oordeelde de Vz. ARRS op 29 april 1991, dat de samenstelling van de welstandscommissie van die gemeente de onafhankelijkheid onvoldoende waarborgde. Geen genade vond in de ogen van de rechter een door de burgemeester en een externe deskundige bemenste commissie. Hier blijkt, dat gebrek aan deskundigheid (één extern lid), leidde tot de conclusie, dat daarmede ook de niet-onafhankelijkheid voortvloeide. ${ }^{98}$

Op basis van de jurisprudentie kan worden vastgesteld, dat de samenstelling van een adviesinstantie zoals de welstandscommissie nauw gekoppeld wordt aan deskundigheid. Deskundigheid veronderstelt kwaliteit, gekoppeld aan het doel van de advisering, waardoor een onpartijdig adviseren met meer waarborgen is omkleed dan in gevallen waarbij leken een oordeel moeten vellen betreffende

96 ARRS 13 januari 1992, B/S 1992, 6.

97 Vz. ARRS 1 juni 1992, BR 1993, p. 130.

V2. ARRS 29 april 1991, Gst. 6957, 9. 
aspecten, waarover een zekere mate van bijzondere expertise wordt verwacht. ${ }^{99}$ Vooral in die gevallen, dat het externe advies moet dienen als wettelijk vereiste in een vergunningsprocedure, is dit van groot belang. Een bouwvergunning kan immers niet worden verleend als de welstandscommissie geen positief advies uitbrengt omtrent de esthetische aanvaardbaarheid van het bouwwerk. Verplichte welstandsadvisering is voorgeschreven in art. $48 \mathrm{WW}$, en art. $44 \mathrm{WW}$ bevat een imperatieve weigeringsgrond indien niet voldaan wordt aan de welstandseisen. Als voldaan wordt aan de distantie ten aanzien van de beleids-en besluitvorming (de welstandscommissie adviseert onafhankelijk van burgemeester en wethouders), is hierdoor niet zonder meer gewaarborgd, dat het deskundigenoordeel ook objectief (onpartijdig) is en verschoond blijft van persoonlijke visie en vooringenomenheid. Het blijft daarom van groot belang dat het deskundigenadvies op zijn zuiverheid kan worden getoetst. ${ }^{100}$

De burger verkeert bij deskundigenadvisering in een kwetsbare en afhankelijke positie; hij of zij kan zijn oordeel tegen een onwelgevallig advies moeilijk adstrueren. Zelfs als de burger zoals in de bovengenoemde zaak van het Amsterdamse stadhuis/muziektheater, verwijst naar andere expertise, levert een ageren tegen deze deskundigenadvisering soms weinig resultaat op. Ofschoon deze Amsterdamse zaak ruim vóór de Awb speelde bestaan achteraf toch enige twijfels over het rechterlijk standpunt ten aanzien van de grief tegen het (subjectieve) welstandsadvies. Een toetsing aan het zorgvuldigheidsbeginsel zou meer voor de hand hebben gelegen. Het is niet uit te sluiten dat de rechter zich heeft laten leiden door het subjectieve karakter van de welstandsadvisering. In de jurisprudentie ten aanzien van welstandsadviezen klonk nogal eens door, dat bij welstandsadvisering tot op zekere hoogte subjectiviteit onvermijdelijk is. ${ }^{\text {ton }}$

Bij medische zaken lag dat zoals hiervoren is gesteld wat anders. Een contraexpertise was mogelijk. Met de komst van de Awb lijkt het niet onwaarschijnlijk, dai het vragen van een second opinion vanwege twijfels over de validiteit van het advies onder deze omstandigheden geboden is. De eerste tekenen daaromtrent zijn waarneembaar in de recente jurisprudentie. In het vervolg van deze paragraaf zal deze ontwikkeling worden aangestipt. In ieder geval lijkt art. 3:9 Awb hiertoe vanuit de gecodificeerde verantwoordelijkheid voor het bestuursorgaan mogelijkheden te bieden. Dat artikel bepaalt immers, dat het bestuursorgaan de verantwoordelijkheid draagt voor de kwaliteit van het uitgebrachte wettelijk advies, en

92 H.R.B.M. Kummeling, a. , p. 92.

100 G.J.A.M. Krijnen en B.W.N. de Waard, Omgan met welstandsadviezen, NTB 1988, p. 158 e. $v$.

nol G.J.A.M. Krijnen en B.W.N. de Waard, a.w "p. 159 
zich er van dient te vergewissen, dat het onderzoek van de adviesinstantie op zorgvuldige wijze heeft plaatsgevonden.

Ook naast het samenstellingsaspect vanuit het deskundigenperspectief van de welstandscommissie is ten aanzien wan de inhoudelijke kant van de advisering niet uit te slluiten dat vooringenomenheid de kwaliteit van het advies kan degenereren. Naast de openbaarheid van vergaderingen van de welstandscommissie is mede van belang dat de leden van de commissie een onafhankelijke positie innemen ten opzichte van $b$ en $w$. Leden van de wellstandscommissie die een architectenpraktijk hebben moeten zich onthouden van de beoordeling van bouwplannen waaraan zij direct of indirect hebben meegewerkt. Dat dit aspect van 'ons kent ons" bij het adviseren wordt onderkend blijkt uit een "Proeve van beginselen van het welstandstoezicht', uitgebracht ter' gelegenheid van de jaarvergadering van de Federatie Welstandstoezicht op 9 mei 1980. Als uitgangspunt bij de wijze van beoordeling van plannen werd in deze proeve benadrukt, dat bij het beoordelen van bouwplannen, de kwaliteit van het ontwerp en niet die van de ontwerper richtinggevend dient te zijn. ${ }^{102}$ Ten aanzien van de samenstelling van de welstandscommissie moet periodieke vervanging van de leden mogelijk zijn, maar terwille van de continuïteit moet wél matiging in acht worden genomen bij het hanteren van een roulatiesysteem.

Ook ten aanzien van een andere adviescommissie, die nauwe verwantschap vertoont met de welstandscommissie, vanwege de gewenste bijzondere expertise, kunnen problemen van deskundigheid, objectiviteit en onafhankelijkheid een rol spelen. Gedoeld wordt hier op de monumentencommissie als bedoeld in art. 15 van de Monumentenwet 1988. Art. 15 van de Mon.w. zegt kort samengevat dat de gemeenteraad bij verordening de inschakeling moet regelen van een commissie op het gebied van monumentenzorg. Deze commissie dient b en w omtrent monumentenvergunningsaanvragen te adviseren. Opwallend is dat de bovengenoemde wet niet tot uitdrukking brengt dat de betreffende advisering dient plaats te vinden door een commissie van deskundigen; over onathankelijke advisering wordt niet gerept. Wel geeft de MvT een indicatie die duidt op deskundigheid. De wetgever verwacht dat bij de samenstelling van de commissie een beroep gedaan wordt op de inzet en deskundigheid van personen en particuliere monumentenorganisaties die ter plaatse actief zijn. ${ }^{103}$

102 Welstandsadvies, welstandsberoep en welstandsjurisprudentie, Serie Welstandstoezicht, Urecht 1980, p. 53 en 54

101 TK 1986-1987, 19881, nr. 3, p. 4. 
Kennelijk haakt de jurisprudentie, waarin de advisering door een monumentencommissie een rol speelt, daarop in.

Ofschoon de Monumentenwet 1988 geen onafhankelijke commissie voorschrijft, blijkt uit een uitspraak van de ARRS, dat evenwicht in de deskundigheid wordt geëist. Daaruit voortvloeiend kan ook een onafhankelijkheidseis worden afgeleid. In de gemeente Graafstroom bestond de mogelijkheid dat een of meer raadsleden deel uit konden maken van de monumentencommissie. Deze commissie bestond naast raadsleden uit personen die niet deskundig waren op het gebied van monumentenzorg. De arob-rechter oordeelde de samenstelling daarom onjuist nu niet voorzien was in de situatie dat deskundigen, 'de deskundigheid' konden waarborgen. De door burgemeester en wethouders van Graafstroom afgegeven sloopvergunning, op grond van de Mon.w. 1966 bleef geschorst, vanwege gebrekkigheid in de advisering door een manco aan deskundigheid en objectiviteit. ${ }^{104}$

In een andere zaak speelde de onafhankelijkheid van de monumentencommissie een rol vanwege een door burgemeester en wethouders aan henzelf verleende monumentenvergunning. Indien vergunningverlening binnen de 'eigen' kring van het bestuursorgaan aan de orde is, wordt een dubbele verantwoordelijkheid ten aanzien van de advisering verlangd teneinde de schijn van partijdigheid te voorkomen. In ieder geval bleek in de bovenbedoelde Muidense zaak, dat de Voorzitter ARRS een nader onderzoek nodig achtte naar de samenstelling van de monumentencommissie. De voorzitter oordeelde:

'het is de vraag of de gemeentelijke monumentencommissie in het onderhavige geval, waarin de belangen van de gemeente zelve zozeer zijn betrokken, in voldoende mate als onathankeliik moet worden geoordeeld. ${ }^{105}$

Tenslotte volgt nog een korte bespreking van een uitspraak, waarbij de onafhankelijke advisering door de Raad voor de Kunst punt van geschil was.

De Raad voor de Kunst is een bij de wet ingestelde onafhankelijke adviesraad met externe leden. Naar aanleiding van de afwijzing van een subsidie-aanvraag door de Minister van WVC op basis van een door de Raad uitgebracht advies, werd dit advies bij de ARRS aangevochten. Het beroep op strijd met het zorgvuldigheidsbeginsel wees de arob-rechter van de hand. Hierbij nam de administratieve rechter in aanmerking, dat als het om de beoordeling van kunst gaat, subjectieve elementen niet te vermijden zijn. De rechter stelde vast dat de samenstelling van

104 ARRS 17 november $1991, \mathrm{HB} / \mathrm{S}, 153$.

105 V. ARRS 2 december 1993, Comp. Monumentenzorg, losbl., Alphen aan den Rjin, art. 15. p. 3. 
de Raad zodanig was dat van een aanvaardbare mate van intersubjecueve beoordelingsbenadering kon worden gesproken. Hierdoor voldeed de advisering aan een redelijke mate van objectiviteit. Er bestond naar de mening van de ARRS geen reden voor de opvatting dat de beoordeling zou hebben platagewonden aan de hand van willekeurige criteria. ${ }^{106}$

\subsubsection{Voorbereiding besluitworming door een materieel-wettelike advies- commissie}

Overgegaan wordt tot een korte bespreking van de advisering aan bestuursorganen, waarbij externen zijn ingeschakeld, zonder dat aan deze wijze van adviseren formeel-wettelijke adviesregels ten grondslag liggen.

Schadebeoordelingscommissies op grond van de WRO (beoordeling planschade) vormen nogal eens voorwerp van ongenoegen bij burgers. Dat ongenoegen is terug te voeren tot bezwaren van de burger tegen een naar hun mening gevoerde partijdige procedure.

De nu in het kort te bespreken interessante zaak duurde liefst bijna 25 jaar! De kwestie speelde overigens van vóór de inwerkingtreding van de WRO.

Wat was er aan de hand? In een Larense (N.-H.) schadebeoordelingscommissie waren door burgemeester en wethouders als deskundigen aangewezen de directeur van gemeentewerken en twee andere (externe) deskundigen. De meerderheid van de leden was van mening dat betrokkene recht had op planschade. De minderheid, in dit geval de directeur van gemeentewerken, was van oordeel dat er geen sprake kon zijn van onevenredige schade en daardoor geen aanspraak kon worden gemaakt op planschade. Zonder op de details in te gaan, bleek dat de directeur uitging van een onjuiste vaststelling van de schade door de bepalingen van de schadevergoedingsverordening te miskennen, voor wat betreft de waardevermindering wan het onroerend goed. Zeer tot bevreemding van de bij de procedure betrokkenen, besloot de gemeenteraad van Laren uiteindelijk het minderheidsadvies (van de directeur) te volgen, en geen schadevergoeding toe te kennen. De Kroon nam met deze gang van zaken geen genoegen en sprak bij $K B$ uit "dat in het onderhavige geval, gelet op deze gang van zaken, sprake was van een ernstige aantasting van het vertrouwen, dat een burger in de onpartijdigheid van de overheid mag stellen. Strijd met het algemeen belang leidde in deze zaak tot vernietiging van het raadsbesluit. ${ }^{107}$ De uitspraak laat zien dat het overnemen van

106 ARRS 18 september 1990, AB $1990,596, \mathbb{B} / \mathrm{S} 1990,104$.

107 KB 21 december 1982, AB 1983, 298. 
een minderheidsadvies, weliswaar op zichzelf genomen niet verwerpelijk behoeft te zijn, maar dat als het minderheidsadvies gebaseerd is op apert onjuiste advisering, de gevolgen vervelend voor het betrokken bestuursorgaan kunnen uitpakken.

In een tweetal zaken dat in beroep aan het oordeel van de AGVB was onderworpen, en waarbij planschade ingevolge art. 49 WRO punt van geschil was, vormde de partijdigheid van de schadebeoordelingscommissie onderdeel van het ingesteld beroep. Daarbij was steeds de positie van de Stichting Adviesbureau Onroerende Zaken $(\mathrm{SAOZ})$ in het spel. Deze stichting is een belangrijke adviesinstantie, en fungeert doorgaans als schadebeoordelingscommissie op grond van de planschadeverordening. Voor een goed begrip van de situatie wordt opgemerkt dat de SAOZ een door overheden in het leven geroepen stichting is, waarin vertegenwoordigers van overheden in het stichtingsbestuur zitting hebben. Voor een appellant was dit in een zaak tegen de gemeente Hoorn aanleiding de partijdigheid van de commissie (SAOZ) in twijfel te trekken. De Afdeling geschillen kwam niet tot het oordeel, dat sprake was van partijdige advisering, omdat tevens externe deskundigen zitting hadden in het bestuur. Naast de constatering dat niet gesproken kon worden van onpartijdige advisering, nam de afdeling daarbij tevens in aanmerking, dat in de WRO geen steur is te vinden voor de opvatting dat onathankelijke deskundigen zouden moeten worden ingeschakeld. ${ }^{108}$

Uit de tweede zaak valt op te maken dat in aangelegenheden die hiervoor werden onderzocht de omstandigheden van het geval vaak bepalend zijn voor het uiteindelijk oordeel of al dan niet sprake is van (on)partijdigheid. Ook in de volgende kwestie die in de gemeente Westkapelle speelde, was de partijdigheid van de SAOZ onderdeel van beroep. Appellanten maakten bezwaar tegen de omstandigheid, dat de gemeenteraad ten onrechte aan de SAOZ gevraagd had een nieuw planschade-advies uit te brengen. Daarbij nam appellant in aanmerking dat de directeur van de bovengenoemde stichting de gemeenteraad vertegenwoordigde ter zitting van de Afdeling geschillen. In beroep werd deze gang van zaken niet als partijdig aangemerkt. Een en ander werd in verband gebracht met de verantwoordelijkheid van de gemeenteraad, om na te gaan of de advisering voldoende basis vormde voor het nemen van een besluit op de voet van art. 5 , lid 2 van de TWK. Bellangrijk punt voor de afdeling vormde de omstandigheid, dat het tweede advies van de SAOZ betrekking had op de omvang van de schade. Hierdoor werd de inschakeling van de SAOZ en de vertegenwoordiging ter zitting niet nadelig geacht voor appellant. Van belang voor de afdeling was tevens dat 
appellanten voldoende in de gelegenheid waren gesteld de adviezen te betwisten. ${ }^{109}$

Op grond van de bovengenoemde jurisprudentie kan worden vastgesteld, dat deze uilspraken een sterk casuïstisch karakter hebben. Er wordt gekeken naar de omstandigheden van het geval en de positie van het bestuursorgaan versus belanghebbende. Uit het besluitvormingsproces moet zijn af te leiden dat de belanghebbende in zijn belangen is geschaad. Uitgangspunt is wel dat uit een oogpunt van zorgvuldige voorbereiding van een beslissing, de advisering door een adviescommissie beoordeeld werd op grond van de mate van deskundigheid van de commissieleden.

Tenslotte is van belang dat de schijn van partijdigheid niet automatisch tot vernietiging van de daarop gebaseerde beslissing leidt. De omstandigheden van het geval zijn van doorslaggevende betekenis. De rechter toetst aan de hand van de feiten of de mate van partijdigheid van doorslaggevende (negatieve) invloed is geweest op de totstandkoming of de inhoud van het besluit. ${ }^{110}$

\subsubsection{Bijzondere uitspraken inzake objectiviteit bij de voorbereiding van de besluitworming}

Soms komt het voor dat gemeentebesturen prudent zijn als het gaat om de bevordering van een situatie dat burgers meer vertrouwen kunnen krijgen in een objectieve en onpartijdige overheid. De gemeente Hilversum gaf al in de tachtiger jaren het goede woorbeeld. In deze gemeente was voor die gevallen dat ambtenaren een bouwvergunning nodig hadden, in afwijking wan de normale gangbare procedure zoals die doorgaans uitsluitend op basis van de WW in acht wordt genomen, een bijzondere screeningstoets ingevoerd. Een Hilversumse gemeente-ambtenaar van wie een bouwvergunning werd geweigerd ging in beroep bij de ARRS. In zijn nadere memorie naar aanleiding van het ingesteld beroep, alsmede ter zitting wees de betrokken ambtenaar op het onderscheid dat tussen ambtenaren en burgers werd gemaakt in de bouwvergunningenprocedure. De Hilversumse ambtenaar oordeelde het onjuist, dat de wethouder die belast was met de portefeuille voor bouwzaken, een extra toets verrichtte als een ambtelijke aanvrager in het spell was. De ARRS oordeelde in deze zaak, dat de 'waakhondfunctie' die de gemeente door een bijzondere procedure woor bouwaanvragen van

109 AGVB 20 alugustus 1993 , BR 1994, p. 512 e.v.

110 H.P.B.M. Kummeling, IV A Advisering, in: Praktijkboek Administratief Recht, losbl. Deventer. p. 9. 
ambtenaren te creëren, vanuit de verantwoordelijkheid van het bestuursorgaan (burgemeester en wethouders) gerechtvaardigd was. "1!

De Hilversumse procedure past aardig in de taakstelling van het bestuursorgaan zoals die in art. $2: 4$, lid 2 wordt verlangd.

Een tweede zaak laat zien, dat het soms vóorkomt dat het bestuursorgaan nog vóórdat formeel op een vergunningsaanvrage is beslist, aan een derde-belanghebbende het negatief standpunt ten aanzien van een ingekomen vergunningsaanvrage mededeelt. Dat een dergelijke mededeling risico's met zich kan brengen blijkt uit de handelwijze van de burgemeester van Delft. "II In een gesprek over de problemen van een gevraagde nachtvergunning voor een dancing had de burgemeester aan een bezwaarde medegedeeld en toegezegd dat de nachtvergunning niet zou worden verleend.

De arob-rechter zag hierin een ongeoorloofde beperking van de beleidsvrijheid door reeds op voorhand, deze mededeling tegenover een derde te doen. De burgemeester werd op de vingers getikt en gebrek aan onbevangenheid verweten, waardoor de schijn van partijdigheid voorafgaand aan het te nemen besluit reeds was opgewekt.

Een laatste kwestie laat zien dat het bestursorgaan een prima oog bleek te hebben voor ongewenste belangenverstrengeling.

Wat was er aan de hand?

Bij een ingesteld beroep bij de ARRS stond ter discussie de vraag of een commissie van de ziekenfondsraad terecht een ingesteld beroep van Yda Consultancy B.V. i.o. in het kader van art. 64 AWBZ ongegrond had verklaard. Het ziekenfonds had een verzoek van een toekomstig orthopedisch bedrijf om overeenkomstig art. 42, eerste lid AWBZ met deze onderneming een zogenaamde medewerkersovereenkomst af te sluiten, niet gehonoreerd. In beginsel bestaat hiertoe voor het ziekenfonds conform art. 45, eerste lid een verplichting; het bedrijf was conform de regels van de $A W B Z$ gevestigd binnen het werkgebied van het betreffende ziekenfonds. De gevraagde medewerkersovereenkomst kan alleen door het ziekenfonds worden geweigerd indien daartegen ernstige bezwaren bestaan. 
Volgens het ziekenfonds bestonden er overwegende bezwaren tegen het aangaan van de medewerkersovereenkomst met het orthopedisch bedrijf. Het fonds was van oordcel, dat door het aangaan van de medewerkersovereenkomst een ongewenste belangenverstrengeling zou ontstaan. Voorschrijvende artsen en orthopedische chirurgen waren 'medewerkers' van thet ziekenfonds, en zouden tevens aandeelhouders worden van het betreffende orthopedisch bedrijf. Het beroep werd door de ABRS ongegrond verklaard. ${ }^{13}$ De bestuursrechter overwoog dat de constructie, waarbij voorschrijvende artsen aandeelhouders zijn in een onderneming, naar welke zij patiënten waaronder verzekerden van het fonds, kunnen verwijzen, kan leiden tot ongewenste verstrengeling van belangen. De ABRS nam daarbij tevens in aanmerking dat de artsenaandeelhouders in aanzienlijke mate in staat moeten worden geacht gezamenlijk het belleid van de vennootschap te bepalen nu zij tezamen over een groter aandelenpakket beschikken dan het orthopedisch bedrijf.

\subsubsection{Vitspraken over (on)partijdigheid bij de beslissingsprocedure}

In het voorgaande werd een bespreking gewijd aan enkele uitspraken, waarin in het voortraject van de besluitvorming de zuiverheid van het bestuurlijk handelen voor de justitiabele een geschilpunt vormde. Belangenverstrengeling, gebrek aan een onbevooroordeelde houding en aan objectiviteit, vormden de inzet van een procedure tegen het betrokken bestuursorgaan naar aanleiding van een genomen besluit.

Aandacht werd besteed aan de voorbereiding van de besluitvorming, waarbij het zwaartepunt werd gelegd op de advisering door zowel formeel-wettelijke als materieel-wettelijke adviescommissies.

In deze paragraaf worden de hoofdlijnen onderzocht van de jurisprudentie van de uitkomsten van de beslissingsprocedure. Voor een goed begrip wordt hierbij opgemerkt, dat met deze beslissingsprocedure die hiervoor aangeduid werd als een fase in de besluitvorming, enerzijds wordt bedoeld het vaststellen van het tijdstip waarop door het bestuursorgaan een besluit zal worden genomen. Aan de andere kant is bij de beslissingsprocedure van belang wie van de leden van een bestuursorgaan deelnemen aan de besluitvorming, in casu de stemming omtrent het te nemen besluit. Aan dit laatste aspect wordt mede in relatie tot de zuiverheid van het bestuurlijk handelen een korte beschouwing gewijd. 
Uitgangspunt hierbij is het verbod tot deelname aan de stemming zoals dit in de (oude) Gemeentewet was opgenomen en thans in het nieuwe gemeenterecht regeling vindt.

Voor wat betreft het oude gemeenterecht valt bij de bespreking van het stemwerbod de nadruk op de eerste zin van art. 52 gem. w. waarin was bepaald:

'Zij (de leden van de raad) onthouden zich van medestemmen over zaken, benoemingen, schorsingen en ontslagen inbegrepen, die hen, hunne echtgenooten of hume bloed- of aanverwanten, tot de derde graad ingesloten, persoonlijk aangaan, of waarin zij als gelastigden zijn betrokken'.

Art. 28 van de thans geldende Gem.w. bepaalt in het eerste lid:

'1. Een lid van de raad neemt niet deel aan de stemming over:

a. een aangelegenheid die hem rechtstreeks of middellijk persoonlijk aangaat of waarbij hij als vertegenwoordiger is betrokken';

Uit deze tegen elkander afgezette oude en nieuwe gemeentewettelijke bepaling kan worden afgeleid dat het nieuwe gemeenterecht in art. 28 , lid 1 , onder a een ruimer criterium hanteert ten opzichte van art. 52 gem.w. Het nieuwe art. 28 bepaalt, dat een raadslid niet aan de stemming mag deelnemen indien het een aangelegenheid betreft die het betrokken lid rechtstreeks of middellijk persoonlijk aangaat. Op de consequenties van de nieuwe redactie van art. $28 \mathrm{Gem}$.w. die in de literatuur de aandacht hebben getrokken in het kader van de Simpelveldse spontane koninklijke vernietigingszaak, zal in par. 2.6.4 nog worden ingegaan. ${ }^{114}$

Uit de jurisprudentie inzake het verbod tot deelname aan de stemming kunnen de volgende ontwikkelingen worden waargenomen voor die gevallen dat persoonlijke belangen van bestuurders zijn betrokken bij de besluitvorming. De correctheid van de beslissingsprocedure wordt hierbij in samenhang bezien met de zuiverheid van het bestuurlijk handelen. Ten behoeve van de volledigheid zij hierbij vooropgesteld, dat niet alleen de uitkomst van door de gemeenteraad genomen besluiten wordt belicht, maar ook die van burgemeester en wethouders. Dit laatste betekent, dat art. 52 gem.w. wordt besproken in samenhang met art. $97 \mathrm{gem}$.w. Deze laatste bepaling voor de stemming van de vergaderingen van burgemeester en wethouders, verklaarde art. 52 van overeenkomstige toepassing. Het nieuwe art. 58 Gem.w. dat art. 97 gem.w. heeft vervangen, wordt buiten beschouwing gelaten, aangezien terzake vooralsnog geen jurisprudentie bekend is.

114 E. Brederveld, Verboden deelneming aan stemmen in de raadsvergadering, Stemmingmakerij over artikel 28 Gemeentewer?, Gst. 7032 , p. 269 e.w. 
In een zaak van de gemeente Westerschouwen hadden burgemeester en wethouders een waarschuwing tot toepassing van bestuursdwang doen uitgaan naar aanleiding van een huns inziens strijdig gebruik van een perceel. Naar het oordeel van b en w betekende de exploitatie van een auto-plaatbedrijf een strijdig gebruik met art. 352 (gebruiksbepaling) van de gemeentelijke bouwverordening. Gelet op dat strijdig gebruik met de bouwverordening moest de betrokken ondernemer de uitoefening van zijn bedrijf staken. In een schorsingszaak die diende bij de vz. van de ARRS bleek het volgende.

De ondernemer die schorsing had gevraagd van het besluit tot waarschuwing van bestuursdwang, wees de arob-rechter op een vonnis, waarin het de wethouder van de gemeente Westerschouwen als privé persoon was ontzegd deze ondernemer te beletten van een pad gebruik te maken, waardoor voor hem het uitwegen op de openbare weg gewaarborgd zou zijn. Dit vonnis was voor de exploitant van het auto-plaatbedrijf reden om in zijn schorsingsverzoek te benadrukken, dat het besluit tot toepassing van bestuursdwang door de relatie van de betrokken wethouder met deze kwestie door persoonlijke belangen van de wethouder, was genomen. Voor de voorzitter ARRS was deze omstandigheid aanleiding de strekking van de art. 97 jo art. 52 gem.w. in ogenschouw te nemen. De voorzitter stelde, dat als gevolg van het reeds uitgesproken vonnis bezwaarlijk kon worden ontkend, dat de wethouder persoonlijk bij het administratieve geschil in casu de waarschuwing tot toepassing van bestuursdwang was betrokken.

De voorzitter constateerde, dat $b$ en $w$ van Westerschouwen hem niet aannemelijk. hadden kunnen maken, dat de wethouder zich aan de besluitvorming inzake de toepassing van bestuursdwang had onttrokken. Zodanige omstandigheid was voor de rechter aanleiding om te constateren, dat de recht-matigheid van het genomen besluit in twijfel moest worden getrokken.

De woorzitter ARRS schorste het waarschuwingsbesluit tot toepassing van bestuursdwang, zij het dat hij daarbij in aanmerking nam, dat voor werzoeker inmiddels cen hinderwetvergunning was verleend, en een ingesteld beroep van de betrokken ondememer om het bedrijf via een nieuw bestemmingsplan "weg te bestemmen", gegrond werd verklaard door gedeputeerde staten. Of deze laatste aspecten van doorslaggevende betekenis zijn geweest in het oordeel van de voorzitter, moet worden betwijfeld; wél is duidelijk dat de voorzitter waarde heeft gehecht aan een juiste en strikte formele toepassing van art. 97 jo art. 52 gem.w. B en $w$ konden de voorzitter immers geen inzicht geven in de gang van zaken tijdens de beslissingsprocedure, bijwoorbeeld door overlegging van een besluitenlijst, waaruit zou kunnen worden opgemaakt of de betrokken wethouder al dan niet aan de besluitworming had deelgenomen. Wat hier ook van zij, de enkele omstandigheid, dat de wethouder zich kennelijk niet aan de besluitworming 
had onttrokken, bleek reden om tot onrechtmatigheid van het genomen besluit te concluderen. ${ }^{115}$

In een uitspraak van de ARRS van 9 juni 1981 blijkt ten aanzien van de toepassing van art. 52 gem.w. het volgende. ${ }^{116}$ Een inwoner van Drechterland had bij de arob-rechter beroep ingesteld tegen een afwijzende beschikking op zijn verzoek om een voorbereidingsbesluit te nemen ten behoeve van de bouw van een tennishal. De raad van die gemeente had na de uitgesproken primaire weigering, eveneens op het bezwaarschrift een afwijzende beslissing genomen. In beroep stelde de Drechterlandse ondernemer, dat in tegenstelling tot zijn broer een ander raadslid zich niet conform art. 52 gem.w. aan de stemming in de raadsvergadlering had onttrokken, en dat daarmede de strijdigheid van het genomen besluit als een gegeven moest worden aangenomen. Van belang was in deze zaak dat er in de gemeente ruilverkavelingsplannen speelden die ten tijde van de beslissing op het bezwaarschrift in een eerste concept-plan waren gepresenteerd. Van een volledige uitwerking van deze plannen was nog geen sprake. Het beroep van appellant dat onthouding van deelname aan de stemming gerechtvaardigd was wegens het persoonlijk belang met deze ruilverkaveling van het betrokken raadslid, werd door de arob-rechter afgewezen. De ARRS oordeelde op basis van de feitelijke omstandigheden ten tijde van de verlengde besluitvorming, dat in dit geval van een persoonlijk aangaan zoals dat in art. $52 \mathrm{gem}$.w. criterium vormde voor stemonthouding, niet kon worden gesproken. Het persoonlijk belang bleek naar het oordeel van de arob-rechter onvoldoende concreet omdat het conceptruilverkavelingsplan slechts uitnodigde tot het maken van verlangens en verwachtingen, en gelet op het stadium van de ontwikkeling van het plan, vooralsnog slechts aanleiding kon geven tot speculaties.

De bovengenoemde uitspraak geeft aan dat een rechterlijke toets terzake het begrip 'persoonlijk aangaan' sterk inhoudelijke, en casuistische trekken vertoont.

Uit de te bespreken derde uitspraak zal blijken dat de arob-rechter in zijn strikte toepassing ten aanzien van het verbod tot medestemmen als bedoeld in art. 52 gem.w. is omgegaan. Voortaan huldigt de administratieve rechter het Kroonstandpunt inzake de uitvoering van het meerbedoeld artikel. In de zaak van de gemeente Westerschouwen, bleek de arob-rechter een strikt formeel-juridisch

115 ARRS 8 november 1979, AB 1980, $328 \mathrm{~m}$. nt. valn C.L.R. Tevens wordi in deze aumotatie aangegeven een aantal Kroon-uitspraken in het kader wan het schorsings- en vernietigingsrecht, watbij de Kroon als criterium voor spontane vermietiging hanteert of de ten onrechte uitgebrachte stem van inwloed kan zijn geweest op de uitslag van de stemming.

146 ARRS 9 juní 1981, tB/S III, 271. 
standpunt in te nemen indien er sprake was van een verboden deelname aan de stemming. De rechter had geen oog voor de effecten van de besluitvorming.

Er kwam een kentering in de opvatting van de ARRS. In de gemeente Westelingwerf had een wethouder deelgenomen aan de stemming inzake de op een bezwaarschrift te nemen beslissing over een voorbereidingsbesluit, teneinde een bestemmingswijziging mogelijk te maken ten behoeve van motorcrossdoeleinden op een perceel. In beroep werd in ogenschouw genomen, dat blijkens de raadsnotulen een wethouder persoonlijk betrokken was bij de besluitvorming; deze wethouder was eigenaar van het betrokken perceel, en had actief aan de beraadslagingen en aan de stemming deelgenomen. Naar uit de stemming in de vergadering van de gemeenteraad bleek, hadden twee raadsleden zich van stemming onthouden, en werd inclusief de stem van de betrokken wethouder, een besluit genomen met acht stemmen vóór intrekking van het voorbereidingsbesluit en negen stemmen vóór handhaving van de bestreden beschikking. Het advies van de commissie voor de bezwaar- en beroepschriften opteerde voor intrekking van het voorbereidingsbesluit. Uit de stemverhouding bleek dat de (verboden) deelname van de stemming door de wethouder van beslissende betekenis was. De afdeling overwoog allereerst dat de bestreden besluiten tot stand waren gekomen in strijd met art. 52 gem.w., en dat deze wijze van totstandkoming zich niet met bedoeld artikel verdraagt. De ARRS oordeelde tot strijd met een algemeen verbindend voorschrift (art. 8, eerste lid onder a Wet arob). Wél knoopte de afdeling hieraan de belangrijke overweging vast die in feite een kentering betekende in een eerder gehanteerd formeel standpunt ten aanzien van de toepassing van art. 52. De afdelingsuitspraak vermeldt:

'De afd. overweegt te dezen nog dat een en ander te meer klemt nu vast staat dat de deelname van de wethouder an de sterming op de totstandkoming van de bestreden besluiten van beslissende invloed is geweest, aangezien betrokkene zijn stem tegen het voorstel heeft uitgebracht en zonder deze stem niet krachtens artikel $57 \mathrm{gem}$.w. voor het tot stand komen van raadsbesluiten vereiste volstrekte meerderheid zou zijn werkregen."11\%

117 ARRS 22 januari 1982, AB 1982, 178, m.nt. van v.d.V. Zie in dit verband ook de uitspraken ARRS 4 septenber 1984, IB/S III, 557 (Kedichem) en ARRS 2 september 1986, B/S 1986. 151 . 


\subsection{De objectieve besluitvorming door bestuursorganen onder de wer- king van de $\mathbf{A w b}$}

\subsubsection{Inleidende overwegingen}

In de par. 2.5 .2 tot en met 2.5.4 werd aan de hand van een bespreking van jurisprudentie-trends, ingegaan op de betekenis hiervan voor de zuiverheid van de bestuurlijke taakvervulling. Daarbij stond de objectiviteit bij de voorbereiding van de besluitvorming centraal. De (on)partijdigheid bij de beslissingsprocedure kreeg aandacht in par. 2.5.5.

Bij deze jurisprudentie-analyse werd als uitgangspunt genomen de periode voorafgaande aan de inwerkingtreding van de Awb.

De Awb is nu enige jaren van kracht, en zowel in de praktijk van het bestuur als de rechtspraak zijn de eerste ervaringen opgedaan met de nieuwe wet.

Het is daarom zinvol om na te gaan wat art. 2:4 Awb aan eventuele nieuwe ontwikkelingen en inzichten, heeft opgeleverd. ${ }^{118}$

Dat de $\mathrm{Awb}$ uit een oogpunt wan rechtsbescherming niet alles op zijn kop zou zetten was vóór de inwerkingtreding van de wet wel duidelijk; in veel gevallen, waarop nu niet wordt ingegaan was en is er immers sprake van een continuering van het besturrsrechtelijk patroon van voór 1 januari 1994. Dit laatste geldt zowel voor de aspecten die betrokken zijn bij de primaire besluitvorming, als die bij de bezwaarschriftenprocedure. Enkele bepalingen van de Awb betekenen voor het terrein van het algemeen bestuursrecht nova, hetgeen duidt op een nieuwe uitdaging voor zowell de met de Awb in aanraking komende bestuursorganen, de burgers, alsmede de administratieve rechters.

Met betrekking tot art. 2:4, is het interessant na te gaan, welk beeld nu is ontstaan ten aanzien van de werking van het vooringenomenheidsverbod in de Awbpraktijk. Op basis van enkelle geselecteerde uitspraken van de bestuursrechter, wordt geprobeerd een eerste en voorlopig inzicht te verschaffen omtrent de wijze waarop aan art. 2:4 praktische toepassing wordt gegeven.

\subsubsection{Voorbereiding besluitvorming formeel-wettelijke adviescommissie}

Parallel aan par. 2.2 waarin het onathankelijkheidsaspect bij de advisering door de welstandscommissie werd besproken, volgt nu een globale weergave van een tweetal uitspraken, waarbij in het kader van de toepassing van de Awb, het

1: H.J. Simon, De kleine rewolutie: één jaar besturen onder de Awb I, JB 1995, 30 
onafhankelijk en onpartijdig functioneren van de welstandscommissie ter discussie stond.

In de gemeente Heteren was een bouwvergunning aangevraagd voor het plaatsen van een 30 meter hoge reclame-mast bij een distributiepunt van een drogisterijketen. Het voor het bouwplan benodigde welstandsadvies werd uitgebracht door de welstandscommissie het Gelders Genootschap, waarbij de gemeente Heteren was aangesloten. $B$ en $w$ van Heteren waren niet tevreden met de uitkomsten van het door de welstandscommissie, in eerste instantie, uitgebracht negatief advies. Voor het Hetersense college was dit aanleiding tot het vragen van een second opinion aan een particulier adviesbureau op het terrein van ruimtelijke ordening en architectuur. Deze door b en w met voorbijgaan van de 'eigen' welstandscommissie ingeschakelde externe adviseur, bracht uiteindelijk een positief welstandsadvies uit. Op basis van dit positief advies lag de weg open voor $b$ en $w$ om gelet op het imperatieve stelsel van de WW, de gevraagde vergunning voor de 'bouw" van de reclame-mast alsnog te verlenen.

De bouwvergunning leidde tot een bezwaarschriftenprocedure door een nabij gelegen bedrijf dat klaagde over een gebrekkige belangenafweging. De reclamemast naast het "Kruidvat" zou de mast van het bezwaarde bedrijf overschaduwen en de attentiewaarde van de op die mast van het bedrijf D.V. Vastgoed b.v. aangebrachte reclame verminderen.

Ook maakte het bedrijf bezwaar tegen de inschakeling van het particulier adviesbureau, dat voor het uutbrengen van een second opinion was gevraagd ten aanzien van het aanvankelijke welstandsadvies. De deskundigheid en de onafhankelijkheid van het adviesbureau werd in twijfel getrokken omdat ditzelfde bureau eerder door de gemeente Heteren was ingeschakeld ten behoeve van het ontwerpen van een bestemmingsplan voor het gebied, waarin de percelen van zowel vergunninghouder als het bedrijf was gelegen.

Het bezwaarmakende en appellerende bedrijf krijgt zowel bij b en w als bij de rechtbank van Arnhem nul op zijn rekest; het ingediende bezwaarschrift werd door burgemeester en wethouders ongegrond verklaard, en eenzelfde lot trof het ingestelde beroep bij de rechtbank.

In hoger beroep oordeelde de Afdeling bestuursrechtspraak van de Raad van State als volgt:

'Voor zover appellante vraagtekens heeft gezet bij de deskundigheid alsmede de onafhankelijkheid van het door burgemeester en wethouders ingeschakelde Bureau Van 
Droffelaar B.V., ten behoeve van de advisering in het kader van de welstand, overweegi de Afdeling het wolgende.

De Afdeling heeft geen aanknopingspunten gevonden voor het oordeel dat voornoemd Bureau - dat het vigerende bestemmingsplan heeft ontworpen - terzake niet gekwalificeerd is. Evenmin kan de Afdeling appellante volgen in haar stelling dat het bureau van Van Droffelaar niet onafhankelijk zou zijn. Het enkele feit dat dit Bureau betrokken is geweest bij het opstellen van genoend bestemmingsplan, brengt niet met zich dat in verband hiermee niet meer kan worden gesproken van een onafhankelijk adviesbureau.'

De bovengenoemde overweging bracht de bestuursrechter tot het oordeel dat het beroep hiermede ongegrond was. ${ }^{119}$

Deze uitspraak is om een aantal redenen ongelukkig en verre van overtuigend. Een van de zwakste schakels in de Heterense zaak lijkt de motivering. Zonder enige toelichting zegt de bestuursrechter dat het betrokken bureau terzake van de welstandsadvisering voldoende gekwalificeerd is. Dit laatste is op zichzelf twijfelachtig, hetgeen terug te voeren is tot het basisprincipe van de Woningwet, waarin de advisering inzake een bouwaanvraag conform art. $48 \mathrm{WW}$ is opgedragen aan een onafhankelijke commissie van deskundigen. Toegegeven moet worden dat de nieuwe Woningwet geen bepaling meer kent zoals het voormalige art. 85, lid 3 Woningwet 1962. Dit artikel ging nog uit van het aanwijzen van een welstandscommissie door de gemeenteraad.

Opvallend is dat de ABRS de uitgangspunten van de WW miskent, omdat advisering in het geval van Heteren plaats diende te vinden door de welstandscommissie het Gelders Genootschap.

Dat burgemeester en wethouders zich conform art. 3:9 Awb een eigenstandig oordeel mochten vormen omtrent het welstandsadvies van het Gelders Genootschap, door daarvan af te wijken, doet hier niet aan af. Maar een zelfstandige betekenis toekennen aan de gevraagde second opinion van een extern adviesbureau is, gezien de wettelijk voorgeschreven externe adviesverplichting van de WW, twijfelachtig. De advisering door de welstandscommissie is van een geheel andere strekking dan het adviseren door een commissie in de zin van art. 7:13 Awb. In het kader van de uitvoering van de WW, heeft de welstandscommissie tot taak te adviseren omtrent de inhoud van een concrete norm in casu of het bouwplan voldoet aan redelijke eisen van welstand. Het Gelders Genootschap was op formele grondslag de wettelijk verplicht aangewezen adviseur. lets anders is, maar dat is nauwelijks voorstelbaar, dat bijvoorbeeld in de Heterense zaak de 
gemeenteraad plotseling voor een nieuwe onafhankelijke commissie van deskundigen heeft gekozen in plaats van het Gelders Genootschap. Daar konnt nog bij dat het moeilijk te rijmen valt met de uitgangspunten van de Woningwet, dat met de voorgeschreven commissie van onafhankelijke deskundigen, ook de inschakeling van een extern adviesbureau is toegelaten in plaats van de welstandscommissie.

In ieder geval wordt bij een welstandscommissie gedacht aan meerdere onafhankelijke deskundigen; dit laatste kwam onder andere naar voren bij de bespreking van de jurisprudentie in par. 2.5.2. Zie in dit verband de Winterswijkse kwestie, waarbij slechts geadviseerd was door één lid van de welstandscommissie. $^{120}$

Uiterst dubieus is ook dat de afdeling geen reden zag het hoger beroep gegrond te achten omdat mogelijk toch de schijn van partijdigheid een rol zou kunnen hebben gespeeld bij de beoordeling door de 'surrogaat-welstandscommissie' van Heteren (extern adviesbureau). Voorstelbaar is dat van een niet geheel onbevangen second opinion sprake kan zijn geweest nu kennelijk de huisadviseur van Heteren nog eens zijn licht mocht laten schijnen over het welstandsaspect van het bouwplan.

Een constructie zoals in de Beverwijkse zaak, waarbij getwijfeld werd aan de onafhankelijkheid van de welstandscommissie, maar waarbij gelet op de aard en de omvang van het bouwwerk, die twijfels werden geëlimineerd door de geringe omvang van het bouwwerk, zou meer voor de hand hebben gelegen. ${ }^{121}$ Het geheel van de uitspraak overziende moet met de annotatoren worden toegegeven, dat de Heterense zaak vraagtekens oproept.

In een Maastrichtse zaak benadrukte de rechtbank nog eens de objectieve onpartijdigheidseisen voor adviesorganen. Ook in deze zaak ging het om de advisering door de welstandscommissie. In het bijzonder stond de wijze waarop het betrokken welstandsadvies tot stand was gekomen ter discussie. De bestuursrechter huldigde de opvatting dat de advisering door de welstandscommissie moet worden gezien als een waarborg voor een verantwoorde en - in zekere mate geobjectiveerde beoordeling van de welstandsaspecten. Naast enkele andere aspecten die hier niet aan bod zullen komen, bleek aan de totstandkoming van het welstandsadvies een fundamenteel gebrek te kleven. Vast was komen te staan, dat in een in eerste instantie uitgebracht welstandsadvies, althans naar burgemeester

170 ARRS 13 januari 1992, tB/S $1992,6$.

21 ARRS 1 jumi 1992, BR 1993, p. 130 en 131. 
en wethouders stelden, een lid van de welstandscommissie architect was van de aanvrager van de bouwwergunning. Gezien de betrokkenheid bij het bouwplan lieten burgemeester en wethouders de bestuursrechter weten, dat het commissielid, zich uit de welstandsvergadering had teruggetrokken toen het door" het betrokken lid ontworpen bouwplan in de vergadering beoordeeld moest worden. Naar burgemeester en wethouders mededeelden, was dat terugtrekken uit de vergadering van de welstandsconmissie in Maastricht een waste gedragscode. Burgemeester en wethouders slaagden er niet in die gedragscode nader te adstrueren, aangezien niet uit de bij de zaak behorende stukken bleek, dat het betrokken lid zich alan de beraadslagingen van de welstandscommissie had ontrokken. Er was in casu geen adequaat verslag.

Een bijzonder aspect in deze (tweede) voorlopige voorzieningszaak wormde nog dat burgemeester en wethouders in het kader van de bezwaarschriftenprocedure de welstandscommissie opnieuw om een advies had verzocht, welk advies ook opnieuw werd uitgebracht. Dit tweede adwies van de welstandscommissie overtuigde de rechter niet. In feite werd het gebrek van het eerste advies meegesleurd door de wijze waarop burgemeester en wethouders met het tweede advies waren omgesprongen. Hiervoor was bepalend de omstandigheid, dat het tweede welstandsadvies identiek was aan het eerste advies. Zonder enige nadere overweging hadden burgemeester en wethouders het advies overgenomen. Die omstandigheid was voor Maastricht fataal. Met zoveel woorden stelde de rechter, onder verwijzing naar art. 3:9 jo 3:2 $\mathrm{Awb}$, dat in beginsel het overnemen van een welstandsadvies geen nadere toelichting behoeft. De gang van zaken bij de eerste welstandsadvisering noopte naar de mening wan de bestuursrechter tot versterkte zorgvuldigheid zijdens het betrokken bestuursorgaan, nu het eerste welstandsadvies ernstige gebreken vertoonde. De wijze waarop het tweede welstandsadvies was uitgebracht en overgenomen, leidde er niet toe dat de onpartijdigheid wan de welstandscommissie buiten twijfel was verheven. Uiteindelijk schorste de Maastrichtse president het primaire besluit, want er was nog niet op het bezwaarschrift beslist. Schorsing werd gebaseerd op zorgwuldigheidsgebreken. Tot een constatering van strijdigheid met art. $2: 4 \mathrm{kwam}$ het overigens niet. ${ }^{122}$ De bovengenoemde uitsprak lijkt juist, gezien de gang van zaken rond de eerste advisering en de uitkomsten van de tweede advisering. De uitspraak leert overigens, dat gelet op de omstandigheden van het geval niet aanstonds door de rechter een toetsing van art. $2: 4$ behoeft plaats te vinden. Volstaan kon worden door strijdigheid met het zorgvuldigheidsbeginsel te construeren.

122 Rb. Maastricht 29 maant 1996, JB 1996, 132. 
Een derde uitspraak waama kortheidshalve wordt verwezen, zegt iets over de wijze waarop een welstandsadvies tot stand moet komen, teneinde aan de eisen van onafhankelijkheid, deskundigheid en de daaruit voortvloeiende objectiviteit te kunnen voldoen. In gevallen dat een welstandsadvies slechts gemandateerd is door een niet daartoe gemandateerde adjunct-secretaris van de welstandscommissie, is dit advies naar het oordeel van de Utrechtse rechtbank op een onjuiste manier tot stand gekomen. ${ }^{123}$

Hiema worden enige uitspraken besproken waarin de partijdigheid van een commissie ex art. 7:13 Awb voorwerp van geschil was. Art. 7:13 stelt speciale eisen aan de samenstelling van een commissie die belast is met het uitbrengen van een advies aan het bestuursorgaan aangaande de op een bezwaarschrift te nemen beslissing. Door die samenstelling zijn wettelijke waarborgen opgenomen teneinde objectiviteit in de advisering te bevorderen door onder andere een externe voorzitter te verlangen die geen deel uit maakt van het bestuursorgaan. Daarnaast is de commissie expliciet belast met het horen van belanghebbenden. De commissie ex art. 7:13 is evenwel geen commissie waarbij specifieke deskundigheid en volledige onafhankelijkheid in het geding is zoals bij de welstandscommissie.

De eerste kwestie die hier aandacht verdient betreft de casus van de Stadsmobiel Amsterdam. Deze zaak is uitvoerig becommentarieerd in een aantal jurisprudentie-rubrieken. ${ }^{124}$

In de zaak van de Stadsmobiel Amsterdam sprak het CBB uit, dat de door het Openbaar Lichaam Taxivervoer AZAM (OLT AZAM) ingestelde adviescommissie ex art. 7:13 een onjuiste samenstelling had. Het dagelijks bestuur van het samenwerkingsverband had de beslissing op een bezwaarschrift doen voorbereiden door een adviescommissie die bestond uit ambtenaren in dienst bij de gemeente Amsterdam. Van belang was hierbij dat door een aantal Amsterdamse belangenverenigingen op het terrein van het taxivervoer en enige belanghebbende taxi-ondernemers, bezwaar was ingediend tegen een door het OLT AZAM aan het Gemeentelijk Vervoersbedrijf (GVB) van Amsterdam verleende vergunning voor het collectief vervoer van gehandicapten. Het GVB was een bedrijf van de gemeente Amsterdam. De concurrerende taxi-exploitanten waren verbolgen over het feit, dat binnen gemeentelijke kring de zaak vergund was aan het GVB, en zij buiten de boot waren gevallen.

123 Rb. Utrecht 4 mei 1994, KG, 219.

124 CBB 21 december 1994, AB 1995, 454, RAwb 1995, 34, Rechtspraak Bestuursrecht, "De Annotaties", 1994-1995, "s-Gravenhage, nr. 10. 
Dat in de ogen van de bezwaarden 'ritselen', was voor de Amsterdamse taxiondernemers aanleiding, om de partijdigheid van de art. 7:13-commissie bij de bestuursrechter aan de kaak te stellen. Uit de uitspraak blijkt, dat de rechter bijzondere eisen stelt aan de onafhankelijkheid en de onpartijdigheid zodra vergunningverlening aan de publiekrechtelijke rechtspersoon in het geding is.

Uiteindelijk sprak het CBB uit dat met de advisering aan het dagelijks bestuur van het OLT AZAM, gelet op de samenstelling van de bezwaarschriften-adviescommissie, onvoldoende recht was gedaan aan het fundamenteel rechtsbeginsel zoals dat is opgenomen in art. $2: 4$, lid $1 \mathrm{Awb}$.

Ten aanzien van deze uitspraak zijn er nogal wat kanttekeningen te plaatsen. Opvallend in deze zaak is het gemak waarmee het CBB toetst aan art. 2:4, lid 1 Awb. Door de samenstelling zou de adviescommissie naar de mening van het CBB de schijn van partijdigheid op zich hebben geladen.

Het $\mathrm{CBB}$ heeft wel wat al te snel art. 2:4, lid 1 aangegrepen om tot een ongewenste grensoverschrijding van de bestuurlijke taakvervulling te concluderen. Tegelijkertijd zou een inhoudelijke beoordeling van de zaak, vanuit het bestuurlijk gezichtspunt bezien een beter resultaat hebben opgeleverd. Daarbij zouden ook de betrokken Amsterdamse ondernemers meer gebaat zijn geweest. De uitspraak is sterk formalistisch, en geeft voldoende reden om aan te nemen, dat de rechter weinig oog heeft voor de praktijk. Gebrek aan inzicht in de gemeentelijke (ambtelijke) bestuursorganisatie kan de bestuursrechter worden tegengeworpen. Dit laatste komt tot uitdrukking in de wijze warop met het verweer van de gemeente Amsterdam is omgesprongen tijdens de openbare behandeling van deze zaak voor het $\mathrm{CBB}$.

De regeling van de werkwijze en de samenstelling van de 7:13-commissie ging uit van een wisselende samenstelling. Het hoofd juridische zaken van de gemeente Amsterdam benoemde voor de behandeling van ingekomen bezwaarschriften drie juristen ter secretarie, waarbij gekeken werd naar de betrokkenheid bij de voorbereiding van de besluitvorming. Amsterdam stelde terecht dat geen sprake was van ambtelijke betrokkenheid en persoonlijk belang bij de primaire besluitvorming inzake de vergunningverlening aan het GVB.

De rechter had in de Amsterdamse zaak geen oog voor het gemeentelijk verweer. Het zou meer voor de hand hebben gelegen, dat de bestuursirechter gekeken zou hebben naar de wijze waarop de organisatie van een grote gemeente zoals die van Amsterdam is ingericht. Bij een gemeente van de omvang zoals Amsterdam is er in de dienstverlening vanwege de gemeentegrootte sprake van een ver doorgevoerde decentrale taakvervulling door de gemeentelijke diensten. Diensten en bedrijven opereren zelfstandig en vaak geheel onafhankelijk van elkander. Dit 
geldt zeker in die gevallen, waarin gekozen is voor privaatrechtelijke constructies zoals een NV-vorm. In mindere mate geldt dit ook voor die gevallen, dat voor een administratief-organisatorische opzet is gekozen door de dienstverlening bij gemeenten decentraal te doen verlopen via de instelling wan diensten en bedrijver. Art. 196 Gem.w. (voorheen art. 252 gem.w.) biedt de mogelijkheid tot de instelling van deze bedrijven of andere takken van dienst. Van een onafhankelijk opereren is bij de instelling van een tak van dienst ex art. $196 \mathrm{Gem}$. W., zoals bij een (privaatrechtelijk) nutsbedrijf weliswaar geen sprake, maar er is toch wel een situatie van administratieve zelfstandigheid. Die zelfstandigheid manifesteert zich bij een tak van dienst in een eigen begroting en rekening voor de dienst.

De bovengenoemde organisatorische situatie in grote gemeenten geeft aan dat deze omstandigheden er veelal toe leiden dat doorgaans minder sprake is van "ons kent ons'. Ook het benoemingsbeleid als taakonderdeel wan het stadsbestuur is geheel in handen van de diensten en de bedrijven. Van enige vriendjespolitiek is vanwege de afstand en het verschil in cultuur tussen de dienstonderdelen in de praktijk geen sprake; sterker nog, vaak komt in grote organisaties het fenomeen van de 'eigen ivoren toren' en het onderlinge rivaliserende karakter in het dienstbetoon aan de burgers tot uiting. Dit laatste manifesteert zich nog al eens door klachten van de burgers over het van het kastje naar de muur sturen wegens gebrek aan coördinatie, en de daarmede "verkokerde' wijze van werken.

De bestuursrechter concludeerde in de zaak Stadsmobiel Amsterdam tot een onrechtmatige voorbereiding van de beslissing op het bezwaarschrift. Een inhoudelijke beoordeling van het bestreden besluit liet de rechter achterwege. Deze formele benadering (onverlet het karakter van de rechtspraak), leidt er toe dat het gehele besluitvormingsproces in de bezwalarschriftenprocedure moet worden herhaald. In veel gevallen zullem appellerende justitiabelen er zeer waarschijnlijk weinig mee opschieten.

Beter zou zijn geweest dat de bestuursrechter zich zou bediend hebben van een praktische opstelling, door het bestreden besluit materieel te toetsen. Als daarbij zou komen vast te staan dat het Amsterdamse 'taxi-besluit' op goede gronden zou zijn genomen, had weliswaar een vernietiging kunnen worden uitgesproken, maar om proceseconomische redenen de rechtsgevolgen van het vernietigde besluit in stand kunnen worden gelaten (art. 8:72, lid $3 \mathrm{Awb}$ ).

Een andere kwestie, waar problemen inzake partijdigheid van een artikel $7: 13$ commissie zich voordeden, speelde in de gemeente Ameland. In een bezwarschriftenprocedure werd in deze gemeente geageerd tegen de verlening van een aanlegvergunning op grond van de WRO. Het ingediende bezwaarschrift werd ongegrond verklaard. In beroep bij de rechtbank van Leeuwarden werd geappel- 
lleerd ten aanzien van de omstandigheid, dat de voormalig waarnemend burgemeester die voorzitter was van de adviescommissie voor de bezwaarschriften. Tijdems de periode dat hij belast was met de waarneming van het burgemeestersambt van de gemeente Ameland had hij als lid van het college van burgemeester en wethouders deelgenomen aan de primaire besluitvorming, waarbij de bestreden aanlegvergunning was verleend.

De rechtbank overwoog met een verwijzing naar de criteria voor de samenstelling van de artikel 7:13-commissie, dat de voorzitter van een dergelijke commissie, omdat hij geen deel uit maakt van het bestuursorgaan ten opzichte van datzelfde bestuursorgaan, een onafhankelijke positie dient in te nemen. In het onderhavige geval strafte de bestuurstechter de anterieure betrokkenheid van de voormalige waarnemend burgemeester bij de primaire besluitvorming. Strikt genomen voldeed de voorzitter tijdens de bezwaarschriftenprocedure aan de eis van art. $7: 13$; hij maakte toen geen deel uit van het bestuursorgaan. De rechtbank oordeelde, dat het gellet op deze omstandigheden moeilijk voorstelbaar was dat de voorzitter zonder enige vorm van vooringenomenheid heeft meegewerkt aan de totstandkoming van het advies. De beslissing op het bezwaarschrift werd vernietigd met de overweging dat gelet op de samenstelling van de commissie de vereiste zorgvuldigheid ontbrak. ${ }^{125}$ Uit de uitspraak valt niet op te maken of strijdigheid met art. 2:4, lid 1 dan wel art. $7: 13$ de grond voor vernietiging betekende.

Hetgeen is gezegd ten aanzien van de zaak Stadsmobiel Amsterdam geldt ook voor de Amelandse kwestie; de bestuursrechter had kunnen beoordelen of het bestreden besluit inhoudelijk gezien aanvaardbaar was. Ook in deze zaak kan men zich afvragen of de voorzitter van de adviescommissie, in redelijkheid gebrek aan onbevangenheid kon worden verweten, en de kwestie niet had kunnen worden afgedaan met toepassing van art. 8:72, lid $3 \mathrm{Awb}$. Deze zaak leert ook dat de rechter weinig pragmatisch omgaat met de aspecten inzake de schijn van partijdigheid.

Een andere uitspraak in het kader van de artikel 7:13-commissie-problematiek laat kort samengevat zien, dat met een beetje pragmatiek in het rechterlijk oordeel, de zaken ook reëler kunnen uitpakken.

De rechtbank van Maastricht overwoog in een artikel 7:13-zaak in het kader van de toepassing van de Wet Sociale Werkvoorziening (WSW), dat de advisering in het kader van de bezwaarschriftenprocedure door de WSW-commissie ook had 
plaatsgevonden ten aanzien van het primaire besluit. Daarmee oordeelde de rechter tot strijdigheid van art. 7:13. Geconcludeerd werd dat het bestreden besluit op goede materiële gronden was genomen. Vernietiging werd uitgesproken, maar de rechtbank liet de rechtsgevolgen van het bestreden besluit, in stand. ${ }^{126}$ Opgemerkt kan hier nog worden dat aan de toepassing van art. 8:72 Awb de voorkeur moet worden gegeven. Ofschoon art. $6: 22$ ook tot de mogelijkheden had kunnen behoren door het besluit in stand te laten, moet aan dit artikel een terughoudende toepassing worden gegeven met het oog op het toekennen van schadevergoeding.

In een zaak die diende voor de bestuursrechter van de Maastrichtse rechtbank, stond weliswaar niet de onafhankelijkheid en onpartijdigheid ter discussie, inzake de toepassing van art. 7:13 Awb, maar maakte iemand bezwaar tegen de voorbereiding van de advisering omtrent de op het bezwaarschrift te nemen beslissing tegen de samenstelling van een hoor- en adviescommissie, die door burgemeester en wethouders was ingesteld met toepassing van art. 92 Gem.w. (advies-commissie ad hoc). Het betrof een adviescommissie die het Maastrichtse college adviseerde omtrent de beslissing op ingekomen bezwaarschriften. Art. 92 Gem.w. maakt het mogelijk dat b en w een adviescommissie instellen.

Een belanghebbende omwonende ging in beroep tegen een ongegrondverklaring van zijn bezwaarschrift tegen de bouw van een gasdrukregelstation in het Céramique-project, welk project in de landelijke pers, vanwege zijn uitzonderlijke bouwkundige opzet, de aandacht had getrokken en waarbij op basis van een partnership-overeenkomst tussen het ABP en de gemeente Maastricht, de financiering van de grond kwam. Bezwalarde verweet $b$ en $w$ dat de adviescommissie ex art. 92 Gem.w. niet overeenkomstig de geest van de Awb was samengesteld. Opmerkelijk is, dat appellant $b$ en $w$ niet het verwijt maakte dat de voorbereiding van de beslissing op het bezwaarschrift niet onafhankelijk en onpartijdig was tot stand gekomen.

Wat was er aan de hand? B en w hadden aan de N.V. Nutsbedrijven van Maastricht bouwvergunning verleend voor de bouw van het genoemde gasdruk-regelstation. De grieven van appellant tegen de samenstelling van de commissie, alsmede het feil dat het een vergunningverlening betrof aan een gemeentelijke instelling, waren kennelijk voor de bestuursrechter aanleiding zich nader te buigen over de samenstelling en de status van de betrokken hoor- en advies- 
commissie. De overweging die thans volgt roept vergelijkingen op met de uitspraak inzake de Stadsmobiel Ansterdam.

$\mathrm{Na}$ allereerst overwogen te hebben, dat géén sprake was van een artikel 7:13commissie, concludeerde de bestuursrechter, dat het horen door de genoemde commissie overeenkomstig de eisen van art. 7:5 Awb was geschied. Die constatering had voor alle duidelijkheid te maken met het feit, dat het aspect betreffende het horen losgekoppeld kon worden van de samenstelling van de adviescommissie, omdat art. 7:13 niet in het geding was. Bij een artikel 7:13-commissie dient het horen immers expliciet door dezelfde commissie te geschieden. Toch maakt de bestuursrechter aansluitend aan deze constatering de opmerking, dat de eis van onpartijdigheid door de samenstelling van de Maastrichtse artikel 92-commissie onvoldoende gewaarborgd is; strijdigheid werd geoordeeld met het bepaalde in art. 2:4, lid $1 \mathrm{Awb}$. Vervolgens citeert de rechter nagenoeg volledig in zijn uitspraak de MvT van art. 2:4 Awb. De rechtbank overweegt:

- Verweerder heeft het bestreden besluit doen voorbereiden door een hoor- en adviescommissie, die bestond uit een wethouder en twee ambtenaren van de gemeente Maastricht. Die commissie heeft ter zake van het bestreden besluit advies uitgebracht, welk advies door verweerder in zijn geheel is overgenomen. Nu de belangen van de N.V. Nutsbedrijven Maastricht zo direct zijn verweven met de belangen van de gemeente Maastricht, oordeelt de rechtbank met betrekking tot de advisering dat ten minste de schijn van partijdigheid is gewekt. Naar het oordeel van de rechtbank had het op de weg van verweerder gelegen voor dergelijke gevallen een onafhankelijke adviescommissie in de zin van artikel 7:13 van de Awb in te schakelen. Door dat na te laten heeft verweerder het fundamentele rechtsbeginsel vervat in artikel 2:4, eerste lid van de Awb in onvoldoende mate recht gedaan. Nu aan de voorbereiding van het bestreden besluit een gebrek kleeft, komt dit besluit reeds op grond van het voorafgaande voor vemietiging in aanmerking en komt de rechtbank niet toe aan een verdere beoordeling wan het bestreden besluit. ${ }^{12 t}$

Deze uitspraak geeft enkele merkwaardige overwegingen te zien. De rechtbank heeft geen oog voor het feit dat een inhoudelijke beoordeling van de zaak om proces-economische redenen praktischer zou zijn geweest. Ofschoon art. 8:72, lid 3 slechts beperkt kan worden toegepast (doorgaans bij gebonden besluiten), had de rechter kunnen beoordelen of de indiener van het beroepschrift met de vernietiging niets opschoot. ${ }^{128}$ De vraag zou kunnen worden gesteld of de besluitvorming tot een andere uitkomst zou hebben geleid. De bestuursrechter stelt voorop, dat het horen correct is geschied, maar alanstonds overweegt hij dat b en w gexien 
de omstandigheid dat het een 'gemeentelijke bouwvergunning' betrof, het Maastrichtse college in dit geval maar een adviescommissie ex art. 7:13 Awb had moeten instellen, nu er sprake is van verstrengeling van belangen. Dit is vreemd omdat de instelling van een adviescommissie ex art. 7:13 betekent, dat het horen dan door deze commissie thad dienen plaats te vinden. Door deze redenering van de rechter zou het horen dus weer niet correct hebben plaatsgewonden. Merkwaardig is ook dat de rechter zich mengt in de vrijheid van een bestuursorgaan. Een verplichting tot instelling van een artikel 7:13-commissie is er niet. De A.BRS heeft het niet verplichte karakter van art. 7:13, lid 1 in een recente uitspraak in hoger beroep bevestigd. ${ }^{129}$ Opmerkelijk is dat de rechter een artikel 7:13-commissie als een onaflhankelijke adviescommissie kwalificeert, terwijl de wetgever slechts de eis van onafhankelijkheid heeft gesteld ten aanzien van de voorzitter.

Mogelijk is, al lijkt speculeren niet uitgesloten, dat de rechter op het kompas heeft gevaren van het nieuwe VNG-model van de hoor- en adviescommissie, waarin gekozen is voor een geheel onafhankelijke commissie. ${ }^{130}$

\subsubsection{Voorbereiding besluitvarming door een materieel-wettelijke advies- commissie}

In par. $2.5 .3 \mathrm{kwam}$ de voorbereiding van de besluitworming ter sprake, voorzover het bestuursorgaan zich daarbij liet adviseren door een schadebeoordelingscommissie. Deze commissie wordt doorgaans ingesteld ten behoeve van de beoordeling van aanvragen om planschade als bedoeld in art. 49 WRO. Gewezen werd op de bijzondere expertise die voor de beoordeling van deze aanvragen om planschade gewenst is. Hoewel de WRO niet eist dat voor de beoordeling van planschadeverzoeken, zowel een onafhankelijke deskundige als een schadebeoordelingscommissie moet worden ingeschakeld, stellen de beginselen van behoorlijk bestuur (zorgvuldige voorbereiding), strenge eisen aan de besluitvorming.

Onder de vigeur van de Awb lijken de eisen door de nieuwe bestuursrechter de ABRS verder te zijn aangescherpt. Ofschoon de hierna te vermelden zaak door de ABRS behandeld werd conform het recht zoals dat gold vóór 1 januari 1994, is deze uitspraak voor de besluitvorming met betrekking tot planschadeverzoeken niet zonder betekenis. In deze zaak van de gemeente Lemsterland, reikt de ABRS

129 ABRS 16 december 1997, JB 1998, $30 \mathrm{~m}$ nt. ARN, ABkort 1998, 30 (Madstricht), Gst. 7077, 5 m. nt. C.P.J. Goorden.

130 Model verordening behandeling bezwaar- en beroepschriften, 23 september 1993, VNG circ. $93 / 216$. 
een nieuwe catalogus van adviseringseisen aan ten behoeve van de beoordeling van aanvragen om planschade.

Deze catalogus van eisen ${ }^{131} \mathrm{kan}$ als volgt worden gerubriceerd:

1. de WRO stelt geen procedure-eisen ten aanzien van de toepassing van art. 49;

2. indien een planschade(procedure)verordening is vastgesteld wordt zowel de voorbereiding van besluiten als de besluitvorming zelve, uitsluitend beheerst door de algemene beginselen van behoorlijk bestuur (toepassing oud recht, onder de Awb is hoofdstuk 3 van toepassing);

3 . in het geval dat geen verordening van kracht is moet:

a. verzoeker worden gehoord;

b. een deskundige worden ingeschakeld;

c. een onafhankelijke schadebeoordelingscommissie worden ingesteld;

4. een stedenbouwkundig adviesbureau kan niet worden aangemerkt als een onafhankelijke en onpartijdige schadebeoordelingscommissie;

5. het instellen van een schadebeoordelingscommissie kan achterwege blijven indien:

a. het verzoek om planschade kennelijk ongegrond of kennelijk niet-ontvankelijk is;

b. indien op eenvoudige wijze, zonder diepgaand onderzoek, kan worden vastgesteld dat het verzoek dient te worden afgewezen.

De bovengenoemde uitspraak lijkt strengere condities aan te geven voor wat betreft het adviseren omtrent planschadeverzoeken.

Met cen (gewoon) stedenbouwkundig bureau wordt geen genoegen genomen; het SAOZ lijkt wél in de ogen van de bestuursrechter aan de eisen van onafhankelijkheid en onpartijdigheid te voldoen (zie jurisprudentie par. 2.5.3). Tevens komt tot uitdrukking dat een planschadebeoordelingscommissie "een must" is. Van de noodzaak tot advisering door een planschadecommissie kan slechts in bijzondere gevallen, vermeld onder punt 5 , worden afgeweken.

\subsubsection{Uitspraken inzake (on)partijdigheid bij de beslissingsprocedure}

Bij de bespreking van de (onypartijdigheid bij de beslissingsprocedure in par. 2.5 .5 (periode vóór 1 januari 1994) kwam vast te staan, dat in navolging van de Kroon-uitspraken ook een 'omsiagpunt' viel te constateren bij de ARRS. Aanvankelijk toonde de arob-rechter een strikt formele opstelling. Indien er 
gesproken kon worden van een persoonlijk belang bij de besluitvorming, behoorde naar het oordeel van de arob-rechter een vernietiging te volgen van het bestreden besluit. In een zaak van de gemeente Westellingwerf oordeelde de ARRS dat voor het uitspreken van een vernietiging van het besluit van belang is of de deelname aan de stemming van invloed is geweest op het resultaat van de besluitvorming. ${ }^{132}$

Uit het KB Simpelveld, dat in par. 2.5.5 terloops werd aangestipt blijkt dat de Kroon deze lijn voortzet voor wat betreft de toepassing van art. 28 , eerste lid, onder a van de Gem.w.

Bij beoordeling van het Simpelveldse raadsbesluit dat door de Kroon werd vernietigd $^{133}$, blijkt dat een deelname aan de stemming wegens een persoonlijk belang ten opzichte van eerdere arob-uitspraken en Kroonzaken, aan hetzelfde criterium van 'doorslaggevendheid' wordt getoetst. Toch geeft het KB een aantal aanknopingspunten dat de feiten en omstandigheden zeer kritisch door de Kroon worden onderzocht. Uit het KB Simpelveld kunnen uit de nota van toelichting de volgende fundamentele overwegingen worden afgeleid, te weten ${ }^{134}$ :

a. het tot stand brengen van het Cultureel Centrum in Bocholtz is een belangrijk project ten behoeve van het verbeteren van de huisvestingsmogelijkheden voor de sociaal-culturele verenigingen;

b. het betrokken raadslid is in zijn hoedanigheid van voorzitter van de Koninklijke Philharmonie Bocholtz (wijk gemeente Simpelveld) vele jaren betrokken geweest bij de verbetering van de huisvestingsmogelijkheden;

c. het betrokken raadslid heeft samen met andere bestuursleden van de harmonie met $b$ en $w$ beraadslaagd over de voorgenomen plannen;

d. de uitgaande brieven van de harmonie inzake het project zijn ondertekend door het betrokken raadslid;

e. de raadsnotullen met betrekking tot het (vernietigde) besluit bevestigen de frequente contacten van het betrokken raadslid met $b$ en w;

f. de deelname door het betrokken raadslid is in strijd met het bepaalde in art. 28 , lid 1 , onder a van de Gem.w.;

132 ARRS 22 januari 1982, AB $1982,178$.

133 Het raadsbesluit werd aanwankelijk geschorst bij $\mathbb{K B}$ van 24 januari 1995, Stb. 1995, 41.

134 KB 19 december 1995, Stb. 1996, 22. De ABRS theeft het KB inmiddels vernietigd. Naar het oordeel van de bestuursrechter gelden voor de inbreuk op art. 28, lid 1 Gem.w. objectieve criteria. De vertegenwoordiging van de vereniging moet in civielrechtelijke zin worden opgevat. Daarvoor is ook statutaire medewerking nodig. De voorzitter kan de vereniging civielrechtelijk niet binden. De schijn van belangenverstrengeling is in casu niet voldoende voor strijd met art. 28, lid 1 Gen.w. ABRS 20 februari 1998, Gst. 7072, 3, JB 1998, 76 m.n. R.J.N.S. en E. Brederveld, Simpelveld: bona causa triumphat!, p. 153 e.v. 
g. de stem van het betrokken raadslid is van beslissende betekenis geweest voor het aannemen van het voorstel (het betrokken raadslid heeft vóór het cultureel project gestemd en het voorstel is aangenomen met acht stemmen vór en zeven stemmen tegen het voorstel);

h. aan het gestelde onder $\mathrm{g}$ zou een mindere betekenis moeten worden toegekend indien het raadsvoorstel met een grotere meerderheid zou zijn aangenomen.

Dat de bovengenoemde overwegingen van de Kroon nogal uitvoerig zijn weergegeven is niet zonder belang. De spontane vernietiging van het raadsbesluit 'Simpelveld' is in de literatuur nogal gekritiseerd. Het KB zou onvoldoende gemotiveerd zijn en het zou de echte belangenverstrengeling onvoldoende aantonen. Verder zouden de gemeentebesturen met 'dit baken in zee" (art. 28, eerste lid onder a Gem.w.) op drijfzand koersen. ${ }^{135}$

De vraag kan worden gesteld of deze kritiek wel terecht is. De lijn van 'beslissende betekenis" op de uitslag wan de stemming wordt door de Kroon, mede gesteund door de arob-jurisprudentie, voortgezet. Daarnaast blijkt uit overwegingen van de Kroon dat het om een project van bijzonder belang gaat. Uit de nota van toelichting behorende bij het $\mathrm{KB}$ blijkt onder andere nog het volgende:

"Ter voldoening aan art. 278, tweede lid, van de Gemeentewet, is op 23 oktober 1995 overleg gevoerd met het gemeentebestuur van Simpelveld. Bij dat overleg waren. krachtens art. 4:8 van de Algemene wet bestuursrecht, tevens aanwezig het betrokken raadslid en een ander bestuurslid wan de Koninklijke Philharmonie." ${ }^{136}$

Men kan verschillend denken over het KB Simpelveld. Onzuiver lijkt het KB niet te klinken, ondanks het feit dat de $\mathrm{ABRS}$ het $\mathrm{KB}$ heeft vernietigd. Het standpunt van Seerden dat de uitspraak van de ABRS de materiële strekking van art. 28, eerste lid onder a miskent lijkt niet zonder grond. De Simpelveldse kwestie raakt immers een onmiskenbare vermenging van belangen. Zolang een bestuurder van een vereniging die tevens lid is van een bestuursorgaan er maar voor zorgt dat hij 'formeel-statutair' niet gebonden is, mag belangenverstrengeling (feitelijk) plaatsvinden. De uitspraak van de ABRS geeft reden tot nadenken. Zeker nu de Gem.w. (en ook de Prov.w. en de WGR), onlangs in art. 15, lid 1 onder c nog eens is aangescherpt in het belang van de zuiverheid in de verhoudingen tussen

E. Brederveld, Verboden deelneming aan stemming in de raadswergadering. Stemmingmakerij over artikel 28 Gemeentewet?, Gst. 7032.

Zie KB 19 december 1995 , Stb. 1996,22, p. 4. 
leden wan de raad en de gemeente. ${ }^{137}$ De stem van het betrokken raadslid is in ieder geval van doorslaggevende betekenis geweest op de besluitvorming. Opvallend is dat de Kroon toepassing heeft gegeven aan art. 4:8 Awb. Dit laatste is niet zonder betekenis. Hoewel art. $2: 4 \mathrm{Awb}$ (verbod van vooringenomenheid) niet 'doorklinkt' in het $\mathrm{KB}$, is uit de resultaten van de hoorzitting op te maken dat de Kroon sterk heeft geleund op deze nieuwe bestuursrechtelijke bepaling. Als algemene norm voor het bestuurlijk handelen had de Kroon dit artikel niet nodig, gezien de bijzondere bepaling van de Gem.w.

Grote projecten staan sterk onder invloed van de publieke opinie. Gelet op de aard van deze projecten zijn zeer veel burgers en groepen van burgers in het gemeentelijk politiek bestel daarbij betrokken. Een 'zuivere en harmonieuze toonzetting' van de besiuitvorming lijkt daarbij geboden, mede in het belang van een voldoende legitimering van bestuursbesluiten. Spontane vermietigingsbesluiten als bedoeld in art. 268, lid 1 Gem.w. zijn immers op grond van art. 281 a Gem.w. lid 1, vatbaar voor beroep (en ook voor bezwaar bij de minister) bij de ABRS. Voor de volledigheid wordt hierbij overigens nog opgemerkt, dat art. 281a, lid 2 Gem.w. de toepasselijkheid wan art. 6:2 Awb heeft uitgesloten. Tegen een weigering om tot spontane vernietiging over te gaan, alsmede het niet reageren op een dergelijk verzoek, bestaat geen rechtsbeschermingsvoorziening op grond van de Awb.

In de zaak van de gemeente Velsen was eveneens de onpartijdigheid van de beslissingsprocedure in het geding.

Ten tijde van het verlenen van een milieuvergunning aan IJmuiden Zeehaven door b en $w$ op grond van de $W m$, was de wethouder van de gemeente Velsen als portefeuillehouder economische zaken in die hoedanigheid, tevens commissaris van deze (gemeentelijke) N.V. Appellante (een vereniging) stelde in een beroepszaak bij de ABRS de partijdigheid van de wethouder ten aanzien van de vergunningverlening ter discussie. Het persoonlijk belang als bedoeld in art. 2:4, lid 2 van de wethouder bij de besluitvorming, werd door de bestuursrechter niet aanwezig geacht. De ABRS beargumenteerde haar oordeel door te stellen dat het commissariaat in kwestie voortvloeide uit de functie van het wethouderschap, en dat de inkomsten van het commissariaat in de gemeentekas vloeien. Op basis van deze functionele benadering van het 'persoonlijk belang', verwierp de afdeling de

137 ABRS 20 februari 1998, JB 1998, 76 m.nt. R.J.N.S., Gst. 7072, 3 m.mt. JG, TK 25766, Stb. 1998, nr. 433 en H.Th.J.A.M. Hennekens en C.J.N. Versteden, Gemeentewet, losbl. Alphen aan den Rijn, Artikelgewijs commentaar art. 28 , p. 1 . 
opgeworpen strijdigheid van de verleende vergunning wegens belangenverstrengeling. ${ }^{138}$

Niet ten onrechte moet met de annotator ${ }^{139}$ worden toegegeven dat deze uitspraak nogal teleurstellend is. De schijn van partijdigheid kan in deze kwestie moeilijk worden ontkend. De lijn van de jurisprudentie is kennelijk nog niet geheel eenduidig ten aanzien van het vervullen van commissariaten door wethouders. De lagere rechter staat klaarblijkelijk nog niet op hetzelfde standpunt als de ABRS. In de Maastrichtse zaak, bleek de omstandigheid dat de wethouder-commissaris die tevens voorzitter was van een niet-conforme 'artikel 7:13-commissie', reden voor de lagere bestuursrechter om strijdigheid uit te spreken met art. 2:4, lid 1 Awb. Die laatste kwestie is reeds besproken in paragraaf $2.6 .2 . .^{140}$

Afrondend kan worden geconcludeerd dat in de literatuur ook verschillend wordt gedacht over het antwoord op de vraag of bij het bekleden van commissariaten door gemeentebestuurders gesproken kan worden van gemeentelijke 'vertegenwoordigers'. ${ }^{14 \mathrm{i}}$

Die laatste kwalificatie van gemeentelijke functionarissen wordt onder andere in verband gebracht met art. 2:140, lid $2 \mathrm{BW}$, waarin is bepaald:

2. De raad van commissarissen heeft tot taak toezicht te houden op het beleid van het bestuur en op de algemene gang van zaken in de vennootschap en de met haar verbonden onderneming. Hij staat het bestuur met raad ter zijde. Bij de vervulling van hun taak richten de commissarissen zich naar het belang van de vennootschap en de met haar verbonden onderneming.'

Toch lijkt het vanuit het perspectief van art. 2:4, lid 2 niet voor de hand liggend om een dominante civielrechtelijke waarde te hechten aan de specifieke functie van commissaris-bestuurder. Vanuit het perspectief van belangenverstrengeling is er meer voor te zeggen om aan de toepassing van de Awb voorrang te geven dan aan het civiele 'onafhankelijkheidsbrevet' van de commissaris. Cumulatie van functies roept doorgaans op $z$ ' $n$ minst de schijn op van belangenverstrengeling.

ABRS 5 juli 1995, JB 1995, 227, m.nt. MAH en R.J.G.M. Widdershoven, NTB 1996, p. 151.

Zie vorige noot.

Maastricht, 5 maart 1996, reg. nr.: 95/1786 WW 50 Z Pol.

14 J.T, van Stegeren, Gemeentelijke vertegenwoordiging in vennootschappen, Gst. 6889, p. 484 en 485. 


\subsection{Conclusies}

Art. 2:4 Awb eist van het bestuursorgaan dat het zijn taak zonder vooringenomenheid vervult. Door deze objectief-rechtelijke omschrijwing is het bestuursorganen op grond van de Awb verboden zich bij de voorbereiding en het nemen van besluiten te laten leiden door subjectiviteit en partijdigheid. Het bovengenoemd vooringenomenheidsverbod is voor het Nederlandse bestuursrecht een nieuw fenomeen.

Met het verrichte onderzoek is beoogd de inhoud en betekenis van art. 2:4 in een rechtens juist perspectief te plaatsen. Met dit uitgangspunt voor ogen is getracht de praktische betekenis van art. 2:4 voor de bestuurspraktijk te verklaren.

Allereerst werd in par. 2.4 een aantal wettelijke bepalingen onderzocht die min of meer in verband staan met correctheidsmaatstaven in het belang van het functioneren wan het openbaar bestuur. Vast kwam te staan dat er in het organieke recht nogal wat bepalingen voorkomen die waarborgen beogen te bieden in het belang van de integriteit en de onpartijdigheid van zowel bestuurders als de aan deze bestuursorganen ondergeschikte personen. Ofschoon het belang van de in par. 2.4 besproken regelingen moet worden onderstreept, blijkt hieruit dat deze (grotendeels) organieke bepalingen meer toegesneden zijn op de individuele taakvervulling; de bepalingen richten zich niet rechtstreeks tot de bestuursorganen. Een uitzondering hierop vormen de regels ter voorkoming van partijdige besluitvorming.

De onderzochte bepalingen over de integriteit en de onpartijdigheid bij bestuursorganen brengen een diversiteit van kwaliteitseisen tot uitdrukking, waaraan personen die deel uitmaken van bestuursorganen, moeten voldoen. Toch bieden deze voorschriften geen voldoende compensatie voor het gemis van een algemene bestuursrechtelijke onpartijdigheidsregeling bij de taakvervulling in het algemeen en de besluitvorming in het bijzonder. Hetzelfde geldt voor een aantal regelingen voor personen die werkzaam zijn onder verantwoordelijkheid van de bestuursorganen. Deze 'personele' bepalingen hebben immers niet een directe betekenis voor het besluitvormingsproces. Er gaat slechts een indirecte werking vanuit.

In par. 2.5 werd aan de hand van de jurisprudentie van vó́r de Awb de zuiverheid van de bestuurlijke taakvervulling op hoofdlijnen onderzocht. Aandacht is besteed aan de advisering door formeel-wettelijke en materieel-wettelijke adviesconmissies. Uit deze jurisprudentie kon ten aanzien van de adviescommissies, die krachtens wettelijk voorschrift zijn ingesteld, worden vastgesteld dat de samenstelling van deze adviescommissies nauw gekoppeld is aan deskundig- 
heid. Gebleken is dat deskundigenadvisering met het oog op de zuiverheid van de voorbereiding van besluiten dient te voldoen aan de eisen van onathankelijkheid en onpartijdigheid. Belangenverstrengeling bij de samenstelling van adviesorganen behoort in het belang van de kwaliteit van de besluitvorming door bestuursorganen te worden vermeden.

De betekenis hiervan werd mede benadrukt vanuit de kwetsbare en afhankelijke positie van de burger. Ten aanzien van de materieel-wettelijke adviescommissies kan globaal uit de jurisprudentie van vóor de Awb worden afgeleid, dat bij de inschakeling van adviescommissies door de rechter, de mate van de deskundigheid van de leden van de adviescommissie werd getoetst. Indien de deskundigenadvisering als voldoende werd geoordeeld volgde uit het rechterlijk oordeel dat hierdoor voldaan was aan de eisen van een zorgvuldige voorbereiding van de besluitworming. Opvallend was well dat de onderzochte uitspraken een sterk casuistisch karakter vertoonden. De rechter toetst vooral de omstandigheden van het geval. Daarbij werd de positie van het bestuursorgaan afgezet tegen het belang van de burger. De positie van de burger werd doorgaans 'gewogen' op basis van het criterium of door de wijze van advisering de justitiabele al dan niet in diens belangen is geschaad. Een rol van betekenis is tevens of de belanghebbende voldoende in de gelegenheid is gesteld de adviezen te betwisten. Ook het EHRM hecht in het belang van een eerlijke procedure (art. 6 EVRM) grote betekenis aan her bieden van voldoende kansen aan de justitiabele om deskundigen-adviezen te betwisten. ${ }^{142}$

Naast de voorbereidingsfase van de besluitvorming, werd in par. 2.5 .5 de (on)partijdigheid bij de beslissingsprocedure in casu het deelnemen aan de stemming op basis van de jurisprudentie onderzocht. Ook hier vond een beoordeling plaats aan de hand van de situatie van vóór de inwerkingtreding van de Awb. Vast kwam te staan dat belangenverstrengeling, gebrek aan onbevooroordeeldheid, het objectief nemen van besluiten in de weg kunnen staan.

Opvallend in het onderzoek is dat de Kroon in het kader van het spontane vernietigingsrecht een deelname aan de stemming wegens een persoonlijk belang toetste aan het criterium of de stem van het betrokken lid van doorslaggevende betekenis was geweest voor de uitslag van de stemming. De arob-rechter volgde atanvankelijk deze lijn niet, en hanteerde een strikt formeel criterium. Was er in de ogen van de arob-rechter sprake van een persoonlijk belang bij de besluitvorming, dan werd zonder meer een vernietiging van het bestreden besluit uitgesproken. Uiteindelijk kwam er ook een kentering in de toetsing door de arob-rechter, en

142 EHRM 18 maart 1997, JB 1997, 112, m.nt. AWH (Mantovanelli). 
hanteerde deze eveneens de 'Kroonlijn' die gebaseerd was op het criterium van "doorslaggevende betekenis". 143

Na de bespreking van deze pré-Awb-aspecten die direct of indirect in verband stonden met een objectieve taakvervulling door de bestuursorganen, werd het onderzoek in dit hoofdstuk afgesloten met de voorbereiding van zowel de formeel-wettelijke als de materieel-wettelijke adviescommissies nog eens te beoordelen aan de hand van objectiviteitsmaatstaven onder de werking van de Awb. Naast een behandeling in hoofdzaken in de paragrafen 2.6.2 en 2.6.3 werd afsluitend eveneens nog aandacht besteed aan enige uitspraken inzake de (on)partijdigheid bij de beslissingsprocedure.

De toetsing aan de hand van de Awb geeft globaal het volgende beeld te zien.

Voorop zij gesteld, dat de casuïstische toetsing zoals die ten aanzien van de deskundigenadvisering plaatsvond vóór de inwerkingtreding van de $A w b$, ook onder de werking van art. 2:4 wordt voortgezet. Dit laatste wekt geen bevreemding. Art. $2: 4$ is immers een 'open' geformuleerde norm die aan de hand van de concrete situatie in het voorbereidingsproces van de besluitvorming moet worden getoetst. Ook de Awb-wetgever benadrukt dat "uiteenlopende situaties" er toe kunnen leiden dat besturursorganen het vooringenomenheidsverbod overtreden. ${ }^{144}$

Bij de taakvervulling door het bestuursorgaan en de toetsing door de bestuursrechter is daarom behoedzaamheid en bedachtzaamheid op zijn plaats. Deze situatie maakt een juiste inschatting omtrent het al dan niet treden in de 'gevarenzone' moeilijk. De laatste omstandigheid plaatst zowel het bestuursorgaan als de bestuurstechter voor een moeilijke opdracht. De 'grilligheid' van de beoordeling van het vooringenomenheidsverbod blijkt bijvoorbeeld uit de kwestie rond de Heterense welstandscommissie. ${ }^{145}$ In deze zaak leidde zowel een door $b$ en $w$ ingewonnen second opinion (bij een particulier adviesbureau) alsmede de eerdere betrokkenheid van een extern bureau bij het ontwerpen van een bestemmingsplan toch niet tot vernietiging van de bouwvergunning. De uitspraak van de bestuursrechter was opmerkelijk. Enerzijds was er geen sprake van het inschakelen van een onafhankelijke (welstands)commissie en anderzijds was de advisering door het ingeschakelde adviesbureau niet van elke schijn van onpartijdigheid ontdaan.

143. Zie in dit verband de noten 115 en 117.

144 PG Awb l. p. 179.

145 Zie noot 119. 
De toetsing van art. 2:4 Awb door de lagere bestuursrechter is strenger dan die door de ABRS ten aanzien van de wijze van advisering in hel kader van de op het bezwararschrift te nemen beslissing. De lagere bestuursrechter hecht aan het onpartijdigheidsaspect in het kader van de op het bezwaarschrift te nemen beslissing, grote waarde. Dit laatste blijkt vooral in die gevallen, dat het openbatar lichaam bepaalde belangen heeft bij de uitkonsten van de bezwaarschriftenprocedure. In die gevallen dat het openbaar lichaam als vergunninghouder betrokken is bij de bezwaarschriftenprocedure legt het CBB striktere onpartijdigheidsmaatstaven aan ${ }^{i 46}$ dan de ABRS. Vooralsnog lijkt de ABRS art. 2:4 terughoudend te toetsen. ${ }^{147}$

Geconcludeerd kan worden dat onder de werking van de Awb de bestuursrechter ten aanzien van de toetsing van artikel 2:4 Awb een onvoorspelbare toetsing aan de dag legt. De rechtbanken en het CBB lijken eerder tot belangenverstrengeling te oordelen dan de ABRS. Wél lijkt de ABRS ingeval van de schijn van partijdigheid te concluderen tot strijd met het zorgvuldigheidsbeginsel. ${ }^{148}$

Zonder af te doen aan het belang van een kritische toets door de rechter over de onpartijdige advisering in het kader van de bezwaarschriftenprocedure, past hier nog een enkele kanttekening.

In die gevallen, dat niet voldaan wordt aan de eisen van een onpartijdige advisering van de op het bezwaarschrift te nemen beslissing, behoort in beginsel prioriteit gegeven te worden aan een strikt formele toepassing van art. 2:4 Awb. Indien de beoordeling van de omstandigheden van het geval er toe leidt dat gesproken kan worden van een schijn van vooringenomenheid, behoort door debestuursrechter een vernietiging van het bestredien besluit te worden uitgesproken. Het adviseren en het in casu beslissen op het bezwaarschrift zijn bestuursrechtelijke aspecten die nauw aan elkander aansluiten. ${ }^{19}$ lets anders is of steeds met instemming moet worden gereageerd op de inhoud van de uitspraak die strekt tot vernietiging. Nu art. 2:4 noopt tot een concrete toetsing van de omstandigheden van het bestreden besluit, aan de hand van uiteenlopende situaties, is het uit een oogpunt van proceseconomie aan te bevelen dat de

w6 Zie in dit verband noot 124 betreffende de kwestie van de Amsterdamse Stadsmobiel en Rb. 19 augustus 1996, Gst. 7663,7 m. nt. C.G.J. Goorden.

1.47 ABRS 16 december 1997, JB 1998, $30 \mathrm{~m}$.nt. ARN en ABkort 1998, 30, Gst. 7077, 5 m.nt. C.P.J. Goorden

148 ABRS 16 april 1997, AB 1998, 75 en ABRS 28 oktober 1997, AB 1997, 458 m.nt. PwB, Gst. 7066,4 , m. $\pi \mathrm{t}$. HH.

B.W.N. de Waard, a.w., p. 345 . 
bestuursrechter de beperkte mogelijkheden van art. $8: 72$, lid 3 in zijn rechtsoverwegingen betrekt.

Binnen de marges van art. 8:72, lid 3 Awb zou deze in zijn uitspraak kunnen bepalen dat de rechtsgevolgen van het vernietigde besluit in stand blijven. Een dergelijke werkwijze lijkt zowel de bestuurspraktijk als ook het bestuursprocesreclit betere diensten te bewijzen. ${ }^{150}$ Een uitgesproken vernietiging van het besluit wegens partijdigheid kan hierdoor toch educatieve betekenis hebben woor het bestuursorgaan.

In par. 2.6.4 (partijdigheid bij de beslissingsprocedure) is vastgesteld dat zowel de trend van de arob-jurisprudentie als de uitspraken in het kader van het schorsings- en vernietigingsrecht wordt voortgezet. Een eerste uitspraak onder de werking van de Awb laat zien dat in die gevallen dat een verboden deelname aan de stemming door de Kroon wordt geconstateerd (art. 28, lid 1 Gem.w.), deze beoordeelt of de verboden deelname van beslissende betekenis is geweest voor het nemen van het besluit. ${ }^{151}$ De A.BRS lijkt een meer (formele) objectief-rechtelijke toets van art. 28 , lid $1 \mathrm{Gem}$.w. voor te staan, die weinig recht doet aan de materiële betekenis van dit artikel. Men kan twijfels hebben over de juistheid van dit rechterlijk standpunt, zulks afgezet tegen de bepalingen van de Gem.w. die een zuivere bestuurlijke taakvervulling beogen te waarborgen. ${ }^{152}$

Ten aanzien van de toepassing van het vernietigingsrecht door de Kroon kan worden opgemerkt, dat het rechtens juister lijkt te opteren voor een strikt formele benadering in geval sprake is van partijdigheid bij de beslissingsprocedure. Het criterium of als gevolg van een verboden deelname aan de stemming deze deelname van beslissende betekenis is geweest op het resultaat van de besluitvorming, ware in het licht van art. 2:4 Awb los te laten. Dit laatste klemt temeer omdat ook in casu voor gemeentelijke besluiten, de Kroon op grond van art. 280 Gem.w., laatste volzin, de bewoegdheid heeft de rechtsgevolgen wan het vernietigde besluit geheel of ten dele in stand te laten. Onder de werking van het nieuwe bestuursrecht als belangrijk instrument voor het verbeteren van de kwaliteit van de voorbereiding van de besluitvorming, alsmede de rechtmatigheid van de beslissingsprocedure, lijkt de toepassing van het aanwankelijke strikt formele criterium van 'het persoonlijk belang', meer recht te doen aan de huidige meningsvorming omtrent de eisen die moeten worden gesteld aan de kwaliteit van her openbaar bestuur.

150 PG Awb II, p. 470.

151 Zie noten 133 en 1.34 .

152 Zie noot 134. 
Het proces van meningsvorming in die gevallen dat belangenverstrengeling en vooringenomenheid bij de besluitvorming wordt geconstateerd is niet of nauwelijks traceerbaar. Of de stem van een belanghebbende bestuurder van doorsiaggevende betekenis is geweest, moet op basis van de norm ten aanzien van de verboden deelname aan de stermming worden beoordeeld. ${ }^{153}$ De belangen die gediend zijn met een betere legitimering van besluiten van bestuursorganen, nopen tot een versterking van het vertrouwen in het openbaar bestuur.

153 B.W.N. de Waard, a.w., p. 345 . 



\section{Het horen: een belangrijke formelle bepaling met materiële betekenis voor de beslissing op het bezwaarschrift}

\subsection{Een verkenning}

Art. 7:2 opent de reeks van een aantal bijzondere bepalingen van de bezwaarschriftenprocedure door aan het bestuursorgaan een hoorplicht op te leggen, alvorens op een ingediend bezwaarschrift te beslissen. Art. 7:2 luidt als volgt:

'1. Voordat een bestuursorgaan op het bezwaar beslist, stelt het belanghebbenden in de gelegenheid te worden gehoord.

2. Het bestuursorgaan stelt daartoe in ieder geval de indiener van het bezwaarschrift op de hoogte alsmede de belanghebbenden die bij de voorbereiding van het besluit hun zienswijze naar woren hebben gebracht.'

De titel van dit hoofdstuk doet al vermoeden dat in de hoorplicht als bedoeld in art. 7:2 Awb een aantal aspecten ligt opgesloten dat van invloed is op de behandeling van het bezwaarschrift. Het horen als formeel-juridische verplichting voor het bestuursorgaan kan door het belang dat dit procedurevoorschrift heeft, voor de voorbereiding van de op het bezwaarschrift te nemen beslissing, een grote betekenis hebben voor de uitkomst van de bezwaarschriftenprocedure. Achter het 'steriel' ogende voorschrift van art. 7:2 gaat méér schuil dan de enkele hoorverplichting doet vermoeden. Een rechtens juiste invulling door het bestuursorgaan van de hoorplicht is van betekenis voor de inhoud van de op het bezwaarschrift te nemen beslissing.

Afdeling $7.2 \mathrm{Awb}$ bevat bepalingen van procedureelrechtelijke aard die door de bezwaarde burger en het bestuursorgaan in acht moeten worden genomen. Bovendien gelden naast de bijzondere bepalingen van afdeling 7.2 de op het bezwaar (en beroep) gemeenschappelijke procedurebepalingen van hoofdstuk $6 .{ }^{1}$

In zijn opzet is de Awb voor wat betreft de daarin opgenomen bestuursrechtelijke regels van procedurele aard voor zover het betreft de bepalingen van de verplichte bezwaarschriftenprocedure. De hoorverplichting vormt een belangrijke schakel in de procedure. De bezwaarschriftenprocedure in de Awb bevat voorschriften van procedurele aard. De meer inhoudelijke kant van de besluitvorming, in casu de op het bezwaarschrift te nemen beslissing, heeft zijn oorsprong in de bijzondere wetgeving die bijvoorbeeld regeling vindt op het terrein van de ruimtelijke ordening, de volkshuisvesting, het bouwrecht en het milieurecht, alsmede de

1 G.P. Kleijn, in: Handboek Algemene wet bestuursrectit ii/afd 7.2, p. 2, losbl., Alphen aan den Rijin. 
HOOFDSTUK 3

autonome dan wel medebewind-regelgeving door de bestuursorganen van de lagere rechtsgemeenschappen.

Vastgesteld is dat de behandeling van het bezwaarschrift zowel beheerst wordt door regels van procedurele aard als door de bepalingen van de bijzondere wetgeving die van materiele betekenis zijn. Op basis van het in eerste instantie vastgestelde procedureelrechtelijk accent van de bezwarregelling van de Awb en de daarin opgenomen hoorverplichting, zal hierna globaal aandacht worden besteed aan de structuur en de systematiek van de Awb. Allereerst wordt gekeken naar een aantal belangrijke bepalingen wan de bezwaarschriftenprocedure die als het ware de "schil" vormen van afdeling $7: 2$.

Het complex van bepalingen dat beoogt algemeen bestuursrechtelijke invulling te geven aan de hoorverplichting, wordt gevormd door de art. $7: 2$ tot en met $7: 9$. De Awb legt in een achttal artikelen de basis voor een van de meest fundamentele beginselen van een behoorlijke procedure, te weten het beginsel van hoor en wederhoor, met als doel het verschaffen aan een gelijkwaardige positie aan de bij het bestreden besluit betrokken belanghebbenden. ${ }^{2}$

Het procedureel beginsel van gelijkwaardigheid van de positie van de belanghebbenden die in een bezwaarschriftenprocedure verwikkeld zijn, komt in de Awb tot uitdrukking in enkele bepalingen die enige basis beogen te verschaffen voor de juridische vormgeving van het beginsel van hoor en wederhoor. Met nadruk wordt opgemerkt, dat gesproken moet worden van 'enige basis'. De bepalingen van de Awb inzake het horen geven geen volledig inzicht in een rechtens juiste invulling van de hoorplicht. De wijze waarop de hoorplicht wordt geconcretiseerd wordt immers overgelaten aan het inzicht van de bestuursorganen.

Uit het onderzoek in dit hoofdstuk zal blijken, dat de betrokkenheid van alle actoren bij de hoorzitting nogal wat eisen stelt aan zowel de hierbij betrokken belanghebbende burgers, als her tot beslissing geroepen bestuursorgaan. In het belang van een goede verwezenlijking van de functie van de bezwaarschriftenprocedure die in art. $7: 11$ wettelijke grondslag vindt onder de noemer van de daarin opgenomen heroverwegingsplicht, is een adequate organisatie van deze bestuurlijke voorprocedure geboden. ${ }^{3}$

2 J.M.H.F. Teunissen, in: Algemene wet bestursrecht, tosbl., 's-Gravenhage, p. E. 6.3.7-1.

3 T.M.H.F. Teunissen, a.w., p. E. 6.3.7 2 . 
De hoorverplichting vervult een centrale functie in de bezwaarschriftenprocedure. Vooruitlopend op de bespreking van het onderwerp van dit hoofdstuk, wordt benadrukt dat het louter voldoen aan de hoorverplichting, voor het bestuursorgaan geen volledige waarborgen biedt voor een vlekkeloze effectuering van de bezwaarschriftenprocedure. De omstandigheid dat art. $7: 2$ geen bepaling van openbare orde is doet hier niet aan af.

Op dit aspect werd in de inleiding van dit boek reeds gewezen. ${ }^{4}$ In veel gevallen zullen de omstandigheden waaronder invulling is gegeven aan de hoorverplichting en de toepassing van de onderscheidene Awb-bepalingen, van doorslaggevende betekenis zijn voor een rechtens juiste invulling van de wijze, waarop het bestuursorgaan het horen als gesprek met de bezwaarmakende burger 'fysiek' gestalte heeft gegeven. ${ }^{5}$ De bestuursorganen zullen een actieve rol dienen te vervullen in het belang van een zorgvuldige voorbereiding van de op het bezwaarschrift te nemen beslissing. De Awb geeft slechts een minimum pakket van eisen die bij het horen van belanghebbenden in acht moeten worden genomen. Toegegeven moet worden dat de bepalingen omtrent de bezwaarschriftenprocedure voor een belangrijk deel op de jurisprudentie uit het arob-tijdperk rusten en de Awb ten opzichte van de Wet arob meer uitwoerige procedure-regels bevat. ${ }^{6}$

Toch blijft een alerte en efficiënte buiten-wettelijke invulling van de inrichting van de hoorverplichting geboden. Het balanceren door het bestuursorgaan op de grens van de Awb-voorschriften kan tegen de achtergrond van de heroverwegingsopdracht als bedoeld in art. $7: 11$ en hetgeen deze plicht met zich brengt onder omstandigheden in de ogen van de rechter als ontoereikend uitvallen. Aan de hand van een aantal accenten die van belang zijn bij de effectuering van de hoorverplichting zal dit nader worden vastgesteld. In ieder geval zal hetgeen in deze inleidende pagina"s als voorschot wordt genomen op de problematiek van de hoorverplichting enige spanning opwekken, en zonder enige overdrijving zal die spanning ook blijven hangen rond datgene dat zich voorafgaand, tijdens en ná afloop van de hoorzitting zal voltrekken.

Niet alleen het bestuursprocesrecht, zoals dat zich tijdens de procedure voor de bestuursrechter manifesteert, maar ook het geheel van procedure-regels tijdens de fase, voorafgaand aan het beroep op de bestuursrechter, maakt het bestuurlijk procedurerecht spannend. Dit geldt zeker voor die bestuursorganen zoals de bedrijfsverenigingen die nog al eens aan kritiek onderhevig zijn voor zower het

4 Zive de noten 26 en 27 in de inleiding.

$\$$ C.M. Breeuwsma, E. Helder, E. Niemeijer en M. Oosting, Beeld van de Arob-bezwaarschriftenprocedure, Deventer 1982, p. 95.

6 PG Awb I, p. 31. 
betreft het behoorlijk nemen van besluiten. Bij de inwerkingtreding van de Awb was de bezwaarschriftenprocedure voor veel sociale verzekeringszaken uitgesteld. Inmiddels geldt conform het overgangsrecht (artikel IV) ook in het sociaal zekerheidsrecht, voor belangrijke wetten zoals de WAO, ZW en AWW de verplichte bezwaarschriftenprocedure.

Het karakter van de regells terzake bezwaarschriftenprocedure is benadrukt als procedurerecht.

Procedure-regels zijn in het kader van de behartiging van de overheidstaak noodzakelijk in her belang van de werkzaamheid van bestuursorganen die besluiten moeten nemen of handelingen moeten verrichten. Procedures zoals die gelden voor de behandeling van bezwaarschriften door bestuursorganen zijn van wezenlijke betekenis. Deze vormen de spelregels waarbinnen de wedstrijd tussen burgers en bestuursorganen gespeell moet worden. ${ }^{3}$

De spellregels die het procedureel karakter van het horen vormgeven komen in afdeling 7.2 als volgt tot uitdrukking.

Voorop zij gesteld, dat aansluitend aan de in art. 7:2 neergelegde hoorverplichting op dit bestuursrechtelijke beginsel, in art. 7:3 Awb enkele uitzonderingen zijn geformuleerd. De Awb somt een viertal situaties op waarin van het horen door het bestuursorgaan kan worden afgezien. Hierbij denkt de Awb aan gevallen van kennelijke niet-ontvankelijkheid en kennelijke ongegrondheid van het bezwaarschrift. Ook kan van de gelegenheid tot het horen worden afgezien in die gevallen dat belanghebbenden daarvan geen gebruik wensen te maken. Tenslotte kan aan de situatie worden gedacht, dat de uitkomst van de beslissing op het bezwaarschrift zodanig is, dat de rechtsgevolgen van de beslissing op het bezwaarschrift de belangen van de daarbij betrokken derden niet schaadt.

Toch kan het tot beslissing op het bezwaarschrift geroepen bestuursorgaan niet zomaar rauwelijks tot het niet horen van belanghebbenden besluiten. De in art. 7:3 Awb gegeven bevoegdheden kunnen tot voetangels en klemmen leiden indien de te maken bestuurlijke afweging op onjuiste feiten en gronden blijkt te zijn gebaseerd. De discretionaire bevoegdheid ex art. 7:3 Awb, alsmede de daarin opgenomen strikte voorschriften geven aanleiding tot een zorgvuldige consideratie bij de toepassing wan dit artikel. 
Ten aanzien van art. $7: 3 \mathrm{kan}$ nog het volgende worden opgemerkt. Art. 7:3 betreft een procedurele bevoegdheid; deze procedure-beslissing is niet vatbaar voor bezwaar. ${ }^{9}$ Wel maakt de beslissing om niet te horen onderdeel uit van de op het bezwaarschrift te nemen beslissing.

Omtrent de wijze waarop deze procedure-beslissing nadere inkadering dient te krijgen in de op het bezwaarschrift te nemen beslissing, wordt nog aandacht besteed in de par. 5.3.9 en 5.4.9. Overigens is het niet nodig dat procedurele beslissingen door het bestuursorgaan zelf worden genomen. Gebruik kan worden gemaakt van de mandaatfiguur en de mogelijkheid om deze beslissingen te delegeren aan ten behoeve van de behandeling van bezwaarschriften ingestelde commissies. Voor het geval dat gebruik wordt gemaakt wan de bevoegdheid om procedurele beslissingen te mandateren betekent dit wel dat deze formeel-juridisch, beslissingen blijven van het bestuursorgaan. Bij het delegeren aan een commissie is dit anders; het bestuursorgaan geeft zijn bevoegdheid dan uit handen. In dit laatste geval worden de procedurele bevoegdheden niet namens het bestuursorgaan uitgeoefend. Voor de bij de wet speciaal genoemde adviescommissie ex art. 7:13 komt daar nog bij dat een procedurele bevoegdheid als bedoeld in art. $7: 3$ op grond van art. 7:13, rechtstreeks wordt uitgeoefend door deze commissie, tenzij bij een afzonderlijk bestuursbesluit of in de vorm van een verordening hiervan wordt afgeweken.

In het begin van deze verkenning is er op gewezen, dat het horen als procedureelrechtelijk beginsel dient plaats te vinden voorafgaand aan de op het bezwaarschrift te nemen beslissing. Nagegaan zal worden op welke wijze het horen een functie kan vervullen ten behoeve van het bestuursrechtelijke uitgangspunt van art. $7: 11$, lid 1 , te weten her heroverwegen van het bestreden primaire besluit. In par. 3.2.1 wordt getracht de functie van het horen als procedureel aspect nader in te vullen. De bestuurlijke kant van het horen die meer ziet op de inhoudelijke betekenis van de relatie tussen het bestuursorgaan en de burgers, krijgt aandacht in par. 3.2.2. Hierin wordt méér het accent gellegd op de materiële betekenis van de hoorverplichting.

- PG Awb I, MvT, p. 283 en 284 en H.J. Simon, Handleiding Awb-praktijk, "s-Gravenhage 1995. p. 1.51 en 152 . 


\subsection{De functie van het horen}

\subsubsection{Het procedureelrechtelijke aspect}

De hoorplicht alls bedoeld in art. 7:2 Awb vormt een belangrijke procedurele schakel in de bezwaarschriftenprocedure. Deze hoorplicht vormt als het ware een onderdeel van een keten; een keten die gevormd wordt vanaf het moment van de ontvangst van het bezwaarschrift tot aan het tijdstip waarop het bestuursorgaan op het bezwaarschrift beslist. De beslissing op het bezwaar is een besluit als bedoeld in att. $1: 3$, hetgeen betekent dat de beslissing schriftelijk moet worden genomen. Dit besluit vormt het laatste beslissingsmoment binnen de kring van het bestuursorgaan en beoogt de pretentie te hebben in het rechtsverkeer zijn intrede te doen. Dat het betreffende besluit als beslissing op het bezwaarschrift door het adiëren van de bestuursrechter zijn rechtskracht kan worden ontnomen, doet hier niet aan af.

De bezwaarschriftenprocedure-regeling is door het bijzondere karakter van de in de Awb opgenomen procedureregels, van een geheel eigen aard en strekking en onderscheidt zich ten opzichte van het primaire besluitvormingsproces. Die eigen aard en strekking van de procedurele bepalingen van de bezwaarschriftenprocedure zal in dit hoofdstuk worden onderzocht aan de hand van de in art. 7:2 Awb opgenomen bestuurlijke verplichting tot het horen van de belanghebbenden. Het onderscheidend karakter van een primaire beslissingsprocedure en een bezwalarschriftenprocedure doet overigens niet af an de omstandigheid dat beide procedures, die zich binnen de kring van het bestuur voltrekken, veelal in én adem worden gekwalificeerd als 'de besluitvormingsprocedures'. In een enkel geval worden in de literatuur, gelet op het object van onderzoek, alleen inspraak en (administratief) beroep genoemd. De bezwaarschriftenprocedure vormde daarbij geen onderdeel van beschouwing. ${ }^{10}$

In deze paragraaf wordt de hoorplicht in het kader van de bezwaarschriftenprocedure gebracht onder de noemer van procedure-recht. De vraag is wat moet. worden verstaan onder procedure-recht en de plats die de hoorplicht in rellatie daarmede temidden van de bezwaarschriftenproceduregels inneemt. Volgens Van Dale's Groot Woordenboek der Nederlandse Taal, kan hieronder worden verstaan de gang van zaken bij een proces. De regels van de bezwaarschriftenprocedure zijn hiertoe te rekenen.

10 Chr. Kooij en F.P.C.L. Tonnaer, Vergunningverlening in stroomwersnelling, VAR XCII, Alphen aan der Rijn 1984, p. 46. 
Ook het begrip proces heeft in het administratief procesrecht een ruimere uitlleg gekregen. In de wetenschappelijke literatuur van wat oudere datum wordt aan het begrip proces een meer algemene betekenis toegekend. Naar de opvatting in deze literatuur is het begrip proces ruim van strekking. Naast het proces zoals zich dat bij de rechter voltrekt, wordt hier ook gedacht aan het proces binnen de overheidsadministratie, dat tot beslissingen van welke aard dan ook leidt. Het proces wordt bezien vanuit die invalshoek, opgevat als een beslissingsproces, als een beleidsproces of in het algemeen als het proces van het besturen."

Dit laat onverlet dat in de wat oudere literatuur voor de betekenis van het begrip proces, aansluiting wordt gezocht bij het traditioneel juridisch spraakgebruik, en voorbehouden wordt voor hetgeen zich bij de rechter voltrekt. Procedurerecht zoals hier genoemd, wordt gereserveerd voor het beslissingsproces binnen 'de administratie', inclusief het administratief beroep. Ook voor de bezwaarschriftenprocedure is naar de opvatting van deze niet meer zo jonge literatuur vast te houden aan het begrip procedurerecht ter onderscheiding van het procesrecht. ${ }^{12}$

Dat hiervoor is vastgehouden aan 'administratiefrechtelijke overblijfselen' uit het rijke bewogen verleden van het administratief recht, is niet zonder enige betekenis. De termen 'administratief recht' en 'administratief procesrecht' hebben met uitzondering van de rechtsfiguur 'administratief beroep' weliswaar plaats moeten maken voor moderne benamingen als bestuursrecht en bestuursprocesrecht, maar de gemaakte onderscheiding in procesrecht en procedurerecht blijft zijn betekenis behouden. De term bestuursrechtelijk proces is gereserveerd voor het proces voor de bestuursrechter, omdat alleen bij die (bestuurs)rechter gesproken kan worden van een echt juridisch proces. ${ }^{13}$ Dat bestuurlijke voorzieningen, zoals bezwaar en administratief beroep naast de bestuursrechtspraak, worden gerubriceerd onder de term 'bestuursrechtelijke voorzieningen', maakt het voor de bezwaarschriftenprocedure gereserveerde begrip 'procedurerecht' acceptabel. Het bestuurshandelen dat zich via besluitvorming in de bezwaarschriftenprocedure manifesteert, is de laatste schakel in de keten van bestuurlijke rechtsvorming. ${ }^{14}$

Een bestuursprocesrechtelijke procedure onderscheidt zich wezenlijk van een bestuurlijke procedure; in een bestuursprocesrechtelijke procedure is sprake van een rechtmatigheidstoetsing ex tunc van het besturshandelen. ${ }^{15}$ Dit laatste is bij

A.G. wan Galen en H.Th.J.F, van Marseveen, Beginselen van administratief procesrecht, VAR LXXXIII, Alphen aan den Rijn 1981, p. 16.

13 A.Q.C.Tak, a.w., p. 1 .

14 PGAwb 11, p. 172.

15 PG Awb II, p. 173. 
een bestuurlijke procedure zoals de bezwaarschriftenprocedure nu juist wezenlijk anders. In deze procedure wenden burgers zich tot het bestuursorgaan om een in hun bezwaarschrift bestreden besluit te herroepen op grond van zowel rechtmatigheids- als doelmatigheidsgronden. Dit laatste is gefundeerd op de in art. 7:11, lid 1 verplichte heroverweging als basis van de op het bezwaarschrift te nemen beslissing.

\subsubsection{De procedureelrechtelijke uitgangspunten van de hoorplicht nader belicht}

In de vorige paragraaf is een eerste aanzet gegeven om de regels van de bezwaarschriftenprocedure, te weten die van het horen, te rubriceren onder het procedurerecht. Hierin bleek dat niet alleen regels van materieelrechtelijke aard, maar ook die van procesrechtelijke aard verwantschappen zijn gaan vertonen dan wel tekenen daarvan ontwikkelen. Wat betekent die ontwikkeling voor het karakter van de hoorverplichting ex art. 7:2 Awb als procedurerecht en voor het gemaakte onderscheid ten aanzien van het bestuursprocesrecht? Die vraagstelling is niet zonder belang omdat ook in de praktijk van het bestuursrecht gaandeweg een vervaging van begrippen is ontstaan.

In de wetenschap wordt onderscheid gemaakt tussen twee categorieën bestuursprocesrecht. Enerzijds wordt gesproken van het contentieuze bestuursrecht terwijl daarnaast de term non contentieus bestuursprocesrecht wordt genoemd. Onder het contentieuze procesrecht wordt begrepen, het procesrecht in engere zin. Tot die engere benadering van het procesrecht zouden dan behoren, de regels van de gerechtelijke en de quasi-gerechtelijke procedures. Tot die categorie procedures waren in dit geval te rekenen een ingesteld beroep tegen een bestuursbeslissing bij een rechterlijke instantie of een bij een bestuursorgaan (administratief beroep) dan wel de procedureregels inzake een ingediend bezwaarschrift.

Het onderscheidende begrip 'non-contentieuze procesrecht' was gereserveerd voor de regels van de (primaire) besluitvormingsprocedure, welke procedure regels zou bevatten aangaande het verplicht inwinnen van adviezen, het horen van belanghebbenden, termijnen en dergelijke. ${ }^{16}$ Anderzijds wordt het procedurerecht in de bezwaarschriften-fase beoordeeld als "materiële bestuursrechispraak", vanwege het geschilbeslechtend karakter door het bestuur. Vanuit de hierbij gekozen rechtspraakachtige optiek zou de organisatie en de inrichting van de bezwaarschriftenprocedure eveneens dienen te beantwoorden aan de eisen die aan een behoorlijke rechtspraak dienen te worden gesteld. ${ }^{7}$

16 Van Wijk/Konijnenbelt, a.w., p. 33.

17 J.A. Smit, De administratieve woorprocedures, in: Nieuw bestuursprocesrecht, Deventer 1992, p. 52 . 
Tot een van de belangrijkste eisen die in het kader van het EVRM zijn ontwikkeld, behoort de eis van hoor en wederhoor als conditie voor een eerlijke (rechtspraak)procedure. Deze eis van 'hoor en wederhoor' wordt als een der belangrijkste waarborgen voor een 'goed' procesrecht oók in de literatuur gekenschetst. In de literatuur wordi het procedurerecht van de bezwaarschriftenfase in verband gebracht met de onafhankelijke rechtspraak en het daarwoor geldende procesrecht. De Waard legt als het ware enige accenten voor de uitstraling die van het bestuursprocesrecht uitgaat naar het procedurerecht van de bezwaarschriftenprocedure. De Waard benadert zijn visie vanuit het geschilbeslechtingsperspectief. Naar de opvatting van De Waard behoeven op basis van de aard van de rechtsgang niet altijd even stringente minimumeisen aan een procedure te worden gesteld. Maar de variatie van (procedure) eisen mag niet willekeurig zijn:

'Soms kan in een eerdere fase in de procedure met minimale waarborgen worden volstaan; maar alleen can als er een mogelijkheid van beroep is waarin een en ander weer wordt gecompenseerd. Men kan daarbij denken aan een soort "verlengde besluitworming": de eerdere beslissing mag zorgvuldigheidsmanco's vertonen, als die maar worden hersteld zodra bezwaar wordt aangetekend. ${ }^{18}$

Bij deze zorgvuldigheidsmanco's dringt zich de vraag op wat het karakter is van het procedurevoorschrift dat bij een ingediend bezwaar belanghebbende, vooraleer een beslissing op het bezwaarschrift moet worden genomen, deze belanghebbende moet worden gehoord. Het horen wordt als zodanig aangeduid als een beginsel van behoorlijk procesrecht waaraan de procedure in ieder afzonderlijk rechtsgeschil moet voldoen. Zulks ter onderscheiding van de inrichtingseisen, welke eisen waarborgen zijn om een beslissing te krijgen, die de eisen geformuleerd in de beginselen van procesrecht moet kunnen doorstaan. Deze inrichtingseisen die een behoorlijke procedure behoren te waarborgen, zijn in het bestuursprocesrecht doorgaans genoemd als: het inquisitoire beginsel; de ongelijkheidscompensatie, het uniteitsbeginsel, het beginsel van non-cumulatie, het vermoeden van rechtmatigheid, het vrij-bewijsbeginsel, het beginsel van procesmondigheid, de kosteloosheid, het openbaarheidsbeginsel en de mondelinge behandeling van de zaak. ${ }^{19}$ Ten aanzien van het beginsel van kostenloosheid en het openbaarheidsbeginsel wordt opgemerkt dat deze beginselen steeds minder kenmerkend worden voor het bestuursprocesrecht. ${ }^{20}$ Deze (bestuursprocesrechtelijke) inrichtingseisen worden niet in dit boek besproken. Toch zijn in de

18 B. W.N. de Waard, Een eerlijk proces (1), Algemene beginselen van behoorlijk procesrrecht, TwO 1983 . p. 145

19 A.G. van Galen en H.Th. van Maarseveen, a.w., p. 30.

20 Wan Wijk/Konijnenbelt, a.w. . p. 656. 
bezwaarschriftenprocedure regels te herkennen die hun oorsprong vinden in het bestuursprocesrecht en die hun inwloed hebben op de inhoud van de inrichtingseisen van deze voorprocedure. $\mathrm{Te}$ denken valt hier aan het beginsel van 'proceduremondigheid' als variant op de procesmondigheid (belanghebbenden worden in de gelegenheid gesteld te worden gehoord), maar kunnen gebruik maken van vertegenwoordiging en/of bijstand; zie in dit verband art. $7: 2$ jo $2: 1$. Voorts is van belang de mogelijkheid van openbaarheid van het horen in de Awb, zij het dat die mogelijkheid niet als verplichting is voorgeschreven, maar als een inrichtingsvereiste die het bestuursorgaan aan de hoorplicht kan stellen (art. 7:5, lid 2). De kostenloosheid is in de bezwaarschriftenprocedure uitgangspunt. Art. $7: 15$ bepaalt dat voor de behandeling van het bezwaar geen recht verschuldigd is.

Tenslotte is de hoorzitting als bedoeld in art. 7:5 Awb gebaseerd op een mondelinge behandeling. Dit laatste laat onverlet de mogelijkheid dat het horen niet steeds behoort plaats te vinden, en op het beginsel van een mondelinge behandeling in art. 7:3 enkele uitzonderingen zijn gemaakt.

Er is reden om behoedzaam om te gaan met de toepassing van art. 7:3. Deze omstandigheid heeft te maken met het kennelijkheidscriterium dat de Awb verbindt aan de uitzondering van de hoorplicht ('kennelijk' niet-ontvankelijk en 'kennelijk" ongegrond). De behoedzaamheid in het hanteren van het criterium 'kennelijk ongegrond' in de zin van art. 7:3, onder b, wordt ook benadrukt in de memorie van toelichting. ${ }^{21}$ Ten aanzien van het toepassen van 'onderdeel a' van art. 7:3 (kennelijk niet-ontvankelijk) is de Awb klaarblijkelijk wat soepeler. Het gegeven voorbeeld lijkt niet zonder reden op wat gespannen voet te staan met de praktijk die vaak blijkens de ruime jurisprudentie onder de Wet arob (en onder de Awb is dat zoals hierna blijkt niet anders) wordt 'gestraft' met een vernietiging van de beslissing op het bezwaarschrift.

Als laatste in het bovengenoemd rijtje van argumenten voor het hanteren van art. 7:3 noemt de Awb als reden dat de toepassing achterwege kan worden gelaten in die gevallen dat een zorgvuldige heroverweging en besluitvorming niet nodig is. ${ }^{22}$ De bovengenoemde argumenten, nopen in beginsel tot een terughoudend gebruik van de uitzonderingsbepalingen van art. 7:3. 
Uit de jurisprudentie van de Wet arob en ook de Awb blijkt met welk wisselend succes de toepassing van preparatoire beslissingen (met name het achterwege laten van de hoorplicht), door de bestuurstechter correct is beoordeeld. ${ }^{23}$

Hierna volgen enkele uitspraken waaruit blijkt dat de bestuursrechter de hoorplicht ex art. $7: 2$ kritisch toetst. Hetzelfde geldt voor het achterwege laten van de hoorplicht (art. 7:3 Awb).

De term 'kennelijk' in art. 7:3 Awb dient aldus te worden verstaan dat in redelijkheid twijfel niet mogelijk is. Zonder bekend te zijn met de gronden van het bezwaar, heeft verweerder het bezwaarschrift kennelijk ongegrond verklaard. Ook voor een gebonden beschikking is deze beslissing onjuist. Het bestreden besluit moet daarom worden vernietigd. ${ }^{24}$

In een andere zaak stelde de bestuursrechter vast, dat er geen sprake was van een kennelijk ongegrond bezwaar. Van belang was hier de overweging van de bestuursrechter, de aard van de zaak, de discretionaire bevoegdheid, de complexe materie, de grondslag van de aanvraag en de inhoud van het bezwaarschrift. ${ }^{25}$

De ABRS vernietigde een beslissing op het bezwaarschrift (met het in stand blijven van de rechtsgevolgen van het vernietigde besluit) omdat de kennelijke ongegrondverklaring in strijd was met art. 7:3. Doorslaggevend voor de vernietiging was de inhoud van het bezwaarschrift en de merites van de in het geding zijnde naamswijziging. ${ }^{26}$ In een andere kwestie werd een kennelijk ongegrond bezwaar als rechtens juist beoordeeld omdat er geen twijfel mogelijk was over de toepassing van art. $7: 3$ (gebonden beschikking). ${ }^{27}$

In hoger beroep werd een uitspraak van de $\mathrm{Rb}$. Zwolle vernietigd door de ABRS. De $\mathrm{Rb}$. was van oordeel dat art. $7: 2$, lid 1 een algemene verplichting inhoudt tot het opnieuw horen bij een nieuwe beslissing op het bezwaar.

De ABRS deelde deze opvatting wan de bestuursrechter niet. Wél wees de ABRS er op, dat het onder omstandigheden, uit een oogpunt van zorgvuldigheid,

23 I.M.H.F. Teunissen, in: Algemene wet bestursrecht, losbl, Den Haag, Commentaar artikel 7:3 (6.3.8), p. E. 6.3.8-5 e.v., H.J. Simon, De kleine revolutie: ến jaar besturen onder de Awb II, JB 1995, 50, p. 182 en H.J. Simon, Handleiding Awb-praktijk, a.w., p. 194-197.

Pres. Rb. Groningen 4 nowember 1994, Awb-katern 1995, 16.

CRvB 2 maart 1995, AB 1995, 315 m.nt. PJS.

ABRS 14 maant 1996, AB 1996, $289 \mathrm{~m} \cdot \mathrm{nt}$, AFMB.

ABRS 25 maart 1996, AB 1996, 288 . 
noodzakelijk kan zijn bij thet nemen van een nieuwe beslissing op het bezwaar, opnieuw te horen. ${ }^{28}$

Een beslissing op het bezwaar werd door het CBB vernietigd omdat in het besluit niet was vermeld dat en waarom appelant op zijn bezwaarschrift niet was gehoord. ${ }^{29}$

In een andere kwestie ging het CBB geheel voorbij aan een kennelijk ongegrond bezwaar omdat appelant op dit gebrek niet had gewezen. ${ }^{30}$

Ook de N.o. heeft zich uitgesproken over het criterium 'kennelijk' ongegrond. Onder verwijzing naar de MvT is de N.o. van oordeel dat een bezwaarschrift of beroepschrift kennelijk ongegrond is, "wanneer uit dit geschrift zelf al direct en zonder nader onderzoek ongegrond blijkt te zijn'.

Wél moet er redellijkerwijs geen twijfel bestaan over die conclusie. ${ }^{31}$

Irimiddels oordeelde de ABRS ook over het karakter van de hoorplicht op grond wan art. 7:2. De ABRS is van mening dat art. 7:2 niet kan worden aangemerkt als een bepaling van openbare orde. Door een appelant was de schending van de hoorplicht niet in zijn beroep bij de $\mathrm{Rb}$. vermeld. De ABRS vernietigde de beslissing van de rechtbank in hoger beroep, ondat deze met de uitspraak was getreden buiten het object van het geschil. Wél erkende de ABRS de hoorplicht als een essentieel onderdeel van de bezwaarschriftenprocedure. ${ }^{32}$ De ABRS bleek in deze zaak niet bereid om ambtshalve met toepassing van art. 8:69 het achterwege laten van de hoorplicht met vernietiging te 'bestraffen'. Of art. 8:69 voor de toepassing van art. 7:3 hiermee volledig vaste rechtspraak is, moet nog maar worden afgewacht.

Wel heeft de ABRS met haar oordeel dat art. 7:2 geen bepaling van openbare orde is, willen aangeven dat zij art. 7:2 ziet als een voorschrift dat afhankelijk van de wil en kennis van partijen moet worden bewaakt. ${ }^{33}$

Als specifiek vereiste voor de inrichting van de bezwaarschriftenprocedure geldt, dat deze besluitvormingsprocedure dient plaats te vinden zonder vooringenomen-

ABRS 15 mei 1997, AB 1997, 263.

CBB 30 januari 1996, nr. 95/1437/108/212.

CAB 27 meil 1997, AB 1997, 279 m.nt. JHWdV.

N.0. 26 september 1997 , AB 1998, 7, m. nt. PJS.

ABRS 29 juli 1996, RAwb, 127 m.nt. Widdershoven en JB 1996, 190, m.nt. MA Heldeweg.

Zie over bepalingen van openbare orde: R.J.G.M. Widdershoven, Formele waarheid en bepaling van openbare orde, NTB 1997, p 67 en M. Schreuder-Vlasblom, De Awb; het bestuursprocesrecht, vijfde dr., Deventer 1997 , p. 116 e.v. 
heid door of zijdens het bestuursorgaan. Naast dit in art. 2:4 gestelde verbod vormen de eisen als bedoeld in art. 7:5 bestuurlijke inrichtingseisen met betrekking tot het horen. Deze bemensingscondities van het bestuurlijke dan wel ambtelijke "hoorforum' beogen waarborgen te scheppen teneinde aan ongewenste vormen van partijdigheid het hoofd te bieden. Een bepaling van gelijke, maar verdergaande strekking, is opgenomen in art. $7: 13$ voor de adviescommissie. Deze laatste commissie vertoont min of meer onafhankelijkheidsaspecten omdat bij deze commissie in ieder geval de voorzitter geen deel mag uitmaken van het bestuursorgaan dan wel niet werkzaam mag zijn onder verantwoordelijkheid van het bestuursorgaan.

De relatie van deze Awb-bezwaarschriften-adviescommissie met het horen is vastgelegd in het derde lid van art. 7:13. Als een 'artikel 7:13-commissie' voor de behandeling van de bezwaarschriften is ingesteld, geschiedt het horen door deze commissie. Noch art. 7:5, noch art. 7:13, garanderen een geheel onafhankelijk horen dat vergelijkbaar is met de openbare behandeling van een beroep bij de bestuursrechter. Toch kunnen deze bepalingen, zij het genuanceerd, in relatie worden gebracht met de inrichtingseis van onafhankelijke rechtspraak. Inrichtingseisen worden aan een procedure gesteld in het belang van het waarborgen van een beslissing die aan de procesrechtsbeginselen voldoet. ${ }^{34}$

Gewezen is op de gemaakte onderscheiding in de waarborgen voor een 'goed' procesrecht. Als waarborg zijn genoemd de toetsingsnormen voor de behandeling van een zaak in concreto. Deze waarborg wordt door De Waard aangeduid met de term beginselen van behoorlijk procesrecht. In de wetenschappelijke benadering van De Waard legt deze een verband tussen de beginselen van behoorlijk procesrecht en de algemene beginselen van behoorlijk bestuur.

'Beiden soorten beginselen zijn ook te zien als voornamelijk procedurele beginselen. Ook de beginselen van behoorlijk bestuur. Deze hebben immers vooral betrekking op de vraag: hoe de beslissing tot stand is gekomen? en niet de vraag: welke bestissing is genomen? Dat geldt voor de zogenaamde formele beginselen van behoorlijk besturur. Dat zulks zij het in mindere mate geldt voor de materiele beginselen van behoorlijk bestuur wordt hier in dit bestek buiten beschouwing gelaten.'

De geciteerde opvatting van De Waard is van belang in het kader van de beoordeling van het procedureelrechtelijke aspect van het horen. ${ }^{35}$ Deze opvatting van De Waard duidt in belangrijke mate op het karakter van het procedureelrechtelijk 
aspect van het horen; hoe het besluit in casu de op het bezwaarschrift te nemen beslissing tot stand komt wordt bepaald door het horen als procedure-voorschrift.

Dat hieruit een (formeel) behoorlijkheidsbeginsel valt te concluderen mag uit hetgeen hiervoren is belicht duidelijk zijn.

De eils van het horen wordt daarom als een belangrijk beginsel van behoorlijke procesvoering aanvaard; naast andere aan de jurisprudentie ontsproten beginselen onder de rechtsmacht van de CRvB, en de voor het arob-tijdperk fungerende ARRS. Die andere aan de bestuursrechtspraak ontleende beginselen omvatten kort samengevat: de doorzendplicht, het verdedigingsbeginsel en het vereiste van consistent proceshandelen. ${ }^{36}$

De procesbeginselen c.q. de procedurebeginselen, zijn gebaseerd op de eis van 'behoorlijkheid'. Deze aan hoor en wederhoor gestelde behoorlijkheidseis als beginsel van behoorlijke 'procesvoering', heeft in het kader van de voorbereiding van een beslissing als formeel zorgvuldigheidsbeginsel, reeds vóór de $\mathrm{A} w \mathrm{~b}$, onder de werking van de Wet arob, ja zelfs onder de werking van de Wet Bab zijn constante inkadering gevonden in de jurisprudentie. ${ }^{37}$ In tegenstelling tot het materiële zorgvuldigheidsbeginsel dat zich richt op de bij een besluit te maken belangenafweging, duidt het formele zorgvuldigheidsbeginsel op de eisen die aan het bestuursorgaan gesteld worden, ten alanzien van de voorbereiding van de besluitvorming. Naast de voorbereiding van de beslissing op een bezwaarschrift, valt daar ook onder de formele voorbereidingszorgvuldigheid die bij de primaire beslissing in acht moet worden genomen. Het formele zorgvuldigheidsbeginsel bij de besluitvorming, in casu de in het kader van de op het bezwaarschrift te nemen beslissing, kan op vele aspecten betrekking hebben. Naast het horen, kan hier worden gedacht aan de wijze waarop met adviezen wordt omgesprongen (afd. 3.3), de kennisvergaringsplicht als bedoeld in art. 3:2 Awb, om in dit verband maar enkele voorbeelden te noemen. ${ }^{38}$

Uit deze in de Awb als rechtsnormen geïnorporeerde beginselen blijkt dat de hoorplicht als bedoeld in art. 7:2 Awb, geen nieuwe procedurele en formele zorgvuldigheidsnorm is die voor de gang van zaken bij de bezwaarschriftenprocedure als principiële procedureelrechtelijke eis geldt.

Van Wijk/Konjunenbell, a.w., p. 663 e.v.

J.G. Steenbeek en F.A.M. Stroink, Wet arob, wierde herziene dr. "s-Gravenhage 1988, p. 256 e.v.

Van Wijk-Konijnenbelt a. a., p. 320 e.v. 
De hierna in her kort te geven schets toont aan dat 'het horen' als procedurele verplichting ook vóór de inwerkingtreding van de Awb gold; zij het dat in sommige gevallen sprake kon zijn van overtreding van een rechtsnorm en in andere gevallen strijd met het zorgvuldigheidsbeginsel in beeld kon komen.

\subsubsection{Het horen in de Awb is geen bestuursrechtelijk novum}

In de $\mathrm{Awb}$ is gekozen voor een uniforme hoorplicht die voorafgaat aan de op het bezwaarschrift te nemen beslissing. Deze in de Awb nagestreefde uniformering ligt ten grondslag aan een der belangrijkste hoofddoelstellingen van deze wet. Vanuit het perspectief van een der hoofduitgangspunten van de $A w b$, te weten het streven naar een zo groot mogelijke harmonisatie, is de hoorplicht op veel terreinen van het bijzonder bestuursrecht ingevoerd. Afwijking van het harmonisatieprincipe van de Awb achtte de wetgever in beginsel ongewenst. ${ }^{39} \mathrm{Dit}$ door de $\mathrm{Awb}$ gekozen uitgangspunt betekent niet dat er op deelterreinen van het bijzonder bestuursrecht geen uitzonderingen bestaan ten aanzien van de hoorplicht ex art. $7: 2$.

Het belastingrecht, kent een afwijking van de hoorplicht. Van de $\mathrm{Awb}$ is afgeweken bij de aanpassingswetgeving. ${ }^{40} \mathrm{Bij}$ deze aanpassingswetgeving is art. $25 \mathrm{Awr}$ gewijzigd, met dien verstande dat in afwijking van art. 7:2 de belanghebbende (belastingplichtige) op zijn verzoek wordt gehoord. Tegelijkertijd is de mogelijkheid geopend om van de voorgeschreven inrichtingswijze wan het horen af te zien. Dit betekent dat niet voldaan behoeft te worden aan het gestelde in art. 7:5. De gewijzigde Awr bepaalt in art. 25, dat indien de omstandigheden daartoe nopen het horen kan geschieden in afwijking van art. 7:5 van de Algemene wer bestuursrecht'.

Aanleiding voor deze uitzonderingspositie van het belastingrecht is geweest, de discussie omtrent de eigen aard van het belastingrecht en de min of meer eigen bestuurscultuur. ${ }^{41}$ De kritiek op een integrale invoering van de Awb woor het belastingrecht was van dien aard dat men stelde dat de Awb niet geschreven was met het oog op de praktijk van de belastingwetgeving. De bezwaren waren grotendeels gericht op de omvang van de bestuurslasten. Daarnaast was er kritiek orndat in het belastingrecht nog de mogelijkheid bestaat om geen toepassing te geven aan art. 7:5 (wie hoort). Praktijk is dat bij de belastingdienst in het merendeel der gevallen het horen in het kader van de bezwaarschriftenprocedure geschiedt door ambtenaren die de bestreden aanslag zelve hebben opgelegd. Op

39. $\quad$ PG Awb I, p. 330 .

40 Wet wan 4 juni 1992, Stb. 422.

4! Ch.P.A. Geppaart, De betekenis van de Algemene wet bestuursrecht voor het belastingrech, Alphen aan den Rijn 1992, p. 10 e.v. 
doelmatigheidsoverwegingen is van het dwingend voorschrift als bedoeld in art. $7: 5$ Awb afgeweken. ${ }^{42}$

Hiervoor bleek dat de hoorplicht als procedure-aspect door de Awb voor een groot gedeelte van het bestuursrecht is ingevoerd. Toch is de hoorplicht geen novum op het terrein van het bestuursrecht. Met deze hoorplicht is veel ervaring opgedaan als procedureel aspect bij geschilbeslechtende besluitvormingsprocedures in het kader van bezwaarschriftenregelingen. Ook op het terrein van het administratief beroep was het horen geen onbekende procedurele rechtsfiguur. Het is niet zó, dat de hoorplicht zonder slag of stoot op enig moment in het ('oude') administratiefrecht "gemeengoed" werd. De ontwikkeling van de hoorplicht als formeel zorgvuldigheidsaspect heeft een lange en moeizame weg gekend.

Dat het horen als procedure-element in het verleden in het kader van de rechtsbescherming niet zo'n vanzelfsprekend aspect vormde, blijkt uit het volgende citaat uit een bekend handboek op het terrein van het Nederlands bestuursrecht. Dit citaat heeft betrekking op een gevolgde procedure op grond van de Wet op de bevoegdheden van de hoogheemraadschappen. ${ }^{43}$ Donner geeft in het kader van de toepassing van art. 14 van dit oude waterschapsrecht de casuïstiek als volgt weer.

'Daarbij werd aan gedeputeerde staten de bevoegdheid gegeven om partijen te horen of hun gelegenheid tot schriftelijke toelichting hunner bezwaren te geven. Hier raakte men aan de zwakke stee, die uit de hitte van het gevecht over het conflictenbesluit aan de aandacht was ontsnapt. Met de procedure voor de behandeling van geschillen door gedeputeerde staten en de Kroon was het droevig gesteld. Door de Raad van State werd nooit enig contact met partijen gezocht: de zaken werden geheel binnenskamers behandeld. Men gaf een advies aan de Koning op de door deze daartoe toegezonden stukken. Over die bescheiden pleegde men nader overleg met de betrokken minister, bij wie of door wie men zo nodig nadere informatie inwon. Maar daarmede liep de zaak dan ook af. Aan het horen van partijen werd nog niet gedacht, het ging nog geheel om de uitoefening van toezicht op de lagere besturen.; ${ }^{34}$

Dit citalat over het vroegere denken van de hoorplicht behoeft geen of nauwelijks enige toelichting.

44 A.M. Donner, a.w., p. 308 en Scholtens, Uit de Praktijk der beslissing van geschillen door de Kroon, 1913, p. 22 e.v. 
Datzelffe kan overigens gezegd worden van een korte weergave van een artikel van Donner omtrent het Rapport ABAR. ${ }^{45}$ In zijn commentaar op dit rapport zegt Donner onder andere in het kader van de in art. 6 van het rapport ABAR opgenomen hoorplicht het volgende:

"Heeft men de artikelen eenmaal "door", dan blijkt dat zij geen keiharde regel geven, doch slechts een geraamte opstellen, dat nog door de praktijk en onder controle van de rechter zall moeten worden ingevuld. Daarbij is een zekere geleidelijkheid mogelijk, in die $z$ in, dat de inhoud van begrippen als "voorbereiding", "betrekken" en "redelijkheid" voor ontwikkeling vatbaar is naarmate ervaring wordt opgedaan en de praktijk onder het kritisch oog van de jurisprudentie - evolueert. Het zijn geen bepalingen, die aanstonds "rechtszekerheid" zullen brengen, noch voor de belanghebbenden, noch voor de "overheidsorganen", maar zij openen een perspectief van "verhoogde rechtsbescherming" eerst naar de ene, en op den duur ook naar de andere zijde. Daarmee is niet gezegd, dat zulke bepalingen en wat er verder aan vastzit, geen vragen oproepen en problemen scheppen. Integendeel.

Het scheppen van een rechtsgang bij het bestuur is een nieuwe onderneming, die goed moet worden onderscheiden van de rechtsgang bij de administratieve rechter. Een eerste punt van verschil is, dat, anders dan bij de rechter, niet kan worden voorgeschreven, dat het beschikkend bestursorgaan zelf de belanghebbenden hoort of met hen overlegt." ${ }^{\text {sh }}$

Tot zover dit citaat waaruit twijfels over de hoorplicht doorklinken.

Door de Awb heeft de hoorplicht inmiddels in het bestuursrecht zijn procedurele verankering gekregen. Die verankering is gegroeid vanuit de ontwikkeling van gespecialiseerde rechtsgangen die wóór de inwerkingtreding van de Awb en ook vóór de Wet arob waren tot stand gekomen.

De behoefte aan een algemene regeling op het terrein van de rechtsbescherming is eerst sinds de inwerkingtreding van de Wet Bab gaandeweg tot ontwikkeling gekomen. Indien op enig onderdeel van het bestuursrecht een beroepsgang bestond, werd in sommige gevallen het beroep op de administratieve rechter, ingeleid door een bezwaarschrift tegen de aangevallen beschikking, bij hetzelfde orgaan dat die beschikking oorspronkelijk gegeven had. De belastingrechtspraak en de pensioenrechtspraak kenden verplichte bezwaarschriftenprocedures. Facultatief was er aanvankelijk een bezwaarmogelijkheid opgenomen in de Wet administratieve rechtspraak bedrijfsorganisatie.

46 A.M. Donner, Algemene bepalingen van administratief recht, NJB 1974, p. 1087 en 1088. 
Van een algemene hoorverplichting was nog geen sprake. Een zelfde situatie bestond in het sociale verzekeringsrecht. Kon men zich niet verenigen met door een verzekeringsorgaan genomen beslissing, dan bestond wél de mogelijkheid om voorafgaand aan het beroep op de administratieve rechter een gemotiveerdle beschikking te vragen. De mogelijkheid bestond een voor beroep vatbare beslissing te vragen. ${ }^{47}$ Maar van een horen in de zin van hoor-en wederhoor, en het mondeling van gedachten wisselen, was vanuit het gezichtspunt van 'de voor beroep vatbare beslissing' geen sprake. Dit laatste kan uit de raadpleging van de oudere literatuur worden bevestigd. Uit het rapport Algemene bepalingen van administratief recht blijkt de terughoudendheid van procedureregels in het kader van het tot stand komen wan beschikkingen. Uit die literatuur blijkt, dat wettelijke totstandkomingsvereisten voor 'beschikkingen' in Nederland schaars waren. Voorbeelden zijn: de verplichting tot het horen van belanghebbenden voordat op een verzoek om een vergunning ingevolge de Hinderwet wordt beschikt (art. 7 e.v. Hinderwet), de verplichting tot het plegen van overleg met de inspecteur van het lager onderwijs, ten aanzien van een woordracht tot benoeming van een onderwijzer bij het lager onderwijs (art. 36 L.O.-wet 1920) en de verplichting tot het horen van een ambtenaar voordat hem een disciplinaire straf wordt opgelegd (art. 82 ARAR). ${ }^{48}$

Ofschoon deze aspecten de voorbereiding van beschikkingen betroffen, blikt hier well dat een hoorplicht geen vanzelfsprekendheid was in het besluitvormingsproces. Van een wettelijke regeling inzake het horen kon niet of nauwelijks worden gesproken.

Onder invloed van de groei van bijzondere administratiefrechtelijke voorzieningen kwam er gaandeweg verandering. In verscheidene wettelijke regelingen werden voorschriften opgenomen op grond waarvan een bestuursorgaan, dan wel een college of commissie van advies, verplicht was de (primair) belanghebbende(n) in de gelegenheid te stellen zich te doen horen, voordat definitief werd beslist, c.q. advies uitgebracht. Als niet uitputtende voorbeelden kunnen hier worden genoemid de art. 34 en 38 Wet RvS, art. 14 Wet arob, art. 109 Provinciewet, de art. 21 en 22 Wet Algemene bepalingen milieuhygiëne, art. 31, tweede lid Vreemdelingenwet en art. 82 Algemeen Rijksambtenarenreglement. ${ }^{49}$

47 ABAR, Groningen 1973, p. 293 e. $v_{\text {. }}$

4s ABAR, a.,., p. 73 e.V.

49 ABAR, Alphen aan den Rijn 1984, p. 128 e.v. Voor een meer uitwoerige aandacht in dit Rapport ABAR kam in dit werband worden gewezen naar Hoofdstuk 9 betreffende Rechtsbescherming. 
De Wet arob als algemene aanvullende rechtsbeschermingsregeling met de daarin aanvankelijk tot de decentrale bestuursorganen beperkte verplichte bezwaarschriftenprocedure, bracht met art. 14 de eerste algemene hoorplicht. Dat in de jurisprudentie zich via het beginsel van behoorlijk bestuur als formeel zorgvuldigheidsbeginsel, overigens een buitenwettelijke hoorplicht ontwikkelde, blijft in dit kader vooralsnog even onbesproken. Hierop zal worden teruggekomen in par. 3.2.1.3 (De juridische consequenties van het achterwege laten van de hoorplicht). In par. 3.2.1.3 worden rechterlijke toetsingscriteria onder de loep genomen, teneinde de ontwikkeling in de (rechterlijke) toetsing ten aanzien van de hoorplicht een scherper contrast te geven.

Uitgangspunt is hierbij om beter zichtbaar te maken wat de toetsing van de hoorplicht betekende bij afwezigheid van enige wettelijke hoorplicht ten opzichte van het horen op grond van art. 14 van de Wet arob, en de plicht tot het horen op grond van art. 7:2 Awb. Alvorens hieraan aandacht te besteden, wordt nog even stilgestaan bij de wettelijke hoorverplichting die zich als procedureel voorschrift in gemeentelijke en provinciale verordeningen vóór de inwerkingtreding van de Wet arob aftekende.

Vaak zijn de lagere gebiedscorporaties de voortrekkers op het terrein van het recht en de ontwikkeling van datzelfde recht, en de "wegbereiders" van nieuwe regelgeving.

Ook op het gebied van de rechtsbescherming hebben de gemeenten via hun verordeningen rechtsbeschermingsvoorzieningen gecreëerd en zijn daarmede vooruitgelopen op de naderhand door de centrale overheid vastgestelde rechtsbeschermingsregelingen. De door de gemeenten in het verleden tot stand gebrachte regelingen op het gebied van lokale rechtsbescherming, kregen gestalte in de vorm van verordeningen, waarin de bezwaarschriftenprocedure en de procedure voor het administratief beroep, nadere uitwerking vonden. Ten dienste van de gemeentelijke bestuursorganen, in casu burgemeester en wethouders en onderscheidenlijk de gemeenteraad, werd al vóór het arob-tijdperk een modelverordening ontworpen door de Vereniging van Nederlandse Gemeenten. ${ }^{50}$ Deze modelverordening bevatte toen al een aantal bepalingen van procedurele aard die vergelijkbaar zijn met de thans voor de bezwaarschriftenprocedure in afdeling 7.2 opgenomen regels. Ook voor het horen van belanghebbenden werd in deze model-verordening een plaats ingeruimd in het belang van de voorbereiding van de op het bezwaarschrift (en ook het administratief beroep op de gemeenteraad) te nemen beslissing. Ofschoon niet expliciet over "het horen" werd gerept, spreekt

so Blawwe reeks nr. 48, Behandeling van bezwaar- en beroepschriften door gemeentebesturen, VNG. "s-Gravenhage 1972. 
het voor zich dat de redactie van art. 7 van de bovengenoemde model-verordening daarop doelde. Art. 7 van deze model-verordening geeft aan, dat de voor de hoorzitting gestelde minimum-eisen nauwe samenhang vertonen met de procedurebepalingen die in de Awb zijn opgenomen.

Art. 7 , lid 2 bepaalde:

1. De voorzitter bepaalt plaats en tijdstip van de vergadering van het beschikkend orgaan tot behandeling van het bezwaar.

2. Hij doet hiervan mededeling aan de belanghebbenden.

3. De belanghebbenden kunnen hun standpunt in deze vergadering persoonlijk of bij gemachtigde toelichten.

4. Een gemachtigde moet een schriftelijke en door de belanghebbende ondertekende machtiging overleggen, tenzij hij als advocaat of procureur is ingeschreven of de belanghebbende met de gemachtigde verschijnt." ${ }^{\text {s. }}$

Ook op andere terreinen van het bestuursrecht zijn in gemeentelijke verordeningen bepalingen terug te vinden inzake een materieel-wettelijk voorgeschreven hoorverplichting. In die gevallen dat door gemeenten geen (algemene) verordening was vastgesteld voor de behandeling van bezwaar- en beroepschriften, kon ook gebruik worden gemaakt van een bijzondere procedure-regeling voor de behandeling wan bezwaren en beroepen. Zo'n voorgeschreven hoorverplichting was bijvoorbeeld ook opgenomen in een uit 1971 daterende model Bouwverordening van de VNG, zij het dat zowel bezwaar en beroep onder een noemer werden gebracht. Hoofdstuk 10 van deze model Bouwverordening bevatte algemene regels ten aanzien van het beroep. Voor het (administratief) beroep op de gemeenteraad bepaalde art. 390 , lid 3 :

'Alvorens de gemeenteraad op een ingesteld beroep beslist, wordt de belanghebbende in de gelegenheid gesteld door de raad of door een door de raad aangewezen commissie te worden gehoord.'

Art. 393, lid I schreef een hoorplicht voor ten behoeve van de behandeling van het 'beroep' (in feite bezwaar) door burgemeester en wethouders. ${ }^{52}$

Ter afronding wordt gewezen op de al bestaande hoorplichtregelingen voór de inwerkingtreding van de Wet arob in de vanouds bestaande procedurevoorschriften, die voorkwamen in provinciale verordeningen ex art. 109 Provinciewet. In

51 Blauwe reeks, a.w., p. 16 e.v. en 33.

52 Model bouwverordening, herdruk 1971, bijgewerkt tot en met $13 \mathrm{e}$ supplement, VNG, "sGravenhage 1971 . 
art. 109, dat voorschreef om ten behoeve van de behandeling van administratieve geschillen een verordening vast te stellen, bepaalde het derde lid dat in deze verordening een hoorplicht moest worden opgenomen. In art. 109, lid 3 was deze hoorplicht als volgt geredigeerd:

3. De verordening verleent de belanghebbenden voorts de bevoegdheid hun standpunt in een vergadering van gedeputeerde staten persoonlijk of door hun gemachtigden toe te lichten."

De nieuwe Provinciewet bevat in art. 168 een gelijkluidend voorschrift dat verplicht tot het vaststellen van een (procedure) verordening voor de behandeling van administratieve geschillen in casu het administratief beroep. De hoorplicht is evenwel niet afzonderlijk voorgeschreven omdat thans afdeling $7.3 \mathrm{Awb}$ bijzondere bepalingen geeft aangaande het administratief beroep. De hoorplicht in het kader van het administratief beroep vindt verankering in art. 7:20.

In beeld is gebracht, dat de hoorplicht ex art. 7:2 Awb in feite geen bestuursrechtelijk novum is, en dat voorafgaande aan de $\mathrm{Awb}$, en ook vóór de inwerkingtreding van de Wet arob de hoorplicht in het kader van voorprocedures geen onbekend procedureelrechtelijk fenomeen was. Zelfs in die gevallen dat geen wettelijke hoorplicht bestond, was het horen een eis op grond van de jurisprudentie (formeel zorgvuldigheidsbeginsel), in het belang van een goede voorbereiding van het bestreden besluit. Door de Awb zijn de diverse verspreid voorkomende hoorverplichtingen als het ware procedureel opgeschoond en als een algemene verplichting in de $A w b$ verankerd. Ter afronding van de procedureelrechtelijke kant van het horen wordt hierna op basis van enige jurisprudentie, globaal in beeld gebracht, wat de (formele) consequenties waren en zijn bij het niet in acht nemen van de hoorverplichting.

\subsubsection{De juridische consequenties van het achterwege laten van de hoorplicht De wettelijke hoorplicht op grond van de Wet arob heeft zich ontwikkeld in de jurisprudentie.}

In de vorige paragraaf kwam vast te staan dat de hoorplicht die uiteindelijk in de Awb als beginselverplichting is opgenomen, kan bogen op een rijke traditie. In de loop der jaren is veel jurisprudentie ontwikkeld over het horen. Het niet nakomen van de hoorplicht werd door de bestuursrechter (om deze meer moderne term maar te gebruiken) regelmatig 'bestraft'. Het is niet de bedoeling een uitputtende 
verhandeling te geven over het achterwege laten van de hoorverplichting. Wél zal worden gewezen op enige aan de jurisprudentie ontleende uitspraken. ${ }^{\$ 3}$

Uit de jurisprudentie kan worden afgeleid, dat het niet in acht nemen van een hoorplicht, ook al was deze niet wettelijk voorgeschreven, tot vernietiging van het bestreden besluit kon leiden. Indien een verplichting tot het horen van belanghebbenden werd aangenomen in andere dan wettelijk omschreven gevallen, vloeide die verplichting naar het oordeel van de toetsende rechter voort uit het beginsel, dat de administratie haar besluiten zorgvuldig moet voorbereiden. Uit deze aan het rapport ABAR ontleende visie moge het volgende blijken. ${ }^{5 / 4}$

"Aan de rechtspraak zijn geen scherpe criteria te ontlenen ter beantwoording van de algemene vraag, in hoeverre de - vrij vage - eis van zorgvuldige voorbereiding insluit dat belanghebbenden gelegenheid behoren te krijgen tot deelneming aan een discussie over de te nemen beslissing, of althans tot het, mondeling of schriftelijk, aanvoeren van argumenten. Intussen biedi de jurisprudentie ook geen steun voor de beperkte opvatting. dat een buitenwettelijke hoorplicht alleen zou kunnen bestaan in gevallen waarin het horen van belanghebbenden nodig is voor het onderzoek natar relevante feiten en omstandigheden."

Een interessante uitspraak van de CRvB laat aan duidelijkheid niets te wensen over en toont aan dat het horen als zorgvuldigheidsaspect bij de voorbereiding van de besluitvorming moet worden betrokken. Dat in deze zaak geen vernietiging werd uitgesproken wegens strijd met het formele zorgvuldigheidsbeginsel, had overigens te maken met het door deze administratieve rechter geconstateerde materiële gebrek. In casu werd strijd met het rechtszekerheidsbeginsel uitgesproken. ${ }^{55}$ Overigens blijkt de literatuur nog in het begin van de jaren tachtig niet eenduidig te denken over de hoorplicht als formeel zorgvuldigheidsbeginsel, voorzover het gevallen betreft watin het horen miet wettelijk was voorgeschreven. ${ }^{56}$

53 Deze voorbeelden hebben zowel betrekking op het primaire besluit als de bezwarfase.

54 ABAR 1984, a.w., p. 129 e.พ.

5s CRvB 11 oktober 1977, AB, 1978, $45 \mathrm{~m}$.nt. De Raad sprak bij de beoordeling van een bestreden beschikking van de Uitkeringsraad over "de zich in administratiefrechtelijke kring baanbrekende gedachten omtrent het voorafgaande aan een beschikking horen van belanghebbende, ook wanneer zulks niet wettelijke is voorgeschreven'. Rapport ABAR 1984, p. 129.

56 ABAR, a.w., p. 130. Zie tevens noot 39. In het rapport wordt daar anders over gedacht, en word een algemene hoorverplichting aangenomen. Zie in dit verband p. 139 
De mogelijkheid bestat ook dat bij organieke wet imperatief wordt voorgeschreven om bij wege van verordening de hoorplicht nader te regelen. In dit geval wordt nog eens gewezen op art. 109, derde lid Provinciewet (oud).

De Provinciewet gaf indertijd een directe regeling van de hoorplicht, maar droeg provinciale staten op de hoorplicht in een verordening vast te leggen. De volgende casus heeft betrekking op het horen op grond van een art. 109-verordening.

In deze casus leidde het niet horen tot vernietiging. In een Zandvoortse Kieswetzaak waarbij de toelating van iemand als raadslid ter discussie stond in het kader van een onderzoek naar de geloofsbrieven, bleek dat bepalingen over de hoorplicht niet in acht waren genomen. Het in administratief beroep door gedeputeerde staten genomen besluit werd vernietigd. De Kroon was van oordeel, dat het bestreden besluit van gedeputeerde staten van Noord-Holland niet op de voorgeschreven wijze tot stand was gekomen. ${ }^{57} \mathrm{Bij}$ dit $\mathrm{KB}$ zij overigens opgemerkt dat enkele hierna uit de literatuur geciteerde administratiefrechtelijke uitspraken nog eens duidelijk laten zien, dat het formele zorgvuldigheidsbeginsel noopte tot een nauwgezette houding wan het bestuursorgaan om een besluit procedureel correct voor te bereiden. Het betrof hier een viertal uitspraken. ${ }^{58}$

"Indien een wettelijk voorschrift een orgaan niet verplicht om degene die van een administratiefrechtelijke voorziening gebruik maakt te horen, neemt zulks niet weg, dat onder bepaalde omstandigheden het niet-horen strijdig is met het beginsel dat besluiten zorgvuldig moeten worden voorbereid en genomen. In casu doet zich een dergelijk geval voor, nu het een betrekkelijk zware sanctie op een slechts eenmaal beweerdelijk gepleegde overtreding betreft. Vz. ARRS 19 juni 1981, Gst. 6693, 4.

Terughoudendheid is geboden bij de uitvoering van een verscherpt beleid als het een bouwwerk betreft dat jarenlang ongemoeid is gelaten. In ieder geval dient een redelijke overgangstermijn te worden gegeven en zo mogelijk in overleg met de betrokkene te worden nagegaan of vervangende voorzieningen kunnen worden getroffen. ARRS 5 september 1979, AB 1980, 32.

Strafontslag met onmiddellijke ingang wegens ernstig plichtsverzuim van een wetenschappelijk ambtenaar. Het ambtenarengerecht acht het besluit (mede) strijdig met het beginsel dat het bestuur zijn besluiten zorgvuldig dient voor te bereiden. Hoewel aan de formele voorschriften met betrekking tot het opleggen van een straf is voldaan vereist een zorgvuldige voorbereiding van een zodanig ingrijpende straf in ieder geval een andere vorm van gesprek en/of overleg dan in casu is gebezigd. Ambtenarengerecht Amsterdam 5 mei 1978, A 1977-14 en 15, Cremers Adm. Rechtspraak 2.2.4.2.3.

s7 KB 19 maart 1969, nr. 44, O.B. 1969, III.11, nr 28652; NG 1969, nr. 33, p. 404; AB 1969, p. 489 en Blauwe Reeks 48 , a.w.

$58 \mathrm{~J}$. in ' $\mathrm{t}$ Veld, derde, geheel herziene dr. doot N.S.J. Koeman, Zwolle 1985, p. 98 e.v. 
Een wetgering om een mesterij aan te wijzen als fokkerij-instelling wordt vernietigd (mede) wegens strijd met het zorgwuldigheidsbeginsel. Door niet in overleg te treden met de eigenaresse van de mesterij teneinde de motieven wan haar hauding te vememen en te keuren is in strijd met het zorgvuldigheidsbeginsel gehandeld. CBB 9 januari $1979, \mathrm{AB} 1979,299^{\circ}$.

Ter afsluiting wan deze paragraaf wordt er op gewezen dat enkele aspecten van hoorverplichting ex art. 7:2 Awb nog zullen worden besproken in de par. 5.3.9, $5.3 .10,5.4 .9$ en 5.4 .10

\subsubsection{Het horen als kans voor burgers en bestuursorganen}

\subsubsection{Algemene aspecten}

In de vorige paragraaf is aandacht besteed aan de procedureelrechtelijke kant van de functie van de hoorplicht. Het onderzoek richtte zich op de functie van het horen als formeel procedureel kader ten dienste van de op het bezwaarschrift te nemen beslissing. Daarbij bleek, dat het horen vanuit de procedurele benadering op zichzelf genomen geen inzicht biedt in de wijze waarop door het bestuursorgaan aan deze hoorplicht bestuursrechtelijke invulling wordt gegeven. Deze zuiver formele benadering beoogde verband te leggen met de vraag langs welke lijnen de procedure is verlopen. Hierbij werd een samenhang geconstateerd met de formele beginselen van behoorlijk bestuur. Het procedurerecht van de bezwaarschriftenprocedure kenschetste zich in de voorgaande paragraaf, voor wat betreft het horen tot een van het procesrecht afgeleid beginsel. Hierbij kwarn vast te staan dat het horen als algemeen beginsel uitgangspunt is in de bezwaarschriftenprocedure.

Dat (procedureel) hoorbeginsel als eis voor een behoorlijk verloop van de be$z$ waarschriftenprocedure, heeft tegen de achtergrond wan de hiervoor gekozen benadering een normatief aspect.

Naast het normatief aspect dat voor het horen geldt, kan dit ook worden gezegd over het verbod van vooringenomenheid als bedoeld in art. $2: 4 .^{59}$

59 R.J.G.M. Widdershoven, a.w., p. 4 en 44. In dit verband wordt opgemerkt dat Widdershoven onpartijdigheid (niet-vooringenomen) en ook hoor en wederhoor als bestuursprocedurechtelijk beginsel benadert. Van onafhankelijkheid bij bestuursorganen die geroepen zijn in het kader van een bezwarschriftenprocedure een beslissing te nemen (en dat geldt ook voor administratief beroep) kan geen sprake zijn. "Er is sprake van functionelle connexiteit tussen het zijn van ambisdrager in een geschubbeslechtende instantie (bijv. administratief beroepsorgaan) en ambtsdrager in een orgata van openbaar bestuur". Zie in dit verband: J.B.J.M. ten Berge en A.Q.C. Tak. Nederlands Administratief Procesrecht, Zwolle 1983, deel 1, nr 44. Viteraard geldt deze opvatting ook woor de door het bestuursorgaan op het bezwaarschrift te nemen beslissing. 
Gaf de inkadering van de hoorplicht als formeel zorgvuldigheidsvereiste alleen aan dat ter voorbereiding van de beslissing op het bezwaarschrift deze hoorplicht in acht moet worden genomen; geen antwoord werd daarbij gegeven op de vraag welke beslissing op het bezwaarschrift het bestuursorgaan moet nemen. Het antwoord op deze wraag moet helderheid geven over de materiele zijde van het horen van de burger door het bestuursorgaan. Van belang is hoe de functie van het horen zich verdraagt met de opdracht van de $\mathrm{Awb}$-wetgever om de beslissing op het bezwaarschrift ten grondslag te leggen aan een heroverweging van het bestreden besluit. Die in art. 7:11 Awb neergelegde besluitvormingsoptie komt er op neer dat het horen van belanghebbenden daarop dient te zijn afgestemd. Vanuit dit in de Awb opgenomen bestuursrechtelijke uitgangspunt, betekent de samenhang tussen art. 7:2 (horen voorafgaand aan de besluitvorming) en art. $7: 11$, lid 1 (beslluiten op basis van een heroverweging) dat aan de hoorplicht naast het geschetste procedurele aspect inhoudelijke betekenis moet worden toegekend. De hoorplicht brengt burger en bestuursorgaan als het ware bij elkaar en noopt beide actoren als betrokkenen bij het actuele geschil, tot actie. In de taalkundige zin heeft het horen beperkte betekenis. Van Dale's Groot Woordenboek der Nederlandse Taal verstaat hieronder: "aandachtig luisteren'. Art. 7:2 Awb is van ruimere en geheel andere strekking. De gewenste input (het horen) voor de besluitvorming zou gering zijn en als gevolg daarvan de kwaliteit van de output (heroverweging in het belang van de te nemen beslissing), nauwelijks beïnloeden.

Art. 7:2 Awb brengt in het tweede lid tot uitdrukking dat onder horen moet worden verstaan het naar voren brengen door belanghebbenden van 'hun zienswijze'. Het is evident, dat deze juridisch geformuleerde betekenis van "het horen," als het naar voren brengen van 'hun zienswijze', onvoldoende recht doet aan datgene wat van de bij de bestreden beslissing betrokken justitiabelen en ook het bestuursorgaan verwacht wordt. Een eerste verduidelijking op dit punt vormt de raadpleging van de $\mathrm{M} v \mathrm{~T}$ van de Awb.

Uit de MvT is af te leiden, dat het horen zowel een waarborgfunctie heeft voor de belanghebbende burgers als voor het bestuursorgaan. Met het oog op deze waarborgfunctie wordt verwacht dat de benodigde informatie die bij het horen verkregen wordi, een bijdrage kan worden geleverd aan een zorgvuldige heroverweging en de daarop af te stemmen besluitvorming. Hierdoor kan de wederzijdse informatie worden versterkt en de kwaliteit van de besluitvorming door een betere onderbouwing worden verbeterd. ${ }^{60}$

60) PG Awb I, p. 329. 
Deze uitgangspunten heeft de Awb-wetgever in een viertal functies geformuleerd ${ }^{61}$ :

'Allereerst biedt de bezwaarschriftenprocedure in een groot aantal gevallen aan betrokkene de belangrijkste mogelijkheid zijn mening naar woren te brengen bij het bestuursorgaan. En aangezien niet iedereen in staat is om zijn gedachten even goed schriftelijk te formuleren, is dit voor velen de beste methode om hun zienswijze toe te lichten.

Het horen kan er in de tweede plaats toe dienen om nadere informatie ter beschikking te krijgen. Zo kan blijken, dat de gegevens waarover het bestuursorgaan beschikt, nog onwolledig en gebrekkig zijn, zodat de oorspronkelijke beslissing herzien moet worden. Juist een mondelinge gedachtenwisseling kan daartoe een goede aanvulling zijn op de lot dan toe langs andere weg verzamelde gegevens opleveren.

In de derde plaats bestaat aldus de gelegenheid om meer in het algemeen naar een oplossing voor de gerezen problemen te zoeken. Die oplossing kan bestaan uit het tegemoet komen aan het bezwaar maar kan ook een ander karakter hebben. In dit geval kan de betrokkene gewezen worden op een andere weg om het door hem beoogde resultaat te bereiken, of kan in gezamenlijk overleg een compromis tot stand worden gebracht dat zonder hoorzitting wellicht niet bereikt zou zijn.

Tenslotte is het horen voor de burger van belang, omdat hij er van overtuigd kan raken dat aan zijn bezwaren ernstig aandacht is besteed. Ook al krijgt hij geen gelijk van het bestuursorgaan dan kan hem toch duidelijk worden dat met zijn standpunt rekening is gehouden. Soms kan hem op de hoorzitting duidelijk zijn geworden om welke reden niet aan zijn bezwaar tegemoet kan worden gekomen. Door de uitwisseling van informatie en wederzijdse standpunten kan het vertrouwen van de burger in de overheid worden wersterkt."

Deze vier functies van de bezwaarschriftenprocedure vormen op zichzelf genomen geen garantie voor een adequate verwulling van de hoorplicht. De Awbwetgever geeft dit ook toe. Enerzijds zijn er sterke onderlinge verschillen tussen de typen van bezwaar. Daarnaast is van evident belang op welke wijze de hoorzitting wordt geleid. ${ }^{62}$ Niet zonder betekenis is dat met de Wet arob veel ervaring is opgedaan. De Wet arob kende voor wat betreft het toepassingsbereik van de bezwaarschriftenprocedure weliswalar niet die omvang van de Awb, maar de in art. 14, lid 1. van de Wet arob opgenomen hoorverplichting heeft in de bestuurspraktijk gefungeerd als één grote proeftuin. De resultaten van deze proeftuin hebben hun weerslag gevonden in de arob-jurisprudentie. 
De minimumeisen die in de Awb ten aanzien van het horen in de art. 7:2 tot en met $7: 9$ zijn gesteld, bieden geen volledige garantie voor de kwaliteit van het horen. Deze procedurevoorschriften hebben wël een voorwaardenscheppende betekenis in het belang van de hoorplicht en kunnen als zodanig waarborgen creëren voor de kwaliteit van het horen. Tegelijkertijd komen deze procedureregels de functie van de bezwaarschriftenprocedure in de aanloop naar de uiteindelijke beslissing op het bezwaarschrift ten goede.

Toch heeft het gemis aan regels omtrent het horen tijdens de arob-periode door het nier vaststellen van de algemene maatregel van bestuur als bedoeld in art. 14, derde lid Wet arob, geenszins remmend gewerkt op de bestuurlijk-juridische beeldvorming ten aanzien van de hoorplicht. Het horen ten tijde van de Wet arob was en is ook nu een van de meest wezenlijke elementen van de bezwaarschriftenprocedure. Ofschoon art. 14, lid 3 Wet arob slechts tot het ontwerpen van een concept-a.m.v.b. leidde, heeft dit gemis aan codificatie van regels het inhoudelijk belang van het horen voor de op het bezwaarschrift te nemen beslissing, niet minder gestalte gegeven. Het gemis van onder andere regels omtrent het horen heeft kennelijk niet belemmerend gewerkt voor het functioneren van de bezwaarschriftenprocedure. ${ }^{6}$ Dit laatste wil overigens niet zeggen dat het belang van het stellen van regels omtrent het horen, welke regels thans zijn opgenomen in de art. 7:2 tot en met 7:9 Awb, hierbij wordt miskend.

Terugkomend op de vier Awb-functies van het horen, kan uit de wettelijke hoorplicht ex art. 7:2 Awb, waarbij de heroverwegingsplicht als bedoeld in art. $7: 11$, lid 1, als referentiekader dient, een aantal bestuurlijk-juridische opties worden geabstraheerd. Op grond hiervan dient de invulling van de hoorplicht zich te richten op enige in de volgende paragraaf uit te werken uitgangspunten. Puntsgewijze komen deze op het volgende neer.

1. De hoorverplichting is een kans voor de belanghebbende( $n$ ) tot informatieverschaffing omtrent de bestaande grieven ten aanzien van het bestreden besluit. Tegelijkertijd is er een plicht zijdens het bestuursorgaan het ter discussie gestelde besluit nader te adstrueren. ${ }^{64}$

2. De op basis van in sub 1 verkregen en te verifièren informatie moet zo nodig kunnen leiden tot het corrigeren van feiten, het wijzigen van een onjuiste toepassing van het recht en het gevoerde beleid. Deze verificatieplicht vloeit voort uit de onderzoeksplicht als bedoeld in art. $3: 2$, die gericht is op de

63 De Arob-bezwaarschriftenprocedure, Eindrapport van de commissie Arob, Den Haag 1987, p. 16 .

64 J.M.H.F. Teunissen, a.w., p. E 6.3.7.2 e.v. 
noodzakelijke kennisvergaring omtrent de relevante feiten en de af te wegen belangen.

3. De hoorplicht biedt de mogelijkheid voor het bestuursorgaan orn zich actief en bemiddelend op te stellen ten aanzien van de in de bezwaarschriftenprocedure naar voren gekomen bezwaren; deze aan het horen toegedachte bemiddelingsfunctie $^{65}$ kan enerzijds betekenen dat het bestuursorgaan een pacificerende rol in de bezwaarschriftenprocedure vervult door een verzoenende houding aan te nemen in een conflict tussen belanghebbenden onderling dan wel tussen belanghebbenden en het bestuursorgaan. Ook kan worden gedacht aan de mogelijkheid dat problemen worden opgelost buiten het onderwerp van het geschil. De mogelijkheid kan immers bestaan dat tijdens het horen het gehanteerde beleid conflictueus blijkt te zijn, dan wel manco's in de uitvoering daarvan zijn waar te nemen. Vanuit dit laatste gezichtspunt bezien, kan van de hoorplicht een evaluerende en corrigerende functie uitgaan.

4. Tenslotte kan uitgangspunt zijn het versterken van de communicatie tussen de belanghebbende burgers en het bestuursorgaan. Op grond hiervan kan het horen door of namens het bestuursorgaan dienst doen als een therapeutische functie, waarbij de legitimatie van het genomen primaire besluit kan worden versterkt. ${ }^{66}$

De functie van de hoorplicht als communicatiemiddel (punt 4) tussen burgers en het bestuursorgaan en als mogelijkheid voor het versterken van de legitimatie voor de bestuurlijke besluitvorming, krijgt hierdoor meer het karakter van een ombudsfunctie. De hoorplicht vervult een signaalfunctie voor zowel het bestuursorgaan als de ambtelijke organisatie. In die gevallen, waarbij tijdens het horen al vaststaat dat heroverweging niet tot een voor de belanghebbenden gewenst resultaat leidt, en de $A w b$ als rechtsbeschermingskader weinig of geen mogelijkheden biedt, krijgen burgers en bestuursorganen als het ware een "tweede kans". Langs een andere minder formeel-juridische weg, kan door het bestuursorgaan aandacht worden besteed aan wensen en werlangens van burgers die nopen tot herstel van tekortkomingen in de bestuurlijke organisatie.

Burgers klagen regelmatig over onzorgvuldig handelen door de overheid. Dit klachtenpatroon van de burgers bestrijkt vele aspecten buiten de werkingssfeer van de $A$ wb. Besluiten zijn immers het voorwerp van toetsing in het kader van de

6 A.W. p. E 6.3.7-4.

66 A.w. . . E.6.3.7-5 
bezwaarschriftenprocedure. Klachten die zich toespitsen op onbehoorlijke gedragingen door of namens het bestuursorgaan vallen daar niet onder. In het kader van deze ombudsfunctie die van het horen kan uitgaan, kan aan klachten van burgers zoals bijvoorbeeld gebrek aan voortvarende behandeling van zaken, administratieve onnauwkeurigheid en incorrecte bejegening ${ }^{67}$, bijzondere aandacht worden besteed. Het bestuursorgaan heef hierdoor een mogelijkheid om langs andere wegen de dienstverlening ten behoeve van de burgers te verbeteren.

Bij het bespreken van de functie van het horen werd gewezen op het op de hoorplicht gebaseerde beginsel van "hoor en wederhoor" als beginsel voor een behoorlijke procedure. Dit 'procesrechtelijke' beginsel beoogt, vanuit zijn materieel perspectief bezien, de actoren in een procedure een gelijkwaardige positie te verschaffen. ${ }^{68}$ Vanuit het belang van dit gelijkwaardigheidsfundament, dat in de $A w b$ bestuursrechtelijk reliëf krijgt via de wederkerigheidsvisie ten aanzien van de relatie tussen bestuur en burger ${ }^{69}$, word in de volgende paragraf ingegaan op de aspecten die betrokken zijn bij "hoor en wederhoor".

\subsubsection{Hoor en wederhoor}

In de vorige paragraaf werd als kenmerkend aspect van 'hoor en wederhoor', gewezen op de gelijkwaardigheid van de bij de hoorplicht betrokken actoren. In dit aspect ligt voor het bestuursorgaan een belangrijke opdracht opgesloten. Naast het uitgangspunt dat de bezwaarschriftenprocedure door art. 7:2 aanspraak geeft op de effectuering van de wettelijke plicht om te worden gehoord, vult het 'gelijkwaardigheidsbeginsel' de hoorplicht nader in. Hierdoor krijgen de hierin opgesloten en veronderstelde 'gelijke proceskansen' nadere invulling. Door De Waard wordi met zoveel woorden gesteld, dat het beginsel van hoor en wederhoor een formeel evenwicht eist in de mogelijkheden tot inbreng in en informatie ower het proces. ${ }^{70}$

Voor alle duidelijkheid wordt opgemerkt dat met het begrip 'proces' niet alleen bedoeld wordt het bestuursprocesrecht maar ook het procedurerecht in het kader van de bezwaarschriftenprocedure. Op deze 'gemeenschappelijkheid' ten aanzien van de begripsvorming van de beginselen van behoorlijke rechtspleging werd reeds gewezen. Er wordt door De Waard geen onderscheid gemaakt in recht-

67 F.D. van Heijningen, Nationate Ombudsman, in: Rondom de Nationale Ombudsmant, is. Gravenhage $1993, \mathrm{p} .10$.

M.A. van der Ham, De gemeente als rechter in eigen zaak: (on)behoorlijke rechtspraak of (onbehoorlijk) bestutur in: Klachten en bezwaren tegen de gemeente, 'suravenhage 1988, p. 82 .

T.C. Borman, Eerste tranche Algemene wet bestuursrecht, AA 1994, p. 98.

B.W.N. de Waand, a.w., p. 247. 
spraak en rechtspraakachtige procedures. ${ }^{71}$ Tegelijkertijd wordt aan het beginsel van gelijke proceskansen of procedurekansen van de 'partijen' (equality of arms) de eis gesteld van goede en voldoende kansen in de procedure (quality en quantity of arms). Behoorlijke invulling van het beginsel van hoor en wederhoor dient zich hierbij vanuit het 'gelijke kansenperspectief' te manifesteren in het maken van aanspraak op een behoorlijke verdediging van belangen. ${ }^{72}$ De Waard komt tot een nadere specificatie van datzelfde op 'gelijke kansen' gebaseerde verdedigingsbeginsel. Voor een belangrijk deel betekent De Waard's verdedigingsbeginsel het recht op informatie (zowel het ontvangen als het verschaffen) ${ }^{73}$ De informatiefunctie zal nader aandacht krijgen in de volgende paragraaf. Naast de bovengenoemde, aan het verdedigingsbeginsel te stellen eisen van behoorlijke informatie, geeft in De Waard's opvatting, nog een tweetal eisen inhoud aan het begrip hoor en wederhoor, te weten:

- er dient voldoende gelegenheid te zijn voor de voorbereiding van de verdediging van het eigen standpunt;

- de processuele mogelijkheden van de ene partij dienen in evenwicht te züjn met die van de andere partij.

Uit het vorenstaande moge blijken, dat niet zonder reden nadruk is gelegd op De Waard"s opvatting omtrent de behoorlijkheidseisen ten aanzien van de hoorplicht die, volgens deze auteur de parameters vormen voor een correcte gang van zaken bij het in acht nemen van de bestuurlijke plicht tot het horen van belanghebbenden.

Gesteld is dat voor een correcte gang van zaken bij de inachtneming van de hoorplicht de eisen van het recht op een behoorlijke verdediging de 'gelijkheidskansen' voor de belanghebbenden in de bezwaarschriftenprocedure behoren te accentueren. Daarbij wordt vanuit de correctheidseis die in het bijzonder voor het bestuurlijk handelen geldt, mede begrepen een afzonderlijk beginsel, te weten het beginsel van correcte bejegening. Dit laatste beginsel zou de omvang, diepgang of nauwkeurigheid van de onderzoeksplicht naar relevante feiten en omstandigheden markeren. Het beginsel van correcte bejegening bevat in het licht van het vorenstaande dle eisen betreffende het horen, het verschaffen van relevante informatie en de eis van "fair play". Deze laatste drie eisen worden allen gebracht onder de noemer van het beginsel van zorgvuldige voorbereiding. ${ }^{\text {75 }}$

7) B.W.N. de Waard, a.w., p. 9.

72 B.W.N. de Ward, a.W., p. 247.

73 B.W.N. de Waard, a. w.

74 B.W.N. de Waard, 塽,

75 Duk, Inleiding 1988, p. 43 en 37, Duk SEW 1986, p. 655, Duk RMTh. 1978. 579 en P. Nicolai, Beginselen wan behoorlijk bestuur, Deventer 1990 , p. 169 e.v. 290 e.v. 
Deze vergaande specificatie van hoor en wederhoor lijkt wat overbodig. Afdeling $2.1 \mathrm{Awb}$ bevat algemene bepalingen over het verkeer tussen burgers en bestuursorganen. Deze afdeling is door de Awb-wetgever 'geschreven' als een vangnetregeling. De betreffende verkeersregeling voor burgers en bestuursorganen bevat een aantal beginselen, dat tot (gedrags)normen is gecodificeerd en ook wel gemodificeerd, en dat niet adequat is onder te brengen onder het regiem van regels dat geldt woor de voorbereiding van (bestuurs)besluiten. ${ }^{76}$ Daarnaast wordt, vanuit de invalshoek dat het beginsel van 'correcte bejegening' valt te rekenen tot zorgvuldige voorbereiding van de besluitvorming, dit 'correctheidsbeginsel' als het ware geüsurpeerd door de norm als bedoeld in art, 3:2 Awb. Dit artikel draagt het bestuursorgaan op om met kennis van zaken de belanghebbende burgers tegemoet te treden en relevante feiten met het oog op het besluitvormingsproces te onderzoeken.

Ofschoon op grond van de harmoniserende en codificerende doelstellingen van de Awb, aan het beginsel van "correcte bejegening" als inkleuring van hoor en wederhoor, geen zelfstandige betekenis behoeft te worden toegekend, biedt dit beginsel wél aanknopingspunten voor het aanleggen van maatstaven hoe de bestuursorganen zich behoren te gedragen in hun communicatie met de burgers. Elementen zoals 'fair play' en 'correcte bejegening' als (beginsel)hoekstenen in het kader van hoor en wederhoor, kunnen het normbesef bij de taakvervulling door het openbaar bestuur aanscherpen. Dat verbetering van dat normbesef moet worden gevoed via de normen voor het bestuurlijk handelen zoals de Awb die voorschrijft lijkt evident; een extra ondersteuning via een "beginsel-inkleuring" zoals die hiervoor is aangestipt door het beginsel van correcte bejegening, kan als 'smeerolie' dienen voor de kwaliteit van de besluitvorming. Die laatste constatering is in het licht van het volgende citaat allerminst overdreven.

'De intensieve rechterlijke toetsing is het resultat van de zwakheid van het bestuur. Een zwak bestuur wordt gewantrouwd door de burger en wak nog meer door de rechters. Vaak is de "subjectiviteit" van een bestuur een probleem. In veel gevallen zijn administratieve organen niet erg toegankelijk voor burgers en neigen ze naar vooringenomenheid. Inspraak wordt dan een zuiver formele aangelegenheid. De kwaliteit van het bestuur zou verbeterd kunnen worden door het inzetten van juridische elementen in het administratieve bes/uitvormingsproces. $" 7 n$

76 PG Awb I, p. 165

77 F. Stroink, Judicial control of the administration's discretionary powers (le billan executif - juge administratif) in: Judicial control. Comparative essays on judicial review, Antwerpen-Apeldoorn $1995, \mathrm{p} .98$. 
Dat de genoemde 'zwakheid" van bestuursorganen zich in allerlei vormen manifesteert blijkt uit de regelmatig gepubliceerde uitspraken van de bestuursrechter. Onder de werking van de Wet arob was er sprake van een ongekend hoog aantal uitspraken; de Awb geeft gezien het toegenomen aantal tijdschriften en jurisprudentieperiodieken, een continuering van het geschetste beeld te zien.

De gebreken in de besluitworming van bestuursorganen kunnen slechts worden verminderd, indien zij zich bij voortduring bewust zijn dat zij bij het nemen van besluiten gebonden zijn aan normen, beginselen van behoorlijk bestuur en algemene rechtsbeginselen.

Enerzijds fungeren de normen in de hoofdstukken 2 en 3 van de Awb als 'richtingaanwijzers' voor het bestuurlijk handelen. Daarnaast behoren de beginselen alls ondersteunende 'bestuurlijke ankers' te fungeren in het belang van een behoorlijke opstelling van het bestuursorgaan in het besluitvormingsproces ten opzichte van de daarbij betrokken belanghebbende burgers.

Een belangrijke rol hierbij vervult de sturende werking van het beginsel van correcte bejegening en het daarmede verband houdende beginsel van fair play als richtsnoer voor het bestuurlijk handelen. De literatuur en de daarin vermelde jurisprudentie brengen het belang van deze beginselen tot uitdrukking. Daaruit blijkt dat de behandeling van de burger door het bestuur dient te getuigen van 'openheid, eerlijkheid en royaliteit'. ${ }^{78}$ Het bestuur dient 'open kaart ${ }^{79}$ te spelen, en mag niet zonder noodzaak heimelijk tegen de burger stappen voorbereiden. Het bij het voorbereiden van een ontslag van een ambtenaar, volledig achter diens rug om klachten verzamelen bij medewerkers 'komt de kwaliteit van fair play en zorgvuldigheid niet toe' 80 Voorts blijkt uit de jurisprudentie dat achterbakse methoden uit den boze zijn; iemand stiekem ('door de desbetreffende alinea af te dekken voordat de fotokopie werd vervaardigd') belangrijke informatie onthouden wordt als "verwerpelijk' en in strijd met het fair play-beginsel geoordeeld. ${ }^{81}$ Van 'fair play' getuigt het zeker niet als het resultaat van een psychologisch onderzoek, waaraan de aanvrager van een vergunning zich heeft onderworpen op advies van het bestuursorgaan en met de indruk dat dit een gunstige beslissing naderbij zou brengen, plotseling, en zonder overleg, op een ander punt dan met 
het oog waarop de aanvrager zich liet testen ten nadele van hem wordt gehanteerd. ${ }^{82}$

Stroink's visie over de neiging van bestuursorganen om vooringenomen op te treden bij hun taakvervulling is niet zonder grond. Bestuursorganen nemen hierdoor het risico door de bestuursrechter te worden 'bestraft'. Tegen de achtergrond van hetgeen onder de aandacht is gebracht is de stap van het vooringenomenheidsverbod naar het beginsel van 'correcte bejegening' niet bijster groot. Bij de bespreking van het verbod van vooringenomenheid kwamen de risico's voor de bestuursorganen aan het licht. Sprekend over risico's voor bestuursorganen bij aspecten zoals die hiervoren zijn geschetst (hoor en wederhoor, correcte bejegening, fair play en het verbod om zonder vooringenomenheid bestuurstaken te vervullen), wordt benadrukt dat deze risico's welhaast inherent zijn aan de bestuursstructuur en cultuur. Daarbij speelt het gebruiken van de mandaatfiguur als bestuursrechtelijk en bestuurlijk effectiviteits-instrument (het in naam van het bestuursorgaan nemen van besluiten door aan het bestuur ondergeschikte medewerkers in ambtelijke dienst), een belangrijke zij het niet altijd even "positieve rol". Een der passages voorkomend in de annotatie inzake de uitspraak Stadsmobiel Amsterdam ${ }^{83}$, waarbij de partijdigheid van de Amsterdamse bezwaarschriftencommissie werd uitgesproken, illustreert dit treffend. ${ }^{84}$

- Wanneer in dergelijke situaties bezwaarschriften uitsluitend door ambtenaren worden beoordeeld - en dat heeft de Awb nu eenmaal bewust niet willen verbieden - is er alltijd een risico dat die ambtenaren worden beïnvloed door hetzij de angst voor informele sancties bij voor het bestuur onaangename beslissingen, hetzij - mijns inziens cen groter risico - door de loyaliteit die iedere goede ambtenaar jegens zijn organisatie voelt. Je collega"s geen extra werk willen bezorgen kan all een bron van beïnvloeding zijn. Trouwens, de bezwaarschriftenprocedure kent sowieso een inherent risico van vooringenomenheid, alleen al in de vorm van een "bestuurscentristische" kijk op de wereld (een rezel gevaar, zoals wellicht ook thet verschil tussen deze annotatie en de annotatie die ik vijf jaar geleden zou hebben geschreven, aantoont). Daarom mag een bestuurlijke beslissing ook nooit een eindbeslissing zijn over de rechtspositie van burgers. Dat is voor mij de essentie van "Benthem" (EHRM 23 oktober 1985, Publ. ECHR Series A, vol. 97, AB 1986, 1 m.nt. E.M.H. Hirsch Ballin). Maar als voorprocedure heeft de wetgever kennelijk de woordelen van de bezwaarschriftenprocedure 20 groot geacht, dat hij het risico van een zekere vooringenomenheid welbewust op de koop toe heeft genomen.'

N. Verheij, Partijdige bezwaarschriftencommissie, in: Rechtspraak Bestuursrechi, p. 94/95-152, 's-Gravenhage, e.v. 
Ten behoeve wan een goede invulling en werking van het beginsel van hoor en wederhoor heeft centraal gestaan het creëren door het bestuursorgaan van een situatie van 'gelijke kansen' voor de bij de voorbereiding van de beslissing op het bezwaarschrift, betrokken belanghebbenden. Het creëren van die beoogde situatie van "gelijke kansen" noopt naast de belichte aspecten tot een bredere inspanningsverplichting door of zijdens het bestuursorgaan teneinde aan de (behoorlijkheids)eisen van hoor en wederhoor te kumnen voldoen.

In het licht hiervan behoeft nauwelijks nog te worden geadstrueerd, dat het begrip hoor en wederhoor een veelomvattend 'bestuurlijk gebod' is. Die veelomvattendheid van hoor en wederhoor brengt met zich, dat naast de in het begrip verdisconteerde plicht om in de gelegenheid te worden gesteld te worden gehoord, daarbij nog de volgende aspecten betrokken dienen te zijn. Naast de eis dat 'de deelnemers' aan de bezwaarschriftenprocedure kennis moeten kunnen nemen van de inhoud van elkaars stukken (art. 7:4 Awb) is van belang dat deze in beginsel in elkaars tegenwoordigheid, overeenkomstig art. 7:6 moeten worden gehoord. Het belang hiervan is dat betrokkenen op elkanders beweringen over en weer kunnen reageren. ${ }^{85}$ Tevens bevat de Awb een complementaire verplichting ten aanzien van hoor en wederhoor. Indien ná afloop van het horen aan het bestuursorgaan feiten of omstandigheden bekend worden die voor de op het bezwaar te nemen beslissing van aanmerkelijk belang kunnen zijn, moeten die feiten en omstandigheden aan belanghebbenden worden medegedeeld. Als deze situatie ontstaat, dient hoor en wederhoor in 'twee mondelinge ronden' plaats te vinden.

Art. 7:9 geeft aanleiding tot het maken van enkele opmerkingen. In dit artikel walt op, dat gesproken wordt over 'feiten of omstandigheden die voor de op het bezwaarschrift te nemen beslissing van aanmerkelijk belang kunnen zijn'. In art. 7:2 (hoorplicht) wordt daarvan geen melding gemaakt. Dit gemis in art. 7:2 behoeft overigens niet te leiden tot een rechtens onjuiste opvatting over het invulling geven aan de hoorverplichting. Art. 3:2 conditioneert vanwege de daarin opgenomen onderzoeksplicht, de hoorplicht. Dit laatste betekent dat de strekking van de hoorregeling zich richt op de beeldvorming van relevante feiten en omstandigheden. De hoorplicht voor het bestuursorgaan moet daarom worden gezien als een middel tot plichtkwijting en belangenafweging. ${ }^{86}$

sa R.M. van Male en B.W.N. de Waard, Besluiten, Monografieèn Algemene wet bestuursrecht, "sGravenhage, p. 65 . 
Wanneer de veelomvattendheid van het begrip hoor en wederhoor in ogenschouw wordt genomen, en dit begrip als voorbereidingsconditie ten behoeve van een op de op het bezwaarschrift te nemen beslissing wordt uitgebreid met beginselen zoals 'correcte bejegening' en 'fair play', dan ontstat het volgende (Awb) totaalbeeld van te ondernemen acties door het besturursorgaan voor de nakoming van de hoorplicht.

De hoorplicht omvat op grond van de Awb een aantal functionele elementen, dat de volgende catalogus van condities verschaft, te weten:

1. de hoorplicht is een vereiste voor de op het bezwaarschrift te nemen beslissing;

2. de hoorverplichting moet leiden tot een selectieplicht van het bestuursorgaan om de bij het bestreden besluit betrokken belanghebbenden te horen;

3. de hoorplicht is een uitvloeisel van de kennisvergaringsplicht (onderzoek naar relevante feiten en de af te wegen belangen);

4. het zorgvuldigheidsbeginsel brengt met zich, dat door de hoorplicht inzicht moet worden gegeven in een door een wettelijk adviseur uitgebracht advies en de gelegenheid moet worden geboden daarop te reageren;

5. de hoorplicht omvat het recht tot het indienen van nadere stukken tot tien dagen voor het horen en het in beginsel inzien van alle op de zaak betrekking hebbende stukken tot ten minste een week vóór de hoorzitting; in deze vormvoorschriften ligt het beginsel van behoorlijke verdediging van belangen opgesloten met het oog op het bieden van voldoende gelegenheid. tot voorbereiding in het kader van de behandeling van de zaak;

6. de hoorplicht gaat uit van het beginsel van hoor en wederhoor, dat zich manifesteert in het voorschrift dat belanghebbenden in elkaars aanwezigheid worden gehoord, behoudens de in de Awb gemaakte uitzonderingen;

7. van datgene wat in de hoorzitting over en weer door belanghebbendien is ingebracht dient ter adstructie van het beginsel van hoor en wederhoor een verslag te worden gemaakt;

8. het recht tot het meebrengen van getuigen en deskundigen ter (hoor)zitting is mede gekoppeld aan thet beginsel van hoor en wederhoor; 
9. het recht van hoor en wederhoor leidt er toe dat aan de belanghebbende voldoende kansen moet worden geboden om deskundigen-adviezen te betwisten; ${ }^{87}$

10. hoor en wederhoor omvat in beginsel mede de verplichting voor het bestuursorgaan om ná de hoorzitting (alsnog) bekend geworden nieuwe feiten of omstandigheden in te brengen in een andermaal te beleggen zitting, teneinde belanghebbenden in de gelegenheid te stellen hierop over en weer te reageren.

Op basis van de bovengenoemde 'catalogus', worden hierna aan de hand van zowel jurisprudentie van vóor de $\mathrm{A}$ wb, alsmede rechterlijke uitspraken onder de werkingssfeer van de $A w b$, enkele belangrijke functionele aspecten van het horen onderzocht.

(a) De onvoorwaardelijke selectieplicht van het bestuursorgaan om de bij het bestreden besluit betrokken belanghebbenden te horen

De mededeling terzake de hoorplicht moet onvoorwaardelijk zijn. Er mogen geen formaliteiten worden gesteld die het horen afhankelijk maken van een daarop te geven reactie door de belanghebbende. ${ }^{8 \%}$

$B$ en $w$ van Vlaardingen hadden een bezwaarschrift tegen een aanschrijving tot het verwijderen van illegaal geplaatste duivenhokken gegrond verklaard. De aangeschrewen overtreder was wél in de gelegenheid gesteld in een hoorzitting daartegen verweer te voeren. De bij de aanschrijving betrokken derde-belanghebbenden waren niet uitgenodigd eventuele bezwaren mondeling toe te lichten. Burgemeester en wethouders hadden de aanschrijving tot verwijdering nu juist doen uitgaan op basis van klachten van deze belanghebbenden. Door de arobrechter werd tot strijdigheid geoordeeld vanwege het niet in acht nemen van de wettelijke hoorplicht. ${ }^{\text {s9 }}$

87 EHRM 18 maart 1997, JB 1997, 112, m.nt. AWH (Mantovanelli).

88 A.RRS 9 maart 1982 ("swravenhage), AB 1982, 302, m.nt. JRSt, S \& J, 1991, p. 456. Zie tevens in dit verband overige vastomlijnde en consistente uitspraken. ARRS 17 juli 1979, tB/S, 170, ARRS 11 juni 1981, Gst. 6681; tB/S 11, 421, ARRS 4 januari 1982, tB/S III, 317, ARRS 13 september 1982, AB 1982, 603, en eveneens CBB 8 maart 1990, AB 1990, 431, alsmede R.W.L. Loeb e.a., p. 145.

89 ARRS 25 mei 1981 , Gst. 6693, 3, m.nt, $k Z, S \& J$, p. 462. 
De volgende uitspraak toont aan dat een zorgvuldige waardering van belangen noodzakelijk is. Na een aanvankelijke vergunningverlening voor het imnemen van een standplaats op de markt, trokken burgemeester en wethouders wan Rotterdam deze vergunning na anderhalf jaar in. Het bestuursorgaan hoorde de belanghebbende vergunninghouder niet in de bezwaarfase, omdat het van oordeel was dat de positie en de belangen van bezwaarde genoegzaam bekend waren. De ARRS kon zich met het bestuurlijk standpunt niet werenigen, omdat het belang van belanghebbende noopte tot het horen teneinde alle in het geding zijnde belangen goed af te wegen. ${ }^{\text {xo }}$

Uit de jurisprudentie van de ARRS blijkt, dat in die gevallen dat bezwaar wordt gemaakt tegen een vergunningverlening, de vergunninghouder altijd in de gelegenheid moet zijn gesteld om te worden gehoord. De arob-rechter oordeelde voor dit soort gevallen vergunninghouders als 'onmiskenbare belanghebbenden'. 91

De jurisprudentie in het kader van de Awb lijkt vooralsnog niet zo talrijk als het gaat om het onvoorwaardelijk invulling geven aan de hoorplicht ex art. 7:2. Ongetwijfeld heeft de Wet arob voor wat betreft het horen als "proeftuin' gefungeerd. De genoemde arob-jurisprudentie was slechts een zeer bescheiden greep uitt de vele gevallen waarin een niet naleven van de hoorverplichting werd bestraft door een uitgesproken rechterlijke vernietiging van de op het bezwaarschrift genomen beslissing. In vergelijking met de arob-jurisprudentie blijkt, dat uit enkele hierna in het kort te beschrijven Awb-zaken omtrent de hoorplicht doorgaans geen nieuwe inzichten te vermelden zijn.

Het hierna te presenteren 'uittreksel' uit de Awb-jurisprudentie geeft het volgende beeld te zien.

Een standaardbrief, waarin enkel gewag gemaakt wordt van de mogelijkheid gehoord te worden, is in strijd met de wet in casu art. 43a WUV. De lijn van een uitspraak van de CRvB kan als wolgt worden weergegeven:

'Gelet tenslotte op het belang dat de wetgever, blijkens de geschiedenis van de totstandkoming van de Wet van 19 mei 1993 voormeld alsmede van de sedert 1 januari 1994 op dil stuk geldende Awb, hecht aan het horen van belanghebbenden tijdens de bezwaarschriftenprocedure, de aard van de onderhavige zaak zoals hieromschreven en

40 ARRS 11 augustus 1981, AB 1982,40, m.nt. vdV, $3 \& \%$, p. 461.

9! VZ ARRS 21 augustus 1980, AB 1981, 350, AR 10 juni $1980, t B / S, 299$, ARRS 8 december 1986, AB 1987, 304, R.W.L. Loeb e.a., De Wet arob toegepast, Nijmegen 1990, p. 144. 
de belangen die voor klaagster te dezen in het geding zijn, acht de Raad het aangewezen om de bestreden beslissing wegens strijd met artikell $43 \mathrm{a}$ WUV te vernietigen.. ${ }^{92}$

Voor een goed begrip van deze uitspraak wordt opgemerkt, dat het in casu een bijzondere hoorverplichting betreft als bedoeld in art. 43a WUV. Deze bijzondere wettelijke hoorplicht komt overeen met de hoorplicht als bedoeld in art. 7:2 Awb. Zie ook CRvB 2 maart 1995, AB 1995, 315.

Een andere door de President van de Rechtbank Groningen gedlane uitspraak betreft eveneens de strekking van een brief, waarin niet onvoorwaardelijk duidelijk was voor de betrokken belanghebbende, dat de wettelijke hoorplicht in het geding was.

'Bovendien hadden verweerders, nu de strekking van de brief wan 24 augustus 1994 niet zonder meer duiclelijk was, de indieners van de brief in elk geval op grond van artikel $7: 2 \mathrm{Awb}$, dienen te horen, zodat verweerders zïchzelf in de gelegenheid zouden hebben gesteld zich nader te informeren over het karakter van de brief. ${ }^{, 93}$

Ook deze uitspraak is op zichzelf genomen niet opmerkelijk, zij het dat in deze zaak het 'wederkerigheidsaspect' wordt benadrukt, enerzijds van de zijde van de bezwaarde, anderzijds vanuit het gezichtspunt van het bestuur in relatie tot de kennisvergaringsplicht.

Een derde uitspraak is afkomstig van het $\mathrm{CBB}$ van 17 november 1994 . Uit deze uitspraak blijkt dat de hoorplicht van art. 7:2 door het Bestuur van de Nederlandse Orde van Accountants-Administratieconsulenten te "s-Gravenhage niet is nageleefd. Kennelijk moest men in de kringen van de 'financiële wereld' nog even wennen aan de Awb-hoorplicht. In deze zaak waarin inzet was het voldoen van een lagere contributieverplichting, was bezwaarde door het bestursorgaan niet gehoord. Bij de beslissing op het bezwaarschrift was geen melding gemaakt van de reden van het afzien van de hoorplicht. ${ }^{94}$ Art. 7:2 werd hierbij in verband gebracht met art. 7:3. Dit artikel geeft enige uitzonderingen op de hoorverplichting. Op de toepassing van art. $7: 3$ is reeds ingegaan in par. 3.2.1.3.

92. CRvB 20 oktober 1994, JB 1994, $288 \mathrm{m.nt}$. ELB/ABJH en H.J. Simon, Handleiding Awbpraktijk, "s-Graventuge 1995, p. 194.

93 Pres. Rb. Groningen 22 december 1994, NA 114, JB 1995, 107 en H.J. Simon, a.w., p. 194.

94 CBB 17 november 1994, JB 1994, 337. 
De hiema vermelde uitspraak geeft inzicht in de wijze waarop hoor en wederhoor gestructureerd dient plaats te vinden. Deze uitspraak van de ARRS laat zien dat de administratieve rechter strikt de hand houdt aan het begrip hoor en wederhoor.

Een belanghebbende was de gelegenheid geboden om tijdens een vergadering van de raadscommissie in de gemeente Utingeradeel het woord te voeren vanaf de publieke tribune. De raadscommissie meende dat in het kader van de behandeling van een ingesteld (administratief) beroep op de gemeenteraad, op deze wijze toepassing kon worden gegeven aan art. 390, lid 3 van de in de bouwverordening voorgeschreven hoorverplichting. Uitgesproken werd door de arob-rechter, dat geen sprake was van processueel horen. Het inbrengen van stukken en het beantwoorden van vragen kon onder deze omstandigheden niet adequaat geschieden.

De annotatie omtrent deze zaak, geeft structuurbepalende elementen aan ten aanzien van de wijze waarop aan de hoorverplichting moet worden voldaan.

Het woord hoorzitting kan blijkbaar op verschillende manieren worden uitgelegd. Naar het oordeel van de gemeente had men appellant kunnen horen in de letterlijke betekenis van het woord. Onder een hoorzitting dient men echter te verstaan een mondelinge behandeling als gebruikelijk in een gerechtelijke procedure, waarin het ingediende beroepschrift centraal staat; het beginsel van hoor en wederhoor wordt toegepast en op het onderwerp betrekking hebbende stukken (kunnen) worden voorgelegd. Dit gestructureerde contact is vooral gericht op het informeren van het orgaan, dat een beslissing op het beroep moet nemen, welk besluit al dan niet openbaar, pas na het horen kan plaatsvinden. ${ }^{95}$

Voorts blijkt uit de wat oudere (arob)-jurisprudentie, dat de inschatting vanwege het bestuursorgaan dat de behandeling van een onbeduidend bezwaarschrift voor het horen een zinloze vertoning lijkt te zijn, tot voorzichtigheid maant. Dit laatste blijkt zelfs in die gevallen dat bezwaarschriften kennelijk niet-ontvankelijk of ongegrond zijn te achten. Ook dan is voorzichtigheid met het nemen van een beslissing om niet te horen, geboden. In die gevallen blijkt nogal eens de strikte opvatting van de arob-rechter ten aanzien van de wettelijke hoorplicht. Hoor en wederhoor werd nogal eens noodzakelijk geacht omdat gegevens en informatie naar voren konden worden gebracht die de belangen van het besluit dienen. ${ }^{96}$

95 HB/S II, 73 en ARRS 17 juli 1979, tB/S II, p. 170.

96. ARRS 26 augustus 1977, AB 1978, 212, 11 november 1977, AB 1978, 245, 7 mei 1979, OB 1979 m. 40884,14 mei $1979, \mathrm{AB} 1980,493$. 
Het gelegenheid bieden tot inspraak kan soms betekenen dat niet aan de wettelijke eisen van de hoorplicht is voldaan. ${ }^{97}$

Hoor en wederhoor vraagt bijzondere aandacht in die gevallen dat ná een uitgesproken vernietiging door het bestuursorgaan opnieuw op het bezwaarschrift moet worden beslist. Het al dan niet horen moet getoetst worden aan de vraag in welk opzicht blijkens de rechterlijke uitspraak, bepaalde punten allsnog of opnieuw inhoudelijk getoetst moeten worden. ${ }^{98}$

In een andere (schorsings)zaak werd toegegeven, dat 'verzoeker' niet was gehoord. Burgemeester en wethouders verontschuldigden zich met de mededeling dat betrokkene een onderhoud had gehad met de burgemeester. Deze gang van zaken werd niet rechtmatig geoordeeld omdat onder deze omstandigheden niet voldaan was aan de hoorverplichting. ${ }^{99}$

Tenslotte kan niet als gestructureerd wettelijk horen worden aangemerkt het geven van spreekrecht voorafgaand aan de raadscommissie en de aanvang van de vergadering van de gemeenteraad (het stellen van vragen door raadsleden ontbrak). ${ }^{100}$

Dat het horen op gestructureerde wijze behoort plaats te vinden bleek uit de arobjurisprudentie-fragmenten. Ook onder de werking van de Awb komen structuurbepalende accenten ten aanzien van het horen tot uiting.

In een zaak die diende voor de Rechtbank van Groningen bleek dat het werkvoorzieningsschap 'De Kanaalstreek' in het kader van de toepassing van de hoorplicht, in de fout ging. Opgemerkt wordt dat het hier een hoorplicht betrof in het kadler van een bezwaarschriftenprocedure op grond van de WSW in casu art. 28, lid 3. Toch blijkt ook het standpunt van de bestuursrechter ten aanzien wan de toepassing van art. 7:2 Awb van belang, hetgeen hierna zal worden aangetoond door het vermelden van enkele citaten uit de uitspraak van de Groningse rechtbank.

97 ARRS 5 juni 1980 (Akkrum), AB 1981, $125 \mathrm{~m}$.nt. vdV. Vgl. ARRS 26 oktober 1982 (Hlontenisse); $\mathrm{tB} / \mathrm{S}, 125$ : de door b en weboden gelegentheid om schriftelijk bezwaar in te dienen kan niet worden aangemerkt als horen in de zin van artikel 30 , lid 3 Bouwverordening. Deze bepaling eist dat een hoorzitting moet worden belegd. F.A.M. Stroink, Wet Arob, a.w., p. 395.

of Vz. ARRS 23 jull 1983. (Hoogvliet, Antennemast, tB/S VI, 14 Idem ARRS 7 juni 1985 (besturs. dwang Asten) AB 1986, 345 en ARRS 12 juli 1985 (subsidie Enschede), AB 1986, 49. Beide uitspraken m.nt. J.H. v.d.V, Stroink, a.w., p. 396.

99 V. ARRS 20 december 1978, AB 1979, IB/S II, p. 132 en 133 (Heesch), J.B.J.M. ten Berge en F.A.M. Stroink, Arob in vogelvlucht, 4 e dr., Alphen aan den Rijn 1989, p. 140 .

100 ARRS 16 oktober 1987, Gst. 6863, 13, m.nt. RP A (Leidschendam). 
HET HOREN

In deze zaak bleek ter zitting dat partijen verschillende lezingen gaven omtrent de toepassing van de hoorplicht. De uitspraak door de bestuursrechter brengt een aantal belangrijke aspecten in kaart:

Nu uit de gedingstukken niets blijkt van een dergelijk horen, waarbij de rechtbank aantekent dat het naar haar oordeel op de weg van verweerder ligt om bij het nemen van een dergelijk ingrijpend besluit (beëindiging dienstbetrekking wegens ziekte) als het onderhavige de procedurevoorschriften na te leven en van het naleven daarvan middels schriftelijke verslaglegging te doen blijken, en de lezing van eiser aannemelijk is nu uil de gedingstukken blijkt dat tegelijkertijd met de onderhavige ontslagkwestie een mogelijke detachering bij "Huize Moria" in bespreking is geweest tussen eiser en verweerder, gaat de rechtbank ervan uit dat eiser niet overeenkomstig bedoeld artikellid in de gelegenheid is gesteld zijn gevoelen kenbaar te maken."

De beslissing op het bezwaarschrift werd vernietigd. Er werd geen toepassing gegeven aan art. 6:22 (schending vormvoorschriften). ${ }^{101}$

Ook een andere uitspraak zegt iets over de consistentie in de jurisprudentie ten aanzien van de juiste structuur in het kader van de invulling van de hoorplicht. Daarbij past overigens wël de opmerking dat het een zaak betrof van vór de inwerkingtreding van de $A w b$, hetgeen echter in dit geval niets af doet aan het bellang van deze zaak voor de toepassing van art. 7:2.

Het ging in deze zaak om de toepassing van de Wet uitkeringen vervolgingsslachtoffers $1940-1945$ art. 43 a (oud); Beroepswet art. 17.

De Centrale Raad van Beroep overwoog onder andere het volgende:

'Het bestreden besluit is genomen zonder dat eiseres (raadskamer WUV) op de in art. $43 \mathrm{a}$ oud van de wet voorgeschreven wijze is gehoord. In de bezwaarfase is eiseres weliswaar door een geneeskundige adviseur van de Pensioen-en Uitkeringsraad aan een medisch onderzoek onderworpen, mar daarmee is geenszins aan de evenvermelde hoorplicht voldaan. ${ }^{102}$

(c) Hoor en wederhoor in relatie tot de kennisvergaringsplicht naar relevante feiten en af te wegen belangen

Art. 14 , lid 1 Wet arob schiep niet alleen slechts waarborgen voor de indiener van 
feiten en omstandigheden die eerst ter hoorzitting zijn aangedragen of gebleken, in ogenschouw moeten worden genomen. ${ }^{103}$

In de volgende zaak werd strijd met de hoorplicht door de arob-rechter geconstateerd omdat het nalaten vanwege $b$ en w om betrokkene te horen, in het betreffende geval zodanig belemmerend had gewerkt doordat bezwaarde niet de gelegenheid was geboden mondeling nadere gegewens naar voren te brengen die in de ogen van de rechter van belang waren. Door op die wijze te werk te gaan hadden burgemeester en wethouders van Bergen de kans voorbij laten gaan relevante inlichtingen te verkrijgen.

Hierdoor zou de beslissing op het bezwaarschrift bij aanwezigheid van relevante informatie tot een andere beslissing hebben geleid. Het excuus van burgemeester en wethouders dat zij toch nog het primaire besluit bij de beslissing op het bezwaarschrift hadden gecorrigeerd, en betrokkene een hogere vergoeding hadden toegekend, mocht in dit geval niet baten. Vernietiging volgde wegens strijd met de hoorplicht. ${ }^{104}$

Een andere kwestie betrof de uitvoering van het Besluit Administratieve Bepalingen Wegverkeer, waarbij ex art. 53 van dat besluit de weigering van een invalidenparkeerkaart in het kader van een TWK-beroep werd aangevochten. Ofschoon dit beroep op grond van het recht plaatsvond zoals dat gold vóór de inwerkingtreding van de $A w b$, is deze zaak niettemin interessant. Weliswaar gold voor genomen primaire beslissingen in het kader van het $\mathrm{BABW}$ vóór 1 januari 1994 nog geen verplichte bezwaarschriftenprocedure, maar deze zaak laat wél zien dat als zij gespeeld zou hebben ten tijde van de rechtskracht van de $A w b$, in een nu wél te volgen verplichte bezwaarschriftenprocedure, het bestuursorgaan zich in deze procedure actiever had behoren op te stellen. Die actieve opstelling in het kader van de kennisvergaringsplicht op grond van art. 3:2 Awb, zou in het kader wan de hoorplicht tot uiting hebben moeten komen. Wat was er kort samengevat aan de hand?

Het dagelijks bestur van het stadsdeel Amsterdam-Noord had een verzoek om een invalidenparkeerkaart afgewezen omdat een medisch onderzoek ten aanzien van appellant had uitgewezen, dat hij in staat zou zijn zich 200 tot 300 meter zonder hulp te voet zou kunnen voortbewegen. Dit laatste werd ook niet in beroep door de 'TWK-rechter' betwijfeld. Ofschoon derhalve de uitslag van de geneeskundige keuring geen punt van discussie was, vond toch vernietiging plaats wegens strijd met het zorgvuldigheidsbeginsel (TWK art. 2, lid 1, onder d). De

103 ARRS 9 maart 1982 ("s-Gravenhage), AB 1982, 302, m.nt. JR. St. S \& J, a.w., p. 456.

ARRS 14 mei 1979, AB 1979, 493, m.nt. IR.St., S \& J, p. 458. 
aanleiding tot deze uitspraak vormde de constatering door de bestuurstechter dat de afwijzing op het verzoek gebrekkig was onderbouwd. Naast de hantering van de bovengenoemde parkeernorm van 200 tot 300 meter, had het bestuursorgaan van de Amsterdamse deelgemeente een onderzoek behoren in te stellen naar de plaatselijke parkeersituatie. ${ }^{105}$

In een beroep bij de $C R v B$ werd geageerd tegen een weigering door de Pensioenen Uitkeringsraad van een uitkering krachtens de Wet Uitkeringen Vervolgingsslachtoffers 1940-1945. In deze zaak bleek dat tijdens de bezwaarfase het bestuursorgaan voorbij was gegaan aan het verzoek van bezwaarde on haar door een medicus met speciale deskundigheid op het gebied van de WUV te doen onderzoeken. Tegelijkertijd was daarbij door betrokkene gevraagd bij nietinwilliging van dit verzoek haar over de afwijzing te berichten. Bezwaarde zou dan zelf een nadere expertise kunnen laten uitvoeren. Bij de behandeling van het beroep bleek, dat door de Pensioen- en Uitkeringsraad geen nader medisch onderzoek was verricht, noch een bericht was verzonden dat de gevraagde expertise niet zou plaatsvinden. De rechter oordeelde dat door deze handelwijze de Pensioen- en Uitkeringsraad de aard en het wezen van de bezwarenprocedure had miskend. De bestuursrechter nam daarbij in aanmerking, dat in casu sprake was van een onjuist gebruik van een discretionaire bevoegdheid dat noopte tot vernietiging van het besluit wegens strijd met het zorgvuldigheidsbeginsel.

Uit deze uitspraak blijkt bovendien dat bestuursorganen nogal eens hardnekkig de fout ingaan. De Pensioen- en Uitkeringsraad werd op de vingers getikt door te wijzen op de bestaande jurisprudentie. De Raad wees er op dat uit haar jurisprudentie blijkt, dat deze (medische) gegevens van zwaarwegende betekenis zijn, omdat bij gebreke daarvan moet worden uitgegaan van uitsluitend de gegevens van betrokkene zelf; die uit hun aard een subjectief karakter dragen en daarom uiterst behoedzaam dienen te worden gehanteerd. ${ }^{106}$

Aan de hand van een aantal voorbeelden van arob-jurisprudentie-gevallen, werd het verband gelegd met hoor en wederhoor. Daarbij werd mede in relatie gebracht de kennisvergaringsplicht van het bestuursorgaan. Uit de daarbij in kaart gebrachte casuistiek, blijken de bestuursrechtelijke condities voor het bestuursorgaan, om aan de verplichting tot hoor en wederhoor zodanige invulling te geven, dat de belanghebbende burger hierbij 'het volle pond' krijgt. Dit laatste betekent dat de aanspraak van de justitiabele op het hebben van gelijke kansen, in 
de fase voorafgaand aan de op het bezwaarschrift te nemen beslissing, voldoende door het bestuursorgaan "zichtbaar" moet worden gemaakt. Het "zichtbaar' maken van deze gelijke kansen voor de bij de bezwaarschriftenprocedure betrokken belanghebbenden, moet in dit geval blijken uit een juiste en adequate invulling van de kennisvergaringsplicht.

Op basis van de nu te bespreken jurisprudentie, op grond van art. 3:2 Awb, waarin de kennisvergaringsplicht tot norm is 'verheven' als zorgvuldigheidsconditie ten behoeve van de besluitvormingsprocedure, kan worden afgeleid dat deze norm gericht is een tweeledig onderzoeksdoel. Enerzijds moet de onderzoeksplicht als bedoeld in art. 3:2 Awb zich uitstrekken tot de relevante feiten, terwijl daarnaast de daarbij af te wegen belangen een rol dienen te spelen. Uit deze laatste zinsnede volgt, dat de beide aspecten, te weten 'de relevante feiten' en 'de af te wegen belangen', op elkaar af te stemmen formeel-juridische factoren zijn, die de omvang van de onderzoeksplicht bepalen en daarbij inhoud geven.

Meer concreet betekent dit dat het inzicht ten aanzien van de bij de besluitvorming betrokken belangen een inhoudelijke betekenis krijgt. Daarbij speelt het belang van de concretisering van de kennisvergaringsplicht een rol, als richtsnoer voor de juiste bepaling van de inhoud van de positie van zowel de belanghebbende burger als het bestuursorgaan. De toepassing van art. 3:2 Awb krijgt hiermede invulling vanuit de reikwijdte van het geheel van rechten en plichten van belanghebbenden en het bestuursorgaan. ${ }^{107}$

Geconstateerd wordt dat art. 3:2 Awb (dit geldt trouwens ook voor de hoorplicht) ruimschoots de aandacht trekt bij die Awb-zaken die voor de bestuursrechter dienen. Deze waarneming is niet opmerkelijk te noemen. De arob-trends zetten zich ook onder de werking van de Awb voort, met dien verstande dat de toetsing van besluiten in bezwaar en beroep zich richt op de in art. 3:2 genormeerde zorgvuldigheidsverplichting. De jurisprudentie met betrekking tot art. $3: 2$ is daarom zeer overvloedig. ${ }^{108}$ Juist in die 'overvloedigheid' ligt tevens de beperking van het geven van een volledig inzicht in de werking van art. 3:2 voor de kwantiteit en de kwaliteit van de onderzoeksplicht. Toch is een poging om de kennisvergaringsplicht nadere inkleuring te geven, in relatie tot de plicht tot hoor en wederhoor, de moeite waard. Daardoor wordt de betekenis van de onderlinge samenhang tussen beide aspecten vergroot. De Awb-zaken tonen het volgende aan. 
Voor de ABRS diende een zaak, waarbij de intrekking van een milieuvergunning op grond van art. 8.25 , eerste lid, onder a van de $\mathrm{Wm}$, in het geding was. B en $w$ van Maarheeze waren bij hun besluit van 4 april 1995 overgegaan tot de intrekking van een in 1971 verleende hinderwetvergunning voor een rundveehouderij. Deze zaak betreft niet een op een bezwaarschrift genomen beslissing, omdat voor een intrekkingsbesluit als het onderhavige rechtstreeks beroep op de Raad van State openstaat.

Toch is de uitspraak niet minder interessant voor de problematiek van hoor en wederhoor in relatie tot de kennisvergaringsplicht.

De ABRS stelt in haar overweging voorop, dat $b$ en $w$ terecht een aantal aspecten bij de besluitvorming hadden betrokken, waardoor zij van hun bevoegdheid tot intrekking van de hinderwetvergunning gebruik hadden kunnen maken. Deze enkele grond bleek niet voldoende om de zorgvuldigheidstoets van art. $3: 2$ met succes te doorstaan. Dienaangaande overwoog de afdeling als volgt:

- De Afdeling stelt vast dat verweerders tot intrekking hebben besloten zonder in te gaan op de vraag of appellant aan de bij het bestreden besluit ingetrokken vergunning nog rechten kan ontlenen, indien het intrekkingsbesluit eerder onherroepelijk wordt dan de vergunning ingevolge de Wet milieubeheer voor het nieuw op te richten bedrijf aan de Vinnen. Gelet op het feit dat ten tijde van het nemen van het bestreden besiuit reeds een ontwerp-besternmingsplan was opgesteld ten behoeve van het realiseren van het nieuwe bedrijf aan de Vinnen en de daarvoor benodigde vergunning ingevolge de Wet milieubeheer reeds bij verweerders was aangevraagd, hadden verweerders bij de afweging van de betrokken belangen hieraan niet zondermeer voorbij mogen gaan, mede daar, gelet op het bepaalde in artikel 4 in samenhang met artikel 9 van de Interimwet, voor nieuwvestiging van een veehouderij in Maarheeze nog maar zeer beperkt vergunning kan worden verleend.

Gelet hierop moet worden geoordeeld dat verweerders in strijd met artikel 3:2 van de Algemene wet bestuursrecht hebben nagelaten ter voorbereiding van hun besluil de nodige kennis omtrent de relevante feiten en de af te wegen belangeri te vergaren. Derhalve is het beroep gegrond en dient het bestreden besluit te worden vernietigd.

Deze uitspraak van de bestuursrechter latit zien dat het bestuursorgaan zich actief dient op te stellen ten aanzien van vragen, verzoeken en suggesties zijdens de belanghebbende. Het onbeantwoord laten van aspecten die tijdens het horen alan de orde komen, en die relevant zijn voor het inkaderen en het afwegen van belangen, kunnen mogelijk tot averij leiden van het bestreden besluit. Vernietiging wegens strijd met art. 3:2 Awb is in zulke gevallen niet uitgesloten. 
De tweede zaak betreft een inactieve houding van het bestuursorgaan bij het horen van een bezwaarde in het kader van de $A$ wb-bezwaarschriftenprocedure. $B$ en $w$ van Heerlen gingen in de fout door aan de hoorverplichting ex art. 7:2 onvoldoende invulling te geven, omdat tijdens deze hoorzitting niet was ingegaan op de vraag of degene die bezwaar had ingediend tegen de bouw van een huisdierenverblijf, belanghebbende was in de zin wan art. 1:2 Awb. Uit het verslag van de hoorzitting, waaruit het belang van het verslag blijkt, was vast komen te staan dat $b$ en $w$ de betrokken bezwaarde niet naar diens belang bij de bouw van het huisdierenverblijf hadden gevraagd. Dit achterwege laten bleek fataal voor de rechtmatigheid van de verleende bouwvergunning.

$B$ en $w$ hadden belanghebbende immers rauwelijks niet-ontvankelijk verklaard.

Tijdens de behandeling van het beroep zette appellant b en $w$ van Heerlen ' $k$ lem' door zijn belang bij de bouw wan het dierenverblijf nader te adstrueren. Appellant gaf tijdens de zitting bij de Raad van State te kennen dat zijn belang bij het bestreden besluit was gelegen in de feitelijke omstandigheid dat hij vanuit zijn tuin uitzicht had op het dierenverblijf en hij tevens eigenaar was van enige belendende percelen. De ABRS oordeelde tot vernietiging wan de op het bezwaarschrift genomen beslissing met 'het verwijt' aan het adres van b en w van Heerlen, dat zij het belang van appellant onvoldoende hadden onderzocht. ${ }^{110}$

Uit een andere uitspraak in het kader van een gevraagde voorlopige voorziening, waarbij nog moest worden beslist op het bezwaarschrift, kon worden opgemaakt dat het bestuursorgaan door dle bestuursrechter alvast een 'boodschap' mee kreeg op welke wijze aan het beginsel van hoor en wederhoor, in samenhang met een nader feitenonderzoek invulling moest worden gegeven. In deze zaak van de gerneente Bunschoten valt op, dat het niet in acht nemen van de hoorverplichting ex art. 4:8 Awb in een schorsingsprocedure niet altijd zonder gevolgen blijft, ook al moet op het bezwaarschrift nog worden beslist. De herstelmogelijkheid van dit zorgvuldigheidsgebrek hield de bestuursrechter 'buiten de deur'. De President van de Utrechtse rechtbank vond de procedurele gebreken zo ernstig dat hij voldoende grond zag voor het treffen van een voorlopige voorziening.

Op basis van een aantal verklaringen ter zitting, alsmede een politierapport, stelde de President vast dat deze gegevens onvoldoende aanknopingspunten boden om aan te nemen dat de bezwarenprocedure zou moeten resulteren in een onmiddellijke opening van de horeca-inrichting. Toch ging de bestuursrechter in deze zaak, waarbij besturursdwang was aangezegd, over tot het treffen van een voorlopige voorziening. 


\section{De Utrechtse bestuursrechter oordeelde als volgt:}

'De eerdergenoemde gebreken in verweerders besluitvorming en de ingrijpende gevolgen van het bevel voor verzoekers bieden anderzijds voldoende aanleiding tot het treffen van een woorziening. Bereikt moet worden dat verzoekers op zo kort mogelijke termijn in de gelegenheid zijn om in het kader van de bezwaarprocedure hun argumenten tegen sluiting naar voren te brengen en overigens hun belangen ten overstaan van verweerder te bepleiten. Verweerder dient daama eveneens op zo kort mogelijke termijn definitief op het bezwaar te beslissen. Indien werzoekers volharden in hun zienswijze met betrekking tot de feiten zal verweerder er uit zorgvuldigheidsoogpunt goed aan doen zich rechtstreeks te vergewissen van het bestaan van woldoende (overtuigende) verklaringen met betrekking tot de handel in en het gebruik van drugs in en rond De Kajuit. ${ }^{111}$

Het niet voldoen aan de hoorverplichting ex art. 4:8 Awb in het kader van de primaire besluitvorming, wordt niet altijd als gebrek gepasseerd, ondanks het bestaan van een compensatiemogelijkheid als gevolg van de hoorplicht ex art. $7: 2$. Dit blijkt vooral in die gevallen, waarbij belastende beschikkingen de inzet vormen van een procedure.

In een Rotterdamse kwestie overwoog de Vz. ABRS in een voorlopige voorzieningszaak:

'Verzoekster is weliswaar in maart 1994 in de gelegenheid geweest haar zienswijze kenbaar te maken over de mogelijke oplegging van een dwangsom, echter zonder dat destijds de thans overtreden voorschriften van kracht waren. Daarnaast merkt de Voorzitter op dat de overtredingen 6 tot en met 9 geen betrekking hebben op de opslag van gevaarlijke stoffen. Gelet hierop is de Voorzitter van oordeel dat niet kan worden gezegd dat werzoekster is gehoord over het geven van het thans bestreden besluit, zoals woorgeschreven in artikel 4:8 van de Algemene wet bestuursrecht. Het standpunt van werweerders dat verzoekster reeds is gehoord over de overtreding van de eisen van de richtlijn CPR 15-2, zoals die zijn opgenomen in de voorschriften waarvoor thans een dwangsom is opgelegd, deelt de Voorzitter niet. In dil verband merkt de Voorzitter op dat destijds slechts een dwangsom kon worden opgelegd voor het zonder toereikende vergunning opslaan van gevaarlijke stoffen in de inrichting, terwijl thans de overtreding van een groot aantal voorwaarden centraal staat. De Voorzitter deelt evenmin de opvatting van werweerders inzake de noodzaak van het horen. Naar het oordeel van de Voorzitter kan bij een belastend besluit als het onderhavige, gemakkelijk verschill van mening bestaan over de feiten en omstandigheden op grond waarvan door het bevoegd gezag tot het treffen van een handhavingsmaatregel wordt overgegaan, ook al zijn deze gegevens deels door de belanghebbende, in dit geval verzoekster, zelf verstrekl.

11. Pres. Rb. Utrecht 7 april 1994, JB 1994, 115. 
In een dergelijk gewal kan naar het oordeel wan de Voorzitter het horen van belanghebbende niet achterwege worden gelaten. Gelet op het voren overwogene is de Voorzitter wan oordeel dat niet is voldaan aan de hoorplicht als bedoeld in artikel 4:8, eerste lid, van de Algemene wet bestuursrecht. De Voorzitter ziet derhalve aanleiding woor inwilliging van het verzoek om voorlopige voorziening door middel van schorsing van het bestreden besluit tot zes weken na de beslissing op bezwaar. Daarbij gaat de Voorzitter ervan uit dat verzoekster alsnog in het kader van de bezwaarschriftenproce. dure zal worden gehoord. 112

De bovengenoemde uitspraak geeft een aantal zwaartepunten te zien dat zich toch wel als enigszins onderscheidend ten opzichte van de toetsing van besluiten tijdens de arob-periode, aftekent. Zeer kritisch wordt in het algemeen door de bestuursrechter geoordeeld als het betreft het niet naleven van de hoorplicht, waarbij tegelijkertijd een nauw verband met de hoorplicht wordt gelegd ten aanzien van de kennisvergaring omtrent feiten en relevante belangen. Voorzover het feiten betreft, blijkt tevens hoe "feitelijk" de bestuursrechter thans te werk gaat. Waarschijnlijk is de reden daarvan gelegen in art. 3:2 Awb, waarin de kennisvergaringsplicht is gecodificeerd. Duidelijk is wél dat in het merendeel van de uitspraken van de bestuursrechter deze ook in de uitspraak expliciet verwijst naar het gestelde in art. $3: 2$.

De afdelingswoorzitter stelt dat vooral ten aanzien van een belastend besluit over feiten en omstandigheden 'gemakkelijk verschil van mening kan bestaan'. Voor dit laatste standpunt is zeker iets te zeggen. Deze redenering van de bestuursrechter snijdt vooral hout in bestuursdwangzaken. Illustratief hiervoor is alleen al de uitgebreide catalogus van algemene vereisten, waaraan een waarschuwing tot het toepassen van bestuursdwang moet voldoen.

De jurisprudentie en de wetenschap hebben tezamen een catalogus van eisen, waaraan een waarschuwing tot bestuursdwang moet voldoen, ontwikkeld. ${ }^{113}$ Deze ontwikkeling van het bestuurlijk sanctierecht staat niet stil, hetgeen blijkt uit de permanente aandacht woor de handhaving van het bestuursrecht. ${ }^{114}$

In het licht van de bovengenoemde rechtspraak is er gezien de geëiste omvang en diepte van de onderzoeksplicht bij bestuursdwangzaken reden om vooral in de

112 VZ. ABRS 18 augustus 1995, JB 1995, 271.

113 Van Wijk/Konijnenbelt, a.w., p. 503 e.w. F.C.M.A. Michiels, Bestumisdwang in de gemeenten, Gst. 6832 en 6833 en P.J.J. van Buren en F.C.M.A. Michiels, Bestuursdwang, Zwolle 1989.

114 I.C.M.A. Michiels, Handhaving van bestuursrech, Nijmegen 1994 en J.T.K. Bos, G.A.M. Giesen. J. de Groot en F.C.M.A. Michiels, Handhaving wan het bestuursrecht, VAR 114, "sGravenhage. 
beginfase van het besluitvormingsproces de kennisvergaringsplicht in relatie tot de (primaire) hoorplicht, 'stevig' accent te geven. Het verdient aanbeveling om bij het primaire besluit strikt de hoorplicht van de art. $4: 7$ en 4:8 Awb in acht te nemen. Hierdoor wordt voorkomen dat na het primaire besluit de kennisvergaringsplicht zo'n zwaar accent moet krijgen dat ook tijdens het horen in de zin van art. 7:2, 'de wonden' van een (gebrekkig) primair besluit niet of nauwelijks kunnen worden 'geheeld'.

Ofschoon art. 7:11 tot een volledige heroverweging noopt door in casu feiten geheel opnieuw te onderzoeken, moet de kans van het opnieuw maken van fouten in de bezwaarschriftenprocedure bij het achterwege laten van de art. 4:7 en 4:8, niet uitgesloten worden geacht. De 'hypotheek' die hierdoor op de bezwaarschriftenprocedure komt te rusten is gezien het vorenstaande dan wat al te groot.

Ter afsluiting van deze paragraaf wordt opgemerkt dat ook de omvang en de inhoud van de onderzoeksplicht ten aanzien van andere belastende besluiten, niet gering is. De juridische problemen bij het intrekken of wijzigen van bijvoorbeeld subsidiebesluiten moeten niet worden onderschat. Bestuursorganen moeten alle zeilen bijzetten om tot een kwalitatief verantwoorde besluitvorming te komen in die gevallen dat belastende besluiten voorwerp zijn van (her)overweging en beslissing. ${ }^{115}$

\section{(d) Hoor en wederhoor en de aanwezigheid van getuigen en deskundigen}

In de Awb is in art. 7:8 opgenomen, het recht van de belanghebbende op diens verzoek, ter hoorzitting meegebrachte getuigen en deskundigen te horen. De Wet arob kende zo'n bepaling niet. Dit betekende niet, dat er vóór de Awb-periode geen regelingen waren ten aanzien van het horen van getuigen en deskundigen. In de sfeer van de aanvullende decentrale regelgeving waren deze regelingen wél getroffen, zij het dat de competentie tot vaststelling geheel van autonome (bestuurlijke) aard was.

De bevoegdheid van belanghebbenden om hun ingediende bezwaarschriften nader te adstrueren aan de hand van getuigen- dan wel deskundigenverklaringen, was opgenomen in procedureverordeningen voor de behandeling van bezwaarschriften. Dit laatste was eveneens voor de behandeling van het administratief beroep het geval. De gemeenteraden stelden deze procedureverordeningen vast aan de 
hand van door de VNG ontworpen model-verordeningen. ${ }^{116}$ De bepalingen in deze modelverordeningen vertonen grote verwantschap met art. 7:8 Awb. ${ }^{117}$ Deze model-verordeningen bevatten geen toelichting over het gebruik van bewijsmiddelen. De oorzaak is wellicht dat het bewijsrecht zich door de toegenomen rechtsbescherming, heeft ontwikkeld in het administratief procesrecht. Het bewijsrecht was aanvankelijk afwezig in het administratief procesrecht. Zowel de wetenschap alsmede de jurisprudentie hebben hieraan een belangrijke bijdrage geleverd. Tot in de jaren tachtig is de ontwikkeling van het bewijsrecht in relatie tot de mogelijkheid van het horen van getuigen, op het niveau van administratief beroep (en ook het bezwaar), 'achtergebleven' ten opzichte van het administratief procesrecht. $^{118}$

In het administratief procesrecht heeft het bewijsrecht vanuit de beginselformulering voor een behoorlijk procesrecht door de wetenschap reeds langer aandacht gekregen. Gewezen kan hier worden op de oorspronkelijk voor het administratief procesrecht gehanteerde beginselen. Als 'zesde beginsel' van de ' 10 geboden' voor het administratief procesrecht, geldt het zogenaamde "vrij-bewijsbeginsel". Dit vrij-bewijsbeginsel was, en is gebaseerd op het uitgangspunt dat het administratief procesrecht geen eigen bewijsmiddelenleerstuk kent.

Van enige gebondenheid of bindende bewijsmiddelen kan in het administratief procesrecht niet worden gesproken. 119

Ook nu heeft het oorspronkelijk in het administratief procesrecht ontwikkelde beginsel van de vrije-bewijsleer in het bestuursrecht zijn waarde als bestuursprocesrechtelijk beginsel volledig behouden. ${ }^{120}$ Sterker nog, binnen het rechtsgebied van het bestuursrecht zijn gaandeweg de contouren van de vrije-bewijsleer ook zichtbaar aan het worden in het non-contentieuze bestuursprocesrecht. Daarbij geldt wel de restrictie dat deze procesrechtelijke contouren in procedures, voorafgaand aan het beroep op de bestuursrechter, beperkt zijn tot de formele

11.6 Blawwe reeks nr. $58 \mathrm{VNG}$ "s-Gravenhage 1976 en nr. $72 \mathrm{VNG}$, "s-Gravenhage, 1986. In de laatste modelwerordening die aanpassing kreag in verband met de Awb komt overigens geen bepaling inzake het horen wan getuigen en deskundigen meer voor. Artikel 7:8 Awb bevat immers een dergelijke regeling.

117 De modellen nrs. 58 en 72, bepaalden respectievelijk in de artikelen 16 en 17: 'De belangheb" benden kunnen ter zitting ter toelichting van thum standpunt getuigen en deskundigen meebrengen."

118 De Waard neemt aan 'dat ook in het administratief beroep gelegenheid moet bestaan on getuigen te doen horen, en in ieder geval: gebruik te maken wan schriftelijke getuigenverklaringen. Enkele arob-uitspraken bevestigen dit standpunt, maar de jurisprudentie is betrekkelijk schaars." De Waard, a.w., p. 315.

119 A.G. van Galen en H.Th.J.F. wan Maarseveen, a.w. p. 30 e.v.

$120 \mathrm{Van}$ Wijk/Konijnenbelt/Van Male, a.w., p. 659. 
aspecten van de vrije-bewijsleer. Deze formele aspecten van de vrije-bewijsleer zeggen iets over de wijze waarop men zijn beroep, of in dit geval het bezwaarschrift nader kan adstrueren. Dat formele aspect van de vrije-bewijsleer komt dan ook tot uitdrukking in de redactie van art. 7:8 Awb. Dit artikel brengt tot uitdrukking dat men in het kader van de bezwaarschriftenprocedure, formeel de mogelijkheid heeft om 'op verzoek getuigen en deskundigen mee te brengen die dan op de hoorzitting kunnen worden gehoord". ${ }^{121}$ Ook art. 8:60 Awb kent een soortgelijke bepaling voor de beroepsprocedure bij de bestuursrechter. Dit art. 8:60 kent voor partijen wél iets uitgebreidere mogelijkheden, doordat deze getuigen en deskundigen kunnen worden opgeroepen.

De art. 8:46 (vooronderzoek), 8:47 (vooronderzoek), 8:60, 8:61, lid 8 en 8:63 Awb, waarin nogal wat formele bevoegdheden inzake het getuigen- en deskundigenonderzoek en verhoor zijn opgenomen, werken deze formele aspecten van de zogenaamde vrije-bewijsleer verder uit. In dit verband kan ook nog worden gewezen op afdeling 8.1.6 waarbij voor zowel getuigen en deskundigen aan deze hoedanigheid verplichtingen zijn verbonden. Voor een door de rechtbank opgeroepen getuige geldt de verplichting om te verschijnen en getuigenis af te leggen (art. 8:33), terwijl de deskundige die zijn benoeming heeft aanvaard zich onpartijdig behoort op te stellen en naar beste weten zijn opdracht behoort te vervullen.

De grotere voorsprong in procesregels ten aanzien van getuigen en deskundigenverhoor is te verklaren vanuit de hierworengenoemde ontwikkelde beginselen in het administratief procesrecht, welke ontwikkeling gecontinueerd en geharmoniseerd is voortgezet in hoofdstuk $8 \mathrm{Awb}$. Verspreid voorkomende procesregelingen ten aanzien van getuigen en deskundigenverhoor in bijvoorbeeld de Wet op de Raad van State (art. 82, 84, 87, 88 en 89), de Wet administratieve rechtspraak bedrijfsorganisatie (art. 45 tot en met 49), de Beroepswet (art. 115 en 117) en de Ambtenarenwet (art. 88 tot en met 90 en 92) zijn komen te vervallen en vinden thans geünificeerd regeling in afdeling 8.2.5 Awb (onderzoek ter zitting).

De aandacht voor het bestuursprocesrechtelijk bewijsrecht heeft zich hiervoor beperkt tot het formele kader van de vrije-bewijsleer. Naast deze formele kant van de bewijsmiddelen die doelt op de wijze van bewijslevering, kent de vrijebewijsleer ook een materiële zijde. Juist die materiële zijde van het bestuursrechtelijk bewijsrecht vormt het fundament van de vrije-bewijsleer in het be-

42. Van Wijk/Konijnenbelt, a.w., p. 659. 
stuursrecht. Deze materiele zijde van het bewijsrecht heeft betrekking op de toelaatbaarheid van bewijsmiddelen. ${ }^{122}$

De toelaatbaarheid van bewijsmiddelen als materieel aspect van het bewijsrecht, markeert zoals hiervoren reeds is aangestipt, voor een groot gedeelte het vrijebewijsstelsel in het bestuursprocesrecht.

Dit vrije-bewijsstelsel is gebaseerd op een 'buitenwettelijk' negatieve invulling van het bewijsrecht. Dit laatste komt tot uitdrukking in het bestuursprocesrechtelijk uitgangspunt dat:

a. de wet niet regelt welke middelen als bewijs mogen dienen;

b. de wet geen regels geeft over de verkrijging van het bewijs;

c. de wet geen regeling geeft over de verdeling van de bewijslast en de waardering door de rechter. ${ }^{123}$

Wêl bieden zowel de Awb alls de bijzondere wetten aanknopingspunten voor een nadere invulling van het (vrije) bewijsstelsel. Voor de Awb valt in dit verband bijvoorbeeld te denken aan de adviezen van de wettelijke adviseur (afdeling 3.3), de gegevens van de aanvraag (afdeling 4.1.1) alsmede de gegevens in het kader van de toepassing van de art. 4:7 en 4:8. Tenslotte kunnen worden genoemd de inlichtingen, gegevens en bescheiden als bedoeld in de art. 5:16 tot en met 5:19 Awb. Voor de bezwaarschriftenprocedure kunnen hieraan worden toegevoegd: de gegevens zoals bedoeld in art. 6:5, de stukken in het kader van art. 7:4 en het verslag van de hoorzitting (art. 7:7).

De bewijslastverdeling zoals die in de besluitvorming in het kader van de bezwaarschriftenprocedures in het bestuursprocesrecht juridische invulling krijgt, werkt ook door. ${ }^{124}$ Deze besluitvorming is in art. 7:11, lid 1 Awb zodanig geconditioneerd dat een volledige heroverweging van de primaire beslissing door het bestuursorgaan dient plaats te vinden. Dit betekent dat bij de adstructie van belangen die in het heroverwegingsaspect liggen opgesloten, zowel vanwege het bestuursorgaan als van de kant van belanghebbende, verplichtingen in de sfeer van de bewijslastverdeling liggen opgesloten.

Er is op gewezen, dat de vrije-bewijsleer voor wat betreft de formele zijde van het bewijsrecht beperkt regeling heeft gevonden in het bezwaarschriftenproce-

122 Van Wijk/Konijnenbelt, a.W., p. 659.

$123 \mathrm{~S}$. Pront-van Bommel, Orrechtmatig verkregen bewijs, in: In de sfeer van het administratieft recht, Utrecht 1994, p. 355 e. $\%$.

124 G.F. Pieters, De bewijspositie van partijen in het bestumsprocesrecht, NTB 1996, p. 42 e.v. 
durerecht (art. 7:8). In hoofdstuk 8 Awb zijn voor het bestuursprocesrecht meer formele bewijsregels opgenomen. De aandacht voor de adstructie van cen bezwaarschrift door middel van getuigen en deskundigen bleek in het verleden gering. ${ }^{25}$ Dit betekende ook dat de aanwezigheid van getuigen en deskundigen in relatie tot het beginsel van hoor en wederhoor, ondanks de toegenomen aandacht voor de rechtsbescherming, aarzelend op gang is gekomen in de jurisprudentie van de ARRS. Widdershoven schreef in een aantekening hierover het volgende.

'Doorgaans thad de Afdeling weinig problemen met het horen van getuigen buiten aanwezigheid wan een belanghebbende zolang deze maar niet in zijn belangen was geschaad (bijv.) AR 10 december 1984, AB 1985, 237, m.nt. J.H. van der Veen; AR 29 november 1983, $\mathrm{BB} / \mathrm{S}$ III, aantekening 2 bij $\mathrm{nr}$. 476). In AR I augusius 1988 (tB/S 1988, $\mathrm{nr} 113$, m.nt. BdeW) was de Afdeling daarentegen weel kritischer (Widdershoven, Rawb 1994, 6, aantekening nr. 3.). ${ }^{126,}$

In de hiernavolgende jurisprudentie wordt een beeld geschetst over de in de rechtspraak ontwikkelde visie ten aanzien van hoor en wederhoor in relatie tot de aanwezigheid van getuigen en deskundigen zoals die op gang is gekomen tijdens de periode voorafgaand aan de inwerkingtreding van de Awb. Aansluitend worden enkele Awb-jurisprudentietrends nader onder de loep genomen.

Een bezwaarschrift ingediend in het kader van de toepassing van de Woonruimteverordening Amsterdam 1984, spitste zich toe op de door een bezwaarde aangeleverde bewijsmiddelen. $B$ en $w$ van Amsterdam hadden de woonsituatie van belanghebbende beoordeeld op basis van een huurcontract. Uit deze huurovereenkomst bleek dat betrokkene samen met twee andere medebewoners met de verhuurster van het pand waren overeengekomen het huis in zijn geheel te huren. Op basis van een schriftelijk contract leidden $b$ en $w$ daaruit af, dat bezwaarde deel uit makkte van een meerpersoonshuishouden. Die omstandigheid was voor het bestuursorgaan reden betrokkene mede te delen, dat het urgentiebewijs (benodigd voor andere passende woonruimte) was komen te vervallen. De bezwaarde bestreed dit standpunt van $\mathrm{b}$ en w. Zij stelde dat de werkelijke woonsituatie niet in overeenstemming was met het huurcontract.

Haar bewering was dat voor de contractsvorm van een meerpersoonshuishouden was gekozen omdat de verhuurster ingeval van een andere wijze van bewoning,

R.J.G.M. Widdershoven, a.w., p. 315.

De Afdeling overwoog destijds dat het "buiten de aanwezigheid van appellanten horem van getuigen (...) waarbij appellanten nitet in de gelegenheid zijn gesteld op de verschafte informatie te reageren, zodanig in strijd is met een goede procesorde dat het bestreden beshit niet in stand kan blijven wegens schending van het algemeen beginsel van behoorlijk bestuur, dat besluiten met de nodige zorgvuldigheid dienen te worden voorbereid en genomen." 
het pand niet zou hebben verhuurd. Bezwaarde adstrueerde dat zij met haar twee medebewoners geen woongroep vormde, maar feitelijk slechts een kamer had gehuurd, en een zelfstandige huishouding voerde. Bij haar bewijsvoering maakte zij gebruik van getuigenverklaringen van de bovengenoemde twee medebewoners en een onderhuurster van een andere kamer in het betreffende pand. Ondanks het aangeleverde getuigenbewijs, gingen $b$ en $w$ van Amsterdam hieraan voorbij, en baseerden zij hun uiteindelijke afwijzende beslissing op het bezwaarschrift op het overgelegde schriftelijk huurcontract.

In beroep over deze zaak oordelend, overwoog de arob-rechter onder andere als volgt:

'Met verweerders is de Afdeling van oordeel dat aan het bepaalde in de hier bedoelde overeenkomst - waarwan zich een kopie bij de stukken bevindt - geen gronden kunnen worden ontleend voor de stelling van appellante dat zij slechts over een kamer in de woning kan beschikken. Hoewel deze door appellante naar voren gebrachte gegevens (getuigenverklaring omtrent de werkelijke woonsituatie) op zichzelf beschouwd niet zonder meer tot de conclusie (behoeven te) leiden dat van kamergewijze bewoning sprake is, hadden deze gegevens naar het oordeel van de Afdeling voor verweerders in het kader van de heroverweging van hun besluit wan 11 juni 1987 aanleiding behoren te zijn een nader onderzoek naar de werkelijke woonsituatie in te stellen. Het onderzoek dat op 13 augustus 1987 heef plaatsgevonden kan niet gelden als een zodanig onderzoek, nu uil het verslag van dit onderzoek blijkt, dat slechts de bouwkundige onderscheidenlijk technische aspecten van de woning zijn onderzocht. Gelet hierop kan naar het oordeel van de Afdeling niet worden gezegd dat verweerders zich een voldoende deugdelijke basis hebben verschaft om een weloverwogen beslissing op het door appellante ingediende bezwaarschrift te nemen., ${ }^{127}$

In dit beroep werd met toepassing van art. 8, lid 1, sub d van de Wet arob vernietiging uitgesproken wegens strijd met het zorgvuldigheidsbeginsel. Uit de Amsterdamse zaak blijkt dat argumenten en beweringen van belanghebbenden indringend c.q. zorgvuldig door het bestuursorgaan moeten worden beoordeeld, door daarop actief en passend te reageren. Met het onbeantwoord laten van vraagpunten "straft' het bestuursorgaan in feite zichzelf.

Ook in zaken, waarbij medische aspecten zijn betrokken kunnen zich bij een achteloze opstelling door het bestuursorgaan identieke problemen voordoen zoals in de Amsterdamse zaak het geval was.

127 ARRS 4 oktober 1990, tB/S 1990, 117, m.nt. F.C.M.A. Michiels. 
Onder de aandacht wordt gebracht de problematiek in het kader van de (oude) Beschikking geldelijke steun huisvesting gehandicapten. Voor wat betreft de zuiverheid van de in het kader van deze regeling genomen subsidiebeschikkingen biedt de jurisprudentie onder andere een goede handleiding, op welke wijze medische aspecten bij de van de behandeling van bezwaarschriften dienen te worden beoordeeld. Met dit laatste wordt gedoeld op beweringen en stellingen door de bezwaarde omtrent diens medische situatie. Uit een uitspraak van de ARRS blijkt, dat in een zaak van de gemeente Enschede een appellant zich in beroep beklaagde over de wijze waarop hij medisch was onderzocht tijdens de primaire besluitvormingsfase. In het ingediende bezwaarschrift had belanghebbende daar al melding van gemaakt. Ook gaf betrokkene in het bezwaarschrift aan, dat zijn behandelend arts bereid was inlichtingen te verschaffen. Ten aanzien van deze omstandigheid dat betrokkene met een medisch deskundige op de proppen kwam, en $b$ en wheraan volledig bij de behandeling van het bezwar schrift voorbij gingen, was de arob-rechter van oordeel dat hierdoor in strijd met het zorgvuldigheidsbeginsel was gehandeld. $B$ en w hadden in de ogen van de bestuursrechter de arts van appellant moeten horen, teneinde daarmee te voldoen aan de zorgvuldigheidseis waartoe de heroverweging in het kader van de beslissing op het bezwaarschrift noopte. ${ }^{128}$

De volgende zaak betreft een kwestie in het kader van het administratief beroep. De ARRS moest uiteindellijk in deze kwestie in beroep oordelen over de rechtmatigheid van de door GS in administratief beroep genomen beslissing. In het geding was het inmiddels vervallen art. $56 \mathrm{WW}$.

Dit oude woningwetartikel vormde de inzet van een administratief-beroep-procedure van een belanghebbende bij GS van Noord-Holland omdat hem een verzoek om toestemming tot onttrekking aan de bestemming van een woning, was geweigerd. De aanvankelijk ten aanzien van betrokken belanghebbende door $b$ en $w$ van Amsterdam uitgesproken weigering tot woningontrekking, werd door GS in beroep 'omgezet' in het alsnog verlenen van de gevraagde toestemming. In beroep werden GS door de arob-rechter op de vingers getikt; het besluit van GS werd vernietigd wegens strijd met het zorgvuldigheidsbeginsel (art. 8 , lid 1 , sub d Wet arob). De ARRS overwoog onder andere het volgende:

"Verweerders (GS) hebben appellante (b en w) niet in de gelegenheid gesteld te reageren op het over de kwaliteit van de woning uitgebrachte advies, alvorens op grond van dit advies hun bestreden besluit te nemen. Evenmin hebben verweerders de 
inspecteur van de Volkshuisvesting gevraagd of evengenoemd advies hem aanleiding gaf tot opmerkingen. ${ }^{\text {129 }}$

Deze zaak leert dat het beginsel hoor en wederhoor met zich brengt dat de justitiabele door het bestuursorgaan de gelegenheid moet worden geboden orm op een uitgebracht advies van een deskundige te reageren. Ook het nalaten om aan een andere adviseur advies te vragen kan tot onzorgvuldigheid leiden.

Onder de vigeur van de Awb komen in de jurisprudentie zaken voor, waarbij getuigen en deskundigen een rol spelen in relatie tot hoor en wederhoor. Op grond van een korte schets kunnen hier de volgende ontwikkelingen worden waargenomen.

In een zaak tussen een inwoner van Hoek van Holland en het dagelijks bestuur van de gelijknamige deelgemeente bleek, dat tijdens een bezwaarschriftenprocedure de commissie voor de beroep- en bezwaarschriften een (hoor)zitting had gehouden die zowel een openbaar als een besloten karakter had. De bezwaarde en diens gemachtigde waren slechts tijdens de openbare zitting gehoord. In een besloten zitting hoorde de bezwaarschriftencommissie een medewerker van de afdeling Bouw- en Woningtoezicht, en verstrekte mede op basis daarvan haar advies aan het dagelijks bestuur van de deelgemeente. Zowel van het openbare gedleelte als van het besloten gedeelte van de hoorzitting was een verslag opgemaakt. Uit het verslag van de besloten hoorzitting kon worden opgemaakt dat de betrokken medewerker van de afdeling Bouw- en Woning-toezicht nogal wat feitelijke gegevens en bouwtechnische aspecten had verstrekt aan de bezwaaradviescommissie. Opmerkelijk was daarbij dat de bezwaarde en diens gemachtigde door de adviescommissie de toegang tot het besloten zittingsgedeelte was ontzegd; hen was niet toegestaan op deze besloten zitting aanwezig te zijn. Deze gang van zaken had voor het besluit van het dagelijks bestuur van de deelgemeente Hoek van Holland negatieve gevolgen. Oordelend in beroep, sprak de Rotterdamse rechtbank het onaanvaardbaar uit over deze handelwijze door de adviesw commissie. De kern van het in deze uitspraak gegeven oordeel kan als volgt worden weergegeven:

'Aangezien het eiseres en haar gemachtigde niet was toegestaan aanwezig te zijn bij het besloten deel van de vergadering, heeft zij, noch haar gemachtigde, de gelegenheid gehad op deze uitlatingen van de heer (...) te reageren. Een dergelijke gang van zaken acht de rechtbank onaanvaardbaar en in strijd met de beginselen, die ten grondslag liggen aan Afdeling 7.2 van de Awb, met het beginsel van fair play en met het in artikel 
$3: 9$ van de Awb neergelegde beginsel dat een advies, waarop een besluit berust, zorgvuldig moet zijn voorbereid. Het bestreden besluit, dat gebaseerd is op het door de commissie voor de bezwaar- en beroepschriften uitgebrachte advies, kan derhalve niet in stand blijven. ${ }^{330}$

Ook de volgende zaak maakt duidelijk dat bestuursorganen ter voldoening aan de eis van hoor en wederhoor, ingewonnen adviezen 'ter tafel' moeten brengen en belanghebbenden de gelegenheid moeten geven daarop te reageren. In deze (arob)-zaak die diende voor de rechtbank van Rotterdam anticipeerde de bestuursrechter op art. 3:9 Awb. Volgens art. 3:9 is het bestuursorgaan verantwoordelijk voor de zorgvuldigheid van het (extern) advies. In haar uitspraak verwees de rechtbank van Rotterdam naar een eerder uitgesproken schorsing van de bouwvergunning door de voorzitter van de ARRS, waarbij met het oog op een anticipatieprocedure was nagelaten de planologische visie in te winnen bij de Provincialle Planologische Commissie (PPC).

Het inwinnen van deze planologische visie werd door de toenmalige afdelingsvoorzitter noodzakelijk geacht in het belang van een verantwoorde belangenafweging. Naar aanleiding van de uitgesproken schorsing vroegen $b$ en w van de betreffende gemeente alsnog een advies van de PPC, teneinde een verantwoorde beslissing op het bezwaarschrift te kunnen nemen. Toen $b$ en $w$ uiteindelijk het positief advies van de PPC ontvingen, verzuimden zij de belanghebbenden daarover te horen. Sterker nog, het PPC-advies werd zelfs niet aan bezwaarde medegedeeld.

Uit de overweging van de rechtbank waaraan de vernietiging van de genomen beslissing op het bezwaarschrift ten grondslag lag blijkt het volgende:

"Verzoekers zijn niet in de gelegenheid gesteld om alvorens verweerder tot zijn beslissing kwam, te reageren op het advies van de PPC. Ook de mogelijkheid om eigener beweging op dit advies te reageren ontbrak voor verzoekers. De president merkt dit aan als een emstig zorgvuldigheidsgebrek in de totstandkoming wan het bestreden besluit."

De president van de Rotterdamse rechtbank oordeelde dit zorgvuldigheidsgebrek zo ernstig, dat hij onmiddellijk uitspraak deed in de hoofdzaak, en de beslissing op het bezwaarschrift vernietigde. Uit dien hoofde werd het verzoek om voorlopige voorziening afgewezen. $\mathbf{B}$ en w van de betrokken gemeente kregen in het kader van de uitgesproken vernietiging de opdracht mee 'een nieuw besluit te 
nemen met inachtneming van deze uitspraak'. Verder commentaar hierop lijkt overbodig, aangezien de inhoud van de uitspraak voor zich spreekt. ${ }^{131}$

In een andere casus, waarmee deze paragraaf wordt afgesloten, wordt nog eens het belang van hoor en wederhoor, ingeval van getuigenverklaringen benadrukt. De uitspraak is echter om meerdere redenen interessant omdat in casu het horen in het kader van een bezwaarschriftenprocedure hier niet ter discussie stond. De opmerkelijke kant van deze zaak is de vraag of een adviseur als bedoeld in art. 3:5 Awb voldoende zorgvuldigheid in acht had genomen door het horen van een getuige in het kader van zijn adviserende taakstelling, buiten aanwezigheid van een tweetal belanghebbende beroepsmilitairen te doen plaatsvinden. In deze zaak was bij de President van de Haagse rechtbank een verzoek om voorlopige voorziening ingediend tegen een besluit van de minister van Defensie, inhoudende het verlenen van ontheffing van een militaire opleiding. Tegelijkertijd was aan beide militairen eervol ontslag uit de militaire dienst verleend. Zonder de op deze zaak betrekking hebbende details in kaart te brengen, bleek dat de commandant van een opleidingscentrum van de Koninklijke Marechaussee zich in deze kwestie had laten adviseren cloor een Commissie van Advies inzake Ontheffing. De betrokken militairen bleken door de adviescommissie te zijn gehoord in het bijzijn van hun vertrouwenspersoon. Daarentegen bleek dat de adviescommissie in een tweede, op een andere datum gehouden zitting, de studiecoördinator als getuige had gehoord zonder dat belanghebbenden daarbij aanwezig waren.

Van deze laatste hoorzitting bleek tijdens de zitting voor de president geen formeel werslag te zijn gemaakt, en beschikte Defensie slechts over enkele aantekeningen van deze laatste zitting. Tevens werd ter zitting bij de president zijdens 'eisers' weersproken dat zij zouden hebben ingestemd met het horen van de getuigende coördinator, buiten hun aanwezigheid. Deze omstandigheden bleken fataal voor de instandhouding van de door de minister van Defensie genomen besluiten (ontheffing van opleiding alsmede ontslag). De president overwoog:

"Naar het oordeel van de president kunnen de bestreden besluiten miet in stand blijven
nu verweerder in strijd heeft gehandeld met het in artikel $3: 2$ Awb gecodificeerde
algemene beginsel van behoorlijk bestur dat een besluit zorgvuldig moet zijn voorbe-
reid." De aantekening behorende bij deze uitspraak is om meerdere argumenten interessant. Art. 3:9 Awb dat het omgaan met externe (wettelijke) adviezen door het bestuursorgaan conditioneert door voor te schrijven dat het bestuursorgaan zich

(3) Pres. Rb. Rotterdam 29 maart 1994, JB 1994, 100. 
ervan dient te vergewissen, dat het onderzoek door de adviseur op zorgvuldige wijze is tot stand gekomen, rept in de memorie van toelichting niet over de wijze waarop een bestuursorgaan een extern advies behoort te toetsen.

Uit de bovengenoemde uitspraak is op te maken, dat de omstandigheid dat een formeel verslag ontbrak van het getuigenverhoor, waarbij de belanghebbende militairen niet aanwezig waren, in deze zaak er toe leidde dat het bestuursorgaan hierdoor niet in de gelegenheid was het advies van de Commissie van advies inzake Ontheffing te toetsen aan het zorgvuldigheidscriterium van art. 3:9. Hieruit vloeide naar het oordeel van de bestuursrechter voort een gebrekkige toepassing van art. 3:2 Awb.

Met de annotator moet worden toegegeven dat het oordeel van de rechtbankpresident instemming verdient. Het uiteindelijke commissie-advies was immers gebaseerd op het verhoor van slechts eén getuige. De regel van hoor en wederhoor was evident geschonden. ${ }^{132}$

\subsubsection{Het horen als informatiefunctie; enige karakteristieken}

In par. 3.2.2.1 werd gewezen op de vier functies van het horen. Tot uitdrukking kwam dat de hoorplicht ex art. 7:2 een aantal bestuurlijk-juridische functies heeft dat inhoud geeft aan de hoorplicht.

Gedoeld werd hierbij op de informatiefunctie van het horen, de bemiddelingsfunctie en de ombudsfunctie. Deze uitgangspunten van de hoorplicht zijn in dit hoofdstuk gefundeerd op het algemeen beginsel van hoor en wederhoor, welk beginsel zich in zijn praktische toepassing manifesteert in het zogenaamde verdedigingsbeginsel. Dit laatste beginsel als eis, voor een behoorlijke rechtspleging, vormt als het ware het hart van de normen van een behoorlijke procedure. ${ }^{133}$ Door De Waard wordt gekozen voor een ruime benadering van de term rechtspleging. Hij ziet het bestuursorgaan ook rechispleging uitoefenen. ${ }^{134}$

Enige deelaspecten van het verdedigingsbeginsel zijn van belang met het oog op de bespreking van de informatiefunctie van het horen. Hierdoor kan deze informatiefunctie in een beter perspectief geplaatst worden. Enkele door De Waard gekozen uitgangspunten inzake het verdedigingsbeginsel vormen een goede

132 Pres. Rb. Assen 17 januari 1994, Rawb 1994, 6, met aantekening van Widdershowen. Zie in dit verband ook EHRM 18 maart 1997, JB 1997, 112 m. nt. AWH (Mantovanelli). Hieruil blijkt dat de regel van hoor en wederhoor ook geschonden kan zijn wanneer de belanghebbende niet in de gelegenheid is gesteld een deskundigenadvies te betwisten.

13 B.W.N. de Waard, a. W, p. 245.

134. B.W.N. de Waard, a.w. 
aanzet voor het in kaart brengen van karakteristieken van de informatieve kant van de hoorverplichting als bedoeld in art. 7:2 Awb. ${ }^{135}$

Het verdedigingsbeginsel als juridisch equivalent van hoor en wederhoor houdt in:

"Het recht om stellingen en eventuele bewijsmiddelen naar voren te brengen en voldoende in de gelegenheid gesteld te worden op door de wederpartij aangedragen stellingen en bewijsmiddelen te reageren; partijen dienen in de gelegenheid gesteld te worden in beginsel alle stukken waarop de geschilbeslechtende instantie haar oordeel zal baseren in te zien. ${ }^{136}$

De begripsomschrijving van het verdedigingsbeginsel kenmerkt zich volgens De Waard door een aantal deeleisen ${ }^{137}$, te weten:

- het recht om informatie te mogen ontvangen over hetgeen waartegen men zich te weer heeft te stellen;

- het recht om informatie, de zaak betreffende, te verschaffen;

- er dient voldoende gelegenheid te zijn voor de voorbereiding van de verdediging van het eigen standpunt;

- de processuele mogelijkheden van de ene partij dienen in evenwicht te zijn met die van de andere partij.

Het is niet de bedoeling in het kader van de bespreking van de informatiefunctie van het horen op al deze (deel)eisen van het verdedigingsbeginsel in te gaan. Met het oog op het aanbrengen van een zekere begrenzing in het informatieve aspect van de hoorplicht, worden deze (deel)eisen van het verdedigingsbeginsel beperkt tot een tweetal elementen, te weten:

a. het recht om informatie te ontvangen en

b. het recht om informatie te verschaffen.

In het belang van een zuivere begripsworming van de informatiefunctie van het horen, wordt het recht van de belanghebbende om informatie te ontvangen nog eens verdergaand beperkt tot een bespreking van twee aspecten. Deze twee aspecten betreffende het recht op ontvangst van informatie worden enerzijds beheersi door de vraag op welke stellingen de wederpartij zich baseert. 
Anderzijds is bij dit 'informatie-ontvangstrecht' van belang de vraag welk ondersteunend materiaal deze wederpartij in de procedure inbrengt. De twee andere aan de literatuur ontleende deelaspecten van het informatie-ontvangstrecht', te weten het kennisdragen van de start en het onderwerp van de procedu$\mathrm{re}$, worden hier buiten behandeling gelaten. ${ }^{138}$

Ten aanzien van het recht van de belanghebbende om informatie te verschaffen aan het bestuursorgaan (in casu 'de geschilbeslechtende instantie') wordt hierbij onder de aandacht gebracht, dat dit "informatie-verschaffingsrecht" in de literatuur wordt beheerst door de volgende aspecten ${ }^{139}$ :

a. gelegenheid tot overleggen van stukken (stukken die dienen ter toelichting van het partij-standpunt; en stukken die dienen als schriftelijk bewijsmateriaal);

b. gelegenheid tot mondelinge toelichting (in persoon aanwezig zijn en eventueel het woord voeren; maar anderzijds, ook het zich in rechte doen vertegenwoordigen of bijstaan);

c. gelegenheid tot het doen horen van getuigen en/of deskundigen;

d. garanties dat het horen de beslissing op deugdelijke wijze beïnvloedt.

Het 'informatie-ontvangstrecht' werd hierworen omschreven als het recht van de belanghebbende om informatie te ontvangen van het bestuursorgaan. Als tegenhanger van dit 'informatie-ontvangstrecht' werd als tweede (deel)eis van het verdedigingsbeginsel (het recht van hoor en wederhoor), genoemd het 'informatie-verschaffingsrecht". Het laatstgenoemde recht kreeg zijn omschrijving als het recht van de belanghebbende om informatie te verschaffen aan het bestuursorgaan. Hieruit blijkt dat het aspect 'informatie' op grond van het verdedigingsbeginsel, benaderd wordt als een 'aansprakenrecht' van de bij de behandeling van het bezwaar betrokken belanghebbende.

Bezien vanuit het wederkerigheidsaspect dat de relatie tussen burgers en besturursorganen beheerst, zou het uitsluitend belichten van het 'aansprakenrecht' van de burger op informatie van het bestuursorgaan tekort doen aan de inhoud van het besluitwormingsproces, in casu de bezwarschriftenprocedure. Ook het bovengenoemde 'aansprakenrecht' van de burger op informatie in het kader van diens relatie tot het bestuursorgaan, heeft tegelijkertijd zijn keerzijde. Die keerzijde 'omarmt' als het ware tevens het 'aansprakenrecht' op informatie door het besturursorgaan van de belanghebbende burger. De concretisering van het bestuurlijk recht op informatie vindt zijn grondslag in het besluitbegrip als bedoeld in 
art. 1:3 Awb. Dit aan art. 1:3 ontleende besluitbegrip suggereert immers een wettelijk vooropgestelde bevoegdheidsprimaatstelling zijdens het bestuursorgaan: 'een schriftelijke beslissing (...), inhoudende een publiekrechtelijke rechtshandeling". De tweede pijler waarop het bestuurlijke recht op informatie rust, vindt zijn grondslag in art. 3:2 inzake de onderzoeksplicht naar relevante feiten en af te wegen belangen.

Deze schriftelijke beslissing van het bestuursorgaan die gericht is op het creëren van een publiekrechtelijke rechtshandeling betekent, dat het bestuursorgaan bij het nemen van een besluit een wettelijke norm concretiseert. ${ }^{140}$ Dat in tweede instantie deze concrete normstelling vanwege het bestuur door de rechter getoetst en eventueel vervangen wordt door een rechterlijke normstelling ${ }^{141}$, doet in feite niets af aan het bestuurlijke primaat ten aanzien van de concretisering van deze normstelling. De bestuurlijke taakvervulling met het oog op de behartiging van het algemeen belang, is wezenlijk anders van karakter dan de rechterlijke toetsing van besluiten van bestuursorganen. In het kader van de beoordeling in hoger beroep door de CRvB omtrent de rechtmatigheid van bonus/malusbeslissingen van bedrijfsverenigingen, werd de inhoudelijke betekenis van "besturen" en 'rechtspreken' door de bestuursrechter nog eens aangescherpt. ${ }^{142}$

De informatiefunctie van het horen vertoont een aantal karakteristieken, waardoor de materiële betekenis van het informatieverkeer tussen de burgers en het be stuursorgaan nadere invulling krijgt. Er werd op gewezen dat het 'informatieontvangstrecht' en het 'informatie-verschaffingsrecht' van de burger als een aansprakenrecht in het besluitvormingsproces kan worden gekwalificeerd. Tegelijkertijd heeft datzelfde aansprakenrecht op informatie in de relatie tussen de burgers en het bestuursorgaan een wederkerigheidsaspect: ook het bestuursorgaan heeft een gelijkwaardig informatie-ontwangstrecht en daarnaast het recht om informatic aan de burger te verschaffen. Dat dit aansprakenrecht een bijzonder

140. P. de Haan, Th. G. Drupsteen en R. Fernhout, Bestumrsrecht in de social w rechtstata, deel 1 , verde geheel herziche dr., Deventer 1996, p. 75.

lall P. de Haan e.a. a a.w., p. 75.

1.42 CRvB 15 februari 1995, JB 1995, 64, A.A 1995, p. 236 e.v. NJCM-Bulletin 1995, p. 421 a.v. en Rechtsprak Bestursrecht, De Annotaties: 94/95 155 e.v. Zie in dit verband rechtsoverwegingen 4: 18 en 4.19: "De malusbeslissingen zouden zich overigens bij uitstek lenen voor een nadere beoordeling in een bezwarenprocedure op grond wan de Awb, zodat mede aan de hand Yan door werkgevers in concrete geval lei geuite bezwaren tegen de malusoplegging, een nadere bestuurlijke weging zou kunnen plaatswinden. In de procedure voor de rechter staat dan primair de beslissing op bezwaar ter beoordeling. 4.19 In zoverte acht de Raad het een gemis dat de malusbeslissing - mogelijk zelfs onbedoeld - niet onderworpen is aan de verplichte bezwarenprocedure van de Awb.' 
accent krijgt vamuit de positie die het bestuursorgaan in het besluitvormingsproces inneemt, bleek hiervoor uit het recht van het bestuursorgaan om besluiten te nemen, en daarmee wettelijke normen te concretiseren.

Dat het bestuursorgaan het primaat heeft ten aanzien van de concretisering van de normstelling, vindt zijn grondslag in de bijzondere plaats die het orgaan inneemt. Het bestuursorgaan neemt immers door middel van juridisch eenzijdige beslissingen (besluiten) de nadere bepaling van de inhoud van de wederzijdse rechtsbetrekking voor haar rekening op basis van haar aan rechtsnormen ontleende bevoegdheid. ${ }^{143}$ Vanuit dit primaat van het bestuursorgaan om de wettelijke normstelling te concretiseren kan worden afgeleid, dat het orgaan in het bestuursrecht tot taak heeft de ordening van de bestuurstechtelijke rechtsbetrekking. ${ }^{144}$ Die aan het algemeen belang gerelateerde taak, markeert tevens de bijzondere positie van het bestuursorgaan in het verkeer tussen de burgers.

De verhouding tussen de actoren in het bestuursrecht, in casu de burgers en het bestuursorgaan wordt immers beheerst door rechtsnormen die de rechtsbetrekking tussen de burgers en het bestuursorgaan bepalen. ${ }^{145}$ Daarnaast worden deze rechtsnormen aangevuld door de werking van de beginselen van behoorlijk bestuur en de algemene rechtsbeginselen. Deze rechtsnormen voor het functioneren van de bestuursorganen hebben juridische consequenties voor de inhoud van de aanspraken die zowel burgers als bestuursorganen hebben in hun onderling (informatie)verkeer. De vaststelling van de inhoud van die aanspraken kan worden inge-vuld op basis van de doelstellingen van de $\mathrm{Awb}$. In het bijzonder wordt hierbij gewezen op de wijze, waarop de Awb de rechtsbetrekking tussen burgers en het bestuursorgaan kenschetst. De Awb ziet de rechtsbetrekking als een betrekking waarin de burger en het bestuursorgaan in een wederkerige relatie staan zodat het bestuursorgaan rekening moet houden met de positie van de burger als (andere) partij. Voor beide partijen heeft dit gevolgen. De Awb heeft de beginselen van behoorlijk bestuur geconcretiseerd tot verplichtingen om rekening te houden met de belangen en zienswijzen van de burger, waar dat verenigbaar is met de taak van het bestuur om het algemeen belang te behartigen. De rechisbetrekking tussen burger en bestuursorgaan brengt naast de bovengenoemde bestuurlijke verplichtingen wél met zich, dat ook de burger zich bewust moet zijn met het bestuurs-orgaan in een rechtsbetrekking te staan, waarin van een zekere mate van weder-kerigheid sprake is. Wel hoeft de burger zich niet spontaan het algemeen belang aan te trekken; dat is de taak van het bestuursor-

143 R.M. van Male, Onvoltooid recht, Zwolle 1993, p. 10.

144 E.M.H. Hirsch Ballin, Wederkerig bestuursrecht, RMTh 1989, p. 3.

145 R.M. van Malle, a.w. 
gaan. Maar deze wederkerigheid betekent ook voor de burger, voor zover hij dit wenst dat men met zijn inzichten en belangen rekening houdt. Wél moet de burger deze belangen op een voor het bestuursorgaan geschikte wijze naar woren brengen. ${ }^{146}$

Dit belangrijke uitgangspunt in de parlementaire stukken van de $A w b$ is niet zonder betekenis voor de informatiefunctie van de hoorplicht. Hieruit kan immers worden afgeleid, dat er gesproken kan worden van een evenwicht in het aansprakenrecht in het (informatie)verkeer tussen de burger en het besturursorgaan in het besluitvormingsproces. Hierdoor wordt het bovengenoemde "evenwicht" tot stand gebracht door het 'oorspronkelijk' beginsel van hoor en wederhoor. Aan dit beginsel van hoor en wederhoor ligt de doelstelling ten grondslag om de actoren in een bestuurlijke woorprocedure een gelijkwaardige positie te verschaffen. ${ }^{147}$

De "gelijkwaardigheid" van positie tussen de belanghebbende burgers en bestuursorganen construeert als het ware een juridische 'evenwichtsbalk' zodra belanghebbenden met het bestuursorgaan worden geconfronteerd tijdens de vervulling van de wettelijke hoorplicht als bedoeld in art. 7:2.

Dit gelijkheidsaspect dat aan de hoorverplichting ten grondslag ligt, wordt in de literatuur op treffende wijze tot uitdrukking gebracht. ${ }^{148}$

'Een hoorverplichting is juist hierom voor het bestuursorgaan nuttig, omdat een mondelinge gedachtenwisseling nadere informatie kan opleveren die voor de uiteindelijke beslissing op het bezwaarschrift relevant is. Al hetgeen woor die beslissing relevant is, moet bekend zijn en dus besproken worden. Tijdens het horen kan blijken, dat de gegevens waarover het bestuursorgaan beschikt, nog onvolledig of gebrekkig zijn.'

Onder de werking van art. 14, lid 1 Wet arob (hoorplicht), is door de ARRS indertijd gesteld, dat de hoorverplichting niet alleen waarborgen schept voor de indiener van het bezwalschrift. Ook worden door deze hoorverplichting waarborgen gecreëerd voor het bestuursorgaan. ${ }^{19}$ De ARRS verwoordde haar standpunt inzake de inhoud van de hoorplicht aldus:

"dat het bestuursorgaan zich er aldus van kan vergewissen dat het over alle relevante gegevens beschikt alvorens tot een nadere overweging over te gaan en tot een nieuwe

146 PG Awb I, p. 39.

147 J.M.H.F. Teunissen, in: Algemene wet bestuursrecht, a.w., p. E 6.3.7 2 .

148 J.M.H.F. Teunissen, a.w., p. 6.3.7 -2.

149 J.M.H.F. Teunissen, a.w. 
beslissing te komen, waarbij ook die feiten en omstandigheden die eerst ter zitting zijn aangedragen of gebleken in ogenschouw moeten worden genomen'.

Naast het gelijkwalardigheidsprincipe dat uit het beginsel van hoor en wederhoor volgt, ligt hierin derhalve een waarborgfunctie opgesloten voor zowel de burger als het bestuursorgaan. Deze waarborgfunctie heeft als dienende functie in het belang wan de hoorplicht van het bestuursorgaan in de Awb, een codificerende en een in feite zelf modificerende betekenis gekregen door art. 3:2. Deze bepaling van de Awb "spoort" het bestuursorgaan aan om bij de voorbereiding van een besluit alsook een handeling de nodige kennis te vergaren omtrent relevante feiten en de af te wegen belangen.

\subsection{Conclusies}

Art. $7: 2$, lid 1 legt het bestuursorgaan een belangrijke verplichting op: voordat op het bezwaar wordt beslist 'stelt" het bestuursorgaan belanghebbenden in de gelegenheid te worden gehoord. Hierdoor wordt in samenhang met de procedurebepalingen in de art. 7:4 tot en met 7:9 Awb voor de bezwaarschriftenprocedure, de basis gelegd voor een van de meest fundamentele beginselen van een behoorlijke procedure, te weten het beginsel van hoor en wederhoor. Dit beginsel heeft tot uitgangspunt het verschaffen van een gelijkwaardige positie van de bij het bestreden bestuursbesluit betrokken belanghebbenden. ${ }^{151}$

Het beginsel van hoor en wederhoor dat procedurele gelijkwaardigheid van de belanghebbenden pretendeert, brengt met zich dat aan de hoorplicht voor de bezwaarschriftenprocedure een diepere betekenis moet worden toegekend dan de tekst van art. 7:2 doet vermoeden. De hoorverplichting is niet alleen van procedureel belang; zij vervult een belangrijke functie ten dienste van de in het kader van de bezwaarschriftenprocedure door het bestuursorgaan te maken heroverweging (art. 7:11, lid 1). Het horen, voorafgaand aan de beslissing op het bezwaarschrift, is daarom mede van materiële strekking in het belang van de hernieuwde en integrale beoordeling van het bestreden primaire besluit. Met het voldoen aan de hoorplicht betreedt het bestuursorgaan het terrein van het materiële recht. Het bestreden besluit waaromtrent belanghebbenden door het bestuursorgaan worden gehoord, vindt immers zijn grondslag in de bijzondere wetgeving.

De hoorverplichting van art. 7:2 en ook de overige procedure-bepalingen van afd. 7.2 , kunnen worden beschouwd als belangrijke pijlers van de bezwaarschriften-

151 J.M.H.F. Teunissen, in: Algemene wet bestuursrecht, losb1. "s-Gravenhage, p. E 6.3.7-1. 
procedure om de uit het materieel recht voortvloeiende rechten en plichten te effectueren. ${ }^{152}$ Of art. 7:2 op een rechtens juiste wijze is toegepast, hangt af van de omstandigheden, waaronder door of namens het bestuursorgaan aan de hoorverplichting concrete inhoud is gegeven. De procedurevoorschriften betreffende het horen, verschaffen het bestuursorgaan een legitimiteitsbasis in zijn contact met de justitiabele. ${ }^{153}$ De hoorplicht voor de bezwaarschriftenprocedure moet worden gezien als een procedurele minimum-eis", zonder een 'eigen' procedurele en organisatorische inbreng door of namens het bestuursorgaan - die overigens niet strijdig mag zijn met de bepalingen van de $\mathrm{Awb}$ - komt de hoorverplichting onvoldoende tot haar recht. Van het bestuursorgaan mag worden verlangd dat het zich op een degelijke manier 'administratief' voorbereidt op de te houden hoorzitting. Dit brengt met zich dat het bestuursorgaan voorafgaand aan het horen van de belanghebbenden, onderzoek behoort te verrichten naar de bij het bestreden besluit betrokken relevante feiten en belangen, alsmede het recht en het beleid. Het horen van de belanghebbenden is immers door de heroverwegingsplicht in art. 7:11 een belangrijke verplichte procedurele schakel ten dienste van de beslissing op het bezwaarschrift.

Hoor en wederhoor is een van de belangrijkste waarborgen voor een 'goed' procesrecht. Ook de hoorplicht in het kader van de bezwaarschriftenprocedure wordt door deze eis, die geldt voor een eerlijke (rechtspraak)procedure, beinvloed. De bezwaarschriftenprocedure kan door de hoorplicht de in een eerdere procedure ontstane zorgvuldigheidsmanco's in de besluitvorming, compenseren. ${ }^{154}$

De verplichte uniforme hoorplicht voor de bezwaarschriftenprocedure die ten grondslag ligt aan het harmonisatieprincipe van de $A w b^{155}$, is geen novum in het bestuursrecht. Met de hoorplicht is vóór de Awb en ook vóór het arob-tijdperk veel ervaring opgedaan in geschilbeslechtende procedures (bezwaar en administratief beroep). Daarmede is niet gezegd dat de hoorverplichting in het bestuursrecht van de een op andere dag als een vanzelfsprekende bestuurlijke verplichting werd gezien. De hoorverplichting is als het ware meegegroeid in het denkproces van de rechtsbescherming tegen de overheid:

152 PG Awb I, p. 18.

153 P.J.J. van Butren en M. de Groot-Sjenitzer, a. 1 , p. 28.

154 B.W.N. de Waard, Een eerlijk proces (I), Algemene beginselen van behoorlijk procesrecht, TrO 1983 , p. 145.

155 PG Awb I, p. 330. 
'Het scheppen van een rechtsgang bij het bestuur is een nieuwe onderneming, die goed moet worden onderscheiden van de rechtsgang bij de administratieve rechter. Een eerste punt van verschil is, dat anders dan bij de rechter, niet kan worden voorgeschreven, dat het beschikkend orgaan zelf de belanghebbenden hoort of met hen overlegt. ${ }^{* 156}$

Aanvankelijk vormde de hoorplicht (soms) een bescheiden procedureel aspect bij het tot stand komen van beschikkingen. Door de toegenomen rechtsbescherming tegen de overheid werd incidenteel in gespecialiseerde rechtsgangen voorzien in een wettelijke hoorplicht. ${ }^{157}$

Vóór de inwerkingtreding van de Awb legde de Wet arob als aanvullende rechtsbeschermingsregeling in art. 14, lid 1 met de invoering van de verplichte bezwaarschriftenprocedure, een belangrijke ontwikkeling vast, ten aanzien van de hoorplicht in het bestuursrecht. Art. 14, lid 1 van deze wet is een belangrijke wette-lijke bron van art. 7:2 Awb. Voor art. 14, lid 1 Wet arob was de jurisprudentie een belangrijke formele rechtsbron. In de rechtspraak werd in die gevallen dat geen wettelijke hoorplicht was voorgeschreven door de administratieve rechter, het door het bestuursorgaan achterwege laten van het horen van de justitiabele, getoetst aan het formele zorgvuldigheidsbeginsel . ${ }^{158}$

In dit hoofdstuk is vastgesteld dat de hoorplicht een procedureel formeel-juridisch kader is ten dienste van de op het bezwaarschrift te nemen beslissing. Deze formele benadering van de hoorverplichting van art. 7:2 Awb, verschaft echter alleen inzicht in het antwoord op de vraag langs welke "lijnen" de beslissing op het bezwaarschrift tot stand is gekomen. Het horen in het kader van de bezwaarschriftenprocedure heeft zoals is geconstateerd, ook een materiële zijde. Met deze materiële zijde van het horen door het bestuursorgaan komt de vraag aan de orde, welke beslissing op het bezwaarschrift moet worden genomen. Door deze vraag wordt het verband gelegd met art. 7:11, lid 1 . Deze bepaling draagt het bestuursorgaan op om op grondslag van het ontvankelijke bezwaar het bestreden besluit aan een heroverweging te onderwerpen. In concreto betekent dit dat het horen moet zijn afgestemd op de inhoud van het bestreden besluit in samenhang met de gronden van het bezwaar. Art. 7:2, lid 2 Awb brengt tot uitdrukking dat het bestuursorgaan belanghebbenden in de gelegenheid moet stellen hun zienswijze naar voren te brengen.

156 A.M. Donner, Algemene bepalingen van administratief recht, NJB 1974, p. 1087 en 1088.

157 R.J.G.M. Widdershoven, Gespecialiseerde rechtsgangen in het administratieve recht, Zwolle 1989.

ABAR, Se dr , Alphen aan den Rijn 1984, p. 129 e.w. 
Vanuit dit gezichtspunt zou het horen door het bestuursorgaan de betekenis hebben van "luisteren" naar informatie over de gemaakte bezwaren. Aan het horen wordt door de Awb echter een belangrijke bestuurlijke functie toegedicht. De hoorplicht vervult in de ogen van de Awb een waarborgfunctie. Deze waarborgfunctie van het horen is gericht op het activeren door het bestuursorgaan van wederzijdse informatie van zowel het bestuursorgaan als de justitiabele. Het verstrekken van deze wederzijdse informatie is gericht op het versterken van de kwaliteit van de besluitworming. ${ }^{159}$ Op basis hiervan formuleert de MvT van art. $7: 2$ een viertal belangrijke functionele bestuurlijke uitgangspunten, te weten:

het mondeling naar voren brengen van de grieven ten aanzien van het bestreden besluit, het verstrekken van nadere informatie, het creëren van oplossingen en het versterken van het vertrouwen in de bestreden beslissing indien de bezwaren geen aanleiding geven tot wijziging van het primaire besluit. ${ }^{160}$

In par. 3.2.2.1 zijn deze wier functies aangescherpt tot een aantal belangrijke functionele uitgangspunten van de hoorplicht:

1. het horen is voor de belanghebbenden een kans om het bestuursorgaan informatie te verschaffen terwijl deze kans voor het bestuursorgaan een plicht inhoudt tot het adstrueren van het bestreden besluit;

2. op het bestuursorgaan rust op grond van art. 3:2 Awb (kennisvergaringsplicht) een verificatieplicht ten aanzien van de feiten, het recht en het beleid;

3. het bestuursorgaan moet actief en bemiddelend optreden;

4. het bestuursorgaan kan de legitimatie van het bestreden besiuit versterken.

Vastgesteld is dat de bovengenoemde aspecten een wezenlijke bijdrage kunnen leveren aan het rechtens inhoud geven aan het uit de hoorplicht voortvloeiende 'gelijkwaardigheidsbeginsel' van hoor en wederhoor. Gelijkwaardigheid betekent vanuit het gezichtspunt van hoor en wederhoor het voldoen aan de eisen van gelijke proceskansen voor de justitiabelen (equality of arms) en de eis van goede en voldoende kansen (quality en quantity of arms). ${ }^{161}$ Op basis van het 'gelijke kansenperspectief' vervult het beginsel van hoor en wederhoor, een belangrijke rol als verdedigingsbeginsel. Daaruit vloeit voort het recht op informatie dat het bestuursorgaan verplicht tot:

- het bieden van de justitiabele van voldoende gelegenheid ter verdediging van standpunten op de hoorzitting;

161 E. W.N. de Waard, a.w., p. 247 
- het in evenwicht houden van de processuele mogelijkheden van de ene belanghebbende ten opzichte van de andere.

Door de bovengenoemde aspecten is het beginsel van hoor en wederhoor een veelomvattend begrip. Het kan worden gekenschetst als 'smeerolie' voor de kwaliteit van de beslissing op het bezwaarschrift. In de context van hoor en wederhoor dienen art. 3:2 Awb, het verbod van vooringenomenheid, het beginsel van correcte bejegening, en het daarmede verband houdende fait play-beginsel als belangrijke juridische fundamenten.

Op basis van de bovengenoemde aspecten is in par. 3.2 .2 .2 voor het beginsel van hoor en wederhoor, als voorbereidingsaspect ten behoeve van de op het bezwaarschrift te nemen beslissing, een tiental functionele elementen geformuleerd. Deze tien elementen vormden de basis voor een jurisprudentie-onderzoek naar:

a. de onvoorwaardelijke selectieplicht van het bestuursorgaan van de bij het bestreden besluit betrokken belanghebbenden;

b. hoor en wederhoor als structuurbepalende (wettelijke) verplichting;

c. hoor en wederhoor in relatie tot de kennisvergaringsplicht en

d. hoor en wederhoor en de aanwezigheid van getuigen en deskundigen.

Uit het onderzoek dat zowel betrekking heeft op de arob-periode als de Awb kan worden afgeleid, dat de jurisprudentie voor wat betreft de onder a tot en met d genoemde aspecten, een sterke relatie legt met hoor en wederhoor en de kennisvergaringsplicht. Vanuit het gezichtspunt van het bieden van gelijke kansen moet het bestuursorgaan aan hoor en wederhoor een zodanige invulling geven, dat de burger 'het volle pond' krijgt. Dit laatste heeft gevolgen voor de omvang van de onderzoeksplicht en de juiste bepaling van de inhoud van de positie van de belanghebbenden in de bezwaarschriftenprocedure. Vastgesteld is dat het bestuursorgaan bij het gelegenheid bieden van hoor en wederhoor, een actieve opstelling ten toon moet spreiden door bijwoorbeeld verzoeken en suggesties niet onbeantwoord te laten.

In par. 3.2.2.2, rubriek $d$, is uitgebreid ingegaan op de betekenis van de aanwezigheid van getuigen en deskundigen tijdens de hoorzitting. In tegenstelling tot de Wet arob kent de Awb in art. 7:8 een regeling voor het meebrengen van getuigen en deskundigen ter hoorzitting. Art. $7: 8$ is een bepaling die nauw verwant is met het bewijsrecht in het administratief procesrecht. Het bewijsrecht is in het kader van het bezwaar en ook het administratief beroep in ontwikkeling achtergebleven ten opxichte van het procesrecht bij de administratieve rechter. Onder de Wet arob was bijvoorbeeld het gebruiken van schriftelijke getuigenverklaringen 
blijkens de jurisprudentie betrekkelijk schaars. ${ }^{162}$ Dit laatste heeft waarschijnlijk te maken met het feit dat in het administratief recht ook eerst in de zestiger jaren gaandeweg de aandacht groeide voor 'het bewijs' in het administratief procesrecht. ${ }^{163}$

Sprekend over het bewijsrecht in 'het administratief procesrecht' werd de aandacht gevestigd op het vrij-bewijsbeginsel als zesde beginsel van administratief procesrecht. ${ }^{64}$ Ter verklaring van het bovengenoemd procesrecht-beginsel is benadrukt dat het vrij-bewijsbeginsel gebaseerd is op het uitgangspunt dat het administratief procesrecht (en ook het nieuwe bestuursprocesrecht) geen eigen bewijsmiddelenleerstuk kent. Het administratief procesrecht noemt in beginse] geen bindende bewijsmiddelen.

Het vrij-bewijsbeginsel in het administratief procesrecht (lees: bestuursprocesrecht) bevat een tweetal aspecten, te weten een formeel en een materieel aspect. Het formele aspect van het vrij-bewijsbeginsel is in verband gebrach met art. 7:8 Awb (meebrengen getuigen en deskundigen ter hoorzitting). Het materieel aspect van het vrij-bewijsbeginsel is het meest fundamenteel voor de vrij-bewijsleer in het bestuursprocesrecht. ${ }^{165}$

Deze materiële zijde van het vrij-bewijsbeginsel, is globaal in rubriek $d$ onderzocht en brengt tot uitdrukking dat er geen bestursprocesrechtelijke (wettelijke) regeling is over de middelen die als bewijs mogen dienen, het verkrijgen van het bewijs en de verdeling van de bewijslast. ${ }^{166}$ Geconstateerd is dat zowel in de Awb als de bijzondere wetten aanknopingspunten zijn te vinden voor een nadere invulling van het (vrije) bewijsstelsel.

Tenslotte is vastgesteld dat toetsing door de bestuursrechter van besluiten op basis van de informatieve functic van het horen (par. 3.2.2.3) een dubbele (waarborg)functie heeft.

B.W.N. de Waard,aw, p. 315.

J.M. Kan, Bewijzen in het administratief recht, RM Themis 1966, p. 519 e.v.

164 A.G. van Galen en H.Th.J.F. wan Maarseveen, Beginselen van administratief procesrecht, VAR LXXXIII, Alphen aan den Rijn 1981, p. 30 e.v.

I6s Van Wijk/Konijnenbelt Wan Male, Hoofdstukken van administratief recht, achtste dr. Utrecht 1993, p. 659 .

166 S. Pront-van Bommel, a.w., p. 355. 
Deze waarborgfunctie is gebaseerd op:

- de beoordeling van een rechtens juiste wijze van hoor en wederhoor (het bieden van gelijke kansen door het bestuursorgaan voor de belanghebbende justitiabelen, waardoor voldaan wordt aan het uit hoor en wederhoor voortvloeiende verdedigingsbeginsel;

- het voorkomen dat belangen van belanghebbenden worden geschaad (de eisen van een goede procesorde). 



\section{Het adviseren omtrent de op het bezwaarschrift te nemen beslis- sing}

\subsection{Typen van advisering}

De Awb komt tot een indeling van een drietal typen van advisering met betrekking tot de bestuurlijke adviesrelaties.'

Het eerste adviseringstype wordt gekarakteriseerd als deskundigenadvisering. Specifieke deskundigheid op een bepaald terrein van het openbaar bestuur wordt geidentificeerd met eisen van onpartijdigheid en objectiviteit. Deskundigenadvisering heeft tot doel om door middel van schriftelijke advisering aan het bestuursorgaan, op basis van wettelijke toetsingscriteria hieraan concrete inhoud te geven in het belang van een rechtens juiste toepassing van wettelijke voorschriften. Te denken valt aan de beoordeling door de welstandscommissie van eisen van redelijke welstand, de toetsing van de monumentale aspecten in het kader van de Monumentenwet/verordening, alsmede het inzicht verschaffen omtrent het antwoord op de vraag of er aanspraak bestaat op planschadevergoeding (art. 49 WRO), en zo ja in welke mate die schade naar billijkheid behoort te worden vergoed.

Deskundigenadvisering kan ook omschreven worden als het geven van uitleg over de toepassing van normen, en in samenhang daarmede de taxatie en interpretatie van feiten. ${ }^{2}$ Naast het aspect van deskundigheid en zorgvuldigheid dient deskundigenadvisering de legitimiteit van besluiten. Gaandeweg is het besef gegroeid dat de betrokkenheid van de burgers bij bestuurlijke beslissingen moet worden vergroot; dit laatste kan worden afgezet tegen een van de uitgangspunten van de Awb (hoofdstuk 2). Hierin ligt opgesloten de intentie van de Awb om de bereidheid van de burgers tot het aanvaarden van negatieve overheidsbeslissingen te vergroten. ${ }^{3}$

Aan de Awb ligt mede een legitimiteitsaspect ten grondslag. Het adviseren in het algemeen en de deskundigenadvisering in het bijzonder, verschaffen kansen voor het bestuursorgaan om bij de besluitvorming de legitimiteitsbasis te vergroten." Het is ook mogelijk deskundigheid te bezien vanuit een waarborgperspectief van

1 PG Awb L, p. 216

2 S.V. Hoogendijk-Deutsch, Advisering in het bestuursrecht, VAR LXXX, Zwolle 1978, p. 20.

3 E.M.H. Hirsch Ballin, Minister van Justitie, De Awb; einde van het oude en begin van thet nieuwe, in: Bestuur, burger en rechtspraak, Mimisterie wam Justitie en Ministerie wan Binnenlandse Zaken, 1994, p. 12.

4 H.R.B.M. Kummeling, a.w., p. 19 e.r. 
de gewenste expertise. ${ }^{3}$ De vergroting van de legitimiteitsbasis door deskundigenadvisering raakt ook aspecten van niet-juridische aard. De machtsbasis van de overheid ligt immers niet alleen in het recht opgesloten. De ongelijkheid in de verhouding tussen overheid en burger manifesteert zich ook buiten de sfeer van het recht. Ten opzichte van de overheid wordt er bij veel burgers een tekort aan bureaucratische vaardigheid geconstateerd." Ook in dit 'grijze' gebied van de verhouding tussen bestuursorganen en burger kan deskundigenadvisering een bijdrage leveren ten behoeve van het vergroten van het vertrouwen van de justitiabele in de overheid. Deskundigenadvisering is een besturursrechtelijk fenomeen, dat niet meer weg te denken is als belangrijke factor in de validiteit van de besluitvorming. In de vraagstelling of dit type van advisering een hulpmiddel is voor het bestuursorgaan", ligt als het ware het antwoord al opgesloten.

Als tweede type van advisering in het bestuursrecht wordt door de Awb de "representatie-advisering" genoemd. ${ }^{8}$ Wat hieronder moet worden verstaan blijkt niet zo helder uit de MvT van de Awb. Bij dit type van advisering moet de adviseur een goed inzicht hebben in de belangen en verlangens van de groepering waartoe hij behoort. Uitgangspunt van de Awb is dat bij de representatie-advisering een zo hoog mogelijke $\mathrm{kwaliteit}$ van de besluitvorming van bestuursorganen wordt nagestreefd. ${ }^{9}$ Als representatie-advisering in commissieverband geschiedt, moet de samenstelling van een commissie zodanig zijn dat de betrokken belangen, die "vaak niet gelijk lopen, aan bod komen". Hoogendijk-Deutsch is duidelijker in haar formulering ten aanzien van de representatie-advisering.

Zij wijst er op, dat in die gevallen dat de primaire functie van raadpleging, gericht is op overleg en inspraak, de adviseur over andere kwalificaties moet beschikken dan bijvoorbeeld bij deskundigen-advisering. Van belang is in dit laatste geval, inzicht en kennis van bepaalde situaties en omstandigheden.

Hierbij speelt ervaring van de adviseur een grotere rol dan kennis. HoogendijkDeutsch noemt een aantal hoedanigheden die bij representatie-advisering van belang zijn. Hoofduitgangspunt is in ieder geval dat voldaan wordi aan representativiteitscondities die doorgaans aan belangenvertegenwoordigers worden gesteld. Dit laatste uitgangspunt dient in de adviescommissie tot uitdrukking te komen. De samenstelling zal zodanig moeten zijn dat op evenwichtige wijze de belangen, waaromtrent geadviseerd moet worden, tot hun recht kunnen komen.

5 M.A. Heldeweg, Normstelling en expertise, diss., Maastricht 1993.

M. Oosting, Kwaliteit van de Overheid, Deventer 1990, p. 21.

E.C.H.J. van der Linden, Advisering in het bestursrecht, JB 1995, 318.

PG Awb I. P. 216.

PG Awb I, a. w。 
Kortom een evenwichtige samenstelling van de (representatieve) adviescommissie moet zijn verzekerd als basis voor de advisering. ${ }^{10}$

Tenslotte kent de bestuurspraktijk de figuur van semi-rechterlijke advisering als een bijzonder soort van advisering voor die gevallen, dat bij de voorbereiding van de bestuurlijke besluitvorming het bieden van rechtswaarborgen aan de burger in het geding is. Dit laatste type van advisering is meer in het bijzonder gericht op de voorbereiding van op bezwaar- en beroepschriften te nemen beslissingen. De Awb noemt als belangrijke conditie voor deze adviseringsvorm het inbouwen van een extra contradictoir accent in de fase voorafgaand aan de besluitvorming. Belangrijke hieraan gerelateerde voorwaarden zijn:

a. het waarborgen van de onpartijdigheid van de adviseur;

b. het creëren van een adwiesprocedure conform de beginselen van behoorlijke rechtspraak.

De semi-rechterlijke advisering onderscheidt zich duidelijk van de twee andere adviesvormen. Toch hebben deze drie typen van advisering geen absolute betekenis. Gemeenschappelijk hebben zij tot kenmerk dat zij dienstbaar zijn aan het bestuurlijke besluitvormingsproces, en elkaar onderling beïnvloeden. De advisering op basis van deskundigheid kan zich zowel voordoen op het terrein van de representatie-advisering als die van de semi-rechterlijke advisering. Ook kan representatie-advisering zich voordoen bij semi-rechterlijke advisering (bijvoorbeeld raadsleden die lid zijn van een bezwaarschriftenadviescommissie).

Met deze in het kort aangestipte accenten ten aanzien van de semi-rechterlijke advisering wordt in de volgende paragrafen overgegaan tot een bespreking van de advisering in het kader van de bezwaarschriftenprocedure.

\subsection{Een schets van de Wet arob als proeftuin voor de ontwikkeling van de advisering op het terrein van de bezwaarschriftenprocedure}

Par. 4.1 werd afgesloten met een bijzonder type van advisering (semi-rechterlijke advisering).

Het adviseren heeft hier als oogmerk om voorafgaande aan geschilbesleching binnen de kring van het bestuursorgaan, de voorbereiding van de op een bezwaarschrift (hetzelfde geldt voor het beroepschrift in het kader van het administratief beroep) te nemen beslissing op een hoger niveau te brengen. Met 'hoger niveau'

10 S. V. Hoogendijk-Deutsch, a.w., p. 22 en 23. 
wordt in dit geval bedoeld dat alle belangen die de besluitvorming in primo raken, nog eens goed onder de loep worden genomen, en dat daarbij gelet wordt op eventuele "primaire" gebreken. Voor het besturursorgaan is dit doorgaans de laatste gelegenheid om op 'intern' niveau gemaakte misslagen, ontstane misverstanden tussen bestuur en burgers uit de weg te ruimen. De bezwaarprocedure fungeert immers als eindfase van de besluitvorming binnen de kring van het bestuursorgaan; deze voorprocedure is tevens het 'voorportaal' van het beroep bij de bestuursrechter.

De geschilbeslechting door de bestuursorganen heeft een bijzondere ontwikkeling doorgemaakt. Onder de werking van de Wet arob werd aanvankelijk op decentraal niveau de bezwaarschriftenprocedure ingevoerd. Naderhand werd overgegaan tot het invoeren van deze procedure bij de centrale overheid, alsmede op andere terreinen van het bestuursrecht (Wet BO). Op deze ontwikkelingen werd gewezen in hoofdstuk $\mathbb{1}$.

Het adviseren omtrent het beslechten van geschillen werd in par. 4.1 in het bijzonder gekarakteriseerd door zijn 'gerichtheid" op het bieden van rechiswaarborgen voor de bij de bestuurlijke procedure betrokken justitiabelen. Vooral door het inschakelen van een adviescommissie voor de bezwaarschriften krijgt deze waarborgfunctie accent. Bij het inschakelen van deze adviescommissie staat een tweetal condities voorop, te weten enerzijds de onpartijdigheid van het adviseren; anderzijds kunnen beginselen van behoorlijke rechtspraak die in dit boek al aan bod kwamen, fungeren als belangrijke elementen voor een rechtens juist verloop van de bestuurlijke (voor)procedure. Dit belangrijke uitgangspunt, dat gericht is op het bieden van procedurele waarborgen is niet zonder betekenis voor de bezwaarschriftenprocedure. Feitelijk, maar ook rechtens worden hiermede inrichtingseisen gecreëerd die gedragen worden door rechtswaarborgen in het belang van de justitiabelen.

Naast het gebruik van de term semi-rechterlijke advisering zou met evenveel redenen gesproken kunnen worden van 'waarborgadviescommissies'."

Kummeling brengt op grond van de waarborgfunctie van de semi-rechterlijke advisering, enkele verfijningen aan in het belang van het adviseren, ten behoeve van geschilbeslechtende besluitvorming door bestuursorganen. Hij oordeelt het gebruik van waarborgadviescommissies op zijn plaats in die gevallen dat het bestuursorgaan judex in causa is. Daaraan verbindt Kummeling de conditie dat er

11 H.R.B.M. Kummeling, a. w., p. 24. 
sprake moet zijn van een sterke afhankelijkheid van de burger ten opzichte van het bestuursorgaan. In die laatste situatie zou dan het contradictoire karakter van de voorbereidingsfase van een (concreet) besluit met extra waarborgen moeten worden omkleed. Voor die gevallen zou dit contradictoire karakter van de besluitvorming, in casu de bezwaarschriftenprocedure, met procedurele waarborgen moeten worden omkleed. ${ }^{12}$

Kummeling en Hoogendijk-Deutsch bepleiten beiden het belang van het creëren van een sterkere rechtspositie van de burger in diens confrontatie met het bestuursorgaan. Een in de ogen van de burger onaanvaardbaar primair besluit, behoort naar hun opvatting alsnog door het bestuursorgaan te worden beoordeeld. Toch is er nog een ander aspect dat semi-rechterlijke advisering onderscheidt van de 'gewone' adviescommissie. Adviescommissies treden doorgaans niet met

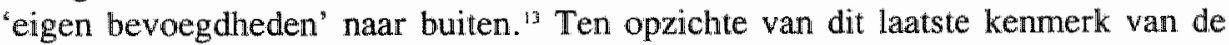
overige adviesrelaties onderscheidt zich de semi-rechterlijke advisering. In het volgende hoofdstuk zal blijken dat het uitvoeren van de hoorplicht, alsmede het nemen wan een aantal preparatoire beslissingen (procedurele beslissingen) door adviescommissies in het kader van de bezwaarschriftenprocedure, deze commissies een belangrijke wissel kunnen trekken op de behandeling van bezwaarschriften. Door hun positie in de bezwaarschriftemprocedure fungeren bezwaarschriftenadviescommissies in feite als een 'verlengde arm' van het bestuursorgaan.

Vooral in de arob-periode is de advisering over bezwarschriften tot ontwikkeling gekomen. Zowel de parlementaire geschiedenis, alsmede de wetenschap en de jurisprudentie, hebben daaraan in ruime mate een bijdrage geleverd. Voor zover wan belang, zal voor een goed begrip en inzicht in de 'semi-rechterlijke' advisering worden ingegaan op de bestuurspraktijk ten tijde van de arob-periode. Ook de praktijk van het adviseren ten tijde van de Wet arbo is van belang voor de advisering in het kader van de bezwaarschriftenprocedure op grond van de $\mathrm{A} w \mathrm{~b}$.

In het belang van het onderzoek wordt tevens aandacht besteedt aan andere in de bestuurspraktijk bestaande adviesvormen in de bezwaarschriftenprocedure. De wetgever heeft nu en in het verleden, de bestuursorganen met betrekking tot de inrichting van de bezwaarschriftenprocedure een zekere mate van vrijheid gelation.

12 Kummeling, a.w., p. 24 en p. 163 e.w., met name 7.3.1. De inrichting van de procedure. Zie ook: Hoogendijk-Deutsch, a.w., 21 en p. 22.

13 Zie in dir verband: A.M. Donner, a w., p. 157 e.v., waarin naar literatuur wordt verwezen met betrekking tot adviescommisies. 
De facultatieve adviesmogelijkheid in de Awb die regeling windt in art. $7: 13$, en waarbij een commissie kan worden ingeschakeld voor het horen en het adviseren, ter voorbereiding van de op het bezwaarschrift te nemen beslissing, is het resultaat van een ontwikkeling die tijdens de arob-periode in gang is gezet. Wél moet worden opgemerkt, dat de samenstelling van de adviescommissie die de Awb in het eerste lid van art. 7:13 dwingend voorschrijft, niet in de Wet arob was geregeld. In art. 14 Wet arob lid 4, was bepaald dat het adviseren kon worden "opgedragen" aan een commissie. Daarnaast bestond conform dit vierde lid de mogelijkheid om op grond van "enige andere wettelijke bepaling de beslissing op het bezwaarschrift op te dragen aan een commissie" (besliscommissie).

Aan de mogelijkheid in de Wet arob om voor het horen en adviseren door een commissie bij a.m.v.b. (nadere) regels te stellen (art. 14, lid 3), werd geen invulling gegeven. Toch kreeg de inrichting van de bezwaarschriftenprocedure in de bestuurspraktijk ruime aandacht. De gemeentebesturen vervulden, geadviseerd door de VNG, een belangrijke rol in de behandeling van bezwaarschriften.

Die vooraanstaande rol op het terrein van bezwaarschriftenprocedures maar ook op het gebied van het administratief beroep, wierp al vóór de Wet arob zijn schaduw vooruit. De inwerkingtreding van de Wet arob betekende immers niet dat de gemeentebesturen voor het eerst geconfronteerd werden met de behandeling van bezwaarschriften. Op gemeentelijk niveau bestonden reeds vóór de arobperiode nogal wat (autonome) rechtsbeschermingsvoorzieningen voor de burger om te ageren tegen genomen besluiten. Ter stimulering van een goede inrichting van de bezwaar- en de beroepsmogelijkheden (administratief beroep bij de gemeenteraad) werd door de VNG een eerste model-verordening voor de behandeling van bezwaar- en beroepschriften ontworpen. ${ }^{4}$

Met betrekking tot de voorbereiding van de op het bezwaarschrift te nemen beslissing kende deze model-verordening een regeling voor het horen; een adviesprocedure via de commissievorm was nog niet in deze concept-regeling opgenomen. Zulks in tegenstelling tot de procedure van het administratief beroep bij de gemeenteraad. De werkgroep van de VNG die belast was met de voorbereiding van de model-verordening meende dat vooralsnog niet voor een afzonderlijke van het primaire beslissende orgaan losstaande adviesrelatie moest worden gekozen. Uit de overwegingen van de VNG-werkgroep blijkt, dat deze indertijd nog sterk leunde op een volledige voorbereiding van de beslissing op het bezwaarschrift binnen de kring van het bestuursorgaan. Dat de bestuurspraktijk

14 Behandeling van bezwaar-en beroepschriften door de gemeentebesturen, VNG Blauwe reeks, nr. 48 , 's-Gravenhage 1972. 
daarmee onder andere uit een oogpunt van overbelasting van het bestuursorgaan, geen recht werd gedaan, bleek naderhand onder de werking van de Wet arob. Een afrondende kanttekening kan hier nog worden gemaakt ten aanzien van het vón de Wet arob gehuldige standpunt van de VNG, dat art. 14, lid 1 van deze wet de inschakeling van een adviescommissie niet zou toelaten. Omdat het horen conform dit artikel zou moeten plaatsvinden door het bestuursorgaan, zou art. 14, lid 1 zich verzetten tegen een onafhankelijke adviescommissie. ${ }^{\text {is }}$ De praktijk van de Wet arob heeft uitgewezen, dat dit laatste standpunt een misvatting was. In de naderhand verschenen model-verordeningen kwam de VNG op haar schreden terug. Voor de behandeling van beroepschriften voorzag het VNG-model nu wél in een aanbeveling tot instelling van een commissie voor de beroepschriften. Voorgesteld werd in de samenstellingsvereisten van de commissie voor de beroepschriften enige onafhankelijkheidsaspecten op te nemen. Uitgangspunt was dat geen leden van het college van burgemeester en wethouders lid mochten zijn van de beroepscommissie. Ook ambtenaren in dienst van de gemeente en arbeidscontractanten waren van deelname van de commissie uitgesloten. ${ }^{i 6}$

De parlementaire geschiedenis van de Wet arob, is duidelijker en ook stelliger dan de Awb ten aanzien van het adviseren op het bezwaarschrift. Een kort citaat uit de parlementaire geschiedenis van de Wet arob geeft het volgende beeld over het belang van het instellen en het functioneren van een adviescommissie:

-De ondergetekenden zijin van oordeel, dat een speciale commissie belast met de voorbereiding van en het uitbrengen van advies met betrekking tot de op een bezwaarschrift te nemen beslissing, van groot belang kan zijn om in daarvoor aangewezen gevallen de bezwaarschriftenprocedure aan haar doel te doen beantwoorden. In het voorafgaande is er reeds op gewezen, dat dit de voorbereiding van de uiteindelijke beslissing en de dossiervorming ten goede zal komen. (...)

Ook de VNG had oog voor het belang van de centrale functie en positie van de bezwaarschriftenprocedure. De inrichting van de bezwaarschriftenprocedure op grond van de Wet arob, werd in een nieuw model voor de behandeling van bezwaarschriften, voorzien van een drietal mogelijkheden voor de gemeentebesturen om invulling te geven aan de behandeling van bezwaren. Zonder hier nader in te gaan op de inhoudelijke betekenis van de door de VNG gepresenteerde

15 VNG Blauwe reeks nr. 48, p. 17.

16. VNG Blauwe reeks nr. 48, p. 37 e.w.

17. Parlementaire geschiedenis van de Wet Arob, J.H. van Kreveld en M. Scheltema, Groningen 1976, p. 296. 
drie modellen, werden de gemeentebesturen de volgende alternatieven geboden, te weten:

modelverordening $\mathbf{I}$ : het administratief orgaan hoort en beslist zelf, modelverordening II: instelling adviescommissie en model III: de instelling van een commissie met beslissingsbevoegdheid ten aanzien van ingediende bezwaarschriften. ${ }^{\text {is }}$

In de literatuur en de jurisprudentie groeide de aandacht woor de Wet arob en ook de discussie over de functie en het karakter van de bezwaarschriftenprocedure. Van verschillende zijden uit de wetenschap werd de bezwaarschriftenprocedure kritisch belicht. De plaats van de bezwaarschriftenprocedure in het besluitvormingsproces, alsmede de institutionele vormgeving van de procedure via commissies, kreeg daarbij ten volle de aandacht. In dit verband mag worden verwezen naar hoofdstuk $1 .{ }^{\text {19 }}$

In de tachtiger jaren is een tweetal belangrijke onderzoeken verricht met betrekking tol de Wet arob. Het eerste onderzoek richtte zich op de werking van de bezwaarschriftenprocedure bij de gemeenten en provincies. In dit onderzoek, werden door de VNG de drie modelverordeningen, op hun praktische werking getoetst. ${ }^{26}$

In het onderzoek kwam vast te staan dat hoofdworm B (VNG-model II), als adviescommissie een betere zeefwerking (filterwerking), vertoonde dan model A. ${ }^{21}$ Bij dit laatste model (VNG-model I), berustte de voorbereiding (inclusief advisering) en de beslissing bij het bestuursorgaan. De variant waarbij de mogelijkheid van een besliscommissie bestond, bleek weinig toepassing te vinden. Kennelijk bleek vanuit de praktijk geen of nauwelijks behoefte aan een besliscommissie. ${ }^{22}$ Enkele jaren na het bovengenoemde rapport als eerste fase van een tweetal geplande onderzoeksfasen, verscheen de eindrapportage. In de eerste fase waren alle gemeenten en provincies object van studie, terwijl in de tweede fase (eindrapportage) het onderzoek beperkt werd tot een zestal gemeenten. ${ }^{23} \mathrm{Het}$ (eind)onderzoek bestreek onder andere ook hier weer de organisatie van de bezwaarschriftenprocedure in de onderzochte gemeenten. Daarbij werden tevens betrokken de adviesrelaties met de bestuursorganen op grond van daarvoor

18. Behandeling wan bezwatschriften ingevolge de Wet Arob door de gemeentebesturen, VNG, 'sGravenhage 1976.

19 Zie in dit werband: De arob-bezwaarschriftenprocedure als keuzevraagstuk, in: Rondom de Wet Arob. Bestuurswetenschappen 1979.

20 Beeld van de Arob-bezwaarschriftenprocedure, a.w., p. 77.

21 Beeld van de Arob-bezwaarschriftenprocedure, a.w., p. 302.

22 Beeld van de Arob-bezwaarschriftenprocedure, a.w. p. 151 e.v.

23 C.M. Breeuwsma, E. Helder, E. Niemeijer e.a. Arob-praktijken, a.w. 
vastgestelde gemeentelijke verordeningen. Het bovengenoemd eindrapport was overigens tevens bedoeld als een evaluatie van de Wet arob.

In het rapport was op basis van het verrichte onderzoek een aantal aanbevelingen opgenomen. ${ }^{24}$ Deze aanbevelingen zullen nog nader worden aangestipt bij de bespreking van de advisering in het kader van de bezwaarschriftenprocedure onder de werking van de Awb. De visie van de onderzoekers met betrekking tot de advisering in het kader van de bezwaarschriftenprocedure wordt hierna beknopt aangestipt.

Kortheidshalve wordt volstaan met het citeren van een enkel fragment uit de conclusies van het bovengenoemd onderzoek.

Op de vraag of de behandeling van bezwaarschriften door een commissie de voorkeur verdient, rapporteerde het onderzoeksteam:

'Voornamelijk met het oog op het verbeteren van de Arob bezwaarschriftenprocedure uit een oogpunt van rechtsbescherming - daarnaast wordt een bijdrage verwacht aan een meer uniforme en doelmatiger praktijk - wordt een voorkeur uitgesproken voor het behandelen van bezwaarschriften door een commissie.

De analyse van de heroverweging in de bezwaarschriftenprocedure (zie hoofdstuk 7) mondde uit in de conclusie, dat de realisatie van de idee van de volledige heroverweging "de beste kansen" krijgt wanneer behandeling van het bezwaarschrift plaatsvindt door een commissie. In deze commissie zou bij voorkeur een inbreng wan drie kanten verzekerd moeten zijn: bestuurlijke inbreng, inbreng vanuit de beleidsmatige voorbereidende afdeling en een onafhankelijk element. De combinatie van deze elementen brengt het "Januskopkarakter" van de bezwaarschriftenprocedure tot uitdrukking: enerzijds verlengde besluitvorming en derhalve terugkoppeling op degenen die betrokken zijn geweest bij de totstandkoming van het aangevochten besluit, anderzijds de eersie stap in de richting van beroep, waarbij enkele waarborgen voor onbevooroordeellheid onmisbaar zijn. Behandeling van bezwaarschriften door een commissie waarin deze elementen aanwezig zijn verdient aanbeveling. Daarbij zou tevens moeten worden voorzien in een bij verordening vastgelegde procedure $(. . .)^{23}$

Duidelijkheidshalve wordt hierbij opgemerkt, dat in het rapport gekozen wordt voor een adviescommissie.

In navolging van de aanbevelingen in het bovengenoemd rapport ${ }^{2 \%}$, kwam de VNG in 1986 met volledig aangepaste model-verordeningen voor de behandeling

24 Arob-praktijken, a.w. p. 343 e.v.

25 Arobmraktijken, a.w., p. 346 e.v.

26 Arob-praktijken, a.w., p. 349. 
van bezwaar- en beroepschriften, waarin geen plaats meer werd ingeruimd voor een besliscommissie. De VNG opteerde op basis van de thierworengenoemde onderzoeksrapporten voor de volgende drie modellen, te weten model I (arobadviescommissie), model II (arob-bezwaarschriftenprocedure zonder commissie) en model III waarbij voor een algemene commissie voor de bezwaar- en beroepschriften werd gekozen. Ook bij dit laatste model was er sprake van het horen en het adviseren door deze commissie, waarbij de beslissing aan het bestuursorgaan was voorbehouden.

In art. 3 van de model-verordening I (arob-adviescommissie) en III (commissie bezwaar-en beroepschriften) vermeldde het tweede lid in beide gevallen:

'2. Tot voorzitter, respectievelijk lid van de commissie, zijn niet benoembaar personen die deel uitmaken van of werkzaam zijn onder verantwoordelijkheid van het administratief orgaan."

Aangaande de samenstelling van de arob-adviescommissie merkt de commissie op dat er voldoende distantie verzekerd moet zijn. Daarnaast zal de commissie op basis van haar samenstelling in staat moeten zijn de bestreden beslissing aan een beleidsmatige toets te onderwerpen. Als belangrijke factor in de samenstelling van de adviescommissie wijst de VNG op de beschikbaarheid van voldoende juridische expertise. Tevens zall de keuze voor de samenstelling van de commissie afhankelijk moeten zijn van de mate van intensiteit van het maken van bezwaar (aantallen bezwaarschriften), alsook de omstandigheid of er sprake is van krachtens mandaat genomen beschikkingen. ${ }^{27}$

Toch bleef de aandacht voor de inrichting van de bezwaarschriftenprocedure niet beperkt tot de bovengenoemde rapporten van de VNG die gericht waren op het bevorderen van een uniforme inrichting van de bezwaarschriftenprocedure.

Gewezen werd op de mogelijkheid van art. 14, lid 3 Wet arob om bij a.m.v.b. regels te stellen terzake van het horen en het adviseren met betrekking tot de op het bezwaarschrift te nemen beslissing. Een dergelijke a.m.v.b. is niet tot stand gekomen. Wél is door de commissie Arob in 1987 een eindrapport inzake de Arob-bezwaarschriftenprocedure gepresenteerd, waarin een ontwerp a.m.v.b. is opgenomen. ${ }^{28}$ Dit rapport van de commissie Arob heeft weliswaar niet geleid tot de inwerkingtreding van de door de arob-wetgever beoogde a.m.v.b., maar heeft toch betekenis gehad voor de verdere ontwikkeling van de adviespraktijk onder de

27 Gemeentelijke behandeling van (arob-) bezwaar- en beroepschriften, Blauwe reeks nr. 72, VNG, s-Gravenhage 1986. 
Wet arob. Het rapport heeft zijn schaduw vooruit geworpen op de in art. $7: 13$, lid 1 Awb genoemde adviescommissie. Commissievoorzitter W.F. de Gaay Fortman kreeg daarbij geassisteerd door zijn secretarissen E.H.M. Hirsch Ballin en M.I. 't Hooft, de opdracht sturing te geven aan een tweeledige opdracht. Enerzijds moest worden geadviseerd omtrent de mogelijkheid van rechtspraak in twee instanties; daarnaast kreeg de commissie de opdracht een advies uit te brengen voor het verbeteren van de inrichting van de bezwaarschriftenprocedure.

In haar advies maakte de commissie De Gaay Fortman zich deelgenoot van de conclusies zoals verwoord in de bovengenoemde twee rapporten inzake de arobbezwaarschriftenprocedure. Voor een goed begrip van de in die rapporten opgenomen conclusies, kan er aan worden herinnerd dat het gebruik van het adviescommissie-model beter filterde dan zonder advisering door middel van een commissie. Maar per saldo genereerden beide modellen nauwelijks minder beroepschriften. Niet primair de zeefwerking, maar het belang en de kwaliteit van de rechtsbescherming zouden nopen tot de inschakeling van een adviescommissie. ${ }^{29}$

Met haar eindrapportage en de concept-a.m.v.b. kwam de commissie Arob tot een advies, waarin de kernpunten in deze a.m.v.b. werden gevormd door de hoofdaspecten, te weten het horen, het voorbereiden en het beslissen op het bezwaarschrift. ${ }^{30}$ Voor wat betreft het beslissingsaspect wijst de commissie het gebruik van de in art. 14, lid 4 Wet arob opgenomen mogelijkheid van een besliscommissie af. De commissie stelde zich op het standpunt, dat de heroverweging die in de bezwaarschriftenprocedure de basis vormt voor de hernieuwde besluitvorming zich er tegen verzet, dat de beslissing op het bezwaarschrift wordt opgedragen aan een ander (bestuurs)orgaan dan het in primo beslissend orgaan. Voor de commissie Arob was dit aanleiding de minister van Justitie als har opdrachtgever, aan te bevelen de figuur van de besliscommissie "uit de wettelijke bepalingen die deze hebben ingesteld of mogelijk maken' te schrappen. ${ }^{31}$ De Awb rept niet meer over de mogelijkheid tot het instellen van een besliscommissie; de bestuursrechter staat afwijzend tegenover de instelling van deze besliscommissies. Op deze (nieuwe) jurisprudentie onder de werking wan de Awb wordt nog teruggekomen.

Het advies van de commissie De Gaay Fortman voorzag tevens in het geven van enkelle aanbevelingen voor samenstellingsvereisten van de bezwaarschriften-

29 Eindrapport commissie Arob, a.w., p. 8.

30 A.W., p. 17

3 A.W. P. 16. 
adviescommissie. Art. 8, leden 2 en 3 van de ontwerp-a.m.v.b. gaf de volgende overigens niet verplichte (inrichtings)regels te zien:

2. De adviescommissie bestaat uit een voorzitter en ten minste twee leden.

3. De woorzitter kan geen deel uitmaken van noch werkzaam zijn onder verantwoordelijkheid van het administratief orgaan. ${ }^{32}$

Ofschoon de commissie niet kwam met een wettelijke verplichting voor bestuursorganen tot instelling van de bovengenoemde adviescommissie, ging de ontwerpa.m.v.b. wél uit van het verplicht naleven van de regeling inzake het adviseren door een adviescommissie, zo deze daartoe is ingesteld. In de toelichting behorende bij art. 7 van de ontwerp a.m.v.b., welk artikel slechts sprak over de bevoegdheid, maar niet een verplichting tot het opdragen van het horen en het adviseren inzake de op het bezwaarschrift te nemen beslissing, werd door de commissie Arob een nauwe band gelegd tussen horen en adviseren door een adviescommissie.

De bezwaarschriftenprocedure wint naar de opvatting van de commissie hierdoor aan kwaliteit. ${ }^{3}$ Op deze samenhang tussen horen en adviseren zal nog worden terug gekomen in de volgende paragraaf.

Uit de bovengenoemde ontwerpbepaling blijkt, dat deze veel samenhang vertoont met art. 7:13 Awb. Ook in de Awb wordt in het eerste lid van art. 7:13 de eis gesteld, dat de bezwaarschriftenadviescommissie dient te bestaan uit een voorzitter en ten minste twee leden. Daarnaast is in onder $b$ van dit eerste lid, de eis gesteld dat de voorzitter geen deel uitmaakt en niet werkzaam is onder verantwoordelijkheid van het bestuursorgaan. Op de inhoudelijke betekenis van het gestelde in art. 7:13, lid 1, onder b. wordt in hoofdstuk 5 nog nader ingegaan.

Ter afronding van de gegeven schets inzake de advisering, voorafgaand aan de op het bezwaarschrift te nemen beslissing, volgen hier nog enkele aantekeningen uit de jurisprudentie.

De inschakeling van een adviescommissie conform art. 14, lid 1, derde volzin van de Wet arob, was eerst dan in overeenstemming met dit artikel geschied wanneer de herkenbaarheid van dit advies is vast te stellen aan de hand van 'een schriftelijk stuk'. Een mondeling advies is niet in overeenstemming met het doel en de strekking, alsmede de totstandkomingsgeschiedenis van art. 14. In deze zaak die diende voor de ARRS vond vernietiging plaats wegens strijd met art. 14,

3) A.w., p. 10 toelichting a.m.v.b. 
lid 1 Wet arob. ${ }^{34}$ Eerst 11 jaar na de inwerkingtreding van de Wet arob "sneuvelde' een afgegeven verklaring van geen bezwaar in het kader van een vrijstelling ex art. 19 WRO op grond van de afwezigheid van een schriftelijk advies van de betreffende adviescommissie.

Toch lijkt er meer aan de hand in deze kwestie. De vraag kan worden gesteld of de inschakeling van de bovengenoemde adviescommissie wel in strijd was met art. 14, lid 1, derde volzin van de Wet arob. Die derde volzin van het eerste lid van art. 14 Wet arob bepaalde immers dat het horen en het adviseren is 'opgedragen' aan een commissie.

Met het 'opdragen' zelve is er niets mis. Aan het advies kleeft in zoverre het gebrek dat het niet 'schriftelijk' is uitgebracht. Hoewel niet nagegaan is of er een verordening bestond aangaande de ingestelde adviescommissie, is doorgaans in de procedure-verordening de schriftelijkheid van het uit te brengen advies neergelegd. Uit de besproken van 1986 daterende modelverordening van de VNG blijkt dat het advies van de commissie wordt ondertekend door de voorzitter en de secretaris van de commissie (art. 22). Daarnaast bepaalde art. 23 van de VNGmodel verordening dat het in art. 22 bedoelde advies aan het administratief orgaan (...) moet worden uitgebracht. ${ }^{35}$

Als de toetsing van dergelijke bepalingen van de verordening in het geding is, ligt het meer in de rede om tot strijd met de toepasselijke bepalingen van de procedureverordeningen te concluderen.

In de volgende uitspraak komt de bevoegdheid inzake het horen en adviseren door een adviescommissie tot uitdrukking. $B$ en $w$ hadden hun bevoegdheid tot het horen vanwege de inwerkingtreding van een procedureverordening verloren.

De ARRS overwoog in deze zaak van de gemeente 's-Gravenland als volgt:

"Na het indienen van het bezwaarschrift is een niewwe verordening in werking getreden waarbij het horen en geven van advies is opgedragen aan een waste commissie. De verordening kent geen overgangsbepaling. Appellant is daarom na de inwerkingtreding van de nieuwe verordening ten onrechte nog gehoord door een vertegenwoordiging wan b en $w$ in stede van de vaste commissie. Het bestreden besluit verdraagt zich niet met de nieuwe verordening juncto artikel 14 , eerste lid, van de Wet arob. Dat de vaste commissie - die well het advies heeft uitgebracht - de beschikking had over een verslag van de gehouden hoorzitting kan aan het vorenstaande niet afdoen. "

ARRS 2 juni 1987, tB/S 1987, 92 , m.nt. J.B.J.M. ten Berge.

35 VNG Bllawwe reeks nr. 72, "s-Gravenhage 1986, p. 19.

ARRS 31 maart 1989. AB 1989, 405, nu.nt. V. JHvdV. en Wes administratieve rechtspraak overheidsbeschikkingen, $\mathrm{S} \& \mathrm{~J}, 154$, Zwolle 1991, p. 461. 
Uit deze uitspraak kan tevens worden afgeleid, dat er een sterke samenhang wordt verondersteld tussen het horen en het adviseren.

In de volgende zaak komt die samenhang eveneens tot uitdrukking, al was in deze zaak de principiële vraag van belang of het horen en het adviseren door een wethouder zich wel verdroeg met de strekking van art. 14, eerste lid Wet arob. De ARRS kwam in deze Zutphense zaak tot het wolgende oordeel:

'De Afd. is wan oordeel dat het bepaalde in art. 14, eerste lid, van de Wet arob, gezien doel en strekking van deze bepaling, zich er niet tegen verzet dat de burgemeester in een geval als het onderhavige het horen van de indiener van het bezwaarschrift en het geven van advies inzake de op het bezwaarschrift te nemen beslissing opdraagt aan de wethouder die met de behandeling van zaken, als waarop het aangevochten besluit betrekking theeft, is belast. Nu voorts is gebleken dat de burgemeester bij thet nemen van zijn bestredlen besluit kennis droeg van hetgeen ter hoorzitting was verhandeld, alsmede dat de wethouder, die appellant heeft gehoord, de burgemeester bij wijze van beoordeling van het ontwerp-bestreden besluit van advies heeft gediend inzake de op het bezwaarschrift te nemen beslissing, is de Afd. wan oordeel dat aldus in het onderhavige geval op genoegzame wijze is woldaan aan het bepaalde in artikel $\mathbb{1 4}$, eerste lid, van de Wet arob." ${ }^{\prime \prime n}$

In een andere zaak blijkt, dat aan het begrip 'commissie' als bedoeld in art. 14 , lid 1 Wet arob strikte betekenis moet worden toegekend.

De arob-rechter oordeelde, dat $b$ en $w$ niet als commissie konden fungeren in de zin zoals bedoeld in art. 14, lid 1 Wet arob. In de betreffende kwestie ging de gemeenteraad naar het oordeel van de ARRS in de fout door een bij hem ingediend bezwaarschrift ter afdoening in handen te stellen van $\mathrm{b}$ en $\mathrm{w} .{ }^{28}$

B en w kunnen ook op een andere wijze betrokken zijn bij de behandeling van een bij de gemeenteraad ingediend bezwaarschrift. De vraag kan worden gesteld of $b$ en $w$ een adviescommissie die de gemeenteraad adviseert omtrent ingediende bezwaarschriften voor de voeten kan lopen, door naast het advies van deze commissie de gemeenteraad een afwijkend voorstel te doen voor wat betreft de door de raad op het bezwaarschrift te nemen beslissing. Uit de bovengenoemde jurisprudentie bleek, dat $\mathrm{b}$ en niet de functie van een adviescommissie mogen overnemen. Uit een uitspraak van de arob-rechter kan worden geconcludeerd, dat

37 ARRS 18 september 1980, Gst. 6658, 3, m.nt. v. JMK en S \& J, a.w., p. 465.

38 ARRS 25 maart 1982, Gst. 67387, 7, m, ut. IMK, BB/S, II 115; zie ook J.G. Steenbeek, Wet administratiove rechtspraak overheidsbeschikkingen, bewerkt door F.A.M. Stroink, vierde herzilene druk, 's-Gravenhage 1988 , p. 397. 
die laatste omstandigheid onverlet laat de bevoegdheid van $b$ en $w$ om zelfstandig, naast het advies van een commissie voor de bezwaarschriften, de gemeenteraad een voorstel te mogen doen aangaande de op het bezwaarschrift te nemen beslissing. Art. 209, aanhef en onder $s$ gem.w. wees b en $w$ immers aan als competent orgaan voor het voorbereiden van 'al hetgeen in den raad ter overweging en beslissing moet worden gebracht', ${ }^{38}$

Deze uitspraak wekt overigens wel enige bevreemding, omdat de bovengenoemde in de (vervallen) gem.w. opgenomen bepaling het 'prerogatief' van de voorbereidende taak van $b$ en $w$ met de conditie beperkte 'zoover het niet aan anderen is opgedragen'. In dit laatste gemeentewettelijk voorbehoud zou in die gevallen dat er een vaste commissie van advies is voor de behandeling van bezwaarschriften voor de gemeenteraad, b en w niet meer aan bod mogen komen door het doen van een eigen voorstel in die gevallen dat de gemeenteraad op een bezwaarschrift moet beslissen. Ook onder de werking van het nieuwe bestuursrecht deed zich inmiddels een soortgelijk geval voor, waarbij b en w, met voorbijgaan aan het advies van de bezwaar- en beroepscommissie, aan de gemeenteraad een eigen voorstel deden, ondanks het feit dat bij de raad een advies voorlag van de bezwaar- en beroepschriftencommissie.

In de betreffende kwestie van de gemeente Aalsmeer fungeerde voor het horen en het adviseren in het kader van de bezwaarschriftenprocedure een adviescommissie in de zin van art. 7:13 Awb. De gemeenteraad beschikte in het kader van de besluitvorming met betrekking tot een verzoek om herziening van een bestemmingsplan over twee adviezen; een advies van de bezwaar- en beroepscommissie en een advies van $b$ en w. Beide adviezen stonden haaks tegenover elkaar. De adviescommissie had geadviseerd tot gegrondverklaring van het bezwaarschrift; $b$ en w daarentegen adviseerden de raad tot ongegrondverklaring van het bezwaar. Dit laatste advies werd door de raad overgenomen. De bestuurstechter stond voor de beantwoording van de vraag of de genomen beslissing door de gemeenteraad zich wel verdraagt met het huidige art. $161 \mathrm{Gem}$.w. (oud 209, letter s), dat in een enigszins andere redactie en als afzonderlijke bepaling voorschrijft:

"Het college van burgemeester en wethouders is belast met de voorbereiding van alles waarover in de vergadering van de raad zal worden beraadslaagd." JHvdV. Zie ook Loeb, Olivier, Troostwijk, De Wet Arob toegepast. vierde druk. Nijmegen 1990, p. 151. 
Het walt hierbij op dat de restrictie in de vervallen gem.w., 'zover het niet aan anderen is opgedragen', ontbreekt in het huidige art. $161 \mathrm{Gem}$. wet. Zonder overigens tot strijd met de Gem.w. jo art. 7:13 Awb te concluderen, sprak de bestuursrechter zijn twijfels uit over de bovengenoemde gang van zaken.

De rechtbank overwoog als volgt:

'Bovendien acht de rechtbank het, gelet op het karakter van de in de Awb geregelde bezwaarschriftenprocedure zeer twijfelachtig, of de in artikel 161 Gemeentewet genoemde voorbereiding inhoudt, dat het college, ingevall de Bezwaar- en beroepschriftencommissie een advies heeft uitgebracht, nog een eigen woorstel tot een beslissing op het bezwaarschrift doet. ${ }^{*}$ "o

De bovengenoemde overweging van de rechtbank leidde niet op die grond tot vernietiging. Het 'onaanvaardbaar" over de gang van zaken in deze Aalsmeerse kwestie werd in de uitspraak van de rechtbank 'verpakt' in een vernietiging wegens strijd met de in art. 7:12 neergelegde motiveringsplicht:

'Als het college daartoe al bevoegd zou zijn, had, naar het oordeel wan de rechtbank verweerder in ieder geval het collegevoorstel niet mogen overnemen, dan na zelf te motiveren, waarom naar zijn oordeel het advies van de Bezwaar- en beroepscommissie moest worden afgeweken. Door dat na te laten heeft verweerder gehandeld in strijd met de art. 3:2, 7:12 en 7:13, zevende lid Awb."

Over deze uitspraak waarin de verhouding adviescommissie en $b$ en $w$ als 'voorbereider" van 's-raads beslissingen ter discussie staat, kan zoals in het kader van het gemeenterecht al werd geschetst, de vraag worden gesteld of er nog wel ruimte is voor een eigen advies van $b$ en $w$, indien een adviescommissie voor de behandeling van bezwaarschriften is ingesteld. Ook de literatuur deelt kennelijk de opvatting, dat er geen plaats is voor een afzonderlijk adviestraject van b en w ingeval een artikel 7:13-commissie is ingesteld. Art. 161 geldt in beginsel als algemeen uitgangspunt dat $b$ en $w$ het competente bestuursorgaan zijn voor het voorbereiden van door de gemeenteraad te nemen beslissingen. Van art. 161 gem.w. kan worden afgeweken door de voorbereiding van de besluitvorming op te dragen aan een adviescommissie.

Uit de literatuur en de Gem.w. kan worden afgeleid, dat op grond van art. 161 Gem.w. geen volledig exclusieve voorbereidingstaak voor $b$ en $w$ is weggelegd. Zie in dit verband art. 91, eerste lid Gem.w. (voorbereiding instelling adviescom-

40 Rb. Amsterdam 15 december 1995, Awb-katern, 24. 
missie door de burgemeester), art. $178 \mathrm{Gem}$.w. (voorstel burgemeester aan gemeenteraad met betrekking tot delegatie bevoegdheden burgemeester aan commissie ex art. 82 Gem.w.) en art. 26, lid 3 Gem.w. (voorstel burgemeester aan de gemeenteraad tot het ontzeggen van de toegang van een raadslid in de vergadering)." Inmiddels heeft de ABRS de interventie van $b$ en $w$ bij het uitbrengen van een advies door een commissie voor de bezwaarschriften aan banden gelegd. ${ }^{42}$

Ter afronding van de bovengenoemde problematiek van de zogenaamde 'dubbele advisering" (advisering door zowel de adviescommissie als b en w), lijkt de meest zuivere manier van het adviseren, dat $b$ en w zich met het voorleggen van het commissie-advies terughoudend opstellen. In de aanbiedingsbrief voor de gemeenteraad zouden $b$ en $w$ in het raadsstuk kunnen volstaan met de mededeling: "Wij stellen u voor hieromtrent een besluit te nemen." Indien art. 7:5 wordt toegepast geschiedt de voorbereiding van de op het bezwaarschrift te nemen beslissing onder verantwoordelijkheid van het bestuursorgaan. Er is dan geen sprake van het gesignaleerde probleem van de "dubbele advisering".

Aan het einde van dit onderzoek door de proeftuin van het 'arob-land' wordt opgemerkt dat bestuursorganen uiteindelijk wél verantwoordelijk zijn voor het beslissingstraject van de bezwaarschriftenprocedure. De Nationale ombudsman huldigt de opvatting dat bestuursorganen het achterwege laten van een beslissing op het bezwaarschrift niet mogen verontschuldigen door te wijzen op het ontbreken van noodzakelijke adviezen. ${ }^{43}$

Ten vervolge op de behandeling van de inhoud en de betekenis van de adviesfunctie bij voorbereiding van de beslissing op het bezwaarschrift ten tijde van de Wet arob wordt in de volgende paragraaf ingegaan op de advisering in het kader van de Awb. ${ }^{.4}$

4l E. Brederveld, Gemeenterecht, derde geheel herziene dr., Zwolle 1994, p. $126 \mathrm{e} . \mathrm{v}$.

42 ABRS 8 april 1997, AB 1998, 106 m.nt. PB.

43. N.o., 16 juni 1995, nr. 95/232, NRO 95-198.

44 Zie in dit werband o.a.: J.G. Steenbesk en F.A.M. Stroink, Wet administratieve rechtspraak overheidsbeschikkingen, bewerkt door F.A.M. Stroink, vierde herziene dr., 's-Gravenhage 1988 en $\mathbb{R}$.W.L. Loeb, B K. Oliwier en H. Troostwijk, De Wet Arob toegepast, vierde druk, Nijmegen 1990. 


\subsection{Het adviseren over het bezwaarschrift op grond van de Awb}

\subsubsection{Impressies en accenten}

In de woorgaande paragraaf is de basis gelegd voor de nu te bespreken advisering in het kader van de Awb. De voorbereiding van de beslissing op het bezwaarschrift onder de werking van de Awb betekent geen breuk met het verleden. In feite is er sprake van een continuering van de gevestigde (arob)-bestuurspraktijk. Toch blijkt uit het systeem en de structuur van de Awb dat niet ten aanzien van alle aspecten dezelfde lijn wordt voortgezet als onder de werking van de Wet arob. Art. 14 van de Wet arob dient tegen die achtergrond mede in de beschouwingen te worden betrokken. De Awb introduceert een aantal uitgangspunten met betrekking tot het horen en het adviseren ter voorbereiding van de op het bezwaarschrift te nemen beslissing dat om nadere aandacht vraagt. Naast de twee belangrijke procedurele scharnierpunten (horen en adviseren) in het besluitvormingsproces van de bezwaarschriftenprocedure, manifesteert zich het moment dat op het bezwaarschrift een beslissing moet worden genomen. Art. 7:10 Awb conditioneert immers het recht van de bezwaarde op het nemen van een beslissing door het bestuursorgaan binnen de in dit artikel genoemde termijn.

De vraag kan worden gesteld of het bestuursorgaan verplicht is zelf op het bezwaarschrift te beslissen. De bestuurspraktijk toont aan dat het nemen van beslissingen vaak aan anderen wordt 'overgelaten'. Met die "anderen" wordt gedoeld op het beslissingsmandaat dan wel de mogelijkheid tot het gebruik van delegatie. Tussen mandaat en delegatie bestaat overigens een principieel verschil. Door de inwerkingtreding van de derde tranche $A$ wb, hebben beide rechrsfiguren een (formeel) wettelijke status. Art. 10:1 Awb definieert het mandaat als de bevoegdheid om in naam van een bestuursorgaan besluiten te nemen. In art. 10:3 komt het verschil van delegatie ten opzichte van mandaat tot uitdrukking:

'Onder delegatic wordt verstalan: het overdragen door een bestuursorgaan van zijn bevoegdheid tot het nemen van besluiten aan een ander die deze onder eigen verantwoordelijkheid uitoefent.'

In die gevallen dat het adviseren is opgedragen aan een adviescommissie is er een sterke samenhang tussen het horen en het adviseren. Een samenhang lijkt er ook te bestaan tussen de aan de organieke wetgeving ontleende adviesrelaties (commissies) en de Awb. Daarom zal hierna aandacht worden besteed aan de wettelijke grondslag van het adviseren. De Awb alsmede de organieke wetgeving zullen hierbij vanuit hun verschillende (wetgevings)optiek aan een nadere beschouwing worden onderworpen. 
Ook de Awb legt in art. 7:13 de samenhang wast tussen het horen en het adviseren. In het derde lid van art. 7:13 is bepaald dat het horen dient te geschieden door de bezwaarschriften-adviescommissie. In die gevallen dat niet gebruik is gemaakt van art. $7: 13$, stelt art. $7: 5$ nadere regels omtrent het horen. Ofschoon art. 7:13 een geheel zelfstandige betekenis heeft, en niet onder de werkingssfeer valt van art. 7:5, wordt dit artikel betrokken bij de bespreking van de $\mathrm{Awb}$ regeling inzake de adviescommissie. De Awb geeft het bestuursorgaan de ruimte om te kiezen voor een andere inrichting van de bezwaarschriftenprocedure. Het horen en het adviseren kan daardoor afzonderlijk geschieden.

Het bestuursorgaan kan ook voor een interne bezwaarschriftenadviesprocedure kiezen, met voorbijgaan aan de eisen van art. 7:13 Awb.

Indien niet gekozen wordt voor een adviescommissie in de zin van art. $7: 13$, moet naar de letter van de Awb in ieder geval worden voldaan aan het bepaalde in art. 7:5. Op de betekenis van art. 7:5 voor de bezwaarschriftenprocedure wordt in het volgend hoofdstuk nader ingegaan. In ogenschouw zal worden genomen de vraag of het zinvol is art. 7:5 te handhaven. Ook art. 2:4 (verbod van vooringenomenheid) zal hierbij aandacht krijgen. Art. 7:5 geeft enige regels over het inrichten van het horen. Hierin wordt in enkele gevallen de deelname aan de hoorzitting uitgesloten vanwege de betrokkenheid van personen bij de primaire besluitvorming. De voorschriften zijn gericht op het bieden van waarborgen ter voorkoming van partijdigheid.

Ook art. $7: 13$ beoogt een te grote betrokkenheid bij de advisering op het be$z w a a r s c h r i f t$ tegen te gaan. De in art. $7: 13$ gestelde eisen zijn strenger dan bij art. 7:5. Strenger, omdat in art. $7: 13$ onathankelijkheidsaccenten zijn 'ingebouwd' (onafhankelijke woorzitter en het horen door een onafhankelijk lid).

Bij de toepassing van art. 7:13 geldt deze onafhankelijkheidsaccentuering als voorwaardenscheppend element in het belang van het voorkomen van partijdigheid. Bij art. 7:5 Awb blijken deze 'objectiviteitsaccenten' wal lichter van aard. Met betrekking tot deze "bemensingsaspecten" bij het horen en het adviseren door een adviesconmissie, wordt opgemerkt, dat zoveel mogelijk ter voorkoming van doublures, vermeden wordt hierbij aspecten van vooringenomenheid en objectiviteit te betrekken. Dit laatste geschiedt slechts in die gevallen dat met het oog op een goede begripsworming van de advisering de strikte noodzaak aanwezig is. Bij de bespreking van het vooringenomenheidswerbod bij de taakvervulling door het bestuursorgaan, kregen deze belangrijke 'zuiverheidscondities' bij het openbaar bestuur al meer dan voldoende aandacht. 
Naast de bespreking van de bevoegdheid tot het instellen van een advies-commissic in de zin van art. 7:13, zal in de par. 4.3 en 4.4 aandacht worden geschonken aan enkele procedurele beslissingsbevoegdheden. Deze laatste in het vierde lid van art. 7:13 genoemde bevoegdheden worden besproken in relatie met de bevoegdheid van het bestuursorgaan om op het bezwaarschrift te beslissen. Men kan zich afvragen of de in art. $7: 13$, lid 4 aan de adviescommissie toegekende bevoegdheden toereikend zijn voor een adequate vervulling van de adviesfunctie.

Een belangrijk aspect bij het adviseren omtrent de op het bezwaarschrift te nemen beslissing, is de door de Awb aan de bestuursorganen gelaten vrijheid om naar eigen inzicht invulling te geven aan de inrichting van de bezwaarschriftenprocedure. Art. 7:13 is immers een facultatieve adviesbepaling met behoud van de eigen bestuurlijke verantwoordelijkheid. Niet zonder betekenis is de vraag of de Awb niet beter een imperatieve adviesbepaling had kunnen creëren, waardoor dan voor het bestuursorgaan geen ruimte zou bestaan voor een eigen inrichting van de procedure. De wijze van samenstelling van de adviescommissie is nauw verwant met het doel en de functie van de bezwaarschriftenprocedure.

Tenslotte zal naast het bovengenoemd aspect van het al dan niet wettelijk verplicht karakter van het adviseren omtrent bezwaarschriften, nader worden ingegaan op het adviescommissievoorschrift.

\subsubsection{De grondsiag wan het adviseren en beslissen omtrent bezwaarschriften}

\subsubsection{Het grondslaguereiste voor het adviseren}

In het begin van dit hoofdstuk is gewezen op de facultatieve mogelijkheid in art. 7:13 van de Awb om een adviescommissie ten behoeve van de beslissing op het bezwaarschrift te laten functioneren onder de werkingssfeer van de Awb. De Awb conditioneert deze wettelijke mogelijkheid op een drietal manieren. Allereerst stelt het eerste lid van art. 7:13 voorop, dat het artikel van toepassing is 'indien (....) een adviescommissie is ingesteld'. De tweede voorwaarde in het eerste lid richt zich op een aantal bemensingscriteria. De commissie dient uil een voorzitter en ten minste twee leden te bestaan. Ten aanzien van het voorzitterschap van de adviescommissie is tevens dwingend bepaald dat deze geen deel uitmaakt van het bestuursorgaan. Dit laatste voorschrift is tevens uitgebreid met de voorwaarde dat diezelfde voorzitter niet werkzaam mag zijn onder verantwoordelijkheid van het besturrsorgaan. De derde clausulering van de eisen die aan een adviescommissie in de zin van art. 7:13 worden gesteld, spitsen zich toe op eventueel 'bij wettelijk voorschrift gestelde andere eisen'. 
Met het oog op het bespreken van de wettelijke grondslag van het adviseren (en het beslissen) is het van belang de parlementaire geschiedenis van de $A w b$, in ogenschouw te nemen.

De Awb plaatst een adviescommissie op de voet van art. 7:13 in een onderscheidend perspectief ten opzichte van andere vormen van advisering in het openbaar bestuur. Daarbij zijn opvallend de volgende kernoverwegingen. Voorop wordt gesteld dat in de praktijk van de advisering in het kader van de bezwaarschriftenprocedure diverse wijzen van adviseren, denkbaar zijn. Gewezen werd op de praktijk van het ambtelijk adviseren bij de beslissing op bezwaarschriften. In die gevallen dat een aantal ambtenaren belast is met het opstellen van een advies voor het bestuursorgaan ten behoeve van de beslissing op het bezwaarschrift, kan gesproken worden van een interne adviescommissie. Een dergelijke (ambtelijke) adviescommissie werkt volledig onder de verantwoordelijkheid van het bestuursorgaan. Van 'eigen' ambtelijke bevoegdheden is in deze interne adviesrelatie met het bestuursorgaan geen sprake; het bestuursorgaan draagt de gehele verantwoordelijkheid voor de voorbereiding van de beslissing op het bezwaarschrift.

Uit de parlementaire stukken blijkt dat in het geval van ambtelijke advisering het moeilijk valt na te gaan of al dan niet door een adviescommissie wordt geadviseerd, dan wel dat adviseren heeft plaatsgevonden door een individuele ambtenaar daartoe bijgestaan door enige andere ambtenaren. Naar de opvatting van de Awb zou de interne organisatiestructur de herkenbaarheid van het al dan niet adviseren door een adviescommissie versluieren. Met de op deze aan de bestuurspraktijk ontleende situatie, heeft de Awb mede gekozen voor een adviescommissiestructuur zoals is omschreven in art. $7: 13 .{ }^{45}$ Kortom een van de bedoelingen van art. 7:13 is het maken van voldoende onderscheidende betekenis. Voor de burger moet het voldoende herkenbaar zijn of er in het kader van de voorbereiding van de beslissing op het bezwarschrift geadviseerd wordt, conform een interne (organisatie-structuur), dan wel of zijn bezwaarschrift voor behandeling is opgedragen aan een adviescommissie.

De parlementaire discussie maakt duidelijk dat de wetgever in zijn overwegingen ten aanzien van de totstandkoming van art. 7:13 oog heeft gehad voor de in de praktijk van de bezwaarschriftenprocedures bestaande adviesrelaties. De Awb laat die praktijk niet geheel los, en spreekt ook niet met zoveel woorden een voorkeur uit voor het al dan miet inschakelen van een adwiescommissie. De beoordeling van 
de noodzaak voor de inschakeling van een adviescommissie wordt door de wetgever overgelaten aan de bijzondere regelgever. ${ }^{47}$ Aanknopingspunt voor het facultatieve karakter van art. $7: 13$ is te vinden in de redactiestructur van deze bepaling.

Naast art. 7:13 stelt art. 7:5, eisen aan de personen die met het horen zijn belast. Hieruit blijkt dat er verschillende situaties in de bestuurspraktijk denkbaar zijn langs welke wegen zich het horen kan voltrekken. Die verscheidenheid van adviesrelaties betekent dat in de bestuurspraktijk hoor-en adviescommissies voorkomen, die zijn samengesteld uit bestuurders en/of ambtenaren en hoor- en adviescommissies met een 'gemengde' samenstelling, waarbij dan zowel bestuurders en/of ambtenaren en buitenstaanders als commissielid fungeren. Ook zijn er adviesrelaties, waarbij het bestuursorgaan kiest voor een zuiver extern adviesmodel. In dit laatste geval bestaat de adviescommissie uit personen, afkomstig buiten de organisatie van het bestuur.

In het licht van de bedoelingen van de Awb om door middel van art. $7: 13$ voldoende onderscheidende betekenis aan te brengen in de in art. 7:13 bedoelde adviesrelatie, ten opzichte van andere in de bestuurspraktijk voorkomende wijzen van adviseren (commissies of ambtenaren), rijst de vraag of de wetgever daarin wel voldoende is geslaagd. Met die laatste wraag spitst de discussie zich toe op de wettelijke grondslag van de advisering door adviescommissies. Voor een goed begrip van die discussie, die hierna aan een nadere beschouwing wordt onderworpen, wordt hierbij opgemerkt dat de ambtelijke advisering buiten de bespreking wordt gelaten. Dit laatste is niet zonder reden.

Ofschoon de ambtenaren doorgaans primair zijn belast met de advisering van bestuursorganen, en derhalve ook een rol kunnen vervullen in de voorbereidingsfase van de beslissing op het bezwaarschrift, is hun "interne" advisering in externe zin minder herkenbaar. Interne advisering is niet of nauwelijks te herleiden tot geschreven of ongeschreven rechtsregels. Hooguit is de ambtelijke advisering af te leiden uit de organisatie-verordeningen, alsmede de organieke functiebeschrijving van de betreffende ambtelijke medewerkers.

47' J.M.H.F. Teurissen, in: Algemene wet bestuursrecht, losbl, 's-Graverhage, p. E 6.3.18-2.

48 J.M.H.F. Teunissen, a.w. , p. E. 6.3.18-13 e.v. Zie in dit verband de in dit hoofdstuk besproken model-verordeningen van de $V N G$. 
De ambtelijke advisering draagt veeleer bestuurskundige aspecten in zich; externe advisering die mede ten grondslag ligt aan geschreven rechtsregels en beginselen van behoorlijk bestuur wordt in bestuursrechtelijke zin "zichtbaar".

In het licht van de opgeworpen vraag of de Awb voldoende duidelijkheid heeft geschapen in de adviesrelaties in het kader van de beslissing op bezwaarschriften, volgt nu mede in samenhang met art. 7:13 Awb een nader onderzoek naar de wettelijke grondslag van het functioneren van adviescommissies voor de behandeling van bezwaarschriften. Daarbij wordt in het belang van dit onderzoek tevens betrokken de bestaande commissiestelsels op grond van de Gem.w. en de Prov.w. Ook de aandacht voor art. 14 van de Wet arob kan als legislatieve 'oorsprong' van het adviescommissiemodel van de Awb, niet ontbreken.

Art. 14, lid 1 Wet arob bepaalde, dat het horen van de indiener van het bezwaarschrift en het geven van advies inzake de op het bezwaarschrift te nemen beslissing kan worden opgedragen aan een commissie. Ofschoon de redactie van het eerste lid van art. 14 Wet arob op het eerste gezicht duidelijk en ook 'onschuldig' van aard leek, heeft de in de Wet arob genoemde adviescommissie vraagpunten opgeroepen.

In de literatuur is ten aanzien van art. 14, lid 1 verdedigd, dat deze adviescommissie voor gemeentelijke bestuursorganen zou betekenen, dat de grondslag voor het instellen van deze commissie moest worden gebaseerd op de art. 61 en volgende van de (vervallen) gem.w. De meningen in wetenschappelijke kring waren daarover verdeeld. Er was ook een stroming die de opvatting huldigde, dat art. 14 Wet arob de gemeentelijke bestuursorganen een zelfstandige grondslag verschafte om tot instelling van een bezwaarschriftenadviescommissie over te gaan. Dit zou betekenen dat de primaire grondslag tot instelling van cen adviescommissie dan zou berusten op art. 14, lid 1 van de Wet arob. Naast deze 'arobinstellingsgrondslag" zou er geen bezwaar tegen bestaan (overigens zonder noodzaak), een adviescommissie mede in het leven te roepen op basis van de gem.w. (oud). ${ }^{\text {so }}$ Deze discussie is niet zonder betekenis, omdat de literatuur onder de werking van de Awb de problematiek van de instellingsgrondslag, zij het misschien onbedoeld nog steeds levendig houdt. Een adviescommissie voor burgemeester en wethouders (en ook voor de burgemeester) voor de behandeling van bezwaarschriften, zou op grond van art. 91 Gem.w. moeten worden inge-

49. J.B.J.M. ten Berge, Besturen door de overheid, Nederlands algemeen bestuursrecht 1, Deventer 1996, p. 102.

50 J.G. Steenbeek en F.A.M. Stroink, a.w., p. 394 e.w. Zie in dit verband ook: R.J.G.M. Jeukents, De hoor-en adviescommissie van de Wet Arob, Tro 1977, p. 54. 
steld." De vraag op welke wijze de grondslag voor het instellen van een adviescommissie juridisch kan worden getraceerd moet allereerst worden bezien op grond van de $\mathrm{Awb}$. Van belang is daarbij tevens art. 14, lid 1 Wet arob (adviescommissie) in het onderzoek te betrekken.

In art. 14, lid 1 Wet arob zijn aanknopingspunten te vinden voor de opvatting, dat een adviescommissie moet worden ingesteld op grondslag van deze bepaling. Art. 14, lid 1 sprak immers met zoveel woorden uit, dat het horen en het adviseren kon worden 'opgedragen' aan een commissie. Daar kwam nog bij dat ook de jurisprudentie over art. 14 hiervan uitging. Indien het horen en adviseren voorwerp van geschil was in beroep, vond door de ARRS toetsing plaats aan het doel en strekking van art. 14, lid 1 Wet arob. ${ }^{52}$ Door die rechtstreekse, zij het facultatieve mogelijkheid van de Wet arob om het horen en het adviseren op te dragen aan een adviescommissie, was het rechtens juist dat de grondslag woor het instellen van de bezwaarschriftenadviescommissie moest worden gezocht in de Wet arob, en niet primair in de gem.w. (oud). Ook het hanteren van art. 14, lid 1 Wet arob als rechtstreekse toetsingsgrondslag door de ARRS wees in die richting.

Tegen de achtergrond van de 'arob-discussie' over de wettelijke (instellings)grondslag van de adviescommissie is het eveneens van belang na te gaan of ook art. 7:13 Awb voldoende aanknopingspunten hiervoor biedt.

De redactie van art. 14, lid 1 Wet arob is niet identiek met die van art. $7: 13$ Awb. Art. $7: 13$ gaat ervan uit, dat de rechtsgevolgen van dit artikel in werking treden zodra conform de Awb-tekst een adviescommissie is ingesteld. Zodra deze veronderstelde bestuurlijke activiteit is geschied, en overigens aan de (inrichtings)eisen van art. $7: 13$ is voldaan, kan worden gesproken van een adviescommissie in de zin van de bedoelingen van de Awb. Aanknopingspunten voor deze opvatting zijin te vinden in de parlementaire stukken. Hieruit blijkt, dat art. 7:13 (6.3.18) Awb "voorschriften inhoudt voor het geval dat een adviescommissie is ingesteld". ${ }^{93}$ Die laatste zinsnede duidt er op, dat vooraleer art. 7:13 onder het bereik wan de (advies)eisen van dit artikel valt, eerst tot instelling van de commis. sie moet zijn overgegaan.

Alt. 7:13 heeft een afgeleide strekking, die de werking van dit artikel afhankelijk makt van de instellingsgrondslag. Deze constatering moet mede in relatie

5. W.G. Verknisen en B.C. Vis, Gemeente en Gemeentewet, achtste herzien dr., Nijmegen 1995, p. 135 .

52 AR 18 september 1980, Gst, 6658, 3, m.nt. JMK en SenS editie Wet Arob, vierde dr., Zwolle 1991, p. 464 en 465.

si PG Awb I p. 353 . 
worden bezien met de bedoelingen van de Awb die de bestuursorganen de vrijheid heeft willen laten om naar eigen inzicht invulling te geven aan de voorbereiding van de op het bezwaarschrift te nemen beslissing. De door de Awb gelaten vrijheid komt mede tot uitdrukking in de afzonderlijke regeling van art. 7:5. Als geen adviescommissie is ingesteld in de zin van art. $7: 13$, is art. 7:5 van toepassing.

Vastgesteld kan worden dat de Awb niet heeft gekozen voor het rechtstreeks creëren van een instellingsgrondslag aangaande de advisering ten aanzien van bezwaarschriften. De instelling van een adviescommissie, en ook een commissie in de zin van art. 7:13, vinden grondslag in een instellingsbesluit krachtens de toepasselijke commissiebepalingen van de organieke wetten. Voor wat betreft de bevoegheidsgrondslag ingevolge de Gem. $w$. betekent dit, dat indien $b$ en $w$ het bevoegde bestuursorgaan zijn om op het bezwaarschrift te beslissen, art. 91 Gem.w. van toepassing is. Ook de advisering ten aanzien van bezwaarschriften waarop de burgemeester een beslissing moet nemen, dient door het instellen van een adviescommissie op grond van art. 91 Gem.w. te geschieden. In beide gevallen dient deze vaste bezwaarschriften-adviescommissie door de gemeenteraad, op voorstel van de beide bestuursorganen, te wordlen ingesteld. Indien gekozen wordt voor de instelling van een vaste adviescommissie moet worden voldaan aan de voorschriften gesteld in art. 91, lid 1 Gem.w.

Naar de letter en de geest van art. 91, lid 1 Gem.w. komt dit laatste er op neer, dat naast de instelling van de adviescommissie bij verordening de samenstelling en bevoegdheden van de adviescommissie regeling vinden.

Deze constituerende elementen bepalen de vaste structuur van de adviescommissies ex art. 91, lid 1 Gem.w..$^{94}$ In die gevallen, dat geen sprake is van een vaste adviesstructuur, en b en w dan wel de burg. zich in een incidenteel geval over bezwaarschriften laten adviseren, kan niet gesproken worden van een vaste commissie. B en $w$ dan wel de burg. kunnen kiezen voor de ad hoc adviescommissie op basis van art. 92 Gem.w. Instelling van deze 'andere commissies' van advies kan door de beide bestuursorganen geschieden, zonder inschakeling van de gemeenteraad.

Een instellingsbesluit is daarbij voldoende. Ook de Prow.w. bevat cenzelfde wettelijke regeling voor de adviescommissies. Vaste commissies van advies voor de behandeling van bezwaarschriften van GS dan wel de CdK dienen op grond van art. 89 Prov.w. voor wat betreft de instelling, de samenstelling en hun 
bevoegdheden, regeling te vinden bij een door provinciale staten vast te stellen verordening (art. 89 Prov.w.). De regeling voor ad hoc adviescommissie vindt haar grondslag in art. 90 Prow.w. die een met art. 92 Gem.w. identieke regeling kert. Ook hier zijn GS clan well de CdK bevoegd tot instelling van deze nietpermanente adviescommissies.

Het instellen van adviescommissies voor de behandeling van bezwaarschriften door PS en de gemeenteraad vindt zijn grondslag in respectievelijk de art. 80 Prov.w. en 82 Gem.w. De art. 83 Prov.w. en 85 Gem.w. geven onder andere een nadere regeling omtrent de openbaarheid van vergaderingen.

De Watersch ${ }_{\text {. }}$. kent geen regeling voor de instelling van adviescommissies. Een regeling aangaande de advisering van bezwaarschriften geschiedt bij waterschapsverordening. Het algemeen bestuur dient een (vaste) bezwaarschriftenadviescommissie in te stellen op grond wan art. 78 Watersch.w. Bij de raadpleging van enkele waterschapsverordeningen wordt het hanteren van de grondslag van art. 78 Watersch.w. bevestigd. De betreffende waterschapsverordeningen hebben immers vanwege de relatie wan de procedurevoorschriften van de Awb externe werking. Het vaststellen van een verordening aangaande de advisering van bezwaarschriften is op basis van art. 78 Watersch.w. 'nodig' voor de behartiging van de waterschapstaak op het terrein van de rechtsbescherming.

Uitvoerig is stilgestaan bij de grondslag van de instelling van adviescommissies voor de behandeling van bezwarschriften. Ter afronding van deze grondslagproblematiek is het maken wan enkele opmerkingen wan belang.

Vast kwam te staan dat de Awb oog heeft gehad voor de vrijheid van de bestuursorganen in het voortraject van de beslissing op het bezwaarschrift. Daarnaast is geconcludeerd dat diezelfde wetgever in het licht van de aan de bestuursorganen gelaten adviesvrijheid, geen aanknopingspunten biedt voor de instellingsgrondslag van adviescommissies. In relatie met de regelingen aangaande de commissiestelsels in de organieke wetgeving (Prov.w. en Gem.w.), mag op redelijke gronden worden aangenomen dat de grondslag voor het instellen van deze adviescommissies moet worden gezocht in de organieke wetten. De organieke wetgeving biedt de mogelijkheid om te kiezen voor een differentiatie van de bestuurlijke organisatie. $\mathrm{Bij}$ het trekken van deze conclusie is nog het volgende van belang. 
Hiervoor bleek dat de grondslag voor hel instellen van een adviescommissie ten tijde van de Wet arob reeds aandacht $\mathrm{kreeg}$ in de literatuur. ${ }^{\text {ss }}$ Die aandacht voor de vrijheid van de bestuursorganen om op eigen wijze invulling te geven aan de inrichting van de advisering woor de behandeling wan bezwaarschriften, heeft waarschijnlijk het belang van de instellingsgrondslag van de adviescommissie versluierd. Ook de bestuursrechter gaat vooralsnog aan het grondslagvereiste, ten behoeve wan het instellen wan adviescommissies, voorbij of schijnt het probleem te omzeilen. Ofschoon hiervoor geen 'harde' aanwijzingen zijn te geven biedt de jurisprudentie onder de werking van de Awb daarvoor, zij het incidenteel, enkele spaarzame aanknopingspunten. Enkele fragmenten van rechtsoverwegingen in uitspraken van de bestuursrechter tonen het volgende aan.

'Artikel 7:13 van de Awb bepaalt dat ten behoeve van de beslissing op bezwaarschriften een adviescommissie kan worden ingesteld. Indien van die mogelijkheid gebruik wordt gemaakt moet aan een aantal vereisten worden voldaan. Zo dient onder meer de voorzitter van die commissie geen deel uit te maken van en niet werkzaan te zijn onder verantwoordelijkheid van het bestuursorgaan". st"

In een andere zaak overwoog de bestuursrechter:

'Gezien het feit dat de voorzitter van de commissie wethouder is, en derhalve deel uitmaakt van het bestuursorgaan dat het besluit in eerste aanleg heef genomen (casu quo geacht moet worden te hebben genomen), is in het onderhavige geval geen sprake van een adviescommissie in de zin van artikel 7:13 van de Awb. Derhalve is het bepaalde in artikel 7:5 van de Awb onverkort van toepassing. ${ }^{139}$

Deze uitspraken geven er blijk van dat de bestuursrechter het grondslagvereiste voor het adviseren koppelt aan de condities als bedoeld in art. 7:13, en voor het overige niet nagaat op welke formele wettelijke grondslag een adviescommissie is ingesteld.

Kennelijk is de aandacht afgedwaald van het indertijd uitgebrachte rapport door de commissie Arob..$^{58}$ Opvallend is dat deze commissie in haar eindrapport wél koos voor een grondslagvereiste voor het instellen van adviescommissies. In dit verband is het interessant te wijzen op art. 8 , lid 1 van de ontwerp-a.m.v.b. ex

Zie noot 50 .

Rb. Maastricht 20 maart 1996, JB 1996, 114 m.nt. FAM S.

Rb. Maastricht 21 augustus 1996, reg. ars. 96/1024 WW 44 V KLR en 96/2063 WW 44 KLR Eerder werd in een andere uitspraak van de Maastrichtse bestuursrechter eenzelfde rechtsowerweging aangehouden Rb. Maastricht 5 maart 1996, 95/1786 WW50 Z Pol. 
art. 14, lid 3 van de Wet arob. Dit eerste lid van art. 8 wan de ontwerp-a.m.v.b. gaf op de volgende wijze invulling aan de formele grondslag tot instelling van adviescommissies:

'1. De adviescommissie ten behoeve van tot de centrale overheid behorende organen wordt ingesteld bij ministeriele regeling. Deze wordt in de Nederlandse Staatscourant bekend gemaakt. De adviescommissie ten behoeve van niet tot de centrale overheid behorende organen wordt bij verordening ingesteld.'

De toelichting behorende bij art. 8, lid 1 van het bovengenoemde ontwerp van a.m.v.b., gaf de volgende opmerkelijke overwegingen te $z^{\text {ien }}{ }^{59}$ :

'In de Wet Arob en in deze regeling wordt onderscheid gemaakt tussen het horen door een administratief orgaan of namens zo'n orgaan door daartoe aangewezen ambtenaren enerzijds en door een adviescommissie anderzijds. Zo verbindt artikel 14 , vierde lid, van de Wet Arob rechtsgevolgen aan het optreden van een adviescommissie: de termijn voor het beslissen op het bezwaarschrift wordt met 30 dagen verlengd. De onderhavige regeling geef enige bijzondere bepalingen inzake de adviescommissie. Het is daarom van belang dat aan de hand wan een formeel criterium kan worden vastgesteld of er sprake is van optreden van een adviescommissie. Deze dient dan ook bij ministeriële regeling c.q. verordening te worden ingesteld. Omdat een ministeriële regeling niet automatisch wordt gepubliceerd, is de publicatie daarvan in de Nederlandse Staatscourant verplicht gesteld. (...)'

\subsubsection{De grondslag voor het beslissen op het bezwaarschrift}

Op grond van de bijzondere bepalingen over bezwaar "geeft de Awb in afdeling 7.2 diverse bevoegdheden aan het bestuursorgaan. Die centralle rol van het bestuursorgaan komt primair tot uitdrukking in de bepalingen over de voorbereiding van de op het bezwaarschrift te nemen beslissing. Deze voorbereidingsfunctie van het bestuursorgaan is neergelegd in de voorschriften van afdeling 7.2 aangaande het horen.

Aan deze overwegingen van de Awb heeft de compensatiegedachte voor het veelvuldig gebruik van het mandaat ten grondslag gelegen. Met de primaire bestuurlijke verantwoordelijkheid voor de bezwaarschriftenprocedure heeft de Awb de betrokkenheid van het bestuursorgaan bij de hernieuwde beoordeling van het besluit in primo willen accentueren en daarbij nader willen aanscherpen. ${ }^{6}$ Dat de Awb de vrijheid laat woor een eigen invulling van de voorbereiding van de op

59 A.W., p. 11 .

60 H. Bolt, in: Pr. Bestuursrecht, losbl., Deventer, p. X-25. 
het bezwaarschrift te nemen beslissing, laat onverlet het bovengenoemd wettelijk uitgangspunt van het primaat van het bestuursorgaan.

In de vorige paragraaf $\mathrm{kwam}$ vast te staan dat art. 7:13 in samenhang met het commissiestelsel van de Gem.w. en de Prov.w., een uitzondering vormt op de Awb-regel dat de voorbereiding van de op het bezwaarschrift te nemen beslissing, geheel onder de verantwoordelijkheid valt van het bestuursorgaan. Voor alle duidelijkheid wordt hierbij benadrukt, dat het begrip 'onder verantwoordelijkheid' beperkte betekenis heeft. Uiteindelijk is het bestuursorgaan formeel-juridisch steeds verantwoordelijk voor het verloop wan de voorbereiding van de bezwaarschriftenprocedure. Voor de toetsing van het bestuit door de bestuursrechter maakt het geen verschil of de voorbereiding nu verloopt via een interne (bestuurlijke en/of ambtelijke) procedure dan wel of er een adviescommissie betrokken is bij de voorbereiding van de beslissing op het bezwaarschrift. lets anders komt de zaak te liggen wanneer er sprake is van het verlenen van een vergunning aan het openbaar lichaam. In dit laatste geval lijkt art. 2:4 (verbod van vooringenomenheid) een zware wissel te trekken op de inrichting van de bezwaarschriften-adviescommissie. ${ }^{61}$

Bezien wordt of naast het voorbereiden van de beslissing op het bezwaarschrift via een adviesprocedure door een commissie de door het bestuursorgaan op het bezwaarschrift te nemen beslissing ook aan 'anderen' kan worden opgedragen. Met die 'anderen' wordt hierbij gedoeld op een commissie dan wel op ambtenaren. De beschouwing ten aanzien van de hiervoren geopperde vraagstelling of de Awb het opdragen van de beslissing op het bezwaarschrift aan 'anderen' overlaat, wordt mede gevoerd aan de hand van de Wet arob, alsmede de commissiebepalingen van de Gem.w. en de Prov.w.

Ook de Wet arob stelde in art. 14, lid 4 voorop dat het administratief orgaan op het bezwaarschrift beslist. Toch maakte de daarop volgende zinsnede van het vierde lid hierop een uitzondering mogelijk door te bepalen: 'tenzij ingevolge enige wettelijke bepaling de beslissing is opgedragen aan een commissie'. Tijdens de parlementaire behandeling van de Wet arob is kort stilgestaan bij de inhoud en de strekking van deze in de Wet arob gemaakte uitzondering op de beslissingsbevoegdheid van het bestuursorgaan. Aan de parlementaire geschiedenis wan de Wet arob kan het volgende worden ontleend:

61 Zile in dit verband de paragrafen 5.3 .5 en 5.4 .5 . 
"Volledigheidshalve zij nog opgemerkt, dat onverlet blijft de, naar het oordeel van de ondergetekenden voor beschikkingen van gemeentelijke organen, speciale regeling van de artikelen 68 (lees: 63) en volgende wan de gemeentewet. Hieraan ontenen de gemeenteraden de bevoegdheid, het behandelen van en het beslissen op een bezwaarschrift aan een commissie over te dragen. Ten einde twijfel over dit punt uit te sluiten stellen zij woor, in het derde lid (oorspronkelijk tweede) lid van artikel 14 een verwijzing naar andere wettelijke regelingen ter zake op te nemen. ${ }^{32}$

Lezing van de bovengenoemde passage geeft een helder beeld over de strekking van de in art. 14, lid 4 door de arob-wetgever gemaakte uitzondering op de beslissingsbevoegdheid van het bestuursorgaan. Op grond van de toepasselijke bepalingen terzake de gemeentelijke commissies, was de gemeenteraad ten tijde van de Wet arob bevoegd de beslissing omtrent bezwaarschriften over te dragen aan een besliscommissie.

Heeft deze bevoegdheidsgrondslag voor het opdragen van de beslissing op bezwaarschriften aan een besliscommissie nu geleid tot een gebruik van deze in art. 14, lid 4 geopperde mogelijkheid?

In vier gemeenten fungeerde een besliscommissie voor de behandeling van bezwaarschriften van $b$ en $w$ en de gemeenteraad. De te nemen beslissing op bezwaarschriften door de gemeenteraad werd in drie gemeenten genomen door een besliscommissie. In één gemeente was er een besliscommissie voor b en wbeschikkingen, terwijl in een geval sprake was van een besliscommissie voor de burgemeester. Voorts kwam bij het onderzoek vast te staan, dat er bij de provincies in het geheel geen belangstelling bestond yoor de besliscommissies. ${ }^{63}$

Voor de VNG was deze geringe animo aanleiding om bij de aanpassing van de model-verordening voor de behandeling van bezwaar- en beroepschriften, de besliscommissie niet meer als een modelkeuze aan te bevelen.

Ook de commissie Arob richtte haar aandacht op de positie van de besliscommissie. De besliscommissie werd blijkens het uitgebrachte eindrapport door de commissie Arob afgewezen. Een belangrijke overweging was, dat deze besliscommissie zich niet zou verdragen met het stelsel van de bezwaarschriftenprocedure, en de hieraan ten grondslag liggende heroverweging. Vooral bezien vanuit het onafhankelijkheidsperspectief van deze besliscommissie, werd dit aspect als een belemmering ervaren voor een verantwoorde heroverweging van de

62 J.H. Kreveld en M. Scheltema, a.w. p. 296.

63 Beeld van de Arob-bezwarschriftenprocedure, p. 151 e.v.

64 VNG, Blawwe reeks 72, p. 10. 
primaire besluitvorming. De commissie Arob stelde voor de besliscommissie als bedoeld in art. 14, lid 4 te schrappen. ${ }^{63}$

Ook in de literatuur is kritiek geleverd op de figur van de besliscommissie. Door de instelling van een besliscommissie zou de bezwaarprocedure meer overeenkomst gaan wertonen met het administratief beroep.

Dit zou haaks staan op de aard van de bezwaarschriftenprocedure. Tevens werder daarbij argumenten aangevoerd tegen het verloren gaan van de algemene beleidsverantwoordelijkheid van het bestuursorgaan. De wettelijke mogelijkheid van een besliscommissie zou in ieder geval er toe leiden dat de beïnvloeding van het beleid zou worden afgezwakt. Op basis van deze argumenten werd de arob-wetgever een wat lichtvaardige legislatieve handelwijze verweten door het opnemen van deze besliscommissie in de Wet arob. ${ }^{6}$ Door Ten Berge wordt overigens nog een ander bezwaar genoemd tegen het functioneren van besliscommissies. Hij wijst er op, dat het oorspronkelijk beslissende orgaan zijn beroepsrecht bij de bestuursrechter verspeelt, wanneer het wenst te ageren tegen een door een besliscommissie onwelgevallig genomen beslissing op het bezwaarschrift. ${ }^{67}$

Nagegaan wordt nu of in het stelsel van de Awb een besliscommissie formeeljuridisch (nog) tot de mogelijkheden behoort.

De Awb heeft alleen gekozen voor een adviescommissie in de zin van art. 7:13; de redactie van dit artikel is van een facultatieve opzet waardoor van een verplichting tot het instellen van deze adviescommissie niet kan worden gesproken.

De mogelijkheid van een besliscommissie blijft in tegenstelling tot art. 14 , lid 4 van de Wet arob, geheel onvermeld. Ook in de parlementaire stukken, zijn geen aanknopingspunten te vinden voor de opvatting of deze besliscommissie vit het arob-tijdperk onder de werking van de Awb nog is toegestaan.

Toch is er inmiddels wat meer duidelijkheid geschapen in de (Awb)mogelijkheden voor een besliscommissie. In een tweetal rechterlijke uitspraken lijkt de "arob-mogelijkheid' tot het instellen van een besliscommissie "exit" ${ }^{68}$

65 Eindrapport, a., w. p. 16.

6. F.A.M. Stroink, a.w., p. 402 en 403

6. J.B.J.M. ten Berge, Bescherming tegen de overheid, Stand van zaken na invoering van de Algemene wet bestuursrecht, tweede dr., Zwolle 1994, p. 204. Zie in dit werband ook de door Ten Berge aangehaalde uitspraak wan de ARRS wan 6 november 1978, B/S IV, 17 p. 71 ; AB 1979.150.

68 Ook de besliscommissie in het kader van het administratief beroep is door de lagere bestuursrechter inmiddels in de ban gedarn. Zie: Rb. Den Bosch 15 oktober 1997, Awb-katern 1998, 43. 
In een eerste uitspraak heeft de ABRS zich gebogen over de toelaatbaarheid van de besliscommissie, en werd de Verordening commissie bezwaar- en beroepschriften van de gemeente Alkemade, onverbindend geacht en het besluit van de besliscommissie wegens een bevoegdheidsgebrek vernietigd. ${ }^{60}$

Uit deze uitspraak blijken de volgende belangrijke rechtsoverwegingen van de bestuursrechter:

\begin{abstract}
"De bezwaarprocedure, als neergelegd in de $A$ wb, voorziet, anders dan ingevolge artikel 14, vierde lid, van de Wet administratieve rechtspraak overheidsbeschikkingen onder de werking van die wet het geval was, niet in de mogelijkheid om het nemen van de beslissing op bezwaar over te dragen aan een ander bestuursorgaan dan het bestuursorgaan dat het primaire besluit heeft genomen. De bevoegdheid van een commissie om in de plaats van het bestuursorgaan dat het primaire besluit heeft genomen, te beslissen op een ingevolge artikel 7:1 van de Awb ingediend bezwaar, behoef derhalve een uitdrukkelijk tot afwijking van de Awb strekkende grondslag in een formele wet. Een zodanige grondslag wordt niet geboden door de algemene bepalingen in de Gemeentewet inzake de overdracht van bevoegdheden. Deze wijken niet uitdrukkelijk af van de Awb. Toepassing yan de Awb doet voorts niet substantieel afbreuk aan hun werking. Zij moeten derhalve zo worden uitgelegd, dat ze niet derogeren aan die van de Awb. Zonder een uitdrukkelijke grondslag in de formele wet is een lagere wettelijke regeling - zoals, in dit geval, een gemeentelijke verordening- die voorziet in een bevoegdheid van een commissic om in de plaats van het bestuursorgaan dat het primaire besluit heeft genomen, te beslissen op bezwaar, in strijd met de Awb en in zoverre onverbindend.'
\end{abstract}

In de tweede uitspraak velde de CRvB een vernietigend oordeel over een genomen besluit door een besliscommissie. ${ }^{70}$ In deze zaak was de CRvB snel met zijn oordeel over de toelaatbaarheid van de besliscommissie van de gemeente "s-Gravenhage, en overwoog:

'De Raad stelt vast dat de bevoegdheid tot het nemen van een bestuit op bezwaar' is overgedragen aan een ander bestuursorgaan dan het bestuursorgaan namens welke het primaire besluit is genomen. De Raad is evenals de Afdeling bestuursrechtspraak van de Raad van State blijkens haar eerdervermelde, aan partijen bekende, uitspraak van 6 januari 1997 en op de in dere uitspraak weergegeven gronden van oordeel dat een dergelijk besluit onbevoegdelijk is genomen. Het besluit dient om die reden dan ook te worden vernietigd.'

Een besliscommissie voor de bezwaarschriften tegen besluiten van b en $w$ (en ook de burg.) lijkt door de bovengenoemde uitspraken weliswaar niet meer te zijn

69 ABRS 6 januari 1997, IB 1997, 25, m.nt. F.A.M. S., Gst. 7053, AB 1997, 86, m.nt. FM.

70 CRvB 25 maart 1997, JB 1997, 91, m.nt. JMED. 
toegestaan, maar de beslissing op bezwaarschriften tegen besluiten van de gemeenteraad dienen immers met de tekst van de Gem.w. in de hand buiten schot te blijven. In samenhang met art. 82 Gem.w. bieden de art. 156 en 165 Gem.w. de mogelijkheid om voor de behandeling wan bezwaarschriften van de gemeenteraad een besliscommissie in te stellen. Die latste mogelijkheid is eveneens opgenomen in de Prow.w. Te dien aanzien geeft ook deze organieke wet een identieke regeling. Op grondslag van de art. 80, 152 en 163 Prov.w. kurnen ook besliscommissies worden ingesteld woor de bezwaarprocedure bij provinciale staten. ${ }^{n}$

Inmiddels is een wetsvoorstel ingediend om ook besliscommissies (op bezwaar) voor provinciale staten en de gemeenteraad niet langer toe te staan. ${ }^{72}$ Dit wetsvoorstel zet in formeel-juridische zin geen zoden aan de dijk. Alleen het 'openbaarheids-aspect' voor de besliscommissies voor de bezwaarschriften wordt met de wetswijziging geschrapt. De wettelijke grondslag die het instellen van besliscommissies in de Prow.w. en de Gem.w. mogelijk maakt is met het voorstel van wet niet komen te vervallen (art. 152 en 163 Prov.w., alsmede 156 en 165 Gem.w.). In de art. 83 Prov.w. en 85 Gem.w. wordt een verband gelegd met besliscommissies voor de bezwaarschriften (en ook beroepschriften). Het motief voor het opnemen van de art. 83 Prov.w. en 85 Gem.w. is niet geweest om deze besliscommissiefiguur als alternatief 'beslismodel' ten behoeve van de besluitvorming, mogelijk te maken.

Daarvoor zijn blijkens de parlementaire stukken andere motieven te traceren. Van doorslaggevende betekenis zijn enkele aspecten die te maken hebben met de openbaarheid van de besliscommissie. Vanwege de raadkamerpraktijken (het vergaderen en considereren) en "beslotenheid" van deze besliscommissie, moest de wetgever zoeken naar een oplossing, teneinde te ontkomen aan de dwingend voorgeschreven openbaarheid voor raads- en statencommissies. ${ }^{73}$

Voor de beslissing op bezwaarschriften door GS kan worden geconcludeerd dat deze wél binnen de strekking vallen van beide uitspraken.

De Watersch.w. kent geen bepalingen over commissies. Dit betekent evenwel toch dat deze waterschapsbesturen zich dienen te richten naar de uitspraken van de bestuursrechter. Ook beslissingen van besliscommissies, krachtens delegatie

7 Zie in dit verband: E. Brederweld, Geen besliscommissies, beslist de Afdeling Rechtspratak, Gst. 7053 meer in hel bijzonder p. 252.

72 TK 1997-1998, 26014, nrs. 1-4. Voorgesteld wordt de art. 83 en 85 Gem. w. te wijzigen.

73 Zic in dit verband: Werkgroep Herziening Gemeentewet, Eindrapport van 20 oktober 1980 , Staatsuitgeverij, "s-Gravenhage 1980, p. 98; MwT TK 19403, nr. 3, p. 62 en 107 en MWA, idem, nr. 10, p. 170, T\&C PGW(Graat), aant. 1 bij art. 85 Gem.w. en aant. 1 bij art. 83 Prow.w. 
van het algemeen bestuur als die van het dagelijks bestuur en de voorzitter, vallen binnen de bestuursrechtellike 'verbodssfeer' voor besliscommissies.

De twee uitspraken over de ontoelaatbaarheid van de besliscommissie, geven aanleiding tot het maken van enkele kanttekeningen.

In beide uitspraken werd op basis van de onverbindendheid van de betreffende verordeningen voor de behandeling van bezwaarschriften tot vernietiging van de beslissing op het bezwaarschrift door de bestuursrechter overgegaan. Alleen in de laatste zaak werd vanwege een aantal hier niet te noemen aspecten met toepassing van art. 8:72 Awb 'beslist' tot het in stand laten van de rechtsgevolgen van het vernietigde besluit. ${ }^{74}$

Deze uitspraken zullen ongetwijfeld gevolgen hebben voor de gemeentelijkeprovinciale en waterschapsverordeningen.

Stroink komt in zijn commentaar op de eerste uitspraak door de ABRS tot de conclusie dat op basis van de functie en doelstelling van de bezwaarschriftenprocedure, de uitspraak van de hoogste bestuursrechter als 'zeer bevredigend" kan worden beoordeeld. ${ }^{\text {" }}$ De Gem.w. heeft in casu terecht plaats moeten maken voor het bezwaarschriftenstelsel van de Awb. Dit laatste klemt te meer omdat de arobwetgever bij de vaststelling van art. 14 , lid 4 expliciet de mogelijkheid van een besliscommissie heeft willen creëren, ten einde iedere formeel-wettelijke onduidelijkheid uit de weg te gaan. ${ }^{7}$ Op redelijke gronden kan daarom worden aangenomen, dat de Awb-wetgever, niet de bedoeling heeft gehad het instellen van een besliscommissie toe te staan. Anders was in de Awb de mogelijkheid van een besliscommissie niet onvermeld gebleven. Volledig opgelost is de problematiek van de besliscommissies zeker niet. De lagere bestuursrechter oordeelde inmiddels dat een besliscommissie (administratief beroep) waraan bevoegdheden van GS zijn overgedragen ook in strijd is met de dwingende bepalingen van afdeling 7.3 Awb."

Stroink wijst in zijn annotatie bij de zaak van de gemeente Alkemade er op, dat "het beter zou zijn indien de Awb (en eventueel ook de Gemeentewet) een uitdrukkelijke bepaling terzake zouden bevatten".

74 Zie noot 70 , alsmede de annotatie van JMED.

75 Zie noot 69, met de annotatie van FAMS.

76 Zie noot 62.

7 Rb. "s-Hertogenbosch 15 oktober 1997, Awb-katern 1998, 43.

78 Zie noot 69 . 
Die laatste kanttekening is niet zonder grond. De meningsverschillen over de juistheid van de uitspraak van de ABRS ower de besliscommissies zullen woorlopig wel blijven bestaan.

\subsubsection{Aanbevelingen voor de besliscommissie}

In het licht van het vorenstaande, verdient het aanbeveling art. $165 \mathrm{Gem}$.w. aan te passen c.q. te wijzigen. Art. 165, eerste lid Gem.w. bepaalt met zoveel woorden, dat de raad aan een commissie als bedoeld in art. 82 Gem.w., bevoegdheden van burgemeester en wethouders kan toekennen. Overwogen zou kunnen worden aan art. $165 \mathrm{Gem}$.w. een nieuw derde lid toe te voegen, waarin de bevoegdheid tot het beslissen op bezwaarschriften als bedoeld in art. 7:1 Awb zou worden uitgesloten. Het huidige derde lid zou kunnen worden vernummerd tot lid 4. In gelijke zin zou art. $178 \mathrm{Gem}$. $w$. kunnen worden aangepast ten aanzien van de bevoegdheden van de burgemeester. Het bestaande tweede lid zou een uitzonderingsclausule dienen te bevatten ten aanzien van de behandeling van bezwaarschriften. Dit laatste zou in samenhang daarmede moeten leiden tot een vernummering van het huidige tweede lid.

In de Prov.w. zou dienovereenkomstig moeten worden overgegaan tot een wijziging van de relevante bepalingen aangaande de commissies. Dit zou moeten leiden tot een aanpassing van de art. 163 Prov.w.

In tegenstelling tot de overdracht van bevoegdheden van GS en de burg. aan een besliscommissie, kent de Prov.w. geen regeling voor de CdK.

Er wordt voor gepleit om ook de besliscommissies voor de bezwaarschriften in de Gem.w. en de Prov.w. uit te sluiten van het overdragen van bestuursbevoegdheden. Daarvoor zou een aanpassing kunnen worden overwogen door een aanvulling van art. 156, lid 2 Gem.w. Dit voorschrift geeft een opsomming van gevallen waarin geen bevoegdheden wan de raad kunnen worden overgedragen aan b en $w$ of aan een commissie als bedoeld in art. 82 .

In het tweede lid van dit artikel zou na sub g kunnen worden toegevoegd lid $h$, luidende als volgt:

'h. het beslissen op een bezwaar als bedoeld in artikel 7:1 van de Algemene wet bestuursrecht.'

80 T \& C PGW (Graat), aant. 1 bij ark. 82 Prow. 
Ook art. 152, lid 2 Prov.w. zou dienen te worden aangepast door een identieke aanvulling zoals voor de Gem.w. wordt aanbevolen. In overeenkomstige zin zou aan dit tweede lid sub i kunnen worden toegevoegd, met een gelijkluidende gewijzigde redactie zoals die voor de Gem.w. wordt voorgestaan.

\subsubsection{Conclusies en aanbevelingen voor het bepalen van de instellingsgrond- slag van de hoor-en adviescommissie als bedoeld in artikel 7:13 Awb}

In par. 4.2.2.1 (grondslagvereiste voor het adviseren) is de vraag opgeworpen of de Awb voldoende duidelijkheid heeft geschapen in de adviesrelaties in het kader van de beslissing op het bezwaarschrift. In samenhang met art. 7:13 Awb werd de wettelijke grondslag van het functioneren van adviescommissies voor de bezwaarschriften onderzocht. In het onderzoek werden tevens betrokken de bestaande adviesstelsels op grond van de Gem.w. en de Prov.w. In samenhang hiermee werd tevens een koppeling gelegd met art. 14 Wet arob. Vast kon worden gesteld dat zowel onder de Wet arob ${ }^{81}$, alsook onder de Awb de discussie van het grondslagvereiste voor het adviseren, maar ook voor het beslissen op het bezwaarschrift nog steeds actueel is. Het vraagstuk van het grondslagvereiste is bovendien onlangs in een tweetal uitspraken van de bestuursrechter opnieuw leven ingeblazen. Geconcludeerd kan worden dat de Awb geen ruimte meer biedt voor het instellen van de besliscommissies. ${ }^{82}$

De vraag kan worden gesteld of de Awb op basis van de recente opvatting van de bestuursrechter, de regels van de Prov.w. en Gem.w. voor wat betreft de organisatie en de inrichting van het bestuur door middel van het instellen van commissies, volledig buiten spel zet. Betekent dit nu ook dat het commissiestelsel van de Gem.w. en de Prov.w. geen grondslag meer kan bieden voor het instellen van bezwaarschriftenadviescommissies in de zin van art. 7:13?

Ten behoeve van de beantwoording van de vraag waaraan de instelling van een adviescommissie ten grondslag ligt - of art. 7:13 Awb of de Gem.w./Prov.w. werd in par. 4.3.2.1 een aantal bevindingen vastgesteld. Kort samengevat komen deze bevindingen op het volgende neer:

art. 7:13 Awb houdt voorschriften in voor het geval dat een adviescommissie is ingesteld ${ }^{\text {sa. }}$; deze omstandigheid duidt er op dat vooraleer art. 7:13 onder het bereik van de (advies)eisen van dit artikel valt, een adviescommissie moet zijn ingesteld;

s. Zie noot 50 .

82 Zie de noten 69 en 70 .

8.) Zie noot 53 . 
- aan art. 7:13 ligt naar de bedoelingen van de Awb mede ten grondslag de herkenbaarheid van deze commissie voor de burger; uit een oogpunt van herkenbaarheid voor de burgers moet duidelijk zijn of de inrichting van de bezwaarschriftenprocedure geschiedt langs de 'lijnen' van een volledig interne (organisatorische) structuur dan wel of de behandeling van het bezwaarschrift is opgedragen aan een adviescommissie in de zin van art. 7:13;

- de Awb heeft niet gekozen voor het rechtstreeks creëren van een instellingsgrondslag in art. $7: 13$;

- de bevoegdheidsgrondslag tot instelling van een adviescommissie in de zin van art. $7: 13$ steunt vooralsnog op het commissiestelsel in de organieke wetten (Gem.w. Prov.w.);

in de ontwerp-a.m.v.b. ex art. 14, lid 3 Wet arob, is indertijd gepleit voor het creëren van een formele grondslag voor het instellen van adviescommissies.

Geconcludeerd wordt dat de Awb ten behoeve van het optreden wan een adviescommissie in de zin van art. 7:13, lid 1 er vanuit gaat dat voldaan is aan een constituerend vereiste. Dit laatste betekent dat deze adviescommissie allereerst moet zijn ingesteld. Omtrent het wettelijk instellingsgrondslagvereiste zwijgt de Awb in tegenstelling tot de voorstellen wan de commissie Arob. Op basis van de bepalingen van het commissiestelsel in de Prov.w. en de Gem.w. is geconstateerd dat conform het huidig recht vooralsnog het grondslagvereiste voor het instellen van een adviescommissie in de zin van art. 7:13. lid 1 zijn basis vindt in beide (organieke) wetten.

De vraag kan worden gesteld of het grondslagvereiste voor het instellen van een adviescommissie zijn verankering moet vinden in de Awb (art. 7:13, lid 1) of in de Gem.w. of de Prov.w..

Reeds vanaf het bestaan van de gern.w. (oud) hebben commissies als "organisatiefenomeen", zij het op een bescheiden wijze, een plaats ingenomen in het gemeentelijk bestel. De 'nieuwe' bepalingen in de (oude) gem. w. inzake de commissies (wet van 9 juli 1984, Stb. 256) waren gericht op decentralisatie en differentiatie van het lokale bestuur. ${ }^{\text {g4 }}$ De nieuwe per 1 januari 1994 geldende bepalingen van het gemeenterecht 'borduren' in feite voort op deze 'historische' ontstaansbronnen van het commissiestelsel. De bepalingen inzake de commissies bieden ook nu nog een grondslag voor het instellen van bezwaarschriftenadviescommissies. Zij vormen in oorsprong het organisatierecht van de bestuursorganen;

84 M. Troostwijk (red), Van Loenen, De gemeentewet en haar toepassing, losbl. Alphen aan den Rijn, p. I-II-A-I e. $y$. 
ook met de komst van de Awb treedt hierin geen verandering op. De Awb is opgezet als algemene regeling voor het bestuursrecht; de structuur en systematiek van deze wet voorziet niet in organisatierecht. Het verdient op redelijke gronden de voorkeur, het instellingsgrondslagvereiste te handhaven in de Gem.w. en Prov.w. Wél is het op basis van dezelfde argumenten van de commissie Arob gewenst in art. 7:13, lid 1 de instellingsgrondslag alsnog op te nemen.

Een hiertoe strekkende wijziging wan art. 7:13, lid 1 is opgenomen in de aanbevelingen, behorende bij dit proefschrift.

Gelet op deze overwegingen wordt het vastleggen van een instellingsgrondslag (formeel criterium), voor de bovengenoemde adviescommissies in de Awb aanbevolen. Dit voorstel lijkt niet in strijd met de opvattingen in het kader van de discussie over de zogenaamde 14-wetsfamilies. ${ }^{85}$

85 Zie: D.W.P. Ruiter, a.W., alsmede F.H. van der Burg e.a., Weigeving en beleidsinstrumentari" um in: Macht en onmacht van de wetgever, Deventer 1978, p. 67 e.v. 
Naar een 'definitief' concept voor het adviseren op grond van de Awb: de advisering als kwaliteitsfactor in de besluitvorming en als object van rechtsbescherming

\subsection{De 'bouwstenen' voor een bezinning op artikel $7: 13 \mathrm{Awb}$}

\subsection{Algemene aspecten}

In par. $4.3 \mathrm{kwam}$ de advisering als aspect van voorbereiding van de op het bezwaarschrift te nemen beslissing ter sprake. Het onderzoek in deze paragraaf richtte zich op een tweetal belangrijke aspecten. In eerste instantie werd in par. 4.3.2.1 aandacht besteed aan het grondslagvereiste voor het adviseren. In par. 4.3.2.2 werd het grondslagvereiste voor het beslissen op het bezwaarschrift onderzocht. Hiermee werd de basis gelegd voor een onderzoek naar de betekenis van de adviescommissie in de zin van art. $7: 13 \mathrm{Awb}$ voor de voorbereiding van de op het bezwaarschrift te nemen beslissing. In dit hoofdstuk wordt dit onderzoek voortgezet.

In het belang van een goede voorbereiding van de beslissing op het bezwaarschrift door het bestuursorgaan, vervullen zowel de hoorverplichting als het adviseren aam het bestuursorgaan, een belangrijke rol. Uitgangspunt is dat de bezwaarde burger aanspraak heeft op een rechtens juiste beslissing. De beslissing op het bezwaarschrift is de laatste mogelijkheid voor het bestuursorgaan om aan de hand van een hernieuwde rechtmatigheids- en doelmatigheidstoets de bestreden primaire beslissing, binnen de eigen bestuurlijke kring, nog eens aan de hand van correctheidsmaatstaven te beoordelen.

Nadat het bestuursorgaan op het bezwaarschrift heeft beslist is "de bestuurlijke grens' gepasseerd. Hierna bestaat de kans dat op basis van een justitiabel appel, het terrein van het bestuursprocesrecht wordt betreden. In dit laatste geval wacht het bestuursorgaan een onvermijdelijke toets van zijn beslissing op het bezwaarschrift. Het bestuursbesluit wordt dan blootgesteld aan het oordeel van de bestuursrechter. Dit is niet zonder betekenis voor de beslissing op het bezwaarschrift. Wil het bestuursorgaan met enig vertrouwen een rechtmatige beslissing op het bezwaarschrift kunnen nemen, dan moet worden voldaan aan een aantal voorbereidingseisen van de $\mathrm{Awb}$. In de voorbereidingsfase vormen het horen en het adviseren de belangrijke pijlers wan de bezwaarschriftenprocedure. De Awb heeft hiervoor de volgende procedurele lijnen uitgezet. 
5.2.1. Het bestuursorgaan als voorbereider van de beslissing op het bezwaarschrift

Allereerst heeft de bezwaarschriftenprocedure in afdeling 7.2 Awb zodanig vorm gekregen, dat deze procedure primair ten overstaan en onder verantwoordelijkheid van het bestuursorgaan wordt gevoerd. '

Afdeling 7.2 bevat een tweedeling. Het samenstel van bepalingen in de art. $7: 2$ A wb tot en met 7:12 bevat een aantal elementen dat er op duidt dat het bestururorgaan de formele autoriteit is in zowel het voorbereidingsproces van de besluitvorming als de aftonding daarvan. Ten behoeve van het afronden van het besluitvormingsproces wordt een aantal 'beslissingsmomenten' tot uitdrukking gebracht in de art. $7: 10$ tot en met $7: 12$. Deze beslissingsmomenten omvatten bepalingen terzake beslistermijnen (art. 7:10), de te maken heroverweging (art. 7:11), alsmede de vereisten wan een deugdelijke motivering, en de regels betreffende de bekendmaking van de beslissing op het bezwaarschrift (art. 7:12).

In het belang van de afronding van het besluitvormingsproces bevat afdeling 7.2 Awb bepalingen van procedurele aard. Deze raken de eerste fase van de behandeling van het bezwaarschrift. Deze fase typeert de voorbereidingsprocedure die voorafgaat aan het moment, waarop het bestuursorgaan op het bezwaarschrift een beslissing neemt. De voorbereidingsprocedure bevat de hoorverplichting van het bestuursorgaan als bedoeld in art. 7:2 Awb.

De verplichting van het bestuursorgaan tot het horen van bellanghebbenden wordt op basis van een aantal eisen, uitgewerkt in de art. 7:3 tot en met 7:9. Nadat in art. 7:3 enkele uitzonderingen op de hoorverplichting worden gemaakt, richt een aantal bepalingen zich op het werkrijgen van de benodigde informatie in het belang van de op het bezwaarschrift te nemen beslissing. Art. 7:4 heeft betrekking op het indienen en de terinzagelegging van de stukken, alsmede de eventuele geheimhouding. In art. 7:7 is een verslag van de hoorzitting verplicht voorgeschreven, terwijl art. 7:8 de mogelijkheid biedt voor de belanghebbende om getuigen en deskundigen ter zitting mee te brengen en te doen horen. Deze informatieketen wordt gesloten door art. 7:9; feiten en omstandigheden die zich tussen het tijdstip van de hoorzitting en het beslissingsmoment van het bezwaarschrift aandienen, moeten vanuit het ex nunc-perspectief, in het besluitvormingsproces worden meegewogen. Dit laatste kan betekenen dat een tweede hoorzitting alsnog geboden is.

H. Bolt, in: Pr. Bestuursrecht, a.w., p. X-25. 
Daamaast zijn enkele bepalingen geformuleerd die inhoud geven aan de wijze en het inrichten van het horen. In art. 7:5 wordt aangegeven wie hoort en of het horen al dan niet in het openbaar moet geschieden. Art. 7:6 geeft invulling aan het beginsel van hoor- en wederhoor, maar maakt het mogelijk orn op grond van feiten en omstandigheden van dit bestuursprocesrechtelijk beginsel gemotiveerd af te wijken.

De uitvoering van de bovengenoemde regels die tezamen het voorbereidingsproces van de bezwaarschriftenprocedure bepalen, geschiedt volledig onder verantwoordelijkheid van het bestuursorgaan. Dit laat overigens onverlet de bevoegdheid van het bestuursorgaan om de uitvoering van de procedurele (voorbereidings)bepalingen te mandateren aan door het orgaan aan te wijzen ambtenaren.

De uitwoering van de art. 7:2 tot en met 7:9 Awb komt dan geheel in handen te liggen van deze gemandateerde ambtenaren. Krachtens mandaat kunnen de bij bestuursbesluit aangewezen ambtenaren worden belast met het horen. Kan aan ambtenaren mandaat worden verleend voor het nemen van een beslissing ten aanzien van het horen in het openbaar. Mandaatverlening ten aanzien van het openbaarheidsaspect van de hoorzitting heeft overigens alleen zin, indien bij 'wettelijk voorschrift' geen nadere regeling inzake de openbaarheid is getroffen (art. $7: 5$, lid 2). Art. 7:5, lid 2 maakt het mogelijk om bij ministeriële regeling dan wel bij een verordening van een gedecentraliseerd bestuursorgaan, de openbaarheid van hoorzittingen nadere invulling te geven. Bij deze regelingen kunmen eventuele beperkingen aan de openbaarheid van hoorzittingen worden gesteld.

De bepalingen van art 7:2 en volgende van de Awb kunnen nopen tot het nemen van preparatoire beslissingen. Voor een goed begrip van deze term wordi opgemerkt dat het uitoefenen van deze beslissingen, bevoegdheden betreffen die los staan van de beslissingsmomenten als bedoeld in de art. 7:10 tot en met 7:12 Awb. Deze preparatoire beslissingen bepalen immers voor een belangrijk deel 'het gezicht" van de formeel-juridische uitwoering van de bezwaarschriftenprocedure (de procedurele voorbereidingsaspecten). De bevoegdheden van het bestuursorgaan die te maken hebben met de uitvoering van de procedurele bepalingen van de bezwaarschriftenprocedure, hebben geen zelfstandig rechtsgevolg, en worden los van de (eind)beslissing op het bezwaarschrift uitgeoefend. Aan de preparatoire bevoegdheid c.q. beslissing ligt niet dezelfde afweging van 
belangen ten grondslag als die waarvan de eindbeslissing een uitvloeisel is.? Anders gezegd het preparatoire besluit is specifiek gericht op de betreffende procedurele bepaling die tijdens de procedure wordt toegepast. Er wordt hiermee geen beslissing genomen die een afronding van het besluitvormingsproces van de bezwaarschriftenprocedure betekent. Wél is het zo, dat de preparatoire beslissing als element van de eindbeslissing op het bezwaarschrift, 'het lichaam' van het (eind)besluit op het bezwaarschrift bij een eventuele bestuursprocesrechtelijke toetsing kan aantasten. Dit laatste kan bijvoorbeeld betekenen dat een (preparatoire) beslissing om een belanghebbende niet te horen (art. 7:3) tot gevolg kan hebben dat de beslissing op het bezwaarschrift door de bestuursrechter wordt wernietigd.

Naast de literatuur heeft ook de Awb oog gehad voor het rechtskarakter van de preparatoire beslissingen. In art. 6:3 is een regeling getroffen voor de bovengenoemde procedurele beslissingen die de voorbereiding van de beslissing op het bezwaarschrift raken. Art. 6:3 geeft in duidelijke bewoordingen aan, dat een beslissing, inzake de procedure ter voorbereiding van een besluit, niet vatbaar is voor bezwaar (noch voor beroep).

Een uitzondering op de regel van art. 6:3 wordt gemaakt in de tweede zinsnede van dit artikel:

'tenzij deze beslissing de belanghebbende los van het voor te bereiden besluit rechtstreeks in zijn belang treft".

Er zijn nogal wat procedurele bepalingen in de Awb, waaruit een preparatoire bevoegdheid valt af te leiden. Hieruit kunnen dan preparatoire beslissingen voortvloeien. Ofschoon het bestuursorgaan het bevoegde orgaan is voor de uitvoering van de procedurebepalingen van de bezwaarprocedure, stuit uitvoering van deze

2 P. Nicolat, Beginselen van behoorlijk bestuur, Deventer 1990, p. 482 e.v.

3 Zile in dit werband: PG Awb I, p. 283 en 284 en H.J. Simon, Handleiding, a.w., p. 151 e.v., alsmede H. Bolt, Recthtsbescherming, Algenene bepalingen en de bestuurlijke voorprocedure, Monografieän Algemene wet bestuursrecht (A 3a), Deventer 1994. Bolt wijst overigens op een aantal aspecten van artikell $6: 3$ die tot verwarring kunnen leiden. Hij attendeert er op, dat in de memorie van toelichting van artikel 6:3 'in het algemeen' wordt gesproken over woorbere" dingshandelingen, terwijl in het betreffende artikel sprake is van "een procedureel woorbereidingsbesluit". Ook de redactie van artikel 6:13 zou met de begrippen 'belanghebbende' en "rechtstreeks in zijn belang treft" tot verwarring ten aanzien van de toepassing kunnen leiden. Deze kritische kanttekeningen, waarnaar hierbij kortheidshalve wordt verwezen, worden hier overigens vanuit de optiek vati deze paragraaf niet nader besproken. 
procedure door het bestuursorgaan zélf, op praktische problemen. Het bestuursorgaan bedient zich daarom van de mandaatfiguur.

Procedureregels worden doorgaans gekenmerkt door een diversiteit van preparatoire beslissingen. Het zou binnen het bestek van dit boek te ver voeren op al die procedurele facetten die preparatoire bevoegdheden kunnen inhouden, in te gaan. ${ }^{4}$ Toch zal een aantal van de belangrijkste preparatoire bevoegdheden worden aangestipt dat voor een groot gedeelte invulling geeft aan de voorbereidingsfase van de bezwaarschriftenprocedure.

Als eerste voorbeeld kan worden genoemd het nemen van een beslissing als bedoeld in art. 7:3 Awb (toepassing uitzonderingsbepaling inzake het horen), alsmede de inzageregeling als bedoeld in art. 7:4.

Tot het nemen van preparatoire beslissingen behoort ook het beoordelen van verzoeken van de belanghebbende burgers om getuigen en deskundigen op de hoorzitting te doen horen. Art. 7:8 Awb dat in hoofdstuk 3 reeds ter sprake kwam, biedt hiervoor de grondslag.

Ook voorafgaand aan het in gang zetten van de bezwaarschriftenprocedure (afdeling 7.2) zijn er enkele bepalingen in de Awb aan te wijzen die onder de directe bevoegdheidssfeer vallen van het bestuursorgaan.

Dit betekent dat de mandaatfiguur dienst zou kunnen doen bij de toepassing van art. 2:2 Awb, voor zover het betreft het nemen van een preparatoire beslissing ten aanzien van het in een bezwaarschriftenprocedure weigeren van bijstand of vertegenwoordiging door een persoon, tegen wie zijdens het bestuursorgaan ernstige bezwaren bestaan. Hoofdstuk $2 \mathrm{Awb}$, waarin art. 2:2 is opgenomen vervult immers een belangrijke functie in het verkeer tussen de burger en het bestuursorgaan. Deze bepaling is niet alleen van toepassing bij de voorbereiding van primaire besluiten, maar is ook van overeenkomstige toepassing ten aanzien van de bezwaarschriftenprocedure. Voor het administratief beroep dienen door het bestuursorgaan eveneens de voorschriften van hoofdstuk 2 Awb in acht te worden genomen. ${ }^{5}$

Een belangrijke bepaling van procedurele aard is voorts de in art. 2:3 opgenomen doorzendverplichting. Naast dit artikel moet het bestuursorgaan zo nodig in samenhang met art. 6:15 Awb - welk laatste artikel mede geldt voor de bestuurs-

4 Zie in dit verband: P. Nicolaï, a.w.

5 PG Awb I p. 166, allsmede H.J. Simon, Handleiding a. . p. 53 e.v. 
rechter - er voor zorgen dat onjuist geadresseerde stukken, alsnog bij het juiste bestuursorgaan correct op tafel komen. Het behandelen door het bestuursorgaan van aanvragen dan wel bezwaar- en beroepschriften, wordt hierbij beheerst door rechtsnormen die vóor de inwerkingtreding van de Awb werdisconteerd waren in de beginselen van behoorlijk administratief procesrecht. ${ }^{6}$

$\mathrm{Er}$ is uiteengezet dat uit een aantal bepalingen van hoofdstuk $2 \mathrm{Awb}$ (Verkeer tussen burgers en bestuursorganen) alsmede afdeling 7.2 (Bijzondere bepalingen over bezwaar) tijdens de bezwaarschriftenprocedure, een aantal preparatoire beslissingen kan voortvloeien. Voor de volledigheid wordt hierbij nog gewezen op het belang van enkele bepalingen van hoofdstuk 6 (Algemene bepalingen over bezwaar en beroep) die ook tot het nemen van preparatoire beslissingen door of namens (mandaat) het bestuursorgaan kunnen leiden. In het kader van de ontvankelijkheidsbeoordeling van het bezwaarschrift kan de bezwaarde burger op grond van art. 6:6 alsnog de gelegenheid worden geboden om diens gegevens met betrekking tot het ingediend bezwaarschrift te completeren. Art. 6:5, eerste lid stelt immers eisen aan de inhoud van het bezwaarschrift. Naast naam en adres van de bezwaarde moet het bezwaarschrift gedateerd zijn en behoort het voorzien te zijn van een uiteenzetting van de grieven tegen het bestreden primaire besluit. Belangrijk is tevens dat in het bezwaarschrift de reden vermeld moet zijn van het bezwaar.

Ten aarzien van het hanteren van preparatoire bevoegdheden is een tweetal aspecten nog van belang.

Art. 7:10 Awb geeft een regeling voor de beslistermijnen voor ingediende bezwaarschriften. In art. 7:10 wordt voor de op het bezwaarschrift te nemen beslissing al een 'juridisch voorschot' genomen op het in de Awb facultatief gestelde voorschrift, om de voorbereidingsfase van de bezwaarschriftenprocedure in handen te leggen van een adviescommissie als bedoeld in art. 7:13. Er werd de aandacht op gevestigd dat de bestuurspraktijk zich van diverse voorbereidingsmogelijkheden kan bedienen om het horen en adviseren in het kader van de bezwaarschriftenprocedure op te dragen aan een hoor- en adviescommissie.

Als een adviescommissie aan de vereisten van art. 7:13 voldoet moet door het bestuursorgaan binnen tien weken na ontvangst van het bezwaarschrift worden beslist. In de gevallen dat de bezwaarschriftenprocedure niet volgens het stramien van art. 7:13 verloopt, bedraagt de beslistermijn conform art. 7:10 Awb zes weken.

6 H.J. Simon, De kJeine revolutie: een jaar besturen onder de Awb I, IB 1995, 30, p. 97 en 98. 
Ook art. 7:10 Awb kan leiden tot een aantal preparatoire beslissingen. Art. 7:10, lid 3, verplicht het bestuursorgaan tot het doen van een schriftelijke mededeling omtrent de verdaging van de beslissing op het bezwaarschrift met vier weken. Het vierde lid van art. 7:10 betreffende het uitstel van de beslissing op het bezwaarschrift verplicht tot het nemen van een preparatoire beslissing.

Het tweede aspect waarmee de bespreking van de preparatoire beslissingsbevoegdheden wordt afgesloten houdt verband met het mandateren van deze beslissingen. Aan het gebruik van het mandaat in de bezwaarschriftenprocedure, verbindt de Awb geen bijzondere restricties, dit laatste in tegenstelling tot het beslissen op een beroepschrift. De mandaatfiguur vindt door de inwerkingtreding van de derde tranche $A w b^{7}$ regeling in afdeling 10.1.1. In art. 10:3 zijn aan de bevoegdheid tot mandaatverlening in het tweede en het derde lid enkele beperkingen verbonden. Conform het tweede lid van art. 10:3, onder $c$, kan het bestuursorgaan geen mandaat verlenen tot het beslissen op een ingesteld administratief beroep. Lid 3 van art. 10:3, bepaalt dat mandaat tot het beslissen op een bezwaarschrift niet wordt verleend aan degene die het besluit waartegen het bezwaar zich richt, krachtens mandaat heeft genomen. De regering beargumenteerde deze beperking van de reikwijdte van het beslissingsmandaat ten aanzien van bezwaarschriften als volgt:

'Op het algemene uitgangspunt dat mandaatverlening terzake van het beslissen op een bezwaarschrift mogelijk moet blijven, moet éen uitzondering worden gemaakt. Het is ongewenst dat het mogelijk zou zijn dat de functionaris die de primaire beslissing nam waartegen bezwaar wordt gemaakt, via mandaat ook weer degene zou zijn die op dat bezwaar zou beslissen (zie CBB 15 mei 1988, uitspraken CBB 1988, nr. 24). Het derde lid van art. $1 A .1 .2$ (nu: art. 10:3, lid 3) staat aan zo"n mandaatverlening in de weg."

Deze uitzonderingsbepaling doet recht aan de eisen van distantie. Art. 7:5, dat regels geeft voor de hoedanigheid van personen die met het horen zijn belast, brengt deze gewenste distantie in beeld. Ook door een commissie op de voet van art. $7: 13$ wordt afstandelijkheid nagestreefd bij de voorbereiding van de beslissing op het bezwaarschrift.

De bovengenoemde bepalingen zijn in feite een bijzonder complement op art. 2:4 A wb dat algemene uitgangspunten formuleert voor de zuiverheid van de besluitvorming. 
Tijdens de parlementaire behandeling van de Awb is vooral aandacht besteed aan de vergroting van de betrokkenheid van het bestuursorgaan bij de bezwaarschriftenprocedure. Uit de gevoerde parlementaire discussie blijkt, dat bezien vanuit de kwaliteitseisen, de bezwaarschriftenprocedure als bellangrijk bestuurlijk instrument is verdedigd." Het veelvuldig gebruik van de mandaatfiguur tijdens de primaire besluitvorming zou moeten worden gecompenseerd door de betrokkenheid van het bestuursorgaan bij de beslissing op het bezwaarschrift te vergroten. De bepalingen van de Awb over de bezwaarschriftenprocedure gaan daarvan uit. Dit latste werd hiervoor al opgemerkt bij het behandelen van de structuur van afd. $72 .^{10}$ Art. 10:3, lid 3 kan uit bestuurlijk praktische overwegingen worden verdedigd.

Toch moet ten aanzien van het gebruik van het beslissingsmandaat een enkele kritische opmerking worden gemaakt. Binnen het kader van het beslissingsmandaat, oefent de gemandateerde rechtens een aantal bevoegdheden uit tot het nemen van preparatoire beslissingen. Ten aanzien van deze preparatoire bevoegdheden is er een grote differentiatie mogelijk binnen het kader van de Awb (par. 5.3.9 en 5.3.10). Mede in het licht van het onderzoek in dit hoofdstuk naar een meer doelmatige en eenduidige inrichting van de bezwaarschriftenprocedure, is het wenselijk het gebruik van mandaat in art. 10:3 uit te sluiten voor wat betreft de preparatoire bevoegdheden. De preparatoire bevoegdheden kunnen beter worden uitgeoefend door een adviescommissie in de zin van art. 7:13, lid 1. Deze commissie is immers belast met de voorbereidingsfase voorafgaand aan de beslissing op het bezwaarschrift.

In het begin van par. 5.2 werd benadrukt dat in de voorbereidingsfase van de beslissing op het bezwaarschrift, de hoorplicht en het adviseren omtrent het ingediende bezwaar een belangrijke rol spelen.

Ingegaan werd op de hoorverplichting met de daarbij behorende procedurebepalingen van de Awb (art. 7:2 tot en met 7:9). Gewezen werd op de structuur van afdeling 7.2 die een tweedeling bevat. In het eerste gedeelte van de procedurele bepalingen van afdeling 7.2 komt tot uiting dat het bestuursorgaan de formele verantwoordelijkheid draagt voor de voorbereidingsfase van de beslissing op het bezwaarschrift (art. 7:2 tot en met 7:9).

De afronding van het besluitwormingsproces wordt daarnaast geregeld in een aantal 'beslissingsmomenten'; deze worden gevormd door de beslistermijnen als

9 PG Awb I, p. 324 e.v.

10 Zie ook: H. Bolt, Pr. Bestuursrecht, a.w., p. X-25. 
bedoeld in art. 7:10, de heroverwegingsplicht als bedoeld in art. $7: 11$, alsmede art. 7:12 (het motiveringsvereiste en de regels betreffende de bekendmaking van de beslissing op het bezwaarschrift). Wat de afronding van het besluitvormingsproces als tweede gedeelte van de structuur van afdeling 7.2 betreft, lijkt er niets bijizonders aan de hand. Gelet op de functie, het doel en het karakter van de bezwaarschriftenprocedure draagt het bestuursorgaan zorg voor de voorbereidingsfase en beslist hetzelfde (oorspronkelijk) bestuursorgaan dat het bestreden primaire besluit heeft genomen. Toch is er een andere invulling mogelijk van de voorbereidingsfase van de beslissing op het bezwaarschrift, waarvan zowel het horen als het adviseren belangrijke componenten vormen.

\subsubsection{Het voorbereiden van de beslissing door een adviescommissie}

De Awb heeft voor wat betreft het horen en het adviseren oog gehad voor de praktijk. Het bestuursorgaan kan aan de voorbereiding van de beslissing op het bezwaarschrift op verschillende manieren invulling geven.

Het kiezen voor een bepaalde wijze van adviseren kan er op neerkomen, dat de gehele voorbereiding van de beslissing op het bezwaarschrift in handen komt te liggen van een adviescommissie. Dit kan betekenen dat het bestuursorgaan zijn verantwoordelijkheid voor het voorbereidingsproces in afwijking van het Awbstramien van afdeling 7.2 afstaat aan deze adviescommissie.

Met het afstaan van de verantwoordelijkheid voor de voorbereidingsfase van de behandeling van bezwaarschriften, wordt gedoeld op de formeel-juridische status die er ontstaat bij het institutionaliseren van adviesrelaties met het bestuursorgaan.

In de bestuurlijke organisatie worden op verschillende manieren personen en commissies ingeschakeld ten behoeve van het adviseren van bestuursorganen.

Bezwaarschriftencommissies zijn in de praktijk verschillend samengesteld. Hooren adviescommissies kunnen een zuivere bestuurlijke samenstelling hebben en bestaan uit bestuurders en/of ambtenaren. Een tweede mogelijkheid is dat er sprake is van een gemengde samenstelling, hetgeen betekent dat zowel bestuurders en/of ambtenaren, alsook personen buiten de bestuurlijke organisatie. Tenslotte kan het bestuur er voor kiezen om de hoor- en adviescommissie een 
volledig extern karakter te geven. In dit geval bestaat een dergelijke commissie geheel uit leden die geen deel uitmaken van de bestuursorganisatie. "

De wijze waarop de bezwaarschriftenprocedure door adviescommissies is ingericht, is van doorslaggevende betekenis voor het antwoord op de vraag welke formeel-juridische status moet worden toegedicht aan het voorbereidingsproces wan de bezwaarschriftenprocedure. Inhakend op de adviesrelaties, kan afhankelijk van de gekozen commissievorm, de volgende formeel-juridische voorbereidingsstatus van de bezwaarschriftenprocedure ontstaan. Deze formeel-juridische status bepaalt wie verantwoordelijk is voor het voorbereidingsproces van de procedure: het bestuursorgaan of de ingestelde adviescommissie. Indien een adviescommissie is samengesteld uit bestuurders en/of ambtenaren draagt het bestuursorgaan de verantwoordelijkheid voor de voorbereidingsfase. Bij hoor-en adviescommissies waarvan de samenstelling van een gemengd karakter is, c.q. deze commissies geheel uit externe leden bestaan, kan het functioneren van deze beide laatste categorieën van commissies er toe leiden dat het voorbereidingsproces niet of niet geheel onder verantwoordelijkheid van het bestuursorgaan verloopt.

Aan het afstaan van deze verantwoordelijkheid voor de inrichting van de bezwaarschriftenprocedure is door de $\mathrm{Awb}$ in art. $7: 13$ een aantal vereisten gesteld. Deze vereisten zijn primair gericht op het bieden van waarborgen voor een objectieve advisering omtrent de op het bezwaarschrift te nemen beslissing. In hoofdstuk 2 werd hierop uitgebreid ingegaan; het belang van een objectieve voorbereiding van de beslissing op het bezwaarschrift zal in de par. 5.3.4 en 5.4.4 nog verder worden aangescherpt. Ook in par. 4.1 (typen van advisering) en par. 4.2 werden globaal de inrichtingsvereisten van de adviescommissie ex art. 7:13 nog eens aangestipt. Naast deze inrichtingsvereisten is er een tweede belangrijk aspect verbonden aan de inschakeling van een adviescommissie in de zin van art. 7:13 Awb. Dit aspect is nauw verbonden met de procedurebepalingen voor de behandelling van het bezwaarschrift, en betreft de voorbereiding van de beslissing op het bezwaar. In par. 5.2.1 bleek dat het bestuursorgaan in beginsel verantwoordelijk is voor de uitvoering van een aantal procedurele bepalingen van de Awb. Bij het instellen van een adviescommissie als bedoeld in art. 7:13 is het mogelijk deze commissie in plaats van het bestuursorgaan te belasten met de uitvoering van een aantal procedurebepalingen (7:13, lid 4). Aan het opdragen van deze procedurele bevoegdheden van deze adviescommissie zal verder aandacht worden besteed in de par. 5.3.9 en 5.4.9.

11 J.M.H.F. Teunissen, a.w., p. E 6.3.18-3/4. 
Op basis van hetgeen hiervoor is besproken, worden in de volgende paragraaf enige aspecten onderzocht die van belang zijn voor een goede voorbereiding van de beslissing op het bezwaarschrift.

\subsection{Bijzondere aspecten}

In par. 4.3.2.1, waarin het grondslagvereiste voor het adviseren op het bezwaarschrift is besproken, werd er op gewezen dat de Awb de bestuursorganen ruimte heeft gelaten om te bezien op welke wijze de advisering in het kader van de bezwaarschriftenprocedure gestalte behoort te krijgen. Daarom is in de Awb door het opnemen van art. 7:13 de facultatieve mogelijkheid gecreëerd om op basis van de in dit artikel gestelde eisen, een adviescommissie voor cen groot gedeelte de voorbereidingsfase voorafgaand aan de beslissing op het bezwaarschrift, voor haar rekening te laten nemen.

\subsubsection{De Awb en de keuzevrijheid van het adviseren}

In par. 4.3.1 is de vraag opgeworpen of de Awb de bestuursorganen de vrijheid had moeten laten om de advisering aan het bestuursorgaan naar eigen inzicht in te vullen. De vraag werd gesteld of het facultatieve voorschrift van art. 7:13 geen imperatief karakter moet hebben. Voor deze vraagstelling is een aantal redenen te geven.

De Awb is in het uitgangspunt van de keuzevrijheid voor het adviseren niet geheel consistent. In de MvT van afdeling 7.1 zijn enkele opmerkelijke passages opgenomen. Gelet op de betekenis hiervan, volgen hierna enige overwegingen uit de MvT die enerzijds het belang van de uniforme regels van afdeling 7.2 benadrukken, en anderzijds de keuzevrijheid met betrekking tot de adviescommissie als bedoeld in art. $7: 13$ accentueren.

'Bij de keuze van de onderwerpen die - verdeeld over de afdelingen 6.2 en 7.1 - voor bezwaar geregeld moeten worden, heeft een aantal overwegingen een rol gespeeld.

In de eerste plaats is gestreefd naar een geheel van bepalingen die de belangrijkste punten zodanig regelen, dat een nadere regeling door de bijzondere wetgever niet nodig is. Deze kan dus, indien er geen duidelijke behoefte is aan bijzondere regels, afizien van het opstellen van bepalingen over bezwaar.

Daarnaast is overwogen dat de regeling voor de burger die met verschiliende bezwaarschriftenprocedures te maken kan krijgen, voldoende cenvormigheid moet brengen. Het is voor hem van belang; dat hij niet in de ene procedure met andere vereisten wordt geconfronteerd dan in de andere. 
Een belangrijk punt waarop de bijzondere regelgever een keuze kan maken, betreft het inschakelen van een adviescommissie. Verwezen zij naar artikel $6.3 .18^{3}$ (lees: 7:13).12

\subsubsection{De kritiek op de wrijheid van het adviseren}

Opvallend is dat de Awb vanuit doelmatigheidsoverwegingen en in het belang van de duidelijkheid voor de burger, eenvormigheid van de procedure-regels voor de bezwaarschriftenprocedure als uitgangspunt hanteert. Tegelijkertijd wordt een uitzondering gemaakt voor de wijze van het adviseren omtrent de op het bezwaarschrift te nemen beslissing. Het maken van een keuze voor het al dan niet inschakelen van een adviescommissie behoort naar de opvatting van de Awb tot de competentie van de bijzondere wetgever. Toch pretendeert de MvT van art. 7:13 impliciet een voorkeur voor een adviescommissie.

Inhakend op de voorgestane keuzevrijheid van 'de bijzondere regelgever' voor het instellen van een adviescommissie in de zin van art. 7:13 verwijst de Awb naar de onderzoeksresultaten van het rapport Arob-praktijken ${ }^{13}$, waarin het instellen van een adviescommissie wordt aanbevolen. ${ }^{14}$ Daarnaast wordt gewezen op de uitgesproken voorkeur van de VNG voor het verplicht stellen van een adviescommissie. ${ }^{15}$ Uit deze overwegingen valt weliswal geen expliciet uitgesproken voorkeur voor een adviescommissie in de zin van art. 7:13 af te leiden, maar kan toch niet geheel voorbij worden gegaan aan de omstandigheid dat de Awbwetgever in zijn wooropstelling ten aanzien van de keuzevrijheid voor een adviescommissie "lonkt' naar de praktische voordelen van een dergelijke commissie. Minder sterk voor de in afdeling 7.2 opgenomen facultatieve regeling van art. 7:13, lijkt in dit verband 'het afrondende argument' van de regering dat de keuze voor een adviescommissie door het bestuursorgaan beter 'per bezwaarschriftenprocedure' kan worden gemaakt. Als argument wordi hier gehanteerd do opvatting dat de bezwaarschriftenprocedures naar karakter kunnen verschillen. ${ }^{16}$ Dit laatste argument lijkt minder sterk en onvoldoende draagkrach tig.

De bezwalarschriftenprocedure is, wat betreft het karakter van deze voorprocedure, niet verschillend van aard. Wél kunnen de bestreden besluiten naar soort verschillend zijn doordat aspecten van rechtmatigheid en doelmatigheid, gelet op

12 PG Awb r, p. 317.

12. PG Awb I, p. 353.

14 A.W. p. 347-349.

15 VNG, Blauwe reeks nr. 72, p. 10.

16. PG Awb I, p. 353. 
de inhoud van de regeling waaraan deze besluiten ten grondslag liggen, minder ruimte bieden voor een te maken heroverweging als bedoeld in art. 7:11. Een vergunning voor het hebben van kansspelen als bedoeld in de Wet op de kansspelen is bijvoorbeld van een geheel ander karakter dan een bouwvergunning, waarbij nogal eens gebruik wordt gemaakt van een anticipatie- en vrijstellingsprocedure. In het proceduretraject van de WW en de WRO komt dan een zeer ruim scala van belangenafweging aan de orde.

Gewezen is op de in de MvT van art. 7:13 gememoreerde voorkeur van de VNG voor een adviescommissie. Het valt hierbij op, dat in het kader van de discussie over het facultatief karakter van art. 7:13 door de Awb slechts verwezen wordt naar de uit 1986 daterende model-verordening van de VNG, inzake de Gemeentelijke behandeling van (arob) bezwaar- en beroepschriften (Blauwe reeks nr. 72). Dit laatste is opmerkelijk omdat de VNG in 1987 een commentaar uitbracht aan de minister van Binnenlandse zaken naar aanleiding van het Voorontwerp Algemene wet bestuursrecht, eerste deel. ${ }^{17}$ In een uitvoerige reactice op art. 7:13 (6.3.18) is een aantal niet onbelangrijke aspecten door de VNG aan de orde gesteld. Dit VNG-commentaar is niet aangetroffen in de parlementaire stukken. Vanwege het belang hiervan, volgen hierna enkele relevante standpunten van de VNG.

De VNG gaf in haar bovengenoemde reactie aan de minister van Binnenlandse zaken het volgende commentaar:

'Wij hebben ons overigens afgevraagd, waarom deze bepaling alleen geldt voor op de in deze bepaling aangegeven wijze samengestelde adviescommissies.

De imperatieve redactie van het derde lid dient naar ons oordeel te worden gewijzigd in een facultatieve. Op die manier kan daaromtrent in de commissieverordening een regeling worden opgenomen.

Het is bijvoorbeeld goed denkbaar dat de beslissing over de toepassing van de genoemde bepalingen aan het bestuursorgaan wordt overgelaten. Volgens de huidige redactic zou dat niet mogelijk zijn.

Ook is er twijfel mogelijk over de vraag of het bestuursorgaan nog wel competent is on bij een in verband met een kennelijke niet-ontwankelijkheid door de commissie achterwege gelaten hoorzitting, deze alsnog te (doen) entameren.

Wij wijzen er verder in zijn algemeenheid op dat er ook problemen kunnen rijzen met de toepasselijkheid van de commissiebepalingen in de gemeentewet. Do vraag kan namelijk worden opgeworpen of aan een adviescommissie, waarvan hier blijkens het eerste lid sprake is, een beslissingsbewoegdheid ten aanzien van een aantal procedurele onderdelen kan worden opgedragen. Volgens het systeem in de gemeentewet is er

17 Ordening in het bestuursrecht (eerste fase), VNG, "s Grawenhage 1987. 
immers sprake van een onderscheid tussen enerzijds adviescommissies en anderzijds cornmissies met een eigen beslissingsbevoegdheid. In deze bepaling is er sprake van een commissie, die beide soorten bevoegdheden heeft.

Wij zijn er voorstander van om deze mogelijkheid open te houden, maar dan dient er wel duidelijkheid te komen over de relatie met de bedoelde gemeentewettelijke bepalingen. Wordt de in deze bepaling bedoelde commissie nu een commissie ingevolge de gemeentewet, ingevolge de Awb of ingevolge beide wetten?

Naar onze mening dient zoveel mogelijk bij de gemeentewet te worden aangesloten.

Deze wet bepaalt als kaderwet immers in beginsel de structuur en de bevoegdheden van gemeentelijke organen. Het verdient onzes inziens dan ook aanbeveling in het ontwerp van een nieuwe Gemeentewet (kamerstuk 19403) een bepaling op te nemen dat aan een adviescommissie beslisbevoegdheden van procedurele aard kunnen worden overgedragen." ${ }^{\text {"x }}$

Het commentaar van de VNG geeft aanleiding tot uiteenlopende vraagstellingen en juridische problemen over de toepassing van art. 7:13 Awb. Yoor een belangrijk deel kregen deze vraagpunten en juridische problemen al aandacht bij de bespreking van de grondslagvereisten voor het adviseren en beslissen op het bezwaarschrift. Zonder dat hier overigens nog eens in herhaling wordt gevallen wordt hierna kortheidshalve de rode draad van het commentaar van de VNG aangegeven. Die "rode draad' van de opmerkingen van de VNG ten aanzien van art. $7: 13$ kan als volgt met commentaar worden 'verstevigd'.

- De VNG bepleitte een ruimere reikwijdte van art. 7:13; ook adviescommissies die anders zijn samengesteld dan conform de bemensingscondities (nader gewijzigd voorstel van wet: art. 6.3.18, onder a. tot en met c.) zouden onder de werkingssfeer van dit artikel moeten worden gebracht. Ook de Raad van State gaf de regering 'in heroverweging' de toepasselijkheid van ook andere categorieën van adviescommissies (andere adviesvormen) in art. 7:13 (6.3.18) mogelijk te maken. De argumenten die de Raad van State daarbij hanteert wijken deels af van die van de VNG. Over de volgende argumenten van dit adviesorgaan bestond eenstemmigheid tussen de Raad van State en de VNG. Die eenstermmigheid met betrekking tot eenduidigheid van voorschriften voor alle categorieën van hoor- en adviescommissies betrof de volgende aspecten:

de herkenbaarheid van de adviescommissie voor de belanghebbende, aan te geven bij het bericht van ontvangst (art. $7: 13$, lid 2 jo $6: 14$; tekst RvS art. 6.3.18 jo 6.3.4); 
NAAR EEN DEFINITIEF CONCEPT VOOR HET ADVISEREN OP GROND VAN DE AWB

zowel het horen als het adviseren door een commissie (art. $7: 13$, lid 3 tekst RvS art. 6.3.18, lid 3)

het inbouwen van een contradictoir element conform de regeling in het vijfde lid van art. 7:13 (tekst RvS vierde lid van art. 6.3.18);

het verplicht voorschrijven van een verslag van de hoorzitting conform art. 7:13, lid 6 (tekst RvS art. 6.3.18, lid 5);

het bij de beslissing op het bezwaarschrift gemotiveerd afwijken van het commissie-advies ex art. $7: 13$, lid $7\left(6.3 .18\right.$, lid 6). ${ }^{20}$

Uit dit standpunt van de VNG blijkt een grote mate van eenstemmigheid ten aanzien van een algemene toepassing van de voorschriften van art. 7:13 voor alle hoor- en adviescommissies voor de behandeling van bezwaarschriften. De Awb heeft aan deze wensen geen gevolg gegeven. Het werd niet nodig geacht interne adviescommissies een eigen verantwoordelijkheid te geven, los van die van het bestuursorgaan. Gedoeld werd hierbij op de procedurele bevoegdheden als bedoeld in art. $7: 13$, lid 4 (art. 6.3.18, lid 3), het contradictoire aspect van art. $7: 13$, lid 5 (art. 6.3.18, lid 4), alsmede het gemotiveerd afwijken van het commissie-advies conform art. 7:13, lid 7 (art. 6.3.18, lid 6). ${ }^{21}$

Het bovengenoemd argument van de VNG is voldoende reden om de door de Awb voorgestane keuzevrijheid ten aanzien van de voorbereidingsfase van de beslissing op het bezwaarschrift, hierna kritisch te onderzoeken.

\subsubsection{De twijfels over artikel 7:5 als inrichtingsconditie voor het horen}

In dit boek is ruim aandacht besteed aan de hoorverplichting als bedoeld in art. 7:2 Awb. Deze hoorplicht vervult een belangrijke functie in het heroverwegingskader van de bezwaarschriftenprocedure. Het horen van belanghebbenden moet niet geschieden door personen die betrokken zijn geweest bij het tot stand komen van het bestreden primaire besluit. ${ }^{22}$ De Awb benadrukt het belang van de hoorplicht door te stellen, dat het horen in art. $7: 2$ een essentieel onderdeel vormt van de bezwaarschriftenprocedure. ${ }^{23}$

19 Oorspronkelijke tekst van voorstel van wet zoals voorgelegd aan de RwS. TK, 1988-1989, 21221. A).

20. PG Awb I. P. 353.

21 PG Awb I, p. 353.

22 H. Bolt, Rechtsbescherming, Algemene bepalingen en de bestuurlijke voorprocedure, Monografieen Algemene wet bestuurstecht A3a, Deventer 1994, p. 86.

PG Awb I, p. 329 e.v. 
In het belang van de doelstellingen van de hoorplicht is uit de Awb af te leiden dat wanneer niet gekozen wordt voor de "adviesoptie" van art. 7:13, waarborgen in het belang van de afstandelijkheid ten aanzien van de beoordeling van het bestreden primaire besluit, kunnen worden geboden door het in acht nemen van de eisen van art. 7:5. Dit artikel stelt een aantal eisen dat op het eerste oog een waarborgscheppende functie heeft ter voorkóming van belangenverstrengeling. In die gevallen dat de bezwaarschriftenprocedure onder verantwoordelijkheid van het bestuursorgaan plaatsvindt, moet naar de redactie van art. 7:5, eerste lid worden voldaan aan de volgende eisen, te weten:

"1. Tenzij het horen geschiedt door of mede door het bestuursorgaan zelf dan wel de woorzituer of een lid ervan, geschiedt het horen door:

a. een persoon die niet bij de voorbereiding van het bestreden besluit betrokken is geweest, of

b. meer dan een persoon van wie de meerderheid, onder wie degene die het horen leidt, niet bij de voorbereiding van het bestreden besluit betrokken is geweest.'

De vraag kan worden gesteld of deze in art. 7:5 Awb gestelde eisen, voldoende waarborgen bieden voor een ongewenste beïnloeding van de voorbereiding van de beslissing op het bezwaarschrift.

Het antwoord hierop is niet zonder reden pessimistisch wanneer dit afgezet wordt tegen de onvangrijke arob-jurisprudentie over de hoorplicht. De in de literatuur vermelde jurisprudentie van de Wet arob, bevestigt een negatief beeld over het voldoen aan de inrichtingeisen van het horen. ${ }^{24}$

Tegen de achtergrond hiervan lijkt art. 7:5, eerste lid als 'kopie' van de arobjurisprudentie twijfelachtig in de toepassing. Deze gecodificeerde bepaling kan geen al te sterke garanties bieden voor het voorkómen van bevooroordeeldheid bij de behandeling van bezwaarschriften. Deze twijfels worden tevens afgezet tegen de woorkeur van de lagere bestuursrechter voor art. 7:13. Dat deze voorkeur van de lagere bestuursrechter zich (vooral) vooralsnog heeft toegespitst op de situatie dat het openbaar lichaam, als belanghebbende tevens vergunninghouder is, doet hier niet aan af. ${ }^{25}$ De ABRS denkt hier inmiddels anders over en benadrukt in een Maastrichtse zaak nog eens dat de wetsgeschiedenis van art. 7:13 Awb het

24 F.A.M. Stroink, a.W., p. 397 en 398 en R.W. L. Loeb, B.K. Olivier en H. Troostwijk, p. 143 en.

25 Zie in dit verband: par. 3.6.2, alsnede par. 5.3 .5 , m. nt. voor wat betreft de uitspraak van de Rb. Maastricht van 5 malart 1996, 95/1786 WW 50 Z Pol. 
bestuursorgaan niet verplicht om een adviescommissie als bedoeld in dit artikel in te schakelen. ${ }^{26}$

\subsubsection{Artikel 7:13 en de waarborgen tegen belangenverstrengeling}

Ook onder de werking van de Awb, staat de zuiverheid van de besluitvorming wel eens door gebrek aan voldoende objectiviteit ter discussie. Een adviescommissie in de zin van art. 7:13 is geen garantie dat het besluitvormingstraject in het kader van de bezwaarschriftenprocedure, van de bestuursrechter een "woldoende" krijgt. ${ }^{27}$ Dit laat onverlet de 'sterke argumenten' die vanwege het "afstandelijkheidspredikaat", pleiten voor het inschakelen van een art. 7:13commissie. ${ }^{28}$ In de literatuur oordeelt men soms wat genuanceerder over art. $7: 13$, door te stellen dat een (partieel) extern samengestelde commissie 'een iets grotere garantie" biedt tegen vooringenomenheid. ${ }^{29}$ Deze voorzichtigheid is niet zonder reden omdat art. 7:13 geen dienst kan doen als volledig "vangnet" voor het tegengaan vam vooringenomenheid dan wel belangenverstrengeling.

Hoe wankel soms de invulling van het begrip 'onafhankelijk' kan zijn, bleek in een kwestie van de gemeente Ameland. In deze gemeente fungeerde een adviescommissie in de zin van art. $7: 13$. Toch bleek de artikel 7:13-conforme samenstelling van de commissie, niet voldoende om de 'gepretendeerde' onafhankelijkheid van de voorzitter 'veilig' te stellen.

De commissie-woorzitter bleek weliswaar ten tijde van de behandeling van het bezwaarschrift, geen deel meer uit te maken van het bestuursorgaan (b en w), maar hij was als voormalig waarnemend burgemeester gerekruteerd voor het hanteren van de voorzittershamer van de bezwaarschriftencommissie. Voor de bestuursrechter was dit voldoende reden om de beslissing op het bezwaarschrift te vernjetigen. ${ }^{30}$ De annotator wijst in zijn commentaar op deze uitspraak naar de strekking van zowel art. $7: 13$ als art. 2:4. Art. 7:13 neemt het onafhankelijkheidsaspect als uitgangspunt, terwijl art. 2:4 tot doel heeft vooringenomenheid (in casu partijdigheid) bij de besluitvorming te voorkomen.

26 ABRS 16 decenber 1997, JB 1998, 30 m.nt. ARN. Zie ook JB 1998, 24 en ABkort 1998, 30, Gst. 7077, 5, m.nt. C.P.J. Goorden.

Zie bijvoorbeeld de kwestie rond de Stadsmobiel Amsterdam CBB 21 december 1994, $\$ B$ 1995, I. AB 1995, 454 m.nt. JHvdH, RAwb 1995, 34 m.nt. BdeW, alsmede $\mathbb{N}$. Verhej Stadsmobiel Amsterdam (nr. 10), Parnijdige bezwaarschriftencommissie in: Rechtspraak Bestuursrecht 19941995: de annotaties, p. 94/95-139 e. $\psi$.

28 H. Bolt, a.w., p. 94 e.v. en TK 21221 , ar. 3, p. 155.

29 I.B.J.M. ten Berge, Bescherming tegen de owerheid, tweede dr, 1994, p. 203.

Rb. 8 februari 1996, JB 1996, $100 \mathrm{~m}$.nt. MAH. 
In de Amelandse zaak werd het bezwaarschrift vernietigd op grond van de schending van het vooringenomenheidsverbod (art. 2:4 Awb). Bij de toepassing van art. $7: 13$ is zoals de annotator terecht opmerkt een vervlechting van 'het begrippenpaar" onafhankelijkheid en onpartijdigheid, niet uit te sluiten. Nu de rechtbank uiteindelijk besloot om een vernietiging uit te spreken op grond van vooringenomenheid, zou bij de bovengenoemde zaak de vraag kunnen worden opgeworpen of een vernietiging wegens strijd met art. 7:13 niet méér voor de hand had gelegen.

Die laatste opvatting lijkt in tegenstelling tot de mening van de annotator minder juist. Ten tijde van de behandeling van het bezwaarschrift fungeerde de voormalig burgemeester immers als onafhankelijk voorzitter omdat hij geen deel meer uitmaakte van het bestuursorgaan. Aangenomen mag worden, dat men in Ameland in de beroepszaak niet voor de eerste keer werd geconfronteerd met de grief dat gesproken kon worden van een schijn van partijdigheid. De voorzitter van de Amelandse bezwaarschriftencommissie had immers de mogelijkheid zich van deelneming aan de behandeling van het bezwaarschrift te onthouden. Die laatste mogelijkheid is overigens als procedureel aspect ingebouwd in de modelverordening van de VNG. Deze model-verordening bepaalt in art. 12 als equivalent van art. 2:4 het volgende:

"De voorzitter en de leden van de commissie nemen niet deel aan de behandeling van een bezwaar- of beroepsschrift, indien daarbij hun onpartijdigheid in het geding kan zijn. ${ }^{3 i}$

Terugkomend op de opvatting van de rechtbank van Leeuwarden, laten de omstandigheden in de Amelandse zaak, onverlet de situatie dat betrokkenheid bij de primaire besluitvorming die 'onafhankelijkheid' kan uithollen door de schijn van partijdigheid. Een argument voor de vernietiging van het bezwaarschrift in de Amelandse kwestie wordt tevens mede versterkt door de opvatting van de bestuursrechter, dat een adviescommissie in de zin van art. 7:13 een bestuursorgaan is in de zin van art. $1: 1$, lid 1 onder a Awb. Op dit laatste aspect wordt hier overigens niet ingegaan.

31 De Algemene wet bestuursrecht, de gemeente en de behandeling van bezwaar-en beroepschriften, Model verordening beluandeling bezwaar en beroepschriften, VNG circulaire 93/216. 
5.3.5. Het openbaar lichaam als belanghebbende vergunninghouder: artikel 7:5 onder druk en de (rechterlijke) voorkeur voor artikel 7:13

Er zijn in de vorige paragraaf twijfels uitgesproken over de toepassing van art. $7: 5$ in die gevallen dat het bestuursorgaan de verantwoordelijkheid draagt voor de voorbereiding van de beslissing op het bezwaarschrift. Die twijfels zijn niet zonder grond; uit de arob-jurisprudentie blijkt dat nogal wat beslissingen op bezwaarschriften "sneuvelden" door een onzorgvuldige voorbereiding. De toepassing van art. $7: 5 \mathrm{kan}$ ook onder druk komen te staan in die gevallen dat het bestuursorgaan niet gekozen heeft voor een adviescommissie in de zin van art. 7:13. In enkele zaken, waarin vanwege de 'dubbelrol' van het bestuursorgaan (de gemeente of een gemeentelijk bedrijf was tevens vergunninghouder) belangenverstrengeling ter discussie stond, werd de toepassing van art. 7:5 getoetst aan art. 2:4 (verbod van vooringenomenheid).

In de eerste uitspraak stelt de rechtbank voorop dat aan de vereisten van art. 7:5 $A w b$ is voldaan. Het betrof in deze zaak een hoor-en adviescommissie die niet was samengesteld conform de eis van art. 7:13. Deze hoor- en adviescommissie had een interne samenstelling, bestaande uit een wethouder en enkele ambtenaren. Nu er sprake was van een vergunningverlening aan de NV Nutsbedrijven - de betrokken wethouder was commissaris van het Maastrichtse nutsbedrijf - oordeelde de rechtbank dat voor wat het adviseringsaspect betrof, niet voldaan was aan het gestelde in art. 2:4, eerste lid Awb. ${ }^{32}$

In art. 2:4, lid 1 is de eis opgenomen dat het bestuursorgaan zijn taak zonder vooringenomenheid dient te vervullen. Ofschoon hier niet wordt ingegaan op de verhouding van een gemeentelijke n.v. ten opzichte van het vergunningverlenend bestuursorgaan ( $b$ en w), deze problematiek werd immers besproken in hoofdstuk 2 , betekende die omstandigheid voor de rechtbank voldoende aanleiding om de vernietiging van de beslissing op het bezwaarschrift uit te spreken. De juistheid wan de uitspraak in het midden latend, geeft deze zaak aanleiding tot terughoudendheid ten aanzien van de instelling van een interne hoor-en adviescommissie. Het instellen van deze interne commissies stuit in ieder geval op bezwaren bij de lagere bestuursrechter.

De bezwaren van de bestuursrechter in de bovengenoemde zaak komen als volgt in de rechtsoverweging tot uitdrukking: 
"Naar het oordeel van de rechtbank had het op de weg van verweerder gelegen voor dergelijke gevallen een onafhankelijke adviescommissie in de zin van artikel $7: 13$ van de $A w b$ in te schakelen. Door dat na te laten heeft werweerder het fundamentele rechtsbeginsel wervat in artikel $2: 4$, eerste, lid van de $\mathrm{Awb}$ in onvoldoende mate recht gedaan.'

De vraag zou kunnen worden opgeworpen of de rechter niet te ver gaat in de hem geboden beoordelingsmarge (rechtmatigheid). De Awb-wetgever heeft bewust gekozen voor een "eigen" invulling van het voorbereiden van de beslissing op het bezwaarschrift; de hoor-en adviescommissie in de zin van art. $7: 13$ is geen bestuurlijke verplichting.

De tweede uitspraak inzake Maastricht is niet minder interessant. Deze zaak toont aan dat de toetsing van art. 7:5 de bestuursrechter voor problemen plaatst.

In deze voorlopige voorzieningszaak werd onmiddellijk uitspraak gedaan in de hoofdzaak, en vond eveneens vernietiging plaats van de beslissing op het bezwaarschrift. $^{33}$

De rechtsoverwegingen in deze zaak zijn wat uitgebreider dan in de eerste Maastrichtse zaak. In deze kwestie stond de rechtmatigheid van een verleende bouwvergunning voor woonwagenstandplaatsen ter discussie. De bestuursrechter constateert allereerst, dat door de samenstelling van de interne hoor- en adviescommissie geen recht is gedaan aan de eis van onpartijdigheid alls bedoeld in art. 2:4 Awb, mede in samenhang met art. 3:2 dat een zorgvuldige voorbereiding van de besluitvorming verlangt. Daarna komt de rechter tot het volgende oordeel, waaruit de moeilijke toetsing van art. $7: 5$ is af te leiden. Vanwege het belang van deze rechtsoverwegingen, worden deze hierna geciteerd.

De lagere bestuursrechter overweegt hier als volgt:

'(...) Verweerder heeft het bestreden besluit doen voorbereiden door een hoor- en adviescommissie, die bestond uit een wethouder en drie ambtenaren van verweerders gemeente. Deze ambtenaren zijn allen werbonden aan de afdeling bouwen en wonen. Ook de aanvrager van de bouwvergunning en degene die (kennelijk) krachtens mandaat op de aanvraag heeft beslist zijn bij deze afdeling werkzaam. Niet valt na te gaan of de betrokken ambtenaren van de hoor-en adviescommissie als ambtenaren wan de afdeling bouwen en wonen niet bij de voorbereiding van het besluit in eerste aanleg betrokken zijn geweest. Daarnaast blijkt uit de gedingstukken dat in ieder gevall een van de ambtenaren van de hoor- en adviescommissie recentelijk verweerder heeft vertegenwoordigd bij de Afdeling bestuursrechtspraak van de Raad van State in een rechtsgeding 
over de aanleg van een woonwagencentrum elders in Maastricht. De hoor- en adviescommissie heeft terzake van het bestreden besluit advies uitgebracht, welk advies door verweerder in zijn geheel is overgenonen. Nu de belangen van de aanvrager van de vergunning, zijnde een ambtenaar van verweerders gemeente, zo direct zijn verweven met de belangen van verweerder, dan wel verweerders gemeente, is de president van oordeel dat met betrekking tot de advisering ten minste de schijn van partijdigheid is gewekt. Zoals hiervoor reeds is opgemerkt dient voorop te staan dat iedere schijn var wooringenomenheid moet worden vermeden. Dat kan onder omstandigheden meebrengen dat ambtenaren die geen enkel privé-belang bij een beslissing hebben toch, met het oog op hun directe ambtelijke betrokkenheid en belang bij de uitkonst van een bepaalde procedure, van feitelijke deelname aan de besluitworming moeten worden uitgesloten. $(\ldots)^{3+}$

In par. 5.3.3 bleek dat de ABRS de voorkeur wan de lagere bestuutsrechter voor een adviescommissie ex art. 7:13 afwijst, in die gevallen dat het bestuursorgaan moet beslissen op een bezwaarschrift tegen de vergunningverlening aan het openbaar lichaam waarvan het bestuursorgaan deel uitmaakt. Het bestuursorgaan is in de opvatting van de ABRS niet verplicht om op basis van de wetsgeschiedenis van art. $7: 13$ een adviescommissie in te schakelen. Een schending van art. 2:4, lid I neemt de ABRS niet snel aan. De bestuursrechter is hier terughoudend en legt sterk de nadruk op de samenhang met art. 2:4, lid 2 . Uit dit laatste artikellid blijkt dat alleen privé-belangen tot een schendig kunnen leiden van het onpartijdigheidsgebod. Ofschoon de omvang van de toetsing beperkt is door objectieve maatstaven gaat de ABRS voorbij aan de MvT waaruit blijkbaar de schijn van partijdigheid bij de bestuurlijke taakvervulling moet worden vermeden. Met de annotator van deze uitspraak inzake de gemeente Maastricht, moet worden toegegeven dat het oordeel van de rechtbank-president over een schending van art. 2:4 te verdedigen is. Indien mogelijk moeten bestuursorganen er voor zorgen dat er een organisatorische scheiding is tussen het primaire besluitvormingsproces en de bezwaarschriftenprocedure. Of de bestuursrechter wel de geeigende instantie is om het onpartijdigheidsgebod te toetsen wordt hierbij in het midden gelaten. Conform artikel 13 Wet $\mathrm{AB}$ is de bestuursrechter in ieder geval verplicht tot toetsing van art. $2: 4 .^{35}$

34. Opvallend is dat de bestuursrechter geen aandacht wijdt aan de omstandigheid dat het bestuursorgaan aanwrager van de vergunning was. Dit latste lijkt rechtens niet juist omdat een bestuursorgaan geen rechtshandelingen verricht maar het openbaar lichaam als zodanig moet optreden. Zie in dit verband de commentaren op het proefschrift van J.A.F. Peters, Publiekrechtelijke rechtspersonen, Zwolle 1997 van F. A.M. Stroink, Publiekrechtelijke rechtspersonen, NTB 1997 , p. 239 e.v. en G.A. van der Veen, Staats-en besturursrechtelijke kroniek, BW 1997, nr. 2, p. 119 e.v.

Zie noot 26. 


\subsubsection{Kanttekeningen bij de ambtelijke advisering}

De in de vorige paragraaf gesignaleerde moeilijke toetsing van art. $7: 5$ toont aan dat het traceren van de ambtelijke betrokkenheid een probleem vormt voor de rechter. De tweede Maastrichtse zaak maakt duidelijk dat de bestuursrechter nogal wat 'spitwerk' moest verrichten om uiteindelijk tot de conclusie te komen dat er iets mis was met de afstandelijkheid van de (interne) adviescommissie.

Ambtelijke advisering heeft een intern organisatorisch karakter. Op basis van organisatieverordeningen en functiebeschrijvingen van ambtenaren is niet altijd vast te stellen hoe de werkelijke positionering van ambtenaren en de organisaticstructuur er uilziet. Dit laatste wordt veelal beînvloed door de permanente ontwikkeling van bestuursorganisaties.

Ook Ten Berge wijst op het bestuurskundig aspect van het adviseren door ambtenaren aan bestuursorganen. Hij is daarover kort en kernachtig:

'Bestuurskundig is deze advisering erg interessant, bestuursrechtelijk echter niet. Er zijn nawwelijks geschreven en ongeschreven rechtsregels die de interne advisering betreffen. ${ }^{36}$ Dat ook de bestuursrechter met dit bestuurskundig fenomeen worstelt kan worden aangetoond in de bovengenoemde Maastrichtse kwesties.

\subsubsection{Enkele "leemten" in de onafhankelijkheidsaspecten van artikel 7:13}

In de beide Maastrichtse zaken gaf de bestuursrechter te kennen dat het in casu in de rede had gelegen dat de advisering van het bestuursorgaan langs de lijnen van art. 7:13 had behoren plaats te vinden. Ook hiervoor bleek bij de Amelandse kwestie (par. 5.3.4) dat een hoor-en adviescommissie die naar de maatstaven van art. 7:13 is samengesteld, niet onder alle omstandigheden onder de druk van art. 2:4, eerste lid Awb overeind blijft. Het is opmerkelijk dat de bestuursrechter een adviescommissie in de zin van art. 7:13 als een onafhankelijke commissie typeert. Die laatste karaktertrek vertoont art. 7:13 geenszins. Hoogstens kan van een hoor- en adviescommissie van gemengde samenstelling worden gesproken, waarin ten behoeve van de afstandelijkheid, ten aanzien van de voorbereidingsfase, gekozen kan worden voor een minimum aan externe leden. Dat art. 7:13 Awb 'onafhankelijkheid" meer benadert vanuit het aspect van "afstandelijkheid", valt op te maken uit het bepaalde in art. 7:13 Awb, lid 3, tweede volzin. Hierin is bepaald dat de hier bedoelde commissie het horen kan opdragen aan de voorzitter 
of een lid dat geen deel uitmaakt van en niet werkzaam is onder verantwoordelijkheid van het bestuursorgaan. ${ }^{37}$

De Awb maakt in de MvT van art. 7:13 een plotselinge wending. In de toelichting van het eerste lid van art. 7:13 wordt niet gesproken over de onafhankelijke positie van de hoor- en adviescommissie. Naast de inschakeling van een adviescommissie in de zin van art. 7:13, lid $\mathbb{1}$, is het wél mogelijk dat een zuiver intern samengestelde commissie (veelal bestaande uit ambtenaren) met de behandeling. van het bezwaarschrift wordt belast. ${ }^{38}$ Een enkel onafhankelijkheidsaccent van de adviescommissie is wêl aangestipt in het ontwerp- $A w b$, betreffende de alsnog ingevoegde zinsnede in het derde lid van art. $7: 13$ (horen door de voorzitter of een lid).

De Awb motiveerde het opnemen van deze bepaling 'als een waarborg voor voldoende onafhankelijkheid'. ${ }^{39}$

De juistheid van dit standpunt kan betwijfeld worden. Art. $7: 13$, lid 1, onder a bezien in samenhang met het gestelde onder b: "waarvan de woorzitter geen deel uitmaakt wan en niet werkzaam is onder verantwoordelijkheid van het bestuursorgaan', is immers niet zodanig geredigeerd, dat van 'echte' ambtelijke dan wel bestuurlijke "buitenstaanders" kan worden gesproken. In de passage van het gestelde onder $b$, van het eerste lid, alsook de alsnog ingevoerde tweede zinsnede van het derde lid van art. 7:13, wordt gesproken over 'het bestuursorgaan'. Hieruit moet worden afgeleid, dat in art. 7:13 enkel de eis is gesteld, dat de voorzitter van de adviescommissie onafhankelijk moet zijn van 'het bestuursorgaan' ('geen deel uitmaakt en niet werkzaam zijn').

Dit betekent dat de burgemeester geen voorzitter mag zijn van een hoor- en adviescommissie in de zin van art. 7:13 voor zover het betreft door hem of haar te nemen beslissingen op bezwaarschriften. Dill laatste geldt mede voor bezwaar schriftencommissies van burgemeester en wethouders en de gemeenteraad. Een zelfde situatie geldt uiteraard voor beslissingen op bezwaarschriften te nemen door de CdK, GS en PS. Ook voor bijvoorbeeld de besturende organen van een waterschap en een bedrijfslichaam in de zin van de Wet BO geldt eenzelfde gedragslijn. Tegelijkertijd moet worden geconstateerd dat de reikwijdte van het begrip "niet werkzaam is onder verantwoordelijkheid van het bestuursorgaan" ook tot problemen van niet-afstandelijkheid kan leiden. Dit kan zich voordoen bij 
eventuele privaatrechtelijke organisatievormen. Een medewerker van bijvoorbeeld een gemeentelijke $n . v$. of stichting kan op grond van art. 7:13 voorzitter zijn van deze commissie. Dit klemt temeer omdat in de Awb het begrip bestuursorgaan een opgerekt begrip is. Art. $1: 1$, lid 1, onder b werstaat immers mede onder een bestuursorgaan: "een ander persoon of college, met enig openbaar gezag bekleed". Volgens de bedoelingen van de Awb kunnen sommige privaatrechtelijke rechtspersonen voor hun gehele handelen binnen het bereik van dit artikel vallen. Als voorbeelden werden in dit verband genoemd de Stichting centraal bureau rijvaardigheidsbewijzen en de Stichting (bureaus) voor rechtshulp. ${ }^{40}$ In het hoofidstuk over belangenverstrengeling bleek bijvoorbeeld dat ook de APK-keurmeester onder het bereik van het begrip bestuursorgaan valt.

Uit de kritische beschouwing van art. 7:5 (het horen door of namens het bestuursorgaan) kan worden geconcludeerd dat er redelijke argumenten zijn die pleiten voor de opvatting dat het horen op basis van dit artikel, vanwege het risico van belangenverstrengeling, moet worden ontraden. In het evaluatie-rapport 'aspecten van de financiële beschikkingverlening" is zelfs geconcludeerd dat art. $7: 5$ enigszins een 'mooi-weerbepaling' is. Het artikel zou onvoldoende garanties inhouden voor een onbevooroordeelde heroverweging. In par. 6.4.1 wordt op dit aspect nog teruggekomen. ${ }^{41}$

De woorkeur moet worden gegeven aan het horen door een adviescommissie in de zin van art. 7:13 omdat deze adviescommissie betere waarborgen biedt voor onpartijdigheid in de voorbereidingsfase van de beslissing op het bezwaarschrift.

\subsubsection{De literatuur en de adviescommissie}

De literatuur gebruikt een aantal argumenten die de balans ten faveure een adviescommissie doet doorslaan. Omwille van de overzichtelijkheid wordt hier volstaan met een beperkte bespreking van de opvartingen in de literafuur. Voor een uitvoerige beschouwing over het adviseren in het kader van de bezwaarschriftenprocedure, wordt verwezen naar par. 6.4. Aan de inschakeling van een adviescommissie wordt de voorkeur gegeven omdat het heroverwegingsaspect ten aanzien wan de bestreden beslissing beter aan bod zou komen. Een adviescommissie als bedoeld in art. 7:13, lid 1 zou meer afstand kunnen nemen van het bestre

40 PG Awb 1, p. 133.

4 M.S. Beerten e, a., p. 153 en 154 . 
den besluit. Daarnaast zouden er minder snel strijdige siruaties kunnen ontstaan met art. 7:5, lid $1 \mathrm{Awb}{ }^{42}$

Onderzoeksresultaten onder de werking van de Wet arob bevestigen het bovengenoemd "beeld" in versterkte mate. Enkele malen is in dit boek gewezen op de uitkomsten van het onderzoek naar de werking van de bezwaarschriftenprocedures in de gemeentelijke bestuurspraktijk. Vanwege het geschetste belang van een goede inrichting van de behandeling van bezwaarschriften in het traject voorafgaande aan de beslissing, wordt hierna gewezen op een aantal belangwekkende conclusies in het verleden. ${ }^{43}$ De bevindingen van de onderzoekers leidden tot het volgende oordeel:

\begin{abstract}
"Voornamelijk met het oog op het verbeteren wan de arob-bezwaarschriftenprocedure uit een oogpunt van rechtsbescherming - daarnaast wordt een bijdrage verwacht aan een uniformer en doelmatiger praktijk - wordt een voorkeur uitgesproken voor het behandelen van bezwaarschriften door een commissie. De analyse van de heroverweging in de bezwaarschriftenprocedure (zie hoofdstuk 7) mondde uit in de conclusie, dat de realisatie van de idee van de volledige heroverweging "de beste kansen" krijgt wanneer behandeling van het bezwaarschrift plaatsvindt door een commissie. In deze commissie zou bij voorkeur een inbreng van drie kanten verzekerd moeten zijn: bestuurlijke inbreng, inbreng vanuit de beleidsvoorbereidende afdeling en een onafharkelijk element. De combinatie van deze elementen brengt het "Janus-kop-karakter" van de bezwaarschriftenprocedure tot uitdrukking: enerzijds verlengde besluitworming en derhalve terugkoppeling naar degenen die betrokken zijn geweest bij de totstandkoming van het aangevochten besluit, anderzijds de eerste stap in de richting van beroep, waarbij enkele waarborgen voor onbevooroordeeldheid onmisbaar zijn. Behandeling van bezwaarschriften door een commissie waarin deze ellementen aanwezig zijn verdient aanbeveling. Daarbij zou tevens moeten worden voorzien in een verordening vastgelegde procedure en in een duidelijke rol voor een vast Arob-secretariaat.'
\end{abstract}

Enkele conclusies van het rapport geven aanleiding tot het maken van opmerkingen.

Het bovengenoemd rapport is uitgebracht ten tijde van de Wet arob. Deze wet bevatte nog een zeer summiere bezwaarregeling, en kende in tegenstelling tot de Awb nauwelijks procedurevoorschriften. Bij de evaluatie van de Awb is vastgesteld dat de terugkoppeling van de uitkomsten van de bezwaarfase met de primai-

F.F.W. Brouwer en L. M. Koenraad, De beslissing op bezwar getoetst, Gst. 7033, p. 298. Zie ook: A.Q.C. Tak, De Algemene wet bestursrecht. Het nieuwe bestuursprocesrecht 3e dr. Zwolle 1995, p. 83.

Arob-praktijken, a.w., p. 347 . 
re beslissers nog steeds verbetering behoeft. ${ }^{44}$ De praktijk wijst uit dat de indertijd zo bepleite terugkoppeling, ook onder de werking van de $\mathrm{Awb}$, zeker voor verbetering vatbaar is. Het 'leereffect' van de voorprocedure van bijwoorbeeld beslissingen op de bezwaarschriften in bijstandszaken, blijkt als volgt.

In 10 procent van de gevallen vindt geen informatie plaats naar de primaire beslisser. De wijze en het niveau van de informatie, voor het resterende percentage ( 90 procent), geven een wisselend beeld te zien. Informatie van de beslissing op het bezwaarschrift geschiedt in 20 procent van de gevallen door toezending van een afschrift van de beslissing. Het gesprekspercentage met betrekking tot de beslissing op het bezwaarschrift bedraagt 16,7 (bespreking met behandelend ambtenaar, chef of directeur). Voor meerdere cijfers wordt verwezen naar het betreffende onderzoek. ${ }^{45}$ Ten aanzien van de zeefwerking (rapport Beeld van de Arob-bezwaarschriftenprocedure), wordt gesteld dat de zeefwerking van de bezwaarprocedure aanvankelijk minder gunstig was dan de huidige cijfers aantonen. ${ }^{46}$ Scheltema merkte in zijn beschouwing naar aanleiding van de inwerkingtreding van de Awb daarover het volgende op:

"Verheugend is het dat de burger een goede werkwijze van het bestuur ook waardeert. En misschien niet minder belangrijk: die waardering kan ook een beloning opleveren in de zin van minder procedures voor de rechter. Naast de bezorgdheid die terecht bestaat over het toenernen van het beroep op de rechter kan gelukkig geconstateerd worden dat gemeenten er steeds beter in slagen door middel van een goede bezwaarschriftenprocedure verreweg het grootste aantal bezwaren intern definitief af te handelen. Minder dan een op de tien bezwaarschriften leidt tegenwoordig tot een beroep op de rechter, terwijl dit aantal in het verleden twee tot driemaal zo hoog was. ${ }^{47}$

Het bovengenoemde recente onderzoeksrapport ${ }^{48}$ is een waarheidsgetrouwe kopie van Scheltema's 'zeefprognose".

Afsluitend is het overigens niet zonder belang er op te wijzen, dat de inrichting van de bezwaarschriftenprocedure (de wijze waarop en door wie het horen plaatsvindt), voor de burger een goed instrument is om de afstand tussen het

44 Toepassing en effecten van de algemene wet bestuursrecht 1994-1996, 's-Gravenhage 1996, $p$. 51.

45 A.J.G.M. van Montfort, Biedt de Awb steun?, De naleving van de Algemene wet bestuursrecht bij de bijstandswerlening in Noord-Nederland, nr. 23 Publikatiereeks Samenwerkingsverband Bestuurswetenschappen Noorden des Lands Rijksuniversiteit Groningen mei 1996, p. 87 e.V.

46. A.w. p. 240.

47 M. Scheltema, Waarom is een codificatie van het bestuursrecht belangrijk? in: Bestuur, burger en rechtspraak, Ministerie van Binnenlandse Zaken, 1994, p. 35.

48 Biedt de Awb steun?, a.w. p. 93. 
bestuur en burger te verkorten. Hierin wordt een van de functies van een goede bezwaarschriften-procedure beter herkenbaar. De bezwaarschriftenprocedure raakt immers als tweede en laatste (interne) bestuurlijke besluitvormingsproces, de uitvoeringsorganisatie van het overheidsbestuur. Anders dan het besturen door het ontwikkelen van het beleid, ligt het besturen in de zin van het uitvoeren van het beleid binnen het gezichtsveld van de burger. In de sfeer van de uitvoering van het beleid vindt dit primair zijn vertaling in de oorspronkelijke besluitvorming. Naar de mening van Oosting stelt dit hoge eisen aan hen die op uitvoerend niveau werkzaam zijn. 'Door hun vertaalarbeid wordt het overheidsbeleid zichtbaar en voelbaar'. ${ }^{49}$ Een goede inrichting van de bezwaarschriftenprocedure als uitvoeringscomponent van het besturen, kan daarom een belangrijke bijdrage leveren aan de legitimiteit van het door het bestuursorgaan ontwikkelde beleid.

\subsubsection{De procedurele bevoegdheden van de adviescommissie}

In deze paragraaf komt ten vervolge op par. 5.2.1 de regeling van de bevoegdheden van de commissie in de zin van art. 7:13 nog eens ter sprake. Die bevoegdheden betreffen de procedurele beslissingen als bedoeld in het vierde lid van dit artikel.

Deze preparatoire bevoegdheden van de commissie in de zin van art. 7:13 hebben in de Awb beperkt regeling gevonden. De Awb heeft aan deze adviescommissie in het vierde lid de volgende procedurele bevoegdheden gegeven, te weten:

a. het nemen van een beslissing op een verzoek van een belanghebbende om het inzagerecht te beperken (art. 7:4, lid 5);

b. het nemen van een besluit over de openbaarheid van de hoorzitting (art. 7:5, lid 2);

c. het nemen van een beslissing over het afzien van de hoorverplichting in de gevallen genoemd in art. 7:3; deze preparatoire bevoegdheid kan slechts door een adviescommissie worden gehanteerd, voorzover het bestuursorgaan deze bevoegdheid niet aan zich heeft gehouden, hetgeen bij wettelijk voorschrift (verordening) moet zijn bepaald.

Tegen deze regeling van de preparatoire bevoegdheden als bedoeld in het vierde lid van art. 7:13 (derde lid art. 6.3.18 Voorontwerp Awb) had de VNG bezwaar. De VNG vond deze regeling te rigide; de imperatieve redactie zou in een facultatief voorschrift moeten worden omgezet door in de Awb te bepalen dat deze bevoegdheden bij wettelijk voorschrift (verordening) zouden kunnen worden geregeld. Van VNG-zijde was men van oordeel dat het gebruik van de prepa- 
ratoire bewoegdheden aan de bijzondere regelgever moest worden overgelaten. ${ }^{50}$ Die keuzevrijheid van de preparatoire bevoegdheden zou er op neer komen dat óf het bestuursorgaan of een ingestelde adviescommissie deze bevoegdheden zouden toepassen. Uit het commentaar van de VNG bleek samenvattend dat men bevreesd was voor competentieproblemen bij het exclusief toekennen van procedurele bevoegdheden als bedoeld in art. $7: 3$ aan de adviescommissie. ${ }^{51}$

Art. 6.3.18, lid 3 van het Voorontwerp Awb was beperkter wan strekking doordat het artikel over het achterwege laten van de hoorplicht (art. 7:3 Awb) slechts drie gronden noemde die tot zo'n beperking kon leiden. Het corresponderend art. 7:3 kent thans een viertal mogelijkheden om af te zien van de hoorverplichting. Bij het wetsontwerp Awb werd een nieuwe b.-grond toegevoegd, die het mogelijk maakt om ook bij een kennelijk ongegrond bezwaar eventueel van de hoorverplichting af te zien.

Er is op gewezen dat de VNG bezwaren had tegen het toekennen van de preparatoire bevoegdheden als bedoeld in art. 7:3. Er zouden competentieproblemen kunnen ontstaan. Getwijfeld werd of het bestuursorgaan nog wel bevoegd zou zijn om een "achterwege gelaten hoorzutting" alsnog te (doen) entameren. ${ }^{52}$ Die twijfels lijken zonder grond. Het bestuursorgaan is immers formeel verantwoordelijk voor de op het bezwaarschrift te nemen beslissing. Toch is het formeeljuridisch niet juist dat het bestuursorgaan in een dergelijke situatie een hoorzitting belegt; dit laatste lijkt in strijd met de uitgangspunten van art. $7: 13$, \id 3 Awb (de commissie moet horen). De Awb heeft ten aanzien van de preparatoire beslissingen een strikte regeling voor ogen gestaan. Een bevestiging hiervan kan worden afgeleid uit de volgende overwegingen van de MvT van de Awb:

'De bewoegdheid om een aantal procedurele beslissingen te nemen, wordt - ingevolge het vierde lid - in handen van de commissie gelegd. Die bevoegdheid kan de commissie niel aan de voorzitter of een lid overdragen, ook niet als de voorzitter of een lid met het horen belast is."

Op grond hiervan kan worden geconcludeerd dat de preparatoire beslissingen inzake de beperking van het inzagerecht (art. 7:4, lid 6), het nemen van besluiten over de openbaarheid van de zitting (art. 7:5, lid 2) en het besluiten tot het afzien van het horen (art. 7:3), indien geen wettelijke beperking is aangebracht, in 
handen behoort te liggen van de adviescommissie. Indien de adviescommissie ex art. 7:13 het horen om wat voor redenen achterwege heef gelaten, en het bestuursorgaan van mening is dat het horen alsnog moet geschieden, resteert het orgaan niets anders dan de adviescommissie te verzoeken belanghebbenden te horen.

Geconstateerd wordt dat het vierde lid van art. 7:13 deels een facultatief karakter heeft, hetgeen blijkt uit de redactie van de zinsneden van art. 7:13, lid 4: 'en, voorzover bij wettelijk voorschrift niet anders is bepaald, van artikel $7: 3^{\prime}$. Op dit aspect wordt in de volgende paragraaf nader ingegaan.

\subsubsection{Kritische kanttekeningen bij de competentieverdeling van de prepara- toire bevoegdheden}

De problematiek van de preparatoire beslissingen geeft, in het licht van de gemaakte opmerkingen van de VNG, alsook de RvS - de Raad wees onder andere op het belang van deze preparatoire bevoegdheden voor alle soorten adviescommissies $^{5.4}$ - aanleiding tot het maken van enkele kritische notities.

Zowel uit een oogpunt van doelmatigheid, alsmede bezien vanuit harmonisatieoverwegingen is het maken van een tweedeling in het procedureverloop van de behandeling van bezwaarschriften, ongewenst. Met die tweedeling wordt allereerst gedoeld op de situatie dat conform art. 7:4, lid 6 en art. 7:5, lid 2 jo art. $7: 13$, lid 4, enerzijds de adviescommissie in de zin van art. $7: 13$ imperatief, een tweetal procedurele bevoegdheden heeft (beperking inzagerecht en het besluiten tot openbaarheid van de hoorzitting). Daarnaast is in de Awb ten aanzien van de toepassing van art. 7:3 voor een alternatieve procedurele bevoegdheid gekozen (afzien hoorverplichting). Op grond van de eisen die aan een doelmatige procedure mogen worden gesteld is dit wettelijk uitgangspunt ongewenst.

Indien een adviescommissie is ingesteld neemit deze kennis van het bezwaarschrift. Na de beoordeling van de inhoud wan het bezwaarschrift, zou deze commissie, indien zij niet over de procedurele bevoegdheden ex art. 7:3 jo art. $7: 13$, lid 4 beschikt, het bezwaarschrift alsnog moeten retourneren aan het bestuursorgaan. Vervolgens moet het bestuursorgaan dan een beslissing nemen over het afzien van het horen. 
Het is de vraag of de adviescommissie hiertoe wel zo snel zal overgaan. Uit de jurisprudentie onder de Wet arob en de Awb komt een ongunstig beeld naar voren over het nemen van besluiten tot het afzien van het horen. Dit klemt temeer omdat onder de Awb ook kennelijke ongegrondheid van het bezwaar, kan leiden tot het afzien van het horen. In het toetsen van de ongegrondheid liggen nog meer risico's opgesloten. Bij het nemen van een onjuiste beslissing door het bestuursorgaan wordt immers het besluitvormingsproces (onnodig) vertraagd, en moet doorgaans alsnog de gehele bezwaarschriftenprocedure worden doorlopen.

Een ander probleem is of de gewenste koppeling tussen het horen en het adviseren wel goed is. Gedoeld wordt hier op het feit dat de Awb een samenhang voorstaat tussen het horen en het adviseren (art. 7:13, lid 3). Er kunnen ook risico"s vastzitten aan de situatie dat de adviescommissie al snel concludeert dat moet worden afgezien van het horen en het bezwaarschrift, ter verdere afhandeling retourneert aan het bestuursorgaan, zonder dat van enige deugdelijke advisering kan worden gesproken. In dit geval is het niet uitgesloten dat het bestuursorgaan een andere mening is toegedaan, en dat het horen alsnog moet geschieden. Dit zou er toe kunnen leiden dat het bezwaarschrift vervolgens andermaal in handen wordt gesteld van de adviescommissie.

Hierdoor ontstaat een aantal procedurele ondoelmatigheden bij het toepassing geven aan art. 7:3 Awb in die gevallen, dat het bestuursorgaan bij het bestaan van een adviescommissie, de procedurele bevoegdheid conform de wettelijke mogelijkheid van art. 7:13, lid 4, zelf uitoefent. Er wordt dan geen recht gedaan aan de eisen van een behoorlijke inrichting van de bezwaarschriftenprocedure. Wanneer een adviescommissie in de zin van art. 7:13 is ingesteld is het doelmatiger dat deze adviescommissie in ieder geval de procedurele beslissingsbevoegdheden als bedoeld in art. 7:13, lid 4 uitoefent. De samenhang in de aan een dergelijke adviescommissie toegedeelde voorbereiding van de bezwaarschriftenfase wordt in het licht van het wettelijk alternatief van art. 7:13 verstoord. Daarnaast kunnen ook de 'geschiktheidsargumenten' die hiervoor bij de bespreking van art. 7:5 Awb onder de loep zijn genomen, voldoende beweegredenen zijn om het facultatieve karakter van de laatste zinsnede van art. $7: 13$, lid 4 te laten vervallen. Een bezinning over de juistheid van de door de Awb gecreëerde gedeeltelijke differentiatie van de preparatoire bevoegdheden, is mede in het licht van de bovengenoemde argumenten, ook om de volgende redenen niet zonder grond.

Er is reden om behoedzaam om te gaan met de toepassing van art. 7:3. Deze omstandigheid heeft te maken met het kennelijkheidscriterium dat de Awb verbindt aan de uitzondering van de hoorplicht ('kennelijk' niet-ontvankelijk en "kennelijk" ongegrond). De behoedzaamheid in het hanteren van het criterium 
'kennelijk ongegrond' in de zin van art. 7:3, onder b, wordt ook benadrukt in de memorie van toelichting. ${ }^{55}$ Ten aanzien van het toepassen van 'onderdeel a' van art. 7:3 (kennelijk niet-ontvankelijk) is de Awb-wetgever klaarblijkelijk wat soepeler in zijn oordeel. Het gegeven woorbeeld lijkt niet zonder reden, op wat gespannen voet te staan met de praktijk die vaak bligkens de ruime jurisprudentie onder de Wet arob (en onder de Awb is dat zoals hierna blijkt niet anders) werd 'gestraft' met een vernietiging van de beslissing op het bezwaarschrift.

Als laatste in het bovengenoemd rijtje van argumenten voor het hanteren van art. 7:3 noemt de Awb-wetgever als argument dat de toepassing achterwege kan worden gelaten in die gevallen dat een zorgvuldige heroverweging en besluitvorming niet nodig is. ${ }^{56}$ Deze argumenten nopen in beginsel tot een terughoudend gebruik van de uitzonderingsbepalingen van art. 7:3.

Toch betekent dit niet dat het bestuursorgaan dan wel de adviescommissie geen oog mag hebben voor de door de Awb gemaakte uitzonderingen op de hoorver plichting. Onnodige werkbelasting en tijdverlies voor het bestuursorgaan of belanghebbenden zijn zeker redelijke argumenten. ${ }^{57}$ Bestuurslasten mogen onder omstandigheden zeker in ogenschouw worden genomen als daardoor de belangen van de justitiabelen uit een oogpunt van rechtsbescherming niet worden geschaad. Snelheid van besluitvorming dient bovendien tevens ook het belang van het bestuursrechtelijk uitgangspunt dat binnen redelijke termijn op een bezwaar moet worden beslist. Dit laatste beginsel van behoorlijk procesrecht is in de literatuur soms een reden om een minder zorgvuldige besluitworming van de besluiten in primo toe te staan. Vooral bij een groot aantal van beschikkingen van financiële aard wordt nogal eens gepleit voor het passeren van het motiveringsbeginsel indien ditzelfde beginsel maar gecompenseerd wordt door snelheid van de primaire besluitvorming. De bezwaarschriftenprocedure zou dan als "verlengd bestuurlijk vangnet' kunnen fungeren. ${ }^{5 *}$ Ook Scheltema pleit voor snelheid van de primaire besluitvorming, en plaatst de besluitvorming in primo tegenover het karakter van de bezwaarschriftenprocedure. Zijn opvatting over de bestuurlijke kritiek op de bestuurslasten van de rechtsbescherming, is niet zonder betekenis.

s8 B.M.J. van der Meulen en E.J. Daalder, Bestuurlijke besluitworming onder de A.gemene wet bestuursrecht, Gst., 7000, p. 621 . 
In het betoog van Scheltema over de fundamentele veranderingen in het bestuursrecht door de invoering van de verplichte bezwaarschriftenprocedure van de Awb, blijken de volgende uitgangspunten ${ }^{59}$ :

'Voor de rechterlijke benadering van de bezwaarschriftenprocedure zou ik enige voorzetten willen geven. Zij betreffen de wijze waarop de jurisprudentie zou kunnen omgaan met gebreken in het primaire besluit en het besluit dat op het bezwaar wordt genomen, inclusief de aansprakelijkheid voor die gebreken en de wijze waarop vertraging in de besluitvorming wordt beoordeeld. Mijn stelling daarbij is dat de jurisprudentie meer aandacht moet besteden aan de snelheid van besluiten, en minder aan de aansprakelijkheid voor fouten bij de primaire besluitvorming. Meer concreet betekent dit laatste dat het bestuur wel aansprakelijk moet zijn voor fouten in de uitspraak op bezwaar, en wel ongeacht verwijtbaarheid; dit is in overeenstemming met de huidige jurisprudentie. Dit moet echter niet gelden voor de aansprakelijkheid voor fouten in het primaire besluit. De gewone methode om gemaakte fouten in een besluit te laten redresseren moet zijn het maken van bezwaar. Het aansprakelijk stellen van het bestuur voor fouten in een besluit dat vatbaar is voor bezwaar, moet uitzondering zijn. Tegelijkertijd moeten vertragingen in de besluitworming het bestuur zwaarder worden aangerekend dan nu veelal geschiedt."

Naast Scheltema heeft ook Stroink oog voor snelheid in de besluitvorming. Hij zet zijn bedenkingen vooral af tegen het volgen van de bezwaarschriftenprocedure, indien er een gedegen voorbereiding van de besluitvorming heeft plaatsgevonden in het kader van een inspraakprocedure. Het belang van het volgen van een inspraakprocedure heeft zijns inziens de voorkeur boven een bezwaarschriftenprocedure, in die gevallen dat het bestuursorgaan enerzijds over beleidsvrijheid beschikt en anderzijds belangen van derden een grote rol spelen. Het (nog eens) volgen van een bezwaarschriftenprocedure is naar de mening van Stroink 'een beetje veel van het goede', zeker in het geval dat een uitgebreide voorbereidingsprocedure wordt gevolgd als bedoeld in afdeling $3.5 \mathrm{Awb}$. Ook het omgekeerde is naar de mening van Stroink het geval: er is geen plaats voor een uitgebreide openbare voorbereidingsprocedure indien het sterk gebonden beschikkingen betreft. Voor dit soort type beschikkingen ziet hij een nuttige "herstelfunctie van de bezwaarschriftenprocedure voor het ongedaan maken van gebreken in de primaire besluitvorming. ${ }^{60}$

59 M. Scheltema, De rechter en de bezwaarschriftenprocedure: meer aandacht voor snelheid en minder woor aansprakelijkheid, in: In de sfeer van het administratief recht Utrecht 1994, p. 377 en 378 .

60 F.A.M. Stroink, Algemeen bestuursrecht, Zwolle 1994, p. 123. Zie overigens nog Stroink's visie ten aanzien van de relatie van inspraak net bezwaar. F.A.M. Stroink, Inspraak vooraf of bezwatr achteraf?. in: Bestuur en norm, Deventer 1986, p. 243 e.w. 
In het licht van zijn pleidooi geeft Stroink een fraai woorbeeld van een uitspraak van de ARRS in een subsidiezaak van 'Economische Zaken', waaruit blijkt dat de RvS in die gevallen dat het een stroom van primaire besluiten betreft, in een gering aantal situaties een wat mindere zorgvuldigheid van de primaire besluitvorming accepteert. Naar de mening van de RvS moet daarbij wel de bezwaarschriften-procedure dienst doen als 'compenserende en corrigerende' factor voor het lagere niveau van zorgvuldigheid van de primaire besluitvorming . ${ }^{61}$ Stroink's voorbeeld uit de jurisprudentie geeft overigens een juist inzicht in het verschil van betekenis tussen het besluit in primo en de beslissing op het bezwarschrift.

Terugkerend naar de problematiek van de hoorverplichting, en het maken van uitzonderingen daarop, wordt er voor gepleit dat het houden van een hoorzitting regel moet zijn. ${ }^{62}$ Dit is niet zonder belang. Er is op gewezen, dat het horen naast het adviseren een belangrijke hoofdpijler vormt wan het voorbereidingsproces in het kader van de bezwaarschriftenprocedure. De bezwaarschriftenprocedure markeert 'een cruciaal moment' in de rechtsbescherming tegen de overheid; er kan immers vermeden worden dat een langdurige procedure in twee instanties voor de bestuursrechter wordt gevoerd. Nog erger wordt het wanneer een beslissing op het bezwaarschrift door de rechter wordt vernietigd, en de zaak opnieuw op het bord van het bestuursorgaan terecht komt, waarna wederom het rechtsbeschermings-traject (opnieuw) moet worden doorlopen. Een dergelijke situatie is niet in het belang van het vertrouwen van de burger in het Nederlandse rechtssysteem. ${ }^{63}$

In het traject van de rechtsbescherming is het bestuursorgaan primair verantwoordelijk "voor het openen van de sluizen" van dit traject.

Het openen van deze 'sluizen' wordt in eerste instantie bepaald door de beantwoording van een aantal "voorvragen' zoals: is er een besluit als bedoeld in art. 1:3 Awb; is er een bevoegd bestuursorgaan in de zin van art. 1:1; is degene die een bezwaarschrift indient een "belanghebbende ${ }^{*}$ als bedoeld in art. $1: 2$, en zijn er uitzonderingen op de (bestuursrechtelijke) rechtsingang gemaakt (art. 1:6 Awb). De opdracht aan het bestuursorgaan voor een rechtens juiste toepassing van de procedure-regels van de Awb is niet gering. De behandeling van bezwaarschriften is immers afhankelijk van het beantwoorden van ontvankelijkheidsvragen. De

6) A.w., p. 123 .

62 H. Bolt, M.A.H. van Dalen-van Bekkum, N.J. Haverkamp, J.G.F.M. van Kessel en J Riphagen, Snelheid van de besluitworming en rechusbescherming op het terrein van het sociaal verzekeringsrecht, Deventer 1988, p. 33.

63 M. de Groot-Sjenitzer in: De omvang van de rechtsbescherming. VAR LXXXVIII, Alphen tan den Rijn 1982, p. 91. 
ervaring heeft geleerd dat de jurisprudentie (Wet arob) het bestuursorgaan noopt tot het correct aangeven van de grenzen woor de ontvankelijkheid van de justitiabele. ${ }^{6}$ Onder de werking wan de Awb zijn die ervaringen niet anders van juridische "toonzetting".

Het is daarom niet zonder reden dat een bepaling als art. 7:3 het bestuursorgaan tot een prudente toepassing verplicht. De omstandigheid dat de in art. $7: 3$ onder a tot en met d genoemde criteria een witzondering maken op de hoorverplichting als bedoeld in art. 7:2, 'kwalificeert' als het ware de te nemen procedurele beslissingsbevoegdheid. Het gebruikte 'geschiktheidsargument' ten aanzien van de keuze tussen art. 7:5 Awb (horen door of namens het bestuursorgaan) en art. $7: 13$ (horen door een adviescommissie), is ook een valide reden om de toepassing van art. 7:3 Awb niet in handen te leggen bij het op het bezwaar beslissend bestuursorgaan. Uit de jurisprudentie van de Wet arob en ook de Awb blijkt met welk wisselend succes de toepassing van preparatoire beslissingen (met name het achterwege laten van de hoorplicht), door de bestuursrechter correct is beoordeeld. ${ }^{65}$

Daarnaast kan er op basis van het systeem van de Awb ten aanzien van de bezwaarschriftenprocedure van een 'versluierde' differentiatie worden gesproken. Deze constatering kan als volgt worden geadstrueerd.

In de situatie dat een commissie in de zin van art. 7:13 functioneert, heeft deze adviescommissie naast de bovengenoemde preparatoire bevoegdheden tevens tot taak uitvoering te geven aan de wettelijke hoorplicht als bedoeld in art. 7:2. Deze in het derde lid van art. 7:13 neergelegde hoorverplichting geschiedt dan niet conform de regels van art. 7:5 (5.3.10). Het bestuursorgaan is niet met het horen belast. ${ }^{6 t}$ De Awb heeft in art. 7:13 een sterke samenhang gelegd tussen het horen en het adviseren.

Een belangrijk gedeelte van het voorbereidingsproces is daardoor in handen gelegd van deze adviescommissie. Het voorbereidingsproces van de bezwaarfase (horen, adviseren, alsmede het toekennen van enkele preparatoire bevoegdheden) door het bestuursorgaan, geschiedt dan door de adviescommissie in de zin van art. 7:13. Dit betekent echter niet dat deze adviescommissie de gehele verant-

64 P.J.J. van Butren, in: De omvang van de rechtsbescherming, 2. w. , p. 44.

$65 \mathrm{~J}$.M.H.F. Teunissen, Algemene wet bestuurstecht, a.w. Conmentaar artikell $7: 3(6.3 .8)$, p. E. 6.3.8-5 e.v., H.J. Simon, De kleine revolutie" én jaar besturen onder de Awb II, JB 1995, 50 , p. 182 en H.J. Simon, Handleiding Awb-praktijk, a.w., p. 194-197.

66 PG Awb l, p. 354. 
woordelijkheid draagt voor helt voorbereidingsproces van de bezwaarschriftenbeslissingsprocedure. In de Awb zijn immers de procedurele beslissingsbevoegdheden wettelijk begrensd in het vierde lid van art. $7: 13$.

Deze 'versluierde' differentiatie is reden tot het maken van een kritische kanttekening omdat de $\mathrm{Awb}$ in de voorbereidingsfase van de beslissing op het bezwaarschrift, een tweedeling heeft aangebracht. Uit de omstandigheden dat de procedurele beslissingsbevoegdheden van de adviescommissie in de Awb enumeratief van karakter zijn, volgt daaruit dat het nemen van "andlere procedurele beslissingen" in beginsel niet tot de competentie van de adviescommissie behoren. Slechts in die gevallen dat door de bijzondere regelgever (bij verordening) die 'andere procedurele beslissingsbevoegdheden' heeft overgedragen, is de adviescommissie bevoegd diezelfde 'andere bevoegdheden' uit te oefenen in plaats van het bestuursorgaan. ${ }^{67}$

Kleijn ${ }^{68}$ vermeldt in zijn commentaar op art. 7:13 dat de volgende procedurele bevoegdheden die niet onder het bereik vallen van art. $7: 13$, in beginsel tot de bevoegdheid behoren van het besturrsorgaan:

$\because$ het ambtshalwe of op verzoek afzonderlijk horen van belanghebbenden (art. 7:6, tweede lid e.v,

- het horen van door een belanghebbende meegebrachte getuigen en deskundigen (art. 7:8) en - het geven van een gelegenheid opnieuw te worden gehoord bij nieuwe feiten en omstandigheden die van aanmerkelijk belang kunnen zijn voor de op bezwaar te nemen beslissing (art. 7:9)'.

De vraag kan worden gesteld of de Awb die ongewenste differentiatie heeft gewild. In de Awb zijn daarvoor geen aanknopingspunten te winden. Wel blijkt uit de MvT dat de bijzondere regelgever nadere wettelijke woorschriften mag stellen ter inrichting van de bezwaarschriftenprocedure.

In het kader van het voorbereidingsproces van de bezwaarschriftenprocedure zijn overigens nog meer 'verborgen' procedurele beslissingsbevoegdheden waar te nemen. Ook voor deze hierna te noemen bepalingen geldt, dat indien geen uitdrukkelijke overdracht van bevoegdheden door de bijzondere regelgever heeft plaats-gevonden, een ingestelde adviescommissie die voldoet aan de eisen van art. 7:13, deze procedurele bevoegdheden niet kan uitoefenen. In dit laatiste geval

67 G.P. Kleijn, Handboek Algemene wet bestuursrecht, a.w., Artikelgewijs commentaar Artikel $7: 13$, ivfart. $7: 13$, p. 4.

A.w. 
ontstaat er wederom een differentiatie in het voorbereidingsproces. Het bestuursorgaan oefent dan naast de adviescommissie ook deze niet gedelegeerde procedurele bevoegdheden uit.

Wil het bestuursorgaan de gewenste uniformiteit in de voorbereidingsfase van de beslissing op het bezwaarschrift nastreven, en daarmede ook de benodigde duidelijkheid creëren voor de belanghebbenden, dan zouden op basis van de bestaande structuur van de Awb de volgende overdracht van procedurele bevoegdheden behoren te geschieden. De bij bijzondere regelgeving over te dragen bevoegdheden betreffen de uitvoering van de artikelen:

- $2: 1$, lid 2 (verlangen schriftelijke machtiging);

- 6:6 (het stellen van een termijn teneinde verzuim als bedoeld in art. 6:5 te herstellen;

- 6:17 het toezenden van stukken aan de gemachtigde;

- $7: 4$, lid 2 betreffende het ter inzage leggen van de stukken;

- 7:6, lid 4 inzake het achterwege laten van de toepassing van het derde lid (geen toezending verslag zitting wegens geheimhouding om gewichtige rede nen). ${ }^{69}$

Uit een "eigen" onderzoek naar de procedurele bepalingen van de bezwaarschriftenprocedure, komt vast te staan dat 'restanten' van Awb-bepalingen worden aangetroffen, waaruit procedurele beslissingen kunnen voortvloeien. De toepassing van art. 2:2, lid 1 (weigeren bijstand/vertegenwoordiging) behoort te leiden tot een procedurele beslissing. Ditzelfde geldt voor het bepaalde ten aanzien van de doorzendplicht als bedoeld in art. 2:3 jo art. 6:15 Awb.

Ten aanzien van de preparatoire beslissingsbevoegdheden wordt vastgesteld, dat de Awb slechts een beperkt aantal procedurele bevoegdheden heeft toegekend aan de adviescommissie (art. 7:13, lid 4). Deze beperking in de Awb geeft aanleiding tot het maken van enkele opmerkingen.

De toepassing van art. 7:3 (uitzonderingen hoorplicht) leidt tot preparatoire bewoegdheden. Ingevolge art. 7:13, vierde lid, is de uitvoering van art. 7:3, behoudens bij wettelijk voorschrift gemaakt voorbehoud, opgedragen aan een adviescommissie.

69 Deze overdracht van procedurele bevoegdheden is ontleend aan de VNG-modelverordening behandeling bezwar-en beroepschriften, behorende bij circulaire van 23 september 1993. $93 / 216$. 
Gewezen is op de strikte toepassing van art. 7:13, lid 4 in die gevallen dat een adviescommissie is ingesteld. De Awb heeft aan de procedurele bevoegdheden van de adviescommissie, een imperatieve betekenis toegekend. De in art. 7:13, lid 4 genoemde bevoegdheden kunnen niet aan de voorzitter of een lid van de adviescommissie worden overgedragen. Ook de omstandigheid dat de voorzitter of een lid van de adviescommissie met het horen is belast (art. 7:13, lid 3, tweede zin) doet hier niet aan af. ${ }^{70}$

Toch blijkt bij de raadpleging van de nieuwe model-verordening van de VNG voor de behandeling van de bezwaar- en beroepschriften ingevolge de Awb" dat in art. 9 van deze verordening aan de voorzitter de bevoegdheid is toegekend voor het nemen van een beslissing inzake de toepassing van art. 7:3 (en ook 7:17 voor wat betreft het administratief beroep). In het licht van de bovengenoemde strikt formele uitgangspunten van de Awb, staat deze (model)bepaling, op gespannen voet met art. 7:13, lid 4. Bij toetsing door de bestuursrechter zou een dergelijke bepaling tot onverbindendheid behoren te leiden, en tot vernietiging van de op een bezwaarschrift genomen beslissing. Dit argument kan worden gebaseerd op de inhoud en strekking van art. 7:13, lid 3, tweede zin. Hierin is immers bepaald dat de commissie het horen kan opdragen aan de voorzitter of een lid. Uit deze bepaling volgt dat de Awb gekozen heeft voor een expliciete toekenning van bevoegdheden aan de adviescommissie. In die gevallen dat aan de commissie niet uitdrukkelijk (procedurele) bevoegdheden zijn toegekend is de commissie noch de bijzondere wetgever, bevoegd tot een uitbreiding van de competentie van deze bevoegdheden.

\subsubsection{De differentiatie van de beslistermijn in antikel 7:10 Awb}

Een ander aspect, dat aandacht vraagt voor een korte kritische beschouwing, en waarmee het onderzoek voor het aandragen van 'bouwstenen' voor een bezinning op art. 7:13 wordt afgesloten, betreft de differentiatie van het stelsel wan beslistermijnen in het kader van de bezwaarschriftenprocedure.

Evenals de Wet arob (art. 14, lid 4) kent de Awb (art. 7:10, lid 1) twee verschillende beslistermijnen voor het geval dat een adviescommissie is ingesteld.

Uit de parlementaire geschiedenis van de Wet arob is een aantal belangrijke desiderata af te leiden die tot deze ruimere termijnstelling hebben geleid: 
'In verband met het in de nota van wijzigingen opgenomen en hierna toe te lichten voorstel, de mogelijkheid te openen een commissie in te stellen die tot taak zal hebben advies uit te brengen inzake de op het bezwaarschrift te nemen beslissing (mede) op basis van het horen van de klager door deze commissie, is de termijn waarbinnen de beslissing moet worden genomen als van deze mogelijkheid gebruik is gemaakt bepaald op zestig dagen, met de reeds genoemde mogelijkheid van verlenging met dertig dagen. Het is duidelijk dat de behandeling van een bezwaarschrift door een speciaal voor dit doel ingestelde adviescommissie meer tijd zal vragen dan afdoening door het orgaan dat de beschikking waartegen het bezwaarschrift is gericht heeft gegeven, ook al schrijft de wet voor dat ook dan de indiener van het bezwaarschrift moet worden gehoord (althans daartoe in de gelegenheid moet worden gesteld). Aangezien echter mag worden aangenomen, dat de behandeling floor een adviescommissie - met commissieleden - die niet betrokken waren bij het tot stand komen van de oorspronkelijke beschikking en waarschijnlijk met leden die ervaring met de behandeling van geschillen hebben - veelal uitgebreider zal zijn en zall leiden tot een dossier waarin alle relevante gegevens op overzichtelijke wijze zullen zijn samengebracht, valt te verwachten dat het "tijdverlies" in dit stadium door de langere termijn voor het werk van de commissie later zal worden "ingelopen" doordat dit "voorbereidende" werk de afdoening van de eventueel nog volgende beroepszaak kan bespoedigen. ${ }^{72}$

Ten aanzien van de ruimere beslistermijn ('tien weken' in de Awb en 60 dagen in de Wet arob) wordt hierin tevens op grond van het argument voor deze ruimere termijn, het belang van een adviescommissie andermaal onderstreept. Toch blijft ook de termijn van 10 weken voor een adviescommissie een probleem. Recente onderzoeken wijzen uit dat ook de ruimere beslistermijn onder de werking van de Awb tot een "beperkte tijdigheid van de besluitvorming in de bezwaarfase heeft geleid'. Die 'beperkte tijdigheid" komt in een recente rapportage op de volgende wijze tot uitdrukking:

In de praktijk blijken zich in de helft van deze gemeenten nooit overschrijdingen van de tien weken-termijn voor te doen. Bij ongeweer twee op de vijf gemeenten die een commissie met een onafhankelijke voorzitter kennen, vindt echter bij meer dan 10 procent van de beslissingen een overschrijding van de tien weken-termijn plaats. Er blijkt overigens een sterk positief verband te bestaan tussen de mate waarin in een gemeente overschrijdingen van de tien weken-termijn plaatsvinden, en het aantal inwoners van de gemeente. Hoe hoger het inwoner-aantal, des te vaker termijnoverschrijdingen plaats-vinden. ${ }^{73}$

Het aspect van de termijnoverschrijding vormt overigens een nog groter probleem in situaties dat bijvoorbeeld gemeenten geen adviescommissie hebben met een

7. J.H. van Kreveld en M. Scheltema, a.w., p. 293 en 294. 
onathankelijke voorzitter. Uit het bovengenoemd onderzoek blijkt dat in een 'aanzienlijk' gedeelte van de gemeenten de beslistermijn wordt overschreden, de gemeenten 'niet al te strak' de hand houden aan de 'gewone' zes-weken-termijn. ${ }^{74}$

De bedenkelijke kant van het in de praktijk kennelijk te 'grote' tijdsbeslag van de bezwaarschriftenprocedure is ook in de evaluatie van de Awb niet onopgemerkt gebleven. De kritische geluiden dienaangaande zullen nader onderwerp van studie vormen. ${ }^{75}$

Deze kritiek over het tijdsbeslag van de bezwaarschriftenprocedure wordt in verband gebracht met art. 6 EVRM (redelijke termijn). Vanwege het belang voor de termijn waarop de beslissing op het bezwaarschrift wordt genomen volgt hierna integraal, een relevante passage uit het evaluatierapport van de Awb inzake het bestuursprocesrecht ${ }^{76}$ :

-Bij een extreem lange doorlooptijd in een individuele zaak kan de grens van het rechtens toelaatbare - het recht op rechtspraak binnen redelijke termijn - worden overschreden. Over de vraag welke fasen van geschilbeslechting in de beoordeling, of schending van de redelijke termijn heeft plaatsgehad, in de beoordeling moeten worden betrokken, heeft het Europese Hof voor de Rechten van de Mens (EHRM) in 1994 twee belangrijke uitspraken gewezen. De voorbereidingstijd voor besluiten inclusief de bezwaarschriftenprocedure, telt volgens het Hof mee bij de bepaling van de totale lengte van de bestuursrechtelijke rechtsgang en het vaststellen wan de redelijke termijn in de zin van artikel 6 EVRM. In de zaken Schouten en Meldrum tegen Nederland (noot 6 EHRM 9 december 1994, Series A, vol. 304, JB 1995, nr, 49 m.nt. AHW) stelt het Hof vast dat de periode die een bedrijfsvereniging nodig had om een voor beroep vatbare beslissing te nemen, meetelt bij het bepalen van de redelijke termijn in de zin van artikel 6 EVRM. In casu leverde de periode die gemoeid was met het nemen van een voor beroep vatbare beslissing, respectievelijk een jaar en negen maanden (Schouten) en een jaar en vijf maanden (Meldrum) een overschrijding op van de redelijke termijngrens van artikel 6 EVRM. Al speelden de zaken Schouten en Meldrum zich vóór de Awb af, en al bestat de mogelijkheid de bestuursrechter te adièren bij het uitblijven van een beslissing op bezwalar (art. 6:2 Awb), toch is de uitspraak van belang ondat ze uitdrukt dat voorbereidingstijd en de duur van de bezwaarschriftenprocedure meetellen bij de bepaling van de redelijke termijn. In een tweede belangrijke uitspraak van het EHRM uit 1994 wordt bevestigd dat ook de voorbereidingstijd van een besluit wordt meegeteld bij de berekening van de redelijke termijn (noot 7 EHRM 26 april 1994

74 A.w. p. 110.

75 J.B.J.M. ten Berge e.a. Ervaringen mer de Awb, Her bestuursprocesrecht, Deventer 1996 , p... 296 [...

76 A.w., p. 288 en 289. 
(Vallé́ w. Frankrijk), Series A, vol. 289, NJCM-bulletin 1994, p. 1086-1092 m.nt. Sander Jansen).'

De aandacht die in het evaluatierapport wordt gewijd aan het belang en het verband van een 'redellike beslistermijn' van de bezwaarschriftenprocedure in relatie tot het bestuursprocesrecht is terecht. Door het bestuursorgaan wordt vaker de besllis-termijn van 6 weken overschreden dan in die gevallen dat er beslist moet worden binnen 10 weken (adviescommissie). Er zijn derhalve meer argumenten om de voorbereiding van de beslissing op het bezwaarschrift door een 'onafhankelijke" adviescommissie te doen geschieden. Door de wetenschap wordt niet zonder reden gewezen op het belang van een spoedige beslissing op het bezwarschrift. ${ }^{77}$

De Awb is in tegenstelling tot de Wet arob, sober in de motivering voor een ruimere beslistermijn. De motivering wordt hier afgedaan met: 'Indien een adviescommissie wordt ingeschakeld geldt een langere beslistermijn dan wanneer het besturrsorgaan de beslissing zelf voorbereidt. ${ }^{78}$ Daarnaast wordt bij de keuze voor een ruimere beslistermijn bij, het inschakelen van een adviescommissie (art. 7:13), betrokken 'de herkenbaarheid' van deze commissie voor de indiener van het bezwaarschrift. ${ }^{79}$

Toch is het maken van een enkele afrondende kanttekening niet zonder betekenis. Gewezen werd op het belang van het decisiebeginsel (beslissing binnen redelijke termijn) dat ook in de bezwaarfase een rol kan spelen bezien vanuit het EVRMperspectief (art. 6 EVRM). Met nadruk is door de regering tijdens de parlementaire behandeling gesteld dat aan 'de langere beslistermijn' bij het adviseren door een adviescommissie een secundaire betekenis moet worden toegekend. Deze secundaire betekenis is gelegen in de verantwoordelijkheid van het bestuursorgaan voor het in acht nemen van (ook) de ruimere beslistermijn. De regering wijst er op dat het bestuursorgaan indien de 'reguliere' beslistermijn niet wordt gehaald, het orgaan verplicht is de beslissing te verdagen. De regering geeft hierdoor de grenzen aan van de verantwoordelijkheid voor de beslistermijn (art. 7:10) in de relatie van de adviescommissie met het bestuursorgaan:

77 Zie naast het rapport Ervaringen met de Awb ook: B.W.N. de Waard, a.w. , p. 238 e.\%. Een belangrijke bijdrage aan de discussie met betrekking tot de redelijke termijn is ook geleverd door J.A. Smit. Bezwaar in belastingzaken, Deventer 1992, Artikel 6 EVRM en de bezwaarfase, $p$. 84-90. Zie werder nog: M.L.W.M. Viering, Het toepassingsgebied van artikel 6 EVRM, Zwolle 1994, 4.6, Aanvang en einde van het geschil, p. 97 e.v.

79 PG Awb I, p. 354. 
"Indien de adviescommissie om een of andere reden niet op tijd een advies uitbrengt, zal het bestuursorgaan de beslissing overeenkomstig het derde lid - en eventueel het vierde lid - moeten verdagen. En indien dan nog geen advies is uitgebracht zal het bestuursorgaan moeten beslissen zonder advies. In dit moeilijk voorstelbare gewal zal het bestuursorgaan dan zelf moeten horen, in afwijking van artikel 6.3 .18 , derde lid. ${ }^{13}$

Uit het bovengenoemde regeringsstandpunt blijkt dat er toch omstandigheden denkbaar zijn die het bestuursorgaan kunnen nopen tot het zelf horen van belanghebbende(n), indien de adviesconmissie het horen achterwege heeft gelaten. De VNG had in haar commentaar aan de minister van Binnenlandse zaken over het Voorontwerp Awb daarover twijfels geuit. ${ }^{81}$ Toch moet een dergelijke situatie om praktische redenen worden voorkomen. Het verdient aanbeveling dat het bestuursorgaan zich tot de adviescommissie wendt met het verzoek alsnog een hoorzitting te beleggen. Deze laatste optie zou ook kunnen worden bepleit vanuit de formeel-juridische verantwoordelijkheid van de adviescommissie voor het voorbereidingsproces, voorafgaand aan de beslissing op het bezwaar. De problematiek van een mogelijk tweeslachtige situatie ten aanzien van het hanteren van de bovengenoemde procedurele bevoegdheid, kwam ter sprake in par. 5.3.9 (de procedurelle bevoegdheden van de adviescommissie).

Vastgesteld kan worden dat het bestuursorgaan er voor moet waken dat de beslistermijnen in het kader van de bezwaarschriftenprocedure niet worden overschreden. ${ }^{82}$. Ook de N.o. dicht bestuursorganen een sterke verantwoordelijkheid toe in het naleven van de beslïstermijn voor het bezwaarschrift, hetgeen blijkt uit een zaak van het waterschap De Brielse Dijkring. De N.o. stelde vast dat het waterschaps-bestuur zich in onbehoorlijk had gedragen door niet tijdig een beslissing te nemen op een bezwaarschrift tegen een aanslag waterschapslasten $1995^{83}$

Deze uitspraak waarin het ontijdig nemen van een beslissing op thet bezwaarschrift niet door de beugel kon, is ook om een andere reden van belang. De

80 PG Awb 1, p. 345 en 346.

8. Ordening in het bestuursrecht, a.w., p. 25:

\$2 Zie in dit werband 0.a.: H.J. Simon, Handleiding Awbupraktijk, p. 204 en 205, alsmede de daarbij vermelde literatuur.

33 N.0. 14 januari 1997, JB 1997, 41. De werkwijze van de overheid in casu de behandelingsduur heeft bijzondere aandacht van de Nationale ombudsman. Zie in dit verband: J.B.J.M. ten Berge, M.P. Gerrits-Janssens en P.J. Stolk, Vereisten van behoorlijkheid, Zwolle 1992, p. 15 e.v. en p. 358. In het kader wan de beoordeling van klachter legt de Nationale ombudsman voor wat betreft de invulling van het begrip "redelijke termijn" doorgaans een relatie met de zes weken-termijn als bedoeld in artikel 7: 10 Awb. Zie in dit verband: M.P. Gerrits-Janssens, Behoorlijke klachubehandeling, Contouren van een geharmoniseerd kllachtprocesrecht, Zwolle 1994, p. 222. 
beslistermijnen als bedoeld in art. 7:10 zijn niet van toepassing in het belastingrecht; art. 25, lid 1 Awr bepaalt immers in afwijking van dit artikel dat binnen Gên jaar na ontwangst van het bezwaarschrift, uitspraak moet zijn gedaan. Het tweede lid van dit artikel kent een verdagingstermijn van eveneens één jaar. Toch werd door de N.o. die fiscale beslistermijn niet gehanteerd. Met een verwijzing naar de wetsgeschiedenis van de afwijkende (fiscale) beslistermijn voor de bezwaarschriften (ingewikkeldheid van een groot aantal belastingbeschikkingen), wees de N.o. op een circulaire van de staatssecretaris van Financiën (Voorschrift Algemene wet bestuursrecht). In deze circulaire was een voorschrift opgenomen dat als uitgangspunt stelde dat 'reguliere bezwaarschriften' binnen drie maanden worden afgehandeld. Aangezien in de zaak van het bovengenoemd waterschap geen sprake was van een 'ingewikkeld' maar van een 'regulier' bezwaarschrift werd zelfs de overschrijding van de "circulaire-termijn' (drie maanden) niet door de Nationale ombudsman geaccepteerd. Schending van de overschrijding van de redelijke termijn was de conclusie van de N.o.

Ter afsluiting van het onderzoek naar 'bouwstenen' voor een bezinning op art. 7:13 Awb, wordt hierna de ballans opgemaakt. Aan de hand van enkele samenvattende conclusies zal in de volgende paragraaf worden bezien of art. 7:13 Awb zijn facultatief karakter moet behouden, dan wel of deze adviescommissie een verplichte bestuursrechtelijke inkadering behoort te krijgen.

\subsection{Artikel 7:13 $\mathrm{Awb}$ : facultatief of imperatief?}

Op basis van het onderzoek in de vorige paragraaf, volgt hierna een gerubriceerde samenvatting van de bevindingen.

In par. 5.2 (Algemene aspecten) is vastgesteld dat de structuur van afdeling 7.2 Awb een tweedeling kent in het voorbereidingsproces van de beslissing op het bezwaar. Deze tweedeling betekent dat het bestuursorgaan op basis van de systematiek van de $\mathrm{Awb}$, primair de verantwoordelijkheid draagt voor de voorbereidingsfase van de bezwaarschriftenprocedure. Het horen geschiedt dan door of namens het bestuursorgalan. Hierdoor geschiedt de uitvoering van de art. $7: 3$ tot en met $7: 9$ onder de volledige verantwoordelijkheid van het bestuursorgaan. Naast de toepassing van de procedurele bepalingen van afd. $7.2 \mathrm{Awb}$, is het bestuursorgaan tevens belast met de uitvoering van de procedure-voorschriften in de hoofdstukken 2 en 6 Awb. Deze procedurele bepalingen van de Awb, nopen tot het nemen van diverse (bestuurlijke) voorbereidingsbeslissingen in het kader van de behandeling van het bezwaarschrift. 
NAAR EEN DEFINITIEF CONCEPT VOOR HET ADVISEREN OP GROND VAN DE AWB

De verantwoordelijkheid van het bestuursorgaan voor het verloop van de voorbereiding van de beslissing op het bezwaarschrift, kan bestuurlijk-praktische invulling krijgen door het gebruik van de mandaatfiguur. Deze wijze van voorbereiding namens het bestuursorgaan leidt tot een ambtelijke behandeling van het bezwaar. Bij de bespreking van het gebruik van het mandaat is gewezen op het bepaalde in art. 10:3, lid 3 (derde tranche); het nemen van een beslissing op het bezwaarschrift krachtens mandaat is hierdoor in beginsel mogelijk.

Door de tweedeling in de voorbereidingsfase van de beslissing op het bezwaarschrift kan de bijzondere regelgever de voorbereiding opdragen aan een adviescommissie. Deze facultatieve regeling biedt de mogelijkheid tot verschillende adviesvormen. Indien een adviescommissie in de zin van art. $7: 13$, lid 1 is ingesteld, treedt deze commissie in de plaats van het bestuursorgaan en oefent deze, behoudens wettelijke uitzondering, preparatoire bevoegdheden uit (par. 5.2.2 en 5.3.9).

De door de Awb geschapen ruimte ten aanzien van de inrichting van de bezwaarschriftenprocedure leidt tot een differentiatie van de voorbereidingsfase. In par. 5.3 (Bijzondere aspecten) is meer fundamenteel ingegaan op de tweedeling en de differentiatie in de Awb van het voorbereidingsproces van de behandeling van bezwaarschriften.

\subsubsection{De Awb en de keuzevrijheid voor het adviseren}

De Awb heeft de bijzondere regelgever de vrijheid gelaten om zelf invulling te geven aan de wijze van het adviseren ten behoeve van de op het bezwaarschrift te nemen beslissing. In het belang van de eenvormigheid van de procedurevoorschriften, alsmede de herkenbaarheid voor de burgers van de inrichting van de bezwaarschriftenprocedure, is gepleit voor verbetering van de doelmatigheid van deze procedure. Deze kritiek is op basis van het onderzoek in par. 5.3 concreet vorm gegeven. In de volgende paragrafen wordt, samengevat, het volgende vastgesteld.

\subsubsection{De kritiek op de vrijheid van het adviseren}

De bestuurlijke vrijheid tot het instellen van een adviescommissie in de zin van art. $7: 13$, is mede onderzocht op basis van de in het verleden uitgebrachte onderzoeksrapporten ten tijde van de Wet arob. Hierin zijn tevens betrokken de argumenten van de RvS en de VNG. 
Vastgesteld is dat een adviescommissie als bedoeld in art. 7:13 Awb de beste waarborgen kan bieden voor een goede heroverweging van de beslissing op het bezwaarschrift.

\subsubsection{De twiffels over artikel 7.5 als inrichtingseis woor het horen}

Indien het bestuursorgaan zorg draagt voor het voorbereidingsproces, voorafgaand aan de beslissing op het bezwaar, houdt dit in dat rekening moet worden gehouden met de inrichtings-eisen voor het horen op grond van art. 7:5.

Met een verwijzing naar de jurisprudentie-trends onder de werking van de Wet arob zijn "pessimistische" kanttekeningen geplaatst bij de uitvoering van de in art. $7: 5$ gestelde onpartijdigheidseisen.

\subsubsection{Artikel 7:13 Awb en de waarborgen regen belangenverstrengeling}

Aan de hand van de jurisprudentie is er op gewezen, dat art. 7:13 ten opzichte van art. 7:5, weliswaar sterkere uitgangspunten biedt voor een meer afstandelijke advisering omtrent de voorbereiding van de beslissing op het bezwaarschrift, maar dat dit nog geen volledige garantie biedt dat het voorbereidingsproces volkomen vlekkeloos verloopt.

5.4.5. Het openbaar lichaam als (belanghebbende) vergunninghouder: artikel $7: 5$ onder druk en de rechterlijke voorkeur voor artikel 7:13

Uit enkele uitspraken valt af te leiden, dat onder de werking van de Awb de lagere bestuursrechter in die gevallen dat het bestuursorgaan 'binnen eigen bestuurlijke kring" een vergunning verleent, in de rechtsoverwegingen een duidelijke voorkeur wordt uitgesproken voor een adviescommissie in de zin van art. 7:13. Ofschoon in die gevallen geen strijd met art. 7:5 kon worden geconstateerd, blijkt wél dat dit rechterlijk standpunt er toe leidt dat art. 7:5 in feite wordt afgewezen. Dat de ABRS hier anders over denkt doet niets af aan het risico dat bestuursorganen lopen bij de beslissing op het bezwaarschrift in die gevallen dat een vergunningverlening aan het openbaar lichaam waarvan het bestuursorgaan deel uitmaakt, aan de orde is. Daarnaast blijkt uit de recente jurisprudentie, dat de bestuursrechter constateert dat indien de voorbereiding van de beslissing op het bezwaarschrift geschiedt onder verantwoordelijkheid van het bestuursorgaan, het moeilijker valt na te gaan of de gewenste afstandelijkheid in de zin van art. 7:5 in acht is genomen. 


\subsubsection{Kanttekeningen bij de ambtelijke advisering}

Het voorkómen van belangenverstrengeling in de voorbereiding van de beslissing op het bezwaarschrift vormt een kritisch aandachtspunt wan de bestuursrechter. Deze heeft kritiek op de dubbelrol van personen in het proces van het horen, de advisering en de besluitvorming. In een uitspraak kwam dit probleem nog eens aan het licht. ${ }^{84}$

De werking van art. 2:4 Awb krijgt bij de rechterlijke toetsing steeds meer aandacht. Niet onbelangrijk is het feit dat de ambtelijke advisering zich aan de openbaarheid onttrekt, en naar aard een intern organisatorisch karakter draagt. De bestuursrechter heeft moeite om besluiten die de schijn van partijdigheid oproepen, te toetsen aan art. 2:4. Dit laatste wordt vooral veroorzaakt doordat de bestuursrechter vaak onvoldoende inzicht heeft in het ambtelijk organisatie-bestel. Een bijkomend probleem is dat organisaties en functies vaak veranderen; ambtelijke taken zijn in de huidige tijd aan grote flexibiliteit onderhevig. Deze omstandigheden maken het vooral bij de toepassing van art. 7:5 Awb moeilijk om te beoordelen of er sprake is van een rechtens juiste wijze van het horen door ambtenaren. Art. 7:5 is als 'afstandelijkheidsvoorschrift' moeilijk te handhaven. Dit laatste kan mede worden afgezet tegen de voorkeur om het horen en het adviseren toe te vertrouwen aan een adviescommissie in de zin van art. 7:13 (par. 5.4.2).

\subsubsection{Enkele leemten in de onafhankelijkheidsaspecten van artikel 7:13}

\subsubsection{De vormgeving van artikel 7:13; conclusies en aanbevelingen}

Vast kwam te staan dat het eerste lid van art. $7: 13$, onder $b$, onvoldoende waarborgen biedt voor de onafhankelijke positie van de voorzitter wan de adviescommissie.

In par. $5.3 .7 \mathrm{kreeg}$ dit onafhankelijksaspect bijzondere aandacht.

Geconcludeerd is dat het gestelde in art. 7:13, eerste lid onder $b$, een leemte vertoont, voor wat betreft de door de Awb toegedichte 'onafhankelijkheid' aan de voorzitter van de adviescommissie. Hiermede zou bezien vanuit het gezichtspunt van de afstandelijke beoordeling door de adviescommissie, niet volledig recht worden gedaan aan de bedoelingen van de Awb. Vastgesteld is dat in het belang van het nastreven van de afstandelijkheid van de adviescommissie, de redactiestructuur onder $b$ van het eerste lid, niet sluitend is. 
Omdat de voorzitter van de adviescommissie alleen maar niet mag functioneren binnen de kring wan het op het bezwaar beslissend bestuursorgaan, biedt de inrichtingseis van art. 7:13 ruimte, om een voorzitter uit de 'eigen' kring van hetzelfde openbaar lichaam te 'rekruteren'.

Art. 7:13, eerste lid onder b heeft daarom "slechts" een beperkte "afstandelijke reikwijdte', voor wat betreft het voorzitterschap van de commissie.

Benadrukt wordt dat art. 7:13 er niet aan in de weg staat, dat de bijzondere regelgever verdergaande samenstellingseisen in het belang van de onafhankelijkheid inbouwt. De VNG opteert zelfs in haar model-verordening voor een geheel onafhankelijke commissie, waarin alleen plaats is woor buitenstaanders. ${ }^{85}$

De vraag kan worden opgeworpen of een onafhankelijke adviescommissie zich wel verdraagt met de heroverwegingsopdracht die in art. $7: 11$ aan het bestursorgaan is gesteld. Een dergelijke adviescommissie benadert al gauw de grenzen van een besliscommissie. Deze commissie staat conform de recente jurisprudentie op gespannen voet met het stelsel van de Awb. Een onafhankelijke adviescommissie zou als het ware als een 'eigen koninkrijk' ten opzichte van het bestuursorgaan kunnen fungeren, en minder oog kunnen hebben voor de beleidsmatige kant van de besluitvorming. Zowel de feiten, het recht en het beleid zijn belangrijke aspecten van de bestuurlijke heroverwegingsplicht. Vooral Stroink legt een zorgvuldig verband met de adviesfunctie van een commissie en de algemene beleidsverantwoordelijkheid van het besturursorgaan. Hij is terecht van mening dat naarmate het zwaartepunt van de beslissing naar een commissie verschuift, deze omstandigheid tot meer reserve leidt. 'Een heroverweging van alle beleidsmerites die bij de oorspronkelijke beschikking in het geding waren, kan daarmede in het gedrang raken en een vernauwde toetsing aan enkel rechtmatigheidsgronden kan daarmee naar voren komen, zulks dan in strijd met de Wet arob (lees nu: Awb). ${ }^{86}$

Ook Borman bepleit afstandelijkheid binnen zekere grenzen, gelet op de belendsverantwoordelijkheid van het bestuursorgaan. In de benadering van Borman

85 A.w., Artikell 3, lid 3 van het VNG model bepaalt: '3. De voorzitter en de leden van de commissie kunnen geen deel uitmaken of werkzaam zijn onder veramtwoordelijkheid van een gemeentelijk bestuursorgaan". In de algemene toelichting behorende bij de model-verordening motiveert de VNG op pagina 10 wan haar advies de keuze voor een onafhankelijke commissie vanuit het tweeledige karakter van de bezwarschriftenprocedure (rechtsmiddel en verlengde besluit vorming).

J.G. Steenbeek/F. A. M. Stroink, a.w., p. 401 en 402. 
betekent een verplichte bezwaarschriftenprocedure, dat gekozen wordt voor een bestuurlijke verantwoordelijkheid voor een te maken heroverweging door het oorspronkelijk beschikkend orgaan. Hierdoor bestaat er een principieel onderscheid ten opzichte van het administratief beroep en het beroep op de rechter.

'Behoud van het overwicht van ambtenaren en leden van het administratief orgaan is dan een eis. Binnen die begrenzing kan overigens nog voldoende naar afstandelijkheid worden gestreefd. ${ }^{87}$

Hoewel Borman's visie niet direct gericht was op de gemengde bemensingsconditie zoals die in art. 7:13 wordt voorgestaan, kenschetst zij zich als "arob-visie" met een zekere mate van realiteit voor de bestuurspraktijk. Door deze visie lijkt de door de Awb gekozen "bemensingsformule" voor de adviescommissie te worden benaderd.

Voor zowel de visie van Stroink als die van Borman is er voldoende ruimte om met behoud van het doel en de functie van de bezwaarschriftenprocedure, een concrete invulling te geven aan de ratio van het inschakelen van een adviescommissie. Tak brengt kort en bondig de motieven in beeld die aan het inschakelen van een adviescommissie ten grondslag liggen. Hij stelt het vergroten van de waarborg tegen partijdigheid voorop. Een tweede belangrijk motief vormt de vergroting van de deskundigheid. Vooral uit overwegingen van deskundigheid ziet Tak belangrijke instrumenten om op basis van juridische expertise sturing te kunnen geven aan een zorgvuldige voorbereiding van de beslissing op het bezwaarschrift, en het adequaat oplossen van de juridische problematiek. Tegelijkertijd ziet hij door het inschakelen van een adviescommissie die aan de bovengenoemde uitgangspunten voldoet, een belangrijke ontlasting van het bestuursapparaat. $^{\text {8\& }}$

Ter afronding van en ter completering van de argumenten die pleiten voor de inschakeling van een adviescommissie, blijkt uit het recente onderzoek in het kader van de evaluatie van het bestuursprocesrecht, dat goede resultaten zijn waar te nemen bij de behandeling van beroepszaken voor de bestuursrechter in die gevallen dat een adviescommissie is ingeschakeld.

Gebleken is dat op basis van (juridische) deskundigheid de beroepszaken doorgaans goed zijn woorbereid. Naast het belang van deskundigheid bij het inschakelen van adviescommissies, blijkt dat als gevolg van de grotere afstandelijkheid van een commissie de belangen van de besluitvorming beter worden gediend. De 
verbetering yan de kwaliteit van de besluitvorming in het kader van de bezwaarschriftenprocedure, heeft inmiddels tot een acceptabele en stabiele zeefwerking geleid van 10 procent. ${ }^{89}$

\subsubsection{De literatuur en de adviescommissie}

Op basis van het 'onderzoeksmateriaal' uit de literatuur blijkt een aantal aspecten dat pleit voor het opdragen van het adviseren aan een adviescommissie met een afstandelijke 'inkleuring'. Hierbij zijn argumenten genoemd zoals uniformiteit, doelmatigheid, kwaliteit van het bestuur en een betere heroverweging en daardoor ook een betere rechtsbescherming. Voor een meer uitvoerige behandeling wordt verwezen naar par. 6.4.

\subsubsection{De procedurele bevoegdheden van de adviescommissie}

Art. 7:13, lid 4 kent een aantal procedurele bevoegdheden rechtstreeks toe aan de adviescommissie. Deze bevoegdheden zijn door het vierde lid gelimiteerd. Bij de bespreking van deze procedurele commissie-bevoegdheden is geconstateerd dat de uitoefening hiervan aan beperkingen onderhevig is. Niet alle procedurele bevoegdheden blijken door de Awb in handen van de adviescommissie te zijn gelegd. Daaruit kunnen competentieproblemen ontstaan tussen het bestuursorgaan en de adviescommissie. Het in art. 7:13, lid 4 gemaakte wettelijk voorbehoud ten aanzien van de toepassing van art. 7:3 (afzien van de hoorverplichting), is niet efficiênt.

5.4.10. Kritische kanttekeningen bij de competentieverdeling van de procedurele bevoegdheden

Vanwege de gekozen uitgangspunten van de Awb om de adviescommissie in de zin van art. 7:13 beperkingen op te leggen in de uitoefening van de preparatoire bevoegdheden, ontstaat er mede een 'versluierd beeld' ten aanzien van de uitoefening hiervan in de relatie tussen het bestuursorgaan en de adviescommissie. De adviescommissie heeft slechts die procedurele bevoegdheden welke limitatief zijn opgesomd in art. 7:13, lid 4. Hierbij blijkt tevens dat binnen de grenzen van dit vierde lid een differentiatie van procedurele bevoegdheden mogelijk is. De bijzondere regelgever heeft conform art. $7: 13$, lid 4 , de mogelijkheid de uitoefening van de bevoegdheden als bedoeld in art. $7: 3$ (uitzondering hoorplicht), te beperken. 
Op basis van 'geschiktheidsargumenten' wordt betwijfeld of het bestuursorgaan well in staat is tot een juiste toepassing van art. 7:3. Deze constatering wordt gestoeld op de vele jurisprudentie ten aanzien van het achterwege laten van de hoorplicht. Daar komt nog bij dat indien het bestuursorgaan het horen achterwege laat, in geval van 'kennelijke ongegrondheid' van het bezwaar, dit orgaan geconfronteerd kan worden met strenge rechterlijke toetsingsmaatstaven.

Ten aanzien van de gedeeltelijke toekenning van enkele preparatoire bevoegdheden aan de adviescommissie (beperking inzagerecht als bedoeld in art. 7:4, zesde lid en beslissingen omtrent de openbaarheid van de hoorzitting conform art. $7: 5$, lid 2), is vastgesteld dat het toepassen van andere procedurele bevoegdheden slechts door een uitdrukkelijke overdracht van de bijzondere wetgever kan worden gerealiseerd. Gewezen is op een aantal verspreid voorkomende bepalin gen in hoofdstukken 2, 6 en 7 Awb.

Uit een oogpunt van doelmatigheid, en uit overwegingen van harmoniserende aard, wordt deze differentiatie ongewenst geacht. De zorgvuldige voorbereiding van het besluitvormingsproces in het kader van de bezwaarschriftenprocedure is hiermee niet gediend. Dit is niet in het belang van de snelheid van de besluitvorming, alsook de herkenbaarheid van de inrichting van de bezwaarprocedure voor de belanghebbenden.

\subsubsection{De differentiatie wan de beslistermijn in artikel 7:10 Awb}

Het 'twee-termijnen-stelsel' voor de beslissing op het bezwaarschrift als bedoeld in art. 7:10 dient niet de belangen van een behoorlijke inrichting van de bezwaarprocedure. Uit recente onderzoeken blijkt dat de termijnen als bedoeld in art. 7:10 door de bestuursorganen regelmatig worden overschreden, en dat het bestuursorgaan daarop kan worden 'afgerekend' bij de toetsing van de beslissing op het bezwaarschrift. Ook in ruimer verband, te weten in relatie tot het gehele traject van het bestuursprocesrecht, is een aantal bedenkingen aan te voeren tegen de te trage besluitvorming van bezwaarschriften. Vooral vanuit het EVRMperspectief met zijn 'redelijke termijn' als bedoeld in art. 6, worden deze bedenkingen nog sterker. Er is een aantal uitspraken van het EHRM, waarin de duur van de bezwaarschriftenprocedure in 'het groter geheel' van de aansluitende procedure bij de bestuursrechter, tot een bestuursrechtelijke verwijtbaarheid kan leiden. Nu op basis van onderzoeken kan worden vastgesteld dat overschrijding van de zes-weken-termijn waker door het bestuursorgaan geschiedt (geen inschakeling wan een adwiescommissie), wordt er woor gepleit de voorbereiding in handen te leggen van de adviescommissie. 
Ook de recente evaluatie van de Awb (in het kader van het bestuursprocesrecht) verstevigt het argument voor een betere aanpak van de termijnoverschrijding.

Gelet op de bovengenoemde onderzoeksresultaten, is het doelmatiger om de voorbereiding van de op het bezwaarschrift te nemen beslissing geheel toe te vertrouwen aan een adviescommissie in de zin van art. 7:13. Op basis van de hiervoor besproken argumenten zou de Awb-wetgever de keuzevrijheid voor het adviseren moeten loslaten, en het facultatieve voorschrift van de adviescommissie moeten omzetten in een algehele advieswerplichting voor de bestuursorganen.

\subsection{Enkele algemene afsluitende conclusies}

Voor de facultatieve redactie van art. 7:13 Awb is geen plaats meer. De advisering in het kader van de voorbereidingsfase, voorafgaand aan de beslissing op het bezwaarschrift, onderscheidt zich steeds meer van overige typen van advisering. Ook de jurisprudentie op grond van de Awb rechtvaardigt mede een imperatieve adviesregeling. Art. 7:13 biedt geen volledige waarborgen ter voorkoming van belangenverstrengeling. Bestuursorganen doen er verstandig aan om zonodig door middel van (aanvullende) regels in het belang van de door de $\mathrm{Awb}$ aan de voorzitter van de adviescommissie toegedichte onafhankelijke positie, extra waarborgen 'in te bouwen' ter voorkoming van belangenverstrengeling. Ook wordt hierdoor een betere uniformering van de procedurele bevoegdheden en de beslistermijnen bereikt. 


\section{De bezwaarschriftenprocedure ter discussie: evaluatie, stand- punten, literatuur en aanbevelingen}

\subsection{Inleiding en verantwoording}

De Awb verplicht in art. 9:1, lid 1, de ministers van Justitie en van Binnenlandse Zaken om voor het eerst, binnen drie jaar na de inwerkingtreding van deze wet, en vervolgens om de vijf jaar, een verslag uit te brengen aan de Staten-Generaal over de wijze waarop zij is toegepast.

De Commissie Evaluatie Algemene wet bestuursrecht (Commissie Polak) bracht in eerste instantie een onderzoeksverslag uit aan het parlement. "Ruim één jaar later volgde het kabinetsstandpunt over het rapport Polak. ${ }^{2}$

De evaluatie van de Awb is zeer breed van opzet en raakt vele facetten van het bestuursrecht. De gegevens over de werking van de Awb die beschikbaar zijn gekomen, reiken verder dan het verslageriterium van het eerste lid van art. 9:1 Awb. De ruime aanpak van de Awb-evaluatie komt tot uitdrukking in de "driefasen-benadering'. Zowel de primaire besluitvormingsfase als de fase van bezwaar en het beroep bij de bestuursrechter, vormden object van onderzoek. Het evaluatie-onderzoek is gebaseerd op de samenhang tussen deze drie fasen.

Het bestuursprocesrecht is in art. 9:1, lid 2, uitgezonderd van de evaluatieverplichting maar is toch geèvalueerd. De bedoeling was om thet bestuursprocesrecht pas te evalueren in het kader van de derde fase van de herziening van de rechterlijke organisatie. ${ }^{3}$ Vanwege het verband tussen de beroepsfase en de eerdere twee fasen (de primaire fase en de bezwaarschriftenfase) is de evaluatie van het bestuursprocesrecht vervroegd. ${ }^{4}$

De Awb-evaluatie omvat vier deelonderzoeken die in boekvorm zijn verschenen in de reeks 'Ervaringen met de Awb' en hebben betrekking op de volgende onderwerpen:

- financiële beschikkingen

- subsidies

Toepassing en effecten van de Algemene wet bestuurstecht 1994-1996, 's-Gravenhage 18 december 1996

2 TK 1997-1998, $25600 \mathrm{VI}, \mathrm{mr} .46$.

PG Awb II, p. 517.

TK 1997-1998, 25600 VI, nr. 46, p. 6.

M.S. Beerten e.a., 1. Aspecten van de financielle beschikkingverlening, Dewenter 1996.

F.B.A. Joma e.a., 4. Subsidiebeschikkingen. 's-Gravenhage 1997. 
- ruimtelijk bestuursrecht en milieu;

- bestuursprocesrecht ${ }^{8}$.

De regering was in eerste instantie van oordeel dat de evaluatie een breed terrein van het bestuursrecht zou moeten bestrijken, maar dat een combinatie van een gerichte, diepgaande evaluatie maar op een beperkt aantal punten zou plaatsvinden. Meer in het bijzonder was het de bedoeling de effecten van de hoorplicht van de bezwaarschriftenprocedure te onderzoeken, met een meer globale evaluatie van de Awb alls geheel. ${ }^{9}$

De Awb-evaluatie is echter ruimer van opzet. De brede evaluatie heeft voor de bezwaarschriftenprocedure anders uitgepakt dan de MvAII van de Awb zou doen vermoeden. De regels van de bezwaarschriften in hoofdstuk 7 Awb zouden het stramien van die procedure voor de toekomst in belangrijke mate bepalen.

'De jurisprudentie zal daaraan nadere interpretaties en verfijningen toevoegen, maar zal - zo mag men verwachten - geen grote vernieuwingen meer brengen. ${ }^{10}$

De bezwaarschriftenprocedure is door de resultaten van de evaluatie, onder druk komen te staan. Dit laatste is in tegenstelling tot hetgeen uit de MvAlI kan worden geconcludeerd.

De evaluatie van de Awb leidde in de periode gelegen tussen het verschijnen van het rapport van de Commissie Polak (18 december 1996) en de presentatie van het kabinetsstandpunt (18 februari 1998), tot veel uiteenlopende reacties. Inspraak- en rechtsbeschermingsprocedures zouden de besluitvorming vertragen. In beroepszaken worden discussies gevoerd die in de rechtszaal niet thuishoren. De verhouding tussen bestuur en burgers en de besluitvorming in het openbaar bestuur zou zijn gejuridiseerd. In haar rapportage wijdde de Commissie Polak een aparte paragraaf (4.6) aan de bestuurlijke juridisering." Dit leidde tot een uitvoerig rapport van een werkgroep, bestaande uit enkele commissarissen van de Koningin en burgemeesters.

7. B.J. Schueler e.a. 3. Besluiten over ruimtelijke ordening, milieu en standplaatsen, Deventer 1996.

8. J.B.J.M. ten Berge e.a., 2. Het besturusprocesrecht, Dewenter 1996.

9 PG Awb I. p. 118 en 119.

10 PG Awb I, p. 31 .

11 A.W., p. $34 \mathrm{e.V}$. 
Kort vóór het verschijnen van het kabinetsstandpunt verscheen van deze bestuurlijke werkgroep het rapport 'Bestuur in geding' (rapport Van Kemenade). Hierin wordt stelling genomen tegen de toegenomen juridisering in het openbaar bestuur. Ook bevat het rapport Van Kemenade een reactie op het evaluatie-verslag van de Awb. ${ }^{12}$

Al vóór het verschijnen van het rapport Van Kemenade waren er discussies over de Awb en de juridisering in het openbaar bestuur. Er vond een symposium plaats met de veelzeggende titel 'Openbaar bestuur in de knel door rechtspraak?"' mige geluiden die op dit symposium doorklonken over de juridisering in het openbaar bestuur spreken voor zich:

1. 'het openbaar bestuur komt ook niet in de knel door rechtspraak, het openbaar bestuur zit in de knel door rechtspraak"

2. 'de bestuurskracht van ons land is in het geding, de legitimiteit van de politieke besluitvormings-organen ligt onder vuur (... $)^{15}$;

3. 'het oneigenlijke gebruik van procedures, de onbevredigende gang van zaken rond vormfouten en de overbelasting die alle betrokken partijen ondervinden van inadequate wet- en regelgeving, zijn symptomen van een crisis in ons staatsbestel ${ }^{16}$.

De discussies over de juridisering en uitkomsten van de evaluatie van de Awb bleven in de (vak) literatuur niet onopgemerkt. Termen als 'de gekooide overheid' illustreren de negatieve lading die op het nieuwe bestuursrecht schijnt te rusten. ${ }^{17}$

Het rapport 'Bestuur in geding' leidde in de vakpers tot een artikeJenreeks. De titels hieruit zijn veelzeggend: "Versterking van de juridische functie hard nodig'18, 'Rechtstaat, rechtersstaat of regentenstaat?' ${ }^{\prime 9}$, 'Ooit een rechter in Sterrenslag gezien?"20, 'Discussie juridisering ontstijgt de borreltafel'21, "Vlucht naar rechter te wijten aan falende politieke controle ${ }^{+22}$ en 'Rechtszekerheid en slagvaardigheid van bestuur in het geding ${ }^{23}$.

12 Haarlem, november 1997.

13 Zie het verslag van dit symposium in: NTB 1997, p. 1-32.

14 A.W., P. 2.

15 A.W., p. 2.

16. A.w., p. 4.

17 J. van Kemenade, De gekooide overheid, OB 1997, 3, p. 2 e.4.

18. H. Winter en M. Herweijer, BB, 1997, 48, p. 22.

19 G.S.A. Dijkstra, BB 1997, 49, p. 15.

20 P.N., BB 1997, 50, p. 17.

21 W. Konijnenbelt, BB 1997, 51-52.

2 A.Q.C. Tak, BB 1998, 7, p. 21.

3) J.A. van Kemenade en C.J.N. Versteden, BB 1998, 8, p. 24 en 25. 
In dit hoofdstuk zullen alleen die aspecten van 'Bestuur in geding' worden besproken die ook in het verslag van de Commissie Polak zijn opgenomen. Hierdoor wordt globaal de lijn aangehouden van het kabinetsstandpunt. ${ }^{24}$

Reeds voór het verschijnen van het rapport van de Commissie Polak is gediscussieerd over het nieuwe bestuursrecht en het spanningsveld tussen bestuur en rechter. De invoering van het nieuwe bestuurs(proces)recht en de formalistische uitwoering van de verplichte bezwaarschriftenprocedure, zouden mede de oorzaak zijn van de toegenomen juridisering. Tussen bestuur en rechter zouden relationele problemen zijn ontstaän. ${ }^{25}$

De werplichte bezwaarschriftenprocedure is regelmatig onderwerp van beschouwingen in de literatuur.

Het nut wan de bezwaarschriftenprocedure is soms scherp gekritiseerd. ${ }^{26}$ De discussies over de bezwaarschriftenprocedure zijn vooralsnog niet verstomd. Naast het rapport Van Kemenade viel ook het evaluatieverslag van de Awb ten deel aan kritiek, over de wijze waarop het onderzoek naar de effecten van de Awb is uitgevoerd. ${ }^{27}$

In dit hoofdstuk wordt ingegaan op een aantal hoofdlijnen van het verslag Toepassing en effecten van de Algemene wet bestuursrecht, het kabinetsstandpunt, alsmede het rapport Bestuur in geding. Tevens zal aandacht worden besteed aan de opvattingen in de literatuur. Alleen aspecten die een relatie hebben met de bezwaarschriftenprocedure zullen worden behandeld.

De evaluatie van de Awb verschaft veel gegevens over de inrichting van de bezwaarschriftenprocedure. ${ }^{28}$ Het is onmogelijk binnen het bestek van dit boek volledig in te gaan op alle analyses, bevindingen en aanbevelingen.

24 A.W., p. 3.

25 J.M. Polak, Bestuur en rechter. Relationele problemen, NJB, 1996, P. 892.

26. Zie 0.a.: M.B.W. Biesheuvel, Weg met de bezwaarschriftemprocedure, NJB 1996, p. 930" Weg met de adwocatuur, NJB 1996, p. 1111 en 1112, E. Alders, Deregulering ook voor de Awb?, NJB 1996, p. 1113, C.A.J.M. Kortmann, Weg met de bezwaarschriftenprocedure?, NJB 1996, p. 1113, Naschrift M.B.W. Biesheuvel, NJB 1996, p. 1114, J.J.A. Bosch, De bezwaarschriftenprocedure moet blijwen, NJB 1996, p. 1214 en 1215 en Naschrift van M.B.W. Biesheuvel, NJB 1996, p. 1215.

27 A.T. Marseille, Als een droom werkelijkheid wordr, RegelMaat 1997, p. 4 e.v. en F.C.M.A. Michiels e.a., Reactie op A.T. Marseille, Als een droom werkelijkheid wordt, RegelMaat 1997 , p. 78 en 79 .

28 TK 1997-1998, 25600 VI, nr. 46 (Kabinetsstandpunt), p. 5. 
Wél wordt hierna een aantal fundamentele lijnen uitgezet om het bestuursrecht en de bezwaarschriftenprocedure van hun knellende banden te ontdoen.

Voorop staat in dit hoofdstuk het beeld van het doel en de functie van de bezwaarschriftenprocedure aan te scherpen. Weerstanden tegen het bestuursrecht moeten op grond van het wetenschappelijk verantwoordelijkheidsbesef voor het bestuursrecht niet bestreden worden met provocaties. ${ }^{29}$ Een realistische kijk op theorie en praktijk van het bestuursrecht, biedt betere uitvoeringsperspectieven voor bestuursorganen en voor hen die deze organen adviseren. Het belang van de burgers is hierbij gediend.

Bij de behandeling van de evaluatie van de Awb is een drietal uitgangspunten in acht genomen.

1. De Awb kent een aantal duidelijke doelstellingen, te weten 'eenheid', 'systematisering', 'codificatie" en 'het treffen van voorzieningen' voor algemene bestuursrechtelijke onderwerpen. ${ }^{30}$

2. De inrichting en het functioneren van de bezwaarschriftenprocedure wordt besproken aan de hand van de uitgangspunten van het drie-fasenmodel van de evaluatie-commissie. Op grond van het systeem van de Awb zijn de primaire fase, de bezwaarfase en de fase van beroep bij de bestuursrechter op elkaar afgestemd. De bezwaarschriftenfase is weliswaar een zelfstandige fase maar heeft connexiteit met de primaire besluitvorming en de fase van toetsing door de rechter. Voor deze drie fasen geldt een trapsgewijze verzwaring van waarborgen en procedurele eisen van de primaire besluitvorming, de heroverwegingsfase en het beroep op de bestuursrechter. Zowel de Commissie Po${ }^{1 a k^{31}}$ als het kabinet $t^{32}$ hebben het drie-fasenmodel als uitgangspunt gekozen bij de opzet van de evaluatie.

3. De bevindingen in dit boek worden in hoofdlijnen afgezet tegen de evaluatieuitkomsten en de commentaren in de literatuur. Een 'herhaling van zetten' van de onderzoeksresultaten in dit boek wordt zoveel mogelijk vermeden.

In de paragrafen 6.2 tot en met 6.6 worden de volgende onderwerpen behandeld:

29. B.W.N. de Waard, Knellend bestuursrecht, NTB 1998, p. 60 e.v.

39 J.M. Polak, De evaluatie yan de Algemene wet bestuursrecht, Regel Maat 1997, p. 1.

31 A.w., p. 5.

32 A.w., p. 5. 
- de verplichte bezwaarschriftenprocedure (par. 6.2);

- de hoorplicht (par. 6.3);

- het adviseren over het bezwaarschrift (par. 6.4);

- de tijdigheid van de beslissing op het bezwaarschrift (par. 6.5);

Dit hoofdstuk wordt afgesloten met enkele conclusies (par. 6.6).

\subsection{De verplichte bezwaarschriftenprocedure}

De verplichte bezwaarschriftenprocedure op grond van de Awb is gebaseerd op de volgende doelstellingen:

1. de zeefwerking levert een aanzienlijke bijdrage aan het voorkómen van procedures bij de bestuursrechter;

2. de bezwaarschriftenprocedure verdient door haar conflictoplossingsfunctie de voorkeur boven een rechtsgang bij de bestuursrechter;

3. los van de zeefwerking biedt deze procedure het bestuursorgaan de kans tot herstel van fouten;

4. zij kan leiden tot verhoging van de kwaliteit van het bestuur vanwege haar 'confronterende' functie; leemten in de regelgeving van het bestuur en een onzorgvuldige uitvoeringspraktijk van voorschriften bieden kansen op terugkoppeling binnen de eigen organisatie (managementinstrument);

5. zij heeft naast de zeefwerking een dossiervormingsfunctie omdat door de beslissing in de bezwaarschriftenprocedure een verduidelijking ontstaat van het geschil. ${ }^{33}$

Er is kritiek op deze doelstellingen omdat zij het bestuursorgaan geen voordelen zouden opleveren. Vooral de burgers en de rechter zouden profiteren van de bezwaarschriftenprocedure. ${ }^{34}$ Deze conclusie is opmerkelijk. De filterwerking van de beslissingen op de bezwaarschriften bedraagt voor een aantal gebonden beschikkingen gemiddeld meer dan 95 procent. ${ }^{3 s}$ Ook de praktijk met een onafhankelijke adviescommissie bij de centrale overheid, duidt er op dat slechts tegen $5 \%$ van de op bezwaarschriften genomen beslissingen, beroep wordt ingesteld. ${ }^{36}$

33 PG Awb l, p. 324 e.v.

34 K. Sanders, Beschikkingen fabrieken en de bezwaarschriftenprocedure, $O B$ 1997, 4, p. 21.

35 A.W., p. 21.

36 C.A.J.M. Kortmann, Weg met de bezwaarschriftenprocedure, Reactie III, NJB 1996, p. 113. 
Deze aanzienlijke filterwerking positiveert het gebruik van de bezwaarschriftenprocedure. Het voorkómen van beroep op de rechter bij de massale beschikkingen op het terrein van het belastingrecht, de studiefinanciering en de kinderbijslag, heeft een aanzienlijke vermindering van de bestuurslasten tot gevolg (minder beroepsprocedures).

De evaluatie van de Awb resulteerde in een aantal bevindingen en aanbevelingen. Deze verschaffen vooral nieuwe inzichten over de inrichting en het functioneren van de bezwaarschriftenprocedure. Ook voor die terreinen van het besiuursrecht waar de bezwaarschriftenprocedure al vóór de Awb functioneerde zijn (andere) conclusies getrokken. ${ }^{37} \mathrm{De}$ inrichting van de bezwaarschriftenprocedure staat hierdoor ter discussie.

De evaluatie-commissie vraagt zich af, of op basis van de uitkomsten van de drie bestuursrechtelijke deelonderzoeken van het financiële bestuursrecht, het milieurecht en het ruimtelijk bestuursrecht ${ }^{38}$, de bezwaarschriftenprocedure nog aan de doelstellingen van de Awb beantwoordt.

Zij concludeert dat de harmonisatiedoelstelling voor deze voorprocedure niet of slechts in beperkte mate is gehaald. Vastgesteld is dat het succes van de bezwaarschriftenprocedure niet uitsluitend kan worden gemeten aan deze doelstelling.

De commissie twijfelt of voor sommige typen van beschikkingen de bezwaarschriftenprocedure nog wel voldoet aan de functies van deze procedure. ${ }^{39}$ In de deelonderzoeken is vast komen te staan dat van bestuursorgaan tot bestuursorgaan en van beleidsterrein tot beleidsterrein verschillen bestaan in de toepassing van de Awb. ${ }^{40}$

Tussen bestuursorganen zijn er verschillen door de aard, schaal en de organisatie van de bestuurlijke taakvervulling. Bestuursorganisaties met grote aantallen beschikkingen, die een veelal financieel en sterk gebonden karakter hebben, worden gekwalificeerd als 'beschikkingenfabrieken'. In deze bestuursorganisaties voltrekt zich een 'fabrieksmatige' besluitvorming. Dit type van organisaties onderscheidt zich van de zogenaamde 'beschikkingenateliers'. Deze 'overheids-ateliers' worden gekenmerkt door hun 'ambachtelijke' besluitvorming. ${ }^{41}$ Bij 'ambachtelijke' besluitvorming is:

37 TK 1997-1998, 25600 VI (Kabinetsstandpunt), nr. 46, p. 5 .

38 Zie de noten $1,5,6$ en 7 .

39 A.w., p. S3.

40 A.W. p. 29.

41 A.W. p. 29 . 
a. sprake van veel kleinere aantallen beschikkingen;

b. een grotere beleidswrijheid;

c. vala een meer-partijen-belang aanwezig.

Men kan verschillend denken over deze 'nieuwe bestuursrechtelijke' benaming van beschikkingen. Als zij moet worden gezien als een poging tot vulgarisering van het bestuursrecht, voegt zij in feite niets toe aan de typering van het gangbare (globale) onderscheid tussen gebonden en vrije beschikkingen in het bestuursrecht. Wél typeert het onderscheid tussen 'fabrieksmatige' en 'ambachtelijke' besluityorming door zijn beeldspraak, het al dan niet massale karakter van de beschikkingverlening. Maar elke indeling wan beschikkingen zal in zekere zin niet geheel nauwkeurig zijn. ${ }^{42}$

De rubricering van besluiten in 'fabrieksmatige" en 'ambachtelijke' besluitvorming, geeft aanleiding tot het maken van opmerkingen.

De milieuvergunning wordt gezien als het 'ideaaltype' van de 'ambachtelijke' beschikking. Toch is ook bij de vergunningverlening in het milieurecht sprake van een zekere standaardisering van voorschriften. De beoordeling van verzoeken om vrijstellingen ex art. 19 WRO is niet minder ambachtelijk en kent een grote mate van beleidsvrijheid. Deze WRO-bevoegdheid houdt strenge maatstaven in voor de belangenafweging. In beroepsprocedures bij de bestuurstechter staat dit type besluitvorming regelmatig ter discussie. ${ }^{43}$ Het aantal besluiten op het beleidsterrein van de volkshuisvesting en de ruimtelijke ordening is doorgaans groot. Het merendeel van de ingediende bezwaarschriften ( $80 \%$ ) was in de arobperiode bij gemeenten ${ }^{44}$, afkomstig uit de "hoek" van de ruimtelijke ordening en het bouwrecht. Dit is nog steeds het geval.

Naast verschillen tussen bestuursorganen (aard, schaal en organisatie), is er ook een discrepantie tussen de beleidsterreinen van bestuursorganen. Bij het ene beleidsterrein (ruimtelijk bestuursrecht en milieurecht) kunnen derden-belanghebbenden zijn betrokken. De openbare (uitgebreide) voorbereidingsprocedures van de afdelingen 3.4 en $3.5 \mathrm{Awb}$ of afdeling 3.3 (externe advisering), worden vrijwel uitsluitend toegepast bij ambachtelijke besluiten. Op andere beleids-

42 Zie in dit verband o.a.: Van Wijk/Konijnenbelt/Van Male, Hoofdstukken wan administratief recht, tiende dr., Den Haag 1997, p. 224 e.v.

43 A.R. Neerhof, Het geschill voorbij, Deventer 1995, p. 118. Zie ook: A.W. KLlassen, Ruimtelijk beleid in theorie en praktijk, vierde dr., "s-Gravenhage 1994, p. 181 e.v.

44 Zie in dit verband: C.M. Breeuwsma, E. Helder, en E. Nijmeijer e.a., Arob-prakijken, Deventer 1984 , p. 310. 
terreinen (subsidie- en financiële beschikkingverlening), spelen deze aspecten lang niet altijd een rol.".5

De uitkomsten van de deelonderzoeken zijn voor de evaluatie-commissie reden tot twijfels over de inrichting van de bezwaarschriftenprocedure voor de 'beschikkingenfabrieken' (onnodig zwaar). De bezwaarschriftenprocedure bij de beschikkingenateliers wordt nogal eens als een doublure ervaren. Voor de "beschikkingenateliers' zou deze procedure soms niet meer dan een herhaling van zetten betekenen.

Men kan hier anders over denken indien de resultaten van de kwaliteit van de beslissingen op bezwaarschriften onder ogen worden gezien. In een groot aantal gevallen zijn de beslissingen op het bezwaarschrift rechtens onjuist. Uit een door K. Sanders gegeven overzicht blijken de volgende vernietigingspercentages ${ }^{46}$ :

- inkomstenbelasting en vennootschapsbelasting elk 29 procent in 1994;

- loonbelasting in 1994, 35 procent;

- studiefinanciering in 1994, 53 procent;

- beslissingen op het bezwaarschrift (1995) in het kader van de kinderbijslag, 25 procent.

Op basis van de uitkomsten van de deelonderzoeken beeft de evaluatiecommissie een zestal varianten geformuleerd voor het onder voorwaarden, achterwege laten van de bezwaarschriftenprocedure. Deze varianten, waaraan ook nadelen kleven, hebben de volgende consequenties ${ }^{47}$ :

1. bij bijzondere wet wordt de bezwaarschriftenprocedure uitgezonderd;

2. conform het Voorontwerp Algemene wet bestuursrecht wordt alsnog tot invoering overgegaan van een facultatieve bezwaarschriftenprocedure;

3. naast afdeling 3.5 (uitgebreide) openbare voorbereidingsprocedure wordt de openbare voorbereidingsprocedure ex afdeling 3.4 van de verplichte bezwaarschriftenprocedure uitgezonderd;

4. de bezwaarschriftenprocedure wordt achterwege gelaten als alle belanghebbenden en het bestuursorgaan daarmee instemmen;

5. de bezwaarschriftenprocedure wordt achterwege gelaten als het besluit met toepassing van afdeling 3.4 is voorbereid en alle belanghebbenden daarmee instemmen;

45 A.w., p. 29.
46 OB 1997, 4, p. 22.
4. A.w., p. 53 e.,.


6. de bezwaarschriftenprocedure wordt achterwege gelaten als hangende deze procedure een voorlopige voorziening is gevraagd en de rechter met instemming van partijen, de zaak ten gronde beslist.

De evaluatiecommissie heeft het kabinet aanbevolen deze zes varianten te doen onderzoeken. ${ }^{4 B}$

De aambeveling van een onderzoek naar alle varianten is niet overgenomen. Het kabinet is van oondeel dat de evaluatie van de Awb heeft aangetoond, dat de bezwaarschriftenprocedure in veel gevallen een grote toegevoegde waarde heeft. Vooral de omvang van het beroep op de bestuursrechter is binnen redelijke grenzen gebleven. ${ }^{49}$ Kennelijk hecht het kabinet grote waarde aan de zeefwerking van de bezwaarschriftenprocedure.

Over de varianten 3 en 5 voor het uitsluiten van de bezwaarschriftenprocedure, indien een besluit is voorbereid met toepassing van afdeling 3.4 (openbare woorbereidingsprocedure), oordeelt het kabinet dat op basis van de evaluatie van het deelonderzoek ruimtelijk bestuursrecht en milieu, geen nader onderzoek nodig is. De bezwaarschriftenprocedure zou bij toepassing van een openbare voorbereildingsprocedure door de ruime gelegenheid tot het inbrengen van bedenkingen, geen toegevoegde waarde hebben. Doorgaans zou het bestuursorgaan niet snel tot een heroverweging overgaan. Een nader onderzoek naar het uitsluiten van de bezwaarschriftenprocedure, voor het geval afdeling 3.4 is toegepast, acht het kabinet niet nodig. ${ }^{50}$ Er zal een wetsvoorstel worden gedaan tot samenvoeging van de afdelingen 3.4 en $3.5 .^{51}$

Over het kabinetsstandpunt om geen (vervolg) evaluatie te verrichten over de praktijk van de toepassing van de afdelingen 3.4 en 3.5 Awb kan verschillend worden gedacht. ${ }^{52}$

Uit de MvT van de Awb is op te maken dat de uitgebreide voorbereidingsprocedure van afdeling 3.4 als een uitgebreide hoorprocedure moet worden gezien en "bepaalde" trekken kan vertonen van het maken van bezwaar vooraf.

Het horen zou zich in deze procedure niet hoeven te beperken tot het vaststellen van gegevens over feiten en belangen. Ook kan in deze procedure aandacht

48. A.W. , p. 55 .

49 TK 1997-1998, 25600 VI, nr. 46 (Kabinetsstandpunt) p. 24.

50 A.W., p. 18.

5) A.W. p. 49.

5. Zie aanbeveling 29 van de evaluatiecommissie, p. 97 
worden besteed aan de bezwaren van belanghebbenden. Afdeling 3.4 wordt gekenschetst als een inspraakprocedure 'op hoofdlijnen' (naar voren brengen van zienswijze door belanghebbenden), die waarborgen biedt voor een zorgvuldige besluitvorming. ${ }^{54}$ De uitgebreide openbare voorbereidingsprocedure van afdeling 3.5 bevat extra waarborgen en is gedetailleerder van opzet (bedenkingen door een ieder). ${ }^{55}$ Een bezwaar tegen het kabinetsstandpunt is dat de lichtere procedure geintegreerd wordt in de zwaardere procedure.

Ofschoon zowel afdeling 3.4 als afdeling 3.5 zwaardere waarborgen beogen te creëren voor de voorbereidingsfase van het primaire besluit, zijn beide procedures niet gericht op een heroverweging zoals die voor de bezwaarschriftenprocedure geldt. De inschakeling van een art. 7:13-adviescommissie is niet mogelijk. Bij deze voorbereidingsprocedures is het vragen van een voorlopige voorziening uitgesloten. ${ }^{56}$ Deze procedure is geen besluit in de zin van art. 1:3 Awb.

Deze argumenten hoeven niet te betekenen dat het kabinetsstandpunt niet zinvol zou zijn. Indien een procedure ter voorbereiding van een primair besluit extra zorgvuldigheidsmaatstaven kent, dan zou in beginsel het alschaffen van de bezwaarschriftenprocedure ter discussie kunnen staan. De bezwaarschriftenprocedure heeft in de praktijk geleid tot een betere inzet van juridische expertise in de bestuurlijke organisaties. Doorgaans worden gebreken in de primaire fase hersteld. Er is sprake van grote administratieve onnauwkeurigheid bij overheidsorganisaties blijkens het jaarverslag (1996) van de N.o. $(63,8 \%)$.

Ook ten aanzien van de motivering $(64,5 \%)$, de zorgvuldigheid $(52,1 \%)$, de actieve informatieverstrekking $(56,3 \%)$, de actieve informatieverwerving $(49,4 \%)$ en de voortvarendheid bij herstel van fouten $(71,7 \%)$, handelen bestuursorganisaties in hoge mate onbehoorlijk. Wanneer hieraan nog wordt toegevoegd een aantal in dit rijtje niet genoemde aspecten van onbehoorlijkheid, dan resteert er een bedenkelijke balans van het handelen door bestuursorganen ten opzichte van de justitiabelen. ${ }^{57}$ Veel primaire bestuursbesiuiten gaan mank aan voldoende juridische deskundigheid. Onvoldoende juridische deskundigheid heeft de kwaliteit van de primaire besluitvorming soms naar een bedenkelijk niveau doen

54 PG Awb II, P. 44.

$\$ 5$ A.W.

st J.M. Stam, Een ingrijpende wijziging van de Algemene wet bestuursrecht, Gst. 6983, p. 121.

37 M. Oostring, De overheid in 1996, beoordeeld door de Nationate ombudsman, Best. $1997, p$. 91. Zie ook jaarverslag N.o. 1997, TK 1997-1998, nurs. 1 en 2. 
dalen. De roep om revitalisering van de juridische kwaliteitszorg bij de overheid is actueel. ${ }^{\text {s8 }}$

Gezien de minder goede situatie wan de juridische kwaliteitszorg in het overheidsbestuur zou het meer voor de hand hebben gelegen, dat het kabinet zijn beslissing in een breder perspectief had overwogen. Het kabinet zou er beter aan hebben gedaan de aanbeveling van de evaluatiecommissie te volgen en de praktijk inzake de toepassing van de afdelingen 3.4 en 3.5 meer diepgaand te laten evalueren. ${ }^{59}$ De beslissing van het kabinet is veeleer gebaseerd op procedurele overwegingen. Een actuele visie over de bestuurspraktijk ontbreekt.

Openbare (uitgebreide) voorbereildingsprocedures zijn primaire besluitvormingsprocedures en bij de uitvoering hiervan manifesteert zich een gebrek aan juridische kwaliteitszorg. Deze juridische kwaliteitsproblemen zijn weliswaar niet af te leiden uit bijvoorbeeld het deelonderzoek ruimtelijk bestuursrecht en milieu, maar wél blijkt dat de (openbare) uitgebreide voorbereidingsprocedures vrijwel nooit vrijwillig benut worden. Alleen een wettelijke plicht schijnt in dit geval als een stok achter de deur te werken. ${ }^{\text {so }}$

De geringe animo wordt door enkele ambtenaren gemotiveerd vanwege het lage rendement van de voorbereidingsprocedures ten opzichte van de aanvraagprocedure als bedoeld in hoofdstuk 4 Awb. De verhoging van de bestuurslasten zou niet opwegen tegen de eventuele effecten van een kwaliteitsverbetering van de besluitvorming. ${ }^{6 i}$

Het verband met de bestuurslasten en de kwaliteitsverbetering is reden tot een meer kritische aandacht voor het probleem van de versterking van de primaire besluitvorming. Hierin schuilt de zwakte van het argument voor de afwijzing van de (vrijwillige) toepassing van de procedures van de afdelingen 3.4 en 3.5 .

Ambtenaren die belast zijn met het primaire besluitvormingsproces staan doorgaans onder hoge druk om zaken snel af te doen. Zij wensen geen extra versterking van de zorgvuldigheid van de besluitvorming. Men ervaart dit als een (extra) (bestuurs)last.

Het kabinetswoorstel tot het samenvoegen van de afdelingen 3.4 en $3.5 \mathrm{Awb}$ is wat overhaast genomen. Een aanvullend empirisch onderzoek zou de consequenties van een dergelijke samenvoeging duidelijker in beeld kunnen brengen. De

58 Bestuur in geding, a.w., p. 13 en 14, Zie ook: par. 6.5 van dit boek.

59 A.W., p. 94.

60 B.J. Schueler e. $a_{n}, a_{1}$, p. 100.

61 A.M. 
(samenhangende) effecten van het vervallen van de bezwaarschriftenprocedure zouden tot betere inzichten hebben kumnen leiden. Door het starten van een proeftuinproject met een versterkte primaire fase (samenvoegen afdelingen 3.4 en 3.5), zou een meer verantwoorde analyse mogelijk zijn geweest.

De huidige mogelijkheid, waarin een uitgebreide voorbereidingsprocedure (afdeling 3.4) kan worden gevolgd, zou kunnen worden gehandhaafd. Wél zou art. $7: 1$, lid 1 onder $d$, kunnen worden uitgebreid met afdeling 3.4. Her voordeel van een dergelijke variant zou meer recht doen aan de problemen van de juridische kwaliteitszorg. Is de primaire besluitvormingsprocedure in een organisatie zwak, dan heeft het bestuursorgaan de mogelijkheid om geen gebruik te maken van afd. 3.4. In dit laatste geval zou dan de bezwaarschriftenprocedure verplicht zijn. Is er sprake van een sterkere 'primaire' juridische expertise, dan zou het bestuursorgaan kunnen kiezen voor het toepassen van afdeling 3.4, waardoor de bezwaarschriftenprocedure kan komen te vervallen.

Het kabinetsstandpunt is nu in hoofdzaak genomen op basis van eenzijdige onderzoeksaspecten (onder andere de doublure van het horen in de bezwaarfase en de inschakeling van een adviescommissie). In de volgende paragrafen wordt hierop nog nader ingegaan.

Het kabinetsstandpunt kan op bijval rekenen van het bedrijfsleven. Men ziet een "standaardprocedure' van de afdelingen 3.4 en 3.5 als 'de uitzonderingen' voor de bezwaarschriftenprocedure (het ei van Columbus). ${ }^{62}$

Over de heroverweging in het kader van de bezwaarschriftenprocedure wordt immers zeer verschillend gedacht.

Het kabinet lijkt gehoor te geven aan de inhoud van het rapport 'Bestuur in geding". De werkgroep Van Kemenade erkent het nut van de bezwaarschriftenprocedure voor typen van besluiten, waarbij sprake is van massabeschikkingen (bijv. op grond van de Algemene bijstandswet) vanwege de grote zeefwerking. Bij besluiten die via maatwerk (bijw. op het terrein van de ruimtelijke ordening en milieu) tot stand zijn gekomen, nadat hieraan een (uitgebreide) openbare voorbereidingsprocedure is vooraf gegaan, ziet de werkgroep de bezwaarschriftenprocedure als een herhaling van zetten. Nieuwe argumenten en het heroverwegen 
zouden nauwelijks tot een ander resultaat van belangenafweging leiden. ${ }^{63}$ De werkgroep beveelt twee wijzigingsvoorstellen aan:

a. het bestuursorgaan kan besluiten de heroverwegingsmogelijkheid achterwege te laten (het bestuursorgaan kan in het primaire besluit bepalen dat de bezwaarschriftenprocedure wordt overgeslagen $)^{64}$;

b. ten aanzien van de voorbereidingsprocedures in bijzondere wetten moet in meer gevallen afdeling 3.5 van toepassing worden verklaard. ${ }^{65}$

De Waard ziet niets in een eenzijdige facultatieve bezwaarschriftenprocedure. Een bezwaar tegen deze oplossing is dat het bestuursorgaan meteen aan de hand van het bezwaarschrift zou moeten beoordelen of een bezwaarschriftenprocedure zin heeft. Indien het primaire besluit geringe gebreken heeft is het beter om deze in een bezwaarschriftenprocedure te herstellen. Een (tweezijdige) facultatieve bezwaarschriftenprocedure verdient volgens De Waard de voorkeur. Het bestuursorgaan en de belanghebbende( $n$ ) moeten de bevoegdheid hebben om aan te geven dat de bezwaarschriftenprocedure wordt overgeslagen. ${ }^{66}$

Ook Bosch ziet in een goede heroverweging betere kansen voor zowel het bestuursorgaan als de burger. Een beter onderbouwd besluit en het alsnog overtuigen van de burger komt het belang van de filterwerking van de bezwaarschriftenprocedure ten goede. Bosch benadrukt dat een goede heroverweging niet synoniem is met het gegrond verklaren van het bezwaar.

De verplichte bezwaarschriftenprocedure verdient de voorkeur. Flexibilisering van deze procedure ter voorkoming van lange behandelingstermijnen, is naar de mening van Bosch mogelijk door een bezwaarschrift versneld af te doen via de kennelijksheidsbepalingen van art. 7:3 (achterwege laten van de hoorplicht bij ongegrond en niet-ontvankelijk bezwaarschrift). Het toepassen van art. 7:3 Awb biedt volgens Bosch meer rechtsbescherming dan de facultatieve bezwaarschriftenprocedure. De rechter toetst de beslissing van het bestuursorgaan immers aan de motiveringsplicht van art. $7: 12 .^{67}$

Soms wordt de bezwaarschriftenprocedure ervaren als een procedure, waarvan de negatieve uitkomst voor het bestuursorgaan bij voorbaat vaststaat. Voor primaire besluiten waarover intensieve contacten tussen het bestuur en het bedrijfsleven

63 A.W., zie 0.a.: p. 85 en 86.

64 A.w., p. 85 en 91 .

65 A.W., p. 91.

66 B.W.N. de Waard Knellend bestuursrecht, NTB 1998, p. 64.

67 J.J.A. Bosch, De bezwaarschriftenprocedure moet blijven, NJB 1996, p. 1215. 
zijn geweest, zal het bestuursorgaan ook ná een ingediend bezwaar, geen duimbreed toegeven aan de bezwaarde(n).

Biesheuvel zegt dat de verplichte bezwaarschriftenprocedure een vergissing is. $\mathrm{Zij}$ moet worden ingeruild voor een facultatieve voorprocedure. ${ }^{68}$ Vanderheijden, bestrijdt het standpunt van Biesheuvel. Hij wijst op de hoge gegrondverklaringen bij op bezwaarschriften genomen beslissingen (1994: 44\% en 1995: 40\%). ${ }^{69}$

Herweijer corrigeert het negatieve beeld over de zin van de bezwaarschriftenprocedure op basis van een onderzoek naar de naleving van de Awb. Uit een Awbonderzoek naar het niveau van de uitvoering van de Werkloosheidswet en de premieheffing werknemersverzekeringen ${ }^{70}$, blijkt de bereidheid van bestuursorganen om in de bezwaarprocedure terug te komen op primaire besluiten. De cijfers over de uitvoering van de Werkloosheidswet spreken voor zich: bij 47 procent van ingediende bezwaren leidde de beslissing op het bezwaarschrift tot een gegrond-verklaring (1995). De bezwaarschriftenprocedure voor premieheffing werknemersverzekeringen gaf een percentage van ongeveer 17 procent gegrondverklaringen te zien. ${ }^{71}$ In tegenstelling tot de meeste negatieve geluiden uit de bestuurlijke hoek en de advocatuur, geeft Herweijer aan dat blijkens een onderzoek bij bezwaarmakers (Werkloosheidswet en premieheffing werknemersverzekeringen), deze nogal positief oordelen over de bezwaarschriftenprocedure. Het valt op dat in $20 \%$ van de gevallen men negatief oordeelt over de bezwaarschriftenprocedure. De ondervraagden zien hierbij in de toekomst af van het indienen van bezwaar. Ook in deze gevallen is er een aanzienlijke zeefwerking ten opzichte van de primaire besluitvorming. ${ }^{72}$ De door Herweijer verstrekte onderzoeksresultaten adstrueren het belang van de burger bij een onderzoek van het nut van de bezwaarschriftenprocedure. Jammer is dat in de (brede) Awbevaluatie geen plaats is ingeruimd voor de justitiabele. Het lijkt vooralsnog een gemiste kans om het nut van de bezwaarschriftenprocedure ook 'relationeel' te beoordelen.

Op grond van het belang van de zeefwerking van de bezwaarschriftenprocedure en de procedurele complicaties bij meer-partijen-geschillen, besloot het kabinet af te zien van een onderzoek naar variant 2 (facultatieve bezwaarschriftenprocedu-

68 M.B.W. Biesheuvel, NJB 1996, p. 9310.

69. P. Vanderheijden, NJB 1996, p. 1112.

70 M.S. Beerten, De Algemene wet bestururstecht, CTSV Zoetermeer 1997 en T. Dammers, De Algemene wet besturssecht en de premiehefting werknemersverzekering.

7 M. Herweijer, Het Nut van de Awb voor bezwaarmakers OB 1997, 10, p. 20.

72 M. Herweijer, a.w. p. 21. 
re). ${ }^{73}$ De discussie over een enkelvoudige bezwaarschriftenprocedure (bij het primaire besluit wordt bepaald of bezwaar kan worden gemaakt) en een dubbele facultatieve voorprocedure (zowel het bestuursorgaan als de belanghebbende zijn bevoegd van de bezwaarprocedure af te zien) ${ }^{74}$, lijkt hiermee gesloten.

Minder nadelen ziet het kabinet in een mogelijke prorogatie conform variant 4 van de evaluatiecommissie. Met instemming van alle partijen kan door deze variant van de bezwaarschriftenprocedure worden afgezien. De Commissie Wetgeving algemene regels van bestuursrecht zal het kabinet adviseren over de voor- en nadelen van prorogatie. ${ }^{75}$ Ook zullen nog twee andere mogelijkheden worden onderzocht, te weten het zogenaamd 'doorpakken' (variant 6 evaluatiecommissie); het achterwege laten van de bezwaarschriftenprocedure tijdens de bezwaarfase in geval van een voorlopige voorziening en de rechter met instemming van partijen ten gronde beslist. ${ }^{76}$

Het kabinet besloot derhalve de eerste twee varianten van de evaluatiecommissie niet over te nemen (het uitsluiten bij bijzondere wet wan de bezwaarschriftenprocedure en het niet facultatief maken van deze procedure). ${ }^{77}$

Een nader onderzoek naar alle door de evaluatiecommissie voorgestelde varianten, wees het kabinet af. ${ }^{78}$

Toch komt het kabinetsstandpunt er op neer dat de advies-opdracht aan de Commissie Wetgeving algemene regels van bestuursrecht, ruim van inhoud en strekking is. ${ }^{79}$ De verplichte bezwaarschriftenprocedure is object van nader onderzoek, terwijl de evaluatiecommissie reeds bij de door haar aangereikte varianten, wees op de nadelen hiervan. ${ }^{80}$ Het kabinet komt zelfs met een aanvullende variant om bij een of meer vervolgbesluiten (op doelmatigheidsgronden) de bezwaarfase over te slaan. De rechter heeft dan de mogelijkheid ook samenhangende besluiten te beoordelen. De doelmatigheid van de bezwaarschriftenprocedure zou bijwoorbeeld twijfelachtig zijn bij besluiten waarin sprake is van een escalerend arbeidsconflict in het kader van het ambtenarenrecht. ${ }^{81}$

73 A.w., p. 25. Zie in dit verband: PG Awb I, p. 318.

74 Art. 6.2.9 en 6.2.10 Voorontwerp Awb.

75 A.w. p. 26.

76 A.W. P. 54.

77 A.w., p. 53 .

78 A.W., P. 25.

79 A.W., P. 50.

80 A.w., p. 54 e.w.

$\$ 1$ A.w. p. 26 en 27. 
Bij het kabinetsstandpunt om varianten te onderzoeken om in een aantal gevallen de bezwaarschriftenprocedure uit te sluiten, zijn enige kanttekeningen te maken.

Uit de diverse deelonderzoeken blijkt dat het eerste evaluatieverslag slechts een beperkt en zeer voorlopig beeld geeft van de bezwaarschriftenprocedure. Een evaluatie-periode van drie jaar bleek voor alle deelrapportages te kort. Voor een meer concrete vaststelling van de effecten van de Awb voor de besturspraktijk is deze wet te veelomvattend en complex. ${ }^{82}$

De evaluatie van de Awb is verricht in een inwerkperiode ${ }^{83}$ Bestuursorganen (en ook de bestuursrechters) die voor het eerst met de invoering van de verplichte bezwaarschriftenprocedure werden geconfronteerd, moesten ervaring opdoen.

Wanneer de (korte) evaluatieperiode wordt beoordeeld aan de hand van de praktijk met de Wet arob, dan blijkt het nut van een evaluatie over een langere periode. De zeefwerking van de bezwaarschriftenprocedure is ten tijde van de werking van de Wet arob sterk geëvolueerd. Deze positieve trend van de zeefwerking is vastgesteld in het rapport Arob-praktijken ${ }^{84}$ :

'Op lokaal niveau is vanaf 1976 (invoering Wet Arob) sprake van een aanzienlijke toename van het aantal bezwaarschriftenprocedures. Opmerkelijk is echter dat het aantal bezwaarschriften zich vanaf 1980 lijkt te stabiliseren. De tendens van toename, die zich in de daaraan woorafgaande jaren al liet karakteriseren als een "afnemende stijging", lijkt zelfss verdwenen.

Nagegaan is of deze stabilisatie ook uit andere gegevens blijkt en of het aantal beroepschriftenprocedures bij de Afdeling rechtspraak zicls stabiliseert.

Allereerst is daartoe onderzocht of er aanwijzingen zijn dat de filterfunctie van de bezwaarschriftenprocedure (de verhouding bezwaarschriften / beroepschriften) door de jaren heen sterk varieert. Voor de jaren 1978 - 1981 wordt echter dezelfde filterfunctie gevonden: ruim één beroepschrift wordt ingediend op vier bezwaarschriften. Tevens blijkt reeds in het enquêteonderzoek onder de gemeenten dat de variatie in de filterfunctie per gemeente betrekkelijk gering is. Tensiotte blijkt uit de jaarverslagen van de Raad van State, dat het aantal beroepschriftenprocedures vanaf 1980 nauwelijks toeneemt, terwijl in de daaraan voorafgaande jaren de stijging steeds geringer werd.

Uit het voorgaande kunnen twee conclusies worden getrokken.

Allereerst kan worden vastgesteld, dat het aantal bezwaarschriftenprocedures zich aan het stabiliseren is. Ten tweede kan worden geconcludeerd dat het aantal beroep-

82 A.w., P. 3.

83 A.W. p. 8.

84 A.W., D. 308 en 309. 
schriftenprocedures de komende jaren wermoedelijk niet sterk zal groeien, zo niet zal stabiliseren."

Deze onderzoeksresultaten tonen aan, dat eerst twee jaar na de inwerkingtreding van de Wet arob, zich in de daaropvolgende periode van vier jaar de effecten van de zeefwerking duidelijk vruchten afwerpen omdat daama stabiliserende factoren van invloed zijn en positieve effecten hebben op de uitvoering van wettelijke voorschriften. Op wat langere termijn zijn de positieve effecten van de zeefwerking van de bezwaarschriftenprocedure nog groter.

Scheltema constateerde bij de invoering van de Awb dat gemeenten er steeds beter in zijn geslaagd om door een goede bezwaarschriftenprocedure verreweg het grootste aantal bezwaren intern af te handelen. Minder dan een op de tien bezwaarschriften leidt tegenwoordig tot een beroep op de rechter, terwijl dit aantal in het verleden twee tot driemaal zo hoog was. ${ }^{85}$

Met Scheltema moet worden toegegeven dat de ervaring moet leren of de door de Awb gemaakte keuzes in alle opzichten de meest geslaagde zijn. ${ }^{86}$ Hiermee is niet gezegd dat op basis van empirische gegevens geen versoepelingen van de bezwaarschriftenprocedure moeten worden overwogen. Maar flexibilisering mag in het belang van een goede ontwikkeling van het bestuursrecht de doelstelling van de Awb niet elimineren. ${ }^{87}$

Door de keuze van het kabinet voor een onderzoek naar de mogelijkheden van de versoepeling van de bezwaarschriftenprocedure, dreigt het wel die kant op te gaan. Bestuursorganen waarvoor de bezwaarschriftenprocedure nieuw is, moeten evenals de gemeenten tijd en ruimte gegund krijgen, in te spelen op de praktische toepassing van deze voorprocedure.

Ofschoon met de evaluatiecommissie moet worden erkend dat het vooralsnog prematuur is om definitieve conclusies te trekken over de zeefwerking ${ }^{88}$, biedt de korte evaluatieperiode toch enkele opmerkelijke cijfers over de zeefwerking. Deze cijfers zijn niet zonder betekenis omdat in aanmerking is genomen dat het hierbij ook gaat om sectoren waarvoor de bezwaarschriftenprocedure nieuw is. In

M. Scheltema, Waarom is een codificatie van het bestursrecht belangrijk?, in: Bestuur, burger en rechtspraak, Alphen aar den Rijn, p. 35.

B6 A.W. p. 35 .

87 A.w. P. 35 .

88 A.w. p. 52 . 
het ambtenarenrecht is bijvoorbeeld het aantal beroepszaken teruggelopen door de invoering van de bezwaarschriftenprocedure. ${ }^{89}$

Ofschoon het voornemen van het kabinet om de bezwaarschriftenprocedure over te slaan bij besluiten die nauw samenhangen met een besluit waartegen reeds beroep is ingesteld om proces-economische redenen niet aanstonds onaantrekkelijk lijkt ${ }^{90}$, is het niet onverstandig deze (aanvullende) kabinetsvariant zorgvuldig te onder-zoeken. Jurisprudentieonderzoek lijkt hier nodig. De ambtenarenrechter toetst besluiten en handelingen van bestuursorganen (extra) zorgvuldig.

Het beoordelen en het bewijzen van feiten is voor menig bestuursorgaan in ambtenaarrechtelijke kwesties of bij de sluiting van drugspanden nogal eens een probleem. Voor het bewijzen van feiten bij het nemen van besluiten in drugszaken is zelfs voor bestuursorganen een protocol ontworpen. ${ }^{91}$

Ontslagbesluiten door bestuursorganen worden door de ambtenarenrechter kritisch getoetst. Er moet sprake zijn van een voldoende onderbouwing door het bestuursorgaan. Bij afvloeiingsregelingen moet door het bestuursorgaan worden aangetoond op welke wijze toepassing is gegeven aan de bepalingen van de afvloeiingsregeling. Hoe feitelijk de ambtenarenrechter oordeelt blijkt uit de volgende overwegingen:

'Dat de afvloeiingslijst van maart 1991 slechts de status van een concept zou hebben is noch duidelijk uit de lijst zelf noch uit het begeleidend schrijven. Gelet op de functie en het karakter van de te hanteren afvloeiingslijst is de raad van oordeel dat bij hel nemen van een besluit als i.c. in geding slechts een afvloeiingslijst kan worden gehanteerd die op de juiste wijze is vastgesteld dan wel zich in een vergaand stadium van vasistelling bevindt en dienovereenkomstig haar uiteindelijke invulling heeft gekregen." 92

In een andere ontslagkwestie kwamen de volgende 'bewijsaccenten' aan de orde. Een ambtenaar was wegens ernstig plichtsverzuim ontslagen. Ter zitting erkende de ontslagen ambtenaar dat hij betrokken was geweest bij de verkoop van de mini containers. Daarentegen bleek uit een meldingsformulier over deze verkoop dat de ontslagen ambtenaar niet was 'herkend als de verkoper' van de mini containers. Eerst tijdens het verhoor van een getuige ter zitting bleck dat de werkoop van de mini containers door een voormalig collega van de ontslagen ambtenaar

89 A.W., P. 52 .

90 A.W. p. 27.

91 Zie in dit verband: H.M.B. Breunese, I.G. Brouwer en A.E. Schidder, Wapemen tegen drugsoverlast, Deventer 1996, p. 261.

92. CRWB 22 september 1994, AB 1995, 42, m. nt. HH. 
had plaatsgevonden. De CRvB concludeerde dat er sprake was van een onzorgvuldige voorbereiding van het strafontslag. Daarbij werd mede in aanmerking genomen dat 'de aard en de omvang van het gedaagde verweten plichtsverzuim zo vaag zijn gebleven dat het de Raad in feite onmogelijk is gemaakt de ernst van het plichtsverzuim goed te beoordelen'.93

Een andere zaak toont aan hoe oplettend bestuursorganen moeten zijn bij het adstrueren van hun besluitvorming in ontslagzaken. Een veroordeling tot een vrijheidsstraf is niet zonder meer een reden tot ontslag. Ook het weigeren van een ontslaguitkering moet kritisch worden beoordeeld. De aanwezigheid van medische rapporten die door de eisende ambtenaar zijn overgelegd zijn ten onrechte buiten de besluitvorming gelaten. De CRvB tikt het bestuursorgaan met de volgende overweging kritiseh op de vingers:

'Zoals de raad meermalen heeft overwogen brengen de ten aanzien van een deugdelijke besluitvorming te stellen eisen met zich dat een administratief orgaan zich op grond van alle relevante feiten en omstandigheden zelfstandig een oordeel dient te vormen.

In het kader van de heroverweging moeten de feiten die aan het primaire besluit ten grondslag liggen opnieuw worden getoetst. Helder meent dat het niet juist is om het vaststellen van feiten 'teveel over te laten aan de bezwaarschriftenfase'. Toch is het opnieuw onderzoeken van de feiten een van de zwaartepunten in de omvang van de heroverweging. Ofschoon met Helder moet worden toegegeven dat de rechter in beroep of hoger beroep vanwege zijn rechtmatigheidstoetsing actief de feiten van het bestreden besluit moet onderzoeken ${ }^{96}$, betekent dit wél dat men het bestuursorgaan hierin een actieve rol toedicht. De rechter moet niet al te snel het leveren van bewijs aan zich trekken. ${ }^{97}$ Door het vaststellen van feiten (het verzamelen van gegevens en het motiveren van het besluit op basis van deze gegevens), vervult het bestuursorgaan een actieve rol ten dienste van de bewijs-voering bij de rechter. ${ }^{98}$

Ten tijde van de Awb blijkt de positieve lijn van de zeefwerking zich door te zetten. Blijkens het deelonderzoek Aspecten van de financiële beschikkingverlening is vastgesteld, dat bij de meeste onderzochte wetten het zeefpercentage,

93 CRvB 3 november 1994, JB 1994, 343 m.nt. ABJH/ELB.

94 CRvB 18 augustus 1994, AB 1995, 16 m.nt. HH.

95 E. Helder, Naar een soepeler bezwaarschriftenprocedure, OB 1997, 9, p. 18.

96 A.W.

97 M. Heldeweg, Normstelling en expertise "Maastricht 1993, p. 283.

96 S. Pront-van Bommel, Onrechtmatig verkregen bewijs, in: In de sfeer wan administratief recht, Utrecht 1994, p. 346. 
landelijk gezien meer dan 90 procent bedraagt. ${ }^{99}$ Bij de inkomstenbelasting blijkt, landelijk slechts in 2,2 procent van de bezwaarschriften, een beroep te volgen. Voor de vennootschapsbelasting en de loonbelasting is een landelijke beroepenratio vastgesteld van respectievelijk 6,6 en 2,1 procent. De bezwaarschriftenprocedure voor de studiefinanciering leidt in 5,3 procent van de gevallen tot een beroepschrift.

Voor de besluiten op het gebied van de sociale zekerheid is de zeefwerking als volgt vastgesteld:

- Werkloosheidswet 2,7 procent van het aantal ingediende bezwaarschriften (SFB);

- Werkvoorzieningen AAW, landelijk percentage: 6, (Detam);

- Bijstandsverlening: 14\% (10\% voor de 'mediane' gemeente).

Wanneer deze 'zeefpercentages' worden afgezet tegen het kabinetsstandpunt om de mogelijkheid van prorogatie te doen onderzoeken, dan kan de noodzaak van een dergelijk onderzoek worden betwijfeld. De mogelijkheid van prorogatie (overslaan van de bezwaarschriftenprocedure) is inmiddels in art. 26 Awr geschrapt. Er is weinig gebruik van gemaakt. ${ }^{100}$ Of de behoefte aan een prorogatieregeling voor de verplichte bezwaarschriftenprocedure doelmatig is ${ }^{101}$, moet gelet op de resultaten van het deelonderzoek financiële beschikkingverlening worden betwijfeld.

Daarbij komt nog dat het voordeel van de bezwaarschriftenprocedure mede afhangt van de vraag hoe intensief de voorbereiding van het aan het bezwaar voorafgaande besluit is geweest. ${ }^{102}$

De deelonderzoeken Besluiten over ruimtelijke ordening en standplaatsen en Subsidiebeschikkingen, geven geen inzicht over de hoogte van het zeefwerkingspercentage. In het evaluatie-verslag wordt opgemerkt dat er 'sterke indicaties zijn dat de zeefwerking in sommige sectoren aanzienlijk is'. ${ }^{103}$ Bij de parlementaire behandeling van de Awb bleek de zeefwerking van de bezwaarschriftenprocedu-

99 A.w., p. 125 e.v.

100 Deelonderzoek handhaven Bestursprocesrecht, p. 27.

$101 \mathrm{~J}$.W. Ilsink en I.M. Fliers, Fiscaal bestuursprocesrecht, Monografieèn Awb, Deventer $1995, p$. 58.

102 Deelonderzoek het Bestuursprocesrecht, $\mathrm{p}, 27$

103 A.W. P. 52 . 
res bij de gemeenten 90 procent te bedragen en bij een enkele provincie 75 procent. ${ }^{104}$ De gemeenten 'scoorden' in ieder geval beter dan de provincies!

\subsection{De hoorplicht}

Op grond van art. 7:2 dient het bestuursorgaan voordat op het bezwaarschrift wordt beslist, de belanghebbenden in de gelegenheid te stellen om te worden gehoord. $^{105}$ Aan deze bestuurlijke verplichting die essentieel is voor de bezwaarschriftenprocedure, is uitvoerig aandacht besteed in hoofdstuk 3 van dit boek. Hierbij is vastgesteld dat de (formele) hoorverplichting materiële betekenis heeft voor de beslissing op het bezwaarschrift.

Het horen heeft zowel een waarborgfunctie voor de belanghebbende(n) als voor het bestuursorgaan. Deze functie is gericht op een zorgvuldige heroverweging. Door het horen kan de kwaliteit van de voor de heroverweging vereiste informatie worden versterkt. De onderbouwing van het bestreden besluit kan hierdoor worden verbeterd. ${ }^{106}$

De waarborgfunctie van het horen heeft de Awb uitgekristalliseerd in een viertal functies: het toelichten van het bezwaar, het verstrekken van nadere informatie, het creëren van oplossingen en het versterken van het vertrouwen in de bestreden beslissing. ${ }^{107}$ In par. 3.2.1.1 zijn deze (hoor)functies nader uitgewerkt. Deze specificatie leidde tot een aanscherping van een aantal belangrijke functionele uitgangspunten van de hoorplicht: het bestuursorgaan heeft door het horen een kans tot informatieverschaffing en tevens een plicht tot het nader adstrueren van het bestreden besluit. Op grond van art. 3:2 Awb (kennisvergaringsplicht) heeft het bestuursorgman een verificatieplicht. De feiten, de toepassing wan het recht en het beleid moeten andermaal worden getoetst. Het bestuursorgaan moet zich tijdens het horen actief en bemiddelend opstellen.

In par. 3.2.2.2 werd het belang van het geven van hoor en wederhoor onderzocht.

Bij het beginsel van hoor en wederhoor is uitgangspunt de gelijkwaardigheid van de belanghebbende( $\mathrm{n}$ ). Bij dit 'gelijke-kansen-aspect' vervult het verdedigingsbeginsel een belangrijke rol. Dit beginsel verplicht het bestuursorgaan tot het bieden van voldoende gelegenheid ter verdediging van standpunten op de hoorzit- 
ting. Hierdoor is het verdedigingsbeginsel belangrijk voor het in evenwicht houden van de processuele mogelijkheden van de ene belanghebbende ten opzichte van de andere.

Art. 7:3 Awb relativeert de hoorplicht doordat in enkele met name genoemde gevallen, het horen achterwege kan worden gelaten. Bij kennelijke niet-ontvankelijkheid en ongegrondheid van het bezwaar kan het bestuursorgaan (of de adviescommissie als bedoeld in art. 7:13), besluiten van het horen af te zien. Ook belanghebbenden kunnen kenbaar maken dat zij afzien van het recht on te worden gehoord.

Onnodige werkbelasting (bestuurslasten) en tijdverlies voor het bestuursorgaan of belanghebbenden, rechtvaardigen een versoepeling van de hoorplicht. ${ }^{\text {tos }}$ Wél blijkt uit de MvT dat een rechtens correct achterwege laten van de hoorplicht zorgvuldig behoort te geschieden; 'het koesteren van twijfels' over een mogelijke overschrijding van de 'zorgvuldigheidsgrens', zou betekenen dat belanghebbenden in de gelegenheid moeten worden gesteld om te worden gehoord.

Bij de parlementaire behandeling van de Awb is uitwoerig gediscussieerd over de evaluatie. Over de effecten van de hoorplicht voor de bestuurslasten kon geen duidelijk inzicht worden gegeven. De hoorplicht zou daarom worden geëvalueerd. ${ }^{109}$ Soms kan het horen geen redelijk doel dienen. In andere gevallen is het wél beter dat het bestuursorgaan de belanghebbende( $(\mathrm{n})$ hoort. Bij de evaluatie van de Awb zou worden bezien of ervaringen met de rechterlijke toetsing reden zou zijn tot bijstelling van de praktijk en de wetgeving. ${ }^{110}$

De evaluatiecommissie benadrukt in navolging van de $\mathrm{Awb}$, dat het horen een essentieel onderdeel vormt van de bezwaarschriftenprocedure. In de deelonderzoeken is ruim aandacht besteed aan de hoorplicht en de in art. $7: 3$ genoende uitzonderingen.

De evaluatiecommissie constateert dat ${ }^{111}$ :

vooral op het terrein van de subsidies de bepalingen van het horen (de hoorplicht en de uitzonderingen) verschillend worden toegepast;

108 PG Awb I, p. 332 a.W.

109 PG Awb I, p. $118 \mathrm{e}$ v.

110 PG Awb I, p. 60.

111 A.w., p. 48 en 49 . 
- het horen op het gebied van het ruimtelijk bestuursrecht en het milieurecht in de bezwaarfase veelvuldig leidt tot een doublure; tijdens de hoorzitting wordt weinig of niets toegevoegd aan hetgeen aan de orde is gesteld in het vooroverleg;

- het horen in het kader van de besluitvorming op het terrein van het ruimtelijk bestuursrecht en het milieu alleen dan geen doublure is indien er sprake is van een tussentijdse wijziging van de omstandigheden of in die gevallen dat een advocaat is ingeschakeld.

Uit de deelonderzoeken blijkt dat bestuursorganen in een aantal gevallen de hoorplicht in de bezwaarschriftenprocedure te rigide en weinig flexibel vinden. Gepleit wordt voor een differentiatie van de hoorplicht. De evaluatiecommissie is van oordeel dat ${ }^{12}$ :

1. de Awb de hoofdregel kent dat het horen in de bezwaarfase geschiedt door middel van een hoorzitting;

2. uit artikel $7: 3$, onder $c \mathrm{Awb}$ (afzien van het horen door belanghebbenden) mag worden afgeleid dat gekozen kan worden voor een minder vergaande "tussenvorm";

3. de Awb zich niet verzet tegen het door de bestuursorganen in overeenstemming met belanghebbenden kiezen voor een andere wijze van horen.

Op grond van de resultaten van het deelonderzoek Aspecten van de financiële beschikkingverlening, doet de evaluatiecommissie enkele bestuurlijke aanbevelingen voor een differentiatie van de hoorplicht.

De aanbevelingen van de evaluatiecommissie voor het bestuursorgaan ${ }^{113}$ die zijn overgenomen van het deelonderzoek financiële beschikkingverlening, komen er op neer dat ${ }^{114}$ :

bij toezending van de ontvangstbevestiging aan de belanghebbende een antwoordkaart wordt meegezondlen; deze antwoordkaart behoort te worden geretourneerd onder mededeling van de bezwaarde of deze all dan niet een hoorzitting wenst;

met instemming van de belanghebbende telefonisch kan worden gehoord, met dien verstande dat er slechts één belanghebbende is en dat het aanbeveling verdient voor het telefonisch horen interne regels vast te leggen $(. .$.$) ; de twee$

114 M.S. Beerten, e.a., a.w., p. 181 en 182 
beperkingen in de tweede zinsnede zijn toegevoegd door de evaluatiecommissie; $^{115}$

de ervaringen met het "flexibel" (telefonisch) horen bij de volgende evaluatie worden betrokken.

Het kabinet is van oordeel dat deze aanbevelingen van de evaluatiecommissie kunnen leiden tot belangrijke verbeteringen van de doelmatigheid van de bezwaarschriftenprocedure.

Het horen op verzoek (mededeling via antwoordkaart) zou in overeenstemming zijn met een redelijke wetsuitleg ten aanzien van artikel $7: 3$, onder $c$. Ook brengt een redelijke wetsuitleg mee dat indien belanghebbende binnen een redelijke termijn niet reageert, het bestuursorgaan mag aannemen dat deze geen gebruik wil maken van de hoorzitting. De aanbeveling van de evaluatiecommissie om telefonisch te horen indien sprake is van twee-partijen-geschillen (het bestuursorgaan en één belanghebbende), heeft het kabinet overgenomen. ${ }^{\| 16}$

De vraag kan worden gesteld of deze aanbevelingen voor een differentiatie van de hoorplicht niet tot praktische uitvoeringsproblemen zullen leiden. De rechterijke toetsingsmaatstaven voor de hoorplicht zijn immers nogal stringent.

De hoorplicht is essentieel voor de functie van de bezwaarschriftenprocedure. ${ }^{17}$ Dit laat onverlet de in art. 7:3 opgenomen uitzonderingen. Nog daargelaten dat deze uitzonderingen van de hoorplicht het bestuursorgaan nopen tot een zorgvuldige toepassing van de (uitzonderings)criteria van art. $7: 3 .{ }^{1 / 8}$

De twijfels over de differentiatie van de hoorverplichting worden versterkt door de duidelijke bedoelingen van de Awb over de functie van de hoorplicht. In de literatuur worden juist vooral de duidelijke bedoelingen van de Awb zo gewaardeerd. 119 In het begin van deze paragraaf is gewezen op het onderzoek van de hoorplicht in hoofdstuk 3 van dit boek. Hierin is vastgesteld dat de hoorplicht een belangrijke inrichtingseis is van de bezwaarschriftenprocedure. Deze inrichtingseis bevordert de kwaliteit van deze voorprocedure. Een weloverwogen en zo objectief mogelijke beslissing wordt veeleer bereikt door het horen dan door het achterwege laten van de hoorplicht. ${ }^{120}$

115 A.W. P. 97.

116 A.W.., p. 28.

117 PG Awb 1, p. 329 e.v.

118 PG Awb 1, p. 332 e.v.

119 A. M. Polak, De evaluatie wan de Algemene wet bestuursrecht, RegelMat, 19, p. 1 .

120 B.W.N. de Waard, a.w., D. 107 e.,. 
Ook Sanders concludeert op basis wan zijn onderzoek over de bezwaarschriftenprocedure bij de beschikkingenfabriek, dat indien een hoorzitting wordt gehouden meer informatie voorhanden is dan in zaken waarin niet is gehoord. Een vergelijking met de beslissing op het bezwaar en de primaire beschikking wijsit volgens Sanders uit, dat de motivering van de beslissing op het bezwaarschrift uitgebreider en "kwalitatief hoogwaardiger" is. ${ }^{121}$

Wanneer het kabinetsstandpunt voor een differentiatie van de hoorplicht wordt afgezet tegen de bevindingen in par. 3.2.2.2, onder b (Hoor en wederhoor als structuurbepalende (wettelijke) verplichting) van dit boek, dan is er reden tot aarzeling bij de flexibilisering van de hoorplicht. Op grond van de jurisprudentie is vastgesteld dat de rechter in beginsel strikt de hand houdt aan de hoorplicht (par. 3.2.1.1). Het horen moet geschieden op een wijze dat gesproken kan worden van "processueel" horen. Telefonisch horen beantwoord niet aan de minimum eisen van de Awb woor het horen in de bezwaarschriftenfase. ${ }^{122}$ De voor het bestuursorgaan gegeven varianten voor de hoorplicht, lijken op grond van de rechterlijke toetsing weinig ruimte te bieden voor flexibilisering.

Ook de onderzoeksresultaten in par. 3.2.2.2, onder c (Hoor en wederhoor in relatie tot de kennisvergaringsplicht naar relevante feiten en af te wegen belangen), indiceren het belang van de hoorplicht.

De praktijk van het beginsel van hoor en wederhoor toont soms aan hoe gebrekkig bestuursorganen met dit beginsel omspringen. Een probleem bij hoor en wederhoor is dat het bestuursorgaan of een adviescommissie, bereid en in staat moeten zijn te streven naar een dialoog met de belanghebbende(n). Een open en vrij overleg met wederzijdse actieve informatieverstrekking is volgens Brasz "theoretisch gezien in beginsel de enige goede houding" om aan hoor en wederhoor invulling te geven. Dit is naar de mening van Brasz vooral nodig omdat er geen sluitend bindend voorschrift van de regel wan hoor en wederhoor, in de bezwaarschriftenprocedure is opgenomen. In de bestuurspraktijk komt het nogal eens voor dat de bezwaar-maker als lastpost wordt ervaren. Een gevolg hiervan is dat dit kan leiden tot erosie van de positie van de behandeling van het bezwaar. ${ }^{123}$

$12 \mathbb{K}$. Sanders, a.w., p. 22.

$122 \mathrm{PG}$ Awb I, p. 330.

123 H.A. Brasz, Dertig jaar beroep- en bezwaarzaken, Een evaluatie, OB 1996, 3, p. 30 . 


\subsubsection{De financiële beschikkingverlening}

In het deelonderzoek Aspecten van financiële beschikkingverlening is uitgangspunt van het onderzoek van het horen ex art. 7:2, de Awb-conformiteit met het horen (primaire fase en bezwaarfase). Voor de bezwaarschriftenprocedures van de inkomstembelasting, de vennootschapsbelasting en de loonbelasting, kent de Awr een afwijking van de hoorplicht van art. 7:2. Op grond van art. 25, lid 4 Awr hoeft de belanghebbende alleen op verzoek te worden gehoord. Voor de studiefinanciering zijn de art. 7:2 en 7:3 tot en met 7:9 Awb niet van toepassing (art. $56 \mathrm{Wsf}$ ).

De uitkomsten van het deelonderzoek geven het volgende beeld over de naleving van de hoorplicht.

In het kader van de bezwaarschriftenprocedure wordt weinig gehoord. De meeste bezwaarschriften worden gegrond verklaard. Door de onbekendheid met de fiscale regeling van 'het op verzoek horen', wordt zelden gehoord. De Belastingdienst wijst in de ontvangstbevestiging niet op de mogelijkheid om te worden gehoord. Wel is er vaak informeel contact met de indiener van het bezwaarschrift. ${ }^{124}$

In de bezwaarfase wordt bij de uitvoering van de studiefinanciering niet gehoord. In die gevallen waarin de toetsing van de hardheidsclausule aan de orde is, wordt soms wél gehoord. ${ }^{125}$

Op het terrein van de socialle zekerheid vindt het horen regelmatiger plaats dan bij de fiscaliteit.

In het kader van de uitvoering van de Werkloosheidswet wordt doorgaans Awbconform gehoord. In ongeveer 25 procent van bezwalschriftenprocedures vindt een hoorzitting plaats. Er wordt meestal geen hoorzitting belegd ondat in veel gevallen $(20 \%)$ het bezwaarschrift wordt ingetrokken. Wél wordt steeds toepassing gegeven aan art. 7:3, sub a en b Awb (achterwege laten hoorzitting bij kennelijke niet-ontvankelijkheid en ongegrondheid van het bezwaar). ${ }^{126}$

In het onderzoek van de hoorverplichting bij de Werkvoorzieningen AAW is vastgesteld dat in ongeveer 75 procent van alle bezwaarschriften wordt gehoord. Een uitnodiging voor de hoorzitting vindt alleen plaats indien belanghebbende de wens te kennen geeft te worden gehoord. In de ontvangstbevestiging wordt de 
bezwaarde gevraagd of er behoefte bestaat aan een hoorzitting. In ongeveer $25 \%$ van de gevallen waarin niet is gehoord, heeft bezwaarde dit aan het bestuursorgaan medegedeeld. ${ }^{127}$

Het deelonderzoek financiële beschikkingverlening wijst uit dat de uitvoeringspraktijk van het horen in het kader van de bijstandsverlening 'in hoge mate' Awb-conform is. De indieners van een bezwaarschrift worden meestal gehoord. ${ }^{128}$

De uitkomsten van het deelonderzoek financiële beschikkingverlening tonen aan dat getwijfeld kan worden aan het kabinetsstandpunt, om de hoorplicht van het bestuursorgaan te versoepelen.

De voorstellen tot een differentiatie van de hoorplicht zijn gekoppeld aan de aanbeveling voor de drie fiscale deellonderzoeken (horen op verzoek). Vooral in de belastingpraktijk wordt weinig gehoord. Opmerkelijk is dat op basis van de onderzoeksgegevens blijkt dat geen antwoord kan worden gegeven op de vraag of het horen op verzoek zinvol is. ${ }^{129}$ Op grond van de eigen aard van de fiscaliteit is er regelmatig op gewezen dat de Awb-hoorplicht niet doelmatig is en kennelijk niet geschikt is voor de belastingwetgeving. ${ }^{130}$

Het onderzoek in het belastingrecht kan nauwelijks representatief zijn voor de uitkomsten van het deelonderzoek financiële beschikkingverlening. In het sociaal zekerheidsrecht wordt in hoge mate Awb-conform gehoord, terwijl het onderzoek van de Werkwoorzieningen AWW uitwijst dat in driekwart van de gevallen 'op verzoek" wordt gehoord.

Het walt op dat in het deelonderzoek financiële beschikkingverlening is geconstateerd dat het niet eenvoudig is om de mate van heroverweging te meten. De heroverwegingsplicht als bedoeld in art. 7:11 is slechts op indirecte wijze gemeten. Er is gebruik gemaakt van twee indicatoren: de motivering van de beslissing op het bezwaarschrift en de mate van het gebruik van standaardmotiveringen van de beslissing op het bezwaarschrift ten opzichte van de primaire

127 A.w. p. 82 .

128 A.W. P. 82.

$₫ 29$ A.w. p. 150 e.v.

130 Zie o.a.: Ch. P.A. Geppaart, De betekenis van de Algemene wet bestuursrecht voor het belastingrecht, Alphen aan den Rijn 1992, p. 30 en 31. In dit verband wordt opgemerkt dat het kabinet besloten theeft om een experiment te starten om na te gaan of de uitzondering van art. 25,1 id 4 Awr (horen op verzoek) kan vervallen. Zie in dit verband: het Kabinetsstandpunt, 2. w., p. 53 en 58. 
besluitvorming. ${ }^{13 \Downarrow} \mathrm{Bij}$ deze wijze van meten worden vraagtekens geplaatsi omdat de motivering van de beslissing op het bezwaarschrift niet op een lijn kan worden gesteld met de heroverwegingsnorm van art. 7:11. De motiveringsplicht is het formeel juridisch sluitstuk van de heroverweging en kan hiervoor niet in de plaats treden.

In de MvT van de Awb is deze voor de bezwaarschriftenprocedure afzonderlijk gestelde eis sterk benadrukt. ${ }^{132}$ Voor andere besluiten dan de beslissing op het bezwaarschrift, geldt de motiveringseis van art. 3:46 Awb.

Er zijn meerdere redenen om kritisch te oordelen over de flexibilisering van de hoorplicht (art. 7:2) en de ruimte die wordt toegedicht aan de toepassing van art. $7: 3$ (afzien van het horen).

\subsubsection{Subsidiebeschikkingen}

Uit het verslag van de evaluatiecommissie kan worden geconcludeerd dat vooral op het terrein van de subsidies de bepalingen over het horen zeer verschillend worden toegepast. Bij de uitvoering van sommige regelingen wordt bijna altijd in de bezwaarfase gehoord en is er een terughoudende toepassing te constateren van art. 7:3. In weer andere gevallen wordt veel minder gehoord door een frequente toepassing van art. $7: 3$, onder $b$ (bezwaar kennelijk ongegrond) en art. 7:3, onder d (bezwaar gegrond). Art. 7:3 wordt veelvuldig toegepast in de 'beschikkingenfabrieken". ${ }^{133}$

Het oordeel van de evaluatiecommissie lijkt niet voldoende 'sterk' voor een versoepeling van de hoorplicht. De Awb gaat er vanuit dat de bestuursorganen primair verantwoordelijk zijn voor de uitvoering van de bezwaarschriftenprocedure. Binnen het bezwaar-harmonie-model (de procedurevoorschriften), kan iedere organisatie het beste beoordelen op welke wijze invulling kan worden gegeven aan de heroverwegingsplicht. Of het horen al dan niet zinvol is kan beter door het bestuursorgaan worden beoordeeld. Naast het bestuursorgaan, heeft ook de justitiabele belang bij een rechtens juiste invulling van de hoorplicht. De doelstelling van de $A w b$ is weliswaar niet het creëren van een volstrekte uniformiteit van besluitvormingsprocessen, mar is gericht op het aangeven binnen welke normatieve grenzen de noodzakelijke variatie in de bestuurspraktijk moet blijven. ${ }^{134}$ Een

13) A.W., P. 98 en 99 .

132 PG Awb I, p. 351.

133 A.W., p. 49 e.v.

134 Evaluatieverslag, a.w, p. 34 en p. 9 van het Kabinetsstandpunt. 
minder sterk punt in het evaluatie-verslag is dat de burger niet in het onderzoek is betrokken. ${ }^{135}$ Dit aspect wordt door de evaluatiecommissie erkend en heeft geleid tot aanbeveling no. 26 om de ervaringen van de burgers bij de volgende evaluatie te betrekken. Uit het Kabinetsstandpunt blijkt niet of deze aanbeveling is overgenomen.

Dat de rol van de burger in het kader van de hoorplicht niet mag worden veronachtzaamd, kan worden vastgesteld aan de hand van de bevindingen bij de subsidieregeling voor kleine warmte-koppelingssubsidies.

Bij de uitvoering van deze subsidieregeling blijkt dat alle indieners van bezwaarschriften worden gehoord. Wëll wordt de belanghebbende in de uitnodiging voor de hoorzitting gevraagd om vooraf te reageren, indien er geen behoefte bestaat aan het horen. Blijkens de bevindingen in het deelonderzoek werd in 1994 nogal eens telefonisch contact opgenomen met de indieners van het bezwaarschrift. Hen is hierbij gevraagd of men van plan was ter zitting te verschijnen. Gezien de minder goede ervaringen met het telefonisch contact, heeft een dergelijke benaderingswijze tot voorzichtigheid geleid. ${ }^{136}$

In het onderzoek is komen vast te staan dat het aantal telefonische contacten drastisch is afgenomen. Slechts in eén dossier (1994) werd een telefoonnotitie aangetroffen. Een ontworpen handleiding voor de behandeling van bezwaarschriften bij de warmtekoppelingssubsidies, heeft bijgedragen tot een scherper besef van de risico's van het (niet formeel) contact. De beduchtheid voor schadeclaims heeft de contacten met de bezwaarden aanzienlijk doen afnemen. ${ }^{137}$ Uit het onderzoek van de warmtekracht-koppelingssubsidies blijkt nog dat voor zowel de aanvraag- als de bezwaarschriftenprocedure, door het uitvoerend agentschap Senter (fusie van twee uitvoerende diensten van het ministerie van Economische Zaken ${ }^{138}$, vanwege zijn financieel-juridische traditie, de Awb-implementatie een marginale inspanning heeft gekost. ${ }^{139}$

De bestuurspraktijk van het (informeel) vooroverleg is door de evaluatiecommissie in relatie gebracht met het informele bestuursrecht. De informele kant van het bestuursrecht is in de praktijk ontwikkeld omdat de wetgeving de bestuurlijke werkelijkheid niet volledig kan normeren. De evaluatiecommissie stelt vast dat

135 A.W. "P. 6.

136 A.w., p. 148.

137 A.W. p. 163 en 164 .

138 A.w. p. 145 .

139 A.W., p. 167. 
uif alle deelonderzoeken is gebleken dat het besluitvormingsproces in een aantal situaties in feite anders verloopt dan de Awb veronderstelt of regelt. ${ }^{140}$

\subsubsection{Ruimtelijke ordening, milieu en standplaatsen}

Het informele bestuursrecht manifesteert zich vooral in het ruimtelijk bestuursrecht en het milieurecht, maar ook in het subsidierecht. ${ }^{141}$ De vrijstellingsprocedures conform art. 19a WRO, lid 5, kennen de mogelijkheid tot het inbrengen van bedenkingen. Opgevallen is dat het horen in de zin van art. 4:7 Awb, voorafgaand aan de primaire besluitvorming door de dominante rol van het vooroverleg. bij vrijstellingsprocedures weinig zinvol wordt geacht. ${ }^{142}$ Bovendien wordt het horen in de bezwaarfase voor de terreinen van het ruimtelijk bestuursrecht en het milieu (door een derde van de respondenten) als een herhaling ervaren ten opzichte van het horen in de primaire fase. Meer dan de helft van de respondenten ziet de hoorzitting in het kader van de bezwaarschriftenprocedure als een doublure. Uit het (totaal)beeld van het ruimtelijke bestuursrecht en het milieugebied is af te leiden dat $90 \%$ van de ondervraagden van oordeel is dat het horen op bezwaar niet wezenlijk verschilt van het horen in de primaire fase. ${ }^{143}$

Er is reden tot enige terughoudenheid bij de bevindingen van het nut van het horen in de bezwaarfase.

Allereerst geeft de vraagstelling 'Komen doublures bij het horen in de primaire fase van besluitvorming en de bezwaarfase voor?', aanleiding tot bedenkingen tegen de uitkomsten van het deelonderzoek ruimtelijk bestuursrecht en millieu. De respondenten wordt al op voorhand een impliciete suggestie tot antwoorden aangereikt. De vraagstelling is bovendien procedureel wan aard, en ziet niet op de inhoudelijke kwaliteit van het horen. Juist dit laatste aspect is reden om hierbij stil te staan.

In het rapport Arob-praktijken is destijds vast komen te staan dat het bouwvergunnings- en vrijstellingsbeleid er doorgaans op gericht is om zoveel mogelijk aan de verlangens van vergunningaanvragers tegemoet te komen. ${ }^{144}$ In de bezwaarschriftenprocedure graaft het bestuursorgaan zich in. Blijkens het rapport Arobpraktijken 'leidt' de geneigdheid om zo enigszins mogelijk bouwvergunningen te

440 A.w. p. 31 .

(4) A.W., p. 31 .

142 Deelrapport rumtelijk bestuurstecht en milieu, p. 35.

143 A.w., p. 54.

14.4 A.w., p. 105 en 106. 
verlenen ertoe, dat de vrijstellingsmogelijkheden die thet bestemmingsplan bieden, meestal worden gebruikt. ${ }^{145}$

Aan deze "praktijk' is geen aandacht besteed in het deelonderzoek. Dit bevestigt nog eens dat het onderzoek ruimtelijke bestuursrecht c.a., en dat geldt voor alle onderzoeken, te zeer is benaderd vanuit de formele kant van de regels van de Awb. Bij de aandacht voor de procedures van de $\mathrm{Awb}$ en ook het bijzonder bestuursrecht, moet in aanmerking worden genomen dat het bestuursrecht meer is dan procedurerecht. Aan de orde is doorgaans de invulling van vage normen: wat is een goede ruimtelijke ordening, bescherming van het milieu, openbare orde en het algemeen belang. ${ }^{146}$ In de arob-periode is all vastgesteld dat het actualiseren van bestemmingsplannen een groot probleem vormt voor de gemeenten, waardoor het verlenen van vrijstellingen in de hand wordt gewerkt. ${ }^{147}$ Aanpassing van bestemmingsplannen zou het aantal bezwaarschriften op het terrein van het ruimtelijk bestuursrecht aanzienlijk doen verminderen. Ook in de Awb-periode komt hieraan blijkens de jurisprudentie nog geen einde; het verlenen van vrijstelling is eerder regel dan uitzondering. Adequate bestemmingsplannen zouden een deregulerend effect kunnen hebben op de bezwaarschriftenprocedures omdat het aantal vrijstellingen hierdoor zou kunnen afnemen. En deregulering staat immers hoog in het vaandel van de werkgroep Van Kemenade. ${ }^{148}$

Opvallend is de slechte respons van het onderzoek bij de gemeenten. (Deelrapport ruimtelijke ordening c.a. p. 27). Bovendien is bij het onderzoek een voorbehoud. gemaakt bij de beantwoording van nogal wat onderzoeksvragen. Veel factoren belemmerden een juiste en valide beantwoording. ${ }^{149}$

$\mathrm{Nu}$ voor het gehele evaluatie-onderzoek door het kabinet is geconcludeerd dat niet kon worden vastgesteld dat de bestuurslasten substantieel zijn gestegen ${ }^{150}$, heeft de auteur van dit boek twijfels over de aanbevelingen voor het differentiëren van de hoorplicht. Kwaliteit en expertise zijn doorgaans mede van belang voor de kwantiteit van uitvoering van regelingen en de snelheid van procedures. De evaluatiecommissie heeft weliswaar een onderzoek van de bestuurslasten aanbevolen, maar waarschuwt voor te hoge verwachtingen. Een betrouwbare meting van de bestuurslasten is nauwelijks mogelijk. ${ }^{\text {is! }}$

A.w., p. 105.

N.S.J. Koeman, Besturrsrecht is meer dan procedurerecht, NTB 1995, p. 94.

147 A.W., p. 106

148 A.w. p. 2.

149 Evaluatieverslag, $p, 16$.

150 A.w., p. 11.

151 A.w., p. 33 en 94. 


\subsection{Het adviseren over het bezwaarschrift}

In de hoofdstukken 4 en 5 van dit proefschrift is het adviseren over de op het bezwaarschrift te nemen beslissing, behandeld. Conform de Awb is her bestuursorgaan in beginsel verantwoordelijk voor de voorbereidingsfase van de beslissing op het bezwaarschrift. Dit geldt zowel voor het horen als het adviseren.

Het horen geschiedt door het bestuursorgaan, de voorzitter of een lid van het orgaan (art. 7:2). Maar het is ook mogelijk dat het horen, met behoud van de bestuurlijke verantwoordelijkheid voor de voorbereidingsfase door 'anderen' geschiedt. Wél moet dan voldaan worden aan enkele objectiviteitseisen voor de personen die met het horen zijn belast (art. 7:5, lid 1). ${ }^{152}$

In het belang van een goed verloop van de bezwaarschriftenprocedure vindt de hoorverplichting van het bestuursorgaan in de Awb nadere regeling in de art. 7:2 tot en met 7:9. Deze bepalingen bevatten minimale inrichtingseisen voor de bezwaarschriftenprocedure. Deze zijn afgestend op het hernieuwd toetsen door (of namens) het bestuursorgaan van de (rechts)feiten en belangen van het bestreden primaire besluit.

Mede door deze inrichtingseisen van de hoorplicht wordt de basis gelegd voor het maken van de heroverweging (art. 7:11, lid $1 \mathrm{Awb}$ ). De beslissing op het bezwaarschrift wordt met inachtneming van de heroverwegingsplicht, in beginsel genomen binnen zes weken ná ontvangst van het bezwaarschrift (art. 7:10, lid 1). Het bestuursorgaan moet een beslissing op het bezwaarschrift nemen die berust op een deugdelijke motivering (art. 7:12 Awb). In deze opsomming van formele verplichtingen van het bestuursorgaan ontbreken in tegenstelling tot het horen, voorschriften over de wijze, waarop het adviseren aan het bestuursorgaan moet geschieden. Toch is het adviseren ower het bezwaarschrift naast het horen, een belangrijk element in de voorbereidingsfase van de beslissing op het bezwaar. Uit art. $7: 10$, lid 1 blijkt, dat indien een commissie als bedoeld in art. $7: 13$ is inge steld, het bestuursorgaan over een langere beslistermijn beschikt (tien weken).

De Awb koppelt een langere beslistermijn aan het inschakelen van een adviescommissie in de zin van art. 7:13. Uit de MvT van de Awb blijkt dat in het systeem van afdeling 7.2 de bijzondere regelgever bepaalt op welke wijze het adviseren in de bezwaarfase gestalte moet krijgen.

152 ABRS 16 december 1997, JB 1998, 24, m.nt. RJNS, ABkort 1998, 30, Gst. 7077, 5 m.nt. C.P.J. Goorden. 
De Awb opteert in beginsel voor een volledige bestuurlijke verantwoordelijkheid woor de inrichting van de adviesprocedure ten behoeve van de beslissing op het bezwaarschrift. Wél wijst de MVT er op dat onder omstandigheden 'sterke argumenten' zijn aan te voeren om een adviescommissie in te schakelen. Het rapport 'Arob-praktijken', de voorkeur van de VNG en het voorstell van de commissie De Gaay Fortman (Commissie Arob), zouden aanknopingspunten bieden voor de noodzaak tot het adviseren door een adviescommissie. ${ }^{153}$

De keuzevrijheid die de $\mathrm{Awb}$ aan de bijzondere regelgever heeft gelaten komt er op neer dat het adviseren over de beslissing op het bezwaarschrift op uitleenlopende manieren mogelijk is. Het bestuursorgaan kan zich laten adviseren door uitsluitend ambtenaren, zonder dat sprake is van een adviescommissie. Ook is het adviseren mogelijk door een volledig intern samengestelde commissie, bestaande uit ambtenaren en/of het bestuursorgaan dan wel leden van het bestuursorgaan. Een adviesprocedure kan ook gecreëerd worden door het inschakelen van een adviescommissie van gemengde samenstelling. In dit geval hebben zowel een of meer personen, afkomstig buiten de kring van het bestuursorgaan en leden die deel uit maken van het bestuursorgaan of aan dit orgaan ondergeschikte personen, zitting in de adviescommissie. Een adviescommissie kan ook volledig uit buitenstaanders bestaan. De samenstelling van de adviescommissie is dan volledig extern en onafhankelijk van het bestuursorgaan.

Indien een adviescommissie is ingesteld die uit externe personen bestaat, beschikt over een voorzitter en ten minste twee leden en deze commissie tevens voldoet aan bij wettelijk voorschrift gestelde andere eisen, dan verbindt de Awb hieraan in art. 7:13, gevolgen voor de voorbereidingsfase van de beslissing op het bezwaarschrift. De verantwoordelijkheid voor het horen en het adviseren omtrent de op het bezwaarschrift te nemen beslissing wordt verlegd van het bestuursorgaan naar de adviescommissie. Ook de instelling van een adviescommissie van gemengde samenstelling kan dezelfde consequenties hebben voor de voorbereidingsfase. Voorwaarde is dan wél dat de voorzitter van deze (gemengde) adviescommissie onafhankelijk is van het bestuurorgaan (art. 7:13, lid 1, onder b) en dat ook aan de overige hiervoor genoemde eisen van artikel $7: 13$, lid 1 wordt voldaan.

In par. 5.2 van dit boek is vastgesteld dat de structuur van afdeling 7.2 Awb door deze facultatieve adviescommissie een tweedeling kent. Het is dus mogelijk dat het bestuursorgaan zelf verantwoordelijk is voor de voorbereidingsfase van de 
beslissing op het bezwaarschrift dan wel een adviescommissie in de zin van art. $7: 13$.

Ofschoon de Awb geen verplichting oplegt dat de bestuursorganen zich in het kader van de bezwaarschriftenprocedure te doen adviseren door een adviescommissie in de zin van art. 7:13, versterkt de wet wél de positie en de verantwoordelijkheid van deze adviescommissie voor de voorbereidingsfase van de beslissing op het bezwaarschrift. Deze positionele versterking komt primair tot uitdrukking in art. 7:13, lid 3, waarin is bepaald dat het horen geschiedt door de adviescommissie. Deze commissie heeft bovendien enige zelfstandige procedurele bevoegdheden, voor zover deze niet bij wettelijk voorschrift zijn uitgezonderd (art. 7:13, lid 4).

Belangrijk is dat de inrichting van de bezwaarschriftenprocedure door het inschakelen van een adviescommissie in de zin van art. 7:13 een contradictoir karakter heeft. Dit contradictoire karakter van de bezwaarschriftenprocedure komt tot uitdrukking in de eis van het vijfde lid van art. 7:13, waarin is bepaald dat een vertegenwoordiger van het bestuursorgaan ter toelichting van het standpunt van het orgaan voor het horen moet worden uitgenodigd. Niet zonder betekenis is de eis van schriftelijkheid van het commissie-advies (art. 7:13, lid 6) en de verplichting van het bestuursorgaan om bij afwijking van het advies van de commissie, de reden in de beslissing op het bezwaarschrift te vermelden.

In par. 4.1 (typen van advisering) is gewezen op het belang van de keuze van een adviesvorm ter voorbereiding van de beslissing op het bezwaarschrift door het inbouwen van extra contradictoire elementen in de inrichting van de bezwaarschriftenprocedure. Dit in de Awb genoemde type van semi-rechterlijke advisering leidt tot rechtswaarborgen voor de justitiabele omdat de onpartijdigheid van het adviseren dan beter is gewaarborgd. Door een semi-rechterlijke adviesprocedure worden voorwaarden gecreëerd die aansluiten bij de beginselen van behoorlijke rechtspraak. ${ }^{154}$

Vanwege de specifieke gerichtheid van het type van semi-rechterlijke advisering op het bieden van rechtswaarborgen voor de belanghebbende en het versterken van diens rechtspositie, is in par. 4.1 vastgesteld dat semi-rechterlijke advisering een waarborgfunctie vervult in de geschilbeslechtende taak van het bestuursorgaan. ${ }^{155}$ 
In haar model-verordening voor de behandeling van bezwaar-en beroepschriften heeft de VNG sterk geleund op deze (rechts)waarborgen voor een behoorlijk verloop van de bezwaarschriftenprocedure. In tegenstelling tot het "Awb-model" van artikel 7:13 met zijn minimum-eisen voor een gemengde samenstelling van de adviescommissie (externe voorzitter), is in de model-verordening van de VNG gekozen voor een volledig onafhankelijke adviescommissie. ${ }^{156}$

De voorkeur van de VNG voor een externe samenstelling van de adviescommissie gaat verder dan de bevindingen en conclusies in het rapport "Arob-praktijken". Ofschoon ook het onderzoek naar de werking van de Wet arob uitwees dat het realiseren van de bestuurlijke heroverweging "de beste kansen" heeft bij een behandeling wan het bezwaarschrift door een adviescommissie, ging de aanbeveling ten aanzien van de samenstelling van een dergelijke commissie destijds minder ver. De aanbeveling voor de samenstelling van de adviescommissie ging uit van een drieledige wijze van samenstelling, te weten een bestuurlijke inbreng, een beleidsvoorbereidende betrokkenheid en een onafhankelijk element. ${ }^{157}$

In par. 5.4.7.1 is de vraag opgeworpen of een onafhankelijke adviescommissie zich wel verdraagt met de heroverwegingsopdracht als bedoeld in art. $7: 11$, lid 1 . Geconcludeerd is dat een dergelijke adviescommissie de grenzen van een besliscommissie benadert. Een adviescommissie met een volledig onafhankelijke samenstelling zou minder oog hebben voor de beleidsmatige kant van het besturen. Voorkomen moet worden dat het adviseren door een commissie voor de bezwaarschriften het bestuurlijke zwaartepunt van de beslissing op het bezwaarschrift verschuift naar een adviescommissie. ${ }^{158}$

Op basis van deze owerwegingen en de argumenten van onpartijdigheid en deskundigheid is in par. 5.4.7.1 gepleit voor inschakeling van een adviescommissie in de zin van art. 7:13, met dien verstande dat is aanbevolen de reikwijdte van de afstandelijkheidseis ten aanzien van de onafhankelijke voorzitter te verruimen. Voorgesteld is om in art. 7:13, onder $b$, de onafhankelijkheid van de voorzitter ten opzichte van thet bestuursorgaan uit te breiden tot "het openbaar lichaam". Tevens is op basis van de geconstateerde differentiatie in de procedurele bevoegdheden (par. 5.3.10 en 5.4.10) en de differentiatie van de beslistermijn voor het bezwaarschrift (par. 5.3.11 en 5.4.10) aanbevolen, de facultatieve redactie van

156 VNG circ. 93/216, 23 september 1993, p. 3,4,10 en 11.

157 Arob-praktijken, a.w., p. 347.

Is F.A.M. Stroink/J.G. Steenbeek, Wet admimistratieve rechtspraak overheidsbeschikkingern, 'sGravenhage 1988, vierde herziene dr., p. 401 en 402. 
art. $7: 13$, lid 1 te wijzigen in een verplichte advisering door een commissie in de zin van dit artikel (par. 5.5).

Ook de advisering over de op het bezwaarschrift te nemen beslissing vormde object van onderzoek bij de evaluatie van de Awb.

In het deelonderzoek bestuursprocesrecht, is op grond van de ervaringen van het merendeel van de gerechten, vastgesteld dat het adviseren door bezwaarschriftencommissies leidt tot een betere 'voorbewerking' van de beroepszaken. Bij een adviescommissie is sprake van een betere juridische expertise. Ook de wat grotere afstandelijkheid van bezwaarschriftencommissies blijkt de kwaliteit van de besluitvorming ten goede te komen. De inschakeling van adviescommissies bevordert een zorgvuldige en brede behandeling van de bezwaren. ${ }^{159}$

Anders klinken de geluiden in het rapport van de werkgroep 'Bestuur in geding'. In dit rapport wordt er op gewezen dat de praktijk met de inschakeling van bezwaarschriftencommissies zich in ongunstige zin heeft ontwikkeld. De inschakeling van bezwaarschriftencommissies, en dit zou nog meer gelden voor besliscommissies, zou 'sluipenderwijs' geleid hebben tot een proces van juridisering van het openbaar bestuur. ${ }^{1600}$

De werkgroep wijst op het toegenomen aantal adviescommissies. In deze commissies zou de juridische deskundigheid in gemeentelijke en provinciale bezwarencommissies "nadrukkelijk' zijn ingebouwd. Deze adviescommissies zouden rechterlijke pretenties hebben gekregen. Naar de mening van de werkgroep leidt deze situatie er toe dat provincies en gemeenten steeds meer op advies van de bezwaarschriftencommissies, 'uitspraak in eigen zaak' doen. Er zou steeds minder geprobeerd worden om met de bezwaarde tot overeenstemming te komen. ${ }^{1611}$

De werkgroep concludeert dat door de toegenomen juridische inbreng in de samenstelling van de adviescommissies, de doelmatigheidstoets ten opzichte van het rechtmatigheidsaspect, bij de heroverweging wordt veronachtzaamd. Ter bevordering van de dejuridisering van de bezwaarschriftenprocedure beveelt de werkgroep een gemengde samenstelling aan van de adviescommissies. Zowel juridische als bestuuriijke elementen moeten worden ingebouwd. Met behoud van

159 A.W., p. 300 .

160 A.w. P. 34.

161 A.W. 
de distantie van de adviescommissie zou de samenstelling van deze commissie tot uitdrukking moeten komen tot een menging van interne en externe leden. ${ }^{162}$

Met het oog op de in dit boek gedane aanbevelingen, om de adviescommissie voor de bezwaarschriften een gemengde samenstelling te geven, wordt de werkgroep op haar wenken bediend (par. 5.4.7).

\subsubsection{De financiële beschikkingverlening}

De evaluatiecommissie signaleert aan de hand van het deelonderzoek Aspecten van de financiẻle beschikkingverlening dat in de sector van de financiële beschikkingen knelpunten bestaan die een onbewooroordeeld verloop van de bezwaarschriften-procedure in de weg $\operatorname{staan}^{163}$

Met uitzondering van de behandeling van bezwaarschriften in het kader van de $A B W$ geschiedt het adviseren aan het bestuursorgaan doorgaans zonder inschakeling van een adviescommissie. ${ }^{164}$ De voorbereiding van de beslissing op het bezwaarschrift verloopt doorgaans via een interne adviesprocedure. Met uitzondering van de Belastingdienst, wordt naast een interne adviesprocedure de 'gewone' bestuurlijke procedure van art. 7:5 (bestuurlijke hoorregeling) toegepast. De (deel)onderzoekers twijfelen of art. 7:5 Awb met het oog op de heroverwegingsfunctie van de bezwaarschriftenprocedure wél voldoende garanties inhoudt voor een onbevooroordeelde heroverweging. Men spreekt zelfs over een "mooiweer-bepaling". Aan het deelonderzoek financiële beschikkingverlening zijn over de toepassing van art. 7:5 Awb de volgende opmerkelijke conclusies ontleend:

'Is het niet enigszins een mooi-weerbepaling? Immers, de ervaring leert dat zaken slechts bij uitzondering en tijdens de hoorzitting worden beslist. Het beslismoment ligr doorgaans - elders in de bezwaarschriftfase. De Awb bevat echter geen bepaling analoog aan artiket $7: 5$ die op de rest van de bezwaarschriftenprocedure betrekking heeft. Uit een oogpunt van een onbevooroordeelde heroverweging, van welk beginsel de bezwaarschriftenprocedure, blijkens artikel 7:5 en ook art. 7:13 Awb, uitgaat, is dat op zijn minst wreemd te noemen. 165

De (deel)onderzoekers concluderen dat op het terrein van de financiële beschikkingverlening een ongewenste band bestaat tussen de primaire fase en de bezwaarfase. Zij bevelen aan om in het belang van een onbevooroordeelde herover-

162 A.w., p. 51 .

163 A. W., p. 14.

164 Aspecten van de financiele beschikkingverlening, a.w. "p. 98.

165 A.W. p. 153 en 154. Zie tevens: noot 26 op pagina 154 . 
weging, in beginsel een scheiding door te voeren tussen de primaire fase en de bezwaarfase. Voor organisaties die zowel in de primaire fase als in de bezwaarschriftenfase over te weinig expertise beschikken bevelen de onderzoekers aan, deze scheiding dan maar niet door te voeren. ${ }^{166}$ Dit is onbegrijpelijk. Het risico van een bevooroordeelde heroverweging wordt voor organisaties met een onvoldoende expertise opgeofferd aan het bestuurlijke onvermogen van de betreffende organisatie.

Soms wordt een 'organisatorische' band tussen de primaire fase en de bezwaarfase als een voordeel gezien in het belang van de 'leerfunctie' van de bezwaarschriftenfase. In het geval dat de behandeling van de bezwaarschriften geschiedt door personen buiten de organisatie-eenheid van de primaire beslissers, zou de leerfunctie van de bezwaarschriftenprocedure minder zijn.

De gewenste terugkoppeling van de resultaten van de bezwaarschriftenprocedure zou meer inspanning vergen. ${ }^{167}$

De evaluatiecommissie constateert in de bestuurspraktijk van de financiële beschikkingen eenzelfde beeld. ${ }^{168}$ De vraag is of dit te wijten is aan het al dan niet gescheiden zijn van de organisatie van de primaire fase en de bezwaarfase. Toch heeft de doorwerking van leereffecten ook te maken met expertise. De hoge vernietigingspercentages van de beslissingen op bezwaarschriften bij de Belastingdienst, de $\mathbb{B B}$-groep (Studiefinanciering) en de SVB (Kinderbijslag), duidt meer op een gebrek aan kwaliteit in de organisaties. ${ }^{169}$

De evaluatiecommissie ziet overigens voordelen in de inschakeling van adviescommissies. Deze commissies zouden het leervermogen van organisaties kunnen ontwikkelen door het uitbrengen van jaarverslagen. ${ }^{170}$

\subsubsection{Het ruimtelijk bestuursrecht c.a.}

Het deelonderzoek Besluiten over ruimtelijke ordening, milieu en standplaatsen, levert ten aanzien van het adviseren in het kader van de bezwaarschriftenprocedure, globaal de volgende resultaten op. Gebleken is dat het onderzoek een aantal beperkingen inhoudt. Er is sprake van een slechte respons (par. 6.1). Vastgesteld is dat bijvoorbeeld voor de sanctiebesluiten (milieurecht) slechts nagegaan is of de uitgebreide openbare voorbereidingsprocedure is gevolgd. Doordat de mate

166 A.w., p. 183 en 184.

167 K. Sanders, a. w., p. 22.

168 A.w., p. 51.

169 Kanders, a.w. p. 22.

170 A.w., p. 51 . 
van beleidsvrijheid bij dit type van besluiten niet is onderzocht, is de evaluatie vooral gericht op procedurele aspecten. ${ }^{171}$

De werkgroep Van Kemenade is van mening dat de jurisprudentie over de toepassing van bestuursdwang een verkeerde weg is opgegaan. Door een onderzoek met een meer beleidsmatige kant over de toepassing van bestuursdwang, zou misschien wél op voorhand een antwoord mogelijk zijn geweest over de juistheid van deze bewering. "

Het deelonderzoek in de sectoren van het ruimtelijk bestuursrecht en het milieurecht toont volgens de evaluatiecommissie aan dat de bezwaarschriftenprocedure meer gericht is op een juridische verfijning van het besluit in primo dan op bestuurlijke heroverweging. Deze procedure heeft veelvuldig een sterk contradictoir karakter, terwijl het accent ligt op het beoordelen van de rechtmatigheidsaspecten. De bezwaarschriftenprocedure heeft blijkens het onderzoek sterke "rechterlijke trekken. $^{173}$

Blijkens dit deelonderzoek is geconstateerd dat 80 procent wan de onderzochte gemeenten een externe adviescommissie inschakelen voor het adviseren over de op het bezwaarschrift te nemen beslissing. ${ }^{174}$ Men kan verschillend denken over een beperkte heroverweging die kennelijk wordt toegeschreven aan de inschakeling van onafhankelijke adviescommissies. Het onderzoek mist aanknopingspunten voor een nadere analyse van deze beperkte heroverweging.

Onderzocht zou moeten worden of een doelmatigheidstoetsing van het beleid achterwege blijft in die gevallen dat juist tegen dit beleid bezwaar wordt gemaakt. ${ }^{175}$

Mogelijk kan aan dit aspect bij een volgende evaluatie aandacht worden besteed. Van belang is om dan een betere respons te activeren. Onderzoeksresultaten baseren op de raadpleging van 14 dossiers, lijken weinig perspectief te bieden voor een juiste vaststelling van de feiten en oorzaken. ${ }^{176}$

Er zijn wél oorzaken aan te geven waarom blijkens het deelonderzoek ruimtelijk bestuursrecht c.a. de heroverweging op de onderzochte beleidsterreinen nogal eens beperkt is.

171 Toepassing en effecten van de Algemene wet bestuurstecht $1994-1996$, p. 15.

17 A.W., p. 14.

173 A.W., p. 46 .

174 A.W., P. 59.

175 Toepassing en effecten Algemene wet bestuursrecht, a. w., p. 47.

176 Besluiten over ruimtelijke ordening, milieu en standplaatsen, p. 28 . 
Tijdens het vooroverieg met de aspirant-bouwer wordt het (ontwerp) bouwplan op zijn haalbaarheid getoetst. Zonodig wordt het voorgenomen bouwplan aangepast. Vastgesteld is dat over het bouwplan al vór de aanvrage om vergunning en vrijstelling (art. 19 WRO), een gemeentelijk standpunt is ingenomen. Nog voordat de formele aanvraagprocedure wordt gestart heeft men afspraken gemaakt en zich vooraf ten aanzien van de uitkomsten van de formele beslissing, "vastge$\operatorname{legd^{x}}{ }^{177}$

Er is op gewezen dat deze situatie in de bestuurspraktijk niet nieuw is. Ook onder de Wet arob bleek uit interviews bij gemeenten dat het beoordelen van vrijstellingsmogelijkheden doorgaans gezien werd als een 'vrijstellingsverplichting' van het bestuursorgaan. ${ }^{178}$ Het vooroverleg kan dus ook de voordelen van het informele bestuursrecht negatief beïnvloeden. ${ }^{179}$ Door de negatieve effecten van het vooroverleg op de beoordeling van vrijstellingsverzoeken in het kader van de bezwaarschriftenprocedure, zou de stelling dat "de adviescommissie in de knel zit door het bestuur", niet al te gewaagd zijn.

\subsubsection{De subsidiebeschikkingen}

Het deelonderzoek Subsidiebeschikkingen is anders opgezet dan de onderzoeken ruimtelijk bestuursrecht c.a. en de financiële beschikkingverlening. Er is gekozen voor een andere praktische en methodologische aanpak. De primaire fase en de bezwaarschriftenfase zijn onafhankelijk van elkaar geanalyseerd. ${ }^{80}$ De onderzoeksbevindingen zijn geformuleerd aan de hand van de mate waarin de bestuurlijke implementatie plaatsvindt op grond van de Awb (implementatiestijien). Het onderzoek maakt bij de implementatiestijlen een onderscheid in waarborgbepalingen, beperkende bepalingen en instrumentele bepalingen. ${ }^{182}$ De omvang van de heroverweging in art. $7: 11$ is niet onderzocht. Voor de bezwaarschtiftenprocedure zijn bijvoorbeeld alleen gegevens verzameld over de uitkomsten van op bezwaarschriften genomen beslissingen (bijvoorbeeld het aantal (on)gegrond verklaarde bezwaarschriften). ${ }^{183}$

Deelonderzoek Besluicen over ruimtel ijke ordening, milieu en standplaatsen, p. 34.

Arob-praktijken, p. 105.

Zie in dit: Toepassing en effecten van de Algemene wet bestuursrecht 1994-1996, p. 37 en 38 en het Kabinetsstandpunt, a.w., p. 9.

180 A.w., p. 38.

181 A.W., zie o.a. p. 31.

192 A.w., zie voor een omschrijving van deze begrippen p. 29 Um 31.

183 A.w. . p. 39. 
Het deelonderzoek Subsidiebeschikkingen biedt geen inzicht in welke mate de advisering over het bezwaarschrift leidt tot een rechtmatigheids- en/of doelmatigheidstoets. Dit is wellicht ook de reden dat de evaluatiecommissie geen aandacht schenkt aan de invloed van de factor van het adviseren op de omvang van de heroverweging. ${ }^{184}$ Wél blijkt uit het onderzoek van de Individuele huursubsidie dat de implementatie van de Awb nauwelijks of geen gevolgen heeft gehad voor de inrichting van de bezwaarschriftenprocedure. Vanaf 1 september 1995 is door een relatief groot aantal vernietigingen van bezwaarschriften, wél drastisch iets veranderd in de inrichting van de organisatie. ${ }^{185}$

In tegenstelling tot de andere evaluaties is het deelonderzoek beperkt tot $1994 .{ }^{186}$ In sommige gevallen is maar een zeer gering aantal bezwaarschriften in het onderzoek betrokken. ${ }^{187}$

Uit het deelonderzoek Subsidiebeschikkingen blijkt dat de adviesprocedures voor de bezwaarschriften als volgt zijn ingericht:

- Individuele huursubsidie: afhandeling primaire en bezwaarschriftprocedures door een unit van de Hoofdafdeling Individuele Subsidiëring (ambtelijk);

- Particuliere woningverbetering gemeente Amsterdam: ambtelijke adviescommissie;

- Particuliere woningverbetering gemeente Rotterdam: adviescommissie ex art. 7:13;

- De Nederlandse gemeenten en particuliere woningverbetering: overwegend door adviescommissies ex art. 7:13;

- Energiebesparing - warmtekoppelingssubsidies: ambtelijk;

- Ooipremieregeling: ambtelijk en adviescommissie ex art. 7:13;

- Rijkssubsidiëring restauratie monumenten: adviescommissie ex art. 7:13.

In het onderzoek subsidiebeschikkingen is alleen getoetst in welke gevallen wél en in welke gevallen geen adviescommissie belast is met de voorbereiding van de beslissing op het bezwaarschrift. 


\subsection{De tijdigheid van de beslissing op het bezwaarschrift}

In par. 5.3.11 is gewezen op de bedenkelijke kant van het "grote" tijdsbeslag van de bezwaarschriftenprocedure. De redelijke termijn als bedoeld in art. 6 EVRM kan een rol spelen bij de overschrijding van de beslistermijn voor het bezwaarschrift. De termijn waarin op het bezwaarschrift is beslist kan (indirect) object van toetsing zijn door de internationale rechter bij het beoordelen van de totale lengte van de bestuursrechtelijke procedure.

Maar naast de internationale rechter staat ook de Nederlandse bestuursrechter kritisch regenover de termijnoverschrijding in de bezwaarprocedure. Als het bestuursorgaan in een beroepsprocedure bij de bestuursrechter er niet in slaagt, gemotiveerd verantwoording af te leggen voor de overschrijding van de (bezwaarjbeslistermijn in art. 7:10, dan kan dit leiden tot een onrechtmatigheidsoordeel door de rechter. ${ }^{18}$

Bij de evaluatie van de Awb was ook de beslistermijn van art. 7:10 Awb object van onderzoek. Gebleken is dat naast de "primaire termijnen", zeer regelmatig door de bestuursorganen de beslistermijn van de bezwaarschriftenprocedure wordt overschreden. ${ }^{189}$

De substantiële termijnoverschrijding wordt toegeschreven aan organisatorische problemen. Het evaluatie-verslag noemt hiervoor drie oorzaken:

bij een organisatorische scheiding tussen de primaire fase en de bezwaarfase (subsidiebeschikkingen) blijkt dat het aanleveren van dossiers en het voorbereiden van verweer te lang duurt;

- er is een lage prioriteit bij de "primaire beslis-afdelingen" voor de behandeling van bezwaarschriften;

- de toetsing en verwerking van de adviezen van een art. 7:13-commissie zou te lang duren. ${ }^{190}$

Er is hier meer aan de hand. De laatste jaren is mede door de discussies over de bestuurlijke kritiek op de rechrsbeschermingsprocedures gebleken, dat de juridische kwaliteitszorg binnen de bestuurlijke organisatie sterk achteruit is gegaan. het Kabinetsstandpunt over de evaluatie van de Algemene wet bestuurstecht, $J B 1998,69$, p. 301 en 302, noOt ARN/MAF. 
De werkgroep Van Kemenade steekt in haar rapport de hand in eigen boezem en wijst op de noodzaak van revitalisering van de juridische kwaliteitszorg. ${ }^{191}$ Dit negatieve oordeel over de kwaliteit van de bestuurlijke organisaties blijkt regelmatig uit literatuur. De oorzaak van de verslechtering van de juridische expertise is te wijten aan de veranderingen in de bestuursorganisaties. De juridische "gaafheid' van beslissingen is "opgeofferd" aan (nieuwe) bestuurlijke items, zoals 'voortvarend' en 'doeltreffend besturr', Juridische organisatie-eenheden zijn ontmanteld en al dan niet geïntegreerd in nieuwe meer vakgerichte diensten. ${ }^{192}$ Technisch opgeleid personeel wordt veelal belast met bestuurlijk-juridische taken in de sfeer van de vergunningverlening; een bouwinspecteur concipieent en/of beslist over de bouwvergunning of een milieu-inspecteur ontwerpt en/of beslist over de milieuvergunning.

Het kabinet concludeert dat ter bevordering van de tijdigheid van de beslissing op het bezwaar en ter verbetering van de vormgeving en de inrichting van de bezwaarschriftenprocedure, ondersteuning aan de bestuurlijke organisaties kan worden geboden door het ontwerpen van een 'Handreiking voor het inrichten en voeren van bezwaarschriftenprocedures’. Ook zou een versoepeling van art. $7: 13$, tweede lid Awb uitkomst kunnen bieden. ${ }^{193}$

De doeltreffendheid van deze voorzieningen moet worden betwijfeld. Het verschaffen van een handleiding voor de bezwaarschriftenprocedure nadat met deze procedure al decennia ervaring is opgedaan, zal waarschijnlijk weinig of niets opleveren. Het probleem van de tijdigheid is enerzijds een bestuurlijk managementprobleem. Aan de andere kant is er een gebrek aan voldoende juridische expertise. Bestuursorganen moeten hun verantwoordelijkheid nemen en hun verminderde interesse voor juridische kwaliteit positief ombuigen. Er is de laatste jaren meer aandacht besteed aan beleidsvoorbereiding dan aan de uitvoering van de besluitvorming. Vooral bij de uitvoering van het beleid komt het rechtsbeschermingsbelang in beeld.

Ook deregulering van de inrichting van procedurele bepalingen van de Awb zal weinig zoden aan de dijk zetten. Men moet in het overheidsbestuur een beter besef hebben van het belang van het procedurerecht. Het formele bestuursrecht heeft een regie-functie.

191 A.w., p. 13 en 14.

192 Zie: C.I.N. Versteden, Tijd voor juridische kwaliteilszorg, NTB 1997, p. 68 en 69 en H.B. Winter, Juridische controlling in opkomst, Gst. 7053, p. 254 e.v.

193 A.w., P. 28 en 29. 
In de bestuursrechtelijke procedures komen door de bestuurlijke toetsingstaak, de materiële aspecten van het (bijzonder) besturursrecht aan bod. ${ }^{194}$

Waar het mér op aankomt is ook de besluitvaardigheid van bestuursorganen. Procedures zijn gericht op het waarborgen van 'ieders rechten'. Hirsch Ballin wijst (zeer realistisch) op een gevaar dat schuil gaat achter het gebrek aan bestuurlijke besluitvaardigheid ${ }^{195}$ :

'Tegelijk moet echter de vraag worden gesteld of in onze juridische en bestuurlijke cultuur niet een soort fixatie op het procederen is ontstaan".

Sommigen wijzen er op dat met een paar eenvoudige procedurele aanpassingen van de $\mathrm{Awb}$ ook mede de bezwaren tegen de gevolgen van juridisering kunnen worden opgelost. ${ }^{196}$

Het is de vraag of de versoepeling van de bezwaarschriftenprocedure kan worden bereikt door middel van procedurele aanpassingen van de Awb. Zó uitgebreid en gedetailleerd zijn de procedure-bepalingen van de $\mathrm{Awb}$ (minimum-eisen van een behoorlijke (bezwaar)procedure) nu ook weer niet. Voldoende juridische expertise is een eerste vereiste voor een rechtens juiste uitvoering van de Awb.

Het is onjuist de inschakeling van adviescommissies in de zin van art. 7:13, als oorzaak te zien voor de juridisering van de bezwaarschriftenprocedures.

De tijdigheid van de beslissing op het bezwaar kan op verschillende manieren worden bevorderd.

Een eerste mogelijkheid is dat in een kritisch en open overleg met de bezwaarde wordt nagegaan of deze alsnog bereid is zijn bezwaar in te trekken ter hoorzitting. Art. 6:21 lid 2 Awb biedt hiervoor een efficiënte oplossing. Dit artikellid biedt de mogelijkheid om tijdens de hoorzitting het bezwaarschrift in te trekken. Ook art. $7: 13$, lid 3 biedt de mogelijkheid om de hoorplicht efficiënt toe te passen door een onafhankelijk lid van de adviescommissie met het horen te belasten.

Soms wordt ervoor gepleit om de overschrijding van de beslistermijnen van de Awb "te bestraffen" met een dwangsom ten laste van het bestuursorgaan. ${ }^{197}$

194 N.S.J. Koeman, Bestuursrecht is meer dary procedurerecht, NTB 1995, p. 94.

195 E.M.H. Hirsch Ballin, NTB 1996, p. 106.

1 ts6 $R$. Neerhof, Enige tegenstrijdige opmerkingen naar anleiding van het rapport-Van Kemenade, JB 1997, p. 1256 en 1257.

197 F. Breure, Zin en onzin van de Awb-bezwaarschriftenprocedure in de besluitvorming, $0 B 1997$ 8, p. 5 en F. Breure OB 1998, 1, p. 31. 
Herweijer signaleert dat er sprake is van onbekendheid van belanghebbenden met art. $6: 2.198$

Het is zinvol de tijdigheid van de beslissing op het bezwaarschrift te activeren door de belanghebbenden te wijzen op de mogelijkheid tot het indienen van bezwaar bij een fictieve weigering.

\subsection{Conclusies}

1. Het kabinet had de omvang van de opdracht tot het evalueren van de Awb beter moeten afstemmen op de eerste korte verslagperiode van drie jaar. De ervaringen met de Wet arob wezen uit dat de positieve effecten van de werking van deze wet eerst na twee jaar optraden.

2. Ten tijde van de parlementaire behandeling van de Awb was het zeefwerkingspercentage van de bezwaarschriftenprocedure bij gemeenten $90 \%$ en bij enkele provincies $75 \%$.

3. Het niet betrekken van de burger bij de evaluatie lijkt vooralsnog een gemiste kans omdat uit een empirisch onderzoek in het kader van de uitvoering van de Werkloosheidswet en de regeling premie-heffing werknemersverzekeringen, blijkt dat slechts 20 procent van de ondervraagden een negatief oordeel heeft over de bezwaarschriftenprocedure.

4. De voorbereidingsprocedures van de afdelingen 3.4 en 3.5 geven betere waarborgen voor de voorbereidingsfase wan de primaire besluitvorming, maar deze procedures zijn niet gericht op een heroverweging in de zin van art. 7:11 Awb. Er ontbreken waarborgen voor een onbevooroordeelde advisering (bijvoorbeeld in de zin van art. 7:13) en er is geen mogelijkheid voor een voorlopige voorziening bij de rechter.

5. Het Kabinet had beter de aanbeveling van de evaluatie-commissie kunnen volgen door de bestuurspraktijk van de afdelingen 3.4 en 3.5 te evalueren. Er is te sterk geleund op de onderzoekssresultaten van het deelonderzoek ruimtelijk bestuursrecht $\mathrm{c}$. a.

6. Bij de voorbereiding van de primaire besluitvorming is er veelal onvoldoende juridische expertise, hetgeen mede kan verklaren dat de procedures van de afdelingen 3.4 en 3.5 doorgaans niet vrijwillig worden toegepast.

198 M. Herweijer, Het nut van de Awb voor bezwaarmakers, OB 1997, 10, p. 22. 
Een eventueel proeftuin-project zou een beter inzicht hebben kunnen verschaffen in de sterke en zwakke kanten van de voorbereidingsprocedures in relatie tot de bezwaarschriftenprocedure.

8. Bestuursorganen zouden zelf op basis van de kwaliteit van de juridische deskundigheid moeten bepalen of gekozen wordi voor een voorbereidingsprocedure. Bij een betere kwaliteit in de primaire fase, zou de bezwaarschriftenprocedure kunnen vervallen door gebruik te maken van de voorbereidingsprocedure. Een aanpassing van art. $7: 1$, lid 1 , onder d met de voorbereidingsprocedure van afdeling $3.4 \mathrm{kan} z$ zinvol zijn.

9. Het kabinet wijst de aanbevelingen van de evaluatiecommissie voor een onderzoek naar zes varianten voor het achterwege laten van de bezwaar schriftenprocedure af. Door een nader onderzoek naar de versoepelingsmogelijkheden van de bezwaarschriftenprocedure, staat deze voorprocedure toch ter discussie.

10. Het nut van prorogatie is twijfelachtig tegen de achtergrond van de grote zeefwerking van de bezwaarschriftenprocedure.

11. De hoorplicht is een essentieel onderdeel van de bezwaarschriftenprocedure. De stringente rechterlijke toetsingsmaatstaven maken een differentiatie van de hoorplicht twijfelachtig. Een flexibilisering van de hoorplicht kan leiden tot praktische uitwoeringsproblemen en onvoorspelbare uitkomsten bij de toetsing van besluiten in beroep.

12. Het onderzoek van een drietal fiscale regelingen wijst uit dat bij de Belastingdienst weinig wordt gehoord. De plannen tot differentiatie van de hoorplicht zijn naww gekoppeld aan de aanbevelingen voor de fiscale regelingen. In de fiscaliteit wordt alleen gehoord op verzoek. Het belastingrecht is niet representatief voor de wenselijkheid tot differentiatie van de hoorplicht.

13. De bepalingen over het horen worden blijkens het deelonderzoek Subsidiebeschikkingen verschillend toegepast. Bij de uitvoering van de subsidie-regeling voor kleine warmte-koppelingssubsidies, blijkt een terughoudende opstelling met betrekking tot het telefonisch horen. Slechts in eên dossier (1994) is een telefonische notitie over het horen aangetroffen.

14. In het ruimtelijk bestuursrecht en het subsidierecht is veelvuldig informeel overleg. Het horen in de bezwaarfase wordt vooral op het terrein van het ruimtelijk bestuursrecht als een doublure ervaren. In het ruimtelijk ordeningsrecht manifesteren zich negatieve effecten van het informele bestuursrecht (informeel overleg). Aan de hand van het rapport Arob-praktijken kan een verklaring worden gegeven voor het feit dat het horen in het ruimtelijk bestuursrecht vaak een doublure is. Verzoeken om vrijstelling in het kader van de WRO worden doorgaans in- 
gewilligd. Door het maken van afspraken in het vooroverleg is er geen ruimte meer om op ingenomen positieve standpunten terug te komen. Het zou wenselijk zijn om bij de evaluatie van de Awb meer aandacht te besteden aan de negatieve kanten van het informele bestuursrecht. Een negatief aspect bij het onderzoek ruimtelijk bestuursrecht c.a. is bovendien de slechte respons en het geringe dossieronderzoek.

15. Het deelonderzoek bestuursprocesrecht toont aan dat de inschakeling van een adviescommissie tot een betere voorbereiding leidt van beroepszaken. Er is een grotere afstandelijkheid bij de advisering en de kwaliteit van de beslissing op het bezwaarschrift wordt hierdoor verbeterd.

16. Het bezwaar van de werkgroep Van Kemenade dat de dominante juridische deskundigheid in adviescommissies tot rechterlijke pretenties van deze commissies hebben geleid, is niet gelegen in de uitgangspunten van de Awb. Veeleer ligt hieraan ten grondslag de keuze van het bestuursorgaan voor een onevenwichtige samenstelling van deze commilssies. Een meer gernengde samenstelling van de adviescommissies leidt tot betere resultaten ten dienste van de omvang van de heroverweging.

17. Het deelonderzoek financiële beschikkingverlening toont aan dat er iwijfels bestaan over een onbevooroordeeld verloop van de bezwaarschriftemprocedure. In tegenstelling tot art. 7:13 wordt art. 7:5 als een 'mooi-weer-bepaling' ervaren.

18. De constatering in het onderzoek ruimtelijk bestuursrecht dat externe adviescommissies doorgaans alleen de rechtmatigheid van besluiten toetsen, zou nader moeten worden geanalyseerd in het licht van de negatieve effecten van het informele overleg.

19. De substantiële overschrijding van de beslistermijn voor bezwaarschrif ten heeft verschillende oorzaken, waaronder mogelijk ook een gebrek aan juridische expertise. Een meer diepgaande evaluatie is gewenst.

20. De Awb biedt zelf ruimte voor meer tijdigheid van de besluitvorming. De mogelijkheden van art. 6:21 Awb tot het intrekken van het bezwaar zouden beter moeten worden benut (betere wijze van horen). Ook art. 7:13, lid 3 zou de snelheid van de beslissing op het bezwaar positief kunnen beïnvloeden door een onafhankelijk lid van de adviescommissie te belasten met het horen. Ter activering van de besluitvaardigheid bij de bezwaarschriften zouden bestuursorganen de belanghebbenden moeten wijzen op het recht om op grond van art. 6:2, een bezwaarschrift in te dienen in geval van overschrijding van de beslistermijn. 


\section{Ter afronding}

\section{Samenvatting en conclusies}

Een belangrijke doelstelling van de $\mathrm{Awb}$ is (mede) het treffen van voorzieningen voor die bestuursrechtelijke onderwerpen die zich niet lenen voor regeling buiten een algemene wet. De Awb-wetgever was van oordeel dat bestuursrechtelijke onderwerpen die binnen het bereik van deze doelstelling vallen voor het gehele terrein van het bestuursrecht moeten gelden. 'De verplichte bezwaarschriftenprocedure als bedoeld in art. $7: 1 \mathrm{Awb}$ is hiervan een uitvloeisel.

De bezwaarschriftenprocedure als bestuurlijke voorprocedure, voorafgaand aan het beroep op de bestuursrechter, is geen nieuw bestuursrechtelijk fenomeen. Deze procedure bestond reeds lang in het belastingrecht ( $\mathrm{Awr}$ ). Daarnaast kenden vooral gemeentelijke verordeningen de mogelijkheid tot het maken van bezwaar tegen beschikkingen van lokale bestuursorganen. Deze verordeningen bevatten aanvullende regels voor het maken van bezwar. ${ }^{2}$

De inwerkingtreding van de Wet arob (Wet van 1 mei 1975, Stb. 284) op 1 juli 1976, leidde aanvankelijk tot de invoering van een verplichte bezwaarschriftenprocedure voor de decentrale bestuursorganen. Voor organen van de centrale overheid was er aanvankelijk een facultatieve bezwaarschriftenprocedure. Deze procedure deed in 1986 zijn intrede in het sociaal economisch recht (Wet arbo). Hiermee werd een belangrijke ontwikkeling afgesloten op het terrein van de rechtsbescherming en de verlengde besluitvorming, die tevens de basis legde voor een verdere uitbreiding van de bezwaarschriftenprocedures in het bestuursrecht. De hoofdstukken 6 en 7 Awb vormen hiervan de weerslag.

De bezwaarschriftenprocedure ligt ingeklemd tussen het primaire bestuurlijke besluitvormingsproces en het beroep op de bestuursrechter. Bij deze voorprocedure is een aantal actoren betrokken, dat werschillend reageert op de uitkomsten van de bezwaarschriftenprocedure.

Burgers zijn soms van oordeel dat zij niet dan wel onvoldoende kansen hebben gehad om op de door of namens het bestuursorgaan gehouden hoorzitting hun bezwaren en argumenten nader toe te lichten. ${ }^{3}$

Soms volgen bezwaarden de gang van zaken tijdens de hoorzitting zó kritisch dat zij aandringen op de toezending van het in art. 7:7 verplichte verslag. Ofschoon

$1 \quad$ PG Awb 1, p. 23.

2 Blauwe reeks, nr. 48, Behandeling van bezwaar- en beroepschriften door de gemeentebesturen, VNG, "s-Gravenhage 1972 .

3. Rb. 's-Hertogenbosch 13 maari 1998, JB 1998, 121. 
de Awb geen regeling bevat ten aanzien van een verplichte toezending van het concept-verslag voor het nemen van de beslissing op het bezwaarschrift, kan het versturen van het verslag er toe leiden dat bij de bestuurlijke beslissing nog rekening kan worden gehouden met eventuele opmerkingen. Uit een oogpunt van zorgvuldigheid doen bestuursorganen er goed aan hierop in beginsel positief te reageren, tenzij blijkt dat de bezwaarde door het niet overleggen van het verslag niet in zijn processuele belangen is geschaad. ${ }^{4}$

Ook klagen de belanghebbenden wel eens over de gang van zaken tijdens een bezwaarschriftenprocedure. Zij menen dat de samenstelling van een hoor en/of adviescommissie van dien aard is dat zij het bestuursorgaan een vooringenomen taakvervulling verwijten.

Bestuursorganen reageren af en toe ontstemd op uitspraken van de bestuursrechter die de "bestuurlijke trein' tot stilstand heeft gebracht door bijwoorbeeld een primair besluit of een beslissing op het bezwaarschrift te schorsen. Of nóg erger: naar aanleiding van een ingesteld beroep volgt een uitspraak van de bestuursrechter, waarbij de beslissing op het bezwaarschrift wordt vernietigd.

De kritiek op de gevolgen van de rechtsbescherming voor bestuursorganen is regelmatig in woord en geschrift waar te nemen. ${ }^{5}$

Er wordt soms gesproken over relationele problemen tussen het bestuur en de rechter. ${ }^{6}$ Zo nu en dan klinkt de onvrede over de gang van zaken bij het aan de bestuursrechter ter toetsing voorgelegde besluit door in de uitspraak:

'(...) De rechtbank acht zulks uit een oogpunt wan zorgvuldige voorbereiding van een besluit beneden de maat. ${ }^{\text {? }}$ of

4. ABRS 12 juni 1997, JB 1997, 188.

s Zie 0.a.: M, B.W. Biesheuvel, Weg met de bezwarschriftenprocedure, NJB 1996, p. 930, R. van Houten, Gemeenten voelen zich bekneld door rechtsprak, Ng 1996, p. 13. De geluiden in het kader van cen verrichte evaluatie naar de werking van het nieuwe bestuursprocesrecht duiden op een nogal verdeeld standpunt omtrent de bezwaarschriftenprocedure. In het algemeen wordt de bezwarschriftenprocedure gewaardeerd als woorportal wan het beroep op de recher. De waardering richt zich vooral op de zeeffunctie van de bezwarschriftenprocedure. Het tijdsbeslag van de procedure lijkt overigens wel punt van kritiek. In het kader van het Awb-evaluatie wordt gemaand tot madenken over de eventuele wenselijkheid van differentiatiemogelijkheden. Zie: J.B.J.M. ten Berge e.a., Erwaringen met de Awb, Het bestuursprocesrecht, Deventer 1996, p. 27 tom 29 en p. 296 e.w.

6. J.M. Polak, Bestuur en rechter. Relationele problemen, NJB 1996, p. 892.

$7 \quad$ Rb. 'sw Hertogenbosch 8 juli 1997, JB 1997, 227. 
"Waar de raad vaker als zijn oordeel heeft doen blijken (...)

Deze fragmentarisch weergegeven inhoud van kritische geluiden met betrekking tot de rechtsbescherming in het algemeen en de bezwaarschriftenprocedure in het bijzonder, heeft de auteur van dit boek geïnspireerd tot het verrichten van een studie over de bezwaarschriftenprocedure. De uitkomsten van de evaluatie van de Awb gaven hieraan een extra impuls. Ditzelfde kan gezegd worden over de discussies met betrekking tot de juridisering in het openbaar bestuur. ${ }^{9}$ In hoofdstuk 6 van dit boek is uitvoerig ingegaan op de evaluatie van de Awb in relatie tot de bezwaarschriftenprocedure. Met dit onderzoek wordt beoogd de bezwaarschriftenprocedure in een juiste context te plaatsen. De zwaartepunten van de bezwaarschriftenprocedure zijn onderzocht op basis van een zestal uitgangspunten, te weten de heroverweging door het bestuursorgaan (hoofdstuk 1 ), het onpartijdigheidsgebod voor het bestuursorgaan als bedoeld in art. 2:4 Awb (hoofdstuk 2) en de hoorplicht (hoofdstuk 3). In twee hoofdstukken (4 en 5) vormden de algemene en bijzondere aspecten van het adviseren aan het bestuursorgaan object van studie. De zes hoofdstukken van dit boek geven kwantitatief en kwalitatief de volgende onderzoeksresultaten te zien.

\subsection{De heroverweging en het bezwaarschrift}

In hoofdstuk 1 van dit boek, is de in de Awb opgenomen plicht tot heroverweging onderzocht. Art. 7:11, lid 1 eist wan het bestuursorgaan dat het oorspronkelijk besluit waartegen bezwaar is gemaakt, wordt heroverwogen. Voor het bestuursorgaan brengt dit met zich dat over het besluit in primo opnieuw ex nunc moet worden geoordeeld, op basis van de feiten, het recht en het beleid. ${ }^{10}$ Deze heroverwegingsaspecten bepalen het bestuurlijke karakter van de bezwaarschriftenprocedure.

De bezwaarschriftenprocedure bevat ook elementen wan individuele rechtsbescherming. Deze rechtsbeschermingsaspecten liggen opgesloten in het vereiste van art. $7: 11$, lid 1 . Het bestuursorgaan moet heroverwegen 'op grondslag' van het ontvankelijke bezwaar. Aan het grondslagvereiste van art. $7: 11$, lid 1 zijn in de MvT voor het bestuursorgaan twee belangrijke restrictieve betekenissen toegekend: enerzijds moet de heroverweging binnen het door de justitiabele gestelde $1997-1998,25600 \mathrm{V1}, \mathrm{nt}$. 46 en Bestuur in geding, Haarlem 1997.

10 Zie o.a.: G.H. Addink e.a., a.w., p. 240. 
"bezwarenkader" geschieden (verbod van ultra petita gaan) en anderzijds moet het bestuursorgaan bij de te maken heroverweging, het verbod van reformatio in peius in acht nemen. Dit verbod moet voorkomen dat de bezwaarde in een ongunstiger positie komt te verkeren dan vóór het maken van het bezwaar. "

Uit dit grondslagvereiste dat ook als uitspraakcriterium geldt voor de bestuursrechter (art. 8:69, lid 1), kan een beperking van de omvang van een volledige heroverweging voortvloeien. ${ }^{12}$ Soms moeten wettelijke voorschriften wijken voor het belang van de rechtsbescherming van de justitiabele. ${ }^{13}$

Doordat de heroverweging van het bestreden besluit dient te voldoen aan de eisen van volledigheid (zowel de doelmatigheid als de rechtmatigheid), onderscheidt de bezwaarprocedure zich van de toetsing door de bestuursrechter. De door de bestuursrechter te verrichten toets is beperkt tot de rechtmatigheid van het bestreden besluit. Deze (rechterlijke) toetsingsmaatstaven betreffen strijd met het geschreven en ongeschreven recht en schending van de algemene rechtsbeginselen (art. 8:77, lid $2 \mathrm{Awb}$ ).

De bestuurlijke heroverweging die een wezenskenmerk is van de bezwaarschriftenprocedure is geen (Awb) noviteit. Art. 7:11, lid 1 positiveert de heroverweging tot een rechtsnorm voor het bestuursorgaan. De arob-rechter baseerde de plicht tot een volledige heroverweging (rechtmatigheid en doelmatigheid) op hoofdstuk III (Bezwaarschriften-procedure) van de Wet arob. ${ }^{14}$ De arob-rechter vernietigde de beslissing op het bezwaarschrift, indien de heroverweging van het bestreden besluit alleen beperkt was tot een oordeel over de rechtmatigheid.

Er kan gesproken worden van een gedeeltelijke 'cosmetische' wijziging van de inhoud van het heroverwegingsaspect in het kader van de Awb ten opzichte van het arob-tijdperk. De Awb bevat een wettelijke regeling voor algemene regels van bestuursrecht; de Wet arob kende in art. 8 een toetsingskader (achteraf) voor beschikkingen door de administratieve rechter. In de Awb is in afd. 3.2 een aantal beginselen van behoorlijk bestuur gecodificeerd als bestuurlijke normen.

Voor het integraliteitsuitgangspunt van de heroverweging betekent dit dat naast de bestuurlijke normen van afdeling $3.2 \mathrm{Awb}$, conform het 'arob-stramien', de

11 Zie o.a.: H.J Simon, Handboek bestuurs(proces)recht volgens de Awb, "s-Gravenhage 1997, p. 260 e.v.

12 Van Wijk/Konijnenbelt/Van Male, Hoofdstukken van administratief recht, thende dr., Den Haag 1997, p. 620 en 621 .

13 F.A.M. Stroink, Kern van de bestuursrechtspraak, 's-Gravenhage 1997, p. 18 en 19.

14 Zie in dit verband hoofdstuk 1 , noot 150 . 
heroverweging ook moet voldoen aan de eisen van de niet-gecodificeerde beginselen van behoorlijk bestuur. ${ }^{15}$ Voor de beslissing op het bezwaarschrift is de motiveringsplicht afzonderlijk geregell in art. $7: 12$, lid 1 . In art. $7: 14$ is een aantal bepalingen van de Awb uitgezonderd van de bewaarschriftenprocedure.

Een niet te veronachtzamen aspect bij de beslissing op het bezwaarschrift, is het bepaalde in het tweede lid van art. 7:11. Als de heroverweging van het bezwaarschrift daartoe aanleiding geeft, moet het bestuursorgaan het primaire besluit herroepen. Bij de beslissing op het bezwaarschrift kan niet altijd volstaan worden met het herroepen van het primaire besluit. Er kunnen ook omstandigheden zijn dat bij de beslissing op het bezwaarschrift het primaire besluit door een nieuw besluit moet worden vervangen (art. $7: 11$, lid 2). ${ }^{16}$

Voor het geval dat er géén beroep tegen de beslissing op het bezwaarschrift wordt ingediend, kan gesteld worden dat deze beslissing devolutieve werking heeft. Hen primaire besluit heeft door de beslissing op het bezwaarschrift - behoudens het geval dat het bezwaarschrift niet-ontwankelijk wordt verklaard - opgehouden te bestaan. In enkele uitspraken legt de Vz. ABRS sterk de nadruk op de relatie van het herroepen van het bestreden besluit met de beslissing op het bezwaarschrift. Deze uitspraken tonen aan dat een beslissing op het bezwarschrift niet zonder meer in de plaats treedt van het besluit in primo. Wordt bij een beroep bij de bestuursrechter de beslissing op het bezwaarschrift (waarbij het primaire besluit is herroepen) vernietigd, dan ontstaat er rechtens een andere situatie. Door deze vernietiging heeft de beslissing op het bezwaarschrift geen devolutieve werking; het primaire besluit herleeft. ${ }^{17}$ Ofschoon de problematiek van de (niet-)devolutieve betekenis van de beslissing op het bezwaarschrift nu minder groot is dan ten tijde van het arob-tijdperk ${ }^{18}$, noopt art. $7: 11$, lid $2 \mathrm{Awb}$, het bestuursorgaan tot behoedzaamheid bij de beslissing op het bezwaarschrift.

De bestuursorganen moeten bij het heroverwegen op grond van art. 7:11, lid 1 attent zijn op de verplichting in het tweede lid van dit artikel, en 'het bestreden besluit herroepen", indien de heroverweging daarvoor aanleiding geeft. Neemt het bestuursorgaan een beslissing op het bezwaarschrift, maar verzuimt het voorzover

is H.J. Simon, Handboek, a.w., p. 261 .

16 H. Bolt Hoofdstuk 7: Algemene wet bestumrsrecht, Bijzondere bepalingen over bezwaar an administratief beroep, in: Nieuw bestursrecht, Nijmegen 1994, p. 241.

17 Zie in dit verband: Van Wijk/KonijnenbelitVan Male, Hoofdsukken van Administratief recht, achtste dr., Utrecht 1993 , p. 556 .

18. Her naderhand gewijzigde artikel $99 \mathrm{RwS}$ creeterde de bevoegdheid woor de ARRS om zelf in de zaak te voorzien waardoor de mogelijkheid bestond om naast de vernietiging van de beslissing op het bezwaarschtift hierbij ook het primaire besluit te betrekken. Zie hierbij overigens artikel $8: 72$ warin een gelijke bevoegdheid is toegekend aan de bestuursrechter. 
de heroverweging daartoe aanleiding geeft, om het (bestreden) primaire besluit te herroepen (art 7:11, lid 1), dan is weliswaar de beslissing op het bezwaarschrift rechtens tot stand gekomen, maar het niet herroepen primaire besluit, blijft bestaan. ${ }^{19}$ In dit geval heeft het bestuursorgaan zelf de niet-devolutieve werking van de beslissing op het bezwaarschrift veroorzaakt. Bestuursorganen doen er goed aan om bij de beslissing op het bezwaarschrift, in het dictum van de beslissing, expliciet aan te geven of het bestreden besluit wél of niet wordt gehandhaafd.

Een bellangrijk aspect van het karakter van de bezwaarschriftenprocedure, is de omvang (de reikwijdte) van de door het bestuursorgaan te maken heroverweging. In bepaalde gevallen is de te maken heroverweging van minder betekenis. $\mathrm{Bij}$ strikt gebonden besluiten zijn de marges van de heroverweging smal. Wél dient bij dit type van besluiten een toetsing van de feiten te geschieden, teneinde vast te stellen of het bestreden primaire besluit al dan niet in strijd is met de (bijzondere) wet.

Een andere beperking van een volledige heroverweging kan zijn gelegen in overwegingen van procedurele aard. De bezwaarschriftenprocedure is er niet op gericht om op een min of meer verkapte wijze een nieuwe procedure voor het aanvragen van bijvoorbeeld een vergunning te starten. ${ }^{20}$

Bij de heroverweging is de toetsing ex nunc uitgangspunt. Het onderzoek in par. 1.4.2 wijst uit dat dit voor de bezwaarschriftenprocedure kenmerkende (grond)beginsel, relatieve trekken kan vertonen. In par. 1.4 .3 is vooropgesteld dat bij de beslissing op het bezwaarschrift het tijdstip van de beslissing, in beginsel het scharnierpunt vormt voor de toetsing van het recht, de feiten en het beleid, maar dat er globaal in een zestal gevallen, een toetsing ex tunc geindiceerd is.

Een ander aspect dat verband houdt met een (beperking) van de omvang van de heroverweging, is het verbod van reformatio in peius. Dit verbod betekent dat men door de beslissing op thet bezwaarschrift niet in een slechtere positie mag komen te verkeren ten opzichte van de situatie dat er door belanghebbende geen bezwaarschrift zou zijn ingediend. Blijkens de analyse in par. 1.4.4 zitten er vele haken en ogen aan dit verbod. De omvang van de bestuurlijke heroverweging wordt hierdoor ondoorzichtig. De figuur van reformatio in peius is conceptueel gesitueerd in een enkelvoudige relatie bestuursorgaan-burger. Van een overtre-

V. ABRS 10 augustus 1995, NJB-Katern 1996, p. 130 en Vz. ABRS 7 juli 1997, JB 1997, 192, m.nt. HJS.

20 H.J. Simon, Handboek, a.w., p. 261. 
ding van het verbod van reformatio in peius is geen sprake wanneer meerdere belanghebbenden met tegengestelde belangen in een geschil zijn betrokken. De ene belanghebbende kan ten opzichte van de andere in een slechtere positie worden gebracht door de uitkomsten van de beslissing op het bezwaarschrift. Tevens kan het verbod van reformatio in peius buiten toepassing blijven indien de rechter zelf in de zaak voorziet. ${ }^{24}$ Dit geldt in de situatie dat gesproken kan worden van nieuwe feiten en omstandigheden en het bestuursorgaan bewoegd en verplicht zou zijn het bestreden besluit ten nadele van appellant te wijzigen.

In het onderzoek naar het toepassingsbereik van het reformatio in peiuswerbod is komen vast te staan dat hierop andere uitzonderingen mogelijk zijn. Het verbod dat een uitvloeisel is van het 'grondslagvereiste', in casu het gemaakte bezwatar (art. $7: 11$, lid 1$)^{22}$, wordt niet toegepast indien de algemene beginselen van behoorlijk bestuur een voldoende compenserende werking bieden, waardoor een verslechtering van de positie van de belanghebbende kan worden voorkomen. De ABRS is op grond van het beginsel van administratief procesrecht, bereid tot een contra legem-toets teneinde een reformatio in peius te voorkomen. ${ }^{23}$

Om redenen van bestuurlijke aard is de toepassing van het verbod van reformatio in peius in het kader van de te maken heroverweging niet positief bevonden. De Awb-wetgever heeft het verbod kennelijk met de haren erbij gesleept, vanwege het identieke bestuursprocesrechtelijke grondslagvereiste, als bedoeld in art. 8:69 Awb. Het ligt meer voor de hand het verbod te reserveren voor de rechterlijke toetsingstaak, die verschilt van de bestuurlijke taakvervulling. De toepassing van. de algemene beginselen van behoorlijk bestuur, sluiten beter aan bij de heroverwegingsplicht dan het verbod van reformatio in peius als beginsel van administratief procesrecht.

Met dit laatste wordt overigens niet gezegd, dat een reformatio in peius zoals die in het verleden nog expliciet werd gereserveerd voor het beslissen op het bezwaarschrift, alsnog van stal moet worden gehaald. ${ }^{24}$

21 Zie hoofdstuk 1 , noten 107,108 en 109.

22 PG Awb 1, p. 347.

23 Zie noot 125 in hoofdstuk 1.

24 Zie in dit verband: Blauwe reeks 48 , artikel 13 model verordening behandeling van bezwaar-en beroepschriften door de gemeentebesturen "s-Gravenhage 1972 en Blauwe reeks m. 58 artikel 16 's-Gravenhage 1976. 


\subsection{Het verbod van vooringenomenheid: tegen vriendjespolitiek of onzorgvuldigheid?}

Het in art. 2:4, lid 1 Awb gestelde onpartijdigheidsgebod voor de taakvervulling door de bestuursorganen, is in de bestuursrechtelijke wetgeving woor Nederlandse begrippen een novum. Al is de idee van een bestuurlijke onpartijdigheidsnorm niet geheel nieuw ${ }^{25}$ In het buitenlands bestuurstecht zou naar de opvatting van de Awb-wetgever een regelling ter voorkoming van besturrlijke onpartijdigheid een grotere rol spelen dan in het Nederlandse recht. ${ }^{26}$

De in art. 2:4, lid 1 Awb opgenomen norm dat het bestuursorgaan zijn taak zonder vooringenomenheid behoort te vervullen, legt een belangrijke ontwikkeling vast in het denken over de kwaliteit van het handelen door de bestuursorganen, ten opzichte van de burgers. In het bestuursrecht zijn ontwikkelingen te constateren die er op duiden, dat de door de bestuursorganen te nemen en genomen besluiten, steeds minder door de justitiabelen worden aanvaard. Bestuursorganen nemen in hun relatie tot de burgers een monopolistische positie in. Deze positie bepaalt de dominante bestuurlijke rol bij het voorbereiden en het nemen van besluiten. Formeel uitgangspunt is dat bij het nemen van besluiten waaraan rechtsgevolgen zijn verbonden, steeds het bestuursorgaan eenzijdig de beslissingen neemt. Dat het bestuursorgaan rekening moet houden met de belangen van de burger, en hierbij (rechts)normen en beginselen in acht moet nemen, doet hier niet aan af.

Van de bestuursorganen als verantwoordelijke actoren in het besluitvormingsproces mag worden gevergd dat zij de belangen van de burgers zodanig behartigen, dat de door hen te nemen besluiten voldoen aan de eisen van een objectiefrechtelijke taakvervulling. ${ }^{27}$ Een van de belangrijke pijlers van deze taakvervulling wordt gevormd door het fundamentele uitgangspunt dat de werkwijze van bestuursorganen dient te voldoen aan eisen wan objectiviteit en onbevooroordeeldheid.

VAR-rapport LXXII, Groningen 1974 , in het bijzonder art. 11 .

26 PG Awb I. p. 179 en 93 e.w. Zie in dit werband: Sir Williarn Wade, Administrative Law, Seventh Edition, Oxford, 1994, Part W Natural Justice, 14 The rule against bias, p. 471 t/m 484. In het Duitse bestuursrecht zijn vrij gedetailleerde onpartijdigheidsbepal ingen opgenomen die woornamelijk gericht zijn op het voorkomen van belangenverstrengeling van ambtenaren die in procedures zijn betrokken. Ferdinand $\mathrm{O}$. Kopp/Ferdinand I. Kopp, Verwaltungsverfahrensgesetz, 6., wesentlich überarbeitete Auflage, München 1996, Par. 20 Ausgeschlossene Personen, $s$. 333-365.

H.J. Simon, Handboek bestuurs(proces)recht volgens de Awb, 's-Gravenhage 1997, p. 121. 
Art. 2:4, lid 1 Awb legt de basis voor de algemene plicht van het bestuursorgaan om zijn taak zonder vooringenomenheid te vervuilen. Het tweede lid bevat een nadere uitwerking wan het in het eerste lid gestelde gebod. ${ }^{28}$ Dit kont er op neer dat bestuursorganen permanent een actief en 'wakend' oog behoren te hebben voor een zuivere besluitvorming. Het bestuursorgaan moet voorkómen dat privébelangen van zijn leden en voor deze organen werkzame personen de besluitvorming beïnvloeden. Ook persconlijke voorkeuren die een onpartijdig oordeel negatief kunnen beïnvloeden moeten zoveel mogelijk worden geëlimineerd. Art. $2: 4$, beoogt hiermede de subjectieve onpartijdigheid bij bestuursorganen aan banden te leggen.

Op basis van de kritiek op art. $2: 4^{29}$ - ook de RvS plaatste vraagtekens ten aanzien van de noodzaak van het vooringenomenheidsgebod omdat de normen van afdeling 3.2 (zorgvuldigheid en belangenafweging) voldoende waarborgen inhouden ten dienste van de besluitvormingsprocedure - heeft de MvT van de Awb benadrukt dat 'objectieve partijdigheid' die zich in gemaakte of te maken beleidskeuzes kan manifesteren, niet onder de werkingssfeer van art. $2: 4$ valt. $^{30}$

Het verbod wan vooringenomenheid leent zich niet voor het geven van algemene regels van gevallen, waarin gesproken kan worden van overtreding van de regel van vooringenomenheid. Deze Awb-norm vertoont daardoor sterke casuïstische trekken.

Voor wat betreft de praktische toepassing van art. 2:4, licht de Awb (MvT) een tipje van de sluier op door te stellen dat de norm van het eerste lid uiteenlopende situaties kan betreffen en dat 'zelfs de indruk van het ontstaan van vriendjespolitiek moet worden vermeden'. ${ }^{31}$ Zonder het uit te spreken heeft de Awb wellicht ook wel beseft dat de opdracht tot een objectieve taakvervulling geen geringe is. Maar de invoering van art. 2:4 Awb werd benadrukt als een fundamentele norm voor de relatie ('verkeer') tussen overheid en burger. Het belang van art. 2:4 is mede 'verdedigd' op grond van de specificerende betekenis voor een van de elementen (gelijke en faire behandeling) die behoren tot een zorgvuldig besluitvormingsproces. ${ }^{32}$ 
Art. 2:4 is als onpartijdigheidsnorm door de $\mathrm{Awb}$ mede gemotiveerd vanwege het bestaan van de wrakings- en verschoningsbepalingen voor de rechterlijke taakstelling die een uitvloeisel zijn van het beginsel 'nemo iudex in re sua'. ${ }^{33}$ Een soortgelijk beginsel voor de bestuursorganen ontbreekt in het algemeen bestuursrecht. In het onderzoek in hoofdstuk 2 is vastgesteld dat in het Nederlands recht toch enige regelingen bestaan ter voorkoming van partijdigheid in het openbaar bestuur.

In par. 2.4 is een aantal wettelijke bepalingen 'opgespoord' dat min of meer verwantschap vertoont met correctheidsmaatstaven in het belang van een goed functioneren van de bestuursorganen. In organieke wetten (Prov.w., Gem.w., Watersch.w. en het sociaal-economisch recht komen bepalingen voor die waarborgen beogen te bieden in het belang van de integriteit, onpartijdigheid en belangenverstrengeling van de bestuurders.

Deze 'individuele' integriteitsvereisten (par. 2.4.1) zijn af te leiden uit art. B 5 Kiesw. Weliswaar zijn deze voor het passief kiesrecht gestelde eisen voor leden van vertegenwoordigende openbare lichamen niet expliciet gesteld in het belang van de integriteit van het openbaar bestuur, maar kunnen zij daarop wél indirect invloed hebben. De bepalingen wan de Kiesw. die uitsluiting van functies in het openbaar bestuur mogelijk maken, vervullen een waarborgfunctie ten dienste van de integriteit van de individuele bestuurders. Zij houden geschiktheidskenmerken in ten aanzien van hen die belast zijn met de uitoefening van de publieke taakvervulling. Integriteitsaspecten die zich tot de individuele leden wan organen van publiekrechtelijke rechtspersonen richten, zijn eveneens af te leiden uit de zuiveringseed en de ambtseed.

Ook de bepalingen voor de benoemingsprocedures voor het ambt van $\mathrm{CdK}$, burg. en voorzitter van een waterschap, vertonen geschiktheidswarborgen. Bovendien geven de rechtspositieregelingen, betreffende de ambten van $C \mathrm{dK}$, burg. en voorzitters van een waterschap of een bedrijfslichaam, indicaties voor integriteitseisen. Dit geldt mede voor de ambtelijke medewerkers in dienst van de openbare lichamen.

In het organieke recht komen verder bepalingen voor die directe betekenis hebben voor de wijze waarop de individuele leden van bestuursorganen hun taak vervullen. Deze bepalingen beogen onverenigbare betrekkingen te voorkomen, en verbieden het verrichten van met name genoemde handelingen (par. 3.4.2). 
Daarnaast zijn er specifieke voorschriften die bestuurders verplichten, nevenfuncties bekend te maken. Yoor ambtenaren bestaan er rechtspositieregelingen die bepalingen inhouden ter waarborging van de integriteit en ter voorkoming van belangenverstrengeling.

In het onderzoek is ook een aantal regelingen betrokken dat de zuiverheid van het besturen en de onpartijdigheid positief kan beïnvloeden. Besproken zijn de (individuele en collectieve) verantwoordingsplicht van leden van de dagelijkse besturen van openbare lichamen en de tussentijdse ontslagregelingen.

Ook petities, brieven, publiciteit in de media, en het spontane vernietigingsrecht kunnen een functie vervullen ter afwering van belangenverstrengeling. Niet zonder betekenis voor de zuiverheid van het besturen zijn eveneens openbaarheidsregelingen zoals de $W O B$ en art. 7:4 Awb (inzageregeling van stukken in het kader van de bezwaarschriftenprocedure) en de ombudsvoorzieningen.

Ofschoon voór de inwerkingtreding van de Awb het bestuursrecht geen bepaling kende van de inhoud en de strekking van art. $2: 4$, betekende dit niet dat er geen 'zuiverheidseisen' bestonden waaraan de bestuurlijke besluitvorming moest voldoen. In par. 2.5 is onderzocht hoe vóór de Awb de objectieve bestuurlijke taakvervulling door administratieve instanties (Kroon en administratieve rechters) werd getoetst. Het onderzoek is onderscheiden in een aantal fasen, te weten de voorbereiding van de besluitvorming, de beslissingsprocedure en de eigenlijke besluitworming. ${ }^{34}$

Nagegaan is aan welke objectiviteitseisen moet worden voldaan door het bestuursorgaan en zijn bestuurders, de adviesorganen (ingesteld krachtens formeel- en materieel-wettelijk voorschrift) en de in ondergeschiktheid aan het bestuursorgaan, werkzame personen.

In het onderzoek omtrent de objectiviteit van de voorbereidingsfase van de besluitvorming zijn de welstandscommissie en de monumentencommissie betrokken. Deze commissies adviseren b en $w$ op basis van specifieke deskundigheid in het kader van de uitvoering van de WW en Mon.w. Deze deskundigenadvisering is in beide wetten, behoudens enkele uitzonderingen, verplicht gesteld. Voor de welstandscommissie geldt de expliciete eis dat deze commissie door haar samenstelling onafhankelijk van het bestuursorgaan moet zijn. 
Vastgesteld is dat de arob-rechter doorgaans de voorbereiding van het besluit (de beslissing omtrent de aanvraag om bouwvergunning) strikt toetste aan de (bijzondere) wettelijke eis van onafhankelijkheid. Bij de advisering door welstandscommissies gaan deskundigheid en onafhankelijkheid 'hand in hand"; uit deze beide elementen vloeit onpartijdigheid voort.

De leden van de welstandscommissie moeten een onafhankelijke positie innemen ten opzichte van b en $w$. Naast openbaarheid van de commissievergaderingen, moeten de leden van de welstandscommissie met een architectenpraktijk zich van de beoordeling van bouwplannen waaraan zij direct of indirect hebben meegewerkt, onthouden.

Voor de beoordeling van bouwplannen behoort richtinggevend te zijn de kwaliteit van het ontwerp, en niet die van de ontwerper. ${ }^{35}$ De toetsingscriteria voor welstandseisen zijn geen volledige garantie voor onbevooroordeelde advisering.

De bepalingen van de Mon.w. bevatten geen uitdrukkelijke eisen ten aanzien van de onafhankelijkheid en deskundigheid van deze verplichte adviescommissie. Wél kan uit de MvT worden afgeleid dat de wetgever er vanuit gaat dat deze commissie op basis van deskundigheid is samengesteld. ${ }^{36}$ De arob-rechter huldigde de opvatting dat de monumentencommissie niet volledig uit deskundigen behoeft te bestaan. Wél is er evenwicht in de deskundigheid geëist zodat de deskundigen van deze adviescommissie 'de deskundigheid' kunnen waarborgen. ${ }^{37}$ Deskundigheid behoort hier waarborgen te scheppen voor objectiviteit, en een zekere mate van onafhankelijkheid van het bestuursorgaan. Deze onafhankelijkheid van de monumentencommissie moet voldoende verzekerd zijn in die gevallen dat de belangen van de gemeente in het bijzonder zijn betrokken bij het besluitvormingsproces. ${ }^{38}$ In een subsidiezaak waarin de Raad voor de Kunst als wettelijk adviseur advies uitbracht, bleek dat subjectieve elementen in de advisering niet zijn uit te sluiten, maar dat een intersubjectieve beoordelingsbenadering een objectieve advisering niet behoeft uit te sluiten. ${ }^{39}$

Het onderzoek van de voorbereiding van de besluitvorming door een materieelwettelijke adviescommissie richtte zich op de advisering omtrent aanvragen on planschadevergoeding als bedoeld in art. 49 WRO (par. 2.5.3). De WRO eist niet

35 Welstandsacties, welstandsberoep en welstandsjurisprudentie, Serie Welstandstoezichti, Utrech 1980 , p. 53 en 54 .

36 TK 1986-1987, nr. 3, p. 4.

37 ARRS 17 november $1991, \mathrm{tB} / \mathrm{S}, 153$.

38 VZ. ARRS 2 december 1993, Comp. Monumentenzorg, losbl., Alphen aan den Rijn, art, 15, p. 3.

39 ARRS 18 september 1990, BB/S 1990, 104, AB 1991, 596. 
de inschakeling van onafhankelijke deskundigen voor het uitbrengen van een advies aan de gemeenteraad. Toch toetste de Kroon de advisering in casu de voorbereidingsfase van de besluitvorming aan de eisen van 'vertrouwen' en 'onpartijdigheid' die de burger mag stellen aan het bestuursorgaan. ${ }^{40}$ Een dergelijke toets aan het zorgvuldigheidsbeginsel is ook in administratiefrechtelijke uitspraken herkenbaar, zij het dat deze uitspraken een sterk casuistisch karakter hadden. De omstandigheden van het geval, de positie van het bestuursorgaan en de vraag of de belangen van de justitiabele niet zijn geschaad, dienden als toetsingsmaatstaven. ${ }^{41}$

In het onderzoek van de (on)partijdigheid van bestuursorganen bij de beslissingsprocedure (par. 2.5.5) is vastgesteld, dat belangenverstrengeling, gebrek aan een onbevooroordeelde houding en objectiviteit 'gewogen' worden aan de hand van de organieke bepalingen die beogen verboden deelname van bestuurders aan de stemming over besluiten. De bepalingen in het organieke recht inzake verboden deelname aan de stemming over een besluit, zijn strikt geredigeerd. Art. 28 Gem.w., lid 1, onder a (art. 52 vervallen gem. w.) bepaalt:

1. Een lid van de raad neemt niet deel aan de stemming over:

a. een aangelegenheid die hem rechtstreeks of middellijk persoonlijk aangaat of waarbij hij als wertegenwoordiger is betrokken;"

Vóór de Awb bleek er aanvankelijk een verschil van opvatting in de toetsing door de Kroon en de arob-rechter. De Kroon oordeelde in het kader van het spontane vernietigingsrecht of de (verboden) deelname an de stemming, van beslissende invloed was geweest op de totstandkoming van het betreffende besluit. ${ }^{42}$ De arobrechter was aanvankelijk strikt in de toetsing, maar huldigde naderhand het Krooncriterium. ${ }^{43}$ Deze 'jurisprudentielijn' wordt blijkens het KB Simpelveld gecontinueerd (par. 2.6.4). ${ }^{44}$ Het KB Simpelveld is overigens door de ARRS vernietigd. De ARRS is van oordeel dat art. 28, lid 1 Gem.w. een fundamenteel recht is van de leden van een gemeenteraad om aan een stemming deel te nemen. Voor het maken van een inbreuk op art. 28 , lid 1 dienen objectieve toetsingscriteria te gelden. ${ }^{45}$ Zo moet naar de opvatting van de bestuursrechter het begrip

$40 \mathrm{~KB} 21$ december 1982, Stb. 768, AB 1983, 298.

41 Zie in dit verband de noten $107 \mathrm{t} / \mathrm{m} 109$ in hoofdstuk 3.

42 Zue noot 115 in hoofdstuk 2.

43. Zie noot 117 in hoofidstuk 2.

ABRS 20 februari 1998, Gst. 7072, 3, IB 1998, 76 m.nt. R.I.N.S. Zie ook: E. Brederveld. Simpelveld: bona causa triumphat!, Gst. 7072 , p. 153 e.v. 
'vertegenwoordiger' als bedoeld in art. 28 , lid 1 in civielrechtelijke zin worden opgevat.

In par. 2.6 is de objectieve besluitvorming door bestuursorganen onderzocht onder de werking van de Awb. Op basis van de jurisprudentie is vastgesteld dat de formeel-wettelijke en de materieel-wettelijke advisering steeds strikter door de bestururstrechter wordt getoetst.

Onder de werking van de Awb staat de voorbereidingsfase (het adviseren) sterk onder invloed van het onpartijdigheidsgebod van art. 2:4, lid 1.6

De jurisprudentie duidt er op dat de bestuursrechter in eerste aanleg en het CBB kritisch oordelen over de bestuurlijke waakzaamheid voor art. 2:4. Vooral de inrichting van de adviesprocedure, voorafgaand aan de beslissing op het bezwaarschrift, is onder druk komen te staan. In een aantal gevallen is de samenstelling van de hoor en adviescommissies voor de behandeling van de bezwaarschriften, op de korrel genomen. Vooral in situaties dat hel openbaar lichaam als belanghebbende vergunninghouder mede in de bezwaarschriftenprocedure is betrokken, blijkt extra zorgvuldigheid geboden bij de voorbereiding van de beslissing op het bezwaarschrift. Een adequate inrichting van de voorbereidingsfase, voorafgaand aan de beslissing op het bezwaarschrift, is van belang. Het tot het openbaar lichaam behorende bestuursorgaan moet elk risico van de schijn van partijdigheid vermijden. ${ }^{47}$

De bestuursrechter in eerste aanleg lijkt strenge onpartijdigheidsmaatstaven aan te leggen die zelfs zóver gaan, dat onverlet de aan de bijzondere regelgever gelaten 'adviesvrijheid', alleen het adviseren door een hoor en adviescommissie in de zin van art. 7:13 de rechtmatigheidstoets kan doorstaan. ${ }^{48}$ In tegenstelling tot het CBB lijkt de ABRS in de beoordeling van een (eerste) hoger beroep over de toepassing van art. $2: 4$, lid 1 , strikte, en enge criteria te hanteren ten aanzien wan het naleven van het onpartijdigheidsgebod in art. $2: 4 \mathrm{Awb}$; de ABRS blijkt niet al te snel een "persoonlijk" belang in de zin van art. $2: 4$, lid 2 aan te nemen."

46 Rb. Maastricht 29 maart 1996, JB 1996, 132, m.nt. EvdL.

47 CBB 21 december 1994, JB, 1, ABN 1995, 454, m. nt. JH vdH, RAwb 1995, 34 mint. BdW.

48 Rb. Maastricht 5 maart 1996, reg. nr.: 95/1786 WW50 Z Pol en Rb. Maastricht 19 augustus 1996, Gst. 7063, m. ni. C.P.J. Goorden.

49 In hoger beroep vernietigde de ABRS op 16 december 1997, JB 1998, 24 m.nt. ARN, ABkort 1998, 30, Gst. 7077,5, C.P.J. Goorden een uitspraak van de Pres. Rb. Maastricht van 10 december 1996, Reg. no. 96/3025 WOW44 V + 96/3045 WOW44 VV KLR. 
Naast art. 2:4 Awb blijft ook het zorgvuldigheidsbeginsel als beginsel van behoorlijk bestuur een functie vervullen ten dienste van een rechtens juiste voorbereiding van de besluitvorming. Dit beginsel is in de Awb voor besluiten gecodificeerd in de art. 3:2 (kennisvergaringsplicht) en 3:9 (bestuurlijke toetsingsplicht van externe wettelijke adviezen). Het zorgvuldigheidsbeginsel kan mede uitkomst bieden om de schijn van vooringenomenheid door bestuursorganen te "bestraffen". Dit laatste kan zich bijvoorbeeld manifesteren in de relatie tussen een bestuursorgaan en de bij dat bestuursorgaan ondergeschikte en werkzame personen. Het kan immers voorkomen dat een ambtelijke werknemer geen faire kans heeft gekregen bij de interne sollicitatie naar een functie en dat bij hem de indruk is gewekt dat het bij de beoordeling van zijn geschiktheid, aan objectiviteit heeft ontbroken. Subjectieve partijdigheid in een sollicitatieprocedure kan leiden tot vernietiging van het beroepen besluit op basis van strijd met het zorgvuldigheidsbeginsel. ${ }^{50}$

Het gelijkheidsbeginsel speelt eveneens in de rechtspraak een rol in de 'strijd" tegen het uitbannen van vooringenomenheid bij de besluitvorming. De bestuursorganen handelen nogal eens onverantwoordelijk in hun handhavingstaak. ${ }^{51} \mathrm{Er}$ wordt soms niet opgetreden tegen illegaal handelen door burgers, waardoor wettelijke voorschriften worden overtreden. In die gevallen dat wel wordt opgetreden, geschiedt dit niet altijd planmatig en 'regeert" het bestuursorgaan via signalen van de burgers. De indruk kan hierbij ontstaan dat bijvoorbeeld een waarschuwing tot het toepassen van bestuursdwang willekeurig plaatsvindt. Bij de 'gepakte' burger ontstaat dientengevolge nogal eens het beeld van 'waarom ik wél, en hij niet?'.

\subsection{Het horen: een belangrijke formele bepaling met materiële betekenis voor de beslissing op het bezwaarschrift}

In hoofdstuk 3 is de in art. 7:2 Awb aan het bestuursorgaan opgelegde hoorverplichting onderzocht. Voorafgaand aan de beslissing op het bezwaar moet het bestuursorgaan - behoudens de uitzonderingen gesteld in art. 7:3 Awb - de belanghebbenden in de gelegenheid stellen om hem te horen.

De Awb-wetgever hecht grote waarde aan het belang van de harmonisatie van de voor de bezwaarschriftenprocedure in art. 7:2 opgenomen bestuurlijke hoorplicht. Het afwijken van de in de Awb opgenomen hoorplicht wordt blijkens de MvAII

so H.J. Simon, Handboek, a.w., p. 121 alsmede Rb. Roermond, JB $1994,68$.

s1 F.C.M.A. Michiels, Bestuurlijke handhaving in ontwikkeling, in: Handhawing van het bestuursrecht, a.w. 114, p. 42 e.v. 
ongewenst geacht. ${ }^{52}$ Het horen is geen novum in het bestuursrecht. In die gevallen dat geen wettelijke hoorplicht was voorgeschreven, toetste de administratieve rechter het achterwege laten van het horen door het bestuursorgaan aan het formele zorgvuldigheids-beginsel. ${ }^{53}$ Vóór de Awb legde de Wet arob met de bezwaarschriftenprocedure in art. 14 , lid $\mathbb{1}$, de hoorplicht vast.

De hoorplicht heeft als essentieel onderdeel van de bezwaarschriftenprocedure een belangrijke functie. ${ }^{54}$

Met de voor de bezwaarschriftenprocedure vereiste hoorplicht wordt de basis gellegd voor het beginsel van een behoorlijke procedure, te weten het beginsel van hoor en wederhoor. Hieraan ligt het uitgangspunt ten grondslag dat het bestuursorgaan de bij het bestreden besluit betrokken belanghebbenden ten opzichte van elkaar een gelijkwaardige positie verschaft. ${ }^{55}$

Hoor en wederhoor is een van de belangrijkste waarborgen voor een 'goed' procesrecht. Ook de hoorplicht in het kader van de bezwaarschriftenprocedure wordt door deze voor het administratief procesrecht gestelde eis beïnvloed. Door de hoorplicht kunnen de in de voorgaande procedure ontstane gebreken in de zorgvuldigheid van de besluitvorming in het kader van de bezwaarschriftenprocedure worden herstelld. ${ }^{56}$

Het horen in het kader van de bezwaarschriftenprocedure vervult een belangrijke waarborgfunctie voor zowel de belanghebbende burgers als voor het bestuursorgaan. Deze waarborgfunctie van de hoorplicht is gericht op het activeren door het bestuursorgaan van wederzijdse informatie van zowel het bestuursorgaan als de justitiabele. Het verstrekken van deze wederzijdse informatie is gericht op het versterken van de kwaliteit van de besluitvorming. De beoogde waarborgfunctie van de hoorplicht wordt door de Awb geaccentueerd door een viertal functionele uitgangspunten.

Allereerst krijgen de belanghebbenden de kans hun grieven ten aanzien van het bestreden besluit nog eens aan het bestuursorgaan nader kenbaar te maken. In de

52 PG Awb 1, p. 330.

53 ABAR, $5 e$ dr., Alphen aan den Rijn 1984, p. 129 e.v.

54 PG Awb 1, p. 329.

55 J.M.H.F. Teunissen, in: Commentaar Algemene wet bestuurstecht, losbl., "s-Gravenhage, p. E $6.3 .7-1$.

56 B.W.N. de Waard Een eerlijk proces (I), Algemene beginselen van behoorlijk procesrecht, TVO 1983, p. 145. Zie in dit verband: CRvB 4 december 1997, JB 1998, 38 m.nt. JMED. 
tweede plaats heeft het bestuursorgaan de gelegenheid om nadere informatie omtrent het bestreden besluit te verschaffen. Voorts kan op basis van de verstrekte wederzijdse informatie door de belanghebbenden en het bestuursorgaan, worden nagegaan of het creëren van bepaalde bestuurlijke oplossingen mogelijk is. In de vierde functie van het horen ligt een legitimiteitsaspect opgesloten: het bestuursorgaan kan het vertrouwen in de bestreden beslissing versterken ook al geven de bezwaren geen aanleiding tot wijziging van het primaire besluit. ${ }^{5}$ ?

Ook de procedurevoorschriften betreffende het horen (art. 7:4 tot en met 7:9), verschaffen het bestuursorgaan een legitimiteitsbasis in zijn contact met de belanghebbenden. ${ }^{58}$ De hoorverplichting van art. 7:2 en ook de overige procedure-bepalingen van afd. 7.2 , zijn belangrijke pijlers van de bezwaarschriftenprocedure om de uit het materieel recht voortvloeiende rechten en plichten te effectueren. ${ }^{\text {s9 }}$

Hieruit vloeit voort dat de hoorverplichting niet alleen betekenis heeft als formele bepaling. Het horen vervult een belangrijke functie ten dienste van de in het kader van de bezwaarschriftenprocedure door het bestuursorgaan te maken heroverweging (art. 7:11). De hoorplicht is als formele bepaling vooral van belang voor het inhoud geven aan de bestuurlijke rechtmatigheids- en doelmatigheidstoetsing. Het bestreden besluit moet immers worden beoordeeld op grond wan het materieel recht in casu de bijzondere wet, waaraan het bestreden besluit ten grondslag ligt.

Hoor en wederhoor eist een formeel evenwicht in het bieden van mogelijkheden door het bestuursorgaan tot het ontvangen en het verschaffen van informatie in het kader van de bezwaarschriftenprocedure. ${ }^{60}$ In par. 3.2 .2 .2 is een tiental functionele elementen uitgewerkt dat belangrijke eisen stelt aan een rechtens juiste vervulling van de bestuurlijke hoorplicht.

Deze tien elementen zijn vervolgens gerubriceerd in vier uitgangspunten die het belang van hoor en wederhoor als gelijkwaardigheidsbeginsel en waarborgbeginsell ten dienste van de voorbereiding van de beslissing op het bezwaarschrift accentueren, te weten:

57 PG Awb I, p. 329.

58 P.J.J. van Buuren en M. de Groot-Sjenitzer, a.w., p. 28.

59 PG Awb I, p. 18.

60 B.W.N. de Waard, a.W., p. 247. 
a. de onvoorwaardelijke selectieplicht van het bestuursorgaan om de bij het bestreden besluit betrokken belanghebbenden te horen;

b. hoor en wederhoor als structuurbepalende (wettelijke) verplichting;

c. hoor en wederhoor in relatie tot de kennisvergaringsplicht naar relevante feiten en af te wegen belangen;

d. hoor en wederhoor en de aanwezigheid van getuigen en deskundigen.

Aan de hand van de jurisprudentie is vastgesteld dat uit de onvoorwaardelijke selectieplicht voor het bestuursorgaan voortvloeit, dat rechtens strikte eisen aan de hoorplicht worden gesteld; belanghebbenden moeten voor de hoorzitting een schriftelijke uitnodiging ontvangen. Deze strikt formeel-juridische lijn geldt ook voor de wijze waarop het horen plaatsvindt. Voor de justitiabele moet herkenbaar zijn dat er sprake is van horen in het kader van de bezwaarschriftenprocedure.

Het beginsel van hoor en wederhoor heeft een informatieve functie. Deze informatieve functie van het horen is van belang voor het rechtens vaststellen van de feiten en belangen die het genomen bestreden besluit moeten dragen. In het kader van de voorbereiding van de beslissing op het bezwaarschrift (en ook het besluit in primo) legt art. 3:2, als kennisvergaringsnorm voor het bestuursorgaan, de verplichting vast voor het rechtens vaststellen van de relevante feiten en belangen. Vooral de kennisvergaringsplicht als bedoeld in art. 3:2 noopt het bestuursorgaan tot een actieve opstelling bij het horen. Dit heeft gevolgen voor de omvang van de onderzoeksplicht en de juiste bepaling door het bestuursorgaan van de inhoud van de (rechts)positie van de justitiabele. Een 'goed' hoor en wederhoor vergt van het bestuursorgaan een houding die er op gericht is dat de burger in zijn verweermogelijkheden "het volle pond" krijgt. Van het bestuursorgaan mag worden geëist dat het de justitiabelen correct bejegent, de beginselen van fair play in acht neemt, en dat het zich onthoudt van (subjectieve) vooringenomenheid.

Een gelijke en actieve houding moet het bestuursorgaan aan de dag leggen in het kader van het horen van getuigen en deskundigen. Voor de bezwaarschriftenprocedure op grond van de Awb is de bepaling van het op verzoek ter zitting meebrengen van getuigen en deskundigen nieuw (art. 7:8). De Wet arob kende een dergelijke regeling niet. In de praktijk van de bezwaarschriftenprocedure werd hier overigens wél gebruik van gemaakt. ${ }^{61}$

61 Zie in dit verband: Behandeling van bezwaarschriften ingevolge de Wet Arob. VNG Blauwe reeks nr. 58, "s-Gravenhage 1976, p. 29. 
Uit het onderzoek in hoofdstuk $3 \mathrm{kan}$ worden geconcludeerd dat de hoorverplichting een zeer sterke wissel trekt op de kwaliteit van de voorbereidingsfase van de bezwaarprocedure, en in belangrijke mate mede bepalend is voor een rechtens juiste beslissing op het bezwaarschrift.

Sommigen oordelen het wenselijk de hoorplicht in de bezwaarschriftenprocedure te wijzigen. ${ }^{62}$ De geluiden dat het horen tot een bestuurlijke belasting leidk zijn niet nieuw. ${ }^{63}$ Toch mag dit argument geen reden zijn om de inrichtingseisen van de bezwaarschriftenprocedure aan te passen. De oorzaak van de klachten is van een geheel andere aard en raakt de kwaliteit van het primaire besluitvormings proces. Betere primaire besluiten verlagen de bestuurslasten in de bezwaarschriftenprocedure.

Het belang van de hoorplicht in het kader van de bezwaarschriftenprocedure is blijkens het onderzoek in hoofdstuk 3 allerminst afgezwakt. Ook niet door de uitspraak van de ABRS dat de hoorplicht op grond van art. 7:2 geen bepaling van openbare orde is. ${ }^{64}$

\subsection{Het adviseren omtrent de op het bezwaarschrift te nemen beslissing}

De voorbereidingsfase van de op het bezwaarschrift te nemen beslissing wordt gekenschetst door een aantal belangrijke aspecten en uitgangspunten.

De Awb heeft ten behoeve van de bezwaarschriftenprocedure, in afdeling 7.2 een aantal procedurele waarborgen alsmede inrichtingseisen opgenomen. Twee aspecten van de bezwaarschriftenprocedure, te weten het horen van de belanghebbende( $n)$, alsmede het adviseren omtrent de op het bezwaarschrift te nemen beslissing, hebben een belangrijke betekenis in de voorbereidingsfase, voorafgaand aan de beslissing op het bezwaarschrift. Het horen en het adviseren, zijn als voorbereidingsaspecten in de voorbereidingsfase van de beslissing op het bezwaarschrift, vooral tot ontwikkeling gekomen ten tijde van de Wet arob. Beide procedurele aspecten zijn van belang voor een rechtens juist verloop van deze voorprocedure.

A.J.G.M. van Montfort en H.B. Winter, Kleime gebreken geem bezwaar? een evaluatie van de bezwaarschriftenprocedure uit de Awb in: In Wederkerigheid, Deventer 1997, p. 196.

63 P.J.J. van Burren, Groei-problemen in: De omwang van de rechtskescherming, VAR-LXXXVIII, Alphen aan den Rijn 1998, p. 21.

ABRS 29 juli 1996, RAwb, 127, m. nt. Widdershoven. 
Het derde adviseringstype voor de geschilbeslechtende bestuursorganen (par. 4.1), te weten de semi-rechterlijke advisering speelt een belangrijke rol in de op het bezwaarschrift te nemen beslissing. Een adviescommissie voor de behandeling van bezwaarschriften heeft ten behoeve van de bestuurlijke geschilbeslechting een waarborgfunctie. ${ }^{65}$

In die gevallen dat het bestuursorgaan 'judex in causa' is, biedt de inschakeling van een onpartijdige adviescommissie rechtswaarborgen voor de belanghebbende(n). De burger is in grote mate afhankellijk van het bestuursorgaan. Door een adviescommissie in te stellen wordt aan de voorbereidingsfase van de beslissing op het bezwaarschrift een contradictoir karakter gegeven. Dit kan leiden tot betere procedurele waarborgen voor de justitiabele. Hierdoor wordt meer rekening gehouden met de beginselen van behoorlijke rechtspraak.

Het adviseren in het kader van de bezwaarschriftenprocedure op grond van de Wet arob leverde een belangrijke bijdrage aan het ontstaan en de ontwikkeling van adviescommissies. Door hun functie en positie in de bezwaarschriftenprocedure zijn adviescommissies voor de behandeling van bezwaarschriften door hun advieswerkzaamheid als een "verlengde arm" van het bestuursorgaan gaan fungeren. Hierin ligt hun onderscheidende betekenis ten opzichte van andere adviesvormen in het openbaar bestuur. Door het horen en het nemen van procedurele beslissingen, in samenhang met het uit te brengen advies aan het bestuursorgaan heeft deze commissie een belangrijke functie gekregen in het besluitvormingsproces van de bezwaarschriftenprocedure.

De parlementaire geschiedenis van de Wet arob, de wetenschap en de jurisprudentie onder de werking van de Wet arob, hebben vanuit het gezichtspunt van de voorbereidingsfase van de beslissing op het bezwaarschrift en de functie van de bezwaarschriftenprocedure, vooral een stimulerende werking gehad op de instelling van bezwaarschriftenadviescommissies door de (gemeentelijke) bestuursorganen. ${ }^{67}$

65 H.R.B.M. Kummeling, a.w. , . 24.

66 H.R.B.M. Kummeling, a.w., p. 42 en 163 e.v. en S.V. Hoogendijk-Deutsch, a.w. , p. 21 en 22

67 Zie o.a.: J.H. van Kreveld en M. Scheltema, Parlementaire geschiedenis van de Wet Arob, Groningen 1976, p. 296, Beeld van de Arob-bezwaarschriftenprocedure, Deventer 1982 en C. Breeuwsma, E. Helder en E. Niemeijer e.a., Arob-praktijken, Deventer 1984, J.G. Steenbeek en F.A.M. Stroink. Wet administratieve rechtspraak overheidsbeschikkingen, vierde geheel herziene dr., 's-Gravenhage 1988, p. 393 e.v. en R.W.L. Loeb, B.K. Olivier en H. Troostwijk, De Wer Arob toegepast, Nijmegen 1990 , p. 149 e.v. 
De Awb continueert de (arob)bestuurspraktijk ten aanzien van het adviseren in de bezwaarschriftenprocedure. Naast het belang van het adviseren door een 'specia$\mathrm{le}^{3}$ adviescommissie $^{68}$ heeft de Wet arob de bijzondere regelgever de vrijheid gelaten om naar eigen inzicht de bezwaarschriftenprocedure in te richten. Deze bestuurlijke vrijheid ten aanzien van de wijze van het adviseren is ook een belangrijk uitgangspunt van de $\mathrm{Awb}{ }^{69}$

Toch heeft de Awb in tegenstelling tot art. 14 Wet arob enige regels gesteld ten aanzien van het horen en het adviseren. Voor het geval dat de gehele voorbereiding van de bezwaarschriftenprocedure onder de verantwoordelijkheid van het bestuursorgaan geschiedt, en het bestuursorgaan niet zelf hoort, zijn in art. 7:5 bijzondere eisen gesteld ten aanzien van de personen die met het horen zijn belast. Deze eisen zijn ontleend aan de arobjurisprudentie.

De Awb bevat in één bijzonder geval voor het adviseren door een advies-commissie, bijzondere regels. In art. 7:13 Awb, lid 1 is bepaald, dat indien ten behoeve van de beslissing op het bezwaar een adviescommissie is ingesteld, en deze commissie voldoet aan de in a tot en met $\mathrm{c}$ gestelde (inrichtings)eisen, de voorschriften van dit artikel van toepassing zijn op deze adviescommissie. Uit dit facultatieve voorschrift vloeit voort dat de adviescommissie op een bepaalde wijze moet zijn samengesteld. In deze samenstellingseisen komen accenten van distantie ten opzichte van het bestuursorgaan tot uitdrukking. De voorzitter mag geen deel uit maken van het op het bezwaar beslissend bestuursorgaan. Ook mag de voorzitter niet werkzaam zijn onder verantwoordelijkheid van dit bestuursorgaan.

De Awb heeft in art. 7:13 een belangrijke koppeling aangebracht tussen het horen en het adviseren; is een adviescommissie in de zin van art. 7:13 ingesteld, dan is deze commissie ook met het horen belast. Tevens is in het vijfde lid van art. 7:13 een contradictoir element ingebouwd. De adviescommissie is verplicht een vertegenwoordiger van het bestuursorgaan "voor het horen" uit te nodigen. Deze moet in de gelegenheid worden gesteld een toelichting te geven op het standpunt van het bestuursorgaan.

De inhoud en strekking van art. 7:13 staat niet op zichzelf, maar is het resultaat van de ervaringen ten tijde van de Wet arob. Voor de (gemeentelijke) bestuurspraktijk werden modelverordeningen ontwikkeld. ${ }^{70}$ De functie en het karakter van

68 J.H. Kreweld en M. Scheltema, a.w., p. 296.

69. PG Awb I, p. 353.

70 VNG, Blauwe reeks nr. 58 en 72 , 's-Grawenhage 1976 en 1988. 
de bezwaarschriftenprocedure, alsmede het belang van de kwaliteit van de beslissing op het bezwaarschrift (heroverweging, betere dossiervorming, het belang van het horen en de invloed van de zeefwerking op het aantal beroepen bij de administratieve rechter) deden de aandacht voor de herkenbaarheid van de wijze van advisering in het kader van de bezwaarschriftenprocedure, groeien. ${ }^{71}$

Ook art. 14, lid 3 Wet arob heeft de aandacht voor de voorbereidingsfase van de beslissing op het bezwaarschrift versterkt. Aan de in dit artikellid gegeven mogelijkheid om bij of krachtens a.m.v.b. regels te stellen betreffende het horen en het adviseren door een commissie, is weliswaar geen uitvoering gegeven, maar de commissie De Gaay Fortman, ontwikkelde belangrijke voorstellen ter verbetering van de kwaliteit van de bezwaarschriftenprocedure. ${ }^{72}$

De voorstellen van de commissie Arob die tevens een ontwerp wan a.m.v.b. bevatten kwamen nagenoeg overeen met art. 7:13 Awb. Voor het adviseren door een adviescommissie werd een facultatieve bepaling opgenomen. De niet verplichte (inrichtings)regels voor de bezwatschriftenprocedure kenden dezelfide elementen wan distantie als het eerste lid van art. $7: 13$ en legden eveneens een nauwe relatie tussen het horen en het adviseren omtrent de op het bezwaarschrift te nemen beslissing. ${ }^{73}$

Naast belangrijke overeenkomsten van art. 7:13 Awb met de voorstellen van de commissie Arob is er ten aanzien van een belangrijk aspect, een opmerkelijk verschill. Art. 7:13, aanhef, eerste lid, bepaalt:

'1. Dit artikel is van toepassing indien ten behoeve van de beslissing op het bezwaar een adviescommissie is ingesteld: (...)'

Art. 8 lid wan de (ontwerp) a.m.v.b. ex art. 14, lid 3, bepaalde dat de adviescommissie van tot de centrale overheid behorende organen, byj ministeriële regeling moest worden ingesteld. De adviescommissie voor de bezwaarschriften, ten behoeve van de decentrale bestuursorganen, diende bij verordening te worden ingestell. De toelichting behorende bij het bovengenoemde ontwerp van a.m.v.b. benadrukte voor zover hier van belang, de noodzaak van het vaststellen van een formeel criterium (het instellen van de adviescommissie bij ministeriële regeling

7 M. Oosting. De arob-bezwaarschriftenprocedure als keuzevraagstuk, Rondom de Wet. Arob, in Best. wet 1979, p. 119 e.v. en Beeld van de Arob-bezwaarschriftenprocedure, a.w., en Arob. praktijken, a. $w$.

72 Eindrapport commissie Arob, 's-Gravenhage 1987.

73 A. W. p. 4. 
of verordening). Aan de hand van dit (instellings)grondslagcriterium zou kunnen worden vastgesteld of er sprake was van het optreden van een adviescommissie. ${ }^{74}$ Ook de Awb plaatst de (keuze)mogelijkheid van een adviescommissie op de voet van art. 7:13 in een onderscheidend perspectief ten opzichte van andere vormen van advisering in het openbaar bestuur. Uit een oogpunt van herkenbaarheid voor de justitiabelen moet volgens de Awb-wetgever duidelijk zijn of de inrichting van de bezwaarschriftenprocedure geschiedt conform een volledig interne (organisatorische) structuur of dat de voorbereiding van de beslissing op het bezwaarschrift (het horen en het adviseren) is opgedragen aan een commissie in de zin van art. $7: 13 .{ }^{75}$

Het adviseren in het kader van de bezwaarschriftenprocedure kan op verschillende manieren geschieden. In de bestuurspraktijk komen hoor- en adviescommissies voor die zijn samengesteld uit bestuurders en/of ambtenaren. Bij het instellen van adviescommissies voor de bezwaarschriften kan ook voor een gemengde samenstelling worden gekozen (bestuurders en/of ambtenaren en buitenstaanders). De adviescommissie kan bovendien een zuiver extern karakter hebben doordat de leden afkomstig zijn buiten de kring van de bestuurlijke organisatie. ${ }^{76}$

Ofschoon zowel de commissie Arob als de Awb herkenbaarheid voorstaan van de wijze van adviseren in het kader van de bezwaarschriftenprocedure, door expliciet het adviseren door een commissie in het wettelijk voorschrift tot uitdrukking te brengen, heeft de Awb ten aanzien van art. 7:13 geen formeel criterium vastgesteld voor een wettelijke grondslag ten behoeve van het instellen van deze adviescommissie. Een verwijzing naar een (materieel) wettelijke bepaling op grond waarvan de adviescommissie moet worden ingesteld, zoals indertijd is voorgesteld door de commissie Arob, is niet opgenomen in de Awb. De Awb biedt geen instellingsgrondslag voor het instellen van een adviescommissie in de zin van art. $7: 13$.

Deze gevolgtrekking kan als volgt worden geadstrueerd.

De redactie van art. 7:13, aanhef, lid 1 Awb is niet identiek met art. 14, lid 1 Wet arob. In deze laatste bepaling was opgenomen dat het horen en het adviseren kon 'worden opgedragen' aan een commissie. In de literatuur is aangenomen dat de instellingsgrondslag primair berustte op art. 14, lid 1 Wet arob. Naast deze 'arob-instellingsgrondslag' zou secundair (maar overigens zonder noodzaak) de

74 Eindrapport commissie Arob, p. 11.

75 PG Awb I, p. 353 en 354.

76. J.M.H.F. Teunissen, in: Algemene wet bestuursrecht, losbl., 's-Gravenhage, p. 6.3.18-3 e.v. 
instelling van de adviescommissie kunnen plaatsvinden op basis van in casu de gemeentewettelijke bepalingen inzake de commissies. ${ }^{77}$ Op redelijke gronden kan worden aangenomen dat ook de arobjurisprudentie in overeenstemming was met de bovengenoemdle opvattingen. Toetsing inzake het horen en adviseren door een adviescommissie geschiedde door de ARRS op basis van art. 14, lid $1 .{ }^{78}$

Art. 7:13, aanhef, lid $1 \mathrm{Awb}$ bepaalt in tegenstelling tot art. 14, lid $\mathbb{1}$ Wet arob, dat indien voldaan is aan het constituerend element, te weten "een advies-commissie is ingesteld' dit artikel van toepassing is indien bij de instelling voldaan is aan de eisen genoemd onder a tot en met $c$ van het eerste lid. Kennelijk gaat hier ook de Awb vanuit door te stellen dat art. $7: 13$ (6.3.18) 'voorschriften inhoudt voor het geval dat een adviescommissie is ingesteld ${ }^{3} .{ }^{79}$

Art. 7:13 Awb heeft een afgeleide strekking. De werking van het artikel is afhankelijk van de wettelijke grondslag voor het instellen van deze adviescommissie. Voor wat betreft het instellen van adviescommissies voor de bezwaarschriften is geconstateerd dat de grondslag hierwoor is gebaseerd op het organieke recht (Prov.w., Gem.w., Watersch.w.).

De bestuursrechter omzeilt vooralsnog het probleem van het grondslagvereiste van de adviescommissie in de zin van art. 7:13. ${ }^{80}$ De meervoudige kamer van de ABRS lijkt eveneens de problematiek van het grondslagvereiste ongemoeid te laten. In een enkele uitspraak komt het probleem van het grondslagvereiste aan de oppervlakte:

'(...) De commissie, een commissie van advies als bedoeld in artikel 92 van de Gemeentewet, bestaat in dit geval (...). De Afdeling is met de president van oordeel dat de Commissie geen adviescommissie als bedoeld in artikel 7:13 wan de Awb is, nu de voorzitter deel uit maakt van het bestuursorgaan $(. .)^{.81}$

Ook de Wet arob stelde in art. 14, lid 4 voorop dat het administratief orgaan op het bezwaarschrift beslist. In de tweede zinsnede van lid 4 maakte de Wet arob een uitzondering voor de beslissingsbevoegdheid van het bestuursorgaan door te bepalen: "tenzij ingevolge enige wettelijke bepaling de beslissing is opgedragen

77 J.G. Steenbeek en F.A.M. Stroink, a.W., p. 394 en R.J.G.M. Jeukens, De hoor- en adviescommissie van de Wet Arob, TrO 1977, p. 54.

78 ARRS 18 september 1980, Gst. 6658, 3, m.nt. JMK en SenS Wet Arob, vierde dr., 1991, p. 464 an 465 .

79 PG Awb I, p. 353.

80 Rb. Maastricht 20 maart 1996, JB, 114 .

8. ABRS 16 december 1997, JB 1998, $30 \mathrm{~m}$ nt. ARN, ABkort 1998, 30, Gst. 7077, 5, m.nt. C.P.J. Goorden. 
aan een commissie'. De uitzondering om de beslissing op een bezwaarschrift op te dragen aan een commissie is op 'volledigheidsgronden' in de Wet arob opgenomen. ${ }^{82}$

In de bestuurspraktijk is van de wettelijke mogelijkheid door gemeentelijke en provinciale besturen nauwelijks gebruik gemaakt. Bij de provincies bleek zelfs in het geheel geen belangstelling te bestaan voor de besliscommissie. ${ }^{83}$ De commissie Arob wees de besliscommissie af vanwege het bestuurlijke heroverwegingskarakter van de bezwaarprocedure ${ }^{84}$ en ook in de literatuur is de besliscommissie ontraden. Door een besliscommissie vertoont de bezwaarschriften-procedure meer trekken met het administratief beroep. ${ }^{85}$ Een ander bezwaar tegen een besliscommissie is dat het bestuursorgaan zijn beroepsrecht verliest wanneer het orgaan zich niet kan verenigen met de beslissing op het bezwaar. ${ }^{86}$

Inmiddels hebben de $A B R S$ en de CRvB de instelling van besliscommissies (in de plaats van $b$ en $w$ ), in strijd geacht met de $A w b^{87}$; de Gem.w. kan naar de opvatting van de bestuursrechter niet als instellingsgrondslag dienen omdat deze wet niet uitdrukkelijk afwijkt van de Awb. Men kan verschillend oordelen over deze uitspraken. De uitspraak van de ABRS is bevredigend, zij het dat het beter zou zijn geweest dat de Awb (of de Gem.w.) het instellen van de besliscommissies zou hebben uitgesloten. De besliscommissie past niet meer in de systematiek van de $A w b^{89}$. In de literatuur is er kritiek op dit standpunt van de ABRS. ${ }^{\text {\% }}$

Maar ook wanneer de uitspraken van beide bestuursrechters voor rechtens juist worden gehouden, dan kunnen deze uitspraken nog geen gevolgen hebben voor de besliscommissies waaraan bevoegdheden zijn opgedragen van provinciale staten en de gemeenteraad. De art. 80, 152 en 163 Prov.w. bieden voor PS de mogelijkheid tot het instellen van besliscommissies. Ditzelfde geldt ook voor de gemeenteraad op basis van de art. 82, 156 en 165 Gem.w. In par. 4.3.2.2 is vastgesteld dat

\section{J.H. Kreveld en M. Schelterna, a.w. p. 296.}

Beeld van de Arobmbezwaarschriftenprocedure, a.w.. p. 151 e.v.

Eindrapport, a.w. . p. 16.

J.G. Steenbeek/F.A.M. Stroink, a.w., p. 402 en 403.

J.B.J.M. ten Berge, Bescherming tegen de overheid, Zwolle 1994, tweede dr. p. 204. Zie in dit verband ook ABRS 6 november $1978, \mathrm{tB} / \mathrm{S}, 17$ en $\mathrm{AB} 1979,150$.

ABRS 6 januari 1997, JB 1997, 25, m.n. A.M. S.; Gst. 7053, 4 en AB 1997, 86, m. nt. FM en CRwB 25 maart 1997, JB, 91, m. nt. JMED.

Noot F.A.M.S., JB 1997, 25.

C.J.N. Versteden, De plaats wan bezwar en administratief beroep in het stelsel van rechtsbescherming, NTB 1995, p. 287.

E. Brederveld, Geen besliscommissies, beslist de Afdeling bestursrechtspraak, Gst. 7053, p. 252 en 253 . Zie noot 77 in hoofdistuk 4 ten aanzien van de besliscommissie en administratief beroep. 
het ingediende wetsvoorstel geen soelaas biedt om het instellen van besliscommissies te elimineren. Met het voorstel van wet om de art. 83 Prov.w. en 85 Gem.w. te schrappen, wordt alleen bereikt dat deze besliscommissies voortaan in het openbaar moeten vergaderen. ${ }^{91}$ Deze wetswijziging geeft reden tot enige bezorgdheid over de wijze, waarop wordt omgesprongen met het telkens ondoordacht en gebrekkig wijzigen van belangrijke organieke wetten. ${ }^{92}$

Toch zijn er op basis van de in het verleden verrichte onderzoeken in de bestuurspraktijk redelijke argumenten aanwezig om de mogelijkheid van besliscommissies onder de werking van de Awb niet langer toe te staan. De jurisprudentie en de literatuur ondersteunen dit standpunt. Het commissierecht in het organieke recht is niet aangepast aan de ontwikkelingen in het nieuwe (algemene) bestuursrecht. De commissie-bepalingen in de organieke wetten zijn veeleer gebaseerd op decentralisatie-principes, en differentiatie van de bestuursorganisatie. Deze bepalingen zijn niet primair 'geënt' op geschil-beslechtende besluitvorming; de Awb streeft naar harmonisatie van het bestuursrecht, in het bijzonder voor wat betreft de verplichte bezwaarschriftenprocedure. Het verdient aanbeveling de bepalingen over de besliscommissie te schrappen. Het is daarom noodzakelijk de reikwijdte van de relevante organieke commissie-bepalingen te beperken. Een beperking van de organisatorische (differentiatie) mogelijkheden van het bestuur moet worden vastgelegd in het organieke organisatierecht en niet in de Awb. De Awb bevat immers algemene regels van bestuursrecht en geen regels omtrent de organisatie van bestuursorganen.

\subsection{Naar een 'definitief' concept voor het adviseren op grond van de Awb: de advisering als kwaliteitsfactor in de besluitworming en als object van rechtsbescherming}

Het adviseren door een adviescommissie voor de bezwaarschriften biedt waarborgen voor de kwaliteit van de geschilbeslechtende besluitvorming door het bestuursorgaan. In hoofdstuk 4 is meer in het algemeen de basis gelegd woor een kritische analyse over de voorbereidingsfase van de beslissing op het bezwaarschrift. Object van onderzoek vormden het (instellings)grondslagvereiste van het adviseren door adviescommissies voor de bezwaarschriften, alsmede de grondslag voor het beslissen op het bezwaarschrift door een besliscormmissie. Hoofdstuk 5 "bouwt" voort op de onderzoeksresultaten wan hoofdstuk 4. Het onderzoek in

91 TK 26014 , nrs. $1-4$.

92 Zie in dit verband de kritiek van E. Brederveld, Awb: wat bouwen we wel en niel aan? De gemeentewet als structuurwet en de Awb, Gst. 7078, p. 341 e.w. 
hoofdstuk 5 richt zich meer in het bijzonder op de inrichting van het voorbereidingsproces van de beslissing op het bezwaarschrift.

De Awb geeft in tegenstelling tot de Wet arob een aantal (procedure)bepalingen voor de voorbereiding van de beslissing op het bezwaarschrift. Het bestuursorgaan heeft op grond van hoofdstuk 6 en afdelling 7.2 Awb een belangrijke rechtsplicht ten aanzien van de uitvoering van deze voorschriften. Afdeling 7.2 is zodanig van vorm dat de bezwaarprocedure primair ten overstaan en onder verantwoordelijkheid van het bestuursorgaan wordt gevoerd.

De uitwoering van de procedurebepalingen in de art. 7:2 tot en met $7: 9 \mathrm{Awb}$ (het horen en het adviseren) behoort in beginsel tot de competentie van het besturrsorgaan. Uit overwegingen van praktische aard kan het bestuursorgaan de uitvoering van deze bepalingen mandateren aan door dit orgaan aan te wijzen ambtenaren. Wél stelt in dit laatste geval art. 7:5, lid 1, onder a en b Awb, bijzondere eisen aan de persoon die hoort of aan hen die met het horen zijn belast. Geschiedt het horen door of mede door het bestuursorgaan zelf dan wel de voorzitter of een lid ervan, dan is art. 7:5 niet van toepassing. ${ }^{93}$ Dit laatste betekent dat het horen geschiedt conform art. 7:2 Awb. Op grond van art. 7:13 Awb is het mogelijk de voorbereidingsfase voorafgaand aan de beslissing op het bezwaarschrift op te dragen aan een adviescommissie.

Uit de bepalingen van procedurele aard kunnen preparatoire beslissingen voortvloeien. Deze preparatoire (procedurele) beslissingen betreffen voorbereidingshandelingen in het kader van de op het bezwaarschrift te nemen beslissing. Zij zijn doorgaans niet (zelfstandig) vatbaar voor bezwaar en beroep (art. 6:3 Awb).

Naast afdeling 7.2 (Bijzondere bepalingen over bezwaar), komen ook in de hoofdstukken 6 (Algemene bepalingen over bezwaar en beroep) en 2 (Verkeer tussen burgers en bestuursorganen), bepalingen voor die preparatoire bestuurlijke beslissingen met zich kunnen brengen.

Op basis van afdeling 7.2 draagt het bestuursorgaan in beginsel imperatief de volledige (formele) verantwoordelijkheid voor de voorbereidingsfase van de beslissing op het bezwaarschrift. Recente jurisprudentie benadrukt het exclusieve karakter van de adviescommissie voor de bezwar- en beroepschriften aan de 
gemeenteraad. Voor interventie door het dagelijks bestuur bij het adviseren aan het hoger bestuursorgaan is geen plaats meer. ${ }^{94}$

Het adviseren omtrent de op het bezwaarschrift te nemen beslissing behoeft niet per definitie te geschieden door een adviescommissie in de zin van art. 7:13 Awb. In hoofdstuk 4 is vastgesteld dat de samenstelling van adviescommissies zeer verschillend kan zijn.

In het kader van het onderzoek ten aanzien van het (instellings)grondslagvereiste wan het adviseren (par. 4.3.2.1) is benadrukt dat de $\mathrm{Awb}$ de bijzondere regellgever de vrijheid heeft gelaten om al dan niet een adviescommissie in te stellen die voldoet aan de eisen in de zin van art. $7: 13$, lid $1 .{ }^{95}$

Ten aanzien van deze (bestuursrechtelijke) adviesvrijheid is op basis van het verrichte onderzoek een aantal kritische kanttekeningen gemaakt.

Op grond van doelmatigheidsoverwegingen en in het belang van de duidellijkheid voor de justitiabele is in de Awb gekozen voor eenvormigheid van de procedureregels voor het maken van bezwaar. Met de aan de bijzondere regelgever gelaten vrijheid omtrent het adviseren over bezwaarschriften, wordt dit uitgangspunt uitgehold. Dit geldt mede voor het uitgangspunt van de Awb dat het adviseren in het kader van de bezwaarschriftenprocedure voor de burger herkenbaar moet zijn. Gezien de verschillen in de wijze van samenstelling van adviescommissies, kan van de justitiabele niet of nauwelijks worden verwacht dat hij een rechtens juiste inschatting maakt óf een adviescommissie conform de uitgangspunten van de Awb functioneert of dat het adviseren anderszins geschiedt. De bestuursrechter zal in het kader van een ingesteld beroep een oordeel kunnen geven over de (formele of informele) status van de adviescommissie.

Een ander minder valide argument voor de vrijheid van het adviseren is de opvatting van de Awb-wetgever dat de advieswrijheid in het kader van de bezwatschriftenprocedure tot een meer flexibele behandeling van bezwaarschriften kan leiden. De keuze voor een adviescommissie door het bestuursorgaan zou beter "per bezwaarschriftenprocedure" kunnen worden gemaakt omdat de be-

94. ABRS 8 april 1997, AB 1998, 106 m.nt. PvB.

95. De ABRS heeft op 16 december 1997, JB 1998, 30, m. nt. ARN, ABkort 1998, 30, Gst. 7077, 5, m.nt. C.P.J. Goorden voor de eerste maal onder de werking wan de Awb, met verwijzing naar de wetsgeschiedenis bepaald dat "het bestuursorgaan niet verplicht is' een adviescommissie in de $z$ in van artikel $7: 13$ "in het lewen te roepen". 
zwaarschriftenprocedures naar 'karakter' kumnen verschillen. ${ }^{96}$ Dit laatste argument lijkt onjuist; bezwaarschriftenprocedures verschillen niet van karakter.

Alleen de besluiten in primo die object zijn van bezwaar, kunnen van karakter verschillen. Ook de herowerwegingsruimte als bedoeld in art. 7:11 kan per type van (bestreden) besluit verschillen.

De volledige heroverweging krijgt 'de beste kansen' wanneer behandeling van het bezwaarschrift plaatsvindt door een commissie die is samengesteld uit een bestuurlijke inbreng, (ambtelijke) beleidswoorbereidende inbreng en een onafhankelijk element. ${ }^{97}$ De bovengenoemde samenstelling van een adviescommissie voor de bezwaarschriften levert een belangrijke bijdrage aan een rechtens juiste inrichting van de bezwaarschriftenprocedure; de legitimiteit van het door het bestuursorgaan ontwikkelde beleid kan hierdoor worden vergroot.

Er zijn nog andere redenen om de adviesvrijheid ten aanzien van de behandeling van bezwaarschriften in de Awb te kritiseren. Vanuit de bestuurspraktijk is gepleit om het adviseren in het kader van de bezwaarschriftenprocedure onder het bereik van afd. 7.2 te brengen. ${ }^{3}$ De argumenten waren gebaseerd op een verruiming van de reikwijdte van art. 7:13, lid 1 (wijze samenstelling adviescommissie). Dit geldt mede voor het advies van de RvS over art. 7:13 (art. 6.3.18 ontwerp Awb) om ook andere categorieën van adviescommissies onder de werkingssfeer van art. $7: 13$ te brengen. Belangrijke aspecten in art. 7:13, te weten het horen en het adviseren (lid 3), de bevoegdheid tot het nemen van preparatoire beslissingen (lid 4) en het contradictoire element in het vijfde lid (het horen door de commissie van een vertegenwoordiger van het bestuursorgaan), zouden naar de opvating van de RvS ook voor andere adviescommissies moeten gellen. ${ }^{99}$

Het argument om ook andere categorieën van adviescommissies onder de werkingssfeer van art. 7:13 te brengen, is los van de vraag naar de wenselijkheid van meerdere adviesvormen voor de behandeling van bezwaarschriften, niet zonder betekenis.

De hoorplicht van het bestuursorgaan (art. 7:2) vormt een essentieel onderdeel van de bezwaarschriftenprocedure. Het horen van de belanghebbende( $n$ ) is gericht op een informatieverstrekking. Onvolledige en gebrekkige gegevens kunnen door

96. PG Awb I. p. 353.

97 Arobupraktijken, a w. p. 347 en F.A.M. Stroink, Kem van de besturursrechtsprack, "s-Grawen. hage 1997, p. 103.

98 Ordening in het besturrstecht (eerste fase), $\mathrm{VNG}^{\prime}$ 's-Gravenhage $1987, \mathrm{p} .25$ en 26.

99 PG Awb I, p. 353. 
het uitwisselen van informatie tussen het bestuursorgaan en de justitiabele worden aangevuld of hersteld. Dit kan aanleiding geven tot herziening van het bestreden besluil in primo. ${ }^{100}$ Tussen het horen en adviseren is derhalve een naww verband. In die gevallen dat geen adviescommissie is ingesteld in de zin van art. 7:13, kan dit er toe leilden dat alleen het horen namens het bestuursorgaan geschiedt conform art. 7:5.

Dit kan betekenen dat het adviseren (afzonderlijk) door anderen binnen de bestuursorganisatie geschiedt, tenzij een interne adviescommissie is ingesteld waaraan zowel het horen als het adviseren is opgedragen. Een situatie waarin het horen en het adviseren afzonderlijk geschieden, is niet doelmatig en niet in het belang van de kwaliteit van de voorbereidingsfase, en kan leiden tot een rechtens onjuiste beslissing op het bezwaarschrift.

Hierdoor krijgt de informatie-functie van het horen onvoldoende gestalte; in het geval dat een commissie in de zin van art. 7:13 is ingesteld gaan het horen en het adviseren in ieder geval verplicht, "hand in hand".

Ook de eisen ter voorkoming van belangenverstrengeling die in art. 7:5 zijn gesteld ten aanzien van hen die door het bestuursorgaan met het horen kunnen worden belast zijn niet doelmatig. Indien het bestuursorgaan zelf (of mede) hoort - hetgeen in de praktijk vanwege de bestuurlijke belasting niet of nauwelijks voorkomt - is art. 7:5 niet van toepassing. Een of meerdere personen die bij de voorbereiding van het bestreden besluit betrokken zijn, kunnen naast het bestuursorgaan met het horen worden belast. Dit geldt ook conform de aanhef van het eerste lid indien de voorzitter of een lid van het bestuursorgaan met het horen is belast. In dit laatste geval kan de belangenverstrengeling een sterkere invloed hebben op het horen; de afhankelijkheid van deze ene bestuurlijke persoon die hoort is dan ten opzichte van een of meer personen die mede horen, groter.

In die gevallen dat het bestuursorgaan het horen heeft opgedragen aan éen persoon die niet bij de voorbereiding van het besluit betrokken is geweest (art. $7: 5$, eerste lid, onder a) is ook hiermede een onbevooroordeeld horen niet gewaarborgd. Voor een dergelijke waarborg tegen voldoende "onafhankelijkheid' heeft art. 7:13 lid 3 (voorzitter of onafhankelijk lid) wél oog. Daarnaast kan het horen door één persoon onvoldoende garanties bieden voor voldoende deskundigheid, hetgeen nadelig kan zijn voor de kwaliteit van de beslissing op het bezwaarschrift. Vooral in complexe en op belangenafweging gerichte besluiten moet het horen door één persoon worden ontraden. 
De toepassing van art. 7:5 verdient geen aanbeveling. Dit artikel is een codificatie van de arob-jurisprudentie, waaruit een negatief beeld is af te leiden ten aanzien van een rechtens juiste uitvoering van de hoorverplichting. Een rechtmatige toepassing van art. 7:5 noopt tot een actieve rechterlijke toetsing. Reeds tijdens de arob-periode bleek dat het horen op de wijze die art. 7:5 toestaat niet steeds voldoende garanties bood ter voorkoming van belangenverstrengeling bij de behandeling van bezwaarschriften. ${ }^{101}$ Onder de werking van de Awb is dit niet anders. ${ }^{102}$

Ook in die gevallen dat het bestuursorgaan op een bezwaarschrift moet beslissen en het openbaar lichaam waarvan dit bestuursorgaan deel uitmaakt, als belanghebbende vergunninghouder in deze voorprocedure is betrokken, is de toepassing van art. 7:5 twijfelachtig. In het kader van de evaluatie van de Awb (deelonderzoek financiële beschikkingverlening) wordt art. 7:5 zelfs als een mooi-weerbepaling gekwalificeerd. ${ }^{103}$ De bestuursrechter in eerste aanleg oordeelde geen strijd met art. 7:5. Toch is uit enkele 'eerste aanlegzaken' af te leiden, dat de lagere bestuursrechter een voorkeur heeft voor het horen en het adviseren door een adviescommissie in de zin van art. 7:13. De ABRS denkt hier inmiddels anders over en benadrukt in een Maastrichtse zaak nog eens dat de wetsgeschiedenis van art. 7:13 Awb het bestuursorgaan niet verplicht om een adviescommissie als bedoeld in dit artikel in te schakelen. ${ }^{104}$

In een recent hoger beroep blijkt bovendien dat de ABRS niet al te snel belangenverstrengeling aanneemt. ${ }^{105}$ Men kan verschillend denken over deze uitspraak. Het bestaan van art. $7: 5$, naast de facultatieve bepaling van art. $7: 13$ verdient geen bestuursrechtelijke schoonheidsprijs.

Er ontstaat hierdoor een spanningsveld in de voorbereidingsfase van de bezwaarschriftenprocedure. Het bestuursorgaan, de justitiabele en de bestuursrechter zijn hiermede niet gediend.

lot Zie in dit verband de literatuur en de hierin opgenomen jurisprudentie, met name: J.G. Steenbeek en F.A.M. Stroink, a.w, p. 397 en 398 en R.W.L. Loeb e. a., a.w. , p. 143 e.v. Zie bijvoorbeeld: CBB 25 april 1996, NJB Katern 1996, p. 1376, n1. 43, CBB 27 februari 1996. NJB Katern 1996, p. 864 nr. 25 en Rb. 's-Hertogenbosch 8 julli 1997, JB 1997, 227.

103 A.W., p. 98.

104 ABRS 16 december 1997, JB 1998, 30 m.nt. ARN. Zie ook: A.R. Neerhof, De beperkte actieradius van art. $2: 4$ lid $1 \mathrm{Awb}, J B 1998,24 \mathrm{en}$ ABkort 1998,30, Gst. 7077 , $5 \mathrm{~m}$,nt. C.P.J. Goorden...

t05 Inmiddels is het oordeel van de bestuursrechter in eerste atanleg door de ABRS rechtens onjuist bewonden. In een uitspraak in hoger beroep (ABRS 16 december 1997, JB 1998,30 , m. nt. ARN, Abkort 1998, 30, Gst. 7077,5, m.nt. C.P.J. Goonden) die een andere Maastrichtse zaak betrof is de besturlijke vrijheild over het horen en het adviseren benadirukt, en blijkt dat strijdigheid met het verbod als bedoeld in art. 2:4, lid 1 niet al te snel mag worden geconstateerd. Toch laat deze uitspraak onwerlet, de bezwaren tegen de toepassing van art. $7: 5$. 
Ter versterking van de voorbereidende taak van de adviescommissie in de zin van art. 7:13, wordt in het vierde lid van dit artikel aan deze commissie een aantal preparatoire bevoegdheden toegekend. Deze adviescommissie heeft in beginsel rechtens, enige niet-overdraagbare bevoegdheden: het beperken van het inzagerecht (art. 7:4, lid 5), het nemen van een besluit over de openbaarheid van de hoorzitting (art. $7: 5$, lid 2) en het nemen van een beslissing over het afzien van het horen in de gevallen genoemd in art. 7:3. Ondoelmatig is de restrictie (art. $7: 13$, lid 4) dat de adviescommissie in de zin van art. 7:13, deze bevoegdheden niet kan uitoefenen indien bij wettelijk voorschrift is bepaald dat het bestuursorgaan deze bevoegdheden aan zich heeft gehouden. Tegen deze facultatieve uitwerking bestaan bedenkingen.

Er is een aantal redenen aan te geven waarom een differentiatie van bevoegdheden in de voorbereidingsfase ongewenst is en niet in overeenstemming is met de eisen waaraan een behoorlijke inrichting wan de bezwaarschriftenprocedure moet voldoen.

De bevoegdheid in art. 7:3 om af te zien van het horen is aan strenge (kennelijkheids)criteria gebonden. Art. 7:3 noopt tot een behoedzame en zorgvuldige toepassing. ${ }^{106}$ Voor de beoordeling van de ontwankelijkheid van het bezwaarschrift komt daar nog bij dat hierbij aspecten van openbare orde in het geding zijn, die nopen tot een strikte en rechtens juiste beoordeling van het bezwaarschrift in relatie tot het object van het geschil (het bestreden besluit). Het verdient aanbeveling de (preparatoire) bewoegdheid op grond van art. 7:3 Awb te doen untoefenen door de adviescommissie, hetgeen de doelmatigheid van de voorprocedure ten goede komt. Hetzelfde geldt voor de overige in art. 7:13, lid 4 genoemde preparatoire bevoegdheden. De adviescommissie heeft alle benodigde informatie en deskundigheid omtrent het bezwaarschrift ten behoeve van de voorbereiding van een rechtens juiste beslissing. Daar komt nog bij dat de adviescommissie in de zin van art. $7: 13$ betere garanties biedt tegen onpartijdige preparatoire beslissingen. Deze beslissingen hebben weliswaar geen zelfstandige rechtsgevolgen, maar kunnen uiteindelijk wel van invloed zijn op het resultaat van de beslissing op het bezwaarschrift.

De Awb geeft om meerdere redenen aanleiding kritische kanttekeningen te plaatsen ten aanzien van de differentiatie van de voorbereidingsfase van de bezwaarschriftenprocedure. Er is een 'versluierde' differentiatie in de voorbereidingsfase waar te nemen omdat aan meerdere bepalingen in het kader van de 
bezwaarschriftenprocedure, preparatoire bevoegdheden kunnen worden ontleend (zie in dit verband par. 5.3.9 en 5.3.10). Ter bevordering van een doelmatige inrichting van de bezwaarschriftenprocedure en ter vermijding van deze differentiatie in de voorbereidingsfase, zouden aan een adviescommissie voor de behandeling van bezwaarschriften, in beginsel alle uit de Awb voortvloeiende preparatoire bevoegdheden integraal moeten worden toegekend.

Een adviescommissie in de zin van art. 7:13 biedt betere objectieve waarborgen tegen belangenverstrengeling omdat de voorbereidingsfase van de beslissing op het bezwaarschrift niet geschiedt onder de verantwoordelijkheid van het bestuursorgaan. De lagere bestuursrechter benadrukt het belang van de instelling van een adviescommissie in de $z$ in van art. 7:13. Hij wijst daarop dat het stelsel van "de wet' immers inhoudt dat bij de behandeling van bezwaarschriften het horen en adviseren door een adviescommissie in de zin van art. 7:13, betere garanties kan bieden voor een faire en zorgvuldige procedure dan het horen en het adviseren door vanwege het bestuursorgaan daartoe aangewezen personen. ${ }^{107}$ Deze betere garanties voor een onpartijdige voorbereiding worden geboden door het samenstel van de bepalingen van art. $7: 13$, te weten:

- de voorzitter moet onafhankelijk zijn van het bestuursorgaan en de commissie moet uit drie leden bestaan (lid 1, onder b);

- het lid van de adviescommissie dat door deze commissie met het horen kan worden belast moet eveneens onafhankelijk zijn (lid 3);

de commissie kan behoudens wettelijke beperking (zelfstandig) preparatoire bevoegdheden uitoefenen (lid 4);

de behandeling van het bezwaarschrift heeft een contradictoir karakter (lid 5).

Deze sterkere waarborgen tegen vooringenomenheid van een partieel extern samengestelde adviescommissie, betekent overigens niet dat een art. 7:13commissie als volledig 'vangnet' kan dienen voor het tegengaan van vooringenomenheid of belangenverstrengeling. De jurisprudentie onder de werking van de Awb geeft enkele indicaties dat de rechtmatigheid van het besluitwormingsproces in het kader van de bezwaarschriftenprocedure onder omstandigheden toch onder druk kan komen te staan. Het adviseren door een Amsterdamse adviescommissie die conform de eisen van art. $7: 13$ het bestuursorgaan adviseerde, bleek in de ogen van de bestuursrechter partijdig omdat de gemeente Amsterdam als openbaar lichaam (belanghebbende) vergunninghouder was in de bezwaarschriftenprocedure. De beslissing op het bezwaarschrift werd vernietigd wegens strijd met 
art. 2:4, lid 1. ${ }^{108}$ In een andere kwestie voldeed een adwiescommissie aan de eisen van art. 7:13, maar werd door de bestuursrechter 'anterieure' belangenverstrengeling geconstateerd. De onafhankelijkheid van de voorzitter kan door "de schijn" van partijdigheid worden uitgehold omdat deze in een vroegere hoedanigheid wan bestuurder betrokken is geweest bij het tot stand komen wan het bestreden primaire besluit. ${ }^{109}$ Inmiddels is gebleken dat de ABRS in hoger beroep stringente maatstaven aanlegt ten aanzien van het onpartijdigheidsgebod als bedoeld in art. 2:4 Awb en niet snel tot partijdigheid concludeert van een adviescommissie. ${ }^{110}$

Naast de omstandigheid dat een adviescommissie in de zin van art. 7:13 per definitie niet steeds elke vorm van partijdigheid kan uitsluiten, is er reden om extra aandacht te besteden aan de in het eerste lid, onder $b$ ingebouwde onafhankelijkheidseis van de voorzitter. De huidige redactie van dit artikel is beperkt tot de relatie van de voorzitter met het bestuursorgaan. Het verdient aanbeveling dat bestuursorganen zonodig via aanvullende regelgeving extra garanties inbouwen ten behoeve van het bewaken van de onafhankelijke positie van de voorzitter.

Op grond van het vorenstaande is in het onderzoek ten aanzien van de voorbereidingsfase van de beslissing op het bezwaarschrift vastgesteld dat uit een oogpunt van uniformiteit (gemengde samenstelling van de adviescommissie), het belang van de doelmatigheid van de inrichting van de bezwaarschriftenprocedure, de herkenbaarheid van de wijze van het adviseren voor de justitiabelen, het voorkómen van de schijn van partijdigheid, het adviseren omtrent de op het bezwaarschrift te nemen beslissingen beter kan geschieden door een commissie in de zin van art. 7:13. Het maken van een onderscheid in het adviseren omtrent de bezwaarschriftenprocedure is niet nodig. Het derde lid van art. 7:13 biedt mogelijkheden om de snelheid van de beslissing op het bezwaarschrift, positief te beinvloeden. Kortheidshalve wordt in dit verband verwezen naar par. 6.6, conclusie 20. Belangrijke neveneffecten zijn hierbij tevens de eenduidigheid in de preparatoire bevoegdheden, alsmede het opheffen van een ongewenste differentiatie van de beslistermijn voor het bezwaarschrift (art. 7:10).

108 Stadsmobiel Ansterdam CBB 21 december 1994, JB 1995, 1; AB 1995, 454, m, nt. JHwdH, RAwb 1995, 34, m. nt. BdeW, en N. Verheij, Stadsmobiel Amsterdam, Partijdige bezwaarschriftencommissie, in: Rechtspraak Bestursrecht 1994-1995: de annotaties, "s-Gravenhage, p. 94/95 139 a..

$109 \mathrm{Rb} .8$ februari 1996, JB 1996, 100 m.nt. MAH.

110 Zie noot 49. 


\subsection{De bezwaarschriftenprocedure ter discussie: evaluatie, standpunten,} literatuur en aanbevelingen

Kortheidshalve wordt hierbij volstaan met te verwijzen naar de uitwoerige conclusies in hoofdstuk 6 (par. 6.6).

\section{Conclusies}

2.1. De bestuurlijke heroverweging is ten opzichte van de Wet arob geen (Awb)noviteit; er kan gesproken worden van een positivering van de heroverweging tot rechtsnorm. Wél onderscheidt de heroverweging op grond van art. 7:11, lid 1 Awb zich ten opzichte van de Wet arob. Dit komt doordat in afdeling 3.2 een aantal beginselen van behoorlijk bestuur als bestuurlijke normen is gecodificeerd.

2.2. De bestuursrechter legt door het gestelde in art. 7:11, lid 1 Awb sterk de nadruk op de relatie van het bestreden besluit met de beslissing op het bezwaarschrift.

2.3. De omvang van de heroverweging is in een aantal gevallen beperkt.

2.4. De toetsing ex nunc die karakteristiek is voor de beslissing op het bezwarschrift vertoont relatieve trekken door een zestal uitzonderingen op dit voor de bezwaarschriftenprocedure geldend beginsel.

2.5. Het verbod van reformatio in peius kan beter aan de toetsing door de bestuursrechter worden voorbehouden vanwege zijn karakter als beginsel van administratief procesrecht. In het kader van de te maken heroverweging ligt het, ter vermijding van een reformatio in peius, meer voor de hand dat het bestuursorgaan rechtstreeks toetst aan de algemene beginselen van behoorlijk bestuur.

2.6. Het wooringenomenheidsverbod in art. 2:4 is ter waarborging van een zuiver bestuurlijke taakvervulling in de Nederlandse bestuursrechtelijke wetgeving een bestuurlijke norm in het belang van een objectieve taakvervulling door bestuursorganen. Toch is er veel geschreven recht zowel in het organieke organisatie-recht (Prov,w., Gem.w., Watersch.w. en Wei $\mathrm{BO}$ ), als in het bijzonder bestuursrecht dat al dan niet rechtstreeks waarborgen beoogt te creëren in het belang van een bestuurlijke taakvervulling in casu de besluityorming. Ook het ongeschreven recht kan een rol spelen ter vermijding van partijdige besluitvorming.

2. 7. Het zorgvuldigheidsbeginsel en het onpartijdigheidsgebod liggen dicht bij elkaar. Het belang van art. 2:4 voor een onpartijdige taakvervulling door bestuursorganen is gelegen in de strekking van het artikel. Het artikel specificeert meer in het bijzonder de zorgvuldigheid van de besluitvor- 
ming. Art. 2:4 sluit aan bij het huidige denken over de kwaliteit van het openbaar bestuur in het algemeen, en meer in het bijzonder kan het een bijdrage leveren ter verbetering van de legitimatie van bestuursbesluiten. Art. 2:4 heeft kenmerken van rechtsstatelijke uitgangspunten ten dienste van het objectieve recht.

2.8. Art. 2:4 vertoont in de toepassing wél sterke casuïstische trekken hetgeen tot uitdrukking komt in de jurisprudentie. Zowel voor de bestuursorganen, de justitiabelen als de bestuursrechter kan de rechtszekerheid soms onder druk komen te staan.

2.9. In gevallen dat gesproken kan worden van de schijn van een partijdige besluitvorming dient art. 2:4 strikt te worden toegepast, en behoort een rechterlijke vernietiging te worden uitgesproken. Met toepassing van de beperkte mogelijkheden van art. 8:72, lid 3 zou de bestuursrechter de rechtsgevolgen geheel of gedeeltelijk in stand kunnen laten.

2.10. De hoorplicht in art. 7:2 Awb legt de basis voor het beginsel van een behoorlijke procedure. $\mathrm{Zij}$ heeft naast een waarborgfunctie voor een "goed procesrecht" een signaalfunctie voor de bestuurlijke organisatie vanwege de mogelijkheid tot het herstel van zorgvuldigheidsgebreken. Door het horen wordt de kwaliteit van de besluitvorming versterkt, hetgeen mede in het belang kan zijn van het aanvaarden van de legitimiteit van de beslissing op het bezwaarschrift.

2.11. Op grond van de heroverwegingsplicht in de zin van art. $7: 11$, lid 1 die toetsing van het materieel recht met zich brengt, heeft deze formele bepaling materiële betekenis.

2.12. Hoor en wederhoor bevordert door een aantal functionele kenmerken formeel evenwicht in de relatie bestuursorgaan-burger, en dient daardoor het belang van een rechtens juiste vaststelling van de feiten.

2.13. De ABRS oordeelt dat de hoorplicht geen bepaling van openbare orde is. Men kan hier anders over denken. De bevoegdheid van het bestuursorgaan om op grond van art. 7:3 af te zien van het horen benadert zeer nauw 'de openbare orde'. Deze bevoegdheid staat niet ter vrije beschikking van het bestuursorgaan, maar heeft een 'gebonden' karakter als beginsel van behoorlijk procesrecht.

2.14. Aan de inrichting van de semi-rechterlijke adviesprocedure die een waarborgfunctie vervult ten dienste van de voorbereiding van het geschilbeslechtende besluit, liggen beginselen van behoorlijke rechtspraak ten grondslag. De adviescommissie voor de bezwaarschriften in de zin van art. 7:13 biedt door de in de Awb gestelde eisen een aantal waarborgen door de contradictoire (inrichtings)eisen.

2.15. De bestuursrechter heeft voor het vereiste van de instellingsgrondslag van de adviescommissie nauwelijks aandacht. Het (organieke) commissierecht 
maakt duidelijk onderscheid tussen het instellen van (advies)commissies en het regelen van de taken en bevoegdheden.

2.16. De bezwaarschriftenprocedure kan mede een nuitige functie vervullen ten behoeve van de controle op het gebruik van mandaat in die gevallen dat het bestuursorgaan de beslissing in primo heeft gemandateerd.

2.17. Art. 7:13, eerste lid bindt het optreden van een adviescommissie aan een constituerende grondslag; de adviescommissie moet zijn 'ingesteld'. Dit voorschrift mist een formeel (instellings)grondslagcriterium.

2.18. De besliscommissie voor de bezwaarschriften wordt onder de werking van de Awb niet langer toegestaan. Het organieke commissierecht behoort te worden aangepast aan de $\mathrm{Awb}$. De regels inzake de commissies zijn gebaseerd op de principes van decentralisatie en differentiatie van de bestuursorganisatie en niet op algemene bestuursrechtelijke uitgangspunten.

2.19. Het facultatieve karakter van de adviescommissie in de zin van art. $7: 13$, lid 1, is ondoelmatig en kan leiden tot een ongewenste differentiatie van de voorbereidingsfase van de beslissing op het bezwaarschrift omdat:

a. de gewenste koppeling van het horen en het adviseren niet verplicht is in geval geen adviescommissie als bedoeld in art. 7:13, lid 1 is ingesteld; het rechtstreeks horen door de adviescommissie doet meer recht aan de informatie-functie van het horen;

b. de effectiviteit van de voorbereidingsfase kan worden belemmerd door de differentiatie van de preparatoire bevoegdheden, hetgeen niet in overeenstemming is met de inrichtingseisen van een behoorlijke procedure;

c. art. $7: 13$, lid 1 , biedt betere waarborgen tegen belangenverstrengeling dan in het geval dat de voorbereidingsfase van de voorprocedure onder de verantwoordelijkheid van het bestuursorgaan geschiedt.

2.20. Door een verplichte adviescommissie in de zin van art. $7: 13$, lid 1 kan art. 7:5 vervallen en de hoorplicht voor het bestuursorgaan worden geschrapt. De problemen van de rechterlijke toetsing van art. 2:4 kunnen hierdoor worden verminderd. Een positief neveneffect hiervan is dat de ongewenste differentiatie van de beslistermijn in art. $7: 10$, lid 1, kan komen te vervallen.

2.21. Art. $7: 13$, onder $b$, bevat geen volledige waarborgen voor de onafhankelijkheid van de voorzitter van de adviescommissie ondat deze deel uit mag maken van het openbaar lichaam waartoe het bestuursorgaan behoort. Dit geldt mede voor het horen door het lid van de adviescommissie (art. $7: 13$, lid 3 , tweede zin). Bestuursorganen kunnen bij wege van (aanvullende) regels extra waarborgen inbouwen ter versterking van de onafhankelijke positie van de voorzitter van de adviescommissie. 


\section{Aanbevelingen}

Op basis van het in het kader van dit proefschrift verrichte onderzoek worden de volgende aanbevelingen ter verbetering gedaan.

I. Op grond van conclusie 8 (par. 6.6) wordt voorgesteld art. 7:1, lid 1 onder d te wijzigen en te lezen als volgt:

'd. is voorbereid met toepassing van de in de afdelingen 3.4 en 3.5 geregelde procedures.'

II. Ten aanzien van art. 7:13 Awb wordt een aanpassing en wijziging voorgesteld.

Naast het algemeen verplicht stellen van het adviseren door een commissie in de zin van dit artikel wordt aanbevolen de redactie van art. 7:13 aan te passen en te wijzigen voor zover het betreft:

a. het grondslagvereiste voor het instellen van de adviescommissie;

b. de preparatoire bevoegdheden van de adviescommissie.

Art. 7:13 van de Algemene wet bestuursrecht ware dienovereenkomstig aan te vullen en te wijzigen.

Art. 7:13, lid 1, aanhef van de Algemene wet bestuursrecht, wordt gewijzigd en gelezen als volgt:

'1. Ten behoeve van de beslissing op het bezwaar wordt bij wettelijk voorschrift een adviescommissie ingesteld:'

Het vierde lid van art. 7:13 van de Algemene wet bestuursrecht wordt gewijzigd en gelezen als volgt:

'4. Voorzover uit de bepalingen van deze wet, voorafgaand aan de beslissing op het bezwaar bevoegdheden voortvloeien worden deze uitgeoefend door de commissie."

III. Art. 7:5 van de Algemene wet bestuursrecht komt te vervallen.

IV. De bepalingen in de Provinciewet en de Gemeentewet inhoudende het overdragen van de bevoegdheid tot het beslissen op het bezwaar ware te schrappen. 
Art. 156, lid 2 Gemeentewet wordt aangevuld als volgt:

'h. het beslissen op een bezwaar als bedoeld in artikel 7:1 van de Algemene wet bestuursrecht.'

Art. 152, lid 2 Provinciewet ware in overeenkomstige zin te wijzigen.

Aan art. 165 Gemeentewet wordt een nieuw derde lid toegevoegd, luidende als volgt:

'3. De bevoegdheid tot het beslissen op een bezwaar als bedoeld in artikel 7:1 van de Algemene wet bestuursrecht kan niet worden overgedragen.'

Het huidige derde lid wordt vernummerd tot 'lid 4'.

Aan art. 163 Provinciewet wordt een nieuw derde lid toegevoegd, luidende als volgt:

'3. De bevoegdheid tot het beslissen op een bezwaar als bedoeld in artikel 7:1 van de Algemene wet bestuursrecht kan niet worden overgedragen.'

Het huidige derde lid wordt vernummerd tot 'lid 4'.

Aan art. 178 Gemeentewet wordt een nieuw tweede lid toegevoegd, luidende als volgt:

'2. De bevoegdheid tot het beslissen op een bezwaar als bedoeld in artikel 7:1 van de Algemene wet bestuursrecht kan niet worden overgedragen."

Het huidige tweede lid wordt vernummerd tot 'lid 3'. 



\section{THE GENERAL ADMINISTRATIVE CODE AND THE PROCEDURE GOVERNING OBJECTIONS}

\section{Summary}

On 1 Jamuary 1994, the Administrative Code (Algemene wet bestuursrecht) came into force in the Netherlands. The Code, containing general provisions in the field of administrative law, emanates from Article 107(2) of the Dutch Constitution. The main purpose of the Code is to codify administrative case law.

Chapter 3 of the Code describes the general standards which must be observed by administrative bodies when issuing administrative regulations (besluiten). Chapter 4 contains special provisions which apply to specific determinations about individual and particular relations (beschikkingen), particularly about the granting of subsidies.

Chapters 6 and 7 of the Administrative Code give general and special provisions about the procedure governing objections. These Chapters, together with Chapter 2 of the Administrative Code, form the mainstay of the study about the objection procedure as set out in this book.

Chapter 8 of the Administrative Code sets uniform rules for filing appeals with the District Courts. These uniform rules of administrative procedural law have also been declared applicable in a number of other Codes.

The Administrative Code sets certain conditions for lodging appeals against administrative regulations with the administrative courts. Pursuant to Article $7: 1$ of the Code, a citizen who disagrees with a regulation issued by an administrative body will, in principle, be obliged to first file an objection with the administrative body in question. This preliminary procedure is the subject of the study described in this book.

The reason for this study is the barrage of criticism expressed by both administrative bodies and citizens about this preliminary procedure. The administrative bodies complain about the strict judicial review of their decisions on the objections filed with them. The citizens are of the opinion that the administrative bodies do not sufficiently take their interests into account. Furthermore, the courts are not always satisfied with the contents of the rulings issued by the administrative bodies in the context of objection proceedings. The results of the study into the procedure governing objections have been illustrated, in terms of both quality and quantity, in the eight chapters of this book. 
Chapter $\mathbb{1}$ of this book deals with administrative reconsideration as a characteristic feature of the obligatory objection procedure. Administrative reconsideration is mandatory under Article 7:11(1) of the Administrative Code. If an objection is fled, the administrative body must fully reconsider the challenged regulation in terms of both lawfulness and efficiency. It is on these two important points that objection proceedings differ from appellate proceedings before the administrative courts. Pursuant to Article 8:77 of the Administrative Code, the courts may only test the challenged regulation against the written and unwritten rules of law.

Although the scope of administrative reconsideration is broad - since all the aspects of the challenged regulation must be reconsidered in full by the administrative body - this study has brought a number of aspects to light which may restrict that scope.

Six situations have been analyzed where the hinge point was not the time at which the decision on the objection was taken (ex nunc). This implies that administrative bodies must decide on the objection ex tunc, meaning that the circumstances prevailing at the time of adoption of the original regulation constitute the yardstick for comprehensive administrative reconsideration.

It has also been established that the scope of reconsideration may be restricted by special laws. Another restriction can be inferred from the rule of reformatio in peius. Although this prohibition imposed on administrative bodies may restrict the scope of reconsideration, it can often be circumvented in practice as a result of the many exceptions to the rule. Another significant aspect is that the principles of due administration, if applied legally correctly, may stand in the way of the prohibition of reformatio in peius. This is why this study questions the usefulness and effect of that prohibition for objection proceedings. It would seems to fit in better with the judicial review of administrative regulations.

Article 2:4(1) of the Administrative Code, which is one of the rules of Chapter 2 of the Code, provides that administrative bodies must perform their duties in an unbiased fashion. This provision is a novelty in the Dutch rules of administrative law. In light of this new administrative norm, chapter 2 of this book devotes a great deal of attention to the standards of impartiality under Dutch law, aimed both directly and indirectly at safeguarding an objective performance of administrative duties.

Although, contrary to the situation in other countries, the administrative principle of impartiality was unknown in the Netherlands until the introduction of the Administrative Code, a study of both the basic laws and the special laws has 
revealed a number of rulles which more or less eliminate the possibility of administrative bias. These rules relate not only to individual members of the administrative bodies, but also to the decision-making procedure leading to the adoption of administrative regulations. Both before and after the introduction of the Administrative Code, the courts set strict requirements to safeguard the objectivity of consultants (to be) engaged by administrative bodies in the preparatory procedure. Especially since the introduction of the Administrative Code, the administrative courts have applied stricter standards when reviewing advisory opinions from the committee handling objections against the principle of impartiality set out in Article 2:4 of the Code.

The principles of due care and equal treatment also act as safeguards against the biased performance of administrative duties. The significance of the prohibition against partiality as laid down in Article 2:4 of the Administrative Code has been defended on the grounds that it distinguishes and specifies the principle of due care. Under the new administrative law, the rule of impartiality, together with the principle of nemo judex in re sua (the right to an unbiased adjudicator), forms a vital tool in adopting pure, objective regulations.

Prior to deciding on an objection, the administrative body is obliged under Article $7: 2$ of the Administrative Code to hear the party concerned. This right to a hearing is examined in chapter 3 of the book. Although Article 7:3 of the Code contains several exceptions to the right to be heard by or on behalf of an administrative body, the study has revealed that the procedural requirement of hearing the party concerned has substantive meaning for the decision to be taken on an objection. Apart from safeguarding the quality of the contents of a decision, the procedural requirement has several other important functions. In the first place, the obligation to hear the party concerned constitutes a significant safety net in administrative procedures. If applied correctly, the obligation may lead to a rectification of the original, incorrect regulation because of the informative aspect of the hearing. On the other hand, by offering the right to a fair hearing, the administrative body may be able to stress the legitimacy of the challenged regulation towards the citizen in question.

Issuing recommendations to administrative bodies is legally relevant in administrative law, because this field of law attaches special requirements to the role of "advisory opinions". Chapter 4 of this book describes the administrative advisory process as a preparatory factor in the decisions to be taken on objections.

The rules of administrative law set functional requirements for the advisory process on the basis of three main starting points: (i) administrative regulations 
must be based on legally correct facts, (ii) the interests of the citizens must be duly weighed up, and (iii) regulations must conform to social reality.

Advisory opinions to administrative bodies are commonly divided into three types, namely expert advice, advice by interest groupings and quasi-judicial advice. Expert advice is characterized by impartiality and objectivity. The expert's duty is to furnish the administrative body with factual information about the implementation of statutory provisions. Expert advice increases the legitimacy of regulations. Advice of this kind is either obligatory on the grounds of a statutory provision or may arise from the fact that statutory provisions necessitate the special expertise of independent experts.

Where advice is given by interest groupings, the focus is on the representative aspect of a grouping in society and on the wishes and desires submitted on behalf of the grouping represented. This type of advice is aimed primarily at involving citizens in administrative organization and usually has its basis in our basic laws, particularly the rules governing the establishment, composition and powers of committees. Both the Provinces Act (Provinciewet) and Municipalities Act (Gemeentewet) contain provisions on advice by interest groupings.

The quasi-judicial advisory process is more specific in nature and focuses on the aspect of contributing towards the dispute resolution task of administrative bodies in the context of objections and appeals. The administrative body effectively acts as the court in its own case. Even before the introduction of the Administrative Code, special advisory procedures were developed for the administrative practice of dispute resolution. Although the Administrative Code does not impose a relevant obligation on administrative bodies, it has adopted the advisory practice as a starting point for the optional opportunity afforded under Article $7: 13(1)$ to set up an advisory committee charged with the task of hearing the parties concerned and making recommendations as to the decision to be taken on the objection. The relevant provisions contain safeguards to ensure a more or less independent advisory procedure. This applies in particular to provisions relating to the position of the committee's chairperson. Furthermore, the structure of the advisory procedure under Article 7:13 is contentious in nature. As a result of its composition and the method of advising, the advisory committee for handling objections is bound almost wholly by the principles of due process.

Chapter 5 describes a number of important aspects of the procedure governing the preparation of decisions to be taken on objections. This preparatory phase takes shape by means of hearing the parties concerned and issuing recommendations on the objection. 
The Administrative Code has adopted the administrative practice of hearing and advising in objection proceedings. Apart from accepting the significance of advisory opinions by a special advisory committee handling objections, the Administrative Code has given the administrative bodies full freedom to organise the preparatory phase in objection proceedings at their own discretion.

The advisory structure in the context of objection proceedings can be given shape in several ways. Administrative practice may involve inquiry and advisory committees whose members are representatives of administrative bodies and/or civil servants. As for the advisory committees handling objections, it is also possible to opt for a mixed composition (representatives of administrative bodies, civil servants and outsiders). Furthermore, the advisory committees may be purely external in nature as a result of their members being elected from outside the administrative organization.

Nevertheless, there is one situation for which the Administrative Code has set specific rules in connection with the advisory work of an advisory committee. Article $7: 13$ (1) provides that, if an advisory committee has been set up for the purpose of handling objections, the committee must meet the (organizational) requirements listed under (a) through (c). It follows from the optional opportunity under Article 7:13 that advisory committees of this kind must be composed in a certain manner. The requirements in question indicate that the members must be detached to some extent from the administrative body.

Apart from the advantage arising from the detachment that must exist between committee members and administrative bodies, the quality of the decisions can be improved by establishing a committee within the meaning of Article 7:13 of the Administrative Code. This is because of the contentious nature of objection proceedings and because the committee not only has an advisory task, but must also hear the parties concerned. One of the shortcomings of Article 7:13, however, is that the legislature has neglected to define the statutory rule on the basis of which advisory committees must be established for handling objections.

In chapter 5 of the book, the study focuses in more detail on the procedural rules governing the phase in which the decision on an objection is prepared. This chapter also contains a number of recommendations - based also on the outcomes of the study as described in chapter 4 - for a uniform and more efficient advisory process in the context of objection proceedings.

The optional nature of advisory committees as afforded under Article 7:13(1) of the Administrative Code is inefficient and may lead to undesired differentiation in 
preparatory phases preceding decisions on objections. If no advisory committee as referred to in Article 7:13(1) is set up, the desired link between the hearing of the parties concerned and the advisory opinion is not obligatory. It is, however, important for the advisory committee to hear the parties concerned, because such a hearing does more justice to the informative aspect of the proceedings.

The effectiveness of the preparatory phase is impeded because the provisions of the Administrative Code make it possible to differentiate in the preparatory powers. This fact is at odds with the formal requirements of due process.

Another aspect which should not be overlooked in connection with the advisory model under Article $7: 13(1)$ is the fact that such a committee offers better safeguards against conflicts of interests than would be the case if the preparatory phase were to be conducted entirely under the responsibility of the administrative body. It would be advisable, however, to tighten the requirements of detachment set out in the advisory model described in Article 7:13 of the Code. The provision that the chairperson of the advisory committee may not be a member of the administrative body does not suffice; the scope of this formal requirement could be broadened by stipulating in Article 7:1.3 that the chairperson of the advisory committee may not belong to the public entity of which the administrative body forms a part.

Opting for the introduction of a mandatory advisory committee as referred to in Article $7: 13$ of the Administrative Code has a number of favourable side effects. For instance, Article 7:5, containing several formal requirements in the event that the preparatory phase takes place under the responsibility of the adrninistrative body, need not be taken into account. Furthermore, the problems relating to the judicial review against the impartiality rule described in Article $2: 4$ can be reduced. Finally, the undesired differentiation in terms of the period prescribed for taking decisions (Article 7:10(1) of the Code) can be resolved by choosing for one uniform advisory committee.

Pursuant to Article 9:1(1) of the Administrative Code, the Code must be evalluated every five years, albeit that the first period of evaluation is somewhat shorter, namely three years. An Administrative Code Evaluation Committee has been set up, which issued its evaluation report to the Dutch Cabinet. The Cabinet has meanwhile forwarded the report, accompanied with its own comments, to the Dutch Parliament.

The evaluation report sets out the results of an investigation into how the Administrative Code has been given effect. The report contains findings about a number 
of important aspects in relation to such matters as financial decisions, subsidies, planning and zoning and administrative procedure.

The report has revealed much important information, particularly about the modus operandi and the structure of objection proceedings. Chapter 6 of this book focuses on the results of the investigation into objection proceedings, paying attention to the evaluation, the points of view, the opinions of legal authors and the recommendations that have been made.

The structure and the necessity of adhering to the objection procedure are discussed on the basis of four aspects: a differentiation of the obligatory objection procedure, the level of flexibility as regards the obligation to hear the party concerned, the advisory opinion on the objection and the partiality of the decision. 



\section{Literatuurlijst}

ABAR, vijfde dr., Alphen aan den Rijn 1984

ABAR, vierde bijgewerkte dr., Groningen 1973

Addink, G.H. en H. Bolt, in: Nieuw bestuursrecht, Nijmegen 1994

Akkermans, P.W.C. en A.K. Koekkoek, De Grondwet, een artikelsgewijs commentaar, tweede dr., Zwolle 1992

Alders, E., Deregulering ook voor de Awb?, NJB 1996, p. 1113

Allewijn, D., Beschikkingsprocesrecht in: Het nieuwe bestuursprocesrechr, VAR

112. Alphen aan den Rijn 1994

Bakker, E, in: Algemene wet bestuursrecht, losbl., 's-Gravenhage

Beerten, M.S., (red.), 1. Aspecten van de financiële beschikkingverlening,

Deventer 1996

Berge, J.B.J.M. ten (red.), Verklarend woordenboek Openbaar Bestuur, Alphen aan den Rijn 1992

Berge, J.B.I.M. ten, (red.), 2. Het bestuursprocesrecht, Deventer 1996

Berge, J.B.J.M. ten en P.M. Langbroek, Van gemeenterecht naar algemeen bestuursrecht, NTB 1993, p. 89 e.v.

Berge, J.B.J.M. ten en M.P. Gerrits-Janssens en P.J. Stolk, Vereisten van behoorlijkheid, Zwolle 1992.

Berge, J.B.J.M. ten (red.), Nieuw bestuursrecht, Nijmegen 1994

Berge, J.B.J.M. ten, Bescherming tegen de overheid, tweede dr., Zwolle 1994

Berge, J.B.J.M. ten, Besturen door de overheid, Nederlands algemeen bestuurs-

recht 1, Deventer 1996

Berge, J.B.J.M. ten, Decentraliseren met commissies, 's-Gravenhage 1978

Berge, J.B.J.M. ten, W. Konijnenbeit, A.J. Modderkolk en J.J.T. Verburg,

Provincie-, Gemeente- en Waterschapswet, Deventer 1994

Berge, J.B.J.M. ten en A.Q.C. Tak, Nederlands Administratief Procesrecht,

Zwolle 1983, deel 1

Biesheuvel, M.B.W., Weg met de bezwaarschriftenprocedure, NJB 1996, p. 930

Biesheuvel, M.B.W. Naschrift, NJB 1996, p. 1114

Biesheuvel, M.B.W., Naschrift, NJB 1996, p. 1215

Biggelaar, G.J.M. van den, De buitengerechtelijke afdoening van strafbare feiten door het openbaar ministerie, Arnhem 1994

Bolt en Lubberdink, Procesdossiers 'De Arobprocedure', Nijmegen 1988

Bolt, H. , De voorlopige voorzieningsprocedure (diss.), Deventer, 1986

Bolt, H., Bijzondere bepalingen bezwaar/beroep, in: Pr. Bestuursrecht, losbl., Deventer

Bolt, H., Rechtsbescherming, Algemene bepalingen en de bestuurlijke voorprocedure, Monografieèn Algemene wet bestuursrecht A3a, Deventer 1994

Bolt, H., M.A.H. van Dalen-wan Bekkum, N.J. Haverkamp, J.G.F.M. van Kessel en J. Riphagen, Snelheid van de besluitworming en rechtsbescherming op het terrein van het sociaal verzekeringsrecht, Deventer 1988 
Bolt, H., in: Nieuw bestuursrecht, Nijmegen 1994

Borgers, H. en $H$. van der Tas, Klachtrecht, de aanvulling van de Awb, AAe 1997,9 , p. 589 e.v.

Borman, J.A., Procesrecht in Arobzaken, tweede dr., Zwolle, 1987

Borman, T.C., Eerste tranche Algemene wet bestuursrecht, AA 1994, p. 98

Bos, J.T.K., G.A.M. Giessen, J. De Groot en F.C.M.A. Michiels, Handhaving van het bestuursrecht, VAR 114, 's-Gravenhage 1994

Bosch, J.J.A., De bezwaarschriftenprocedure moet blijven, NJB 1996, p. 1214 en 1215

Bots, A.M.M.M., Op weg naar een zelfstandig bestuursrechtelijk kort geding?, Deventer 1995

Brasz, H.A., Dertig jaar beroep- en bezwaarzaken. Een Evaluatie, OB 1996, 3, p. 30

Brederveld, E., Geen besliscommissies, beslist de Afdeling bestuursrechtspraak, Gst., 7053, 252

Brederveld, Schroot en Wijma, Begrip van de Nederlandse gemeente, deel I, Tweede geheel herziene dr., Alphen aan den Rijn 1990

Brederveld, E., Gemeenterecht, derde geheel herziene dr., Zwolle 1994

Brederveld, E., Verboden deelneming aan stemming in de raadsvergadering, Stemmingmakerij over artikel 28 Gemeentewet?, Gst. 1996, 7032, p. 269 e.v. Brederveld, E., Simpelveld: bona causa triumphat!, Gst. 7072, p.

Breeuwsma, C.M., M. Oosting e.a., Beeld van de arob-bezwaarschriftenprocedure, Deventer, 1982

Breeuwsma, C.M., M. Oosting e.a., Arobpraktijken, Deventer 1984

Brenninkmeijer, A.F.M., Spannend bestuursprocesrecht, NJB 1994, p. 12 e.v.

Breunese, H.M.B., J.G. Brouwer en A.E. Schilder, Wapenen tegen drugsoverlast, Een onderzoek naar het bestuurlijk juridisch instrumentarium, Deventer 1996

Breure, F., OB 1997, 8, p. 5 en OB 1998,1, p. 31

Breure, F., Zin en onzin van de Awb-bezwaarprocedure in de besluitvorming, $\mathrm{OB} 1997,8$, p. 5

Brouwer, F.F.W. 10 Jaar Arob-bezwaarschriftenprocedure, hoe nu verder?, Gst. 6829 , p. $81-84$

Brouwer, F.W. en L.M. Koenraad, De beslissing op het bezwaar getoetst, Gst. 7033, p. 298

Burg, F.H. van der, Het voorontwerp Algemene wet bestuursrecht getoetst, NTB 1987, p. 7

Burkens, M.C. en F.A.M. Stroink, Sociale verzorgingsstaat en consensuele besluitvorming, $N J B, \| 980$, p. 749 
Burkens, M.C., S.W. Couwenberg, H. Franken en J.B. Brinkhorst, Staatsrechtelijke vernieuwingen, Commentaar op het rapport van de Commissie Deetman, Zwolle 1991

Buuren, P.J.J. van, De omvang van de rechtsbescherming, Alphen aan den Rijn 1982

Buuren, P.J.J. van, in: Beginselen van administratief procesrecht, Van Galen en Van Maarseveen, Geschrift van de VAR LXXXI, Alphen aan den Rijn 1981

Buuren, P.J.J. van en F.C.M.A. Michiels, Bestuursdwang, Zwolle 1989

Buuren, P.J.J. van, Groei-problemen in: De omvang van de rechtsbescherming, Alphen aan den Rijn 1982

Buuren, P.J.J. van en $M$. de Groot-Sjenitzer

Claessens, P.D.A., in: Akkermans/Koekoek, de Grondwet, tweede druk, Zwolle 1992

Daalder, E.J., G.R.J. de Groot, De parlementaire geschiedenis van de Algemene wet bestuursrecht, Eerste Tranche, Alphen aan den Rijn 1993

Daalder, E.J., G.R.J. de Groot en J.M.E. Breugel, De parlementaire geschiedenis van de Algemene wet bestuursrecht, Tweede Tranche, Alphen aan den Rijn 1994

Dales, C.I., De Awb en het bestuur in: Bestuur, burger en rechtspraak, Alphen aan den Rijn 1994

Damen, L.J.A., Bestaat de Awb-mens? in: Aantrekkelijke gedachten, Beschouwingen over de Algemene wet bestuursrecht, Deventer 1993

Dammers, T., De Algemene wet bestuursrecht en de premieheffing werknemers verzekering, Zoetermeer 1997

Derksen, W., Tussen correctheid en corruptie, Best.w. 1995, p. 245

Dölle, A.H.M. en D.J. Elzinga, Handboek van het Nederlandse gemeenterecht, Groningen 1993

Dommering, E., Algemene belangen in het burgerlijk recht, Deventer 1982

Donner, A.M., Algemene bepalingen van administratief recht, NJB 1974, p. 1087 en 1.088

Donner, A.M., Nederlands bestuursrecht, Algemeen deel, vijfde herziene dr., Alphen aan den Rijn 1987

Gaay Fortman, de, De Arob-bezwaarschriftenprocedure, Eindrapport commissie Arob, 's-Gravenhage 1987

Galen, A.G. van, en H.Th.J.F. van Maarseveen, Beginselen van administratief procesrecht, VAR LXXXIII, Alphen aan den Rijn, 1981

Geppaart, Ch.P.A., De betekenis van de Algemene wet bestuursrecht voor het belastingrecht, Alphen aan den Rijn 1992

Gerrits-Janssens, M.P. , Behoorlijke klachtbehandeling, Contouren van een geharmoniseerd klachtprocesrecht, Zwolle 1994

Gerrits-Janssens, M.P., Het Voorontwerp Klachtrecht, NTB 1997, p. 175 e.v. 
Goede, B. de en H. van den Brink, Beeld wan het Nederlands Bestuursrecht, vijfde dr., "s-Gravenhage, 1986

Goorden, C.P.J., Awb-procesdossier, Nijmegen 1996

Goorden, C.P.J., in: Algemene wet bestuursrecht, losbl., 's-Gravenhage

Groot-Sjenitzer, $M$. de, in: De omvang van de rechtsbescherming, VAR LXXXVIII, Alphen aan den Rijn 1982

Haan, P. de, Th.G. Drupsteen en R. Fernhout, Bestuursrecht in de sociale rechtstaat, deel 1, vierde geheel herziene $\mathrm{dr}$., Deventer, 1996

Ham, M.A. van der, De gemeente als rechter in eigen zaak: (on)behoorlijke rechtspraak of (onbehoorlijk) bestuur in: Klachten en bezwaren tegen de gemeente, 's-Gravenhage 1988

Heijningen, F.D. van, Nationale Ombudsman in: Rondom de Nationale Ombudsman, 's-Gravenhage 1993

Hellder, E., Bezwaar en beroep, in: Praktijkdossiers Awb, Alphen aan den Rijn, 1993

Helder, E., Naar een soepeler bezwaarschriftenprocedure, OB 1997, 9

Heldeweg, M.A., Normstelling en expertise, diss., Maastricht 1993

Hennekens, H.Ph.J.A.M., Vernietigen door de administratieve rechter van een besluit: enkele knellende punten belicht, Gst. 7027, p. 127

Hennekens, H.Ph.J.A.M. en C.J.N. Versteden, De Gemeentewet en haar toepassing, losbl., Alphen aan den Rijn 1994.

Herweijer, M., Het nut van de Awb voor bezwaarmakers, Openbaar Bestuur 1997,10, p. 20

Hirsch Ballin, E.M.H., Wederkerig bestuursrecht, RMTh 1989, p. 3

Hirsch Ballin, E.M.H., De Awb: einde van het oude en begin van het nieuwe, in: Bestuur, burger en rechtspraak, 's-Gravenhage 1994

Hirsch Ballin, Besluitvaardigheid, NTB 1996, p. 106

Hoogendijk-Deutsch, S.V., Advisering in het bestuursrecht, VAR LXXX, Zwolle 1978

Hugenholtz, W. en W.H. Heemskerk, Hoofdijnen van het Nederlands Burgerlijk Procesrecht, Utrecht 1996

Ilsink, J.W. en I.M. Fliers, Fiscaal bestuursprocesrecht, Monografiën Awb, Deventer 1995

Jeukens, R.J.G.M., De hoor- en adviescommissie van de Wet Arob, TvO 1977 , p. 54

Jong, J.P. de, Bestuursrecht van vreemde herkomst, Zwolle 1988

Jorna, F.B.A., (red.), 4. Subsidiebeschikkingen, "s-Gravenhage 1997

Kabinetsstandpunt evaluatie Awb, TK 1997-1998. 25600 VI, nr. 46

Kan, J.M., Bewijzen in het administratief recht, RMTh 1966, p. 519 e.v.

Kemenade, J. van, (red.), Bestuur in geding, Haarlem 1997

Kemenade, J. van, De gekooide overheid, $\mathrm{OB} 1997,3$, p. 2 e.v. 
Kemenade, J. en C.J.N. Versteden, BB 1998, p. 24 en 25

Klaassen, A.W., Ruimtelijk beleid in theorie en praktijk, vierde dr., 's-Gravenhage 1994

Kleijn, G.P., in: Handboek Algemene wet bestuursrecht, losbl., Alphen aan den Rijn, III artikelgewijs commentaar art. $7: 11$

Knierum, De verzekerde gemeente verzekerd!?, Bezwaar en administratief beroep, NTB 1995, p. 309 e.v.

Knoop, T., Reformatio in peius in bezwaarschriftprocedure mogelijk?, Gst., 6910 , p. 465 e.v.

Koeman, N.S.J., De wraking gewraakt, NTB 1994, p. 93

Koeman, N.S.J., Bestuursrecht is meer dan procedurerecht, NTB 1995 , p. 94

Konijnenbelt, W., Discussie juridisering ontstijgt de borreltafel, BB 1997, p. 51-

52

Koopman, R.J., Bewijslast in belastingzaken, Deventer, 1996

Kooij, Chr. en F.P.C.L. Tonnaer, Vergunningverlening in stroomversneiling,

VAR XCII, Alphen aan den Rijn, 1984

Kortmann, C.A.J.M., Weg met de bezwaarschriftenprocedure?, NJB ?, p. 1113

Kortmann, C.A.J.M., Weg met de bezwaarschriftenprocedure, Reactie III, NJB 1996 , p. 1113

Kreveld, J.H. van, en Scheltema, Parlementaire Geschiedenis van de Wet Arob,

Groningen 1976

Kreveld, J.H. van, Systeem en algemene begrippen van de Algemene wer bestuursrecht, Monografieën Algemene wet bestuursrecht A1, Deventer 1995

Krijnen, G.J.A.M. en B.W.N. de Waard, Omgaan met welstandsadviezen, NTB 1988 , p. 158 e.. $\mathrm{V}$.

Kummeling, H.R.B.M., Advisering in het Publiekrecht, Arnhem, 1988

Kummeling, H.R.B.M., IVA Advisering, in: Praktijkboek Administratief Recht, losbl., Deventer

Linden, E.C.H.J. van der en Tak, A.Q.C. (red.), Eenzijdig of wederkerig,

Deventer 1995

Linden, E.C.H.J. van der, Advisering in het bestuursrecht, JB 1995, 318

Loeb, R.W.L., B.K. Olivier en H. Troostwijk, De Wet Arob toegepast, vierde dr., Nijmegen 1990

Lubberdink, H.G., De Awb: hoedster van de individuele vrijheid?. in: Aantrekkelijke gedachten, Deventer 1993

Male, R.M. van, Enkele aspecten van het begrip belanghebbencle in de Algemene wet bestuursrecht, VAR 108, Alphen aan den Rijn, 1992

Male, R.M, Onvoltooid recht, Zwolle 1993

Male, R.M. van en B.W.N. de Waard, Besluiten, Monografieèn Algemene wet bestuursrecht, 's-Graventhage

Marseille, A.T., Als een droom werkelijkheid wordi, RegelMaat 1997, p. 4 e.v. 
Meewis, Rechtsbescherming Struikelblok of stimulans voor ondernemende gemeenten?, TvO 1988 , p. 388 e.v.

Meulen, B.M.J. van der en E.J. Daalder, Bestuurlijke besluitvorming onder de Algemene wet bestuursrecht, Gst., 7000, p. 621

Michiels, F.C.M.A., in: Algemene wet bestuursrecht, losbl., 's-Gravenhage, p. E 8.2.6.5a-2

Michiels, F.C.M.A., Bestuursdwang in de gemeenten, Gst. 6832 en 6833

Michiels, F.C.M.A., Handhaving van bestuursrecht, Nijmegen, 1994

Michiels, F.C.M.A., Reactie op A.T. Marseille, Als een droom werkelijkheid wordt, RegelMaat 1997, p. 78 en 79

Ministerie van Justitie en Binnenlandse zaken, Algemene wet bestuursrecht, 'sGravenhage 1993

Montfort, A.J.G.M. van en H.B. Winter, Kleine gebreken geen bezwaar?: een evaluatie van de bezwaarschriftenprocedure uit de $\mathrm{Awb}$, in: In wederkerigheid, Deventer 1997

Montfort, A.J.G.M. van, Biedt de Awb steun?, Groningen 1996

Neerhof, A.R., Het geschil voorbij, Deventer 1995

Neerhof, A.R., Enige tegenstrijdige opmerkingen naar aanleiding van het rapport-Van Kemenade, JB 1997, p. 1256 en 1257

Neerhof, A.R., De beperkte actieradius van art. 2:4, lid 1 Awb, JB 1998, 24, p. $119-126$

Nicolaï, P., Olivier, Damen en Troostwijk, Bestuursrecht, vijfde herziene druk, Amsterdam 1994

Nicolaï, P., B.K. Olivier, I.C. van der Vlies, L.J.A. Damen, en B.J. Schueler, Bestuursrecht, zesde herziene druk, Amsterdam 1997

Nicolaï, P., Beginselen van behoorlijk bestuur, Deventer 1990

Oosting, M., De arob-bezwaarschriftenprocedure als keuze-vraagstuk, Bestuurswetenschappen, 1978 , p. 119 e.v.

Oosting, M., e.a., Beeld van de arobbezwaarschriftenprocedure, Deventer 1982 en C.M. Breeuwsma, M. Oosting e.a., Arobpraktijken, Deventer, 1984

Oosting, M., Kwaliteit van de overheid, Deventer 1990

Oosting, M., De overheid in 1996 beoordeeld door de Nationale ombudsman, Best.w. 1997, p. 91

Openbaar bestuur in de knel door rechtspraak, NTB 1997, p $\mathbb{1} t / \mathrm{m} 32$

Peters, J.A.F., Publiekrechtelijke rechtspersonen, Zwolle 1997

Pieters, G.F., De bewijspositie van partijen in het bestuursprocesrecht, NTB 1996, p. 42 e.v.

Polak, J.M., Combinaties van functies en belangenverstrengelingen, NJB 1996 , p. 629 e.v.

Polak, J.M., Bestuur en rechter, Relationele problemen, NJB 1996, p. 692 
Polak, J.M., Kroniek van het Algemeen deel van het bestuursrecht, NJB 1996, p. 391. e.v.

Polak, J.M. Toepassing en effecten van de algemene wet bestuursrecht 1994 1996, 's-Gravenhage 1996

Polak, J.M., De evaluatie van de Algemene wet bestuursrecht, RegelMaat 1997, p. 1

Pront-van Bommel, S., Onrechtmatig verkregen bewijs in: In de sfeer van het administratief recht, Utrecht 1994

Rapport ABAR, VAR LXXII, Groningen 1974

Ruimschotel, D. Corruptie als combinatie van irreguliere bevoordeling en infaam verraad, NJB 1994, p. 1554 e.v.

Ruiter, D.W.P. en F.H. van der Burg e.a., Wetgeving en beleidsinstrumentarium in: Macht en onmacht van de wetgever, Deventer, 1978, p. 67 e.v.; bepalingen in bestuursrechtelijke wetten in: Wetgevingsleer Themanummer BW 1980 , p. 269 en 270

Sanders, K., Beschikkingenfabrieken en de bezwaarschriftenprocedure, Openbaar Bestuur 1997, p. 21 (nr.)

Scheltema, M., De Algemene wet bestuursrecht, NJB, 1994, p. 6

Scheltema, M., Waarom is een codificatie van het bestuursrecht belangrijk? in: Bestuur, burger en rechtspraak, 's-Gravenhage 1994

Scheitema, M., De rechter en de bezwaarschriftenprocedure: meer aandacht voor snelheid en minder voor aansprakelijkheid in: In de sfeer van het administratief recht, Utrecht 1994

Schoor, C.W.J., De bezwaarschriftenprocedure in de Awb, bezien in het licht van die procedure op grond van de Wet Arob (slot), Gst., 6946, p. 348-350

Schoor, C.W.J., De bezwaarschriftenprocedure in art. 7:11, NJB 1993, p. 859 en 860

Schreuder-Vlasblom, M., de Algemene wet bestuursrecht, vierde dr., Deventer, 1996

Schreuder-Vlasblom, M., De Awb; het bestuursprocesrecht, vijfde dr., Deventer 1997

Schueler, B.J., e.a., Ervaringen met de Awb, Besluiten over ruimtelijke orde ning, milieu en standplaatsen, Deventer 1996

Schueler, B.J., Vernietigen en opnieuw voorzien, Zwolle 1994

Simon, H.J., Handleiding Awb-praktijk, 's-Gravenhage 1995

Simon, H.J., De kleine revolutie: één jaar besturen onder de Awb I, JB 1995, 30 Simon, H.J., Handboek bestuurs(proces)recht volgens de Awb, 's-Gravenhage 1997

Smit, J.A., Bezwaar in belastingzaken, Deventer, 1992, p. 19 e.v.

Smit, J.A., De administratieve voorprocedures in: Nieuw bestuursprocesrecht, Deventer, 1992, p. 52 
Smit, J.A., De Administratieve voorprocedures in: Nieuw bestuursprocesrecht, Deventer, 1992, p. 47 e.v.

Stam, Een ingrijpende wijziging van de Algemene wet bestuursrecht, Gst. 6983, p. 121

Steenbeek, J.G., Wet administratieve rechtspraak overheidsbeschikkingen, 'sGravenhage 1976, en Hand. 29-4-1975, n.a.v. een vraag van het Eerste Kamerlid Polak, p. 189 noot 5

Steenbeek en F.A.M. Stroink, Wer Arob, vierde herziene druk, 's-Gravenhage 1988

Stegeren, J.T. van, Gemeentelijke vertegenwoordiging in vennootschappen, Gst. 6889, p. 484 en 485

Stroink, F.A.M., Het leerstuk der deconcentratie, 's-Gravenhage 1978

Stroink, F.A.M., Wet administratieve rechtspraak overheidsbeschikkingen, vierde herziene dr., 1988, 's-Gravenhage

Stroink, F.A.M., Het leerstuk der deconcentratie, "s-Gravenhage 1978

Stroink, F.A.M., Algemeen Bestuursrecht, Zwolle 1994

Stroink, F.A.M., Judicial control of the administration's discretionary powers (le bilan executif - juge administratif) in: Judicial control, Comparative essays on judicial review, Antwerpen-Apeldoorn, 1995, p. 98

Stroink, F.A.M., Publiekrechtelijke rechtspersonen, NTB 1997, p. 239 e.v.

Stroink, F.A.M., Inspraak vooraf of bezwaar achteraf? in: Bestuur en norm, Deventer, 1986, p. 243 e.v.

Stroink, F.A.M., Kern van de bestuursrechtspraak, 's-Gravenhage 1997

Tak, A.Q.C., Het Moment X, TvO, 1990, p. 134

Tak, A.Q.C., Hoofdlijnen van het Nederlands besturursprocesrecht, 3e dr., Zwolle, 1995

Tak, A.Q.C., Normaal bestuur in: Bestuur en norm, Deventer, 1986, p. 256

Tak, A.Q.C., Binnenlands Bestuur 1998, 7, p. 21

Tak, A.Q.C. De Algemene wet bestuursrecht. Het nieuwe bestuursprocesrecht $3 \mathrm{e}$ dr., Zwolle, 1995, p. 83

T\&C PGW (Graat), aant. 1 bij art. 154 Gem.w.

Teunissen, J.M.H.F., in: Algemene wet bestuursrecht, losbl., 's-Gravenhage

Teunissen, J.M.H.F., Toetsing ex tunc of ex nunc? in: Nieuw bestuursproces recht, Deventer 1992, p. 111 e.v.

Teunissen, J.M.H.F., Het burgerlijk kleed van de staat, Beschouwingen over de tweewegenleer, Zwolle, 1996

Tonnaer, F.P.C.L., Regels voor het besturen, Gst. 6831, p. 130

Tonnaer, F.P.C.L., Vergunningverlening in stroomversnelling, VAR XCII, Alphen aan den Rijn 1984 
Troostwijk. M. (red.), De gemeentewet en haar toepassing, losbl., Alphen aan den Rijn

Veen, G.A. van der, Staats- en bestuursrechtelijke kroniek, Best.w. 1997, p. 119 e.v.

Veld, J. in 't, derde, geheel herziene dr. door N.S.J. Koeman, Zwolle 1985

Verheij, N., Stadsmobiel Amsterdam, Partijdige bezwaarschriftencommissie in: Rechtspraak Bestuursrecht 'De Annotaties' 1994-1995, 's-Gravenhage

Verkruisen, W.G. en B.C. Vis, Gemeente en Gemeentewet, achtste herzien dr., Nijmegen 1995

Versteden, C.J.N. en T. Renes, Provincierecht, Zwolle, 1994

Versteden, C.J.N., Voorontwerp Algemene wet bestuursrecht reden tot juichen voor het lokaal bestuur?, Gst. 6845, p. 410

Versteden, C.J.N., De plaats van bezwaar en administratief beroep in het stelsel van rechtsbescherming, NTB 1995, p. 287

Versteden, C.J.N., Tijd voor juridische kwaliteitszorg, NTB 1997, p. 68 e.v. en ook: K.F. Schuiling en H.B. Winter, Juridische controlling in opkomst, Gst. 7053 , p. 254 e.v.

Viering, M.L.W.M., Het toepassingsgebied van artikel 6 EVRM, Zwolle 1994

Vlies, I.C. van der, Wet wijkt voor ongeschreven recht, AAe, 1996, 6, p. 458

Vlies, I.C. van der, Regulering van subsidies, NJB 1992, p. 819-823

Vlies, I.C. van der, in: Handboek Algemene wet bestuursrecht, losbl., 's-Gravenhage

Vlies, I.C. van der, Algemene wet bestuursrecht, Wetsvoorstel ingediend, Publiek domein, 1989, p. 215

VNG, model-bouwverordening, herdruk 1971, bijgewerkt tot en met 13e supplement, 's-Gravenhage 1971

VNG, Blauwe reeks nr. 48, Behandeling van bezwaar en beroepschriften door de gemeentebesturen, "s-Gravenhage 1972

VNG, Blauwe reeks nr. 58, 's-Gravenhage 1976

VNG, Besturen met beleid, Groene reeks nr. 48, 's-Gravenhage 1980

VNG, Besturen met minder middelen, Groene reeks nr. 73, 's-Gravenhage 1984

VNG, Blauwe reeks nr. 72, 's-Gravenhage 1986

VNG, Ordening in het bestuursrecht (eerste fase), Groene reeks nr. 95, 'sGravenhage 1987

VNG, De Algemene wet besturursrecht, de gemeente en de behandeling van bezwaar- en beroepschriften, circulaire $93 / 216$

Vries, J. de, Verzekeren van overheidsaansprakelijkheid, Euroforum-studiedag 16 mei 1995

Vries, J. de, Fouten bij de besluitvorming, (Ervaringen van een Arob-rechter), Gst. 6851 , p. 102 en 103 
Waard, B.W.N. de, Een eerlijk proces (1), Algemene beginselen van behoorlijk procesrecht, TvO 1983 , p. 145

Waard, B.W.N. de, Een eerlijk proces (II), Artikel 6 eerste lid, EVRM, TvO 1983 , p. 176 e.v.

Waard, B.W.N. de, Beginselen van behoorlijke rechtspleging, Zwolle, 1987, p. 363

Waard, B.W.N. de, Na de uitspraak, NTB, 1987 , p. 80

Waard, B.W.N. de, Beginselen van behoorlijke rechtspleging, Zwolle, 1987, p. 363

Waard, B.W.N. de, Knellend bestuursrecht, NTB 1998, p. 60 e.v.

Waard, B.W.N. de, Algemene uitgangspunten in: Algemene wet bestuursrecht, "s-Gravenhage, losbl. C 2-12 e.v.

Wade, William Sir Administrative Law, Seventh Edition, Oxford 1994

Welstandadvies, welstandsberoep en welstandsjurisprudentie, Serie Welstandstoezicht, Utrecht 1980

Werd, M. de, Tobben met de rechtsstaat, NJB 1996

Werkgroep Herziening Gemeentewet, Eindrapport van 20 oktober 1980, "sGravenhage 1980

Wiarda, Algemene beginselen van behoorlijk bestuur, VAR-geschrift XXIV, Haarlem, 1952, p. 81 en ABAR, vijfde geheel herziene dr., Alphen aan den Rijn, 1984, p. 122

Widdershoven, R.J.G.M., Gespecialiseerde rechtsgangen in het administratieve recht, Zwolle, 1989

Wijk, van/Konijnenbelt/Van Male, Hoofdstukken van administratief recht, Utrecht, 1993

Wijk, van/Konijnenbelt/van Male, Hoofdstukken van administratief recht, achtste dr., Utrecht 1993, p. 659

Winter, H. en M. Herweijer, Binnenlands Bestuur 1997, 49, p. 15 H.H. Winter, Bestuurders moeten wooral zelf hun werk goed doen, Binnenlands Bestuur, 1966 , p. 50 en 51

Winter, H.B., Juridische controlling in opkomst, Gst. 7053, p. 254 e.v.

Wulffraat-Van Dijk, M.S.E., Feitenonderzoek door de bestuursrechter, Zwolle, 1995, p. 7

Zundert, J.W. van, Ruimtelijk bestuursrecht, Deventer 1996 


\section{Jurisprudentieregister}

\section{Europees Hof woor de Rechten van de Mens}

EHRM 23 juni 1981, NJ 1982, 60213

EHRM 9 december 1994, NJCM-Bulletin 1995 (Schouten en Meldrum) 106, 323

EHRM 28 september 1995 (Procola), AB 1995, 588, JB 1995, 252 106, 117

EHRM 18 maart 1997, JB 1997, 112 (Mantovanelli) 169, 210, 233

\section{Hoge Raad}

HR 3 april 1947, NJ 38175

HR 14 januari 1949, NJ 557, ARB, p. 75175

HR 25 februari 1949 , NJ 55875

HR 12 april 1978, BNB 135-137, AB 1979 en NJ 1979, 53368

HR 16 mei 1979, AB 1979, 528113

HR 24 februari 1984, AB, 39920

HR 3 mei 1985, NJ 1986 (Zuiderbad) 71

HR 27 maart 1987, AB 1987, 273 (Amsterdam-Ikon) 71

HR 24 april 1992, AB 1992, 54271

HR 29 april 1994, RvdW 1994, 107, AB 1994, 530, BR 1994, p. 773 e.v. Schuttersduin) $2 I$

\section{Afdeling bestuursrechtspraak Raad van State}

ABRS 24 juni 1994, JG 95.0043220

Vz. ABRS 27 september 1994, AB 1995, 5217

ABRS 31 oktober 1994, Gst. 7007, 864

ABRS 27 november 1994, Gst., 7007, 7, AA 1996 (Venray), p. 454 e.v. 64, 389 ABRS 10 februari 1995, AB 1995, 348146

ABRS 9 maart 1995, Gst. 7029,486

VZ. ABRS 1 mei 1995, AB 1995,48541

ABRS 4 juli 1995, AB 1995, 53046

ABRS 5 juli 1995, JB 1995, 227, NTB 1996, p. $151 \quad 167$

VZ. ABRS 7 juli 1995, AB 1996, 17747

Vz. ABRS 10 augustus 1995, NJB-Katern 1996, p. $130 \quad 388$

VZ. ABRS 18 augustus 1995,JB 1995, 271222

ABRS 21 september 1995, JG 96.002386

ABRS 30 november 1995 , M en R 1996, nr. 31. Stcrt. 1996, 86, p. 4118

ABRS 7 december 1995, AB 1996, 186118

ABRS 18 december 1995, AB 1996, 187120

ABRS 5 januari $1996, \mathrm{JB} 1996,56,118$

ABRS 16 januari 1996, AB 1996, 12164

ABRS 25 januari 1996, JB 1996,58153

ABRS 4 maart 1996, JG 96.03185 
ABRS 5 maart 1996, AB 1996,251163

ABRS 14 maart 1996, AB 1996, 289185

ABRS 25 maart 1996, AB 1996, 288185

ABRS 20 juni 1996, NBABM 1996,56219

ABRS 29 juli 1996, RAwb 1996, $12711,177,186,401$

ABRS 6 januari 1997, JB 1997, 25, Gst. 7053, 4, AB 1997, 86, 278, 407 ABRS 20 maart 1997, Gst. 7070, 7, 68

ABRS 8 aprill 1997, AB 1998, 106, m.nt. PvB, 263, 410

ABRS 16 april 1997, AB 1998, 75, 171

ABRS 21 april 1997, Gst. 7075, 743

ABRS 15 mei 1997, AB 1997, 263186

ABRS 29 mei 1997, RAwb, 23

ABRS 12 juni 1997, JB 1997, 188405

VZ. ABRS 7 juli 1997, JB 1997, 192388

ABRS 28 oktober 1997, AB 1997, 458, Gst. 7066, 4171

ABRS 16 december 1997, JB 1998, 24, 30, ABkort 1998, 30, Gst. 7077, 5, 162 ,

$171,300,367,396,406,409,413,415$

ABRS 20 februari 1998, Gst. 7072, 3, JB 1998, 76, 164, 166, 395

\section{Afdeling rechtspraak Raad van State}

ARRS 26 augustus $1977, \mathrm{AB} 1978,212213$

ARRS 11 november 1977, AB 1978,245213

ARRS 12 januari 1978 , tB/S III, 50, p. 22661

ARRS 2 juni 1978, tB/S II, 2049

ARRS 6 november 1978, tB/S IV, 17, p. 71, AB 1979, 150277,407

Vz. ARRS 20 december 1978, AB 1979, tB/S II, p. 132 en 133 (Heesch) 214

Vz. ARRS 1 maart 1979, AB 1979, 350, tB/S II, 37 (winkelpand Borculo) 22

ARRS 7 mei 1979, OB 1979, 40884 213

ARRS 14 mei 1979, AB 1980, 493213,216

ARRS 17 juli $1979, \mathrm{~B} / \mathrm{S}$ II, p. 170210,213

Vz. ARRS 24 augustus 1979, AB 1980, 8137

Vz. ARRS 8 november 1979, AB 1980, 328149

ARRS 24 april 1980, AB 1980,559 (Duiveland) 25

ARRS 5 juni 1980, AB 1981, 125 (Akkrum) 214

ARRS 10 juni 1980, tB/S III, 299211

Vz. ARRS 21 augustus 1980, AB 1981, 350211

ARRS 18 september 1980, Gst. 6658, $3260,270,406$

ARRS 19 januari 1981 , tB/S III, 232229

ARRS 24 april 1981, Gst. 6638, 5 (Valkenburg (ZH)) 72

ARRS 25 mei 1981, Gst. 6693, 3, 210

ARRS 9 juni 1981 , tB/S III, 271149 
ARRS 11 juni 1981 , Gst. 6681 , $\mathrm{B} / \mathrm{S} \mathbb{I}, 421210$

ARRS 11 augustus 1981, AB 1982, 40 210

ARRS 4 januari $1982, \mathrm{BB} / \mathrm{S}$ III, 317210,229

ARRS 22 januari 1982, AB 1982, 178150,164

ARRS 9 maart 1982, AB 1982, 302 ("s-Gravenhage), 210, 216, 239

ARRS 25 maart 1982, Gst. 6738, 7, tB/S II, 115260

ARRS 26 augustus 1982, tB/S III, 371230

ARRS 13 september 1982, AB 1982, 603210

ARRS 26 oktober 1982, $1 \mathrm{~B} / \mathrm{S}, 125$ (Hontenisse) 214

ARRS 11 januari 1983, AB 1983, 330145

ARRS 22 april 1983, AB 1984, 212, 261

Vz. ARRS 23 juli 1983, tB/S VI, 14 (Hoogvliet Antennemast) 214

Vz. ARRS 16 december $1983, \mathrm{tB} / \mathrm{S}, 14253$

ARRS 4 september 1984, tB/S III, 557 (Kedichem) 150

ARRS 8 november 1984, AB 1987, 133137

ARRS 4 februari 1985, tB/S II, 154, tB/S 1992, 9361

ARRS 7 juni 1985, AB 1986, 345 (bestuursdwang Asten) 214

ARRS 12 juli 1985, AB 1986, 49 (subsidie Enschede) 214

ARRS 11 november 1985, tB/S IV, 127, p. 55724

ARRS 2 september $1986, \mathrm{tB} / \mathrm{S} 1986,151150$

ARRS 8 december 1986, AB 1987, 384211

VZ. ARRS 20 januari 1987, tB/S 1987, 9 (Brandweerkazerne Amerongen) 43

ARRS 2 juni 1987, tB/S 1987, 92259

ARRS 19 juli 1987, tB/S 1987, 114 (Uitrit Stad Delden) 43

ARRS 16 oktober 1987, Gst. 6863, 13 (Leidschendam) 214

VZ. ARRS 2 november $1987, \mathrm{tB} / \mathrm{S} 1987,170145$

ARRS 3 november $1987, \mathrm{tB} / \mathrm{S} 1987,171, \mathrm{tB} / \mathrm{S} 1992,9361$

ARRS 18 februari $1988, \mathrm{tB} / \mathrm{S} 1988,2250$

ARRS 13 maart $1990, \mathrm{~B} / \mathrm{S}, 26$ (Pijnacker) 62

ARRS 31 maart 1989, AB 1989, 405260

ARRS 6 april 1990, Gst. 6906, 7, AB 1991, 602261

ARRS 6 juli 1990, tB/S, 7361

ARRS 18 september 1990 , tB/S 1990, 104, AB 1991, 596 142, 394

ARRS 4 oktober 1990, tB/S 1990, 117228

ARRS 13 november $1990, \mathrm{tB} / \mathrm{S} 1990,135, \mathrm{t} / \mathrm{B} / \mathrm{S} 1992,9360$

Vz. ARRS 29 april 1991, Gst. 6957, 9138

Vz. ARRS 17 mei 1991 , tB/S 1991, 6743

ARRS 18 juni $1991, \mathrm{tB} / \mathrm{S} 1991,7943,49$

ARRS 2 september $1991, \mathrm{tB} / \mathrm{S} 1991,11461$

ARRS 5 september $1991, \mathrm{tB} / \mathrm{S}, 118,51$

ARRS 17 november 1991, tB/S, 153141,394 
ARRS 13 januari 1992, tB/S 1992, 6138,154

ARRS 15 mei $1992, \mathrm{tB} / \mathrm{S} 1992,65, \mathrm{tB} / \mathrm{S} 1992,9361$

VZ. ARRS 1 juni 1992, BR 1993, p. 130 en 131 138, 154

ARRS 7 augustus 1992, tB/S 1992,9362

ARRS 17 maart 1993, tB/S 1993, 2543

Vz. ARRS 12 april 1993, tB/S 1993, 5343

Vz. ARRS 2 december 1993, Comp. Monumentenzorg, art 15, p. 3 141, 394

\section{Afdeling geschillen van bestuur Raad van State}

AGVB 16 november 1989, BR 1990 , p. 462 e.v. 143

AGVB 1 september 1992, JABW 1992, 25448

AGVB 1 september 1992, AB 1993, 96

AGVB 20 augustus 1993, BR 1994, p. 512 e.v. 144

\section{Centrale Raad van Beroep}

CRvB 11 oktober $1977, \mathrm{AB}, 1978,45196$

CRvB 24 december 1981, AB 1982, 254206

CRvB 2 januari 1986 , TAR 1986,63206

CRvB 9 mei 1988, TAR 1988, 140206

CRvB 26 juli 1994, RAwb 1995,862

CR wB 18 augustus $1994, A B 1995,16354$

CRvB 22 september 1994, AB 1995, 42371

CRvB 20 oktober 1994, JB 1994, $288 \quad 212$

CRvB 3 november 1994. JB 1994, 343354

CRvB 10 november 1994, AB, 1995, 45217

CRvB 15 februari 1995, JB 1995, 64, AA 1995, p. 236 e.v., NJCM-Bulletin 1995 , p. 421 e.v. en Rechtspraak Bestuursrecht, De Annotaties: 94/95 p. 155 e.v. 236

CRvB 28 februari 1995, RSV 1995, 20148

CRvB 2 maart 1995, AB 1995, 315185

CRwB 21 maart 1995, AB 1995, 603 83

CRvB 30 mei 1995, AB 1995, 461, JB 1993, 288, AB 1995, 44215

CRvB 10 november 1995, JB 1997, 227385

CRvB 25 februari 1997, AB 1997, 23844,48

CRvB 25 maart 1997, JB 1997, 91278,407

CRvB 8 augustus 1997, JB 1997, 22368

CRvB 4 december 1997, JB 1998, 38421

College van Beroep voor het bedrijfsleven

CBB 28 augustus $1970, A B 1971,10207$

CBB 8 maart $1990, \mathrm{AB} 1990,431210$ 
CBB 6 juli 1993, ABkort, 93, 43

CBB 14 september 1994, AB 1995, 20445

CBB 17 november 1994, JB 1994, 337212

CBB 21 december 1994, JB 1995, I, AB 1995, 454, RAwb 1995, 34 en Rechtspraak Bestuursrecht 1994-1995, 10 156, 207, 301, 396, 416

Pres. CBB 10 maart 1995, AB 1995, 49645

CBB 25 april 1996, NJB Katern 1996, p. 1376, nr. 43

CBB 17 mei $1995, J B 1995,17546$

CBB 30 januari 1996 , nr. $95 / 1437 / 108 / 212,186$

CBB 27 mei 1997, AB 1997, 279 186

CBB 8 juli 1997, JB 1997,227

\section{College van Beroep Studiefinanciering}

Cbsf 23 maart 1995, JB 1995, 11746

\section{Rechtbanken}

Pres. Rb. Assen 17 januari 1994, RAwb 1994, 1233

Rb. Rotterdam, 26 januari 1994, JB 1994, 899

Pres. Rb. 's-Gravenhage 9 februari 1994, RAwb 1994, 6246

Pres. Rb. Rotterdam 29 maart 1994, JB 1994, 100232

Pres. Rb. Utrecht, 7 april 1994, JB 1994, 115221

Rb. Utrecht 4 mei 1994, KG, 219156

Pres. Rb. Groningen 4 juli 1994, Awb-katern 1995, 6452

Rb. Assen 19 juli 1994, AB 1995, 12883

Pres. Rb. Alkmaar 8 augustus 1994, Awb-katern 1994, 16599

Pres. Rb. Utrecht 26 september 1994, JB 1995, 7, 951

Rb. Groningen 30 september 1994, KG 1994, 407, JB 1996, 56118

Pres. Rb. Utrecht 6 oktober 1994, JB 1995, 7, 9 II

Pres. Rb. Groningen 4 november 1994, Awb-katern 1995, 16185

Pres. Rb. Groningen 22 december 1994, NA, 114, JB 1995, 107212

Pres. Rb. "s-Gravenhage 11 mei 1995, RAwb 1996, 863

Rb. Maastricht, 13 juni 1995, reg. nr. 94/2420 WRO19 Z DAL 82

Rb Groningen 17 juli 1995, Awb-katern 1995, 141 215, 267

Rb. Maastricht 31 juli 1995, 95/1551 WRO19 VV VRS n.g. 80

Rb. Arnhem 27 september 1995, Awb-katern 1995, 16355

Rb. Rotterdam 4 december 1995, JB 1996, 63231

Rb. Amsterdam 15 december 1995, Awb-katern 1996, 24, Gst. 7034,4 262

Rb. Leeuwarden 8 februari 1996, Awb-katern 1996, 53, JB 1996, 100159

Rb. Rotterdam 8 februari 1996, JB 1996, $10165,301,416$

Rb. 's-Gravenhage 19 februari 1996, Awb-katern 1996, 43134

Rb. Maastricht 5 maart 1996, 95/1786 WW50 Z Pol 161, 167, 300, 303, 396 
Rb. Maastricht 15 maart 1996, JB 1996, $132168,172,417$

Rb. Maastricht 20 maart 1996, JB $1996,114160,273,406$

$\mathrm{Rb}$. Maastricht 29 maart $1996, \mathrm{JB} 1996,132155$

Pres. Rb. Zutphen 9 april 1996, JB 14965

Pres. Rb. Maastricht 19 augustus 1996, Gst. 7063, 7 171, 304, 322, 418, 435

Pres. Rb. Maastricht 10 december 1996, 96/3025 WOW44 V/96/3045 418

Rb. Utrecht 19 maart 1997, A wb-katern 1997, 3435

Rb 's-Gravenhage 10 april 1997, BR 1997, p. 663 e.v. (Vinex-locatie PijnackerZuid) 96

Rb. "s-Hertogenbosch 8 juli 1997, JB 1997, 227328

Rb. 's-Hertogenbosch 15 oktober 1997 , Awb-katern 1998,43280

Rb. 's-Hertogenbosch 13 maart 1998, JB 1998, 121407

\section{Nationale ombudsman}

N.o. 21 november $1989, \mathrm{AB} 1990,89135$

N.o. 16 juni 1995 , nr. 95/232, NRO 95-198 263

N.o. 14 januari 1997, JB 1997, 41343

N.o. 26 september 1997, AB 1998, 7186

\section{Kroon}

KB 19 maart 1969 , nr. 44, O.B. 1969, III.11, nr 28652; NG 1969, p. 404; AB 1969, p. 489197

KB 1 juni 1981, AB 1981, $483 \quad 1 / 8$

KB 21 december 1982, AB 1983, $298155,142,395$

KB 24 januari 1995 , Stb. 1995,41164

KB 19 december 1995, Stb. 1996, JG 96.0060, $22 \quad 165,168,395$ 


\section{Curriculum vitae}

Jo Notten werd op 6 juli 1942 in de toenmalige gemeente Geulle geboren. Na het afronden van de ULO-opleiding startte hij na enige tijd zijn ambtelijke loopbaan bij de gemeente Borgharen in januari 1959. Nog voor zijn militaire dienstplicht behaalde hij in 1962 de akte Gemeente-Administratie I.

Vanaf 1 januari 1964 was hij hoofd Sociale Zaken in de gemeente Elsloo en secretaris-penningmeester van de Gemeentelijke instelling voor maatschappelijke zorg.

In die tijd slaagde hij voor het diploma Middelbare Sociale Arbeid.

Ingaande 1 januari 1966 volgde zijn benoeming tot hoofd Sociale Zaken van de gemeente Maasbree, alwaar hij tot 1 december 1970 werkzaam was.

Aansluitend trad hij in dienst bij zijn huidige werkgever de gemeente Maastricht.

Hij vervulde in Maastricht diverse bestuurlijk-juridische functies en was daarnaast regelmatig belast met de uitvoering van bijzondere projecten. Aanvankelijk was hij werkzaam bij de Afdeling Algemene Dienst en Kabinet, waarna hij in 1987 de overstap maakte naar de Afdeling Milieu van de Dienst Stadsontwikkeling en Grondzaken. Bij deze dienst is hij nu werkzaam bij de Afdeling Bouwen en Wonen. In de gemeente Wittem is hij lid van de commissie voor de bezwaar- en beroepschriften.

In 1980 behaalde hij de akte GA-II en slaagde hij in 1982 voor het diploma Management in Overheidsorganisaties. Via het colloquium doctum kreeg hij toegang tot het wetenschappelijk onderwijs. Van 1988 tot en met 1991 studeerde hij aan de Rijksuniversiteit Limburg (thans Universiteit Maastricht) en slaagde hij voor het doctoraal examen Nederlands Recht. 